Universidade de São Paulo

FFLCH - Faculdade de Filosofia, Letras e Ciências Humanas Departamento de Letras Modernas

Área Língua e Literaturas Espanhola e Hispano-Americana

Patrícia Gimenez dos Santos Minari

\title{
Elementos de cortesia e atenuação no Português rio-pretense e no Espanhol malaguenho - um estudo comparativo
}

Vol. 1

Exemplar corrigido 
Patrícia Gimenez dos Santos Minari

\section{Elementos de cortesia e atenuação no Português rio-pretense e no Espanhol malaguenho - um estudo comparativo}

Vol. 1

Tese de Doutorado apresentada ao Programa de PósGraduação do Departamento de Letras Modernas, da Faculdade de Filosofia, Letras e Ciências Humanas da Universidade de São Paulo, como requisito para obtenção do título de Doutor em Letras.

Área de Concentração: Língua e Literaturas Espanhola e Hispano-Americana

Orientadora: Prof ${ }^{\text {a }}$ Dra. Maria Zulma Moriondo Kulikowski

Exemplar corrigido

SÃO PAULO

2011 

Patrícia Gimenez dos Santos Minari

Elementos de cortesia e atenuação no Português rio-pretense e no Espanhol malaguenho - um estudo comparativo

Tese de Doutorado apresentada ao Departamento de Letras Modernas da Faculdade de Filosofia, Letras e Ciências Humanas, da Universidade de São Paulo, como exigência para obtenção do título de Doutor em Letras.

Área de pós-graduação: Língua e Literaturas Espanhola e Hispanoamericana Área de Concentração:

Orientadora: Profa. Dra. Maria Zulma Moriondo Kulikowski

\section{Banca Examinadora:}

Profa. Dra. Maria Zulma Moriondo Kulikowski

Instituição: FFLCH - USP

Instituição:

Instituição:

Instituição:

Instituição: 
Ao Gustavo, por fazer parte dos melhores capítulos da minha vida. Ao Rafael, nosso tesouro em comum.

Aos meus pais, Valdir e Isabel, por sempre estarem presentes na minha vida, dando apoio, encorajamento, amor e pelos ensinamentos que formaram a base $d a$ minha história. 
"Resulta muito mais fácil educar os povos para a guerra do que para a paz. Para educar no espirito bélico basta apelar aos mais baixos instintos. Educar para a paz implica ensinar a reconhecer o outro, a escutar os seus argumentos, a entender as suas limitações, a negociar com ele, a chegar a acordos. Essa dificuldade explica que os pacifistas nunca contem com a força suficiente para ganhar... as guerras." 


\section{Agradecimentos}

A Deus por iluminar meu caminho, dando-me sabedoria para enfrentar os momentos mais difíceis, sobretudo aqueles em que o cansaço parecia querer vencer e me fazer fraquejar e também por colocar ao meu lado pessoas maravilhosas, sem dúvida, os alicerces da minha vida.

Ao meu anjo, Rafael, que com dias de vida já parecia compreender as minhas necessidades e dormia, ao som do teclado e da impressora como canção de ninar.

Aos meus pais, Valdir e Isabel e ao Gustavo, meu marido, por muitas vezes acreditarem em mim mais do que eu mesma. Em especial ao meu pai, agradeço sua imensa ajuda técnica com o manejo dos gráficos que possibilitaram a exposição dos dados da pesquisa.

Ao meu querido avô Luís, que não teve tempo de me ver vencer mais esta etapa da minha vida. Tenho certeza que de onde quer que esteja, estará me aplaudindo com suas palavras Estudia, hija. Eso es lo único que nadie te lo podrá quitar.

À Maitê, por toda a disponibilidade em corrigir o texto, emprestar livros e os ombros também...

À Profa. Dra. Maria Zulma Moriondo Kulikowski, pela confiança em mim depositada, por todo o auxílio e paciência durante a orientação e pelo seu bom humor contagiante.

Ao Prof. Dr. Sebastião Carlos Gonçalves, da UNESP de São José do Rio Preto por toda a disponibilidade em me fornecer as entrevistas.

Aos Profs. Drs. Letícia Rebollo Couto e Luiz Antonio da Silva pelas valiosas sugestões e críticas no exame de qualificação. Em especial ao Prof. Luiz por ter me auxiliado desde a escrita do pré-projeto, emprestando grande parte da bibliografia.

A todos aqueles que estiveram presentes direta e indiretamente durante todo o período do Doutorado - meus irmãos, sogros, cunhados, amigos que mesmo sem entender bem o que eu tanto estudava, compreendiam as minhas alegrias e angústias. 
O objetivo deste trabalho é a análise dos elementos de cortesia e atenuação no Português falado na região de São José do Rio Preto e no Espanhol falado na região de Málaga. Os corpora analisados foram obtidos por meio de entrevistas semidirigidas e fazem parte do Projeto ALIP - Amostra Linguística do Interior Paulista, o brasileiro, e PRESEEA - Proyecto para el Estudio Sociolingüistico del Español de España y América, o espanhol. Analisamos um total de 24 entrevistas, sendo 12 de nível médio e 12 de superior, seis em cada idioma, divididas igualmente entre falantes do sexo feminino e do sexo masculino. Os falantes de nível médio tinham idades entre 25 e 45 anos, enquanto que a faixa etária entre os de nível superior era entre 50 e 70 anos. Partindo da teoria pragmática dos Atos de Fala e de estudos mais recentes sobre cortesia e atenuação de teóricos como Leech (2007), Bravo (2001, 2004, 2005), Kerbrat-Orecchioni (2004, 2005, 2006), entre outros, analisamos tanto a fala dos entrevistadores quanto a dos informantes. A partir da fala dos entrevistadores, pudemos observar como as perguntas, as solicitações de informações eram elaboradas em ambos os idiomas. Tal análise possibilitou a verificação de como o entrevistador se posicionava e quais eram as estratégias utilizadas - verbos no imperativo, enunciados diretos, uso de atos de preparação ou verbos que visavam a proteger a face do informante. Já a análise da fala dos informantes objetivou a averiguação do uso de outras estratégias, cuja intenção era a defesa pessoal ou de terceiros, protegendo sua própria face ou a do entrevistador. Entre essas estratégias citamos a desfocalização do eu, a proteção à própria face ou à do outro, o uso de elementos atenuadores no momento de expressar opiniões, entre outras. Ao longo de nossa análise investigamos também o posicionamento de cada entrevista no eixo de solidariedade ou poder de acordo com a teoria de Brown e Gilman (1960). Para isso, foi necessário o estudo das formas de tratamento empregadas, bem como o uso ou não de formas nominais. Os resultados obtidos, dentro dos corpora estudados, mostram que a Língua Espanhola é uma língua de mais aproximação com o interlocutor, enquanto que a Língua Portuguesa denota maior distância. Observou-se ainda que determinados elementos como o uso de um tratamento mais formal no caso da Língua Portuguesa se caracteriza mais como uma estratégia conversacional do que uma distância social.

Palavras-chave: cortesia, atenuação, pragmática, ALIP, PRESEEA 
The present paper aims at the analysis of the politeness and attenuation elements in both the Portuguese spoken in São José do Rio Preto region and in the Spanish spoken in Malaga region. The studied corpora were obtained by means of partially guided interviews and are part of the ALIP Project (São Paulo's Countryside Linguistic Sampling), the Brazilian one, and the PRESEEA ( Project for the Sociolinguistic Study of the Spanish Spoken in Spain and America), the Spanish one. A total of 24 interviews were analysed, being 12 of those on an average level and the other 12 on a superior one, six in each language, equally divided into male and female speakers. The average level speakers range aged from 25 to 45 whereas the superior level ranged from 50 to 70 . Considering the pragmatic theory of Speech Acts and other more recent studies on politeness and attenuation by theorists such as Leech (2007), Bravo (2001, 2004, 2005), Kerbrat-Orecchioni (2004, 2005, 2006), among others, both interviewers' and interviewees' speeches were analysed. From the interviewers' speeches it was possible to observe how the questions, the information required, were built up in both languages. Such an analysis made possible verifying how the interviewer was positioned as well as which strategies were used: verbs in imperative, direct enunciations, preparation acts usage or verbs aiming at protecting the informer's face. Yet the informers' speech analysis aimed at the inquiry of other strategies usage being the intention of such the personal or third parties' defense, proctecting oneself's face or the interviewer's one. Among these strategies we mention defocusing the self, protecting oneself's own face or the other's one, attenuating elements usage when expressing opinions, among others. Throughout our analysis we investigated also the positioning of each interview coming to the axis solidarity or power according to Brown and Gilman's theory (1960). For such, it was made necessary the study of the treatment forms applied as well as the use or not of noun forms. The achieved results in the studied corpora showed that the Spanish language proves to be a language of more approximation coming to the interlocutor whereas the Portuguese language denotes more distance. It could also be noticed that certain elements such as the use of a more formal treatment coming to the Portuguese language are characterized more as a conversational strategy than as a social distance element.

Key Words: politeness, attenuation, pragmatic, ALIP, PRESEEA. 
El objetivo de este trabajo es el análisis de los elementos de cortesia y atenuación en el Portugués hablado en la región de São José do Rio Preto y en el Español hablado en la región de Málaga. Los corpora analizados fueron obtenidos por medio de entrevistas semidirigidas y forman parte del Projeto ALIP - Amostra Linguística do Interior Paulista, el brasileño, y PRESEEA - Proyecto para el Estudio Sociolingüístico del Español de España y América, el español. Analizamos el total de 24 entrevistas, siendo 12 de nivel medio y 12 del superior, seis en cada idioma, divididas igualmente entre hablantes del sexo femenino y masculino. Los hablantes de nivel medio tenían edades entre 25 y 45 años, mientras que la edad entre los de nivel superior era entre 50 y 70 años. Partiendo de la teoría pragmática de los Actos de Habla y de estudios más recientes sobre cortesía y atenuación de teóricos como Leech (2007), Bravo (2001, 2004, 2005), KerbratOrecchioni (2004, 2005, 2006), entre outros, analizamos tanto el habla de los entrevistadores como de los informantes. A partir del habla de los entrevistadores, observamos como las perguntas, las solicitudes de informaciones eran elaboradas en los dos idiomas. Tal análisis, posibilitó la verificación de cómo el entrevistador se posicionaba y cuáles eran las estrategias utilizadas - verbos en imperativo, enunciados directos, uso de actos de preparación o verbos que pretendían proteger la face del informante. El análisis del habla de los informantes objetivó la comprobación del uso de otras estrategias, cuya intención era la defensa personal o de terceros, protegiendo su propia face o la del entrevistador. Entre esas estrategias citamos la desfocalización del yo, la protección a la propia face o a la del otro, o el uso de elementos atenuadores en el momento de expresar opiniones, entre otras. A lo largo de nuestro análisis investigamos también el posicionamento de cada entrevista en el eje de solidaridad o poder de acuerdo con la teoría de Brown e Gilman (1960). Para eso, fue necesario el estudio de las formas de tratamiento utilizadas, y también el uso o no de formas nominales. Los resultados obtenidos, dentro de los corpora estudiados, señalan que la Lengua Española es una lengua de más proximidad del hablante con el interlocutor, mientras que la Lengua Portuguesa apunta mayor distancia. Se observó aun que determinados elementos como el uso de un tratamiento más formal en el caso de la Lengua Portuguesa se caracteriza más como una estrategia conversacional que una distancia social.

Palabras-clave: cortesía, atenuación, pragmática, ALIP, PRESEEA 
Introdução

1. Afinal, por que estudar a cortesia?

2. A origem das hipóteses do Doutorado............................................. 22

3. Objetivos da pesquisa............................................................... 23

4. Organização do trabalho.................................................................. 24

Capítulo 1 - Descrição dos Corpora.............................................................. 25

1.1. Contexto linguístico....................................................................... 26

1.1.1. O Espanhol na Andaluzia........................................................ 26

1.1.2. O Português no Brasil........................................................................ 28

1.2. Características comuns aos corpora ................................................. $\quad 30$

1.2.1. Gênero textual - entrevistas...................................................... 30

1.2.2. Obtenção do material.................................................................. 30

1.2.3. Temas abordados...................................................................... 30

1.2.4. Seleção sociolinguística.............................................................. 31

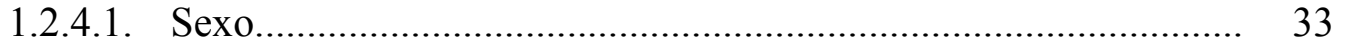

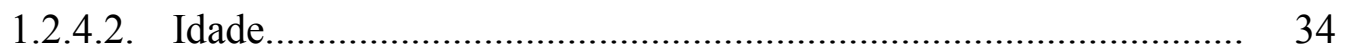

1.4.2.3. Nível de instrução.................................................................... 35

1.2.4.4. Procedência geográfica............................................................ 35

1.3. Características das entrevistas............................................................... 36

1.3.1. Estrutura interna - traços verbais e não verbais............................. 36

1.3.2. Nível situacional - contexto interativo........................................... 37

1.3.3. Estrutura externa................................................................... 37

1.4. Corpus espanhol........................................................................... 37

1.5. Corpus brasileiro.......................................................................... 38

Capítulo 2 - Fundamentação teórica........................................................ 40

2.1. Cortesia e Pragmática.............................................................................. 40

2.1.1. A importância da Pragmática nos estudos da Cortesia.................... 40

2.1.2. Os atos de fala................................................................... 42

2.1.2.1. Atos performativos explícitos.................................................... 43

2.1.2.2. Atos performativos implícitos................................................ 43

2.1.3. Atos de linguagem e valores ilocutórios...................................... 44

2.1.4. Pergunta X Solicitação............................................................ 47

2.1.4.1. A pergunta......................................................................... 48

2.1.4.1.1. A pergunta expressa diretamente........................................... 48

2.1.4.1.2. A pergunta expressa indiretamente.......................................... 49

2.2. O ponto de partida para os estudos da cortesia................................... 50

2.2.1. As máximas de Grice - o princípio cooperativo................................ 52

2.3. Princípio de cortesia................................................................... 53

2.4. A cortesia propriamente dita.......................................................... 54

2.4.1. Afinal, o que é a face?................................................................ 55

2.4.2. A teoria de Brown e Levinson.................................................... 57

2.4.3. Atos reparadores da face............................................................. 61

2.5. Um pouco mais sobre a Cortesia...................................................... 62

2.6. Atos de fala não-corteses e corteses..................................................... 64 
2.6.1. Atos de fala não-corteses.................................................................... 64

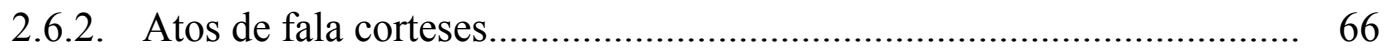

2.6.2.1. Atos comissivos......................................................................... 66

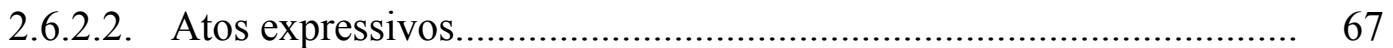

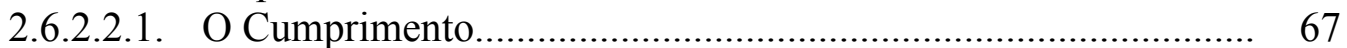

2.6.2.2.2. O Agradecimento................................................................... 68

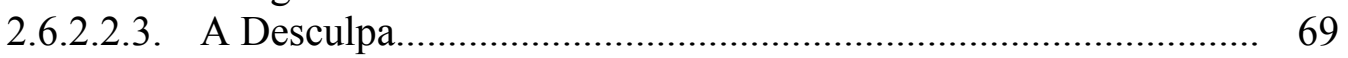

2.6.2.2.4. O Elogio............................................................................ 70

2.7. Aspectos gerais da atenuação.................................................................. $\quad 70$

2.8. Formas de tratamento........................................................................... 75

2.8.1. Tú e usted - o sistema pronominal Espanhol Peninsular..................... 78

2.8.2. Você e o senhor - o sistema pronominal do Português do Brasil......... 79

2.8.3. Evolução - você / usted ...................................................................... 79

2.8.4. Formas nominais......................................................................... 81

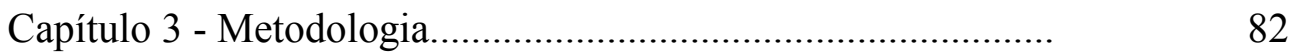

3.1. Enunciados interrogativos............................................................... 84

3.2. Verbos no imperativo......................................................................... 85

3.3. Desfocalização do eu ...................................................................... 86

3.4. Prevenção e ameaça à face.................................................................. 87

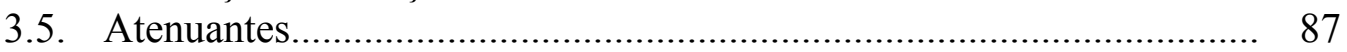

3.6. Expressão de opinião..................................................................... 88

3.7. Cortesia valorizante........................................................................ 88

3.8. Invasão de território pessoal........................................................... 89

3.9. Solidariedade.......................................................................... 90

3.10. Formas de tratamento................................................................... 90

3.11. Análise dos resultados.................................................................. 91

Capítulo 4 - Análise - corpus espanhol........................................................... 94

4.I. PRESEEA - nível médio................................................................ 94

4.1. Amostra 20..................................................................... 94

4.1.1. Imperativo............................................................................ 102

4.1.2. Desfocalização do $e$ u................................................................ 103

4.1.3. Prevenção de ameaça à face.......................................................... 103

4.1.4. Ameaça à face.......................................................................... 104

4.1.5. Atenuantes.............................................................................. 106

4.1.6. Expressão de opinião..................................................................... 107

4.1.7. Invasão de território pessoal.......................................................... 108

4.1.8. Solidariedade............................................................................. 109

4.1.9. Formas de tratamento................................................................... 109

4.2. Amostra 22 …………………………………………....... 110

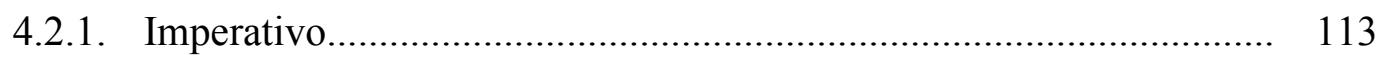

4.2.2. Desfocalização do $e u$..................................................................... 113

4.2.3. Prevenção de ameaça à face............................................................. 114

4.2.4. Ameaça à face........................................................................... 115

4.2.5. Atenuantes.............................................................................. 115

4.2.6. Expressão de opinião....................................................................... 116

4.2.7. Cortesia valorizante....................................................................... 117

4.2.8. Formas de tratamento.................................................................... 117

4.3. Amostra 24 ............................................................................ 118 


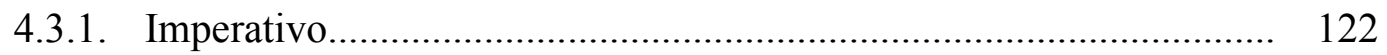

4.3.2. Desfocalização do eu................................................................... 123

4.3.3. Prevenção de ameaça à face........................................................ 124

4.3.4. Ameaça à face........................................................................... 124

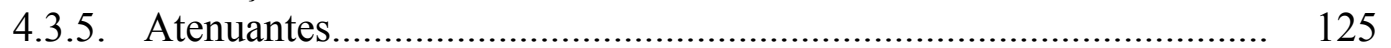

4.3.6. Expressão de opinião.................................................................. 125

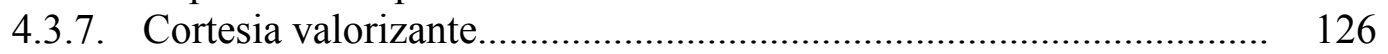

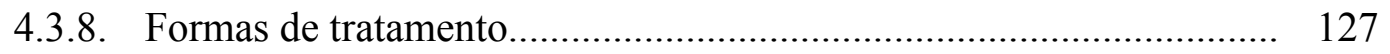

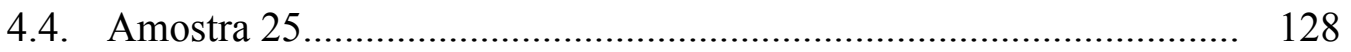

4.4.1. Imperativo................................................................................. 136

4.4.2. Desfocalização do $e u$................................................................. 136

4.4.3. Prevenção de ameaça à face....................................................... 137

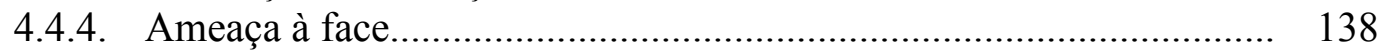

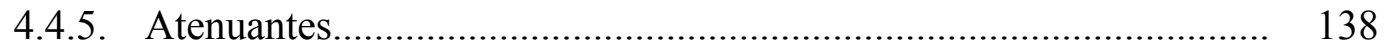

4.4.6. Expressão de opinião..................................................................... 139

4.4.7. Invasão de território pessoal.......................................................... 140

4.4.8. Solidariedade........................................................................ 141

4.4.9. Formas de tratamento................................................................. 141

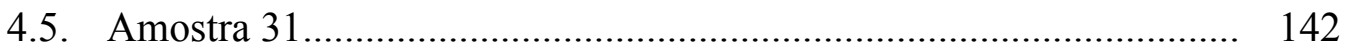

4.5.1. Imperativo.............................................................................. 147

4.5.2. Desfocalização do $e u$.................................................................. 147

4.5.3. Prevenção de ameaça à face............................................................. 149

4.5.4. Ameaça à face............................................................................ 149

4.5.5. Expressão de opinião.................................................................... 150

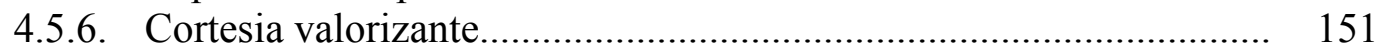

4.5.7. Solidariedade........................................................................ 151

4.5.8. Formas de tratamento............................................................... 152

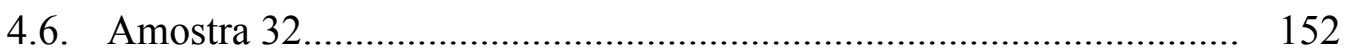

4.6.1. Imperativo........................................................................... 156

4.6.2. Desfocalização do $e u$................................................................. 157

4.6.3. Prevenção de ameaça à face........................................................... 157

4.6.4. Ameaça à face........................................................................... 158

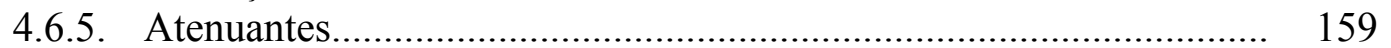

4.6.6. Expressão de opinião.................................................................. 159

4.6.7. Cortesia valorizante....................................................................... 160

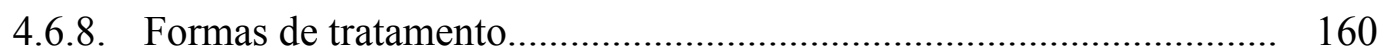

4.7. Análise comparativa - Málaga - nível médio................................. 161

4.7.1. Fala do entrevistador............................................................... 162

4.7.2. Uso do imperativo....................................................................... 164

4.7.3. Desfocalização do $e u$................................................................... 165

4.7.4. Prevenção de ameaça à face............................................................ 166

4.7.4.1. Proteção à própria face.............................................................. 166

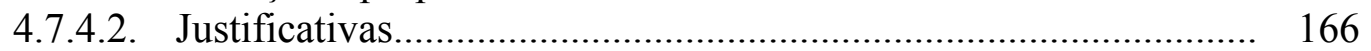

4.7.5. Proteção à face do entrevistador....................................................... 167

4.7.6. Proteção à face do informante 167

4.7.7. Ameaça à face.......................................................................... 167

4.7.7.1. Exposição da própria face......................................................... 168

4.7.7.2. Ameaça à face do interlocutor................................................... 168

4.8. Atenuantes............................................................................ 169

4.9. Expressão de opinião............................................................... 170 


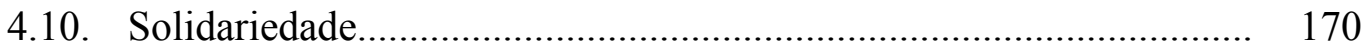

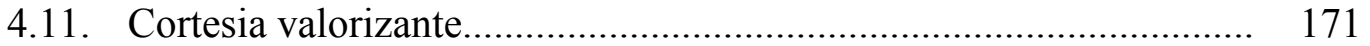

4.12. Invasão do território pessoal......................................................... 171

4.13. Formas de tratamento..................................................................... 171

4.II- PRESEEA - nível superior.......................................................... 173

4.8. Amostra 54 ............................................................................. 173

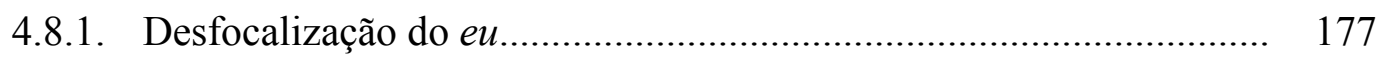

4.8.2. Prevenção de ameaça à face............................................................ 178

4.8.3. Atenuantes.............................................................................. 179

4.8.4. Expressão de opinião................................................................. 179

4.8.5. Invasão do território pessoal........................................................ 180

4.8.6. Formas de tratamento.................................................................... 180

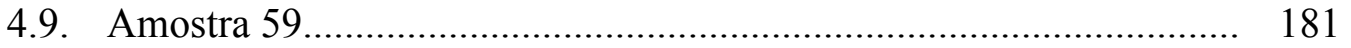

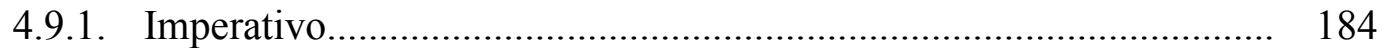

4.9.2. Desfocalização do eu .................................................................. 184

4.9.3. Prevenção de ameaça à face............................................................ 186

4.9.4. Ameaça à face............................................................................. 186

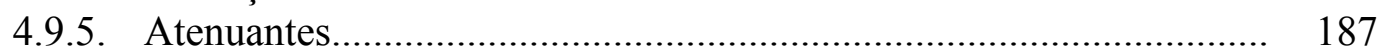

4.9.6. Expressão de opinião.................................................................... 187

4.9.7. Cortesia valorizante.................................................................. 188

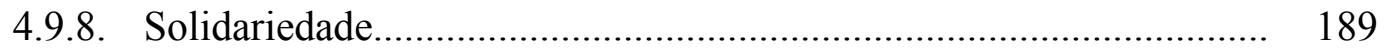

4.9.9. Formas de tratamento.......................................................................... 189

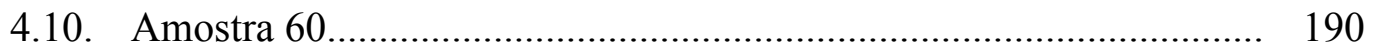

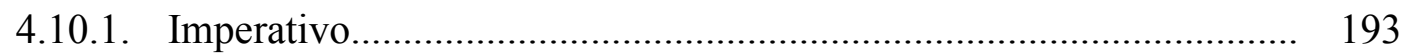

4.10.2. Desfocalização do $e u$.................................................................. 194

4.10.3. Prevenção de ameaça à face............................................................ 196

4.10.4. Ameaça à face.............................................................................. 197

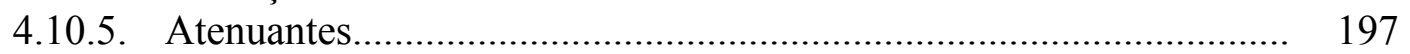

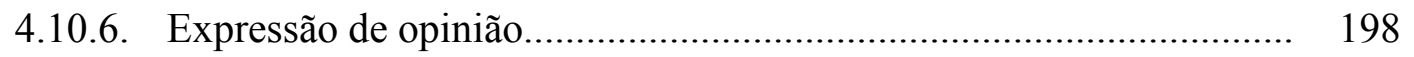

4.10.7. Formas de tratamento.................................................................. 199

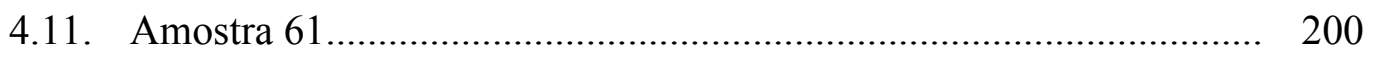

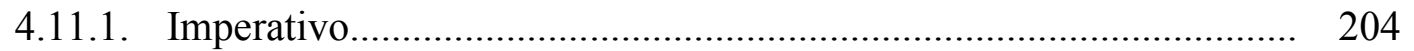

4.11.2. Desfocalização do $e u$................................................................ 205

4.11.3. Prevenção de ameaça à face........................................................ 206

4.11.4. Ameaça à face............................................................................. 207

4.11.5. Atenuantes................................................................................. 208

4.11.6. Expressão de opinião................................................................... 209

4.11.7. Solidariedade......................................................................... 210

4.11.8. Formas de tratamento................................................................ 210

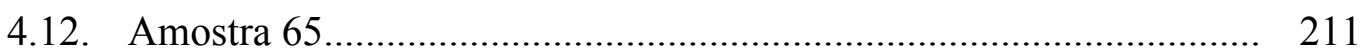

4.12.1. Imperativo............................................................................ 213

4.12.2. Desfocalização do $e u$.................................................................. 214

4.12.3. Prevenção de ameaça à face............................................................ 214

4.12.4. Ameaça à face............................................................................. 216

4.12.5. Atenuantes............................................................................... 216

4.12.6. Expressão de opinião.................................................................. 217

4.12.7. Formas de tratamento.............................................................. 217

4.13. Amostra 67 ...................................................................... 218

4.13.1. Imperativo........................................................................ 221

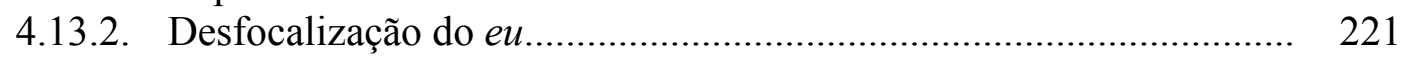


4.13.3. Prevenção de ameaça à face........................................................... 222

4.13.4. Ameaça à face....................................................................... 222

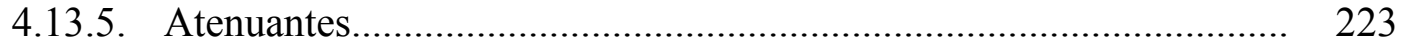

4.13.6. Expressão de opinião................................................................... 224

4.13.7. Formas de tratamento...................................................................... 225

4.14. Análise comparativa - Málaga - nível superior............................... 225

4.14.1. Fala do entrevistador................................................................... 226

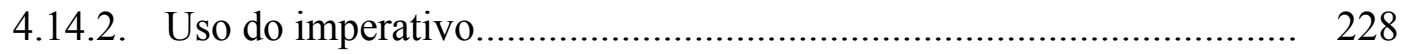

4.14.3. Desfocalização do $e u$...................................................................... 229

4.14.4. Prevenção de ameaça à face............................................................ 230

4.14.4.1. Proteção à própria face................................................................ 231

4.14.4.2. Justificativas.......................................................................... 231

4.14.4.3. Prevenção de ameaça à face do informante..................................... 231

4.14.5. Ameaça à face.......................................................................... 231

4.14.5.1. Exposição da própria face.............................................................. 232

4.14.5.2. Falta de modéstia......................................................................... 233

4.14.5.3. Ameaça à face do interlocutor..................................................... 233

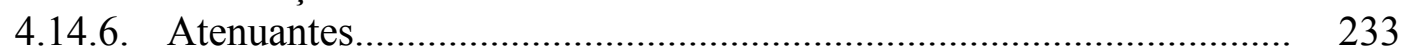

4.14.7. Expressão de opinião.................................................................... 234

4.14.8. Cortesia valorizante.................................................................... 235

4.14.9. Invasão do território pessoal.......................................................... 235

4.14.10 Solidariedade............................................................................... 235

4.14.11 Formas de tratamento..................................................................... 235

Capítulo 5 - Análise - corpus brasileiro....................................................... 238

5.I. $\quad$ ALIP - nível médio............................................................... 238

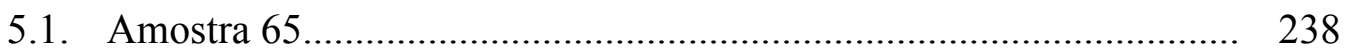

5.1.1. Desfocalização do eu.......................................................... 241

5.1.2. Prevenção de ameaça à face............................................................. 242

5.1.3. Ameaça à face............................................................................ 242

5.1.4. Expressão de opinião.................................................................. 243

5.1.5. Invasão do território pessoal.......................................................... 243

5.1.6. Formas de tratamento.................................................................. 244

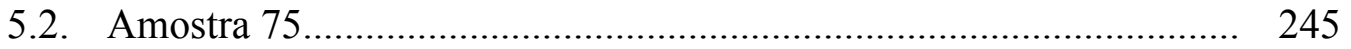

5.2.1. Desfocalização do eu.................................................................... 247

5.2.2. Prevenção de ameaça à face........................................................... 247

5.2.3. Ameaça à face............................................................................ 248

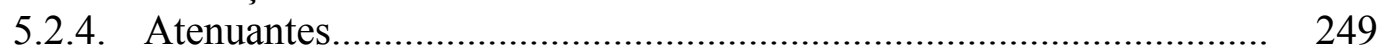

5.2.5. Expressão de opinião................................................................... 249

5.2.6. Formas de tratamento................................................................ 249

5.3. Amostra 76 .................................................................... 250

5.3.1. Desfocalização do eu.............................................................. 252

5.3.2. Prevenção de ameaça à face.......................................................... 252

5.3.3. Ameaça à face............................................................................. 253

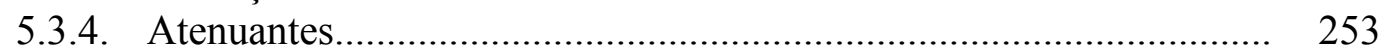

5.3.5. Expressão de opinião................................................................ 254

5.3.6. Cortesia valorizante............................................................... 254

5.3.7. Invasão do território pessoal...................................................... 255

5.3.8. Formas de tratamento................................................................ 255

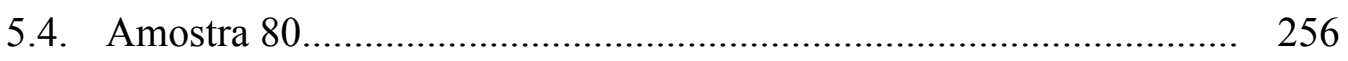


5.4.1. Desfocalização do eu................................................................ 258

5.4.2. Prevenção de ameaça à face........................................................... 259

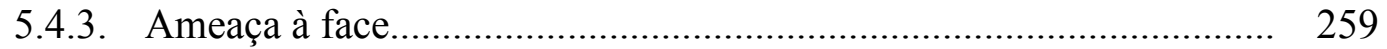

5.4.4. Expressão de opinião.................................................................... 259

5.4.5. Cortesia valorizante................................................................. 260

5.4.6. Formas de tratamento................................................................ 260

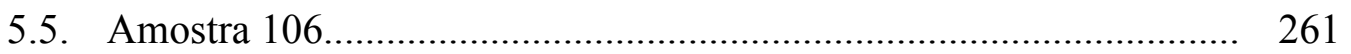

5.5.1. Desfocalização do eu.................................................................... 263

5.5.2. Prevenção de ameaça à face............................................................ 265

5.5.3. Ameaça à face.............................................................................. 265

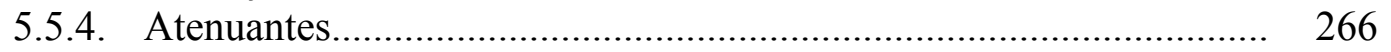

5.5.5. Expressão de opinião.................................................................... 266

5.5.6. Cortesia valorizante......................................................................... 267

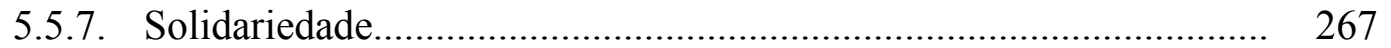

5.5.8. Formas de tratamento................................................................. 267

5.6. Amostra 109 …..................................................................... 268

5.6.1. Desfocalização do eu.................................................................. 270

5.6.2. Prevenção de ameaça à face............................................................. 271

5.6.3. Ameaça à face............................................................................. 272

5.6.4. Atenuantes................................................................................ 273

5.6.5. Expressão de opinião................................................................. 273

5.6.6. Invasão de território pessoal.......................................................... 275

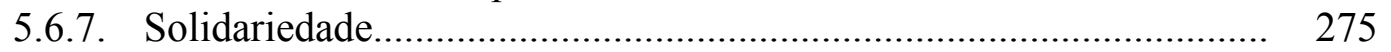

5.6.8. Formas de tratamento................................................................ 275

5.7. Análise comparativa - ALIP - nível médio..................................... 276

5.7.1. Fala do entrevistador................................................................ 277

5.7.1.1. Enunciados diretos................................................................... 277

5.7.1.1.1. Enunciados sem ato preparatório............................................. 277

5.7.1.1.2. Verbos no imperativo............................................................. 277

5.7.1.2. Enunciados indiretos............................................................... 278

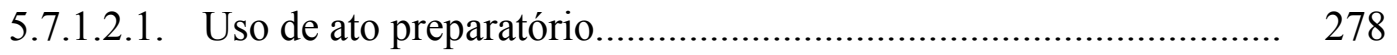

5.7.1.2.2. Verbos de proteção à face........................................................... 278

5.7.2. Desfocalização do eu.................................................................... 280

5.7.3. Prevenção de ameaça à face........................................................ 282

5.7.3.1. Proteção à própria face.................................................................. 282

5.7.3.2. Justificativas.......................................................................... 283

5.7.3.3. Proteção à face do entrevistador.................................................. 283

5.7.3.4. Proteção à face do informante...................................................... 283

5.7.4. Ameaça à face.......................................................................... 284

5.7.4.1. Exposição da própria face........................................................... 284

5.7.4.2. Falta de modéstia..................................................................... 285

5.7.4.3. Ameaça à face do interlocutor................................................... 285

5.7.5. Atenuantes........................................................................... 285

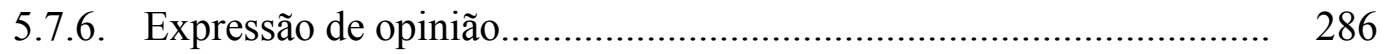

5.7.7. Cortesia valorizante.................................................................... 287

5.7.8. Invasão do território pessoal......................................................... 287

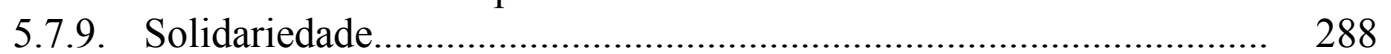

5.7.10. Formas de tratamento............................................................. 288

5.II. ALIP - nível superior............................................................. 290

5.8. Amostra 115 ......................................................................... 290 
5.8.1. Desfocalização do eu................................................................. 291

5.8.2. Prevenção de ameaça à face........................................................ 292

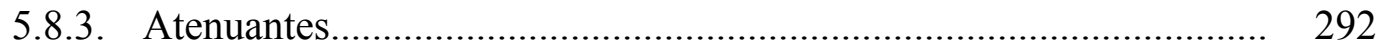

5.8.4. Expressão de opinião................................................................... 292

5.8.5. Formas de tratamento................................................................ 293

5.9. Amostra 119 .......................................................................... 294

5.9.1. Desfocalização do eu.................................................................. 295

5.9.2. Prevenção de ameaça à face........................................................... 296

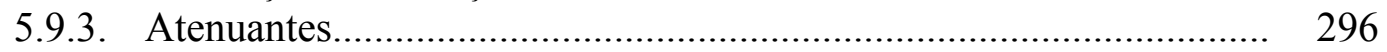

5.9.4. Expressão de opinião...................................................................... 296

5.9.5. Formas de tratamento............................................................... 297

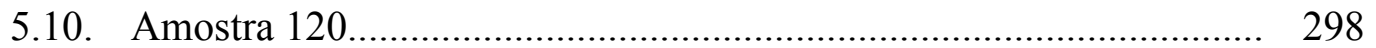

5.10.1. Desfocalização do eu....................................................................... 300

5.10.2. Prevenção de ameaça à face.............................................................. 301

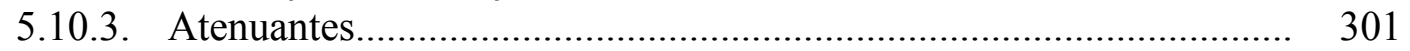

5.10.4. Expressão de opinião.................................................................... 301

5.10.5. Formas de tratamento................................................................. 302

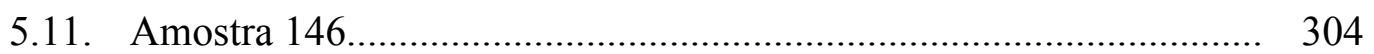

5.11.1. Desfocalização do eu.................................................................. 306

5.11.2. Prevenção de ameaça à face............................................................ 306

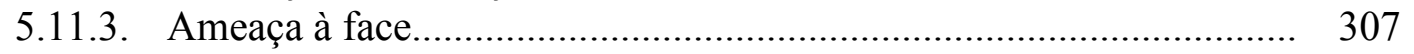

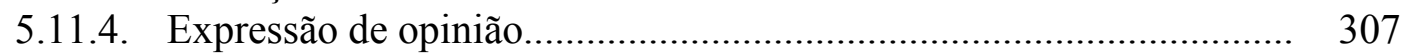

5.11.5. Formas de tratamento................................................................... 307

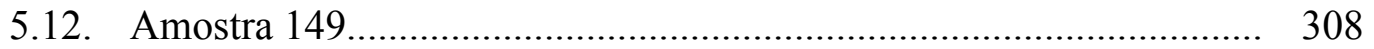

5.12.1. Desfocalização do eu.................................................................. 311

5.12.2. Prevenção de ameaça à face........................................................... 312

5.12.3. Ameaça à face............................................................................ 312

5.12.4. Atenuantes......................................................................... 312

5.12.5. Expressão de opinião.................................................................. 313

5.12.6. Formas de tratamento................................................................ 313

5.13. Amostra 150 ......................................................................... 315

5.13.1. Desfocalização do eu................................................................ 316

5.13.2. Prevenção de ameaça à face........................................................... 316

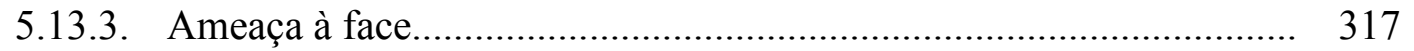

5.13.4. Proteção à face............................................................................ 317

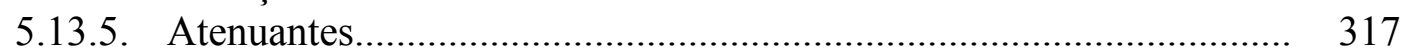

5.13.6. Expressão de opinião.................................................................. 318

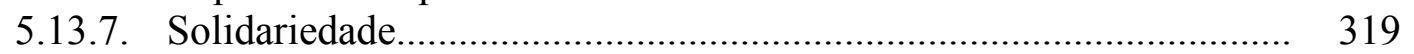

5.13.8. Formas de tratamento................................................................. 319

5.14. Análise comparativa - ALIP - nível superior............................... 320

5.14.1. Fala do entrevistador.......................................................... 321

5.14.1.1. Enunciados diretos............................................................ 322

5.14.1.1.1. Enunciados sem ato preparatório............................................... 322

5.14.1.1.2. Verbos no imperativo........................................................ 322

5.14.1.2. Enunciados indiretos............................................................ 322

5.14.1.2.1. Uso de ato preparatório.......................................................... 322

5.14.1.2.2. Verbos de proteção à face......................................................... 322

5.14.2. Desfocalização do eu................................................................. 324

5.14.3. Prevenção de ameaça à face........................................................... 326

5.14.3.1. Proteção à própria face................................................................ 326 


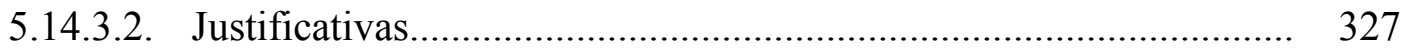

5.14.3.3. Prevenção de ameaça à face do entrevistador............................... 327

5.14.4. Ameaça à face......................................................................... 327

5.14.4.1. Exposição da própria face............................................................ 328

5.14.4.2. Falta de modéstia....................................................................... 328

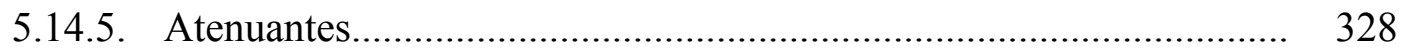

5.14.6. Expressão de opinião..................................................................... 329

5.14.7. Solidariedade................................................................................ 329

5.14.8. Formas de tratamento............................................................... 330

Capítulo 6 - Confrontação dos dados............................................................ 332

6.1. Comparação nível médio............................................................ 332

6.1.2. A influência do sexo do informante................................................. 336

6.2. Comparação nível superior............................................................... 337

6.2.1. A influência do sexo do informante............................................. 340

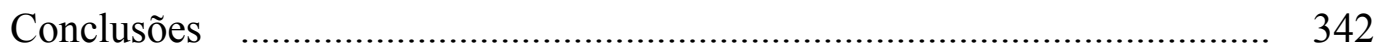

1. A comprovação das hipóteses iniciais........................................... 342

2. Relevância do estudo.................................................................. 343

3. Considerações Finais................................................................... 344

Referências Bibliográficas ............................................................................ 347 


$$
\begin{aligned}
& \text { Anexos (vol.2) } \\
& \text { Anexo A - Amostra } 20 \text { - PRESEEA } \\
& \text { Anexo B - Amostra } 22 \text { - PRESEEA } \\
& \text { Anexo C - Amostra } 24 \text { - PRESEEA } \\
& \text { Anexo D - Amostra } 25 \text { - PRESEEA } \\
& \text { Anexo E - Amostra } 31 \text { - PRESEEA } \\
& \text { Anexo F - Amostra } 32 \text { - PRESEEA } \\
& \text { Anexo G - Amostra } 54 \text { - PRESEEA } \\
& \text { Anexo H - Amostra } 59 \text { - PRESEEA } \\
& \text { Anexo I - Amostra } 60 \text { - PRESEEA } \\
& \text { Anexo J - Amostra } 61 \text { - PRESEEA } \\
& \text { Anexo K - Amostra } 65 \text { - PRESEEA } \\
& \text { Anexo M - Amostra } 65 \text { - ALIP } \\
& \text { Anexo N - Amostra } 75 \text { - ALIP } \\
& \text { Anexo O - Amostra 76-ALIP } \\
& \text { Anexo P - Amostra } 80 \text { - ALIP } \\
& \text { Anexo Q - Amostra } 106 \text { - ALIP } \\
& \text { Anexo R - Amostra } 109 \text { - ALIP } \\
& \text { Anexo S - Amostra } 115 \text { - ALIP } \\
& \text { Anexo T - Amostra } 119 \text { - ALIP } \\
& \text { Anexo U - Amostra } 120 \text { - ALIP } \\
& \text { Anexo V - Amostra } 146 \text { - ALIP } \\
& \text { Anexo X - Amostra } 149 \text { - ALIP } \\
& \text { Anexo Z - Amostra } 150 \text { - ALIP }
\end{aligned}
$$


Se reconoce fácilmente a uma persona cortés cuando se comporta de manera descortês. Baron Von Knigge

As ideias para a realização desta tese surgiram quando ainda estávamos nos estudos do Mestrado. Nesse trabalho ${ }^{1}$ abordamos a presença e a manifestação da oralidade em textos de entrevistas escritas. Para isso, utilizamos como corpus as entrevistas publicadas na revista VIVA, parte integrante do jornal argentino Clarín. Enquanto analisava o material, observava que havia forte marca de cortesia por parte do jornalista para com o entrevistado. É certo que entendemos que por se tratar de um texto escrito, essa cortesia nem sempre é espontânea, muitas vezes é construída para melhor adaptar-se ao contexto situacional.

Após o término do Mestrado, passamos a focar-nos nas principais teorias sobre o estudo da cortesia e, considerando as questões que envolvem as diferenças entre fala e escrita, acreditamos que para a nossa pesquisa de doutoramento nossa análise teria mais fidelidade se fosse feita com amostras reais de fala, pois um corpus oral oferece dados empíricos reais sobre os quais se deve basear uma pesquisa pragmalinguística.

Como falante nativo do português e ouvinte nativo do Espanhol surgiu o interesse de se fazer o traçado do perfil comunicativo de ambos os idiomas, observando o que há em comum ou não com relação às estratégias de cortesia e atenuação, o que poderia remeter a marcas culturais, a um ethos que nos aproximasse de um maior conhecimento desses mecanismos linguísticos nos intercâmbios verbais.

Álvarez Muro (2005, p.16) define a cortesia como uma comunicación lograda, ou seja, não se trata de um produto do emissor, mas sim de um processo recíproco, no qual tanto o receptor quanto a mensagem, a nosso ver, são partes fundamentais do processo.

Acreditamos que essa pesquisa tem também o objetivo de apontar ideias estereotipadas que se podem fazer sobre um idioma, quando se tenta analisá-lo, sem levar em conta fatores culturais. Assim, quando um brasileiro faz a interpretação da fala de um espanhol, a partir da cultura brasileira, caracteriza o espanhol como grosseiro, autoritário, pedante. Por outro lado, quando é o espanhol que interpreta os comportamentos verbais da cultura brasileira, acredita que somos polidos demais ao fazer solicitações, sobretudo

\footnotetext{
${ }^{1}$ Defendido em dezembro de 2005. Minari, P.G.S. A manifestação da oralidade em entrevistas escritas. São Paulo, 2005. Dissertação de Mestrado - FFLCH - Faculdade de Filosofia, Letras e Ciências Humanas, Universidade de São Paulo.
} 
tratando-se de situações informais. Situações essas que geram malentendidos entre os falantes.

As generalizações são sempre perigosas, quando se tratam de manifestações verbais que obedecem a regras de comportamentos sociais com muitas variáveis sociolinguísticas e sociopragmáticas.

Não é muito difícil comprovar o exposto acima. Ao longo de nossos estudos sobre a cortesia, deparamo-nos com muitos textos bastante específicos, como A cortesia no Uruguai ou A cortesia na fala das mulheres da cidade $X$. Ou seja, ainda que se trate do mesmo idioma, há que se considerar os costumes, a cultura local, para que não se façam falsas interpretações. Isso demonstra que não há lugar para generalizações, pois devemos considerar a heterogeneidade do espanhol e do português no que diz respeito a suas variantes sociolinguísticas - sexo, idade, nível de instrução, entre outros e às características próprias das comunidades de fala analisadas.

Entendemos que o estudo dos diferentes aspectos do Português e do Espanhol tem elevada importância, pois ainda que se tenha o imaginário de que são idiomas próximos por serem línguas com origens comuns, há muitas diferenças linguístico-discursivas e culturais que influenciam acentuadamente as marcas de cortesia. Como poderemos observar ao longo de nossa fundamentação teórica, o que é cortês em um país, não é em outro e a falta desse conhecimento pode levar o falante a pré-julgamentos que podem comprometer a comunicação.

\section{Afinal, por que estudar a cortesia?}

Toda sociedade possui na sua dinâmica social regras de convivência e trato. É esperado que os indivíduos constituintes dessa sociedade tenham conhecimento dessas regras e as usem, quando necessário. Dotados dessa competência social, entende-se que quando o falante faz uso de elementos de cortesia, sua fala é marcada, enquanto a inexistência de tais elementos denota uma fala não-marcada.

Considerando, como bem apresenta Kerbrat-Orecchioni (2004, p.39) que a cortesia é universal ${ }^{2}$ por estar presente em todas as sociedades, há que se pensar que seu estudo começou muito antes de teóricos como Goffman, Brown e Levinson entre outros, despertarem interesse pelo tema. Isso porque as regras de etiqueta já eram uma demonstração de que os indivíduos tinham a preocupação em se adequar diante de

\footnotetext{
${ }^{2}$ A autora complementa que a cortesia também não é universal, uma vez que se apresenta de maneiras diferentes, de acordo com cada cultura.
} 
diferentes situações. Vale lembrar que o Manual de urbanidad y buenas maneras de Antonio Carreño, citado por Álvarez Muro (2005) data de 1853. Tal manual normatizou comportamentos sociais e também linguísticos durante gerações.

É interessante ressaltar que tais manuais já apresentavam certa preocupação com a face do falante. De acordo com Alvarez Muro (2005, p.69), os princípios desse manual de urbanidad são os princípios morais, de forma que a moral e a cortesia apareciam juntas. Entre os princípios que compunham o manual, a autora cita exercer os direitos próprios, com o menor desagrado dos demais, sacrificar as afeições pessoais ao interesse público, entre outros. Como poderá ser constatado, não é difícil de se fazer uma analogia entre esses princípios e as definições de face positiva e negativa, que serão apresentadas ao longo de nossa fundamentação teórica.

Assim, pode-se entender a etiqueta como um sistema de regras, criado por cada sociedade com a finalidade de ajudar os indivíduos a se comportarem diante das mais diversas situações. Muitas dessas regras já estão presentes no senso comum de cada grupo de falantes justamente por fazerem parte da cultura. Além disso, o uso dessas regras está relacionado a classes sociais e seu reconhecimento e serve de modelo para outras classes em muitos casos.

Goffman (1970, p.104) menciona que nas situações em que os indivíduos se encontram um na presença do outro, existe a necessidade de se trabalhar uma imagem adequada para si, respeito pelos outros indivíduos presentes e uma consideração satisfatória pelo contexto em que a situação está inserida.

A atividade humana apresenta as mais diversas situações de comportamentos nas quais são esperadas condutas sociais estabelecidas tacitamente. A violação das regras faz com que as pessoas envolvidas se mobilizem para o que Goffman chama de restabelecimento da ordem cerimonial. É mediante a ordem cerimonial que se mantém, por meio de um sistema de etiqueta, que se socializa a capacidade do indivíduo em uma conversação, aumentando o valor ritual de uma função social ${ }^{3}$.

Ainda segundo o autor ${ }^{4}$, as obrigações de participação são definidas pelo contexto social em que o indivíduo se encontra. Em algumas dessas situações, o que mais importa é a sua presença física, a conversação ou o próprio tema dela é algo secundário. Em outras, o papel e a posição social de determinado participante será expresso pelo seu direito a tratar uma conversação de forma altiva, participando dela ou não, de acordo com

\footnotetext{
${ }^{3}$ Ibidem, p. 104.

${ }^{4}$ Ibidem, p. 117.
} 
o momento. Daí a importância de se estudar essa dinâmica que modaliza as atividades sociais e permite inferir características do perfil comunicativo de diversas comunidades de fala.

\section{A origem das hipóteses do Doutorado}

Como já observamos anteriormente, o interesse inicial para se estudar as teorias da cortesia, aplicando-as a um corpus real de fala surgiu a partir das entrevistas analisadas no decorrer de nosso mestrado. Já a comparação entre o Português e o Espanhol surgiu depois, quando já havíamos iniciado as primeiras leituras.

Comparar $^{5}$ as duas línguas, nos recortes e contextos selecionados, não seria só comparar como cada falante fazia uso das estratégias de cortesia ou atenuação, mais do que isso, seria a comparação desses comportamentos linguísticos entre culturas diferentes e a possibilidade de se tentar desmistificar alguns estereótipos comuns entre estudantes de Espanhol como Língua Estrangeira. Talvez o maior deles é a ideia de que os espanhóis são grosseiros, imperativos.

$\mathrm{Na}$ elaboração de nossas hipóteses, partimos de ideias dedutivas para depois chegarmos às indutivas. Assim, baseando-nos em nossos conhecimentos de falante nativo de uma língua e estrangeiro da outra, devemos apontar que também compactuávamos falsas ideias e estereótipos.

Sendo assim, as hipóteses que motivaram o desenvolvimento dessa tese são:

1. A Língua Espanhola parece formular seus enunciados de maneira mais direta do que a Língua Portuguesa;

2. a Língua Portuguesa se vale de mais elementos atenuadores do que o espanhol peninsular nos diferentes intercâmbios verbais dentro do gênero entrevista;

3. a atenuação em ambas as línguas possui objetivos e estratégias diferentes, os resultados obtidos podem até ser opostos.

4. a percepção do que pode representar comportamentos verbais corteses, que nem sempre são considerados como tais na cultura do outro.

\footnotetext{
${ }^{5}$ Ressaltamos que embora utilizemos o termo comparar limitar-nos-emos a analisar as estratégias de cortesia e atenuação em apenas um gênero textual, em um corpus obtido em comunidades de fala específicas - Málaga e São José do Rio Preto, portanto não será possível chegar a generalizações que atinjam toda a língua espanhola e a portuguesa.
} 


\section{Objetivos da pesquisa}

Os objetivos desta pesquisa são analisar amostras de fala, coletadas por meio de entrevistas semidirigidas, de brasileiros da região paulista de São José do Rio Preto e espanhóis da região andaluza de Málaga, para responder, refutar, comprovar ou não às hipóteses apresentadas anteriormente. Para tanto, analisamos a fala dos entrevistadores e dos informantes de nível médio com idade entre 25 e 45 anos e nível superior, cuja faixa etária está entre 50 e 70 anos.

Partindo das teorias que envolvem a Pragmática, a Cortesia e a Atenuação, as quais serão apresentadas na Fundamentação Teórica, selecionamos e analisamos alguns marcadores de atenuação, bem como as perguntas elaboradas pelos entrevistadores, por meio da teoria dos atos de fala, a fim de que pudéssemos comprovar ou não as hipóteses que motivaram este trabalho.

É também nosso objetivo contribuir aos estudos das manifestações de cortesia num âmbito maior, o âmbito das relações interculturais em ambas as línguas

\section{Organização do trabalho}

$\mathrm{Na}$ introdução apresentamos as características gerais do trabalho. A continuação, há a descrição dos corpora analisados, em que houve também a preocupação em se fazer um breve estudo sobre a Língua Espanhola falada na região de Málaga e a Língua Portuguesa na região de São José do Rio Preto.

Na sequência apresentamos a Fundamentação Teórica, a qual, acreditamos estar abrangente, pois contempla as teorias da Cortesia e da Atenuação, bem como da Pragmática e dos Atos de Fala, incluindo também os estudos sobre as formas de tratamento, os quais foram necessários para a complementação de nossa análise.

Subsequente à Fundamentação Teórica está a apresentação da metodologia da nossa pesquisa. Como analistas, procuramos elaborar uma metodologia que visasse a facilitação da leitura dos dados tanto ao longo da pesquisa, quanto em sua conclusão. Assim, elaboramos tabelas e gráficos de acordo com a necessidade da análise.

No Capítulo I, apresentamos a análise do corpus espanhol dos níveis médio e superior, bem como um estudo comparativo entre as amostras analisadas de cada nível. $\mathrm{O}$ mesmo ocorre no Capítulo II, porém com o corpus brasileiro. 
Já no III Capítulo, procuramos expor uma confrontação dos dados obtidos entre todas as amostras analisadas, antecipando as considerações finais, as quais são apresentadas na sequência da confrontação.

Após as considerações finais, apresentamos a bibliografia utilizada e as entrevistas na íntegra, anexadas, as quais estão em tomo à parte.

\section{Capítulo 1 - Descrição dos Corpora}

O material de análise de nosso trabalho está composto por dois corpora, um referente à Língua Espanhola e outro à Língua Portuguesa. Para a apresentação dos mesmos, faremos algumas considerações sobre as características comuns a ambos e posteriormente trataremos de aspectos individuais dos materiais.

Nosso trabalho visa à comparação de manifestações de cortesia entre o Português do Brasil- região de São José do Rio Preto e o Espanhol Peninsular - região de Málaga. Ao iniciar nossa pesquisa, tínhamos a intenção de analisar o material do Projeto NURC (Projeto de Estudo da Norma Linguística Urbana Culta) produzido por professores da USP - Universidade de São Paulo, no qual há entrevistas com pessoas oriundas da região metropolitana de São Paulo. Ao mesmo tempo, analisaríamos amostras do grupo PRESEEA (Proyecto para el Estudio Sociolingüistico del Español de España y América) colhidas na região metropolitana de Madrid. No entanto, já de início, deparamo-nos com um fator determinante que impossibilitaria a sincronia de nossas análises: a variação diacrônica. O material brasileiro era muito mais antigo do que o espanhol e, em se tratando de cortesia, vinte anos podem ocasionar mudanças cruciais no comportamento dos falantes, fator esse que pode alterar significativamente os resultados finais da investigação.

A partir daí, iniciamos um processo de busca de um material brasileiro que fosse passível de comparação com um corpus espanhol. Acreditamos que as amostras do Projeto ALIP (Amostra Lingüística do Interior Paulista) de São José do Rio Preto atenderam nossas necessidades. Como se tratava de uma região do interior do estado de São Paulo, decidimos comparar as entrevistas com outras produzidas também pelo grupo PRESEEA, porém colhidas na região de Málaga - Espanha. Ambas são cidades importantes no contexto em que estão inseridas, porém não são as mais importantes do país. Outra justificativa para a escolha dessa cidade espanhola é o fato de os 
entrevistadores possuírem a mesma faixa etária dos entrevistadores brasileiros. Moreno, (2005, p. 49) considera que a idade dos falantes é um dos fatores sociais que determinam os usos linguísticos, condicionando a variação linguística com mais força e clareza.

Entendemos que em qualquer país, seja qual for, sempre haverá um sentimento de superioridade de uma região sobre a outra, na qual quem se sente superior procurará enaltecer suas características, depreciando as características de quem é posto como inferior, seja pela posição geográfica, pela influência imigratória ou por qualquer outro motivo.

Acreditamos que as fronteiras criadas pela língua em uma sociedade são mais sólidas do que as marcadas pela geopolítica. A língua tem o poder da inclusão e da exclusão, pois onde não há compreensão comunicativa, não há relação entre os falantes.

\subsection{Contexto linguístico}

Antes de apresentarmos as cidades estudadas e de abordar assuntos como população e localização geográfica, entendemos que é relevante a apresentação do contexto linguístico em que tais cidades estão inseridas.

\subsubsection{O Espanhol na Andaluzia}

Tratando especificamente da Língua Espanhola, é interessante ressaltar que embora o castelhano/espanhol ${ }^{6}$ seja a língua oficial do país, ela não é a única e tampouco a mais utilizada nas regiões bilíngues. Além dos diversos dialetos existentes, oficialmente, convivem com o espanhol outras três línguas: o catalão, o galego e o vasco, também conhecido como eusquera.

Apenas fazendo referência à história da Espanha, convém lembrar que durante a ditadura franquista, período que durou entre o fim da Guerra Civil Espanhola e a morte de Francisco Franco (1939-1976) a única língua permitida em todo o território nacional era o espanhol, havendo a proibição absoluta do uso de todas as outras línguas e dialetos regionais, inclusive na vida privada.

Após a morte de Franco, houve a busca pela recuperação das outras línguas e, consequentemente, as regiões que possuíam uma segunda língua passaram a utilizá-la

\footnotetext{
${ }^{6}$ Os termos castelhano/espanhol são usados como sinônimos, no entanto, doravante utilizaremos apenas o termo espanhol. Sobre esse tema consultar García Mouton, P. Lenguas y dialectos de España. Madrid: Arco/Libros, 1999.
} 
com mais intensidade do que a própria língua espanhola. É possível constatar na atualidade certa disputa pela defesa das identidades linguísticas.

$\mathrm{Na}$ Andaluzia, a situação é diferente, uma vez que o andaluz não é uma língua, mas sim um dialeto ${ }^{7}$. Aguilar González (2000, p.167) considera o andaluz como um enorme conjunto de falas, cuja origem deveria ser investigada no mesmo processo genético e evolutivo do espanhol.

Ao longo de nossos estudos, pudemos observar que as características mais relevantes do espanhol falado na Andaluzia que o difere de outras regiões da Espanha se referem às questões fonéticas. Não resta dúvida de que tais questões motivaram certo preconceito dos espanhóis oriundos de outras partes do país. De maneira geral, pode-se dizer que o espanhol andaluz é estigmatizado, marcado negativamente desde o ponto de vista do prestígio linguístico. García Mouton (1999, p.39) elenca uma série de características do espanhol andaluz, entre elas estão:

- tendência a perda do $-\mathbf{l}, \mathbf{- r}$, e $-\mathbf{n}$ finais. $\mathrm{O}$-n final costuma ser velar e fechar a vogal anterior, especialmente quando essa é um -o e nasalizar a vogal antes de desaparecer.

- neutralização do r e $\mathbf{l}$ em posição implosiva ou em final absoluto. Socialmente não é um traço bem considerado.

- perda do -d e de outras sonoras intervocálicas. Quando o verbo está no particípio essa característica se torna bem evidente.

- aumento do yeísmo.

- perda do momento oclusivo na articulação da ch gráfica. Não é uma característica de todas as regiões, no entanto em Málaga se ouve inclusive entre pessoas cultas.

Geograficamente, a Andaluzia está dividida em Oriental e Ocidental, sendo que cada uma dessas regiões contêm as principais cidades andaluzas: na parte ocidental, está Sevilha e na oriental está Granada e entre os próprios andaluzes existe certa desavença, considerando que o padrão regional ou sevilhano tem grande aceitação nas escolas e nos meios de comunicação. Em ambas as áreas, as variedade vernaculares ligadas à lealdade e à cultura local convergem parcialmente com o estándar nacional ${ }^{8}$ e também entre si. No entanto, na zona ocidental, as variedades estão mais próximas do estándar, de forma que a

\footnotetext{
${ }^{7}$ De acordo com Moreno (2005, pág. 93) um dialeto existe quando os falantes se consideram membros de uma comunidade de fala circunscrita em um determinado território, ou seja, quando consideram que essa variedade é suficientemente diferente de outras e quando interpretam e valorizam de forma semelhante a variação linguística.

${ }^{8}$ Estándar nacional - educação formal, contato com os meios de comunicação, situação do falante no mercado social, cultural e linguístico. Situação contrária para a variante dialetal regional, a qual denota acesso restrito à educação formal e aos meios de comunicação, o que faz com que esses falantes se voltem unicamente para os valores locais (García Mouton, 1999).
} 
convergência entre elas coincida e reforce os processos de nivelamento com o estándar nacional. Há que se considerar também que os movimentos populacionais ocorridos nos últimos anos como a migração da zona rural para a urbana e o próprio turismo contribuíram para que houvesse certa neutralização das diferenças existentes entre as zonas oriental e ocidental.

Ainda nos referindo às diferenças existentes entre as regiões ocidental e oriental da Andaluzia, a região ocidental, representada pela cidade de Sevilha, demonstra traços fonológicos bem aceitos e socialmente prestigiosos, talvez o mais relevante deles seja o seseo. De acordo com Villena Posoda (2000, p.113), esse andaluz culto seria uma variedade com possibilidades de estabelecer-se como um modelo de pronúncia para boa parte dos falantes andaluzes, criando certa integração com a identidade regional.

No que diz respeito a Málaga, ressaltamos que é a maior cidade da Comunidade Malaguenha, localizada na costa sul do país, conhecida como Costa do Sol, no

Mediterrâneo. É uma cidade muito heterogênea e cosmopolita. É a quinta maior cidade do país, com mais de 560 mil habitantes.

Cabe observar que devido a sua posição geográfica - situada entre as duas áreas mencionadas, é possível que se encontrem tanto traços mais próximos da língua estándar, mais prováveis em falantes de maior grau de educação formal e com mais contato com os meios de comunicação, quanto traços próprios da variante regional, mais comum em falantes de menor escolarização e com menos contato com os meios de comunicação. A cidade é considerada pelos sociolinguistas um bom laboratório de observação e experimentação.

\subsubsection{O Português no Brasil}

No tópico anterior, procuramos mostrar que embora a Andaluzia tenha importância histórica, econômica, cultural bastante significativa, o preconceito linguístico para com os seu falantes ainda existe.

Pensando especificamente no Português falado no Brasil, Bagno (2004, p.20) em seu estudo sobre o preconceito linguístico aponta que o mito de que só em Portugal se fala bem o Português reflete o complexo de inferioridade com relação ao Português de Portugal. Essa inferioridade tem motivações históricas, por termos sido colônia de Portugal, mas também por outros aspectos como o fato de sermos um país em desenvolvimento, de nos encontrarmos no hemisfério sul, etc. $\mathrm{O}$ autor afirma que não é 
difícil encontrar intelectuais renomados que considerem o português do Brasil como uma língua de matutos, de caipiras infelizes, arremedo tosco da língua de Camões.

O autor (op.cit. p. 24) chama atenção ainda para o fato de utilizarmos o termo português para a nossa língua, por mera comodidade histórica. Embora uma recente reforma ortográfica tentasse aproximar os dois idiomas, temos que considerar que o português falado no Brasil é diferente da língua falada em Portugal, tornando-se muitas vezes incompreensível entre os falantes, seja pelo vocabulário ou pelas construções sintáticas.

Diferentemente da situação espanhola, o Brasil é um país monolíngue, porém até por conta de suas dimensões continentais, não se pode esperar que não haja nenhum tipo de variedade linguística e, assim como ocorre em todas as partes do mundo, uma variedade tende a mostrar-se mais prestigiosa do que outra, seja pela localização geográfica ou importância econômica do Estado ao qual pertence. Além disso, não se pode deixar de considerar que o Português do Brasil sofreu influências bastante variadas como a presença de três raças - o índio, o português e o africano, bem como da imigração europeia de maneira geral.

O nosso corpus é proveniente do Estado de São Paulo, sem dúvida um dos estados mais importantes do país. No entanto, não podemos deixar de mencionar o preconceito linguístico que existe contra os falantes oriundos do interior do Estado com relação aos da capital.

São José do Rio Preto está situada a $450 \mathrm{~km}$ da capital. É a maior cidade da região noroeste do estado. É um importante polo regional e sua economia está baseada no comércio, prestação de serviços, indústrias diversas e agricultura.

De maneira geral, qualquer pessoa nascida fora dos arredores da capital e litoral é chamada de caipira. É certo que muitas vezes tal apelido tem uma conotação pejorativa.

Ainda assim, há que se considerar que os informantes de nosso corpus não são os mesmos caipiras descritos na obra de Amadeu Amaral (1955), o qual com muito louvor apresenta inclusive um dicionário sobre o dialeto caipira.

Há diferenças sim entre os falantes da região de São José do Rio Preto e da capital, entendemos que isso não poderia ser diferente. Primeiro devido aos quase 450 $\mathrm{Km}$ que separam as duas cidades. Segundo pelas influências imigratórias que ambas regiões sofreram e terceiro pelos próprios hábitos criados entres as respectivas comunidades de fala. 
Ressaltamos que as principais diferenças ou talvez, as mais marcadas hoje, referem-se à estrutura fonológica com $r$ aproximante alveolar [ $\square]$ ou retroflexo [ $\square]$, além da omissão da consoante $d$ dos verbos no gerúndio. Cabe destacar ainda que entre os falantes dessa região, as pronúncias mencionadas acima não se caracterizam como discriminatórias, por isso a presença das mesmas em diferentes classes sociais.

\subsection{Características comuns aos corpora}

Entendemos que para se fazer uma análise comparativa, é necessário que alguns aspectos sejam comuns aos corpora em questão no que diz respeito a:

\subsubsection{Gênero textual - entrevistas}

Medina (2002, p.8) define o gênero entrevista como uma técnica de interação social, de interpenetração informativa, a qual pode servir à pluralização de vozes e à distribuição democrática da informação. Acrescenta ainda que constitui um meio cujo fim é o inter-relacionamento humano, em que ambos os participantes interagem, se modificam, se revelam, crescem no conhecimento do mundo e deles próprios.

Nossos corpora estão compostos por textos em forma de entrevistas, caracterizadas como semidirigidas, ou seja, há uma planificação prévia sobre as perguntas que serão feitas, no entanto existe certa flexibilidade com relação à ordem e, além disso, se algum outro tema surge no decorrer do diálogo, o mesmo pode ser abordado e novas perguntas podem ser feitas.

Gómez Molina (2005, p. 25) acredita que esse tipo de entrevista permite aplicar estratégias para que o entrevistador desenvolva uma observação participante. Não é um discurso preparado, pois os entrevistados não sabem exatamente o que lhes será perguntado. Entendemos que quando o autor aborda as estratégias, faz uma oposição às amostras espontâneas, em que não há um direcionamento na fala do entrevistado.

\subsubsection{Obtenção do material}

Ambos os materiais foram obtidos por meio de gravação. É importante ressaltar que todos os informantes tinham conhecimento prévio da gravação e deram seu consentimento para isso. É fundamental que esse aspecto ocorra em ambos os materiais, pois não poderíamos comparar amostras espontâneas com amostras gravadas com consentimento dos entrevistados. 


\subsubsection{Temas abordados}

Embora as amostras de entrevistas tenham divisões diferentes e nomenclaturas próprias, a temática não especializada é semelhante: descrição da casa, da cidade, vida familiar, problemas cotidianos, problemas mundiais, regionais, experiências de mundo dos informantes. Entendemos que o fato de apresentarem temas comuns pode ser um ponto favorável na análise dos dados. Mais adiante trataremos individualmente a composição de cada corpus.

\subsubsection{Seleção sociolinguística}

Em ambos os corpora houve a preocupação de análise de dados sociolinguísticos, na qual é mencionada a idade, o sexo, o nível de instrução e a profisssão. Além disso, todos os informantes deveriam ao menos residir nas cidades estudadas ou redondezas desde a infância. Não havia a necessidade de serem nativos do lugar.

Cabe ressaltar que para esse estudo não nos focaremos em diversos autores, preferimos seguir apenas a teoria de Moreno-Fernández (2005) e alguns preceitos de Preti, considerados mais gerais, pois cada autor tem uma abordagem diferente a cada variável social - sexo, idade, raça, etc. Entendemos que se o objetivo deste trabalho fosse exclusivamente a análise sociolinguística, seria imprescindível a apresentação de vários autores até para confrontar as diferentes teorias.

Em seus estudos sobre Sociolinguística, Preti (1982, p.18) além de apresentar as variáveis que citamos acima, com a mesma abordagem de Moreno (2005), trabalha a questão da variedade linguística, dividindo-a em dos amplos campos, nos quais o primeiro abrange o segundo:

1. Variedades geográficas (ou diatópicas) - Segundo o autor, são aquelas que ocorrem num plano horizontal da língua, são os chamados regionalismos, provenientes de dialetos ou falares locais. Essas variedades conduzem a uma posição fundamental: linguagem urbana / linguagem rural. A urbana é mais próxima da linguagem comum por conta dos fatores culturais que a influenciam (escola, meios de comunicação, literatura). A tendência da segunda é extinguir-se com a chegada da civilização.

2. Variedades sócio-culturais (ou diastráticas) - Ainda segundo Preti (op. cit. p. 19), ocorrem num plano vertical, dentro da linguagem de uma comunidade específica - urbana ou rural. Essas variações socioculturais podem ser influenciadas por 
fatores ligados diretamente ao falante (sexo, idade, profissão, etc.) ou ao grupo a que pertence (raça, local em que reside, etc.) ou também a ambos.

Moreno (2005, p. 23) define comunidade linguística como "El conjunto de hablantes de una lengua en un momento y en un territorio determinado." Já a comunidade de fala é definida pelo autor como um conjunto de falantes que compartilha ao menos uma língua, e, além disso, compartilha também um conjunto de normas e valores de natureza sociolinguística: as mesmas atitudes linguísticas, as mesmas regras de uso, um mesmo critério na hora de valorizar socialmente os fatos linguísticos e os mesmos padrões sociolinguísticos.

Por levarmos em conta a definição de comunidade linguística, fizemos a escolha definitiva de nosso corpus, pois as línguas já estavam definidas - Português do Brasil e Espanhol Peninsular, porém havia que se fazer o recorte no tempo e no território. Como já dito, a ideia inicial que tínhamos era trabalhar com o material do Projeto NURC (Projeto de Estudo da Norma Linguística Urbana Culta de São Paulo) da USP, a fim de elaborar um trabalho comparativo com as amostras do corpus espanhol. A dificuldade encontrada foi com relação ao recorte temporal, pois, como já abordamos anteriormente, o material espanhol era muito mais recente do que o brasileiro e em se tratando de cortesia vinte anos é muito tempo. Talvez se a análise fosse com relação à sintaxe da língua, por exemplo, esse fator não seria relevante. Assim, optamos em trabalhar com o material brasileiro do Projeto Alip (Amostra Linguística do Interior Paulista), realizado por um grupo de professores da UNESP, no entanto esbarramos em outro problema: o territorial, pois comparar amostras de fala de uma região metropolitana com outras do interior não nos traria resultados tão fiéis. Dessa forma, optamos por analisar o material do PRESEEA (Proyecto para el Estudio Sociolingüístico Del Español de España y de América), realizado com falantes da região de Málaga, uma cidade grande, assim como São José do Rio Preto. Ressaltamos que, diferentemente do que ocorre em Málaga, São José do Rio Preto não é a capital do Estado, porém é considerada a cidade mais importante da região noroeste paulista.

Entendemos que para uma pesquisa ter dados reais é necessário que o uso linguístico seja analisado em contextos e situações reais.

Moreno (2005, p. 39-40) aponta que existem certos níveis de língua nos quais se espera com mais probabilidade a incidência de fatores extralinguísticos (fonética, fonologia, morfologia) e é inegável que existam fatos linguísticos e sociais recorrentes. $\mathrm{O}$ autor argumenta que não é possível reconhecer de antemão quais são as variantes sociais 
que vão atuar sobre os elementos linguísticos de uma comunidade. Isso ocorre por dois motivos: em primeiro lugar porque os fatores sociais atuam sobre a língua de forma irregular, ou seja, em duas comunidades diferentes a variação sociolinguística de um mesmo fenômeno necessariamente não se manifesta da mesma forma e em segundo lugar porque os fatores sociais não estão configurados de forma idêntica em todas as comunidades, ainda que falem modalidades próximas de uma mesma língua.

Diante dessa explicação, pode-se compreender, tendo o próprio estado de São Paulo como exemplo, como é possível que a Capital fale de uma forma, reagindo a determinados estímulos de uma maneira e cidades próximas falem e reajam aos mesmos estímulos de maneira diferente.

Em seus estudos sobre a Sociolinguística, Moreno-Fernández (op. cit.) apresenta alguns tipos de variáveis sociais que podem ser determinantes nos estudos sociolinguísticos como, por exemplo, na escolha do vocabulário utilizado. As variantes estudadas pelo autor são: sexo, idade, classe, modo de vida, nível de instrução, profissão e procedência geográfica.

Para a escolha das entrevistas que fariam parte de nosso corpus não consideramos todas essas variáveis. Para nós, as variáveis que eram de importância significativa eram o sexo e a idade, uma vez que a procedência geográfica e o nível de instrução já faziam parte do pré-requisito de cada corpus. No entanto, abaixo apresentaremos todas as variáveis relevantes aos corpora, na tentativa de se fazer uma justificativa sobre o motivo que nos levou a trabalhar com tal dado. Ressaltamos que a seleção de uma ou outra variável depende exclusivamente do tipo de investigação que se pretende obter.

\subsubsection{Sexo}

Moreno (2005, p. 41) aponta que há divergências sobre a variável sexo nos estudos sociolinguísticos. Existem estudos que mostram que homens de uma determinada região têm um vocabulário maior por ter contato com outras pessoas, enquanto a mulher, por ficar em casa, tem um vocabulário menor. Certamente, se esse estudo fosse refeito nos dias de hoje os resultados seriam diferentes, pois a sociedade mudou e, ao menos nos contextos que estamos estudando, não é raro encontrarmos mulheres que trabalham fora de casa.

Estudos comprovados pela sociolinguística deixam o sexo como um fator secundário. O nível sociocultural e o estilo mostram-se como fatores mais determinantes. 
Entretanto, o sexo combinado com a idade dos participantes são elementos importantes nos estudos sociolinguísticos.

O autor acrescenta (op. cit. p. 43) que pesquisas em centros urbanos descobriram e descreveram uma série de fatos relevantes relativos ao sexo como variante social. O mais importante deles é que a mulher, geralmente, é mais sensível às normas de prestígio do que os homens, em que estes usam formas que não são padrões com maior frequência.

Além disso, Moreno não deixa de considerar fatores que influenciam a sociolinguística nos dias de hoje como a televisão. Esse meio de comunicação tem a capacidade de transformar-se em um modelo de referência para os falantes de qualquer comunidade, rural ou urbana, sejam eles homens ou mulheres.

Entendemos que a variante sexo é importante para o nosso corpus, quando pensamos na comparação que faremos entre as duas línguas. Dessa forma, tomamos o cuidado de selecionar $50 \%$ das entrevistas para cada sexo. A nossa intenção é que nossa análise seja o mais fiel possível e, ao compararmos homens com mulheres, poderíamos descaracterizar essa fidelidade proposta.

\subsubsection{Idade}

É um dos fatores sociais que mais determinam os usos linguísticos de uma comunidade de fala. Para Moreno (Op. Cit, p. 47) "en contraste con el factor clase social o con el género, la edad es un factor constante, dado que su realidad no se ve alterada por cambios socioeconómicos, de actitud o de organización."

Mais adiante o autor segue com sua explicação sobre a importância da idade como variável social:

\footnotetext{
La edad conforme el tiempo transcurre, va determinando y modificando los caracteres y los hábitos sociales de los individuos, incluidos los comunicativos y los puramente lingüísticos. Por eso es posible distinguir en la vida lingüística de un individuo distintas etapas, aunque no exista acuerdo unánime sobre cuáles son y cómo han de caracterizarse. También puede ocurrir que la edad, como factor social, covaríe o se solape con otros factores, como el nivel de instrucción. (MorenoFernández, op. cit., p. 47)
}

O autor chama atenção ainda para um cuidado que os pesquisadores devem ter em não entrevistar falantes com idade inferior a 18 anos, a não ser que o objetivo da pesquisa seja obter dados específicos dessa faixa etária. A justificativa do autor é que até essa idade não se tem certeza sobre a maturidade no uso social da língua. 
O motivo que nos fez escolher a variante idade para a seleção de nosso corpus é semelhante ao do sexo. Não poderíamos comparar a fala de uma pessoa de 50 anos com a de um jovem de 20, certamente haveria diferenças entre as mesmas, são gerações diferentes e os valores culturais mudaram bastante nos últimos anos. Dessa forma, é mais prudente que a comparação do jovem de 20 anos seja com a fala de outro jovem de idade equivalente; o mesmo ocorre com a pessoa de 50 anos.

Ressaltamos que nossas análises estão divididas em dois grupos de acordo com a faixa etária dos mesmos. Assim, há o grupo de 20 a 35 anos, cujo nível de instrução é o médio e o grupo de 36 a 70 anos, cujo nível de instrução é o superior. O nosso objetivo é poder estabelecer também uma comparação entre esses dois grupos, considerando a idade e o nível de instrução ao mesmo tempo.

\subsubsection{Nível de instrução}

Está diretamente relacionado ao tempo, ou melhor, aos anos que cada informante passou na escola. Moreno (op. cit. p. 61) acrescenta que a Sociolinguística comprovou que o nível educativo dos falantes determina de forma direta e clara a variação linguística: é normal que as pessoas mais instruídas façam maior uso das variantes consideradas mais prestigiosas ou mais próximas da norma.

Além disso, o autor aponta uma questão que é bastante importante para a análise de nossos corpora, diz que a classificação minuciosa dos graus ou títulos obtidos pelos participantes é muito difícil, por isso é comum que se trabalhe somente com categorias gerais: analfabetismo, ensino primário, ensino secundário ou médio, ensino universitário ou superior. No entanto, isso não é nenhuma regra, cada estudo pode ter a sua própria nomenclatura. O corpus de Málaga trabalha com a nomenclatura baixo, médio e superior. Já o de São José do Rio Preto utiliza a nomenclatura da educação brasileira ensino fundamental, médio e superior.

Assim como na variante idade, utilizamos o nível de instrução para dividir o nosso corpus. Falantes com idade inferior a 35 anos pertencem ao nível médio e superior a 36 pertencem ao nível superior de cada material.

\subsubsection{Procedência geográfica}

Com relação a essa variante, não foi necessário que fizéssemos seleção alguma, pois combinada com o nível de instrução, essas variantes foram determinantes na elaboração do corpus pelos seus organizadores. 
Essa variante é determinante em nosso corpus, porém sem tanta rigidez. Era imprescindível que os informantes espanhóis morassem em Málaga ou nas proximidades da cidade. Com relação aos brasileiros, a exigência era de que morassem em São José do Rio Preto ou em outras seis cidades próximas, pré-definidas pelos organizadores.

Entendemos que exigir rigidez com relação aos bairros é de extrema importância em cidades muito grandes, como é o exemplo de São Paulo, pois a variante linguística de uma pessoa que vive no extremo leste da Capital Paulista pode ser diferente da variante de quem vive na zona central, embora houvesse a necessidade de se fazer uma análise para que tais dados pudessem ser efetivamente comprovados, uma vez que as pessoas tendem circular pela cidade, ou seja, podem morar em determinada região, mas estudar e trabalhar em outra.

\subsection{Características das entrevistas}

Gómez Molina (op. cit., págs. 28-29) apresenta algumas características das entrevistas do corpus espanhol que acreditamos serem comuns também ao brasileiro:

\subsubsection{Estrutura interna - traços verbais e não verbais:}

- O conteúdo linguístico é produto da atividade discursiva dos interlocutores, há uma flexibilidade sobre isso, ou seja, alguns temas podem ser mais explorados ou também excluídos. Observamos, ao longo das análises, que quem determina essa extensão ou não de determinado tema é o entrevistador. Assim, se ele tem interesse ou conhecimento do mesmo, pode expandi-lo, caso contrário, mudá-lo.

- Gestos, fórmulas apelativas e marcadores fáticos complementam o conteúdo linguístico (elementos léxicos, morfossintaxe e recursos fonológicos). Em ambas as transcrições houve a preocupação de se apresentarem esses elementos. Apesar disso, optamos por não utilizá-las em nossas análises, considerando apenas o conteúdo verbal de cada entrevista. - Mudança na atuação discursiva, de acordo com a classe de pergunta (tipos de texto descritivo, narrativo, expositivo). Observamos que no material brasileiro houve a preocupação em se obter tal diversidade, já no espanhol, não. A preocupação maior nesse último diz respeito ao tempo médio que cada entrevista deveria durar.

- Traços típicos da oralidade - repetições, reduções, etc.

- Meio de produção face a face; trata-se de uma interação simultânea, imediata e com a presença dos interlocutores. 
- O registro oscila entre o neutro e o coloquial. A produção é mais ou menos espontânea, porém não pode ser classificada como preparada ou planificada. Observa-se que em ambos os materiais há baixa planificação e que os temas vão surgindo no decorrer de cada entrevista, inclusive no material brasileiro, em que há certo direcionamento, os temas não são fixos.

\subsubsection{Nível situacional - contexto interativo}

- Presença de rituais de abertura e fechamento como apresentações, cumprimentos e despedidas. Entendemos que deveriam ser comuns, porém não foram observados, com exceção dos agradecimentos em algumas entrevistas do material brasileiro, motivo que fez com que desconsiderássemos tais rituais.

- Turnos de fala - obrigação de o entrevistador fazer as perguntas e do entrevistado respondê-las. Em algumas ocasiões, ocorre troca de papéis e também várias interferências de um na fala do outro. Entendemos que a interação estabelecida entre os participantes pode aumentar ou não essa troca de papéis, fazendo com que os mesmos "esqueçam" que se trata de uma entrevista.

\subsubsection{Estrutura externa}

- Tanto as entrevistas espanholas quanto as brasileiras estão dentro da esfera privada entrevista a um indivíduo que está envolvido emocionalmente com o tema abordado. Ainda que posteriormente o conteúdo torne-se público, a identidade de todos os entrevistados é preservada.

- A seleção dos informantes se efetua, de acordo com categorias sociais já previamente estabelecidas no projeto (sexo, idade, nível sociocultural, etc.)

\subsection{Corpus espanhol}

Como dissemos anteriormente, o material foi extraído do grupo PRESEEA. O objetivo desse estudo é a criação de um macrocorpus linguístico do espanhol falado a partir de amostras orais, representativas de um conjunto de cidades pertencentes a países de todo o mundo hispânico. As comunidades estudadas devem ter mais de cem mil indivíduos.

Há certa preocupação com a duração de cada entrevista. As diretrizes metodológicas do projeto especifica que as gravações devem durar entre 45 e 90 minutos.

Neste trabalho, analisaremos as amostras colhidas na região de Málaga no ano de 1999. Todo o material está dividido em três níveis socioculturais: baixo, médio e alto. 
Optamos por analisar o nível médio com falantes de 20 a 35 anos e o superior com falantes de 36 a 70 anos.

De acordo com as diretrizes do PRESEEA, todos os informantes da amostra de nível médio possuem estudos secundários e realizaram estudos complementários como secretariado, contabilidade, idiomas, etc. Já os de nível superior são aqueles que possuem ao menos uma faculdade.

\subsection{Corpus brasileiro}

O corpus brasileiro faz parte do Projeto ALIP (Amostra Lingüística do Interior Paulista) foi uma iniciativa concebida no interior do Grupo de Pesquisa em Gramática Funcional $^{9}$ (GPGF) do IBILCE, campus de São José do Rio Preto da UNESP entre os anos de 2002 e 2003. O projeto se constituiu sob os auspícios da Fundação de Amparo à Pesquisa do Estado de São Paulo - FAPESP (Proc. 03/08058-6).

O objetivo do Projeto foi de constituir um banco de dados com amostras de fala sistematicamente controladas por variáveis sociais, e representativo, portanto, do dialeto falado no interior paulista, em razão de este ser ainda pouco conhecido, em bases científicas, por seus usuários e pelos próprios linguistas. Essa iniciativa marca o ineditismo do projeto, uma vez que não há, até onde se sabe, banco de dados organizado com amostras representativas do português falado no interior do Estado de São Paulo.

As amostras analisadas por nós são denominadas Amostras de Censo. Como dissemos anteriormente, ocorrem na forma de entrevistas com prévio consentimento de gravação do informante.

Os informantes foram selecionados, de acordo com a faixa etária, escolaridade, renda familiar, cidade e sexo. Com relação à cidade todos moravam em São José do Rio Preto ou cidades próximas, entre elas estão: Bady Bassit, Cedral, Guapiaçu, Ipiguá, Mirassol e Onda Verde.

Enquanto o corpus espanhol dividiu os informantes em três níveis de acordo com a escolaridade, o brasileiro fez essa divisão em 4 níveis: Ensino Fundamental I, Ensino Fundamental II, Ensino Médio e Ensino Superior. Trabalharemos com as amostras de Ensino Médio e Ensino Superior.

Diferentemente do que ocorre no corpus espanhol, há uma subdivisão no corpus brasileiros em 5 tipos de textos que se pretende obter em cada entrevista. Optamos por

\footnotetext{
${ }^{9}$ GONÇALVES, Sebastião Carlos Leite Gonçalves. Banco de dados Iboruna: amostras eletrônicas do português falado no interior paulista. Disponível em: http::/www.alip.ibilce.unesp.br/iboruna.
} 
não modificar a nomenclatura estabelecida pelos organizadores do corpus. Os textos selecionados na coleta foram:

A. Narrativa de experiência - o entrevistador pede que o informante conte uma história que aconteceu com ele. Há várias perguntas sobre a história.

B. Narrativa recontada - o informante deve recontar uma história que lhe pareça interessante, dizer quem contou e como tal história aconteceu.

C. Descrição - pede-se para o informante descrever um local qualquer que ele goste, pode ser um lugar inteiro ou apenas parte dele, como a casa, por exemplo.

D. Relato de procedimento - o informante deve relatar algo que ele saiba fazer e o procedimento de execução. Pode ser, por exemplo, uma receita.

E. Relato de opinião - o informante deve escolher um tema e opinar sobre o mesmo. O entrevistador pode ajudá-lo, dando sugestões do tema que pode ser tratado. 


\section{Capítulo 2 - Fundamentação teórica}

"Uma teoria não é o conhecimento, ela permite o conhecimento. Uma teoria não é uma solução, é a possibilidade de tratar um problema."

Edgar Morin

\subsection{Cortesia e Pragmática}

\subsubsection{A importância da Pragmática nos estudos da Cortesia}

Este trabalho tem como objetivo a análise de algumas manifestações da cortesia na língua falada em espanhol e português. Por ser a cortesia um tema bastante complexo que envolve outras áreas de conhecimento, entendemos que não podemos, nem devemos focar-nos específica e unicamente em tais estudos sem antes tratar de alguns aspectos teóricos da Pragmática. É certo que ao longo do desenvolvimento do trabalho, também nos apoiaremos em conceitos da Sociolinguística, já mencionados ao longo da descrição dos corpora, uma vez que os critérios de seleção dos informantes que compõem os nossos corpora foram o sexo, a idade, o nível de instrução e a região onde moravam.

A Pragmática Linguística é uma disciplina relativamente recente que demorou para fundamentar suas teorias, pois como mostram alguns estudos, entre outros Leech, Levinson e Kerbrat-Orecchioni, aquilo que não se sabia bem para que servia na língua era atribuído à Pragmática, ou seja, o que não podia ser explicado por outras teorias já existentes como a Sintaxe, a Semântica dizia-se que era do campo da Pragmática. Atualmente já se pode afirmar que está bem fundamentada como disciplina linguística. De acordo com Leech (1997, p.41) não se pode compreender a natureza de uma língua sem que se compreenda a sua pragmática, isto é, como a língua é utilizada na comunicação entre os falantes.

Entendemos que uma das dificuldades encontradas para que a Pragmática tivesse suas teorias fundamentadas foi o fato de tanto ela quanto a Semântica trabalharem com o significado, causando certa confusão entre ambas. No entanto, ao aprofundarmos nosso estudo nas teorias pragmáticas, a diferenciação entre esses dois ramos da Linguística fica evidente, pois o significado semântico pode ser definido como uma propriedade das expressões de uma determinada língua, enquanto que o significado pragmático envolve, além do significado semântico, também o usuário da língua e o contexto em que está inserido. 
Estamos de acordo com Leech (op.cit., pág. 48) e Levinson (2007, pág. 47) que defendem os campos semânticos e pragmáticos como complementários. O falante pode ter o conhecimento do léxico de um determinado idioma, porém é imprescindível que saiba em qual contexto deve aplicá-lo. Afinal, ter pleno conhecimento das regras da Língua Portuguesa não nos torna aptos a interpretar um bilhete encontrado na rua com os dizeres Te encontro amanhã na portaria, pois para tal seriam necessários conhecimentos prévios como quem são o eu e o $t u$, além disso, o componente temporal só poderia ser interpretado como o dia depois de hoje se esse bilhete tivesse sido escrito hoje, informação essa que desconhecemos e por fim, o componente espacial portaria, havia a necessidade de se saber de onde é essa portaria - da empresa, da faculdade, etc.

Levinson (op.cit., pág.12) complementa que a pragmática estuda todas as características não semânticas codificadas nas línguas.

Entendemos que a Pragmática tem um aspecto mais amplo e flexível por trabalhar com questões que envolvem inferências ${ }^{10}$, o conhecimento de mundo do emissor e o conhecimento mútuo entre os interlocutores, além de fatores contextuais como as identidades dos interlocutores, parâmetros temporais e espaciais, crenças e intenções dos participantes, características essas que a diferencia de teorias mais pontuais como a sintaxe ou a semântica de uma língua, as quais são pautadas em regras, mostrando-se menos flexíveis.

Levinson (2007) apresenta um longo estudo no qual pretende apresentar qual a melhor definição para Pragmática. Entre as várias teorias trabalhadas, o próprio autor entende que são mais plausíveis aquelas que consideram o contexto ${ }^{11}$ como parte fundamental para que se possa fazer uma perfeita interpretação da estrutura linguística.

Em uma conversação, nem sempre o que o falante diz representa o que ele queria dizer. Assim, cabe à Gramática a explicação do significado e à Pragmática a interpretação do mesmo.

Escandell Vidal (2006, p.40) propõe um quadro, o qual acreditamos elucidar a relação existente entre a Pragmática e os outros componentes da língua envolvidos diretamente na interação.

\footnotetext{
${ }^{10}$ De acordo com Levinson (2007, p.129) as inferências, por definição, são implicaturas conversacionais, onde se pretende que o termo implicatura contraste com termos como implicação lógica, acarretamento e consequência lógica, que são geralmente usados para fazer referência a inferências que derivam unicamente do conteúdo lógico ou semântico.

11 Levinson (op.cit., p.352) descreve contexto como um conjunto de proposições, que descrevem as crenças, o conhecimento, os compromissos dos participantes de um discurso. Mais adiante aprofundaremos essa questão ao tratar o contexto como um dos pontos fundamentais nos estudos da cortesia.
} 


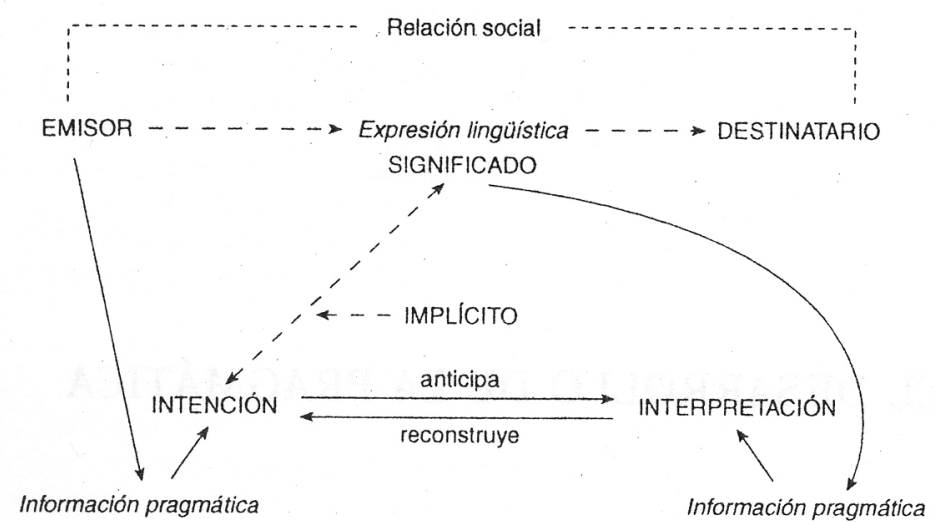

Como podemos observar acima, cabe ao emissor a intenção de sua enunciação ${ }^{12}$, porém essa nem sempre será correlata à interpretação dada pelo destinatário, na qual estarão envolvidas as inferências elaboradas a partir do significado linguístico, mas também, sem destinar-lhes menor importância, de seu conhecimento de mundo e do conhecimento mútuo, compartilhado entre emissor e destinatário.

Um dos pilares dos estudos da Pragmática, dedicada ao estudo dos intercâmbios verbais, é a teoria dos atos de fala. Entendemos que tal teoria tem importância significativa em nossa análise, sobretudo na observação da forma como o entrevistador aborda o entrevistado por meio de suas perguntas. Sendo assim, é relevante a apresentação dos pontos principais dos estudos de Austin e Searle, os quais apresentaremos sob a ótica de Kerbrat-Orecchioni (2005) e Levinson (2007).

\subsubsection{Os atos de fala}

De acordo com Levinson (2007, p. 288) os atos de fala, juntamente com a pressuposição e a implicatura são um dos fenômenos centrais que qualquer teoria Pragmática Geral deveria explicar.

Em nosso trabalho, entendemos a importância de se apresentar alguns aspectos da teoria dos atos de fala devido o nosso corpus ser composto por alguns desses atos, sobretudo pelos atos diretivos, como será exposto mais adiante. Além disso, considerando que a função desses atos é interagir, influenciar, argumentar, procuraremos observar como são essas manifestações ao longo das entrevistas que compõem o nosso corpora. Pretendemos também, de acordo com as ocorrências encontradas, estabelecer comparações sobre o uso de tais atos de fala entre os corpora.

\footnotetext{
${ }^{12}$ Levinson (2007, p.22) faz a diferenciação entre sentença e enunciação, sendo a primeira uma entidade teórica abstrata, definida numa teoria da gramática, enquanto a segunda é a emissão de uma sentença, um análogo de sentença ou fragmento da mesma, num contexto efetivo.
} 
Ainda de acordo com Levinson (op. cit. p. 289) Austin lançou a teoria dos atos de fala quando observou que algumas sentenças declarativas da linguagem comum não são usadas só para dizer coisas, mas também para fazer coisas. Ao pedir desculpas, não há só um dizer do falante, mas também uma ação, o mesmo ocorre com a promessa e com outros atos que apresentaremos mais adiante.

Austin chamou de performativas as enunciações que permitem a realização de algo, contrastando com as declarações ou asserções, cujo enunciado é simplesmente constativo. Os atos de fala performativos, diferentemente do que ocorre com os constativos não podem ser considerados verdadeiros ou falsos. Eles podem sim, dar certo ou errado, pois para realizar tais atos performativos, muitas vezes são necessários alguns pré-requisitos para que a enunciação não se torne nula. Assim, uma pessoa só pode batizar uma criança e dizer Eu te batizo... se for um sacerdote, caso contrário esse ato não terá valor algum.

A diferença dos atos de fala está na realização que os mesmos implicam. Dizer: eu como não é realizar o ato de comer e esse enunciado pode ser verdadeiro ou falso. Porém, dizer: eu prometo comprar o ingresso é realizar o ato de prometer e esse tipo de ato não pode ser verdadeiro ou falso, pode sim, ser sincero ou não. Diferentemente do que ocorrem com as sentenças performativas, as constativas em que se encontram as declarações, asserções e enunciados correspondentes, essas sim, podem ser consideradas verdadeiras ou falsas.

\subsubsection{Atos Performativos Explícitos}

Os atos performativos explícitos podem ser classificados em puros, quando seus enunciados estão centrados em torno de um verbo na primeira pessoa do Presente do Indicativo e quase-performativos, quando atendem àquilo que constitui o critério essencial nesta matéria: a presença, de uma maneira ou de outra, do termo geralmente utilizado para designar o ato principalmente realizado pelo enunciado.

\subsubsection{Atos Performativos implícitos}

São todos os enunciados que vêm dotados de uma força ilocucionária. É o caso de Eu the ordeno que faça tal coisa. Aqui se realiza o ato de ordenar.

Austin faz também uma introdução aos já mencionados atos locutórios, ilocutórios e perlocutórios. Os atos ilocutórios são a menor unidade completa possível da comunicação, enquanto que os perlocutórios referem-se aos efeitos sobre as ações, 
pensamentos ou crenças dos ouvintes. Searle (1981, p. 37) ao mencionar os estudos de Austin apresenta como exemplo que ao sustentar um argumento, podemos persuadir ou convencer alguém, informando posso esclarecer, inspirar, fazer tomar consciência, essas expressões em itálico designam alguns exemplos de atos perlocutórios. Em outro trabalho, o autor (2000, p. 127) esclarece que em geral os atos ilocutórios devem ser realizados intencionalmente. Se a intenção é prometer ou afirmar, há que se querer isso, no entanto os perlocutórios não são, necessariamente, intencionais. Pode-se persuadir alguém de alguma forma, sem que haja intenção. Além disso, faz uma classificação dos diferentes valores ilocutórios que uma enunciação qualquer pode receber. A distinção é feita em cinco grandes classes:

1. Os veredictivos ou judiciários - como declarar inocente, condenar, decretar, etc.

2. Os exercitivos que formulam um julgamento favorável ou não, sobre uma conduta preconizada - condenar, exortar, perdoar, etc.

3. Os promissivos ou comissivos que visam a obrigar o locutor a adotar certa conduta - prometer, garantir, jurar, etc.

4. Os comportativos que expressam uma atitude do locutor em relação à conduta anterior ou iminente de alguém - desculpar-se, agradecer, deplorar, criticar, maldizer, etc.

5. Os expositivos - utilizados para expor ideias, conduzir argumentação, clarificar emprego de certos termos - afirmar, negar, admitir, explicar.

Para Searle (1981, p. 26) falar uma língua é realizar atos de linguagem: fazer afirmações, dar ordens, fazer perguntas, promessas, etc. Esses atos, em geral, só se tornam possíveis graças à evidência de certas regras que regulam o emprego dos elementos linguísticos, e é em conformidade com essas regras que eles se realizam. Os atos de fala são a unidade básica ou mínima da comunicação linguística.

\subsubsection{Atos de linguagem e valores ilocutórios}

Como Austin, Searle considera que todo enunciado visa a produzir certo efeito e implicar uma modificação da situação interlocutiva. Essa força ilocutória vem se aplicar ao conteúdo proposicional do enunciado. 
Os enunciados podem ter o mesmo conteúdo proposicional, porém com diferente força ilocutória. Assim, a força ilocutória de um enunciado interrogativo é diferente de um declarativo. Levinson (2007, p.297) menciona o exemplo Vá que, dependendo do contexto em que está inserido, pode ser o oferecimento de um conselho, uma tentativa de convencimento, uma ordem ou um desafio.

No entanto, acreditamos que dependendo da intenção do falante, pode-se ter um enunciado declarativo cuja força ilocutória tem valor interrogativo. Esse fato pode ser observado quando analisamos trechos de uma situação de interação e não apenas enunciados isolados. Abaixo procuramos elucidar o exposto com um exemplo retirado de nosso corpus. O trecho pertence à amostra 20, PRESEEA, nível médio.

(linha 792) I: Bueno / España ha mejorado bastante / eso sí que es verdad pero todavía sigue mucha corrupción / cosas sin aclarar / y han incitado mucho al consumismo y ahora estamos como estamos (linha 795) E: piensas que ése es el problema. (linha 796) I: si

Searle (Op. Cit., p. 34) aponta que ao executar cada um dos quatro atos diferentes apresentados abaixo, o falante executa outros atos que são comuns a todos eles: a referência e a predicação, embora em cada caso a mesma referência e a mesma predicação ocorram como partes de um ato de fala completo, diferente dos outros três. Austin batizou esses atos de fala completos como atos ilocucionais.
(1) João fuma muito.
(3) Fume muito, João!
(2) João fuma muito?
(4) Queira Deus que João fume muito!

Kerbrat-Orecchioni (2005, p.28) acrescenta que terminologicamente convém distinguir os atos de linguagem ou atos ilocutórios de forças ilocutórias, sendo os primeiros correspondentes às diferentes ações que podem ser realizadas por meio da linguagem como prometer ou ordenar, enquanto que as forças ilocutórias se referem ao componente que permite ao enunciado funcionar como um ato particular. Feche a porta pode ter a força de uma ordem ou de um pedido, dependendo da intenção do emissor.

Para Searle, para que alguns atos ilocutórios aconteçam, muitas vezes é necessário que haja algumas condições para isso. É o caso, por exemplo, da ordem, em que a condição essencial para que se possa falar em ordem é que o locutor, ao apresentar sua enunciação, atribua-lhe a função de levar o outro a executar o ato em questão, mas esse ato é submetido a questões como:

1. O locutor deve ser capaz de exercer sua autoridade sobre o ouvinte.

2. Ele deve realmente desejar que se realize o ato ordenado. 
Baseando-se em Searle, Levinson (2007, p. 305) propõe cinco tipos básicos de ações que alguém pode executar ao falar:

1. Representativos ou assertivos - têm o objetivo de comprometer a responsabilidade do locutor sobre a existência de um estado de coisas, sobre a verdade da proposição expressa. Como afirmar ou concluir.

2. Diretivos - constituem tentativas por parte do locutor de mandar o outro fazer alguma coisa; tentativas que podem ser modestas como convidar ou sugerir ou mais ardentes como ordenar, exigir, insistir.

3. Comissivos ou promissivos - têm a função de obrigar o locutor a adotar uma conduta futura.

4. Expressivos - expressam o estado psicológico especificado na condição de sinceridade diante de um estado de coisas especificado pelo conteúdo proposicional - agradecer, parabenizar, desculpar-se, etc.

5. Declarativos - encontram-se nessa categoria todos os performativos no sentido estrito do termo, cujo funcionamento se apoia na existência, no mundo extralinguístico de tal instituição (igreja, lei, constituição) e regras rituais bastante precisas.

Para a análise das perguntas presentes em nosso corpus acreditamos que seja fundamental o estudo do contexto em que essas perguntas estão inseridas. De acordo com Kerbrat-Orecchioni (2005, p.56) "o locutor deve escolher a formulação mais apropriada à situação comunicativa, pois, diante de um mesmo valor ilocutório, as diferentes formulações diretas e indiretas não são pragmaticamente equivalentes entre si." Como já tratado anteriormente, na análise pragmática os fatores extralinguísticos tem fundamental importância, bem como a intenção do emissor e a interpretação dada a tal ato pelo destinatário.

Durante essa análise não podemos deixar de considerar o fator cultural. Em um primeiro momento temos a percepção de que o falante espanhol é mais direto em suas enunciações do que o brasileiro, dado que procuraremos comprovar ou não ao longo de nossas análises, no entanto se isso ocorre ou não é porque o fator cultural o permite. Acreditamos que esse tipo de dado, extralinguístico, ajuda a compor o contexto da interação bem como sua interpretação. Voltaremos a essas considerações mais adiante

\subsubsection{Pergunta $x$ solicitação}

Após a descrição acima, procuraremos nos ater aos atos de fala que analisaremos, os quais são imprescindíveis em nossos corpora. O fato de trabalharmos 
com entrevistas é que os faz ter tal destaque, uma vez que esse gênero textual é formado por perguntas e respostas. Sendo assim, apresentaremos a seguir algumas características dos enunciados interrogativos, objeto de nosso estudo.

Mencionando os estudos de Searle, Kerbrat-Orecchioni (op.cit., p.99) aponta que a ordem e a pergunta pertencem à família dos atos diretivos, aqueles que tentam fazer com que o outro faça algo, considerando a pergunta como um caso particular de ordem.

Na mesma obra, a autora se refere às diferenças entre pergunta e solicitação, em que embora aparentemente sejam termos sinônimos apresentam diferenças com relação ao seu valor ilocutório. Os exemplos abaixo foram retirados do corpus do material brasileiro ALIP, amostra 149, nível superior:

(01) [linha 02] Seu P. gostaria que o senhor contasse para mim alguma história que aconteceu com o senhor.

(02) [linha 22] E no começo quando você se formou foi difícil pra você encontrar emprego foi seu primeiro emprego ser professor?

De acordo com a classificação de Kerbrat-Orecchioni, ambas ocorrências acima são exemplos de perguntas, no entanto a primeira é uma pergunta expressa indiretamente $^{13}$, enquanto a segunda é diretamente. Observa-se que ambos têm o mesmo objetivo: fazer com que o informante forneça os dados solicitados.

Os exemplos mencionados acima foram utilizados apenas com a intenção de se elucidar a diferença entre perguntas indireta e direta, respectivamente. Ressaltamos que é imprescindível que todo o contexto seja considerado, pois os atos preparatórios podem estar presentes nos enunciados que antecedem a pergunta propriamente dita.

Como o nosso corpora está composto pelos dois tipos de atos de fala mencionados acima, enunciados diretos e indiretos apresentaremos as definições e classificações propostas por Kerbrat-Orecchioni (2005). Ressaltamos que faremos um recorte na teoria, detendo-nos apenas nos aspectos relevantes a nossa análise.

\subsubsection{A pergunta}

É todo enunciado cuja finalidade é obter uma informação. Kerbrat-Orecchioni (op.cit., p.101) classifica a pergunta em dois tipos: total em que a informação pedida relaciona-se ao valor de verdade do conteúdo proposicional e parcial em que a

\footnotetext{
${ }^{13}$ Há que se fazer aqui uma distinção entre como a gramática considera direto / indireto e como a pragmática o faz, pois no caso do exemplo Eu lhe pergunto aonde você vai a pergunta é direta do ponto de vista pragmático, é explícita, porém indireta do ponto de vista gramatical.
} 
informação diz respeito apenas a parte dos constituintes da frase. Em outras palavras, a pergunta total é mais geral, podendo ter várias respostas e a parcial é mais específica, pois a necessidade de informação do interrogador fica clara.

A natureza do gênero textual entrevista é a existência de perguntas e respostas, assim a partir do momento em que um informante aceita participar de um diálogo com essas características, está subentendido que haverá um entrevistador que lhe fará perguntas, as quais deverão ser respondidas por ele. A forma como são feitas essas perguntas e a necessidade de respondê-las ou não é um tema que abordaremos mais adiante ao trabalhar com a cortesia.

\subsection{A pergunta expressa diretamente}

Kerbrat-Orecchioni (op.cit., p.103) apresenta os diferentes tipos de marcadores de pergunta. Os marcadores que acompanham as perguntas diretas podem ser:

- de natureza lexical como aqueles que utilizam o verbo performativo: perguntar, saber, etc.

- morfossintática - em que há a presença de um morfema interrogativo. Além dos pronomes interrogativos, consideram-se aqui também aqueles marcadores presentes no início das frases: Será que... ou no final não é? Né?

- sintática com a inversão do pronome pessoal reto.

- prosódica na fala com a ascensão ou tipográfico na escrita com o pronome de interrogação.

A autora acrescenta que o tipo de marcador utilizado depende da situação comunicativa e do tipo de interação. Entendemos que, além disso, o interlocutor também é determinante na escolha por um ou outro tipo de marcador.

Abaixo apresentamos alguns exemplos encontrados em nosso corpora.

(03)E: mas você tem filhos do primeiro casamento ou não? (linha 102, amostra 076 - ALIP nível médio)

(04)E: O valor que tava faltando era muito alto? (linha 46, amostra 115 - ALIP nível superior)

(05)E: ¿sí? ¿dónde naciste? / ¿en qué parte de Málaga? (linha 05, amostra 61 - PRESEEA nível superior)

(06)E: ¿pero tú estuviste muchos años viviendo aqui / en Benalmádena? (linha 23, amostra 25 - PRESEEA nível médio)

\subsection{A pergunta expressa indiretamente}

As perguntas que são expressas indiretamente são aquelas que são acrescentadas a outro ato de linguagem. Rosa (1992, p.69) denomina esses atos de linguagem que 
aparecem antecedendo o ato principal de atos de preparação. Assim, o emissor prepara o seu destinatário antes de lhe fazer a pergunta propriamente dita.

Entendemos que esse tipo de ato tem extrema relevância em nossa análise, pois acreditamos que o falante que não utiliza os atos de preparação antes de sua pergunta é muito mais direto e objetivo do que aquele que os utiliza. Dessa forma, procuraremos observar em quais corpora tais atos aparecem e qual a frequência dos mesmos. Abaixo, apresentamos alguns exemplos, retirados de nosso corpus.

(07)E: bom... agora eu queria que cê descrevesse algum local assim algum lugar bonito que você já tenha ido conhecer. (linha 130 - amostra 075 - ALIP - nível médio)

(08)E: agora então eu gostaria que você me contasse uma história que tenha ocorrido com alguém que você conheça que tenha sido interessante... alegre ou triste. (linha 108 amostra 115 - ALIP - nível superior)

Observa-se que o entrevistador não faz a pergunta de prontidão, ao contrário disso, utiliza, no exemplo 07, o verbo querer no Pretérito Imperfeito acompanhado do verbo principal no Pretérito Imperfeito do Subjuntivo e no exemplo 08 o verbo gostar no Futuro do Pretérito também acompanhado do verbo principal no Pretérito Imperfeito do Subjuntivo. Ainda de acordo com Rosa (op.cit.) o uso de tais atos preparatórios é uma forma de se atenuar uma possível ameaça à face do interlocutor. Escandell Vidal (2006, p.152) acrescenta que a cortesia é o princípio que justifica o emprego de formas indiretas. São mais corteses porque não impõem uma obrigação, mas levam o ouvinte a pensar que existe a possibilidade de realizar ou não o ato solicitado.

Entendemos que o fato de a Pragmática trabalhar com o significado além do significado linguístico, englobando outros aspectos da língua como já apresentado anteriormente é o que faz com que tenha uma estreita relação com a cortesia, pois o conceito de mais ou menos cortês só pode ser dado a partir da interpretação do outro. Interpretação essa que depende tanto dos significados linguísticos quanto dos pragmáticos.

\subsection{O ponto de partida para os estudos da cortesia}

Centraremos nossos estudos sobre a cortesia, apoiando-nos, entre outros, nas teorias de Bravo. Para a autora, ${ }^{14}$ o estudo da cortesia linguística tem seu ponto de partida

\footnotetext{
${ }^{14}$ Placencia, M.E; Bravo, D. Actos de habla y cortesía en español. Lincom Europa, 2002, p. 01.
} 
com o trabalho de Grice (1975), ainda que os fundamentos dos modelos propostos mais sobressalentes são encontrados em concepções da interação social proveniente da antropologia, sociologia e psicologia social.

A análise das teorias sobre a cortesia é bastante significativa quando se pretende estudar e entender as diferentes culturas existentes. Como poderá ser observado ao longo de nossa explanação teórica, o que é cortês em determinada cultura, necessariamente não é em outra. Briz (2004, p.68) coloca que é bastante difícil fazer afirmações taxativas de que determinada cultura é mais cortês do que outra. $\mathrm{O}$ autor prefere utilizar termos como cultura de maior ou menos aproximação ou maior ou menor distância.

Em nosso entendimento, a única forma de não se fazer falsas interpretações e julgamentos no que se refere à cortesia de determinada cultura é considerar o contexto no qual a situação, seja de fala ou não, está inserida. Além disso, há que se levar em conta que as regras de uma sociedade mudam com o decorrer do tempo, adequando-se a novos valores e novos costumes, impostos pelos próprios indivíduos que formam determinada sociedade.

Kerbrat-Orecchioni (2006, p. 33) considera a importância do contexto em dois processos: o de produção e o de interpretação. O primeiro diz respeito ao conjunto de escolhas discursivas que o falante deve efetuar - formas de tratamento, tema, atos de fala etc. Já o segundo desempenha um papel decisivo, bem como o primeiro, para a identificação da significação implícita do discurso dirigido.

Quando falamos em contexto, temos que pensar que é um conceito bastante amplo que abrange várias situações. Hernández Flores (2004, p. 96) entende por contexto sociocultural os contextos específicos que envolvem comportamentos, atitudes e valores conhecidos e praticados por uma comunidade de falantes.

Já Albelda Marco (2004, p. 114) faz uma distinção importante entre contexto e situação de uso, termos esses que muitas vezes são postos como sinônimos. Para a autora, o contexto de qualquer unidade estrutural de fala é constituído de todos os fatores extralinguísticos que o acompanha: fatores culturais, fatores geográfico-espaciais, variáveis sociológicas dos falantes e também das características situacionais. Já a situação de uso tem a peculiaridade de ser o componente extralinguístico que integra todos os outros, ou seja, é o último subconjunto de traços atuantes (quase inconscientemente na mente dos interlocutores) na eleição de uma forma linguística ou outra.

Dessa forma, entendemos que a situação de uso também é dependente do contexto, uma vez que contempla todos os fatores constituintes do mesmo. 
Bravo (2004, p.21) apresenta duas correntes distintas que trabalham com a importância do contexto do usuário da língua. De um lado está a etnografia da fala e a sociolinguística, em que o contexto é aquele que se pode observar dentro da mesma sociedade onde a fala é produzida e em outro polo está a Pragmática, a Análise do Discurso e a Análise da Conversação, para as quais é importante o contexto interpessoal e interacional, as intenções, crenças, racionalidade, além da configuração psicológica do indivíduo.

Entendemos a importância das duas definições citadas acima, porém acreditamos que não podem ser estudadas como tipos de contextos opostos, pois um é dependente do outro. Assim, as características sociais dos participantes, apresentadas pela Sociolínguística como gênero, idade, raça são fundamentais na criação do contexto da comunidade de fala (grupos, parâmetros culturais, conhecimentos compartilhados, crenças, etc.)

Além do estudo apresentado acima, Bravo ${ }^{15}$ destaca a necessidade de se estabelecer relações válidas entre a produção e a interpretação de expressões relacionadas à cortesia e diferentes níveis contextuais como:

1. Cotexto - refere-se a tudo aquilo que dentro da unidade textual produz um significado mutuamente dependente. Inclui recursos comunicativos concomitantes assim como as condições relativas ao intercâmbio. As redes de significação criadas dentro da dinâmica do discurso e da própria interação são consideradas partes do cotexto.

2. Contexto - refere-se a tudo que não é cotexto, conhecido normalmente como extralinguístico, envolvendo desde ações físicas até elementos externos à própria situação como as características sociais dos participantes, suas crenças, atitudes e valores. É o fator sociocultural.

Como dissemos anteriormente, quem cria as regras de cortesia são as próprias pessoas de uma determinada comunidade, a partir dos fatores extralinguísticos ali presentes. Isso não quer dizer que pessoas, pertencentes a grupos distintos não possam interagir. Apenas há a necessidade de adequação dos fatores extralinguísticos como o papel que desempenham, o nível de formalidade exigido pela situação, o conhecimento do tema, etc. Acreditamos que a indispensabilidade da comunicação faz com que isso seja instintivo para os falantes.

\footnotetext{
${ }^{15}$ Ibidem p.27
} 
Entendemos que é a partir do contexto situacional que uma pessoa pode ser qualificada como cortês, descortês, educada, mal-educada, amável, etc. Isso quer dizer que ser descortês em determinada situação não significa receber a mesma classificação em outro contexto, diferente.

\subsubsection{As máximas de Grice - o princípio cooperativo}

Considerando que para Bravo o estudo da cortesia linguística tem seu ponto de partida com o trabalho de Grice, acreditamos ser relevante apresentar as máximas que compõem o princípio cooperativo.

Levinson (2007, p. 126) aponta que para Grice, existe um conjunto de suposições que guiam a conduta da conversação. Tais suposições podem ser formuladas como diretrizes para o uso eficiente e eficaz da língua. Grice identifica como diretrizes quatro máximas básicas que juntas expressam um princípio cooperativo, o qual diz que o falante deve fazer sua contribuição como for exigida, na etapa na qual ela ocorre, pelo fim ou direção aceitos da troca convencional em que o falante está envolvido. São elas:

1. Máxima da quantidade - que sua contribuição seja tão informativa quanto exigido, nem mais, nem menos.

2. Máxima da qualidade - que sua contribuição seja verdadeira. Não diga o que acredita ser falso ou coisas para as quais careça evidências adequadas.

3. Máxima da relevância - dizer somente aquilo que for relevante.

4. Máxima do modo - evite a obscuridade e a ambiguidade; seja breve e ordenado.

Ainda que as máximas tenham um tom altamente imperativo, para Grice o importante não é tanto o cumprimento das mesmas, mas sim que os interlocutores atuem como se descontassem seu cumprimento. Sem essa atitude dos falantes, não haveria implicaturas e a conversação talvez não fosse possível.

Lakoff $(1998$, p.266) aborda um problema que, segundo ele, também é um problema para Grice. $\mathrm{O}$ autor se refere à determinação da qualidade das máximas. Assim, quanto é muito? O que é pertinente? Quando uma expressão é obscura? Além disso, o que é extremamente claro e válido para quem fala pode não ser para quem escuta. Acreditamos que o instrumento de medida para esses quesitos é o contexto em que cada situação de interação está inserida. Somente ele definirá a quantidade adequada de informação, bem como a pertinência da mesma.

A partir desses estudos de Grice, outros foram surgindo, Leech (1997) e posteriormente Briz (2004, p.72) apresentam a necessidade de se incluir o princípio de 
cortesia complementando às máximas criadas por Grice. De acordo com Briz, as máximas de Grice são gramaticalizadas e o nível dessa gramaticalização é tão alto que uma construção como ¿Tendrías tabaco por ahí? não seria interpretada como uma petição cortês, com ação menos direta, mais atenuada, que busca a proximidade social através do distanciamento linguístico.

É muito difícil um falante seguir estritamente essas máximas. Em uma conversação uma ou outra norma sempre é violada, pois para segui-las seria necessário pensar nas mesmas o tempo todo. Para Lakoff (1998, p. 267) as máximas conversacionais se respeitam de maneira estrita nas situações em que o conteúdo do enunciado é mais importante que o ato de dialogar.

Retomando a questão da inserção da máxima da cortesia junto às outras máximas de Grice, Lakoff (op. cit.) considera que a clareza, por exemplo, entraria em conflito com a cortesia, pois essa última se impõe sobre a primeira. Assim, se considera mais importante em uma conversação evitar ofensas que obter clareza. Ainda assim, Leech (op.cit., pág. 52) defende a inclusão de tal máxima, argumentando que os princípios/máximas ${ }^{16}$ podem entrar em conflito uns com outros e também infringir-se sem que se anule o tipo de atividade que desenvolvem.

\subsection{Princípio de cortesia}

Concordamos com Leech (op.cit. p.177) quando o autor diz que a cortesia é essencialmente assimétrica, pois se fosse o contrário, não haveria necessidade de uso de uma série de estratégias com o intuito de deixar o discurso menos direto.

Lakoff $(1998$, p.268) apresenta de maneira bastante simples as máximas da cortesia, classificando-as em Não importune; Ofereça alternativas e Faça com que o interlocutor se sinta bem, comporte-se amigavelmente. Leech (op.cit., p.208), por sua vez, divide o Princípio de Cortesia em seis máximas, relacionando-as aos atos de fala de Searle, já apresentados anteriormente nesse trabalho. Todas as máximas apresentadas a seguir estão relacionadas à teoria do custo / benefício, na qual quanto maior for o custo para o ouvinte, menos cortês será o enunciado e, ao contrário, quanto maior for o benefício para o ouvinte, mais cortês será.

1. Máxima do tato - concerne aos atos comissivos - há que se reduzir ao mínimo e aumentar ao máximo o custo para o outro.

\footnotetext{
${ }^{16}$ Leech (1997) nessa obra não faz distinção entre os termos princípios e máximas.
} 
2. Máxima da generosidade - também refere-se aos atos comissivos e é o oposto da máxima apresentada anteriormente. Aqui há que se reduzir ao mínimo o benefício e aumentar ao máximo o custo para o eu.

3. Máxima da aprovação - refere-se aos atos expressivos e assertivos, há que se reduzir ao mínimo as críticas e aumentar ao máximo os elogios para o outro.

4. Máxima de modéstia - também se refere aos atos expressivos e assertivos, ao contrário da anterior, há que se reduzir ao mínimo os elogios e aumentar as críticas para o eu.

5. Máxima do acordo - refere-se aos atos assertivos, há que se reduzir os desacordos e aumentar os acordos entre eu e o outro.

6. Máxima da Simpatia - também se refere aos atos assertivos, há que reduzir ao mínimo a falta de simpatia e aumentar ao máximo a simpatia entre eu e o outro.

Como pode ser observado, o que diferencia a teoria de Lakoff e a de Leech é que o primeiro foi bastante sucinto ao apresentar tais máximas, enquanto o segundo tratou de detalhá-las, esclarecendo qual era o papel de cada interlocutor.

Entendemos que essas máximas são fundamentais no estudo de nossos corpora. Como se poderá comprovar por meio de nossas análises, é por meio de tais máximas que procuramos observar como cada entrevistador elaborou seus enunciados de modo que o informante não se sentisse importunado, sentindo seu território pessoal invadido com perguntas íntimas e muitas vezes desnecessárias. Observamos o grau de imposição dos enunciados interrogativos e também a interação criada entre os participantes de cada entrevista, pois acreditamos que esse fator interfere na preservação ou ameaça à face dos participantes.

\subsection{A cortesia propriamente dita}

Ao iniciar nossos estudos sobre cortesia, lendo as diversas abordagens teóricas, pudemos observar que por mais que procurem mostrar o assunto por diferentes autores, a maioria delas são unânimes em citar autores como Goffman e Brown e Levinson como precursores do tema. O primeiro como criador da teoria da face e os segundos como os sistematizadores de tal teoria. Embora façamos mais tarde uma exposição detalhada da teoria de Brown e Levinson, cabe ressaltar aqui a importância dos autores na criação de uma metodologia de análise da teoria da face, fazendo com que diversos outros autores seguissem tal estudo. 
$\mathrm{Na}$ sequência, apresentaremos alguns conceitos teóricos fundamentais. Sobre os quais nossa pesquisa foi embasada.

Para Goffman $(1970,13)$ toda pessoa vive num mundo de encontros sociais que a compromete em contatos cara a cara. Nesses contatos sempre se faz uma avaliação dos participantes e, principalmente, de si mesmo. $\mathrm{O}$ autor relacionou a teoria da imagem à Pragmática. Em seu trabalho sobre Ritual da Interação de 1970 mostra os primeiros estudos que fez sobre a teoria da face ou da imagem.

Acreditamos que a cortesia está relacionada com a recepção que o interlocutor dá a determinado enunciado, no entanto na parte que concerne ao falante, entendemos que a preocupação com o outro é uma estratégia persuasiva, intencional.

\subsubsection{Afinal, o que é a face ${ }^{17}$ ?}

De acordo com Goffman (1970, p.13) face é um valor social positivo que uma pessoa reclama efetivamente para si. É a imagem da pessoa delineada em termos de atributos sociais aprovados, seja pela sua profissão, pelos seus atos, etc.

A construção da imagem de uma pessoa depende de uma série de fatores como as regras do grupo e a situação em que se está inserida. Essa imagem muda continuamente, conforme se alteram tais fatores. Assim, a face que um indivíduo tem perante determinado grupo não é necessariamente a mesma diante de outro grupo diferente. Mais uma vez, o contexto em que a situação está inserida é o regulador para que o falante adote determinada face.

Para o autor, toda vez que alguém inicia a interação com outras pessoas, conscientemente ou não, cria uma linha de conduta e o julgamento de si mesmo e dos outros será inevitável. Assim, assume-se o risco de essa linha de conduta estar de acordo ou não com a linha existente entre as outras pessoas.

Durante uma conversação o ideal é que todas as faces sejam preservadas e os participantes dessa conversação têm essa obrigação. Eles precisam preservar a sua própria face - ação defensiva e procurar não agredir a face do outro - ação protetora, quando isso ocorre, são necessários alguns recursos para atenuar tal agressão. De acordo com Goffman (op.cit., 19) a conservação da face é uma condição da interação, não o seu objetivo.

\footnotetext{
${ }^{17}$ Alguns autores adotam o termo "cara" como é o caso de Goffman, outros optam por "face" e outros por "imagem". Em nosso trabalho adotaremos o termo "face".
} 
A face é o que de mais valioso se possui. Além da construção que se faz sobre si mesmo, é a construção da imagem que os outros fazem desse indivíduo, é o julgamento sobre seus atos, seus pensamentos, seus valores.

Como citamos anteriormente, para que exista uma interação é necessário que haja a preservação das faces em questão, porém quando ocorre algum incidente que ameaça tal preservação é fundamental que todos os participantes da interação trabalhem juntos para a recuperação da face ameaçada. É o que Goffman chama de cooperação tácita, em que não só se defende a própria cara, como também se trabalha para proteger a face do outro. As regras de etiqueta representam um exemplo desse tipo de cooperação, outro exemplo é a desvalorização por si mesmo que normalmente ocorre quando se está recebendo um elogio, a pessoa recusa o elogio, mostrando ser demasiadamente modesta.

Para ele, existem três situações que podem fazer com que o locutor atinja a face do interlocutor: a inocência, também conhecida como gafe; a malícia, quando o insulto é provocado intencionalmente e as ofensas incidentais em que o ofensor tem consciência de que pode agredir o outro, como a crítica, por exemplo.

$\mathrm{O}$ autor acrescenta que esses três tipos de ameaças podem ser introduzidos pelo próprio participante contra sua própria face, por ele mesmo contra a face dos demais ou pelos demais contra a face dele.

Já dissemos que a conservação da face é o ideal de uma conversação. Porém, muitas vezes isso não é possível e é necessário salvar essa face. Ainda de acordo com Goffman (op.cit, págs. 22-27) podemos observar que há dois tipos de "salvamentos" da face:

a) O processo de evitação, em que como medida defensiva os participantes de uma conversação são preparados sobre o que vai ocorrer.

b) $\mathrm{O}$ processo corretivo - quando em algum momento da interação há um conflito, um desequilíbrio entre as partes é necessário que as partes se restabeleçam. Esse processo apresenta quatro fases que podem ou não ser seguidas: desafio, o qual consiste no reconhecimento do erro; oferecimento em que há a possibilidade de correção da ofensa; aceitação do oferecimento por parte das pessoas que foram ofendidas e agradecimento, cujo movimento é terminal e de intercâmbio, em que a pessoa perdoada transmite um sinal de gratidão a quem proporcionou o perdão.

Miguel $(2001,34)$ em seu livro sobre "La vida cotidiana de los españoles en el siglo XX" de maneira amena descreve em outras palavras o que é face negativa e face positiva: “Todo consiste en tener siempre como norma el 'que dirán' o el juicio pendiente de los 
demás." Dessa forma, aquilo que quero que pensem de mim será a imagem positiva e a negativa é justamente o contrário, ou seja, o que não quero que pensem de mim.

Ainda que seja muito estudada, precursora dos estudos da cortesia, a teoria de Goffman recebe também algumas críticas. Estudiosos como Bravo (2004, p.21) defendem a ideia de que é uma teoria egoísta, centrada em seu próprio benefício. É como se pelo fato de uma pessoa se comportar bem com os demais, já garanta boa imagem e face preservada.

\subsubsection{A teoria de Brown e Levinson}

Posteriormente aos estudos de Goffman, os autores Brown e Levinson (1994, p. 61) complementam a teoria da autoimagem, acrescentando que existem dois tipos de imagens: uma positiva e outra negativa. Sendo a positiva o desejo de reconhecimento por parte do interlocutor e a negativa referente à reserva do território pessoal, em que se pode exercer a liberdade individual de ação sem preocupar-se com "o que os outros irão pensar".

Carrasco (1999, p.5) faz um estudo no qual procura fazer uma revisão e uma avaliação do modelo de cortesia de Brown e Levinson e acrescenta que a imagem positiva seria uma verdadeira imagem, já que corresponderia a uma noção de imagem generalizada, imagem pessoal, enquanto a negativa seria um conglomerado de desejos de liberdade que denominamos liberdade de ação. É a proteção de seu território para poder atuar e projetar a imagem pública.

Essa teoria de Brown e Levinson apesar de ser citada por diversos autores que abordam o tema da cortesia é também bastante criticada, sobretudo por tratar a mesma como algo universal. No entanto, acreditamos que muitas vezes os autores são mal interpretados, pois defendem a ideia de que a cortesia é universal porque todos os sujeitos falantes possuem em comum certas propriedades como a preocupação em preservar o território e o impulso narcisista e em todos os lugares as interações estão submetidas a obrigações comuns; mas Brown e Levinson explicam que a aplicação desses princípios muda de uma cultura para outra (Kerbrat-Orecchioni, 2004, p. 46). Além disso, como já abordado anteriormente, o contexto exerce um papel crucial na cortesia. KerbratOrecchioni aponta que a cortesia não é um conjunto de orações, mas sim de enunciados e que fora de um contexto próprio a mesma não ocorre. 
Entendemos que é muito difícil de se criar um modelo universal de cortesia, pois há uma série de fatores que podem influenciar e determinar uma ação como cortês ou não. Além disso, como os aspectos culturais têm especial relevância, o que é cortês em determinada cultura, pode não ser em outra. Haverkate (2004, p. 61) aponta que a cultura espanhola não dá valor particular às fórmulas de agradecimento como respostas verbais a atos rotineiros. $\mathrm{O}$ mesmo já não podemos dizer da cultura brasileira, a qual dá extrema importância ao agradecimento e ao pedido acompanhado da expressão modalizadora por favor. Assim, é fundamental que um analista tenha ciência da importância desses aspectos culturais para que não faça falsas interpretações, levantando dados pouco fundamentados.

Hernández Flores (2004, pág.99) coloca que

El objetivo de la cortesía podría ser no sólo satisfacer los
deseos de imagen del otro, como se deduce en la teoría de
Brown y Levinson, sino satisfacer tanto los deseos de
imagen como del otro como los de uno mismo. De
acuerdo con esa postura, la imagen del hablante sí se ve
afectada por el uso de la cortesía, ya que, al satisfacer los
deseos de imagen de su destinatario, está realizando un
comportamiento que es evaluado positivamente por la
sociedad, y eso favorece su propia imagen.

Partilhamos da ideia da autora quando diz que a teoria de Brown e Levinson supõe que o objetivo da cortesia é apenas satisfazer os desejos do outro. Ao contrário, é certo que ao satisfazer os desejos do outro, o locutor também procurará se beneficiar da ação.

Além da teoria das faces positiva e negativa, Brown e Levinson (op. cit. p. 65-66) defendem a teoria dos FTAs - atos ameaçadores da face. De acordo com os autores, as situações em que tais atos se manifestam são as seguintes:

a) Desaprovação, insultos e acusações - são os atos que ameaçam a face positiva do interlocutor.

b) Pedidos, ordens, elogios - atos que ameaçam a face negativa do interlocutor.

c) Auto-humilhação, auto-confissões - ameaçam a face positiva do locutor.

d) Agradecimentos, desculpas, aceitação de ofertas - ameaçam a face negativa do locutor.

A estratégia de uso de tais atos pode ocorrer de maneira clara ou implícita, por meio de metáforas ou de insinuações. Quando é praticada de maneira clara, pode ser de forma indisfarçada, sem elementos atenuadores ou com elementos atenuadores, obtendose assim uma cortesia positiva ou negativa. 
Outro ponto importante da teoria de Brown e Levinson (1994, p. 76) está na identificação de três fatores considerados cruciais para os estudos dos atos de fala: o poder relativo dos participantes, a distância social entre eles e o grau de imposição que um ato tem para os falantes. Assim, quanto maior o poder de um falante, maior será a distância com seu interlocutor, maior será o grau de imposição de sua fala e, ao contrário, quanto menor o poder, menor será a distância, menor o grau de imposição. Haverkate (1994, p.37) associa esse aspecto da teoria de Brown e Levinson à análise do custobenefício. No entendimento do autor, o falante escolherá a estratégia de cortesia que alcance o seu objetivo comunicativo com menor custo verbal.

Em seus estudos sobre cortesia, Bravo (2004, p.30) tentando expressar a dualidade existente entre os contextos universais propostos por Brown e Levinson e os contextos socioculturais defendidos por ela e por outros linguistas, apresenta as categorias de autonomia e afiliação. Sendo que autonomia seria a condição do indivíduo que não depende de ninguém em certos conceitos, o qual relacionamos à face negativa e afiliação como a associação de uma pessoa a outras, formando uma corporação ou sociedade ${ }^{18}$, essa sim referente à face positiva do falante.

Em linhas gerais, essas definições preveem que um integrante do grupo adquira um contorno seu dentro do próprio grupo. A nosso ver, a autora apresenta a necessidade de individualidade de cada um sem deixar de lado a importância que o todo tem para cada indivíduo formador desse grupo.

Bravo (op. cit., p.31) complementa ainda que se entende por autonomia qualquer condição do indivíduo que o faz diferente dos outros aos quais se assemelha e com os quais forma um grupo. Porém, se esse desejo de autonomia deve ser concebido como a necessidade de liberdade de ação apresentada por Brown e Levinson dependerá dos conteúdos socioculturais que cada sociedade ou grupo social considere atuais para essa categoria.

Briz (2004, p.68) acrescenta que autonomia e afiliação são aspectos fundamentais na definição da cortesia. $\mathrm{O}$ autor expressa que a aproximação que supõe o fato cortês desde o ponto de vista social contrasta com o distanciamento que muitas manifestações corteses supõem desde o ponto de vista pragmalinguístico. Assim, o falante se distancia da mensagem e se aproxima do interlocutor com a intenção de alcançar seu objetivo.

\footnotetext{
${ }^{18}$ Essas definições, segundo a autora, foram retiradas do Diccionario de la Lengua Española.
} 
Aplicando a teoria da face em nossa análise, acreditamos que o contexto em que as entrevistas estão inseridas naturalmente expõe tanto a face do informante quanto do entrevistador. Por outro lado, é fundamental que o entrevistador preserve a face do informante, evitando ameaçá-la. Para isso, é preciso que elabore suas perguntas de forma que obtenha as respostas desejadas sem que o outro sinta sua face ameaçada, e caso isso aconteça, o restabelecimento deve ser imediato para que não haja nenhum comprometimento no produto final - a entrevista.

Assim, faz parte de nossa metodologia de análise averiguar se há ameaça e preservação das faces, tanto do informante, quanto do entrevistador e também a forma como se dá essa ameaça e, além disso, se há algum trabalho para a recuperação e restabelecimento do equilíbrio da conversação.

Outro assunto que também está relacionado à teoria da face é a relação existente entre cortesia e poder. São vários os autores que trabalham com esse tema. Álvarez Muro (2005, p. 142) apresenta algumas definições de poder para alguns estudiosos. Para Van Dijk o poder pode ser concebido como um controle; Bravo, por sua vez, aponta a questão dinâmica em que se trabalha poder e distância nas relações sociais no mundo hispânico, onde, além da existência de uma relação entre esses conceitos e a familiaridade, a frequência e o tempo do contato, o afeto entre os interlocutores e a liberdade entre eles são importantes.

Apoiando-se nos estudos de Fairclough, Álvarez Muro (op.cit., p.142) aclara que para esse autor o poder se exerce através do discurso. Há um poder no discurso e outro atrás do discurso. O primeiro é exercido nos encontros face a face, o chamado encontro desigual está relacionado com fatores da situação discursiva, as relações sociais das pessoas que participam no discurso. $\mathrm{O}$ segundo remete às ideias que a ordem social do discurso se junta e reúne como um efeito oculto do poder.

A manipulação exercida por quem detém o poder nem sempre é transparente, muitas vezes o papel que determinado interlocutor ocupa por si só é uma manipulação indireta.

Ainda relacionando o poder com a cortesia, não podemos deixar de mencionar que um dos principais objetivos da cortesia é a preservação da face alheia e do território pessoal do outro. Ao invadir esse território, demonstrando nosso poder, estamos deixando de ser cortês. Segundo Haverkate (1994, p.40) a cortesia aumenta na medida em que a distância que separa os interlocutores é maior; é maior o poder do interlocutor; o grau de imposição do enunciado é maior. 
É possível observar a influência do poder em algumas amostras de nossos corpora. Assim, sempre que o informante apresenta algum prestígio ou alguma posição hierárquica superior ao entrevistador, é ele quem detém o poder, porém quando não há essa hierarquia de maneira declarada entendemos que o entrevistador passa a detê-lo, pois é ele quem deve conduzir a entrevista. Por meio das análises será possível observar que, de maneira geral, o entrevistador procura criar uma condição de igualdade entre ele e seu informante, de forma que essas posições de igualdade ou superioridade não interfiram no andamento do diálogo.

Acreditamos que as formas de tratamento e formas nominais também são manifestações do poder que um interlocutor exerce sobre o outro. Assunto esse que expomos mais adiante.

\subsubsection{Atos reparadores da face}

Como citamos anteriormente, na teoria de Brown e Levinson os autores defendem que alguns atos são potencialmente ameaçadores para a face negativa do destinatário e também para sua própria face positiva, como a crítica ou o reproche, por exemplo. São atos que ameaçam simultaneamente ambas as faces, os chamados FTAs. Em contrapartida a essa teoria, estão os FFAs, ou atos reparadores da imagem, que são aqueles que procuram atenuar a fala de quem critica, por exemplo, para que nem sua face positiva seja muito ameaçada nem a negativa do interlocutor também.

Complementando a teoria de Brown e Levinson, Kerbrat-Orecchioni (2004, p.44) acrescenta que os FTAs representam a cortesia negativa, aqueles atos que servem para reparar um dano cometido e os FFAs seriam a cortesia positiva, buscando realçar a imagem do interlocutor. Um claro exemplo para o segundo tipo são os elogios, os quais muitas vezes nem são esperados pelo interlocutor. A autora coloca que o desenvolvimento de uma interação é um constante e sutil jogo de gangorra entre FFAs e FTAs. Alguns autores mencionam os FTAs como "cortesia mitigadora" e os FFAs como "cortesia valorizante".

Ainda fazendo menção ao nosso corpus, entendemos que quem tem a principal função de equilibrar o diálogo é o entrevistador, sempre procurando evitar as ameaças, porém na impossibilidade disso ocorrer, é ele também quem deve utilizar da melhor forma os FFAs, devolvendo equilíbrio à interação.

Acreditamos que a interpretação de um ato como ameaçador da imagem não é fixa, dependendo de variáveis como o contexto e a relação entre os interlocutores. 
Essa relação é nitidamente observada em nosso material de análise. Sempre que existe uma posição hierárquica de superioridade do informante para o entrevistador, automaticamente aumenta a distância e a interação fica comprometida. Por outro lado, essa relação nunca aponta o entrevistador como aquele que detém um maior poder. Observamos que normalmente ele procura se colocar no mesmo nível do informante, aumentando a interação entre entrevistador e informante.

Vale ressaltar que não relacionamos o aumento da interação com a não incidência de atos ameaçadores da face, isso porque entendemos que ao aumentar a interação, pode haver um aumento da intimidade entre os participantes, intimidade essa que pode proporcionar maior liberdade para perguntas que invadam o território privado dos falantes e de atos ameaçadores da face. Procuraremos elucidar esse dado por meio de nossas análises.

\subsection{Um pouco mais sobre a cortesia}

Como já apontado anteriormente não há como estudar as estratégias de cortesia sem ter conhecimentos teóricos sobre a Pragmática. Apoiando-nos nos estudos de Leech (1997) e Bravo (2004), entendemos que devemos estudar a cortesia por meio de um duplo enfoque: o da Pragmática Sociocultural e o da Pragmalinguística.

De acordo com Leech (op. cit. Pág. 54) não há dúvidas de que tanto o Princípio de Cooperação quanto o de Cortesia funcionam de maneira diferente de acordo com a cultura ou comunidade linguística em que estão inseridos. Já a Pragmalinguística se refere à parte linguística da Pragmática, na qual são considerados os recursos disponíveis em determinada língua que poderão ser utilizados pelos falantes, sejam eles verbais ou não.

Bravo (2004, p.8) coloca que a Pragmática Sociocultural focaliza as relações da linguagem com a sociedade, considerando que o falante de uma língua possui recursos interpretativos que provêm de seu entorno social e de suas experiências comunicativas prévias, as quais compartilha parcialmente com outras pessoas.

Os falantes estariam dentro de uma comunidade sociocultural e dentro dessa comunidade sociocultural há uma comunidade de fala, que ainda segundo a autora (2005, p. 23) refere-se a um grupo de pessoas que compartilha regras sobre o uso da língua e sua interpretação.

Acreditamos que essa definição da autora complementa a teoria da face apresentada por nós anteriormente. Tanto o que concerne à parte individual, quanto à 
coletiva pode ser relacionada com a definição de face positiva e negativa, defendida por Brown e Levinson, pois em ambos os casos há a exposição de tais faces por parte do falante.

A partir dessas definições, é possível entender a importância da Sociolinguística na organização de um corpus. Dificilmente haverá homogeneidade em determinada comunidade de fala, isso porque há fatores pessoais que influenciam cada falante como, por exemplo, conhecimentos prévios adquiridos a partir de vivências pessoais como leituras, lugares visitados, etc. No entanto, ao selecionar um grupo por meio de determinados critérios como idade, sexo, nível de instrução, a tendência é que essa distância entre os dados obtidos se torne menor.

Para Leech (op. cit. pág. 57) o estudo da cortesia envolve tanto traços dinâmicos quanto estáticos da comunicação. Os primeiros se referem ao tipo de requerimento ilocutivo que o falante solicita ao ouvinte - perguntando, aconselhando, ordenando, enquanto que os segundos são fixos como a distância social entre os interlocutores ou o poder estabelecido entre ambos, por exemplo.

Bravo (2001, pág. 300) defende o termo cortesia linguística em lugar do mais conhecido cortesia verbal, pois a tratando por linguística, seriam abarcados tanto os enunciados verbais como os não verbais.

Estamos em total acordo com a autora ao defender o termo cortesia linguística, pois temos conhecimento da importância dos aspectos não verbais que fazem parte da interação como os gestos, as expressões faciais, etc. No entanto, a análise de nosso corpus está baseada apenas nos aspectos verbais. Há a descrição de alguns aspectos não verbais durante as entrevistas, mas entendemos que são poucos, comparados aos verbais, para que se possa fazer uma análise consistente e verossímil.

Além da Pragmática Sociocultural, entendemos que nosso estudo deve apoiar-se também na Pragmalinguística, pois a nossa metodologia de análise tem como foco o conteúdo linguístico das entrevistas, mais especificamente o conteúdo verbal, no qual procuramos observar as estratégias de cortesia e atenuação utilizadas pelos falantes em suas respectivas línguas. Para tanto, apoiaremo-nos nas teorias de Briz e Haverkate, as quais serão descritas no capítulo referente aos corpora.

Acreditamos ser completamente plausível o estudo da cortesia sob a ótica da Pragmática Sociocultural e da Pragmalinguística, pois a escolha de certos elementos linguísticos que o falante faz sofre forte influência do entorno social e de suas experiências comunicativas prévias. 
Escandell Vidal (2006, págs. 142 e 144) apresenta a cortesia como uma norma social e como uma estratégia conversacional. É uma norma social estabelecida por cada sociedade, a qual visa regular o comportamento adequado de seus membros, proibindo algumas normas e condutas e favorecendo outras. Essa definição ajuda a explicar a universalidade da cortesia descrita por Kerbrat-Orecchioni (2004), apresentada ao longo da introdução deste trabalho. Por outro lado, é também uma estratégia conversacional, pois o falante utiliza a comunicação verbal para atingir um determinado objetivo com relação a seu interlocutor, assim, por meio da linguagem é possível mitigar possíveis conflitos que toda situação de interação possa apresentar.

A nosso ver, a cortesia está relacionada com a recepção do interlocutor. A forma como o outro interpreta um enunciado é que o transforma em cortês ou descortês. Acreditamos que essa interpretação também está relacionada a fatores sociais e linguísticos. Sociais no que se refere ao contexto como a sociedade em que estão inseridos, as normas que regem essa sociedade de maneira geral e os fatores linguísticos se referem aos meios, verbais ou não, utilizados pelo falante para expressar seu enunciado.

Além disso, as características culturais da sociedade em que esse falante está inserido são fundamentais para a interpretação de tal enunciado.

\subsection{Atos de fala não-corteses e corteses}

Ao iniciar a explanação deste embasamento teórico, apresentamos a importância dos atos de fala em nossos estudos, uma vez que as amostras analisadas contêm este tipo de enunciado, especialmente os diretivos, na fala dos entrevistadores.

Sem deixar de mencionar a importância dos aspectos socioculturais que envolvem os estudos da cortesia, Haverkate (1994) faz um estudo sobre os atributos linguísticos, relacionando os atos de fala já apresentados anteriormente a atos corteses e não-corteses.

\subsubsection{Atos de fala não-corteses}

Para o autor (1994, p.116) os atos não corteses são aqueles cujo objetivo ilocutivo não serve para beneficiar o interlocutor. Entendemos que devido às características de nosso corpora, esse tipo de ato de fala deve ser encontrado predominantemente na fala dos informantes das entrevistas, uma vez que esses apresentam menos responsabilidade com relação ao outro, pois como já tratamos anteriormente, o entrevistador deve estar 
permanentemente preocupado com o equilíbrio do diálogo e deve evitar qualquer tipo de ato que possa ameaçar seu interlocutor.

Esse tipo de ato pode manifestar-se semântica ou pragmaticamente. Em nossos estudos nos centraremos na manifestação pragmática, cujas estratégias nos foram úteis na observação de algumas manifestações de cortesia e atenuação que analisamos em nosso corpora.

A primeira delas, definida por Haverkate (op.cit., p.122) como estratégias léxicas foi utilizada em nossas análises no momento em que o informante expõe sua opinião sobre determinado assunto. Essas estratégias são divididas pelo autor em predicados epistêmicos, doxásticos e dubidativos. Sendo que para defini-los, poderíamos pensar em uma escala na qual os epistêmicos representam a certeza do ato descrito, os doxásticos a quase certeza e os dubidativos a dúvida.

Apoiando-nos nessa teoria, procuraremos observar em nossa análise se o falante impõe ou apenas expressa sua opinião sobre determinado tema. Além disso, observaremos também se faz uso de algum tipo de verbo reforçando a sua posição como crer, acreditar, achar, etc.

Já a segunda estratégia, denominada dêitica (op.cit., p.129), foi encontrada quando o falante faz uso de outra pessoa do discurso para distanciar-se do eu. É uma estratégia que Haverkate (op. cit., p.131) nomeia desfocalização do eu, cujo objetivo é o distanciamento do falante para minimizar seu próprio papel ou o do ouvinte.

Abaixo apresentamos dois exemplos, retirados de nosso corpora, tanto em português quanto em espanhol para elucidar essa questão.

(09) ... são fatos que mudam vidas que transforma mas que você tem que ter um sentimento assim... eh... de compreensão das coisas né? (linha 191, amostra 150 - ALIP - nível superior)

(10) ... suelen darte / o viviendas / o a lo mejor / no sé / polideportivos / campos de fútbol / entonces tú eliges (linha 65, amostra 25 - PRESEEA - nível médio)

Conforme será possível observar em nossas análises, há esse tipo de ocorrência em todas as entrevistas, as quais também aparecem com a primeira e terceira pessoas do plural e no caso específico da Língua Espanhola com a partícula uno.

Fiorin (2001, p.59) apoiando-se nos estudos de Benveniste aclara que nas diferentes línguas, sempre se emprega a terceira pessoa quando não se designa a pessoa. $\mathrm{O}$ autor chama esse fenômeno de expressão impessoal, em que a produção de um processo relatado não está relacionada a qualquer agente ou causa. 
Os exemplos apresentados acima foram retirados de nosso material de análise, entendemos que é interessante reforçar que ainda que na língua espanhola seja mais frequente o uso da segunda pessoa verbal, essa se refere a uma terceira pessoa no discurso e não especificamente ao interlocutor em questão.

Já Haverkate (op. cit., p. 137) entende a desfocalização como uma estratégia atenuadora, a qual serve para manifestar solidariedade ao grupo e também para proteger a imagem positiva do falante.

Entendemos que essa manifestação de solidariedade ao grupo fica bastante evidente quando o falante utiliza o plural, no caso do português com os pronomes nós e a gente e no espanhol com nosotros. Acreditamos que esse uso denota uma estratégia de cortesia denominada por Haverkate (op. cit.) como plural de modéstia. Esse tipo de estratégia, além de expressar modéstia, favorecendo a face positiva do falante, envolve outras pessoas, ainda que desconhecidas, na ação. Ao longo de nossas análises será possível observar quando o falante optou por esse uso e os efeitos do mesmo no discurso.

\subsubsection{Atos de fala corteses}

Servem para apoiar ou reforçar a imagem positiva do interlocutor. São divididos em atos comissivos e expressivos

\subsubsection{Atos comissivos}

São aqueles que expressam a intenção do falante em realizar uma ação em benefício do ouvinte - a promessa e o convite são os tipos mais comuns. Diferentemente dos atos expressivos, denotam uma situação futura. Haverkate (1994, p. 107) aponta que para que ocorram dependem de três condições prévias: habilidade, aceitação e razoabilidade.

A habilidade se refere à capacidade do falante em efetuar o ato prometido, a aceitação diz respeito ao ouvinte, o qual deve desejar ou não que o falante efetue tal ato. Já a razoabilidade concerne aos motivos que o falante tem para efetuar o ato comissivo.

Não nos aprofundaremos em tais atos pelo fato de os mesmos não fazerem parte de nossos corpora. Ainda que normalmente expressem cortesia positiva, o contexto em que estão inseridas nossas entrevistas não exige que entrevistador e informante realizem esse tipo de ato de fala, o que justifica a ausência dos mesmos ao longo dos diálogos.

\subsubsection{Atos expressivos}


Haverkate (1994, p.80) apoia-se nos estudos de Searle, dizendo que na definição original desse autor o conteúdo proposicional do ato expressivo descreve uma propriedade atribuída seja ao falante, seja ao ouvinte. Entretanto, entre os exemplos dados por Searle (agradecer, felicitar, pedir perdão, dar os pêsames, lamentar, dar as boasvindas) não figura nenhum ato que denote uma propriedade atribuída apenas ao falante, todos especificam uma reação do falante ante uma situação na qual o ouvinte tem uma participação ativa ou passiva. Para Haverkate (op.cit. p. 82) o valor cognitivo dos atos expressivos é reduzido, sua função não é derivada do intercambio de informação factual, serve apenas para ressaltar o componente social da interação verbal.

Deixar de agradecer, de cumprimentar uma pessoa pelo seu aniversário, por exemplo, ou de dar os pêsames pela perda de um ente querido são atitudes descorteses por parte do interlocutor.

O autor observa que alguns atos expressivos estão centrados no ouvinte, como agradecer, felicitar e dar os pêsames, acrescentando que este pode ter um papel passivo ou ativo. Concordamos em parte nesse aspecto, pois quando o falante agradece algo é porque o ouvinte executou alguma ação, dessa forma acreditamos que o ato de agradecer é resultado de um papel ativo do ouvinte.

Haverkate faz um estudo detalhado sobre outros quatro atos expressivos: o cumprimento, o elogio, o agradecimento e a desculpa. Nesse estudo, nós os apresentaremos de forma bastante sucinta. Ao iniciar nossa análise, tínhamos a expectativa de encontrar tais atos com certa frequência, no entanto nos surpreendemos com a ausência deles, sobretudo o cumprimento e o agradecimento. Como será possível observar ao longo das análises, no material brasileiro, há algumas ocorrências de agradecimento, porém o único ato que denota cortesia valorizante encontrado em ambos os corpora é o elogio. Cabe aclarar que toda a exposição abaixo está baseada nos estudos de Haverkate (1994).

\subsection{O Cumprimento}

É um ato idiossincrático por algumas razões, entre elas: é universal, ou seja, está presente em todas as culturas, ainda que de forma diferente; sua realização formal está baseada em fórmulas rotineiras; o ato de cumprimentar não serve para transmitir informação proposicional.

As principais funções interativas do cumprimento são abrir o canal comunicativo, ou seja, mostrar ao interlocutor que há possibilidade de intercambio verbal; evitar que se 
produza uma tensão social, o cumprimento é o ato de fala que se presta, por excelência, a introduzir a comunhão fática; estabelecer ou confirmar uma determinada relação interacional, tal como se define por fatores como posição social, grau de intimidade e afeto.

No campo semântico, o cumprimento pode ainda ser analisado por três fatores: significado léxico, dimensão temporal e distância social.

Com relação ao primeiro, há uma diferença entre os cumprimentos monoléxicos que são aqueles que não apresentam conteúdo proposicional, são fórmulas fixas que servem unicamente para cumprimentar, ex. olá, oi, tchau. A segunda categoria é aquela que há um conteúdo proposicional, normalmente se pergunta sobre o bem estar ou saúde do interlocutor, porém tanto no Português quanto no Espanhol quando alguém pergunta Como vai? ou Hola, ¿qué tal? Não se espera que o interlocutor responda verdadeiramente como ele está, por mais que não esteja bem, normalmente a resposta será bem, obrigada.

A dimensão temporal, também existente em ambas as línguas se manifesta através do sistema tripartido bom dia, boa tarde e boa noite de acordo com a hora do dia.

A distância social é o fator mais complexo dos três apresentados, pois pode operar tanto em um eixo horizontal - entre pessoas desconhecidas - como no vertical - nesse caso a distância é hierárquica, baseada no poder ou autoridade de um interlocutor sobre o outro.

É importante ressaltar que junto aos cumprimentos estão as despedidas e que algumas fórmulas servem tanto para cumprimentar quanto para se despedir e outras servem só para um dos casos. Além disso, conforme mostra Haverkate (op. cit., p. 87) a despedida não se faz mediante uma fórmula isolada, normalmente é iniciada por um pedido de desculpa ou por alguma justificativa, considerando os fatores culturais de cada língua.

\subsection{O Agradecimento}

Como dissemos anteriormente, a realização do ato de agradecer é dependente de uma ação anterior executada pelo interlocutor. Haverkate (op. cit. p. 93) chama esse ato de reativo. De acordo com o autor, é um ato de fala que tem a finalidade particular de restabelecer o equilíbrio da relação custo-benefício entre falante e ouvinte. $\mathrm{O}$ ato de deixar de agradecer, deixar de restabelecer esse equilíbrio é uma forma descortês de comportamento. Além disso, é cortês também informar a quem agradece que não há necessidade desse restabelecimento de custo-benefício. Tanto no Português quanto no Espanhol existem algumas expressões fixas como não há de que, você merece, não foi nada. 
$\mathrm{O}$ ato de agradecimento não é universal, está presente na cultura das duas línguas que estamos estudando nesse trabalho, porém de forma um pouco diferente. Como já mencionamos anteriormente, a cultura espanhola não dá valor particular às fórmulas de agradecimento em situações rotineiras, já a brasileira sim, além de ser cortês, é comum que se agradeça ao garçom por servir a comida ou que ao comprar uma passagem se agradeça ao vendedor, por exemplo.

Ao iniciar nossa análise existia a expectativa de podermos analisar esse tipo de ato de fala, porém nos deparamos com um problema presente em ambos os corpora - a interrupção da gravação ou um corte entre uma entrevista e outra apagou esse trecho final de algumas entrevistas, o que impossibilitou tal análise. Antecipamos que algumas entrevistas do corpus brasileiro apresentam esse ato de fala entre os temas, assim quando deseja mudar de tema, o entrevistador faz uso de um agradecimento, isso nos possibilita uma comparação intracorpus, verificando entre quais informantes essas fórmulas estão presentes, quais são as fórmulas e a frequência encontrada.

\subsection{A Desculpa}

Para Haverkate (op. cit. p.97) o falante que se desculpa realiza um ato de fala expressivo, cujo objetivo ilocutivo é mostrar ao interlocutor que alguma norma social foi violada e que ele, o falante, é ou se sente responsável por tal violação. É um ato que reforça a imagem positiva do interlocutor e ameaça a do falante.

Para o autor, a desculpa faz com que o falante adote atitudes contrárias: uma retrospectiva - reconhecer a violação de alguma norma e outra prospectiva - voltada para a reintegração do falante na comunidade como membro social aceito.

No nível do discurso, Haverkate cita duas situações diferentes: a desculpa autônoma - oferecida pelo falante e a não-autônoma que é aquela que serve de resposta a um reproche explícito dirigido ao falante pelo interlocutor.

Esse tipo de ato de fala é mais difícil de ser encontrado em nossos corpora, pois se espera que em uma entrevista o entrevistador minimize qualquer tipo de ameaça à face do outro, o que faz com que as desculpas sejam desnecessárias.

\subsection{O Elogio}

A função do elogio é bastante peculiar, diferente dos atos de fala estudados até o momento. De acordo com Haverkate (op. cit. p. 88) o objeto ilocutivo do elogio se deriva de um motivo social geral que consiste em criar ou manter um ambiente de amabilidade. É 
uma estratégia de cortesia eficaz para introduzir um ato de fala que ameaça a imagem negativa do ouvinte. É um poderoso instrumento persuasivo quando o balanço custobenefício pode ser objeto de negociação em uma conversação.

Como poderá ser observado em nossas análises, nem sempre o elogio é usado para introduzir um ato de fala que ameaça a imagem negativa do ouvinte. Em nossas entrevistas, averiguamos que muitas vezes é utilizado como cortesia valorizante, apenas enaltecendo alguma característica do informante, sem que antes tenha ocorrido qualquer tipo de prejuízo à face do mesmo.

Outro ato de fala que tem características semelhantes ao elogio é a felicitação. Haverkate faz uma comparação entre esses dois atos e comprova que ambos têm em comum a expressão de cortesia positiva, além disso a relação entre ambos é tão estreita que às vezes é difícil traçar uma linha divisória e diferenciá-los, mostrando que normalmente o elogio se refere a situações produzidas pela intervenção ativa do interlocutor, enquanto a felicitação é uma categoria mais ampla, envolve também situações que não são produto de uma atividade humana, como, por exemplo, fazer aniversário.

Haverkate apresenta também o papel do interlocutor no momento em que recebe um elogio. Esse pode apresentar as seguintes reações de acordo com o autor: 1- aceitar o elogio reduzindo-o; 2- aceitar o elogio atribuindo-o a uma terceira pessoa; 3- devolvendo-o ao falante.

\subsection{Aspectos gerais da atenuação}

Ao longo da explanação de nossa fundamentação teórica, apresentada até aqui, referimo-nos por diversas vezes às estratégias de atenuação. Entendemos a atenuação como uma estratégia de cortesia e acreditamos que devido a sua relevância em nossas análises, é importante ressaltar seus pontos principais. Poderá ser observado que algumas das estratégias de atenuação aqui contidas já foram mencionadas anteriormente, porém sentimos a necessidade de reuni-las com o intuito de facilitar a leitura e consequentemente o entendimento das mesmas.

É relevante em um primeiro momento apontar a diferenciação existente entre atenuação e cortesia. Diversos estudos são unânimes em tratar a primeira como uma estratégia da segunda. É comum que em atitudes corteses apareçam marcadores de atenuação com o intuito de preservar as faces envolvidas na interação. No entanto, é possível encontrarmos também marcadores de atenuação sem cortesia. Isso ocorre porque de acordo com Briz (2007, p.12) a cortesia sempre está relacionada com a face do locutor 
e a atenuação não. Tal fato comprova a tese de que cortesia e atenuação não podem ser estudadas como conceitos sinônimos.

Ainda de acordo com o autor (op. cit., p. 6) a atenuação é uma manifestação linguística, semântico-pragmática da cortesia. É um mecanismo mais complexo e aparentemente contraditório, pois há a necessidade de um distanciamento da mensagem, no intuito de suavizá-la, para que assim haja uma proximidade social. Isto é, o indivíduo se distancia do que diz linguisticamente para se aproximar socialmente de seu interlocutor.

Há alguns exemplos claros e comuns de atenuação em conversações cotidianas, como a impersonalização do eu, as dúvidas e desconhecimentos fingidos, as táticas verbais empregadas que modificam a força do enunciado, evitando opiniões mais sinceras e possíveis perdas de face.

Estratégia presente em nossas amostras, a desfocalização do eu, na qual o falante manipula a conversação de forma que o que esteja sendo dito não o caracterize diretamente. Assim, usa, por exemplo, a terceira pessoa, generalizando o conteúdo de seu enunciado. As dúvidas e desconhecimentos fingidos evitam respostas ou comentários que o falante não queira fazer e simultaneamente previnem possíveis ameaças à face. Já as táticas verbais que modificam a força do enunciado correspondem ao uso de determinados verbos que explicitam indiretamente o posicionamento do falante sobre determinado tema. Ao utilizar verbos epistêmicos como achar, crer, entre outros, antes de expor seu argumento o emissor diminui o peso de seu enunciado, atenuando também sua responsabilidade sobre o que está sendo dito. Em nossos corpora tal recurso pode ser observado ao longo das expressões de opinião dos informantes.

Dessa forma, pode-se entender que a função principal da atenuação é a obtenção da meta de uma conversação - o acordo ou a diminuição do desacordo entre os participantes.

De maneira geral, os autores que trabalham com a cortesia também estudam a atenuação e seguindo sua linha de investigação, apresentam os recursos que podem ser usados como marcadores de atenuação. Em nossa pesquisa, trabalharemos com três teóricos: Haverkate, Puga e Briz.

De acordo com Haverkate (1994, p. 131) podem ser utilizados para fins atenuadores: o pronome reflexivo; a $2^{\mathrm{a}}$ pessoa do singular; a $1^{\mathrm{a}}$ do plural; o condicional e o imperfeito de cortesia. Para o autor, ao utilizar as $2^{\mathrm{a}}$ pessoa do singular e $1^{\mathrm{a}}$ pessoa do plural, o falante desfocaliza seu enunciado, com o objetivo de reduzir ou minimizar seu 
próprio papel. O autor acrescenta ainda que a desfocalização pode expressar modéstia, criar a impressão de que o ouvinte compartilha o mesmo ponto de vista e esquivar do falante a responsabilidade de ter provocado uma situação indesejada. Por outro lado, o uso do condicional e do imperfeito evitam a ameaça à face negativa do interlocutor, atenuando os enunciados diretivos.

No entendimento de Haverkate (op. cit., p. 140) assim como a cortesia e contrariando estudiosos como Leech e Briz, a atenuação não deve ser enquadrada entre as máximas de Grice, pois ao usar a $1^{a}$ pessoa do plural como plural de modéstia, o falante burla a máxima da qualidade.

Puga (1997, p. 38) também entende esse distanciamento do emissor como uma estratégia de atenuação. A autora acrescenta o uso da partícula uno, a qual cria certa impessoalidade ao enunciado. Em nossa análise, acrescemos o uso de a gente e de você como recursos que afastam o emissor da mensagem. Tais generalizações proporcionam a proteção da imagem do locutor.

Assim como Haverkate, Puga (op.cit., p. 40) também considera a distância do tempo da enunciação como um recurso de atenuação. Para a autora, quanto mais evidentes sejam as marcas de subjetividade do falante, mais atenuado será o discurso. A rigidez do tempo presente pode ser atenuada por meio do uso do condicional, do subjuntivo e do imperfeito.

Outro recurso mencionado pela autora (op. cit., p. 41) é o distanciamento da mensagem. Em nosso material, acreditamos que tal recurso possa ser encontrado tanto na fala dos entrevistadores, quando precisam fazer alguma pergunta que dê margem à invasão do território pessoal do interlocutor, quanto na fala dos informantes quando precisam expor sua opinião, mas temem, com isso, levar o entrevistador a possíveis julgamentos sobre a mesma.

Por fim, o último recurso mencionado pela autora (op. cit., p. 43) é o distanciamento do receptor, no qual estão envolvidos os papeis sociais, ou seja, a hierarquia. Assim, o falante que se encontra em posição inferior, certamente fará uso de mais recursos atenuadores e o contrário acontecerá com o falante que se encontra em posição superior. A autora expressa que quando a relação entre locutor e interlocutor é recíproca, em que tanto um quanto o outro pertencem ao mesmo nível hierárquico, a interação é marcada basicamente pelos pronomes informais, porém quando a distância social é significativa, os tratamentos usados serão os formais do nível baixo para o mais alto e os informais do alto para o baixo. 
Esse fator é uma questão que já está internalizada na mente dos falantes, o que diminui a possibilidade de ameaça à face por não seguir essas regras. O que pode ocorrer, quando se tem dúvida, é o uso de um tratamento mais formal e, caso o interlocutor dispense a formalidade, a transição para o tratamento mais informal.

Em consonância com o exposto está a teoria de Brown e Gilman (1960) que será apresentada mais adiante, a qual apresenta os eixos de solidariedade e poder. Considerando a importância de tal dado, analisamos essa questão por meio das formas de tratamento utilizadas ao longo de nossas amostras.

Briz (2002, p. 18), por sua vez, defende a ideia de que a atenuação é uma tática de distanciamento, pois se há proximidade entre os interlocutores, não há por que se atenuar um ato de fala. Além disso, nesse aspecto em acordo com os outros teóricos apresentados, o autor aponta que utilizar recursos atenuantes é uma estratégia de minimização daquilo que é dito e defendido pelo enunciador.

O teórico também apresenta os mesmos recursos atenuadores propostos por Haverkate e por Puga, porém acrescenta (op. cit., p. 32) ainda uma escala de atenuação utilizada para mensurar as culturas de distanciamento e proximidade. De acordo com o autor, nas culturas de menor proximidade, a frequente atenuação cortês é uma estratégia de aproximação social ao outro e se há essa necessidade de aproximação, é porque existe um distanciamento. Abaixo apresentamos a escala proposta pelo autor.

intensificação

atenuação $\leftarrow$

Entendemos que essa escala será um importante instrumento que complementará a nossa análise, pois uma vez que buscamos comparar tais aspectos entre as duas línguas, acreditamos que o uso desse recurso facilitará a visualização dos resultados obtidos. Além disso, ainda seguindo os estudos de Briz, verificaremos qual das duas culturas, a rio-pretense e a malaguenha, apresenta-se como de maior ou menor proximidade.

Ao trabalhar as teorias que envolviam a cortesia, procuramos elucidar a importância do contexto em cada situação. Ocorrência semelhante ocorre com os recursos de atenuação. Acreditamos que embora presentes em várias línguas, a atenuação não pode ser vista como algo universal. Diferentes culturas atenuam de forma distinta e o que pode ser recurso atenuador em determinada cultura, pode não ser em outra. Além das culturas, há que se ter em mente toda a situação comunicativa, pois dentro de uma mesma 
cultura é normal que existam diferenças entre as estratégias de atenuação utilizadas. Essas diferenças podem ocorrer devido à idade dos interlocutores, ao sexo, ao grau de proximidade ou distância, ao assunto que se pretende atenuar e também ao tipo de pedido que se deseja fazer. Todos esses fatores fazem com que o rodeio explicativo e a necessidade de reformulações sejam maiores ou não.

Considerando o contexto que envolve as amostras que compõem o nossos corpora, entendemos que o estudo dos marcadores de atenuação é bastante relevante, pois nos ajudará a observar e analisar as duas línguas, obtendo respostas mais concretas. Dentre os vários aspectos que podem ser analisados, a hipótese que mais se sobressai ao tratar esse assunto é a forma como o entrevistador elabora suas perguntas e como o entrevistado reage ao precisar dar respostas que envolvam a exposição de sua opinião sobre determinado tema, seja ele polêmico ou não.

Para isso, nos apoiaremos nos três teóricos apresentados para observar em nossa análise os marcadores de atenuação que consideramos importantes em nosso corpus.

$\mathrm{Na}$ fala do entrevistador:
a) Modificação do verbo performativo - uso do Futuro do Pretérito e condicional.
b) Pela ação do verbo performativo (pensar, crer, imaginar, parecer) - aqui também poderíamos incluir modalizadores do tipo por favor.
c) Perguntas indiretas, usadas em ambas as línguas.

Na fala do informante:

a) A desfocalização do $e u$, seja por meio do uso do plural de modéstia, da partícula se, do uso de terceira pessoa, etc.

b) Rodeios que visam justificar ações ou pensamentos do entrevistado que possam levar o entrevistador a um possível julgamento.

c) Uso de verbos performativos que procurem atenuar a maneira de pensar sobre determinado assunto.

\subsection{Formas de tratamento}

Ao longo de nossa análise, pudemos observar que não bastava apenas estudar as teorias da cortesia para entender a maneira como essa se manifestava em português e 
espanhol. A forma como os interlocutores se tratavam também tinha muito a nos dizer sobre tais manifestações.

Entendemos que a análise da seleção pronominal feita pelos interlocutores é de fundamental importância uma vez que indica o grau de solidariedade ou distância existente, bem como o nível de compromisso que um apresenta para com o outro. Medina (2005, p.99) complementa a definição de cortesia dada por Escandell Vidal ${ }^{19}$ ao apresentar as formas de tratamento como pertencentes à norma social. Segundo o autor, as formas de tratamento são parte integrante do conjunto de regras sociais que regem o comportamento verbal dos membros de uma comunidade e são específicas de cada cultura.

Silva (2003, p.173) coloca que não se pode desvincular a linguagem da sociedade e que é preciso conhecer o conjunto de normas que regulam o comportamento adequado dos membros de um meio social. O autor complementa que as formas de tratamento fazem parte dessas regras sociais que sancionam determinados comportamentos como adequados ou inadequados.

Analisar as formas de tratamento como um tratamento cortês ou descortês é mais que observar se o falante usa um tratamento formal ou informal ${ }^{20}$. Há que se verificar todo o contexto que envolve a interação. Assim, quem são os participantes, qual a relação existente entre eles, a existência ou não de diferenças hierárquicas são fundamentais para que se possa classificar os envolvidos dentro de uma cultura de mais aproximação ou mais distanciamento.

A partir da obtenção dos dados acima, é possível analisar se a relação entre os interlocutores é simétrica ou assimétrica, em que o poder de um interlocutor sobre o outro é decisivo à forma de tratamento utilizada. Esse poder é exercido pela hierarquia seja pela diferença de idade, pela profissão, pela classe social de maneira geral e também de acordo com o grau de intimidade/familiaridade.

A relação de simetria e assimetria é bastante relevante aos estudos da cortesia. De acordo com Brown e Gilman (1960, p.255), pioneiros nesse estudo, a sociedade está polarizada por duas forças: poder e solidariedade, são essas forças que retratam a relação entre os interlocutores. O poder associa-se ao uso não recíproco dos pronomes, seja por

\footnotetext{
${ }^{19}$ Vide pág. 49

20 A questão da formalidade é pensada aqui em um contexto sócio-cultural. Na Língua Espanhola a dicotomia tú - informal / usted - formal não só é válida em contextos que dão valor específico a essa forma, como no caso do espanhol peninsular. Em alguns países como a Colômbia, por exemplo, há regiões em que essa dicotomia é nula, pois usted é usado tanto em situações formais quanto informais.
} 
questões hierárquicas por autoridade, seja por idade. Já a segunda força aponta mais solidariedade entre os falantes, em que há o uso recíproco dos pronomes formais e informais.

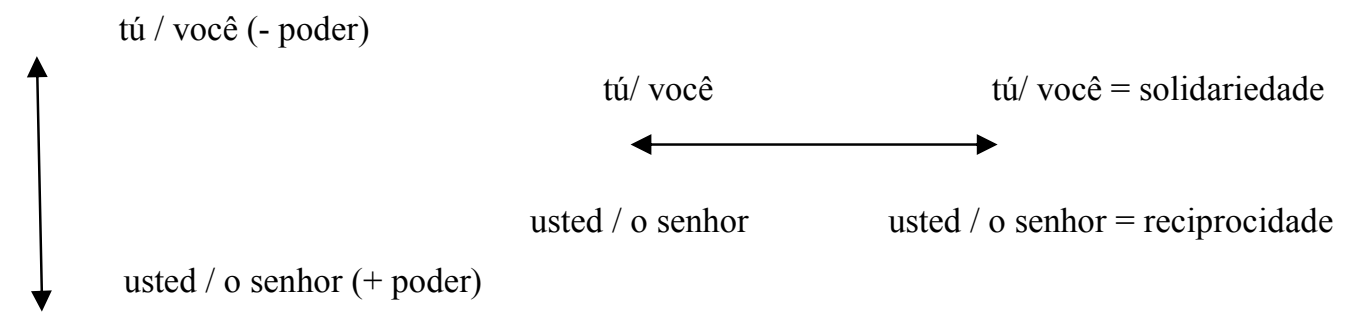

A ilustração acima procura elucidar as duas formas apresentadas - poder e solidariedade - sendo o eixo vertical o que representa o poder, encontrado em relações assimétricas em que há diferenças no tratamento entre os interlocutores. Assim, aquele que é tratado por o senhor é quem detém maior poder sobre o outro. Já no eixo horizontal temos uma relação de solidariedade quando ambos fazem uso de um tratamento informal e de reciprocidade, quando se tratam de maneira mais formal. Esse tipo de tratamento é comum em conversações simétricas.

Acreditamos que o sistema pronominal de uma língua reflete a ligação entre os falantes. A forma como se tratam pode nos mostrar como se dá a criação da imagem do outro, ou seja, se é uma imagem em que o tratamento mais adequado é o que os aproxima ou os distancia.

Silva (2008, p.158) acrescenta que as formas de tratamento têm papel fundamental na busca constante do equilíbrio que deve haver em qualquer situação de interação. Ainda de acordo com o autor, o uso de um tratamento inadequado pode colocar em risco o bom andamento da interação.

Em outro trabalho, Silva (2003, p. 173) chama atenção para um dado importante embora, no Português do Brasil, a forma você tenha um caráter mais informal, de maior proximidade, nem sempre o uso dessa forma aponta falta de cortesia por parte do falante. Muitas vezes, no intuito de mostrar proximidade, seguindo inclusive uma das máximas de Lakoff $^{21}$ Seja amigável! o falante usa a forma mais informal para estreitar o vínculo com o interlocutor. Como já apontado anteriormente, ao apresentarmos as teorias sobre Cortesia, é o contexto interacional que determinará qual melhor forma deve ser utilizada, pois a forma $o$ senhor, empregada fora de um contexto próprio também pode ser caracterizada como descortês.

${ }^{21}$ Vide pág. 53 
Outro dado que podemos observar em nosso dia a dia, em nossas próprias relações pessoais é a perda ou diminuição da formalidade em determinadas situações. Essa questão foi abordada por Preti (2000, p.94), que credita esse dado a uma melhor estratégia de comunicação ou ao prestígio de uma filosofia de vida jovem, mostrando uma contínua luta do homem contra as forças hierarquizadoras.

Carricaburo (1997, p.10) aponta certa extensão do tú sobre o usted. De acordo com a autora, isso se deve às mudanças no relacionamento entre as pessoas, fazendo com que o tú ganhe mais espaço frente ao usted.

Blas Arroyo (1994-1995, p.23) apoiando-se nos estudos de Criado de Val, aclara que existem línguas como o inglês que estabelecem diferenças de tratamento; no entanto em idiomas como o espanhol e o português é necessário não só um profundo conhecimento do idioma, mas também dos costumes sociais para que se usem acertadamente tais pronomes.

Em nossa análise abordaremos a questão das formas de tratamento usadas pelos envolvidos nas entrevistas - entrevistador e informante em ambos os corpora. Assim, observaremos o uso das formas você / o senhor no Português do Brasil e tú / usted no Espanhol Peninsular. Além do uso de tais formas, procuraremos analisar se há a passagem do formal para o informal ou vice-versa, se há algum pedido de permissão para o uso da forma mais informal, bem como se os verbos utilizados com tais pronomes seguem corretamente seu paradigma gramatical, ou seja, terceira pessoa verbal com as formas você e o senhor no Português e segunda pessoa verbal para o pronome tú e terceira para usted no Espanhol.

Além das formas de tratamento, observaremos também se há alguma forma nominal que antecede o nome do interlocutor, como Senhor, Dona e também se há concordância entre outros pronomes que eventualmente possam ser utilizados ao longo das entrevistas.

Abaixo, apresentaremos como funcionam os sistemas pronominais nos dois idiomas estudados. 


\subsubsection{Tú e usted - o sistema pronominal espanhol peninsular}

Carricaburo (op. cit., p.9) mostra que as formas pronominais em espanhol apresentam um sistema dual ou triádico, ou seja, é um sistema constituído de uma forma mais formal - usted e duas menos formais - tú e $\operatorname{vos}^{22}$.

De acordo com o autor, a Andaluzia, região onde está situada a cidade de Málaga, não segue o mesmo esquema pronominal do restante da Espanha, mas sim o mesmo esquema presente na região das Ilhas Canárias, no qual em vez de se utilizar vosotros para indicar informalidade plural, se opta por ustedes, mantendo a mesma forma tanto para as situações formais como informais.

No entanto, estudando outros autores, observamos que há certa divergência sobre esse aspecto. Matte Bon (1998, p. 244) não faz essa distinção da variante de Andaluzia com o restante da Península. De acordo com o autor, a Península utiliza vosotros para relações informais e usted para relações formais. Já Fontanella de Weinberg (1999, p.1403) é mais específica ao fazer a diferenciação entre Andaluzia Ocidental e Oriental ${ }^{23}$. A autora considera que a parte ocidental utiliza ustedes, tanto para relações formais quanto informais.

Analisando o mapa da Andaluzia, observamos que a comunidade de Málaga está entre as zonas oriental e ocidental, o que possivelmente seja a causa da divergência entre os teóricos estudados.

Entendemos que esse dado não afeta o resultado de nossa análise, uma vez que as entrevistas são feitas com um informante por vez, o que obrigatoriamente faz com que se utilize a forma singular, a qual é a mesma em toda a Península. No entanto procuraremos observar também, quando possível, o uso das formas ustedes e vosotros. A partir de nossas análises, pretendemos elaborar um quadro contendo os usos de pronomes retos e oblíquos da língua espanhola falada na região de Málaga entre os falantes de nível médio com idade até 35 anos e entre os de nível superior com idade de 50 a 70 anos.

O contexto do corpus espanhol que nos propusemos a analisar permite ao entrevistador tanto o uso da terceira pessoa, representada pela forma usted quanto da segunda, representada por tú. Isso porque em todas as entrevistas temos um entrevistador jovem entrevistando informantes de diversas idades e profissões, características essas que podem denotar maior poder para o informante. O que buscaremos comprovar por meio de

\footnotetext{
${ }^{22}$ É a forma utilizada para designar a segunda pessoa do singular na chamada América voseante.

${ }^{23}$ Sobre esse assunto, vide pág. 26. Ressaltamos apenas que não há nenhuma divisão administrativa entre as regiões Ocidental e Oriental, essa diferenciação refere-se apenas à localização geográfica.
} 
nossas análises é se prevalece o eixo de poder ou o de solidariedade, sobretudo entre os interlocutores que apresentam essas diferenças de idade e/ou profissão mais acentuadas. Por outro lado, por razões óbvias, se espera que o eixo de solidariedade prevaleça quando as diferenças forem mais tênues, no entanto apenas as análises poderão comprovar tal dado.

\subsubsection{Você e o senhor - o sistema pronominal do Português do Brasil}

O Português do Brasil também apresenta um sistema pronominal triádico se pensarmos que em algumas regiões existem dois pronomes menos formais - você e $t u^{24} \mathrm{e}$ é dual nas regiões que usa apenas você para indicar menor formalidade.

Assim como ocorre com o corpus espanhol, no material brasileiro também trabalharemos unicamente com o sistema pronominal dual, pois a região de onde $\mathrm{o}$ material brasileiro foi coletado não usa o pronome $t u$, restringindo-se apenas a você.

Cabe ressaltar que você e o senhor não são pronomes pessoais, porém exercem tal função ${ }^{25}$. De acordo com Cunha e Cintra (2001, p.289) "há certas palavras e locuções que valem por verdadeiros pronomes pessoais, como você, o senhor, Vossa Excelência."

Ao longo de nossa análise, procuraremos observar a forma como os interlocutores utilizam os pronomes você e o senhor. Bem como ocorre com o material espanhol, o contexto em que as entrevistas estão inseridas também permite o uso de ambas formas, pois há um entrevistador jovem entrevistando pessoas de diversas idades e profissões. Observaremos se prevalece o eixo de solidariedade ou de poder quando se considera a idade e/ou profissão do entrevistado e também se há a passagem da forma formal para a informal e em caso positivo, como se manifesta tal passagem.

\subsubsection{Evolução - você / usted}

Para trabalharmos com os pronomes você / usted no português e no espanhol é relevante que apresentemos as mudanças que ocorreram em ambas as línguas até que se chegasse às formas usadas hoje.

De Jonge (2005, p.1) apresenta a evolução do pronome espanhol. De acordo com o autor, os primeiros usos de vuestra merced se produziram em uma etapa em que vos

\footnotetext{
${ }^{24} \mathrm{O}$ pronome $t u$ é usado em algumas regiões do Brasil, no estado de São Paulo há a predominância do pronome você.

${ }^{25}$ É considerando a função exercida pela forma de tratamento você que a expomos como pronome.
} 
ainda era uma forma de reverência. As duas formas se alternavam no mesmo contexto para indicar a mesma pessoa.

Ainda segundo o autor, o estudo mais extenso e mais completo sobre o desenvolvimento vuestra merced - usted é o de Pla Carceles de 1923. Depois de estudar diversos exemplos da Língua Espanhola, chega a conclusão de que houve dois desenvolvimentos diferentes, dos quais sobrevive a forma usted, nascida em meados do século XVII.

Abaixo segue o esquema apresentado pelo autor sobre esse desenvolvimento, com base nos estudos de Pla Cárceles.

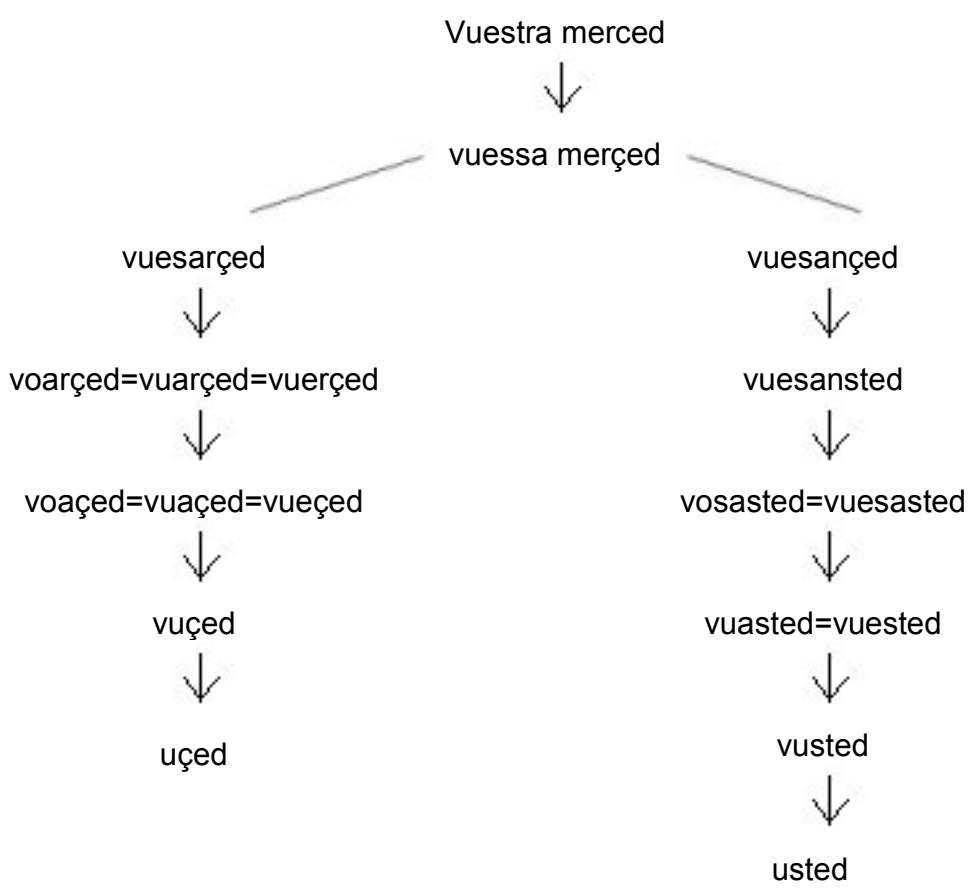

Com o Português do Brasil, o pronome de tratamento você surgiu a partir de uma evolução da forma vossa mercê. De acordo com Faraco (1996, p.58) a forma vossa mercê marcava um tratamento formal. No entanto, com o surgimento de uma nova classe social - a burguesia, a qual competiria com a nobreza, houve a necessidade da criação de uma nova posição de autoridade para o rei, pois a forma vossa mercê não era mais considerada suficiente para marcar tal status. A difusão de vossa mercê foi tão ampla no tratamento informal que houve a perda de seu valor honorífico.

O autor (op.cit. p.55) acrescenta que nas línguas da Península Ibérica há um traço particular, pois tanto você como usted são pronomes de segunda pessoa do discurso que estabelecem concordância com a terceira pessoa verbal.

É interessante ressaltar que a forma você tomou rumos diferentes no português de Portugal e do Brasil. A respeito desse assunto, Faraco (op.cit., p.63) coloca que a marca 
de relativa formalidade ligada a Vossa Mercê se manteve em Portugal, onde tu é ainda corrente no tratamento íntimo e você é usado no tratamento entre iguais não solidários ou entre interlocutores de status diferentes. Já no Brasil, você é o pronome de uso comum para o tratamento íntimo, estando o $t u$ restrito a algumas variedades regionais.

Tendo em vista o exposto, podemos afirmar que existe a relação entre você e usted entre o Espanhol Peninsular e o Português de Portugal, uma vez que o pronome espanhol também é utilizado entre iguais não solidários ou como marca de poder, seja devido à condição social ou à idade do interlocutor.

Atualmente o estágio atual do pronome você é a forma cê, amplamente usada em situações informais no Português do Brasil.

\subsubsection{Formas nominais}

No estudo apresentado acima, associamos as formas de tratamento às relações simétricas e assimétricas entre os interlocutores, relacionando-as aos eixos de solidariedade e poder. Fontanella de Weinberg (1999, p.1418) acrescenta que o estudo das formas de tratamento se torna inviável quando não se vincula também as formas nominais. A autora complementa que a diferença entre as formas nominais e as pronominais de tratamento é que a primeira é mais fechada, formada por vários subtipos de elementos. Assim, há as que se referem ao parentesco, à profissões, à relações de amizade, etc.

Devido ao tipo de relação existente entre entrevistador e informante, em nosso material de análise, há certa restrição quanto às formas nominais que podem ser encontradas, limitando-se apenas às que indicam profissão como professor, doutor e às gerais como senhor, senhora, dona.

Ao analisar as formas de tratamento utilizadas ao longo de cada entrevista, observaremos também se há a presença ou não de formas nominais e quais delas são usadas com maior frequência: as que se referem à profissão do informante ou as gerais, fazendo algum tipo de menção à idade do mesmo.

Entendemos que em ambos os casos a presença de tais formas está no eixo de poder e a ausência das mesmas no eixo de solidariedade. 


\section{Capítulo 3 - Metodologia}

Ao longo de nossa exposição sobre os estudos da cortesia, é possível a comprovação de que se trata de uma teoria bastante complexa que, para ser compreendida, necessita de leituras interdisciplinares como a Pragmática, Sociolinguística, entre outras.

No caso específico das entrevistas que compõem o nosso material de análise, o apoio em teorias Sociolinguísticas se mostra importante, pois foi por meio dos parâmetros levantados por tal teoria que houve a seleção dos informantes que participariam da pesquisa. Ressaltamos que parte dessa seleção foi feita pelos organizadores de cada corpus ao separá-los de acordo com o nível de instrução e região onde moravam. A outra parte foi determinada por nós, ao selecionar o mesmo número de entrevista de cada sexo e também ao pré-determinar a idade dos informantes, de acordo com o nível de instrução, assim como também a interpretação dos dados obtidos. Por consequência, obtivemos dois tipos de material de análise: um composto por informantes cujo nível de instrução é médio e idades até 45 anos e outro cuja instrução é superior e faixa etária de 50 a 70 anos. Diante de tal situação, outras questões sociolinguísticas não foram consideradas como a profissão, a renda mensal da família, o modo de vida e a classe social.

Por mais que existam diversos autores que abordem o tema, é muito difícil que uma teoria de cortesia possa ser plena e unicamente aplicada a determinada análise, sem que se faça algum tipo de recorte ou correspondência entre diferentes autores.

Como já exposto ao longo de nossa fundamentação teórica, acreditamos que é possível e necessário estudar a cortesia sob a ótica da Pragmalinguística e também da Pragmática Sociocultural, pois nosso corpus é composto por entrevistas realizadas com informantes que trazem consigo uma bagagem cultural que é insispensável para a compreensão e interpretação e, por outro lado, analisamos o conteúdo verbal de cada diálogo, o qual é o resultado e a materialização de tal contexto cultural.

Dessa forma, entendemos que cabe a cada analista procurar adequações para elaborar sua própria metodologia, observando em um primeiro momento as características que mais se sobressaem no corpus a ser analisado para, então, selecionar as teorias mais compatíveis com o material. A nosso ver, é bastante difícil a análise de todos os aspectos da cortesia, por isso é imprescindível que se faça um recorte, de forma que a parte selecionada seja analisada com a maior profundidade possível. 
Os passos seguidos para a elaboração de nossa metodologia consistiram em:

1. Determinação do tema, do gênero que seria analisado, dos objetivos, bem como das hipóteses principais.

2. Seleção de dois corpora que fossem passíveis de comparação. Nesse momento, tivemos a preocupação de que os materiais tivessem características semelhantes, como a época em que foram elaborados; a maneira como os informantes foram abordados - entrevistas semidirigidas e também as idades tanto dos entrevistadores quanto dos informantes.

3. Seleção das amostras que seriam analisadas, considerando que o gênero entrevista oferecia algumas limitações referentes a nossa análise.

4. Recorte teórico dos temas contidos em nossas análises:

a) Enunciados interrogativos, presença de marcas de imposição por parte dos entrevistadores;

b) Posição do sujeito (entrevistador / informante ${ }^{26}$ ) - desfocalização do eu, prevenção e ameaça à face, cortesia valorizante, formas de tratamento;

c) Expressão de opinião;

d) Atenuação;

e) Invasão do território pessoal;

f) Solidariedade.

5. A partir das análises individuais, realizamos uma análise comparativa entre as amostras de cada corpus e posteriormente uma confrontação de dados entre os corpora. Para isso, elaboramos gráficos quando esses facilitavam a visualização dos resultados ou apenas fizemos uma descrição dos dados.

Mais adiante apresentaremos detalhadamente as tabelas utilizadas e também a maneira como cada aspecto foi tratado ao longo de todas as análises.

Nossa análise teve como principal objetivo a comprovação ou não das hipóteses principais que motivaram esse estudo. Desse modo, formulamos algumas perguntas que facilitaram a elaboração de nossa metodologia:

a) As formas de comunicação nas intervenções verbais em Espanhol são mais diretas do que em Português?

b) É possível afirmar que há mais ou menos formalidade nos intercâmbios verbais em uma ou outra língua?

\footnotetext{
${ }^{26}$ Os termos entrevistador/informante foram adotados por nós ao fazer referência a ambos os corpora. O corpus ALIP utiliza em suas amostras documentador/informante e o PRESEEA entrevistador/informante.
} 
c) Podem-se encontrar mais ou menos marcadores de atenuação nas interações e em quais situações isso ocorre?

d) Quando há atenuação a mesma serve para marcar uma estratégia conversacional ou um distanciamento social?

Sendo assim, observamos que havia a necessidade de se analisar tanto a fala dos entrevistadores quanto dos informantes, pois a partir das perguntas elaboradas e da participação do entrevistador poderíamos tentar responder às questões apresentadas acima, além de averiguar como se dá a interação entre os participantes. Por outro lado, a partir da fala dos informantes, poderíamos constatar questões relacionadas à atenuação, à expressão de opinião, à desfocalização do eu e, por fim, a partir do diálogo como um todo, a constatação dar-se-ia em questões mais específicas das teorias que envolvem a cortesia, como a prevenção e ameaça à face do outro e as formas de tratamento utilizadas, verificando se há predominância do eixo de poder ou de solidariedade entre os participantes das entrevistas selecionadas.

Considerando todos esses dados apresentados, a disposição gráfica de nossa análise destina-se à facilidade de interpretação dos possíveis leitores de tal trabalho. Optamos pela elaboração de tabelas, para separar todas as falas dos entrevistadores e, posteriormente, partimos para a análise dos tópicos já mencionados, em que pode haver a fala tanto do entrevistador quanto do informante. Quando apenas a fala do informante for considerada, haverá tal explicação com justificativa ao longo de cada análise. Entendemos que devido à quantidade de amostras analisadas, em alguns momentos essa análise parecerá exaustiva, no entanto não encontramos outra maneira de fazê-la, de forma que todos os dados selecionados fossem contemplados.

Abaixo, apresentamos cada questão analisada e as justificativas teóricas que nos motivaram tal seleção.

\subsection{Enunciados interrogativos}

Uma das primeiras perguntas que nos fizemos ao iniciar os estudos da cortesia está relacionada à objetividade do falante. Como falante nativo do português e estrangeiro do espanhol, sempre houve a impressão de que a língua espanhola é mais direta do que o português, fazendo menos rodeio ao se dirigir ao outro. A análise da presença ou ausência de atos preparatórios, a necessidade de justificativas e explicações, o pedido de desculpas na elaboração dos enunciados interrogativos contidos em nossas entrevistas era um 
caminho para responder a essa pergunta e comprovar se a impressão que tínhamos sobre o nosso próprio idioma e sobre o idioma estrangeiro era falsa ou não.

Partindo de tais premissas, elaboramos tabelas contendo todas as falas dos entrevistadores. Essas tabelas eram separadas por tópicos. No caso do corpus brasileiro, seguimos a divisão feita pelos organizadores, a qual era composta por cinco partes. $\mathrm{O}$ material espanhol não apresentava divisão alguma, assim sendo, nós elaboramos a separação de acordo com os tópicos discutidos em cada entrevista. Fizemos menção sobre essa divisão nas análises individuais e ressaltamos que cada amostra do corpus espanhol possui número de tópicos diferentes, segundo os temas tratados em cada diálogo.

Abaixo apresentamos a tabela elaborada para a análise, a qual foi dividida em três partes:

\begin{tabular}{|c|c|c|}
\hline Perguntas principais & Perguntas secundárias & $\begin{array}{c}\text { Comentários / opiniões / } \\
\text { marcadores de } \\
\text { interação }\end{array}$ \\
\hline
\end{tabular}

Para efeito de análise quantitativa, consideraremos apenas as perguntas principais, cabendo à segunda coluna as perguntas complementares da primeira. Já a terceira coluna auxiliará a analisar a interação que houve entre os participantes da entrevista, por meio dela será possível visualizar os comentários e opiniões dados pelos entrevistadores.

Com relação à fundamentação teórica, apoiar-nos-emos nos estudos de KerbratOrecchioni (2005) já apresentados anteriormente ${ }^{27}$. Assim, procuraremos observar:

a) a forma como cada entrevistador se manifesta para elaborar sua pergunta;

b) se há predominância de enunciados diretos ou indiretos;

c) se há o uso de atos de preparação, de verbos no imperativo, ou enunciados que visam proteger a face do informante.

\subsection{Verbos no imperativo como marcadores discursivos}

Como tratado anteriormente, acreditávamos que um dos meios de se averiguar qual língua era mais direta era por meio do emprego de verbos no imperativo por considerar que esse modo tinha a função primordial de mandato. Como falante nativo do português, não nos dávamos conta do uso de tal modo verbal em nossa língua e, ademais, tínhamos a ideia, talvez por influência dos livros didáticos, de que era um modo verbal usado em abundância para atos diretivos na língua estrangeira em questão. Também percebemos que o modo imperativo em espanhol não é uma forma exclusiva para dar

\footnotetext{
${ }^{27}$ Vide pág. 48
} 
ordens, e sim pode ter conteúdos pragmáticos diversos, assim como existem outras estratégias linguísticas para esse fim, utilizando diversas formas modo-temporais.

Ao iniciar nossas análises, deparamo-nos sim com esse modo verbal nos enunciados interrogativos, porém pudemos observar outras situações de uso do mesmo exclusivamente na língua espanhola.

Entre essas outras situações de uso, focamos quatro verbos fijarse, imaginarse, oír e mirar, os quais eram utilizados fora do contexto de enunciado interrogativo, bem como fora da ideia de ordem ou solicitação.

Recuero (2001, p.254) classifica esses verbos como antigos imperativos, uma vez que perderam sua função inicial e passaram a ser empregados como marcadores discursivos, constituindo estratégias de cooperação com o interlocutor.

Assim, em nossa análise, observamos o uso do modo imperativo nos enunciados interrogativos e especificamente na análise do material espanhol, apresentamos as ocorrências que contêm tais verbos com esse segundo uso apresentado, seguidas de breve comentário.

Embora existam na Língua Portuguesa marcadores discursivos que se constituem como estratégias de cooperação com o interlocutor, optamos por não estabelecer comparação entre os materiais sobre esse tema, uma vez que tais verbos não são utilizados como estratégia de cortesia ou atenuação.

\subsection{Desfocalização do eu}

Apoiando-nos nas teorias de Haverkate (1994), expostas em nossa fundamentação teórica $^{28}$, entendemos por desfocalização do eu toda estratégia de atenuação cujo objetivo é a expressão de solidariedade e proteção da imagem positiva do falante, em que o uso causa certa aproximação entre os participantes e, consequentemente, aumenta a interação entre ambos.

Observando nossas entrevistas, verificamos que a incidência de situações em que o falante faz uso de outra pessoa verbal para descrever ações que se passaram com ele mesmo era relativamente alta.

Acreditamos que para que se pudesse fazer uma análise consistente era necessária a visualização dessas ocorrências, assim, nas análises individuais, citamos todas as falas que continham tal estratégia, de modo que pudéssemos averiguá-las em termos

\footnotetext{
${ }^{28}$ Vide pág. 72
} 
quantitativos para uma possível análise comparativa entre os corpora. Para melhor visualização dos resultados, apresentaremos gráficos com os números encontrados de cada tipo de desfocalização do eu na análise comparativa de cada material, a qual apresentaremos mais adiante.

\subsection{Prevenção e ameaça à face}

Como já tratado anteriormente, nosso material de análise é composto por entrevistas semidirigidas. A natureza desse tipo de material dá pouca margem para enunciados que ameacem a face do interlocutor, sobretudo quando essa ameaça parte do entrevistador para o informante, pois ao se sentir ameaçado o mesmo poderia finalizar a entrevista, fazendo com que os objetivos do entrevistador não fossem alcançados.

Ainda assim, encontramos ocorrências tanto de prevenção quanto de ameaça à face, seja do outro ou de si mesmo. Como poderá ser observado em nossas análises, optamos por criar dois tópicos distintos - um de prevenção e outro de ameaça à face de forma que pudessem ser analisadas separadamente.

Para análise dos resultados, transcrevemos e agrupamos todas as ocorrências encontradas em cada entrevista e na sequência apresentamos uma breve análise individual. Ressaltamos que em alguns momentos, foi necessária a extração de um trecho do diálogo entre entrevistador e informante para que a análise do mesmo pudesse ser compreendida pelos leitores.

\subsection{Atenuantes}

Entendemos que a análise dos marcadores de atenuação ${ }^{29}$ se faz importante, à medida que procuramos observar qual das línguas estudadas atenua mais ou menos, ainda que esse não seja o único instrumento utilizado para responder a essa questão, uma vez que os próprios enunciados interrogativos também podem nos auxiliar na obtenção de tal resposta.

Como pode ser observado ao longo de nossa exposição teórica ${ }^{30}$, existem vários tipos de recursos que podem ser utilizados como estratégias de atenuação, entre eles está o uso do diminutivo. Quando se leem na íntegra as entrevistas que compõem o nosso corpora, pode-se observar que há falantes que o usam abundantemente, no entanto

${ }^{29}$ Ressaltamos que a desfocalização do eu também é um exemplo de marcador de atenuação, entretanto optamos por separá-los e analisar nesse espaço marcadores como o uso de diminutivo, advérbios, entre outros, cuja função principal é mitigar a força do enunciado.

${ }^{30}$ Vide pág. 70 
devemos ressaltar que não é todo uso de diminutivo que corresponde a uma estratégia atenuadora, muitas vezes isso se refere a uma característica pessoal do informante.

Para a análise desse tipo de ocorrência, procuramos transcrever e agrupar os trechos em que as mesmas se encontram e na sequência apresentamos uma breve análise individual das ocorrências encontradas em cada entrevista. Quando são observadas ocorrências, como o caso do diminutivo mencionado acima, que embora possuam a forma, mas não a função de estratégia de atenuação, explicamos o ocorrido na própria análise individual.

\subsection{Expressão de opinião}

Entendemos que a expressão de opinião também poderia ser usada como instrumento de análise, pois por meio dela, podemos observar a maneira como cada informante se posiciona ao tratar determinado tema, seja ele polêmico ou não. Assim, podemos averiguar se há certo distanciamento da opinião dada ou não. Para isso, procuramos observar o uso de verbos e expressões chamados epistêmicos como crer, acreditar, pensar, etc. Acreditamos que nem sempre o uso de determinados verbos indicam dúvida do informante com relação ao que está sendo exposto, muitas vezes é a forma encontrada para prevenir a própria face, apontando que aquela é sua opinião e nem sempre é compartilhada com outros membros da sociedade.

Para analisar tal questão, também optamos por agrupar as ocorrências, destacando, quando há, os verbos epistêmicos. Na sequência, também apresentamos uma breve análise individual das ocorrências encontradas ao longo de cada entrevista.

Devemos ressaltar que devido à organização de cada corpus há certa diferença na apresentação da opinião de cada informante, isso porque no material brasileiro há uma pergunta destinada ao relato de opinião do informante, enquanto que no espanhol essas opiniões são dadas no decorrer da entrevista, sem que haja a necessidade de uma pergunta específica para isso. Logo, poderá ser verificada, algumas vezes, uma maior quantidade de relatos de opinião no material espanhol.

\subsection{Cortesia valorizante}

Como pode ser observado, há uma série de fatores que podem ser observados na identificação de marcadores de cortesia e atenuação ao longo de uma entrevista. Ainda desse modo, consideramos como cortesia valorizante atos de fala como saudações, despedidas, agradecimentos e também os elogios. 
Ao longo de nossa fundamentação teórica e apoiando-nos nos estudos de Haverkate $^{31}$, observamos que os espanhóis não têm o hábito de realizar agradecimentos, por exemplo, em situações cotidianas, nas quais está pressuposto que o ato realizado pelo outro não é um favor, mas sim a sua função, como no caso de um garçom ao servir a bebida, por exemplo.

A nossa proposta ao analisar tais atos de fala é justamente observar a presença ou ausência desse tipo de ocorrência tanto na fala dos brasileiros quanto dos espanhóis. Acreditamos que, especialmente na cultura brasileira, o uso de tais atos enaltece a face do interlocutor, contribuindo favoravelmente com a fluidez do diálogo.

Também é um tipo de ocorrência que não é frequente em todas as amostras e assim como fizemos para analisar outras estratégias de cortesia, transcrevemos os trechos e na sequência realizamos uma breve análise.

\subsection{Invasão de território pessoal}

Entendemos que na contramão dos marcadores de atenuação e cortesia, estão as ocorrências de invasão de território pessoal, nas quais se corre o risco de ameaçar a própria face e, principalmente, a do outro. Como por exemplo, tratar de aspectos da vida pessoal do informante, perguntando qual é o seu salário, questões relacionadas à vida sentimental, entre outros. Fatos que podem ser considerados invasão de privacidade em algumas culturas.

Expusemos anteriormente que nosso corpus trata de entrevistas semidirigidas. No entanto, em muitas delas, observa-se que a interação entre os participantes é acentuada, o que as deixa com características também de uma conversação informal. Ao adquirir tais aspectos, aumenta-se o risco de se fazerem perguntas mais pessoais que invadam a intimidade do informante.

Tais questões foram observadas em algumas amostras. Como meio de análise, extraímos e transcrevemos os trechos e elaboramos uma breve análise, com o intuito de verificar se houve ou não algum tipo de prejuízo à face do informante.

Assim, como a estratégia de cortesia valorizante, não são todas as amostras que apresentam tal tipo de ocorrência.

\footnotetext{
${ }^{31}$ Vide pág. 58
} 


\subsection{Solidariedade}

Como já apontado ao longo de nossa fundamentação teórica, a palavra-chave de qualquer situação de interação é equilíbrio. Os participantes devem estar sempre alerta para que não ameacem sua própria face e tampouco a de seu interlocutor.

Entendemos também que existem maneiras de se expressar solidariedade para com o outro ao longo de qualquer diálogo, seja no cuidado com a tomada de turno e até com o próprio conteúdo do mesmo.

Em nossas análises, não nos propusemos a verificar como se dava a tomada de turno ou qual recurso cada entrevistador utilizava para mudar o tópico da conversação.

Apenas consideramos como solidariedade as ocorrências em que um falante completa a fala do outro, quando esse demonstra algum tipo de esquecimento. Entendemos que além de aumentar a fluidez do diálogo, demonstra que o outro está atento ao que está sendo contado.

Para análise, transcrevemos os trechos em questão e fizemos uma breve análise individual. Ressaltamos que esse tipo de ocorrência não é comum em todas as amostras analisadas.

\subsection{Formas de tratamento}

Como já mencionado ao longo de nossa exposição teórica, a análise das formas de tratamento e formas nominais utilizadas pelos falantes das entrevistas que selecionamos nos ajudam a verificar como a cortesia é construída em cada língua, pois a seleção de uma ou outra forma se relaciona com a criação da imagem do outro e com as relações de mais ou menos poder, mais ou menos solidariedade ou reciprocidade ${ }^{32}$.

Devido à pré-análise que fizemos na leitura de cada entrevista na íntegra, acreditamos que não há a necessidade de se criarem tabelas ou gráficos para a análise individual, bem como de se fazer análise quantitativa. Dessa forma, apresentaremos os dados observados em cada entrevista e no final faremos uma análise qualitativa e por meio de uma tabela apresentar-se-ão os dados obtidos em todas as amostras analisadas.

Como pode ser observado ao longo das análises individuais de cada amostra, foram analisadas apenas as falas dos entrevistadores, pois como os mesmos se dirigem aos informantes diretamente, entendemos que seria possível encontrar vários tipos de pronomes, além dos pessoais do caso reto, como os oblíquos e os possessivos, por

\footnotetext{
${ }^{32}$ Eixo de solidariedade e poder de Brown e Gilman, vide pág. 76.
} 
exemplo, o que de fato ocorreu. Além disso, como não era nosso objetivo fazer uma análise quantitativa, não nos preocupamos em retirar todos os exemplos encontrados. Transcrevemos apenas um exemplo de cada tipo de pronome, com exceção apenas do material brasileiro, o qual apresentou certa irregularidade com relação aos pronomes de segunda e terceira pessoa, o que nos levou a transcrever todas as ocorrências encontradas.

Após a apresentação das formas de tratamento e nominais contidas em todas as entrevistas, procuraremos elaborar um esquema de uso de tais formas nas regiões estudadas.

\subsection{Análise dos resultados}

A partir das análises individuais com cada grupo de entrevistas - quatro no total, sendo: falantes de nível médio com idades até 35 anos e falantes de nível superior com idades entre 50 e 70 anos no português e no espanhol, elaboramos uma análise comparativa intra-corpus, analisando cada grupo como um todo.

Para analisar questões como a fala do entrevistador e desfocalização do eu, apoiamo-nos em gráficos, para que o leitor possa ter uma visão geral das ocorrências encontradas, bem como da frequência em que as mesmas se apresentam. Abaixo expomos um exemplo de maneira a explicar como cada gráfico deve ser interpretado, ainda que essa mesma explicação conste ao longo da análise do mesmo.

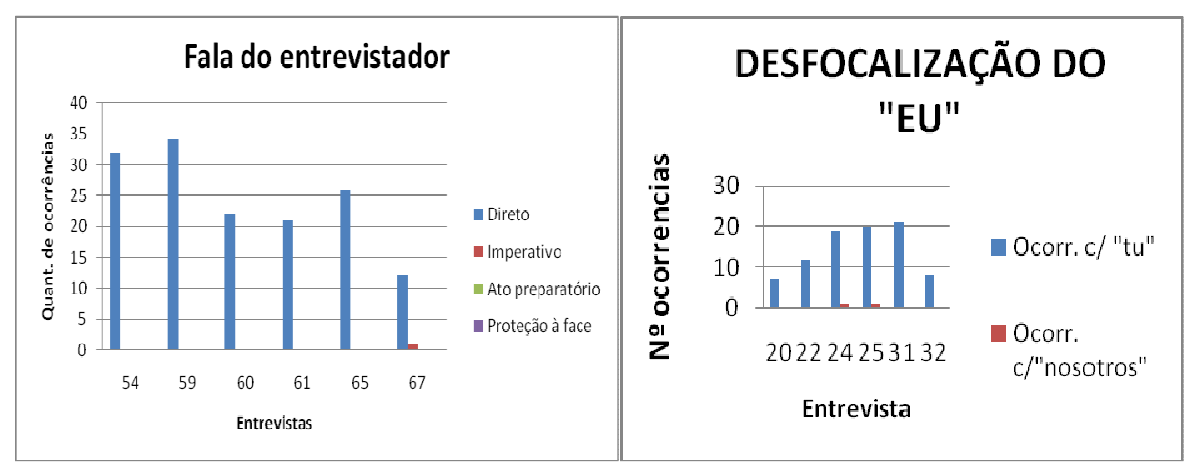

No primeiro gráfico, os números que aparecem abaixo das barras são referentes ao número de cada entrevista, designados pelos organizadores do corpus. No lado esquerdo das barras há o número de ocorrências encontradas e no direito uma legenda colorida com o tipo de ocorrência, separadas em: enunciados diretos, utilização de verbos no imperativo, de atos preparatório como eu gostaria, eu queria e proteção à face como você se lembra, você poderia me contar, etc. Para que cada amostra seja analisada de forma adequada, é fundamental que se observem as cores indicadas para cada ocorrência. 
No segundo gráfico, o objetivo é a análise das ocorrências de desfocalização do eu. No caso do exemplo apresentado acima, há apenas dois tipos de desfocalização, utilizando tú e nosotros. No entanto, como poderá ser observado em outras análises, poderá ocorrer também a presença de outros tipos de desfocalização. Os números apresentados na horizontal se referem ao número de cada entrevista, que como já apresentado anteriormente, foram designados pelos organizadores do material. Já a numeração na linha vertical é referente ao número de ocorrências encontradas em cada amostra. Entendemos que dessa forma, a visualização das entrevistas como um todo ficou esclarecedora.

Com relação à ocorrência de prevenção de ameaça à face, ao fazer a análise comparativa de cada material, sentimos a necessidade de fazer uma separação dos tipos de prevenção encontrados ao longo das análises individuais. De maneira geral, as ocorrências foram classificadas em: proteção à própria face, justificativas e proteção à face do interlocutor. Como transcrevemos os trechos nas análises individuais, apenas mencionamos as ocorrências mais frequentes estabelecendo uma comparação entre as amostras.

O mesmo procedimento tivemos com relação às ocorrências de ameaça à face, em que separamos as ocorrências mais comuns, classificadas de maneira geral em: exposição da própria face, falta de modéstia e ameaça à face do interlocutor. $\mathrm{Na}$ intenção de evitar que nossa análise ficasse muito repetitiva, não transcrevemos novamente os trechos com tal ocorrência, apenas mencionamos as mais frequentes, comparando as amostras.

Já com relação ao uso de atenuantes, expressão de opinião, solidariedade, invasão de território pessoal e cortesia valorizante, fizemos uma análise geral, mencionando as amostras que apresentavam ou não tais ocorrências.

Por fim, apresentamos a análise das formas de tratamento. Elaboramos uma tabela, a qual será apresentada abaixo, de maneira que o leitor possa ter uma visão geral dos pronomes encontrados, bem como da presença ou ausência das formas nominais.

\begin{tabular}{|c|c|c|c|c|c|}
\hline Amostra & $\begin{array}{c}\text { Sexo } \\
\text { do Inf. }\end{array}$ & Pron. Pessoal & $\begin{array}{c}\text { Pron. } \\
\text { Oblíquo }\end{array}$ & $\begin{array}{c}\text { Pron. } \\
\text { Possessivo }\end{array}$ & $\begin{array}{c}\text { Forma } \\
\text { Nominal }\end{array}$ \\
\hline & & & & & \\
\hline & & & & & \\
\hline
\end{tabular}


Ressaltamos que o exemplo acima tem apenas o efeito ilustrativo, para que seja possível compreender os meios utilizados em nossa análise.

Após as análises comparativas intra-corpus, partimos para a confrontação dos dados obtidos e conclusão de nosso estudo. 
Ao longo da explanação da metodologia selecionada e utilizada por nós para a realização desse trabalho, procuramos detalhar os critérios considerados, pois ainda que os corpora estudados sejam materiais diferentes, tentamos aproximá-los, de forma que as análises fossem mais uniformes e fiéis ao funcionamento das línguas - Português e Espanhol - dentro da comunidade linguística em que estão inseridas.

A seguir apresentaremos as análises, iniciaremos pelo corpus espanhol, níveis médio e superior e na sequência, o corpus brasileiro, níveis médio e superior. Após tal apresentação, há uma análise comparativa entre as entrevistas de cada nível e no final há outra análise entre os corpora, a fim de facilitar a leitura dos dados obtidos.

Ressaltamos que em todas as análises há tabelas contendo as falas do entrevistador e posteriormente a descrição das estratégias de cortesia e atenuação presentes nas amostras. Além disso, a extensão de cada análise varia conforme os conteúdos de cada entrevista.

\section{I. PRESEEA - Nível Médio}

\subsection{Amostra 20}

Informante masculino - 27 anos

Entrevistador feminino -24 anos

Tema 1 - Málaga e o colégio

\begin{tabular}{|c|c|c|}
\hline Perguntas principais & Perguntas secundárias & $\begin{array}{l}\text { Comentários / opiniões / } \\
\text { marcadores de } \\
\text { interação }\end{array}$ \\
\hline $\begin{array}{l}\text { (01) Bueno / en primer lugar } \\
\text { vamos a hacer la / el cuestionario } \\
\text { sociológico / dime para empezar } \\
\text { cómo te llamas } \\
\text { (03) ¿cuántos años tienes? } \\
\text { (05) ¿veintiséis? / ¿dónde naciste? } \\
\text { (07) ¿cuánto tiempo llevas en } \\
\text { Málaga? } \\
\text { (11) muy bien / y ¿dónde vives? } \\
\text { (19) de acuerdo muy bien// y ¿a qué } \\
\text { te dedicas? } \\
\text { (25) bien / y ¿qué estudios tienes? } \\
\text { (29) el al colegio y eso donde ibas / } \\
\text { ¿cómo se llamaba el colegio? } \\
\text { (44) muy bien / y // ¿cómo te iba en } \\
\text { el colegio? Por ejemplo / ¿eras buen } \\
\text { estudiante? }\end{array}$ & $\begin{array}{l}\text { (09) desde que naciste } \\
\text { (15) ¿en qué barriada? } \\
\text { (17) ¿es una barriada que está } \\
\text { cerca de La Luz? } \\
\text { (21) y ¿cómo se llama la empresa? } \\
\text { (42) o sea que ha viajado bastante } \\
\text { ¿no? } \\
\text { (46) sí ¿no? } \\
\text { (50) ¿y en bachillerato también? }\end{array}$ & \\
\hline
\end{tabular}


Tema 2 - Aficiones

\begin{tabular}{|l|l|l|}
\hline \multicolumn{1}{|c|}{ Perguntas principais } & \multicolumn{1}{|c|}{ Perguntas secundárias } & \multicolumn{1}{c|}{$\begin{array}{c}\text { Comentários / opiniões / } \\
\text { marcadores de interação }\end{array}$} \\
\hline $\begin{array}{l}\text { (56) bueno / ¿qué aficiones tienes? } \\
\text { / ¿qué es lo que te gusta? Por }\end{array}$ & $\begin{array}{l}\text { (59) practicas ¿practicas alguno? } \\
\text { ejemplo// de deportes / por practicas por ejemplo } \\
\text { ejemplo }\end{array}$ & \\
$\begin{array}{l}\text { el tenis? } \\
\text { (64) ¿y en cuánto a música? }\end{array}$ & \begin{tabular}{l} 
(68) yqué grupos o qué solistas o? \\
\hline
\end{tabular} & \\
\hline
\end{tabular}

Tema 3 - Trabalho

\begin{tabular}{|c|c|c|}
\hline Perguntas principais & Perguntas secundárias & $\begin{array}{l}\text { Comentários / opiniões / } \\
\text { marcadores de interacão }\end{array}$ \\
\hline $\begin{array}{l}\text { (76) muy bien// y // antes de } \\
\text { trabajar en esta empresa } \\
\text { ¿trabajaste en algún sitio más? }\end{array}$ & (81) ¿de qué era la tienda? & \\
\hline
\end{tabular}

Tema 4 - Leitura

\begin{tabular}{|l|l|l|}
\hline \multicolumn{1}{|c|}{ Perguntas principais } & \multicolumn{1}{|c|}{ Perguntas secundárias } & $\begin{array}{l}\text { Comentários / opiniões / } \\
\text { marcadores de interação }\end{array}$ \\
\hline $\begin{array}{l}\text { (84) y por ejemplo / de libros y eso } \\
\text { / ¿tú sueles leer? } \\
\text { (88) ¿qué tipo de periódicos? }\end{array}$ & $\begin{array}{l}(90) \text { ¿tada danto de noticias asín / } \\
\text { generales como de deportes? } \\
\text { (92) ¿y revistas? } \\
\text { (94) ¿cómo se llama? }\end{array}$ & \\
\hline
\end{tabular}

Tema 5 - Família

\begin{tabular}{|c|c|c|}
\hline Perguntas principais & Perguntas secundárias & $\begin{array}{l}\text { Comentários / opiniões / } \\
\text { marcadores de interação }\end{array}$ \\
\hline $\begin{array}{l}\text { (96) muy bien// vamos a hablar } \\
\text { un poquito de tu familia / de / tus } \\
\text { padres ide dónde son? } \\
\text { (102) itu madre es de Málaga } \\
\text { capital? } \\
\text { (105) ¿y tus hermanos? / ¿cuántos } \\
\text { hermanos tienes? } \\
\text { (109) ¿y a qué se te parece ¿no? / } \\
\text { y ia qué se dedica? } \\
\text { (113) ¿y tus abuelos? / ¿tú los } \\
\text { conoces? } \\
\text { (126) y ¿qué relación mantienes / } \\
\text { por ejemplo con tu hermana? } \\
\text { ¿cómo te llevas con ella? }\end{array}$ & $\begin{array}{l}\text { (107) ¿qué edad tiene? } \\
\text { (111) empresariales y ¿cómo le va? } \\
\text { (118) los abuelos de de / o sea tus } \\
\text { abuelos por parte de tu padre / son } \\
\text { de Marruecos también ¿no? } \\
\text { (120) muy bien// y ia qué se } \\
\text { dedicaban? / por ejemplo } \\
\text { (131) ¿y eso? }\end{array}$ & $\begin{array}{l}\text { (99) de Fez / entonces tú } \\
\text { tienes familia allí ¡claro! }\end{array}$ \\
\hline
\end{tabular}

Tema 6 - El barrio / o trabalho dos pais

\begin{tabular}{|c|c|c|}
\hline Perguntas principais & Perguntas secundárias & $\begin{array}{l}\text { Comentários / opiniões / } \\
\text { marcadores de interação }\end{array}$ \\
\hline $\begin{array}{l}\text { (135) hablando un poquito asín } \\
\text { de tu barrio / ¿te gusta el sitio } \\
\text { donde vives? } \\
\text { (139) ¿es una barriada grande o? } \\
\text { (143) ¿dón / dónde vivías en } \\
\text { Madrid? } \\
\text { (146) y allí ¿en qué trabajaba tu } \\
\text { padre? } \\
\text { (163) ¡hombre! ¡claro! Normal/ y } \\
\text { // y en tu bloque / ¿tú conoces a la } \\
\text { gente de tu bloque? Por ejemplo / }\end{array}$ & $\begin{array}{l}\text { (137) ¿por qué? } \\
\text { (150) entonces actualmente su } \\
\text { trabajo aquí en Málaga es ese ¿no? } \\
\text { (156) ¿dónde vive ahora? } \\
\text { (158) ¿y tu madre? } \\
\text { (168) ¿tu madre mantiene buenas } \\
\text { relaciones con la gente de? } \\
\text { (176) ¿dónde te gustaría vivir? }\end{array}$ & \\
\hline
\end{tabular}


¿tienes trato con ellos?

(171) ¿suele salir por ejemplo con ellos a?

(174) muy bien entonces a ti te gustaría vivir en otro sitio ¿no?

(179) de hecho de hecho tienes un pisillo por algún lado ¿no?

Tema 7 - A família

\begin{tabular}{|c|c|c|}
\hline Perguntas principais & Perguntas secundárias & $\begin{array}{l}\text { Comentários / opiniões / } \\
\text { marcadores de interação }\end{array}$ \\
\hline $\begin{array}{l}\text { (186) vale / vamos a hablar un } \\
\text { poquito de lo que es tu núcleo } \\
\text { familiar entonces ¿quiénes / } \\
\text { quiénes trabajan en tu casa? } \\
\text { (191) ¿qué ingresos económicos } \\
\text { tienes? / por término medio / todos } \\
\text { los meses / en casa? } \\
\text { (193) sí ¿no? / y el // el trabajo en } \\
\text { casa ¿quién lo hace? } \\
\text { (198) y ¡bueno! / tú ya eres } \\
\text { bastante mayorcito ¿no? pero / } \\
\text { ¿quién manda en tu casa? } \\
\text { (209) ¿qué relación mantienes tú } \\
\text { con tu madre y con tu padre? / } \\
\text { ¿cómo te llevas con ellos } \\
\text { actualmente? } \\
\text { (214) y cuando tú eras más } \\
\text { pequeño// tus padres / por ejemplo } \\
\text { con tus amistades y eso ¿cómo? / } \\
\text { ¿eran abiertos o conocían a tus } \\
\text { amigos? }\end{array}$ & $\begin{array}{l}\text { (189) los nos ¿no? } \\
(195) \text { ¡tú nada! } \\
(202) \text { ¿y cuando eras más pequeño? } \\
\text { (217) ¿son de una mentalidad asin } \\
\text { abierta? }\end{array}$ & $\begin{array}{l}\text { (204) tu padre era el que } \\
\text { (206) como todas las madres } \\
\text { ¿no? }\end{array}$ \\
\hline
\end{tabular}

Tema 8 - Tempo livre

\begin{tabular}{|l|l|l|}
\hline \multicolumn{1}{|c|}{ Perguntas principais } & Perguntas secundárias & $\begin{array}{l}\text { Comentários / opiniões / } \\
\text { marcadores de interação }\end{array}$ \\
\hline $\begin{array}{l}\text { (219) bueno y tu tiempo libre / ¿a } \\
\text { qué lo dedicas? }\end{array}$ & (227) hay mucha gente ¿no? & \\
\hline
\end{tabular}

Tema 9 - Namorada e sua família

\begin{tabular}{|c|c|c|}
\hline Perguntas principais & Perguntas secundárias & $\begin{array}{l}\text { Comentários / opiniões / } \\
\text { marcadores de interação }\end{array}$ \\
\hline $\begin{array}{l}\text { (229) ¿tú tienes? ¿sales con algún } \\
\text { amigo? / ¿tienes novia o algo? } \\
(237) \text { ¿cuánto tiempo llevas con } \\
\text { ella? } \\
\text { (243) muy bien / entonces } \\
\text { prácticamente cuando sales / } \\
\text { sueles salir con ella ¿no? } \\
\text { (251) por aquí por donde tú vives } \\
\text { ¿hay sitios así de ambiente? } \\
\text { (254) y ¿qué relación mantienes } \\
\text { por ejemplo con la familia de / de } \\
\text { tu novia? } \\
\text { (262) ¿sueles salir? Cuando salís y } \\
\text { eso ¿sueles salir a lo mejor con tus } \\
\text { cuñados y eso? o }\end{array}$ & $\begin{array}{l}\text { (231) ¿cómo se llama } \\
(233) \text { ¿cuántos años tiene? } \\
(235) \text { ¿a qué se dedica? } \\
(248) \text { ¡claro! / y ¿dónde soléis / } \\
\text { soléis ir? }\end{array}$ & $\begin{array}{l}\text { (241) ya no hay ya no hay } \\
\text { marcha atrás }\end{array}$ \\
\hline
\end{tabular}


Tema 10 - Identificação com algum grupo

\begin{tabular}{|l|l|l|}
\hline \multicolumn{1}{|c|}{ Perguntas principais } & Perguntas secundárias & $\begin{array}{l}\text { Comentários / opiniões / } \\
\text { marcadores de interação }\end{array}$ \\
\hline $\begin{array}{l}\text { (266) muy bien// ¿tú te identificas } \\
\text { con algún grupo heavy o algo así? }\end{array}$ & $\begin{array}{l}(268) \text { o jipi / nada de eso ¿no? } \\
(270) \text { tú por libre } \\
(272) \text { a tu aire }\end{array}$ \\
\hline
\end{tabular}

Tema 11 - Tempo livre / viagens

\begin{tabular}{|c|c|c|}
\hline Perguntas principais & Perguntas secundárias & $\begin{array}{l}\text { Comentários / opiniões / } \\
\text { marcadores de interação }\end{array}$ \\
\hline $\begin{array}{l}\text { (274) cuando tienes vacaciones y } \\
\text { eso ¿sueles viajar? / o ¿has } \\
\text { viajado? } \\
\text { (283) cuéntame un poquito } \\
\text { (285) cuéntame un poco lo del } \\
\text { viaje a Roma } \\
\text { (297) la gente / por ejemplo de } \\
\text { Italia que son europeos / ¿sabes? / } \\
\text { tú notas mucha diferencia con } \\
\text { respecto a la gente de de } \\
\text { Marruecos o la gente de Túnez/ tú } \\
\text { que has viajado } \\
\text { (318) ¿qué diferencias ves tú con } \\
\text { respecto Roma como ciudad a } \\
\text { Málaga? } \\
\text { (326) ¿y en Túnez qué ¿fuisteis al } \\
\text { desierto? Cuéntame un poco } \\
\text { (343) y la gente allí es bastante } \\
\text { hospitalaria ¿no? }\end{array}$ & $\begin{array}{l}\text { (279) ¿dónde has ido? } \\
(302) \text { ¿los árabes? } \\
(307) \text { ¿cómo es la gente allí? ¿es un } \\
\text { poco más? } \\
(316) \text { ¿la gente es hospitalaria? } \\
(340) \text { ¿en camello? }\end{array}$ & $\begin{array}{l}\text { (295) que tú ya estás un poco } \\
\text { más familiarizado } \\
\text { (311) eso ya es una } \\
\text { diferencia ¿no? } \\
\text { (313) entonces allí la gente } \\
\text { va de marcha de día } \\
\text { (329) las aventuras del } \\
\text { desierto }\end{array}$ \\
\hline
\end{tabular}

Tema 12 - Família e vizinhos

\begin{tabular}{|c|c|c|}
\hline Perguntas principais & Perguntas secundárias & $\begin{array}{l}\text { Comentários / opiniões / } \\
\text { marcadores de interação }\end{array}$ \\
\hline $\begin{array}{l}\text { (348) muy bien / y tus parientes // } \\
\text { te tienen ¿los ves con frecuencia? } \\
\text { O cuéntame un poco qué } \\
\text { relaciones familiares mantenéis } \\
\text { (362) ¿tu madre cuántos hermanos } \\
\text { tiene? } \\
\text { (370) y ¿tienes / primos asín de tu } \\
\text { edad? } \\
\text { (375) ¿y con la familia de tu } \\
\text { padre? ¿con qué frecuencia sueles } \\
\text { ir tú a Marruecos? por ejemplo } \\
\text { (378) ¿cúantos padres tie? } \\
\text { ¿cuántos hermanos / tiene tu } \\
\text { padre? } \\
\text { (399) ¿allí qué es? / ¿dónde viven? } \\
\text { ¿en una ciudad pequeña grande? o } \\
\text { ¿cómo? } \\
\text { (405) ¿a qué se dedican / así por } \\
\text { encima? } \\
\text { (410) ¡ah! / ¡claro! / mira está } \\
\text { bien?no? / y ¿suelen llamar por } \\
\text { teléfono / escribir? ¿soléis } \\
\text { escribir? ¿o? } \\
\text { (418) ¿sueles ir solo? ¿vas con tu } \\
\text { madre? ¿con tu hermana? ¿o? } \\
\text { (424) ¿a ti te gusta el mundo este }\end{array}$ & $\begin{array}{l}\text { (356) tu abuela era madre de tu } \\
\text { padre / ¿o de tu madre? } \\
\text { (364) ¿y dónde viven? } \\
\text { (380) que tu padre se casó que tu } \\
\text { abuelo } \\
\text { (382) ¿pero a la vez o? } \\
\text { (442) ya como ¿cómo se dice como } \\
\text { ¿cómo es? } \\
\text { (447) pero / tu madre un poquito } \\
\text { más ¿no? } \\
\text { (452) ¿allí al mismo barrio? } \\
\text { (458) ¿hay algún bingo cercano? }\end{array}$ & $\begin{array}{l}\text { (358) madre de tu madre } \\
\text { (368) el tío con el que tú } \\
\text { trabajas en Honda / es } \\
\text { hermano de tu madre } \\
\text { (374) que tira cada uno para } \\
\text { un lado } \\
\text { (384) hombre! / en su } \\
\text { cultura / es normal ¿no? } \\
\text { (388) pero ya no mantiene } \\
\text { relaciones } \\
\text { (394) juh! icuando venga } \\
\text { Lourditas / entonces lo con } \\
\text { los de Marruecos has dicho } \\
\text { que de vez en cuando }\end{array}$ \\
\hline
\end{tabular}


de vivir allí en Marruecos y eso? ¿te gusta o no?

(435) ¿entonces el nivel de vida allí es es bajo alto o

(444) como marajás/ eso/ muy bien / tú me has dicho que no te sueles relacionar mucho con tus vecinos ¿no?

(449) con ¿qué suele hacer con las vecinas? ¿hay alguna peña? / ¿suele ir a los bares a tomar café? (460) ¿y de qué suelen hablar? / bueno no sé si lo sabrás / tu madre $\mathrm{y}$ eso / cuando se une con sus amigas y eso /// ¿les gusta cotillear de las demás vecinas?

(465) tu padre cuando estaba aquí con ustedes ¿se relacionaba con los vecinos?

Tema 13 - ambiente de trabalho

\begin{tabular}{|c|c|c|}
\hline Perguntas principais & Perguntas secundárias & $\begin{array}{l}\text { Comentários / opiniões / } \\
\text { marcadores de interação }\end{array}$ \\
\hline 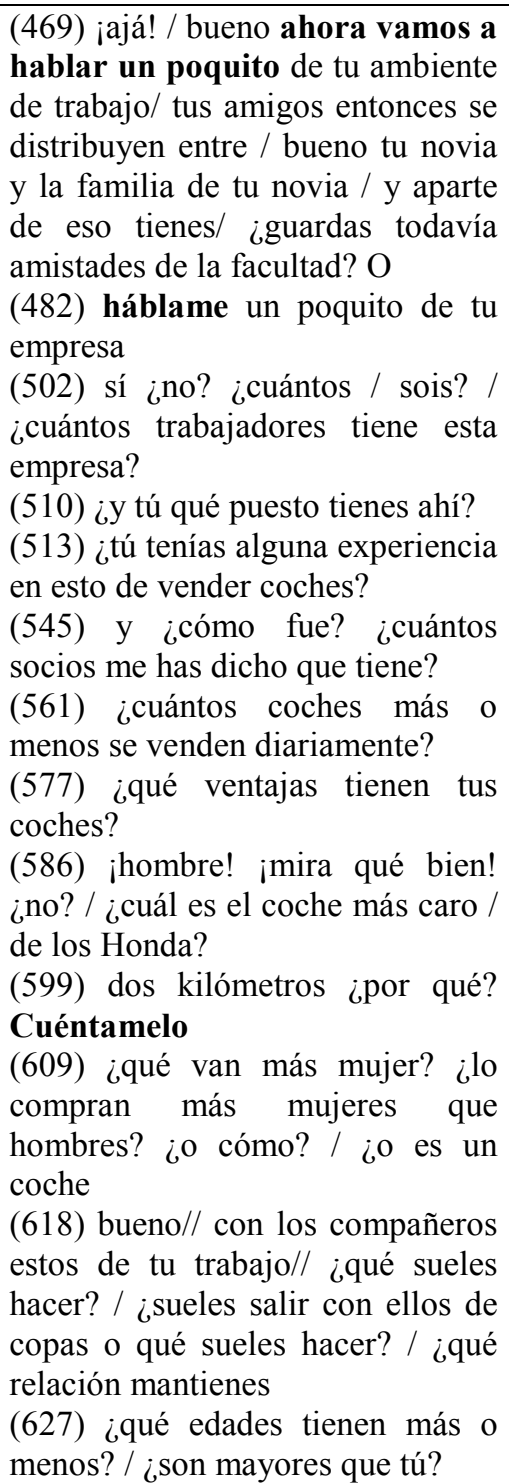 & $\begin{array}{l}\text { (476) ¿qué pueblo es? } \\
\text { (486) es la única / es exclusiva en } \\
\text { Málaga / ¿no? } \\
\text { (516) y te has amoldado bien a este } \\
\text { trabajo ¿no? / ¿te gusta? } \\
\text { (522) ¿cuál es el coche más barato? } \\
\text { (527) ¡claro! ¿y el más caro? } \\
\text { (529) el más caro que tú has } \\
\text { vendido ¿cuál es? } \\
\text { (539) Honda es como una marca } \\
\text { japonesa ¿no? } \\
(541) \text { ¿y vendéis motos y eso } \\
\text { también? O sólo } \\
\text { (547) ¿y tú sabes más o menos } \\
\text { cómo fue la historia de crear esta } \\
\text { empresa aquí? ¿cómo? / era } \\
\text { bastante arriesgado ¿no? } \\
\text { (564) eso es un ritmo bueno ¿no? } \\
\text { (580) ahora se ha remodelado línea } \\
\text { ¿no? / por ejemplo del Concierto } \\
\text { ¿no? } \\
\text { (593) ¡once kilos! // ese fue el que } \\
\text { yo vi ¿no? } \\
(602) \text { y / ¡claro! Me has dicho que } \\
\text { la gente que va a comprar esos } \\
\text { coches son gentes con / con } \\
\text { dinerillo ¿no? } \\
\text { (605) normalmente ¿a qué se suelen } \\
\text { dedicar por ejemplo? } \\
\text { (615) sí ¿no? / ¿tú a qué piensas } \\
\text { que se puede deber eso? } \\
(631) \text { y ¿están casados y eso? } \\
\text { (640) para ti ¿qué es un amigo? } \\
\text { (642) ¿y algo más? }\end{array}$ & $\begin{array}{l}\text { (491) pero ¡vamos! La } \\
\text { empresa va para arriba ahora } \\
\text { tenéis una nave / bastante } \\
\text { (533) siete kilos / una } \\
\text { maravilla de coche ¿no? } \\
\text { (566) sobre todo que hablan } \\
\text { de la crisis ésta y que tanto } \\
\text { que no } \\
\text { (568) se venden coches } \\
\text { (591) el Ferrari japonés }\end{array}$ \\
\hline
\end{tabular}


(635) ¿soléis salir en parejas? / tú con tu novia y ellos y eso ¿o no?

(638) ¡claro! ¿tú los consideras amigos tuyos

Tema 14 - amizades

\begin{tabular}{|l|l|l|}
\hline \multicolumn{1}{|c|}{ Perguntas principais } & \multicolumn{1}{|c|}{ Perguntas secundárias } & $\begin{array}{l}\text { Comentários / opiniões / } \\
\text { marcadores de interação }\end{array}$ \\
\hline (646) muy bien// vamos a ver/ & $(660)$ no / sí que eras jovencito así & \\
¿qué mas te puedo preguntar? // & ino? & \\
¿mantienes relación? Me dijiste & $(668)$ ¿tenías entonces una especie & \\
que estuviste viviendo en Madrid / & de pandilla? & \\
¿mantienes contacto con alguna & $(670)$ ierais todos niños / niñas o & \\
amistad de allí? & cómo? & \\
(652) cuando vivías en Madrid & & \\
¿qué edad tenías? & & \\
(662) iy salías con tus amigos por & & \\
/ por ahí o & & \\
\hline
\end{tabular}

Tema 15 - temas polêmicos

\begin{tabular}{|c|c|c|}
\hline Perguntas principais & Perguntas secundárias & $\begin{array}{l}\text { Comentários / opiniões / } \\
\text { marcadores de interação }\end{array}$ \\
\hline $\begin{array}{l}\text { (674) muy bien/ vamos a hablar } \\
\text { un poquito por ejemplo / ¿qué } \\
\text { piensas de de la iglesia? / ¿tú eres } \\
\text { musulmán o no? } \\
\text { (681) ¿es que es más eficaz / la } \\
\text { religión musulmana? ¿Cuándo a } \\
\text { uno le va mal algo? ¡mira qué } \\
\text { bien! } \\
\text { (687) ¿cómo es la? Explícame un } \\
\text { poco ¿tú sabes cómo es la cultura } \\
\text { esta musulmana? } \\
\text { (697) el Ramadán / ¿qué? ¿qué } \\
\text { cons? Eso ¿qué es? } \\
\text { (710) tu padre eso / ¿lo ha } \\
\text { practicado también? } \\
\text { (718) tú que conoces dos } \\
\text { religiones ¿cuál te parece más? / } \\
\text { ¿qué opinión tienes? / ¿son las dos } \\
\text { / iguales / en el fondo o? } \\
\text { (729) ¿y tu madre se ha? ¿ha } \\
\text { adoptado también las costumbres } \\
\text { de tu padre? ¿o no? } \\
\text { (732) ¿cómo se conocieron tus } \\
\text { padres? } \\
\text { (736) muy bien/ en cuanto/ por } \\
\text { ejemplo a la sanidad y eso / ¿qué } \\
\text { piensas de ella? } \\
\text { (754) ¿tú piensas que / que aquí en } \\
\text { España / se llegará algún día a eso } \\
\text { / a que haya más clínicas privadas } \\
\text { que // que lo que es la pública / } \\
\text { que la gente vaya más a lo privado } \\
\text { que a lo público? }\end{array}$ & $\begin{array}{l}\text { (677) en tu familia tu padre sí lo es } \\
\text { ¿no? } \\
(690) \text { ¿tú lo haces? } \\
(692) \text { ¿cuándo? } \\
(694) \text { ¿por qué? } \\
\text { (712) ¿y ha intentado / ¡bueno! ¡no } \\
\text { obligaros! Sino que? } \\
\text { (714) ustedes / si lo habéis hecho es } \\
\text { porque habéis querido } \\
\text { (724) ¿tú eres? } \\
\text { (726) ¿tú eres religioso o eres } \\
\text { católico o? } \\
\text { (738) tú eres fuerte de salud ¿no? } \\
\text { (742) ¿y en Marruecos cómo llevan } \\
\text { eso de la sanidad? } \\
\text { (748) o sea que tienes que pagar } \\
\text { ¿no? } \\
\text { (758) ¿tú antes de ir a un hospital } \\
\text { público / vas a uno privado? }\end{array}$ & $\begin{array}{l}\text { (700) un mes sin comer } \\
(702) \text { ¡ah! / ipor la noche! } \\
(704) \text { ipor la noche nada } \\
\text { más! } \\
(708) \text { ¡qué horror! ¿no? } \\
(750) \text { y entonces ¡claro! / irá } \\
\text { la gente que tiene dinero } \\
\text { ¿no? }\end{array}$ \\
\hline
\end{tabular}


Tema 16 - cotidiano

\begin{tabular}{|l|l|l|}
\hline \multicolumn{1}{|c|}{ Perguntas principais } & \multicolumn{1}{|c|}{ Perguntas secundárias } & $\begin{array}{l}\text { Comentários / opiniões / } \\
\text { marcadores de interação }\end{array}$ \\
\hline $\begin{array}{l}\text { (763) no ibueno! / no sé si lo } \\
\text { sabes pero tu madre por ejemplo / } \\
\text { ¿dónde suele ir a hacer las } \\
\text { compras? ¿por dónde se suele } \\
\text { mover? }\end{array}$ & $\begin{array}{l}\text { ¿dónde soléis ir? } \\
\text { (770) ¿qué bien! / pues / } \\
\text { semana o? }\end{array}$ & \\
\hline
\end{tabular}

Tema 17 - política

\begin{tabular}{|c|c|c|}
\hline Perguntas principais & Perguntas secundárias & $\begin{array}{l}\text { Comentários / opiniões / } \\
\text { marcadores de interação }\end{array}$ \\
\hline $\begin{array}{l}\text { (773) muy bien // vamos a hablar } \\
\text { / ahora de / algo importante } \\
\text { (777) ¿qué ideología / es la tuya? } \\
\text { (789) ¿tú piensas que si ponen a } \\
\text { otra persona como / presidente } \\
\text { ganan? } \\
\text { (791) y ¿tú cómo ves a España } \\
\text { bajo los socialistas? } \\
\text { (803) tú por ejemplo / ¿sabes o? } \\
\text { ¡bueno! No sé si tu padre lo vivió } \\
\text { a qué / ¿el régimen franquista? } \\
\text { (814) tu padre cuando llegó aquí } \\
\text { era musul / es musulmán iclaro! } \\
\text { ¿se sintió rechazado en algún } \\
\text { momento o? ipor la sociedad que } \\
\text { encontró que se encontró cuando } \\
\text { llegó? } \\
\text { (823) ¿tú piensas que España es } \\
\text { racista? } \\
\text { (836) y aparte de ¡bueno! / ya que } \\
\text { estamos hablando de esto / los } \\
\text { conflictos que se forman todos los } \\
\text { veranos / con lo s con los } \\
\text { musulmanes / ¿qué opinión te da } \\
\text { eso? } \\
\text { (844) ¿quién te da pena? } \\
\text { (861) y y con los / con los } \\
\text { emigrantes con la / ¡bueno! Con la } \\
\text { ley esta del gobierno de controlar } \\
\text { la la emigración de los de los } \\
\text { musulmanes que quieren venirse a } \\
\text { trabajar a España y eso ¿qué te } \\
\text { parece? } \\
\text { (871) pero / tampoco me/ ¡bueno! } \\
\text { Me imagino que tampoco te } \\
\text { parecerá justo el modo / en que se } \\
\text { les trata ¿no? } \\
\text { (880) hablando ya así de racismo } \\
\text { y eso ¿tú sientes que España es } \\
\text { racista? / iyo que sé! / por } \\
\text { ¿ejemplo con los gitanos? } \\
\text { (890) lo que ha pasado } \\
\text { últimamente en Alemania con lo } \\
\text { de / la mujer ésta que han } \\
\text { quemado y eso ¿a ti qué? } \\
\text { (896) ¿tú piensas que ese es el } \\
\text { problema? / ¿Qué se le está dando }\end{array}$ & $\begin{array}{l}\text { (775) de política } \\
\text { (783) ¿tú pensabas que iban a } \\
\text { volver a ganar los socialistas ahora } \\
\text { con las elecciones? } \\
\text { (785) ¿por qué? } \\
\text { (795) piensas que ése es el } \\
\text { problema } \\
\text { (806) iy te habla te? O ¿te ha } \\
\text { hablado de ello? } \\
\text { (819) ¿tú crees? } \\
(821) \text { y e incluso hasta ahora ¿no? } \\
(828) \text { tú ibueno! / ¿tú te has sentido } \\
\text { alguna vez rechazado? } \\
\text { (830) ¿tú cómo lo dices? } \\
\text { (838) lo que ha pasado hace poco / } \\
\text { bueno hace poco } \\
(852) \text { por eso vienen siempre } \\
\text { cargados ¿no? } \\
\text { (883) tú particularmente ¿lo eres? } \\
\text { (884) ¿y por qué? } \\
(893) \text { ¿tú no notas que en Europa } \\
\text { están volviendo otra vez los } \\
\text { movimientos estos / de xenofobia? } \\
\text { (899) de todos modos / tú crees que } \\
\text { es totalmente injusto ¿no? } \\
\text { (903) y ¿por q por qué? } \\
\text { (905) entonces ¿qué eres? ¿objetor } \\
\text { de conciencia? } \\
\text { (910) y piensas que es una pérdida } \\
\text { de tiempo } \\
\text { (919) ¿y por qué? } \\
\text { (921) ¿Por qué te da envidia de la } \\
\text { mujeres? ¿o que? } \\
\text { (923) por ejemplo / entra en tu } \\
\text { negocio una mujer y que resulta } \\
\text { que vende más coches que tú / ¿tú } \\
\text { que sientes? } \\
\text { (943) entonces llegará un momento } \\
\text { en el que / si tienes que fregar lo } \\
\text { hagas ¿no? } \\
(945) \text { y más cosas } \\
\text { (958) ¿tú conoces así gente que le } \\
\text { haya afectado / este momento? } \\
\text { (963) pero Málaga es una ciudad } \\
\text { costera y / hay mucho trabajo en } \\
\text { hostelería y la verdad es que hay } \\
\text { mucho menos turismo ¿no? }\end{array}$ & $\begin{array}{l}\text { (797) que le han ofrecido } \\
\text { demasiadas cosas a la gente y } \\
\text { (811) en tu casa entonces } \\
\text { prácticamente sois / de } \\
\text { derecha ¿no? } \\
\text { (833) porque ¡claro! } \\
\text { Evidentemente tú te sientes } \\
\text { también musulmán ¿no? } \\
\text { tienes raíces } \\
\text { (835) eso / árabe } \\
\text { (848) es una verdadera } \\
\text { hazaña lo que hacen ¿no? } \\
\text { (858) iclaro! / porque se } \\
\text { traen una lavadora y se la } \\
\text { venden allí a cualquiera y eso } \\
\text { es un objeto de lujo allí ¿no? } \\
\text { / o no. } \\
\text { (866) de la gente esta de la } \\
\text { que viene de / que quiere } \\
\text { trabajar aquí de los } \\
\text { musulmanes que quieren } \\
\text { (928) pues iprepárate! } \\
\text { (930) iprepárate! } \\
\text { (932) iprepárate! } \\
\text { tranquilo que ya verás } \\
\text { (936) iya ves!/ janda y que } \\
\text { no! de todos modos / en tu } \\
\text { casa ¡bueno! Porque siempre } \\
\text { estás en tu casa con tu madre } \\
\text { / pero el día de mañana si te } \\
\text { casas o o vas a vivir con } \\
\text { (939) te vas los dos trabajáis } \\
\text { Lourditas si lo }\end{array}$ \\
\hline
\end{tabular}


demasiada publicidad?

(901) muy bien / tú por ejemplo ¿has hecho la mili?

(913) ¿tú crees que debería ser voluntaria?

(915) ¿tú eres machista / Mohamed?

(941) ¿tú no piensas que debes apoyar un poquito / también?

(951) bueno / hablando asín / tú que te mueves en un ambiente que ser relaciona con / con la economía porque las ventas ¿no? / ¿tú cómo ves la situación ésta de actualmente en España?

(961) tienes razón / y el para y eso ¿qué opinión te da?

(980) ¿tú crees que España puede competir con esos países europeos?

(982) ¿y podrá llegar a competir o no?
(970) no sí en parte llevas razón y España y Europa / iqué te parecen?

(984) ¿tú crees que sí?

(986) ¿qué? ¿qué habría que cambiar?

(988) ¿a lo españoles / la política / la economía / o qué?

Tema 18 - o bairro

\begin{tabular}{|c|c|c|}
\hline Perguntas principais & Perguntas secundárias & $\begin{array}{l}\text { Comentários / opiniões / } \\
\text { marcadores de interação }\end{array}$ \\
\hline $\begin{array}{l}\text { (998) ¡ah! ¡muy bien! / bueno } \\
\text { vamos a hablar un poquito de } \\
\text { bueno de tu barrio me has dicho } \\
\text { que no tienes mucha relación con } \\
\text { él ¿no? } \\
\text { (1008) bueno / ¿en cuanto por } \\
\text { ejemplo a delincuencia // y droga? }\end{array}$ & $\begin{array}{l}\text { (1002) aparte de eso es un barrio } \\
\text { que está bien comunicado ¿no? } \\
\text { (1004) ¿sabes si hay asociaciones } \\
\text { de vecinos y eso? } \\
(1012) \text { ¿a ti te han robado alguna } \\
\text { vez? / ¿o algo? } \\
\text { (1014) y ¿tú notas distinción de } \\
\text { clases sociales en tu barrio? } \\
\text { (1016) allí básicamente la gente } \\
\text { que vive / ¿qué es? }\end{array}$ & \\
\hline
\end{tabular}

Tema 19 - a entrevista / forma de falar dos espanhois

\begin{tabular}{|c|c|c|}
\hline Perguntas principais & Perguntas secundárias & $\begin{array}{l}\text { Comentários / opiniões / } \\
\text { marcadores de interação }\end{array}$ \\
\hline $\begin{array}{l}\text { (1020) y bueno / itú piensas que } \\
\text { ha cambiado tu forma de hablar } \\
\text { durante la entrevista? } \\
\text { (1025) bueno / ¿tú piensas que se } \\
\text { habla bien en Málaga? } \\
\text { (1033) itú tienes alguna ciudad } \\
\text { española que sea/ digamos un } \\
\text { estereotipo que sea un modelo? } \\
\text { (1042) ¡muy bien! / me dijiste que } \\
\text { veías bastante la ibueno! La tele } \\
\text { sobre todo programas deportivos } \\
\text { ¿no? / ¿tú / crees que los locutores } \\
\text { de televisión hablan bien? } \\
\text { (1057) bueno y para finalizar } \\
\text { ¿conoces alguna palabra castiza // } \\
\text { de aquí de Málaga o de tu barrio o } \\
\text { alguna palabra que utilicéis en tu } \\
\text { trabajo? }\end{array}$ & $\begin{array}{l}\text { (1027) ¿por qué? } \\
(1046) \text { ¿sueles ver Canal Sur? } \\
(1048) \text { ¿qué canales son los que } \\
(1051) \text { ¿películas? } \\
(1053) \text { ¿cuáles te gustan? } \\
\text { (1060) no caes ¿no te acuerdas de } \\
\text { ninguna? }\end{array}$ & $\begin{array}{l}\text { (1037) los madrileños que } \\
\text { hablan muy bien }\end{array}$ \\
\hline
\end{tabular}


Como pode ser observado por meio das tabelas apresentadas, trata-se de uma entrevista bastante extensa. Optamos por dividi-la em 19 partes, de acordo com os temas tratados, a fim de facilitar a análise e também aproximá-la das entrevistas do corpus brasileiro que já apresentam uma divisão prévia dos temas tratados.

Entendemos que essa grande quantidade de temas tratados se deve a baixa interação entre entrevistador (E) e informante (I), havendo maior necessidade de se aumentar a quantidade de perguntas para manter a fluidez do diálogo. Assim, em vez de ampliar as respostas do I por meio de comentários, o E opta por fazer novas perguntas.

Com relação à planificação, observamos que há certo padrão para a inicialização, assim, o E pergunta se o I é de Málaga, em que lugar da cidade mora, etc. Ainda que a quantidade de temas tratados seja relativamente grande, verifica-se que o planejamento é bastante superficial, dado que se comprova pela quantidade de vezes que se retomam temas anteriormente tratados. Além disso, a temática gira em torno da vida do I. Ressaltamos que a divisão por temas apresentada anteriormente foi elaborada por nós, com a finalidade de facilitar a análise, uma vez que a entrevista na íntegra é apresentada em um único bloco de perguntas e respostas.

O número de perguntas principais, cujo tema tem maior relevância, é bastante alto. Entre elas, observamos quatro tipos de enunciados: os interrogativos diretos e interrogativos com o uso de imperativo - esse muitas vezes usado quando o $\mathrm{E}$ quer que o I detalhe algum tema e os enunciados indiretos, os quais são divididos em proteção à face e o uso de ato preparatório. Além disso, podemos afirmar que os papéis de E e I são bem definidos nessa entrevista, não há ocorrências em que o I faz perguntas ao E, por exemplo. A baixa interação entre os participantes justifica a ausência desse tipo de ocorrência, bem como a definição dos papéis.

\subsubsection{Imperativo}

Além das ocorrências mencionadas sobre o uso do modo imperativo em algumas de suas perguntas, principalmente quando o seu objetivo é que o I lhe dê mais detalhes sobre o tema tratado, encontramos também uma única ocorrência em que o uso desse modo verbal apresenta diferente intenção, no caso envolver o interlocutor com aquilo que está sendo exposto, chamando-lhe a atenção. 
(868) I: ¡ah! !ya! / que que no / que hacen bien / si no hay trabajo para los españoles pues / imagínate que entre gente de fuera...

\subsubsection{Desfocalização do eu}

Como já abordado ao longo da fundamentação teórica desse trabalho, é bastante comum que entrevistas com as características de nosso corpus apresentem ocorrências em que o falante procure se distanciar da enunciação, fazendo uso da segunda ou terceira pessoas do singular ou ainda da primeira ou terceira pessoas do plural. Abaixo apresentamos os trechos em que ocorre esse tipo de estratégia.

(291) I: ... pues es un sitio más turístico / estilo aquí a la costa / si te metías en alguna ciudad de Túnez porque hicimos por Túnez un tour ¿no? Para ver al algo más / y te metías en alguna ciudad de estas pues ya veías cosas típicas...

(298) I: ... por ejemplo de Italia que son europeos / ¿sabes? / tú notas mucha diferencia con respecto a la gente...

(347) I: ... entonces cuanto más simpáticos eran pues / tenías que dar propinas / que era de lo que viven más o menos

(430) I: un ambiente completamente distinto / mucho más tranquilo y si quieres vivir como se vive aquí pues necesitas dinero // allí hay o o tienes o no tienes / o no haces nada / lo que son discotecas y todo esto para salir / como aquí exactamente igual es / bastante caro // si te quieres tomar una cerveza o güisqui / que te lo tomas aquí / fácil vamos / que eso no es / no es caro...

(641) I: una persona en la que confías

(759) I: si // el trato es más personal // y tú puedes tener mucha más información de / de / del médico que que / que te puede tratar me / te puede dedicar más tiempo que que uno de la Seguridad Social que no te puede dedicar más que cinco minutos / o que te operan y subes / te dicen tres tonterías y se van

(809) I: ... había trabajo para todos mucha seguridad / ibas por la calle y no pasaba nada a las tantas de la noche...

Observa-se que entre todas as ocorrências apresentadas há apenas a utilização da segunda pessoa do singular. Interpretamos esse recurso como uma estratégia de o informante incluir o entrevistador em sua fala, aproximando-se do mesmo. Assim, fala de maneira geral, sem especificar diretamente se se refere a ele ou a qualquer outra pessoa, inclusive ao próprio interlocutor.

\subsubsection{Prevenção de ameaça à face}

Ao analisar a questão de prevenção de ameaça à face, observamos que há três casos diferentes. O primeiro, no qual foram encontradas cinco ocorrências, em que o I faz uma dupla prevenção à face. No segundo caso, é o E quem procura preservar a face do I ao incluir em suas perguntas expressões como más o menos, ou no sé si lo sabes... ele já previne o outro, caso não saiba responder sua pergunta. Abaixo apresentamos os trechos encontrados, seguidos de breve análise.

(36) I: ... ¿qué más? / ya no me acuerdo // hasta sexto después pasé a otro colegio que no me acuerdo cómo se llamaba / en el mismo Madrid...

(108) I: veintitrés me parece 
(138) I: no lo sé pero no / no me gusta no te puedo dar una explicación

(229) E: ¿tú tienes? ¿sales con algún amigo? / ¿tienes novia o algo?

(266) E: muy bien// ¿tú te identificas con algún grupo heavy o algo así?

(336) I: ... al norte me parece que era / al norte de Túnez / viendo ya cosas típicas / digamos hasta cerca de la frontera con con Argelia me parece que era / con Argelia...

(370) E: y ¿tienes / primos asín de tu edad?

(460) E: ¿y de qué suelen hablar? / bueno no sé si lo sabrás / tu madre y eso /cuando se une con sus amigas y eso // ¿les gusta cotillear de las demás vecinas?

(547) E: ¿y tú sabes más o menos cómo fue la historia de crear esta empresa aquí? ¿cómo? / era bastante arriesgado ¿no?

(561) E: ¿cuántos coches más o menos se venden diariamente?

(733) I: pues / mi padre se vino a trabajar aquí // muy joven / y aquí la conoció // trabajando aquí / porque montó un negocio aquí // con dieciocho años me parece que vino // montó un negocio y se conocieron // más detalles no sé

(763) E: no ¡bueno! / no sé si lo sabes pero tu madre por ejemplo / ¿dónde suele ir a hacer las compras? ¿por dónde se suele mover?

O uso de verbos performativos ou expressões parentéticas que indicam certa dúvida do I sobre aquilo que está sendo exposto gera uma proteção na sua face, caso o dado não seja preciso e também protege a face do outro, no caso o entrevistador, que evitará fazer perguntas mais específicas sobre tal tema. Isso fica bastante claro nas ocorrências encontradas nas linhas 138 e 733, nas quais o I não se nega a responder a pergunta feita, mas já procura esclarecer ao E a impossibilidade de dar mais detalhes sobre o tema.

Já nas linhas 229, 266 e 370, observa-se outro tipo de proteção à face, semelhante ao segundo caso mencionado, nele o E utiliza expressões vagas como algo, algo así, asín ao elaborar suas questões, de forma que o I fique mais livre ao responder essas perguntas. Ao não ser tão específico, o E previne uma possível ameaça à face do I, caso não tenha uma resposta.

\subsubsection{Ameaça à face}

Como já observado ao longo de nossa fundamentação teórica, não é comum que se encontre em uma entrevista atos que ameacem a imagem do interlocutor. Nessa amostra, em especial, pensávamos ser difícil isso acontecer, uma vez que E e I não se conheciam e apresentaram poucos momentos de interação ao longo do diálogo. No entanto, encontramos sim algumas ocorrências interpretadas como ameaça à face do I. Acreditamos que a proximidade de idade entre os participantes tenha gerado tal liberdade. Liberdade essa que cabe às duas partes: ao $\mathrm{E}$ ao elaborar tais perguntas e ao I ao não querer respondê-las. Para facilitar a interpretação dos dados, apresentaremos de forma separada as ocorrências em que o $\mathrm{E}$ ameaça a face do I e quando é o próprio I que ameaça sua própria face. 
Fala do E:

(191) ¿qué ingresos económicos tienes? / por término medio / todos los meses / en casa?

(681) ¿es que es más eficaz / la religión musulmana? Cuando a uno le val mal algo? ¡mira qué bien!

(772) ¿qué ideología es la tuya?

(880) hablando ya así de racismo y eso ¿tú sientes que España es racista? / ¡yo que sé! Por ¿ejemplo con los gitanos?

(883) tú particularmente ilo eres?

(884) sí / racista sí / lo puedo decir

(900) entonces ¿qué eres? / objetor de conciencia

(910) ¿tú eres machista / Mohamed?

(916) ¿Por qué te da envidia de las mujeres?

(936) ¿tú no piensas que debes apoyar un poquito / también?

(938) entonces llegará un momento en el que / si tienes que fregar lo hagas ¿no?

Fala do I:

(27) ... me salió el trabajo y lo he ido abandonando / pero de todas formas no iba muy bien

(53) ... menos en COU bachillerato bien / menos em COU que fue un cambio muy radical en Tanger y / allí hice unas amistades peligrosas y entonces ...

(138) ... no lo sé pero no / no me gusta no te puedo dar una explicación.

(222) ... ahora casi no puedo / casi no puedo porque // el dinero va muy justo ya

(678) ... a rachas / cuando le va mal sí

(750) E: y entonces ¡claro! / irá la gente que tiene dinero ¿no?

(751) I: no / también cuando se está enfermo se saca dinero de donde sea para / por la salud vamos / para curarse la salud se saca el dinero de donde sea / prefieren visitar clínicas privadas.

(828) E: porque ¡claro! Evidentemente tú te sientes también musulmán ¿no? tienes raíces

I: no sentirme no musulmán no / sentirme árabe sí / un poquito

(830) E: eso / árabe

Podemos observar que são diversas as situações em que o E corre o risco de ameaçar a imagem do I, há claramente a invasão do território pessoal e entre as ocorrências que consideramos mais acentuadas estão a primeira em que pergunta quanto a família ganha mensalmente, a questão da religião, na qual houve a necessidade de uma correção para que houvesse o reequilíbrio da imagem e também o último caso, no qual o E demonstra fazer uma recriminação ao I pelo fato de ele já ter dito anteriormente que não fazia serviços domésticos. Levando em consideração as respostas dadas pelo I, acreditamos que a única que afetou a sua imagem foi realmente a da religião, em todos os outros casos, ele respondeu às perguntas sem demonstrar estranheza ou algum tipo de incômodo.

Com relação às ocorrências encontradas na fala do $\mathrm{I}$, podemos observar que o mesmo não demonstra preocupações em expor suas opiniões, ainda que isso coloque em risco a sua imagem. Ao contrário, ele é bastante sincero em admitir que é racista, em dizer claramente que não sabe sobre determinado assunto e também ao falar sobre religião, ameaçando a imagem de seu pai, ao dizer que só procura a religião quando precisa. 
É justamente essa questão da religião que nos faz acreditar que o I procurou gerar um clima de liberdade entre ambos ao longo da entrevista, pois brinca com o fato, tampouco se preocupando com a imagem negativa que poderia criar com sua fala.

Acreditamos que o fato de ter consciência de que se tratava de uma entrevista com finalidade de análise linguística e a idade próxima entre os participantes contribuíram para que um clima mais informal fosse criado e também que não houvesse demasiada preocupação com as imagens dos interlocutores.

\subsubsection{Atenuantes}

Ao longo dessa entrevista foi possível observarmos também algumas estratégias de uso de marcadores de atenuação. A maioria das ocorrências foi encontrada na fala do E. Abaixo apresentamos os trechos, seguidos de breve análise. Para facilitar a leitura, separamos as falas do I e do E.

Fala do I:

(221) I: ... me gusta ver los deportes en televisión// salir un poquito por la noche...

(224) I: y nada y ahora en verano pues supongo que un poquito la playa ¿no? Pero se está poniendo...

Fala da E:

(96) muy bien // vamos a hablar un poquito de tu familia

(135) hablando un poquito de tu barrio

(179) de hecho de hecho tienes un pisillo por algún lado ¿no?

(186) vale / vamos a hablar un poquito de lo que es tu núcleo familiar...

(198) y ¡bueno! / tú y eres bastante mayorcito ¿no? pero / ¿quién manda en tu casa?

(469) ... bueno ahora vamos a hablar un poquito de tu ambiente de trabajo

(603) ¡claro! Me has dicho que la gente que va a comprar esos coches son gentes con dinerillo ¿no?

(660) no / sí que eras jovencito ¿no?

(674) muy bien // vamos a hablar un poquito por ejemplo...

(998) ... bueno vamos a hablar un poquito de bueno de tu barrio me has dicho que no...

$\mathrm{Na}$ fala do I foram encontradas apenas duas ocorrências, ambas com o uso do adjetivo poco acompanhado do sufixo de diminutivo. Entendemos esses dois exemplos apenas como uma forma de enfatizar a resposta, intensificando o conteúdo de sua fala. Levando o leitor a acreditar que ele gosta bastante de sair à noite ou de ir à praia.

Já na fala do E foram identificadas maior número de ocorrências dessa estratégia, sendo que podemos dividi-las em dois tipos: o uso do adjetivo poco acompanhado do sufixo de diminutivo e o uso de substantivos no diminutivo. 
O primeiro caso acontece sempre em perguntas, geralmente iniciando uma mudança de tópico e o interpretamos como uma forma cortês de o E invadir a privacidade do I e fazer perguntas sobre sua família, seu bairro, seu trabalho.

Nos outros três casos apresentados - linhas 186, 198 e 603 - a interpretação é um pouco diferente: no primeiro exemplo (linha 186) acreditamos ser mais uma forma carinhosa de o E se referir ao imóvel do I. No segundo caso (linha 198), acreditamos que não havia perigo de ameaça à imagem do I, foi uma forma que o $\mathrm{E}$ encontrou para expressar que o I não precisava que ninguém mandasse nele ou que mesmo com certa idade, ainda era possível que o pai ou a mãe "mandassem" na casa. Já o terceiro exemplo (linha 603) pode ser interpretado como ironia por parte do E, uma vez que ele queria dizer justamente o contrário, ou seja, que quem compra os carros vendidos pelo I são pessoas que têm muito dinheiro.

\subsubsection{Expressão de opinião}

Nesse campo, procuramos observar se ao emitir suas opiniões o I faz uso de algum tipo de verbo ou expressão performativo com o objetivo de atenuar o conteúdo de sua fala, tais verbos encontram-se destacados em negrito. Abaixo apresentamos os trechos encontrados ao longo da entrevista. Todas as ocorrências abaixo pertencem à fala do I.

(320) diferencias Roma es una ciudad mucho más cultural que Málaga muchas más cosas que ver muchas / hay mucha historia allí // Málaga es un sitio turístico de vacaciones simplemente para pasarlo tomando el sol y y refrescándose en el agua / ya está/ en Málaga no hay nada que ver

(720) es lo mismo / todo es creer en algo // en el fondo van a lo mismo las dos / lo que pasa es que / que en el mundo árabe se lleva / todo lo que es la religión se lleva // no más a rajatabla / pero hay más // más gente religiosa / la gente en general es religiosa // aquí no

(759) si // el trato es más personal // y tú puedes tener mucha más información de / de / del médico que que / que te puede tratar me / te puede dedicar más tiempo que que uno de la Seguridad Social que no te puede dedicar más que cinco minutos / o que te operan y subes / te dicen tres tonterías y se van

(792) bueno / España ha mejorado bastante / eso sí que es verdad pero todavía sigue mucha corrupción / cosas sin aclarar / y han incitado mucho al consumismo y ahora estamos como estamos

(798) muchas cosas que / que después no se han podido hacer / hubo unos años muy buenos / nos gastamos lo que no teníamos/ y eso es lo que pasa ahora / todo viene derivado de ahí / y cosas hechas a a destiempo / aquí en Málaga sin ir más lejos las las autovías estas nuevas / todas a destiempo // muchas obras que hay que repetir mal hechas / mucho gasto

(824) sí / hay bastante racismo

(873) bueno / ellos ¡claro! / tienen sus motivos para salir de allí también / allí es miseria total // tienen que buscarse la vida como sea / a mí me parece fenómeno que vengan también por si pueden conseguir algo / lo que pasa que son la mayoría son trabajos de lo que puedan conseguir / trabajos campo o de limpieza o lo que sea...

(892) eso ya es racismo a lo bestia

(913) por supuesto / siendo voluntario hay mucha más profesionalización // y no ir / y no ir allí a a perder el (974) pienso ¡vamos! / no he salido mucho por ahí / he salido una vez a Europa pero ¡vamos! / por lo que veo por ahí / yo trato a mucha gente muchos extranjeros / los extranjeros se ríen cada vez que vienen aquí. 
Como se pode averiguar, há diversas partes ao longo da entrevista em que o $\mathrm{E}$ pede para o I expressar sua opinião sobre algum tema e ele o faz sempre que solicitado. Em apenas duas ocorrências encontramos verbos performativos, que interpretamos como expressão de opinião e não como indicador de dúvida por parte do I. Em todas as outras ocorrências, independentemente do tipo de opinião que deveria dar, o I não faz uso desse tipo de verbo ou expressão, porém como pode ser observado nos exemplos apresentados nas linhas 320, 798 e 974, o I usa outros recursos que objetivam a preservação de sua face.

No trecho apresentado na linha 320, observa-se o uso de justificativa para depois dar a sua opinião sobre as atrações encontradas em Málaga. Já no caso das linhas 798 e 974, o I apresenta expressões que atenuam a sua fala, esclarecendo que o que é dito é restrito à região de Málaga no caso da linha 798 e ao que ele tem contato no excerto 974. Entendemos que são formas de se precaver de uma possível ameaça à face.

Já nos outros trechos transcritos, há a expressão de opinião explícita, sem qualquer tipo de marcador de atenuação ou modalizador.

Como pode ser observado na terceira coluna da tabela apresentada no início desta análise, em diversos momentos o $\mathrm{E}$ também contribui com opiniões e comentários. Interpretamos tais ocorrências como benéficas para a interação entre os participantes, bem como para a fluidez do diálogo, no entanto, preocupamo-nos em analisar apenas a fala do I, no intuito de averiguar como esse falante expressa sua opinião sobre o tema tratado ao longo da entrevista.

\subsubsection{Invasão do território pessoal}

Além das ocorrências apresentadas acima, acreditamos ser relevante destacar as ocorrências que se configuram como invasão do território pessoal do informante.

(54) I: “...menos en COU bachillerato bien / menos em COU que fue un cambio muy radical en Tanger y / allí hice unas amistades peligrosas y entonces / bueno para la es la primera vez que fui a septiembre." (191) E: ¿qué ingresos económicos tienes? / por término medio / todos los meses / en casa?

(777) E: ¿qué ideología es la tuya?

Observamos que no primeiro exemplo apresentado o I expressa um dado de sua vida pessoal e o E não se aprofunda no tema, evitando invadir o território privado do informante, ele opta por mudar o tema a ser tratado.

Já nas outras duas ocorrências apresentadas, as quais pertencem ao entrevistador, identificamos perguntas que invadem o território privado do outro. Entendemos que são 
perguntas de âmbito pessoal do I, sobretudo a primeira ocorrência, além de não apresentar grande relevância para o conteúdo da entrevista. No entanto, não acreditamos que essas duas perguntas tenham interferido no andamento da entrevista, pois o I as respondeu sem demonstrar qualquer tipo de problema. Além disso, caso se sentisse constrangido poderia optar em não respondê-las.

Como pode ser observado, os trechos mencionados já foram analisados como ameaça à face, porém por se tratarem também de invasão do território pessoal, optamos por mencioná-los novamente.

\subsubsection{Solidariedade}

Por fim, outro tipo de ocorrência encontrada, refere-se à solidariedade entre os participantes da entrevista, na qual um complementa a fala do outro quando percebe tal necessidade. Abaixo os trechos em que isso acontece:

(442) E: ya como ¿cómo se dice como ¿cómo es?

I: como marajás

E: como marajás / eso / muy bien / y / tú me has dicho que no te sueles relacionar mucho con tus vecinos ¿no?

(888) E: siempre hay algún pero ¿no?

I: hay algún recelo

Nos dois casos é o I quem complementa a fala do E. Entendemos esse recurso como uma estratégia de cortesia, pois esse tipo de atitude permite a fluidez do diálogo. A língua falada tem a característica de ser muito dinâmica e é comum que esses lapsos ocorram. Na fundamentação teórica de nosso trabalho aclaramos que de acordo com Goffman é dever de todos os participantes da interação procurar manter o equilíbrio das faces; a solidariedade entre os falantes contribui para que o equilíbrio seja mantido sem causar danos a nenhum dos participantes.

\subsubsection{Formas de tratamento}

Observa-se que o tratamento dispensado ao informante dessa amostra é a forma tú acompanhado dos verbos na segunda pessoa. Abaixo apresentamos alguns excertos da fala do entrevistador.

(01) Bueno / en primer lugar vamos a hacer la / el cuestionario sociológico / dime para empezar cómo te llamas

(03) ¿cuántos años tienes?

(96) muy bien// vamos a hablar un poquito de tu familia / de / tus padres ¿de dónde son?

(126) y ¿qué relación mantienes / por ejemplo con tu hermana? ¿cómo te llevas con ella? 
Devido à regularidade com que as formas de tratamento são apresentadas, retiramos apenas alguns trechos da entrevista. Como pode ser observado por meio dos exemplos acima, o E usa apenas a segunda pessoa do singular, estabelecendo concordância com pronomes possessivos e pronomes pessoais oblíquos.

Não há uso de formas nominais, fato esperado devido à idade do informante.

\subsection{Amostra 22}

Informante masculino - 32 anos

Entrevistador feminino - 28 anos

Tema 1 - A viagem de lua de mel

\begin{tabular}{|c|c|c|}
\hline Perguntas Principais & Perguntas complementares & $\begin{array}{l}\text { Comentários / opiniões / } \\
\text { marcadores de interação }\end{array}$ \\
\hline $\begin{array}{l}\text { (01) ¿tú naciste en Málaga? } \\
\text { (376) y ¿hay cruceros por el Rin } \\
\text { por el Danubio? } \\
\text { (396) pero y ¿y son tan limpias } \\
\text { las playas de Canarias como las } \\
\text { de Mallorca? }\end{array}$ & $\begin{array}{l}\text { (05) ¿en dónde? } \\
\text { (19) ¡ah! o sea que volviste en } \\
\text { seguida ¿no? } \\
(25) \text { ¿sí? ¿en Paris o? } \\
\text { (29) ¿a Paris? } \\
\text { (32) ¡ah! a Tenerife ¡mejor! / } \\
\text { preferís esa zona } \\
\text { (35) ¿por qué? } \\
\text { (52) demasiado ¿no? } \\
\text { (68) y ¡claro! / es que tres días } \\
\text { allí en Eurodisney tres días en } \\
\text { Paris nada más y / pero tres días } \\
\text { en Eurodisney es } \\
\text { demasiado ¿no? / para vosotros } \\
\text { (86) ¿vendrán ellos a la boda? } \\
\text { (96) ¿tienes mucha relación con } \\
\text { ellos? } \\
\text { (110) ¿tú lo conoces ya? } \\
\text { (118) yo nunca he estado / ¿qué? } \\
\text { ¿como es Tenerife? } \\
\text { (125) y la ciudad es ¿o pequeña } \\
\text { o? } \\
\text { (150) te ha dado tiempo a beber } \\
\text { más ¿no? } \\
\text { (152) te ha dado tiempo a beber } \\
\text { más / hasta las cuatro de la } \\
\text { mañana } \\
\text { (179) ¿qué es? / ¿más a vuestro } \\
\text { aire o con un programa? } \\
\text { (225) ¿cómo se llama? } \\
(334) \text { iah! / ¡que la comida no va } \\
\text { incluida! } \\
\text { (348) ¿puede ser? }\end{array}$ & $\begin{array}{l}\text { (61) ¡claro! } \\
\text { (66) ¡claro! / en Paris en abril } \\
\text { todavía hace } \\
\text { (78) ponte cómodo } \\
\text { (82) entonces tendrías que ir a } \\
\text { verlos } \\
\text { (94) ¡qué bien! ¿no? } \\
\text { (98) lo digo para visitarlos en los } \\
\text { Alpes } \\
\text { (104) ¡qué bien! } \\
\text { (106) ¡te saldría más barato! } \\
\text { (156) si te cierran antes en } \\
\text { Tenerife } \\
\text { (161) sí es verdad } \\
\text { (171) no sé porque tiene una } \\
\text { temperatura distinta ¿no? / yo } \\
\text { creo que en abril hará buen } \\
\text { tiempo } \\
\text { (176) y ¡claro! / el plan de } \\
\text { Tenerife es mucho más tranquilo } \\
\text { ¿no? que } \\
\text { (185) ¡ah! ¡claro! } \\
\text { (198) ¡qué curioso! } \\
\text { (202) no como aquí } \\
\text { (206) así que vuestra idea sería } \\
\text { alquilar un coche y pasearos por } \\
\text { (227) Aicor / Aircoz } \\
\text { (232) Icod de los Vinos } \\
\text { (234) ¡claro! } \\
\text { (240) ¡ah! ¡claro! } \\
\text { (242) alfombras } \\
\text { (244) esa alfombra me la } \\
\text { trajeron a mí de Tenerife unos } \\
\text { canarios amigos de mis suegros. } \\
\text { (248) ijoder! / ¡te vas a hinchar } \\
\text { de comprar entonces! } \\
\text { (261) sí / te compensa el viaje } \\
\text { ¡claro! / ¡qué bien! } \\
\text { (270) a mí me pasaba igual } \\
\text { (iemo }\end{array}$ \\
\hline
\end{tabular}




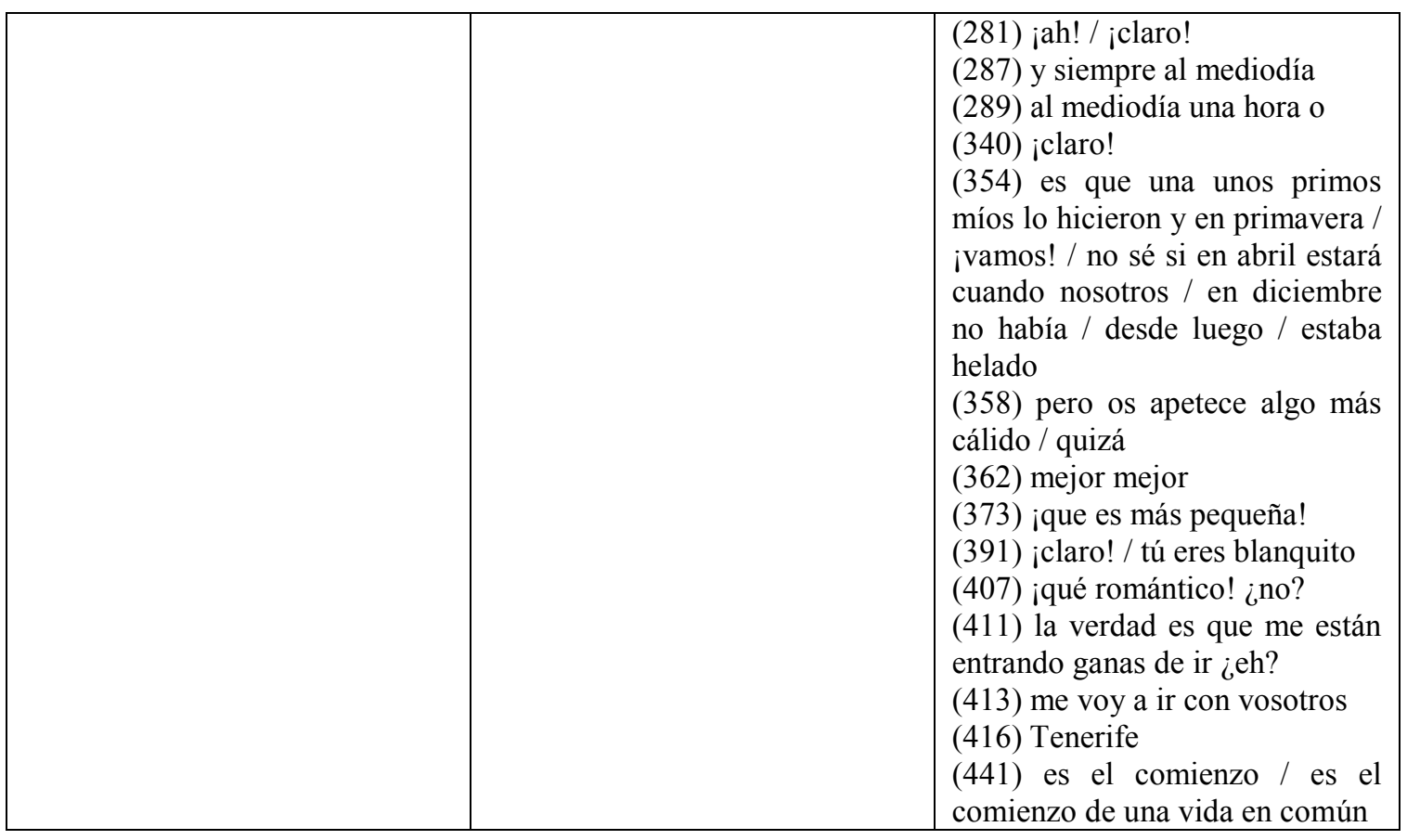

Tema 2 - Casamento

\begin{tabular}{|c|c|c|}
\hline Perguntas Principais & Perguntas complementares & $\begin{array}{l}\text { Comentários / opiniões / } \\
\text { marcadores de interação }\end{array}$ \\
\hline $\begin{array}{l}\text { (452) y ¿qué tal los preparativos } \\
\text { de la boda? / ¿cómo los llevas? } \\
\text { (471) te gusta la lectura ¿no? } \\
(639) \text { y ¿tienes muchas fotos? } \\
\text { (656) itú bebe! ¡tú bebe! } \\
\text { ¿quieres algo más fresco? ¿o } \\
\text { algo? } \\
\text { (712) ¿y cuál es el argumento de } \\
\text { la historia? } \\
\text { (769) ¿y tiene mucho público } \\
\text { esa? } \\
\text { (771) ¿Cómo lo descubriste? } \\
\text { (1336) ¿por qué los rechazó? }\end{array}$ & $\begin{array}{l}\text { (469) tenéis muchos / ¿no? } \\
\text { (548) ¿el qué? } \\
\text { (623) ¿qué te ponías en el mismo } \\
\text { morro? } \\
(625) \text { ¿en el morro? } \\
\text { (757) ¿qué salen? / ¿en navidad? } \\
\text { / ¿todos los años salen? } \\
\text { (783) Nueva Ibérica está en calle } \\
\text { Nueva ¿no? } \\
\text { (819) ¡ah! ¿en el Corte Inglés } \\
\text { tampoco? } \\
\text { (850) ¡sí! / además es que se lo } \\
\text { ordenaron y él no quería / ¿no? } \\
\text { (1033) de que pero / ¿de qué año } \\
\text { es la película? } \\
\text { (1246) las reservas ¿qué eran? / } \\
\text { espacios que }\end{array}$ & $\begin{array}{l}\text { (459) ¡no me digas! } \\
(461) \text { iay! / ienhorabuena! } \\
\text { (464) iqué bien! } \\
\text { (499) ibueno! } \\
\text { (508) sí pero se te queda ya } \\
\text { (511) ¡qué barbaridad! } \\
\text { (529) ¿sí? } \\
\text { (569) iqué barbaridad! } \\
\text { (577) no / no te preocupes } \\
\text { (584) muchos muertos también } \\
\text { (590) iqué barbaridad! } \\
\text { (592) no sabía que te interesase a } \\
\text { ti el mar / tanto } \\
\text { (616) icreo que sí! } \\
\text { (630) iclaro! Por donde entras } \\
\text { por la misma entrada del puerto } \\
\text { (637) iqué barbaridad! } \\
\text { (660) iclaro! / tienes que } \\
\text { mantenerte. } \\
\text { (669) Patrick O’Brian } \\
\text { (731) ¿sí'? } \\
\text { (755) iqué interesante! ¿no? } \\
\text { (778) yo también } \\
\text { (815) en El Corte Inglés te } \\
\text { puedes leer el libro ¡es verdad! } \\
\text { (840) el otro día vi un } \\
\text { documental sobre } \\
\text { (889) ¡ah! ¿sí? } \\
\text { (907) cayó el andar } \\
\text { (924) en vez de rendirse se } \\
\text { (935) muy interesante / muy } \\
\text { interesante } \\
\text { (977) o sea / a base de hambre }\end{array}$ \\
\hline
\end{tabular}




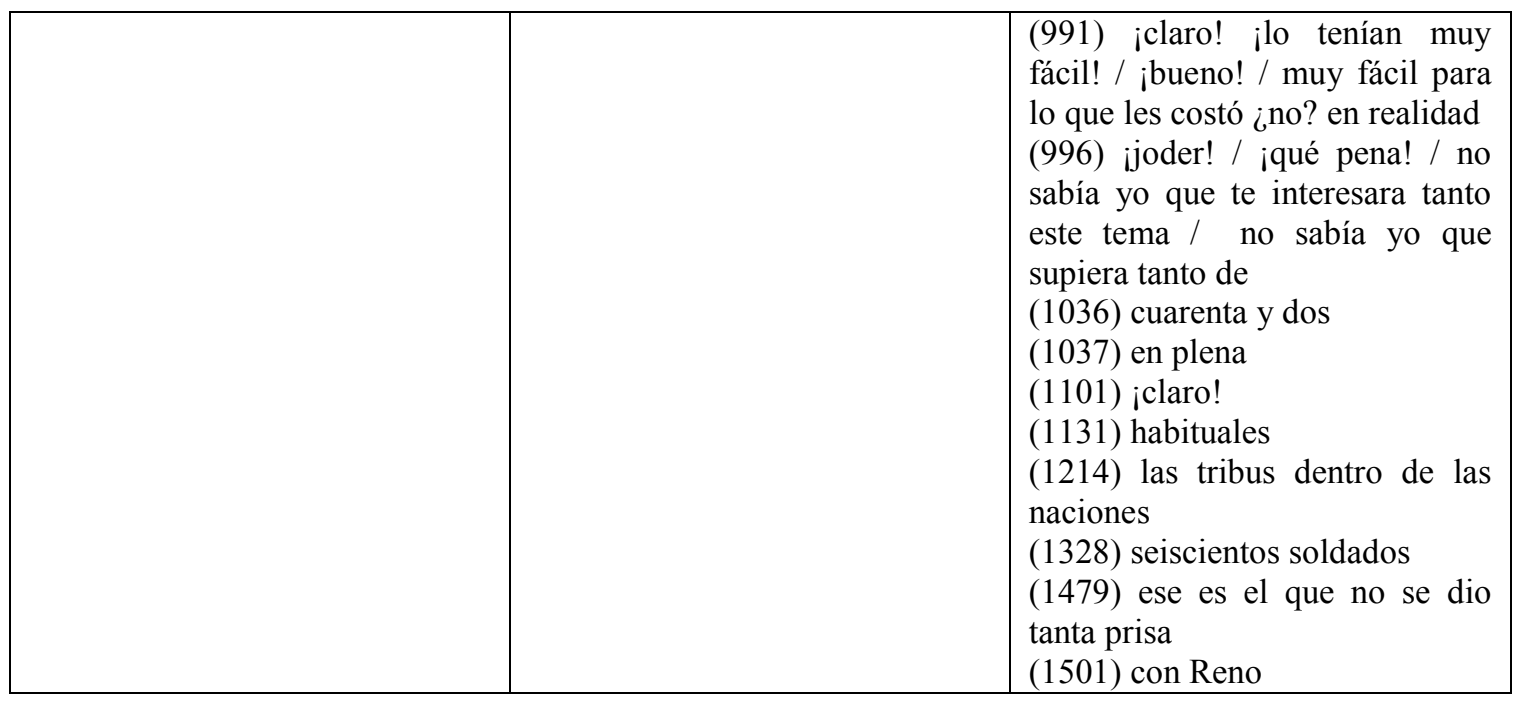

Analisando essa entrevista, observamos algumas características peculiares que devem ser tratadas primeiramente. Há três pessoas que participam da mesma: o entrevistador E; o informante I e a namorada do informante. No entanto, na classificação dessa entrevista no corpus, a segunda participante $\mathrm{P}$ não é considerada informante, devido a isso, consideramos apenas a fala de Javier, o informante, propriamente dito. Isso também pode ser comprovado por meio das perguntas da E, as quais, geralmente, estão direcionadas para ele e não para os dois, salvo algumas exceções.

Outro dado que deve ser destacado é a extensão do diálogo, em média há 500 linhas a mais que os outros materiais do corpus. Acreditamos que esse dado não interferirá nos resultados de nossa análise, pois após as perguntas do $\mathrm{E}$, tanto o informante quanto a namorada começam a falar de filmes que assistiram, livros que leram, etc. o que deixa a entrevista bastante enfadonha. Por meio da tabela acima, podemos comprovar que, embora haja alguma participação do E, essa participação é mínima, pois $\mathrm{I}$ e $\mathrm{P}$ se revezam contando histórias e pouco deixam o $\mathrm{E}$ interferir no diálogo.

A interação entre os participantes é bastante acentuada, o que pode ser demonstrado por alguns fatores como a emissão de opinião do $\mathrm{E}$ e a inversão de papéis, na qual o I faz perguntas ao E. Acreditamos que o fato de ambos serem jovens contribui para que essa interação ocorra mais rapidamente.

Com relação às perguntas elaboradas pelo $\mathrm{E}$, todas se configuram como enunciados diretos, não há uso de verbos performativo no Futuro do Pretérito ou Imperativo nas solicitações de informações. Embora essa entrevista seja mais extensa do que as outras que pertencem ao mesmo corpus, observa-se que há poucas perguntas 
principais. Como pode ser constatado por meio das tabelas apresentadas, optamos por dividir todo o diálogo em apenas dois temas.

\subsubsection{Imperativo}

Como já abordamos anteriormente, não há registros, ao longo dessa entrevista, de uso de verbos no modo Imperativo na elaboração de enunciados interrogativos, porém encontramos algumas ocorrências desse modo verbal utilizado com diferente função. Abaixo apresentamos os trechos seguidos de breve análise.

(278)... imagino que te recomendarán ¡oye! id a ese sitio / que en aquel sitio está más barato y más bueno... (492) ... que esa sí me gusta tenerla / porque ¡oye! / una enciclopedia del cine / es bonito...

(531) ... porque a mí me gusta cogerlas / ¡oye! / yo soy de esas personas que cojo un tomo de una enciclopedia...

(1191) ... se la dieron al que había estado temporalmente al mando // pero ¡fíjate! que es lo que te digo que / que...

Observa-se que entre as quatro ocorrências apresentadas, três se referem ao uso do mesmo verbo: oír e uma com o verbo fijarse. No caso do verbo oír entendemos que há intenções diferentes no uso de tal verbo. No primeiro exemplo apresentado, o falante busca expressar um conselho dado por terceiros, enquanto que nos outros dois exemplos há uma busca de aproximação do falante com seu interlocutor, no qual ele cita a expressão de seu gosto pessoal por enciclopédias. Já no caso de fijate é um marcador discursivo que visa chamar a atenção do interlocutor para o conteúdo daquilo que será dito.

\subsubsection{Desfocalização do eu}

Ao longo dessa entrevista, encontramos diversas ocorrências que visam desfocalizar o eu. Abaixo apresentamos os trechos seguidos de breve análise.

(102) ... entablar otra vez la la relación / y seguro que te dirían que que fueras a los Alpes (119) ... lo primero que te dicen cuando te reúnen en el primer día en el hotel / el guía turístico lo primero que te dice es ¡mira! Aquí no hay problemas de robo ni tirones ni nada

(235) a Santa Cruz puedes ir en taxi perfectamente...

(271) ¡ah! / y es es muy gracioso / es muy simpático porque te ponen / lo que es la relación del día / la relación de de visitas / visita a tal sitio / tal museo /visita a no sé dónde... / te tienen que dar el tiempo libre para visitar la ciudad / ¡claro! / y imagino que te recomendarán ...

(329) aparte lo que te gastes

(374) y yo / no sé y de todos los sitios que he ido / yo he estado en en Mallorca// en Mallorca me gustó las calitas / las playas / el hecho de bañarte en la playa / eso sí me gustó...

(447) que estás de viaje de novios y / y se van a pasar los

(495) ...luego tengo otra distinta / que esta sí es más extensa / te explica más lo que es la historia del cine...

(533) ... es interesante / te va / te va captando / como haya cosas que / que te interesen y / como muchas veces una entrada de una enciclopedia te lleva a otra

(566) ... Cabo de Hornos / tenías que atravesar todo el continente americano / y subirlo otra vez...

(570) entonces eso // aparte de tiempo que perdías / tiempo y dinero / o sea / entonces... 
(1039) sí / entonces / hay que comprenderlo / no puedes reprochar nada / entonces...

(1308) ... una vez que estás en el campo solo / tienes que actuar al su a tu criterio / ...

Como se pode observar, em todas as ocorrências o falante utiliza a segunda pessoa do singular. Entendemos que é uma forma de se aproximar do interlocutor, envolvendo-o com o tema tratado.

Após a análise individual de todas as entrevistas, apresentaremos uma análise comparativa de forma que possamos visualizar as ocorrências encontradas em todas as amostras desse corpus.

\subsubsection{Prevenção de ameaça à face}

Tratando das questões que envolvem ameaça e proteção à imagem, tanto do $\mathrm{E}$ quanto do I, abordaremos os trechos que apresentam uma prevenção de ameaça à face, seja do informante, seja do entrevistador. Abaixo apresentamos os trechos:

(570) I: ... pues si em um extremo era muy largo / intentaban buscar um paso más más más cercano / y creían que habían un paso entre / entre no /entre por Canadá / por el la / lo que es el / el el est el est ¡ay! / es que no lo tengo ya muy

(577) E: no / no te preocupes

(578) I: no lo tengo muy fresco / porque ya hace tiempo / ¡bueno! / el mar / el Mar de Baffin me parece que es / ¡bueno! / el caso que era un paso por el norte...

(615) I:... que es el el el muelle que hay en el morro ¿sabes cuál te digo? ¿el morro?

(934) I: bueno / perdón por la digresión

E: muy interesante / muy interesante

No primeiro trecho, podemos notar que a sequência da frase colabora para essa prevenção de ameaça à imagem do I, pois ele faz duas justificativas e depois faz uso do verbo "parecer" para explicar o enunciado. O entrevistador, por sua vez, procura atenuar o problema dizendo que ele não deve se preocupar com isso, contribuindo também para que a imagem do I seja preservada.

No segundo caso encontrado, entendemos que há uma preocupação com a imagem do E, pois o I procura se certificar de que o entrevistador sabe do que ele está falando. Ao fazer tal pergunta, o falante se certifica se pode ou não prosseguir sua fala.

Já no terceiro exemplo há uma prevenção de ameaça a própria face, pois a intenção do informante é justificar-se e evitar que o E faça algum julgamento sobre a história que ele conta. O E, por sua vez, atenua a questão enfatizando que a história é muito interessante. 


\subsubsection{Ameaça à face}

Além dos enunciados que visam a prevenção de ameaça da imagem, encontramos também aqueles que de fato ameaçam tanto a imagem do I quanto do E. Abaixo apresentamos os exemplos encontrados.

(304) I: en abril / piedras viejas no me atrae ¡no! ¡sí! / realmente me gustaría ver (306) E: la Grecia clásica

(380) I: ... ¡está todo lleno de ingleses! / !sí sí! / lo tú lo / ¡vamos! había tres tipos de ingleses / los recién llegados / blancos / completamente blancos / ¡como la leche! / los que llevarían unos días / completamente colorados / ¡colorados colorados colorados!/ y los que quizás lleven ya un tiempo / que estén más morenos / se los diferenciaba bien / con sus con ca sus camisetas de fútbol / ¡claro! Las tiendecillas...

(390) I: ... yo estaba también co / colorado como como una langosta

(772) I: sí yo un día bueno a mí El Corte Inglés era mi segunda casa / los libros de El Corte Inglés / mi segunda casa / no porque a mí realmente me da coraje comprar en centros comerciales / prefiero casi comprar en una / una tienda // en una librería pero ¡bueno! / esto es pura hipocresía / porque luego compro en el centro comercial...

Todas as situações apresentadas acima foram encontradas na fala do I. Observamos que em todas elas ele ameaça sua própria face. No primeiro exemplo, ele se refere de maneira não muito simpática à Grécia e em seguida atenua sua fala dizendo que gostaria de conhecer o país. No segundo trecho, há a ideia que os espanhóis têm dos ingleses, como se houvesse apenas turistas ingleses e o estereótipo que esses turistas causam. Além disso, na sequência, ele também diz que estava queimado pelo sol, o que causa certa estranheza uma vez que ele pouco antes zomba dos ingleses sobre sua cor. Já no terceiro exemplo a hipocrisia a que ele se refere é com relação a sua própria atitude na compra de livros. Observa-se que o I faz uma autocrítica, tendo a percepção da própria imagem como desfavorável.

\subsubsection{Atenuantes}

Outro ponto relevante encontrado ao longo dessa entrevista são as situações de atenuação, proferidas tanto pelo informante quanto pelo entrevistador. Abaixo apresentamos os trechos seguidos de breve análise.

(88) I: no // lo dudo / eso sería que coincidiera / mis primos están ya un poquito desvinculados de de lo que es España

(108) I: sí // pero por lo menos a mí particularmente me gusta un poquito más Tenerife es es un sitio muy bonito / a mí es que el entorno me

(304) I:en abril / piedras viejas no me atrae ¡no! ¡sí! / realmente me gustaría ver

(306) I: la Grecia clásica

(390) I: ... yo estaba también co / colorado como como una langosta

(391) E: ¡claro! / tú eres blanquito y te pondrías 
(739) I: ... el segundo libro ya / complica un poquito el argumento / porque ya introduce...

(799) I: ... son libros muy gordos de trescientas páginas / y y eran algo carillos para entonces

Como pode ser observado, encontramos exemplos bastante diversificados ao longo dessa entrevista. O primeiro, segundo e penúltimo trechos são exemplos de uso do adjetivo poco no diminutivo, sendo que apenas o primeiro e o segundo são utilizados com a função de atenuação. O segundo trecho - linha 108 - não atenua o enunciado, mas sim o enfatiza. Ainda referindo-se ao uso do diminutivo, temos o último exemplo que visa atenuar o adjetivo caro. No caso é uma justificativa para o I não ter comprado o livro do qual fala.

O trecho que está entre as linhas 304 e 306 já mencionado quando tratamos de ameaça à face, visa atenuar o enunciado anterior, o qual trata o país como piedras viejas. É interessante observar que a única estratégia de atenuação utilizada pelo I nesse momento é dizer que lhe gostaria conhecer a Grécia clássica. Não há nenhum enunciado que vise impedir algum julgamento por parte do $\mathrm{E}$.

Por fim, encontramos um trecho em que a atenuação é por parte do E. Está entre as linhas 390 e 391 em que o próprio E justifica o motivo pelo qual o I ficou muito queimado ao se expor ao sol.

\subsubsection{Expressão de opinião}

Conforme já dissemos anteriormente, o material espanhol não apresenta temas pré-estabelecidos para as entrevistas. Assim, muitas vezes são os próprios informantes que vão determinando os temas tratados ao longo do diálogo. O mesmo ocorre com os pedidos de expressão de opinião, não há ordem certa para que apareçam, à medida que o tema necessita, o I expõe a sua opinião sobre o que está sendo tratado.

Abaixo apresentamos os trechos encontrados, todos eles presentes na fala do I.

(141) ... y eso yo es ló que veo que que / el ambiente ¡bueno! / más sano/ pero un poco distinto / ¡por lo menos a mí no me gusta! / ese ambiente que hay de de cuatro o cinco de la madrugada

(361) yo creo / me atrae la zona sur / me atrae el calor

(841) sí es que realmente esos / esos barquitos / ¡pobrecitos! / (...) ¡salían de uno en uno! / y conforme iban saliendo / los iban hundiendo y eso llamarlo luego batalla pues es un eufemismo ¿entiendes? es ridículo

O fato de os temas de essa entrevista girar em torno dos livros que o I leu faz com que haja poucas oportunidades em que há a necessidade de expressar sua opinião.

No caso do primeiro exemplo apresentado - linha 141 - o I se previne de uma possível ameaça à face, caso o E não compartilhe da mesma opinião e deixa claro que 
pelo menos ele não gosta. É como se ele dissesse não sei se você gosta, mas eu não gosto. No segundo exemplo há o uso do verbo creer, mas é uma mera expressão de opinião, observa-se que não se trata de nenhum tema polêmico. Já no terceiro excerto linha 841 - há a expressão de opinião sem se fazer uso de nenhum tipo de atenuante, não havendo a preocupação de preservação da face.

Observa-se também as expressões de opinião e comentários emitidos pelo E. Acreditamos que esse tipo de ocorrência é benéfico para a fluidez do diálogo, porém como já apontado anteriormente, não é nosso objetivo analisá-lo.

\subsubsection{Cortesia valorizante}

Encontramos também nessa entrevista uma única ocorrência de cortesia valorizante na fala do E:

(996) ijoder! / ¡qué pena! / no sabía yo que te interesara tanto este tema / no sabía yo que supiera tanto de

Trata-se de um elogio que a $\mathrm{E}$ faz ao I devido as suas explicações sobre as batalhas, guerras em geral. Esse tipo de ocorrência é extremamente benéfica para a face do interlocutor.

\subsubsection{Formas de tratamento}

Como já explicado no início dessa análise, além do informante, está presente também a sua namorada no momento da entrevista. Ressaltamos que o corpus considera apenas um informante.

Acreditamos que o fato de haver duas pessoas sendo entrevistadas é importante para que possamos averiguar se a forma de tratamento utilizada corresponde a segunda ou terceira pessoa do plural, a fim de que possamos comprovar se essa região da Andaluzia utiliza ou não o pronome vosotros ou apenas o verbo na segunda pessoa do plural acompanhado do pronome ustedes, fato que gera controvérsias entre os teóricos por nós consultados.

Abaixo apresentamos algumas ocorrências encontradas ao longo dessa amostra.

(01) ¿tú naciste en Málaga?

(150) te ha dado tiempo a beber más ¿no?

(179) ¿qué es? / ¿más a vuestro aire o con un programa?

(358) pero os apetece algo más cálido / quizá

(413) me voy a ir con vosotros

(471) te gusta la lectura ¿no?

(639) y ¿tienes muchas fotos? 
Como é possível observar por meio dos exemplos acima, quando o entrevistador se refere ao informante utiliza a forma tú e, quando se refere ao informante e sua namorada, utiliza a forma vosotros acompanhada dos devidos pronomes possessivo e oblíquos também na segunda pessoa do plural. Não há ocorrência de pronome possessivo na segunda pessoa do singular.

A partir desses dados, podemos observar que o uso contraria teóricos como Carricaburo, ao menos no que se refere à cidade de Málaga, reforçando a ideia de que nessa região a norma seguida é a mesma utilizada pelo restante da península, como já apontado ao longo de nossa fundamentação teórica. Ressaltamos que, esse não é o objetivo principal de nossa investigação, porém por meio das amostras analisadas, tentaremos observar tal questão.

Como era esperado, por conta da idade do informante, não há a presença de formas nominais.

\subsection{Amostra 24}

Informante feminino - 30 anos

Entrevistador feminino - 28 anos

Tema 1 - A infância

\begin{tabular}{|c|c|c|}
\hline Perguntas principais & Perguntas secundárias & $\begin{array}{l}\text { Comentários / opiniões / } \\
\text { marcadores de } \\
\text { interação }\end{array}$ \\
\hline $\begin{array}{l}\text { (01) Entonces cuéntame tú que } \\
\text { tú eres de Málaga ¿no? } \\
\text { (04) ¿sí? ¿y dónde? ¿qué recuerdos } \\
\text { tienes de la infancia? / ¿dónde } \\
\text { naciste? / ¿a qué colegio fuiste? } \\
\text { (44) ¡ah! Y ¿qué recuerdos? ¿tienes } \\
\text { algún recuerdo de la guardería? / } \\
\text { ¿de los juegos? / ¿de los } \\
\text { compañeros o algún? } \\
\text { (65) y que ¿cómo era la / la casa? } \\
\text { ¿tú te acuerdas de la guardería } \\
\text { cómo era? / me la podrías } \\
\text { describir? } \\
\text { (88) ¡ah! / o sea / ¿cómo? / ¿cómo } \\
\text { era? / estaba la clase } \\
\text { (100) ¡ah! / iya ya ya! / ¿y erais } \\
\text { muchos niños en el? } \\
\text { (123) y al chico este que sale con tu } \\
\text { hermana / ¿no lo habías vuelto a } \\
\text { ver? } \\
\text { (128) ¿y a qué colegio fuiste tú? } \\
\text { (136) y ¿cuál era tu asignatura } \\
\text { favorita en el colegio? O ¿qué te }\end{array}$ & $\begin{array}{l}\text { (17) ¡no me di! / y ¿a qué } \\
\text { guardería ib / fuiste tú? } \\
(26) \text { ¿era una casa que tenía jardín? } \\
\text { (38) ¡claro! / ¡claro! / porque } \\
\text { vosotros vivíais por allí cerca } \\
\text { entonces } \\
\text { (48) ¿sí? / ¿cómo eran? } \\
\text { (57) y ¿no bailabas ni nada? } \\
\text { (60) y entonces ¿qué elegían? ¿los } \\
\text { padres lo? / ¿las cosas que? } \\
\text { (81) eso era el jardín } \\
\text { (95) a uno / y pero ¿no tenían los } \\
\text { servicios una puerta o? } \\
\text { (131) ¿a qué altura está? / me } \\
\text { parece que fui una vez }\end{array}$ & $\begin{array}{l}\text { (24) ¡ah! ¡sí! / en } \\
\text { Pedregalejo ¡claro! } \\
\text { (32) pero las guarderías de } \\
\text { entonces } \\
\text { (42) ¡ah! / pero que tu madre } \\
\text { conocía a la dueña de } \\
\text { (69) a la de Juan se } \\
\text { (97) ¡ah! ¡ya! / ¡ya! / ¡ya } \\
\text { entiendo! // entonces tú } \\
\text { tenías que cerrar el pestillo } \\
\text { de una de las dos clases } \\
\text { (115) o sea / que eran todos } \\
\text { amigos tuyos. } \\
\text { (118) ¡sí! / que no es meterte } \\
\text { en una clase / donde no } \\
\text { conoces a nadie } \\
\text { (134) ¡sí! ¡es verdad! / que } \\
\text { no está muy / muy arriba } \\
\text { tampoco }\end{array}$ \\
\hline
\end{tabular}




\begin{tabular}{|c|c|c|}
\hline Perguntas principais & Perguntas secundárias & $\begin{array}{l}\text { Comentários / opiniões / } \\
\text { marcadores de } \\
\text { interação }\end{array}$ \\
\hline $\begin{array}{l}\text { (143) ¿tú haces manualidades? } \\
\text { (180) y / pero para policromarlos } \\
\text { ¿qué haces? / ¿lo pintas o también } \\
\text { lo forras en papel? } \\
\text { (193) pero eso ¿cómo lo pintas? } \\
\text { ¿con un pincel o? } \\
\text { (195) y ¿Cómo cuánto tiempo } \\
\text { tardas en hacer un / un friso de esos } \\
\text { por ejemplo? } \\
\text { (221) iya ya ya ya! / o sea / intentas } \\
\text { buscar el / el efecto envejecido ese / } \\
\text { ¿y qué más cosas haces / de } \\
\text { manualidades? ¿misterios? } \\
\text { (226) ¿eso todo lo haces tú? } \\
\text { (260) ¿y dónde aprendiste a hacer / } \\
\text { la manualidades? } \\
\text { (283) ¿y va mucha gente a ese } \\
\text { centro? } \\
\text { (289) ipor eso! / que es mejor en } \\
\text { grupillos reducidos ¿no? / ¡ay! iqué } \\
\text { interesante! ¿no? // y en madera / } \\
\text { aparte de marcos de fotos ¿qué? } \\
\text { (300) ¿el dibujo austríaco cómo es? } \\
\text { (309) que son para la nieve ¿no? / o } \\
\text { algo de eso / iya ya ya ya! / y mue y } \\
\text { ¿qué tipo de madera trabajas? ¿con } \\
\text { qué tipo de madera? ¿da igual el } \\
\text { tipo de madera o? } \\
\text { (337) ¡ah! / en los veinte duros } \\
\text { mismo lo compras / ¿qué los } \\
\text { compras? ¿blancos y pintas } \\
\text { después? } \\
\text { (349) y ¿qué tipos de trabajos } \\
\text { hacíais en / en la clase? } \\
\text { (356) eso lo hacía yo / se me daba } \\
\text { fatal / ¿y qué modelábais? ¿arcilla o } \\
\text { barro o? } \\
\text { (375) y ¿qué hacíais? / ¿manteles o? } \\
\text { (382) jah! iya ya ya! Y ¿qué otras } \\
\text { asignaturas tenías/ que te gustasen? }\end{array}$ & 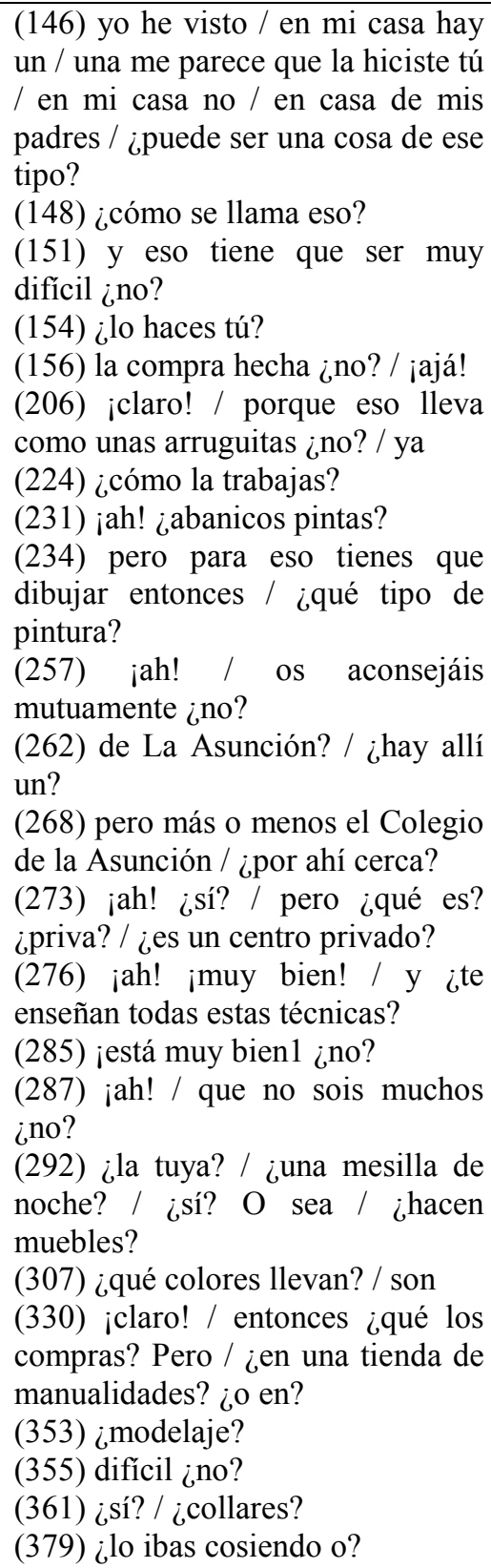 & $\begin{array}{l}\text { (169) ¿sí? / o sea que son } \\
\text { ¡finos finos! } \\
(171) \text { jah! / o sea } \\
\text { (174) ¡ah! / o sea eso lo } \\
\text { lleva / ¡está como forrado en } \\
\text { papel! } \\
\text { (201) ¿sí? / pero después } \\
\text { tienes que se } \\
\text { (243) ¡ajá! / pero los colores } \\
\text { síl los te los } \\
\text { (264) pues no / ¡no sé! / yo } \\
\text { es que la verdad es que } \\
\text { Pedregalejo / quitando Juan } \\
\text { Sebastián Elcano y / poco } \\
\text { más no // no conozco mucho } \\
\text { (271) yo no sabía que por } \\
\text { allí había un taller } \\
\text { (297) iqué bien! ¿no? } \\
\text { (305) jah! / ¡ś́ sí sí! } \\
\text { (332) iya ves! / si se te da } \\
\text { bien / por lo visto eres una } \\
\text { artista / ya veo que eres una } \\
\text { (342) jah! / iya ya ya! iqué } \\
\text { artista! ino? / iqué } \\
\text { barbaridad! } \\
\text { (347) iclaro! / que erais } \\
\text { muchos en el colegio/ } \\
\text { muchos por clase } \\
\text { (367) costura } \\
\text { (371) iah! / o sea que } \\
\text { bordábais o }\end{array}$ \\
\hline
\end{tabular}

Tema 3 - Centro Javier

\begin{tabular}{|c|c|c|}
\hline Perguntas principais & Perguntas secundárias & $\begin{array}{l}\text { Comentários / opiniões / } \\
\text { marcadores de } \\
\text { interacão }\end{array}$ \\
\hline $\begin{array}{l}\text { (394) ¿y desde siempre habéis } \\
\text { vivido aquí en / en esta casa? } \\
\text { (396) y en las vacaciones ¿habéis } \\
\text { estado aquí o ibais a? } \\
\text { (414) iy dónde os vais de } \\
\text { convivencia con el Centro Javier? }\end{array}$ & $\begin{array}{l}\text { (417) ¿al de aquí? / ¿al de Málaga? } \\
\text { (427) ¿en qué os habéis ido? } \\
\text { ¿ahora a la nieve o? } \\
\text { (429) y ¿qué tal? / ¿mucho frío? } \\
(434) \text { ¿qué era? ¿una casa de esas? } \\
(459) \text { ¡ah! / ¡ya! ¡sí! Y ¿son muy }\end{array}$ & $\begin{array}{l}\text { (412) ¡claro! / ¡lógico! / no } \\
\text { te vas a quedar aquí } \\
\text { encerrada todo el año. } \\
\text { (419) ¡qué bonito es! ¿eh? } \\
\text { (442) pero nunca he estado } \\
\text { metida }\end{array}$ \\
\hline
\end{tabular}


(436) ¡ah! // ¿en qué consisten las convivencias del Centro Javier?

(439) ¿a qué se dedica el Centro Javier? Porque yo he oído hablar mucho de él / pero

(457) pero ¿qué tipo de ejercicio tienes que hacer?

(468) pero ¿qué es lo que tienes que hacer? ¿leer textos o?

(471) entonces tú te vas allí y ¿qué es lo primero que haces? / los retiros ¿dónde son? ¿en el seminario?

(523) ¡ah! / y en los retiros ¿qué son? ¿estáis?

(553) personalmente ¿no? / y ¿qué? $\mathrm{Y}$ ¿cómo se personaliza? $\mathrm{O} /$ ite conocen a ti de antes las personas que te proponen los

(568) entonces / te dan unos textos y tú ¿reflexionas sobre ellos o vas tomando nota?

(582) ¡ah! ¡ya ya ya! / que hayas perdido / o tenido una pérdida familiar / cercana / entonces tienes que cambiar de tema o algo ¿no? (654) o sea / ¿cómo te introduces en el barrio?

(656) por eso te pregunto / o sea ¿cómo?

(658) ¿a través de la parroquia e o del cura? ¿o cómo? ¿quién te introduce allí en?

(711) ¡qué interesante! / ¿y tú te dedicas a algún tipo de labor de estas? ¿o?

(728) ¡normal! / ¡oye! pero las / y las reuniones semanales ¿en qué consisten? / ¿tratáis algún tema determinado?

(750) ¡ah! / ¡qué interesante! / sí también según como vaya surgiendo / y ¿sois gente de la misma edad / en general?

(754) sí / que no es una cosa / pues está muy bien lo de Centro Javier porque / había oído hablar mucho de él / pero no sabía realmente / nunca me había comentado nadie // en qué consistía su labor / pues es interesante / y ¿cuántos lle años llevas?

\section{frecuentes?}

(463) ¿en silencio?

(482) pero ¿no tienen eso en cuenta? / pero ¿qué es siempre? ¿en el mes de agosto?

(484) ¡qué horror! / ¿y te has tenido que ir en el mes de agosto a Córdoba?

(497) ¡qué bárbaro! / y entonces ¿qué hacéis? / ¿llegáis allí ya os calláis o?

(502) en la cena sí se habla.

(504) ¡ah! en las demás no

(519) ¡claro! / y el ¿y el resto del año?

(528) ¡total! que como no habláis / pues no importa que os mezcléis ¿no?

(534) eso / ¿no se os hace largo / tantos días sin hablar?

(537) ¡bueno! / estáis todo el día estudiando ¿no? o trabajando

(578) o todo lo contrario ¿no? que (618) ¡sí! ¡que hay mucha labor por hacer! ¿no? / y las labores fuera del Centro Javier tipo de / como ir a la cárcel todo esto también / ¿te lo organizan allí mismo? ¿tú allí te puedes informar para?

(633) y en un barrio marginal / ¿qué tipo de labor se realiza?

(635) ¿cómo se puede ayudar?

(650) entonces te tienes que ir a / al parque / y jugar con los niños y / pero los padres ¿conocen eso o?

(700) o de un colegio

(718) tiene que ser muy cansado ¿no?
(445) no / del Centro Javier sí / de las comunidades marianas no.

(492) ¿sí? ¡Dios mío!

(516) ¡muy bien!

(550) ¡claro! / que eso te tiene que servir para el resto del / ¡claro! / haces el retiro para

(586) que lo afrontes mejor ¿no? / puede ser / ¡ah! / ¡ya lo entiendo!

(593) ¡qué interesante! ¿no? / no sabía todo eso de / del Centro Javier

(603) o sea / a lo largo del año se supone / que desempeñas algún tipo de labor

(726) ¡te entiendol ¡te entiendo!

(738) el tiempo / la época del año

(759) un montón ¿no?

(763) ¡ah! ¡ya ya ya! / pero más o menos desde esa época

(767) ¡oye! / pues está muy!

Tema 4 - Estudos

\begin{tabular}{|l|l|l|}
\hline \multicolumn{1}{|c|}{ Perguntas principais } & Perguntas secundárias & $\begin{array}{c}\text { Comentários / opiniões / } \\
\text { marcadores de } \\
\text { interação }\end{array}$ \\
\hline $\begin{array}{l}\text { (771) y ¿en qué? ¿qué rama hiciste } \\
\text { de FP? }\end{array}$ & $\begin{array}{l}(793) \text { iclaro! O sea que habría } \\
\text { mucha gente / que no tendría }\end{array}$ & $\begin{array}{l}(781) \text { jes lo mejor! } \\
(788) \text { tú estabas más madura }\end{array}$ \\
\hline
\end{tabular}


(773) ¡ah! / ¡muy bien! / ¿en qué? ¿en qué? ¿en en dónde lo hiciste? ¿en qué centro?

(865) ¿y qué? ¿y que bas? ¿qué? ¿qué programas sabes manejar del ordenador?

(894) y ¿qué trabajas? ¿aquí en Málaga?
(799) entonces ¿qué horario teníais? ¿a partir de las seis?

(821) ¡qué completo! ¿no?

(825) ¡qué barbaridad! ¿qué son? / ¿dos años?

(833) que era antes / tú entraste directamente ahí

(855) para que descanses / ¡qué barbaridad! // ¿informática sabías / entonces?

(859) ¡ajá! / o sea tú has seguido formándote en ese sentido.

(880) ¡ya ya ya! / o sea que estás trabajando por las tardes ¿no? / ¡ah! ¡muy bien!

(889) te lo vio en la voz ¿no?

(891) ¡ah! pues ¡muy bien! / ¿y trabajas entonces por las tardes?

(901) ¿salís muy tarde?

(904) sí // pero a esa hora todavía está abierto el comercio / está cerrando ¿no?
/ y entiendo / ¡claro!

(796) tienen que / que formarse / ¡claro!

(801) ¡ah! / 1 muy bien!

(805) pues ¡muy bien!

(811) igual ¿no?

(830) ¡claro! / porque está el FP1 y el FP2.

(848) al día / sí porque / a lo tonto ¡claro! / por eso tenías diez el primer año o

(850) o sea tú tenías trece / en realidad tú / tú hacías trece asignaturas / las diez tuyas

(871) ¡ah! ¿sí? / ¡ah! ¡muy bien!

(885) o sea que estás muy cómoda / muy a gusto entonces

(896) ¡ah! / ¡muy bien!

(898) ¡claro! / ¡muy cómodo!

(908) ¡qué susto!

(913) 1un rato!

(918) ¡qué mala sombra! ¿no? pues tampoco es tan tarde las ocho y cuarto / como para que estuviese / ¡qué susto!

(921) y iqué hora también para quitar adornos! ¿no? / ¡teniendo todo el día!

(923) ¡claro! / cuando no hay gente

Tema 5 - Málaga

\begin{tabular}{|c|c|c|}
\hline Perguntas principais & Perguntas secundárias & $\begin{array}{l}\text { Comentários / opiniões / } \\
\text { marcadores de } \\
\text { interação }\end{array}$ \\
\hline $\begin{array}{l}\text { (934) ¿y qué? La verdad es que } \\
\text { Málaga ha cambiado ¿no? / en ese } \\
\text { sentido / ¿tú crees que antes había } \\
\text { tanta delicuencia como ahora? } \\
\text { (953) ¡pues no! / la verdad es que } \\
\text { no en fin / ¿y llevas mucho tiempo } \\
\text { trabajando con la procuradora? } \\
\text { (956) ¡muy bien! // ¿cómo } \\
\text { recuerdas Málaga cuando eras } \\
\text { pequeña? / ¿ha cambiado mucho? } \\
\text { (1000) ¡qué amable! ¿y tu tiempo } \\
\text { libre? } \\
\text { (1016) ¿por dónde salís? ¿por qué } \\
\text { zona? }\end{array}$ & $\begin{array}{l}\text { (944) sí / que no ha cambiado ¿no? } \\
(962) \text { ¡claro! / ¿que no salías } \\
\text { mucho! ¿no? } \\
(975) \text { ¿y qué hiciste? } \\
(988) \text { pero tú eras muy pequeña } \\
\text { ¿no? } \\
(1002) \text { fines de semana } \\
(1005) \text { ¿sois muchos? } \\
(1009) \text { pero administrativos ¿o? } \\
(1011) \text { ¿todos procuradores? } \\
(1014) \text { ¿y sales con ellos? } \\
(1018) \text { ¡ah! ¿sí? / ¿cómo es eso? } \\
(1022) \text { entonces / yo es que casi } \\
\text { nunca salgo por el centro / muy } \\
\text { rara vez y / pero no sabía que ¿qué } \\
\text { estás lleno de? }\end{array}$ & $\begin{array}{l}\text { (947) ¡qué lástima! } \\
\text { (951) hacer daño } \\
\text { (983) ¡qué susto! ¿no? / ¡tu } \\
\text { madre la pobre! } \\
\text { (990) ¡claro!// muchos años } \\
\text { viajando con él / se acuerda } \\
\text { de ti } \\
\text { (994) ¡claro! / se acuerda de } \\
\text { ti / ¡lógico! }\end{array}$ \\
\hline
\end{tabular}


Devido aos temas tratados, optamos por dividir essa amostra em cinco grandes partes: a infância, o artesanato, o centro de ajuda onde trabalha a informante, os estudos e a cidade de Málaga. Observa-se que o E sempre se aprofunda no tópico abordado, mudando o mesmo apenas quando não há nada mais a ser explorado. Além disso, nota-se que se ele desconhece determinado assunto, faz diversas perguntas de forma a esclarecer todas as suas dúvidas. Esse dado elucida o baixo grau de planificação existente na entrevista. Muitas vezes um assunto se enlaça em outro, porém geralmente é o E quem direciona um novo tema, mudando-o de forma súbita ou fazendo uso de alguns recursos como muy bien, en fin, pues no, etc.

Entre as perguntas elaboradas pelo E, observamos apenas um caso de proteção à face, sendo todos os demais enunciados diretos.

Logo no início da entrevista, observamos que o I dá uma grande abertura para perguntas que invadam seu território pessoal, inclusive desviando o tema central para falar de sua vida pessoal. O E mostra-se bastante discreto, retomando o tema inicial.

Como já observado em outras amostras que compõem esse corpus, há um ritual de iniciação em que se pergunta se o informante é de Málaga, de qual parte da cidade, etc. Interpretamos tal estratégia como uma forma de se iniciar a entrevista, pois a partir daí é fácil entrar em outros temas, como o colégio, a cidade, etc. temas recorrentes em outras entrevistas analisadas.

A interação entre os participantes pode ser comprovada pelas perguntas que o I faz ao E e pelas ocorrências de expressão de opinião do E. Além disso, acreditamos que o fato de apresentarem idades próximas favorece a interação.

\subsubsection{Imperativo}

Com relação aos enunciados interrogativos, não encontramos ocorrências de uso de verbos no imperativo, no entanto esse modo verbal pode ser observado em outros momentos com diferentes funções ao longo da entrevista, tanto na fala do informante quanto do entrevistador. Abaixo apresentamos os trechos, seguidos de breve análise.

Fala do I:

(481) (...) toca en Córdoba / o toca em Sevilla o toca em / imagínate lo que puede ser (510) te van dando / pues todos lós dias um guión de / de ló que debes hacer /entonces tú le dices a tu director / a tu guía / ¡mira! / que yo no he llegado (...) pues insite o si no / ¡mira! / te ofrezco esto otro... (579) ¡oye! O con una tristeza / y una depresión que no puedo más ¡mira! / pues hija ¡cambia!...

(860) sí ¡hombre! / porque tampoco puedes decir ¡oye! que cuándo terminé yo esto...

(937) yo creo ;fíjate! / que siempre la ha habido ¿eh?

(980) (...) con el hermano de una tía mía / ¡vamos! Dela / de Lola a recogerme / ¡mira! / aquello fue... 
Fala do E:

(728) E: ¡normal! / ¡oye! Pero las / y las reuniones semanales ¿en qué consisten?...

(767) E: ¡oye! / ipues está muy!

Assim como pudemos observar em outras entrevistas analisadas, os verbos no imperativo são os mesmos: oír, fijarse, imaginarse e mirar. Entendemos que ao utilizar mira e oye o falante procura se aproximar de seu interlocutor, buscando inclusive certa compreensão com o que está sendo dito. Já ao usar fijate e imagínate o falante busca uma chamada de atenção para com seu interlocutor, pois considera que a informação que ali está sendo transmitida tem relativa importância com relação às outras.

$\mathrm{O}$ fato de o E também fazer uso da forma oye na tentativa de se aproximar ainda mais de seu interlocutor se justifica pela interação criada entre ambos ao longo da entrevista.

\subsubsection{Desfocalização do eu}

Exemplos de desfocalização do eu também foram encontrados nessa entrevista. Abaixo apresentamos os trechos, todos presentes na fala do I, seguidos de breve análise. (280) (...) siempre hay cosas que te gustan más / y luego terminas haciendo una cosa más que otra / porque se te da mejor / porque te gusta más / porque es tu tipo de...

(315) porque tampoco muchas veces te compensa el precio / dices ¡bueno! / esto para que es para una (...) pues dices ijoder! / busco una madera así más más buena / pero muchas veces dices ¡oye! / ...

(380) sí // iba cosiendo / por ejemplo si tenías un gorrito / iba rellenando el gorrito...

(410) (...) tú te vas ipues mira! / tú vienes / 1 pero es que yo estoy aquí todo elaño!

(424) (...) ¡como no vas a a presumir de calor ni de frío! ...

(437) pues en un poco / en ¡no sé! / como en orientación de / lo que quieras hacer durante / a lo largo...

(452) (...) si no te pongan un puñal en el pecho y te / te tengas que ir (...)/ pues muchas veces $¡$ hija! / te coinciden con épocas de trabajo y dices...

(464) que ¡bueno! / tienes / me parece que es veinte minutos...

(499) (...) si hay gente que no conoces / porque viene de fuera (...) / y luego pues ya empiezas en plan

(531) (...) eso sí que es importante / porque si no / se te hacen los días / dices ¡cinco días!...

(580) (...) pues hija ¡cambia! / ¡no cojas ese tema! te ofrezco este otro...

(584) ¡sí! / o te van intentando orientar / a lo mejor el tema / que lo cojas de otra manera

(630) (...) le dices que vas de mi parte / que me conocen / y entonces pues a lo mejor / te metes en otro

(632) en otra zona / pero estás haciendo la misma labor ¿no?

(721) (...) pero lo mismo que decimos nosotros de los curas de aquí de San Miguel...

(743) (...) un poco todo también / lo vas organizando / un poco sobre la marcha ¿no?

(748) (...) y tú vas a leer la petición de no sé qué / y tú vas a hacer no sé qué...

(932) (...) pero tendrás que buscar una hora / de dos a tres

(992) dice ¿cómo quieres que no te salude? / después de esa trastada / y después de tantos días como llegabas tarde te tenía que esperar

(1020) (...) que cuando tienes ya / treinta / y treinta y tantos años...

Observa-se que são diversas as ocorrências em que o falante busca desfocalizar o eu da enunciação. Entre todas as citadas, em apenas uma encontramos o uso da primeira pessoa do plural, em todas as outras há o uso da segunda pessoa do singular. Entendemos esse recurso como uma estratégia do falante de incluir o interlocutor em seu discurso, 
deixando-o participar ativamente do diálogo. Tal recurso aumenta a interação e consequentemente diminui a distância entre os participantes.

\subsubsection{Prevenção de ameaça à face}

São poucos os trechos encontrados que visam prevenir uma possível ameaça à face dos participantes dessa entrevista. Abaixo apresentamos os excertos, seguidos de breve análise.

(130) I: yo fui a La Asunción / en Pedregalejo a ¿sabes dónde está?

(464) I: que ¡bueno! / tienes / me parece que es veinte minutos / o una cosa así / para...

(702) I: si ¡bueno! Es que esto/ el colegio de El Palo hace muchísimos ya / iban por allí // y / exactamente no te sé explicar el origen de cómo se introdujeron // ipero eso! (...) / o // no sé muy bien explicarte / porque como esto empezó hace muchísimo más tiempo de que yo entrara / pues ya muchas veces las cosas / las tomas directamente / tal y como vienen ¿no?

As três ocorrências foram encontradas na fala do informante. Temos dois tipos de prevenção. A primeira visa prevenir uma possível ameaça à face do E, assim o I já lhe pergunta se tem conhecimento ou não sobre o que vai falar para saber se pode ou não prosseguir a sua fala. Já nos dois casos seguintes, a prevenção se refere à face do próprio informante. No primeiro caso o verbo parecer atenua a intensidade da afirmação, dando margem à dúvida e no segundo o falante se previne da ameaça justificando o motivo pelo qual não é capaz de responder a pergunta feita pelo E. É interessante ressaltar que o diálogo que antecede essa afirmação da linha 702 é permeado por perguntas do E visando obter esse dado e em vários momentos o I se esquivou da resposta até não poder mais evitar a negativa. Essa entrevista na íntegra pode ser encontrada nos anexos desse trabalho.

\subsubsection{Ameaça à face}

Como já dissemos anteriormente, em um diálogo com características de entrevista é pouco provável que contenha atos que ameacem a face de um dos interlocutores, sobretudo quando esse interlocutor é o informante ou entrevistado. Ainda assim, encontramos uma ocorrência. O trecho completo pode ser encontrado nos anexos do trabalho. $\mathrm{O}$ informante conta que participa de um retiro em que é fundamental o silêncio e as orações que faz. O E expõe suas impressões:

(457) E: pero ¿qué tipo de ejercicio tienes que hacer?

(463) E:¿en silencio?

(482) E: pero ¿no tienen eso en cuenta? / pero ¿que es siempre? ¿en el mes de agosto?

(484) E: ¡qué horror! / ¿y te has tenido que ir en el mes de agosto a Córdoba

(497) E: ¡qué bárbaro! / y entonces ¿qué hacéis? / ¿llegáis allí ya os calláis o?

(534) E: eso ¿no se os hace largo / tantos días sin hablar? 
Acima apresentamos algumas falas do E quando o informante lhe explica como funcionam os retiros que frequenta. Entendemos que embora possam ameaçar a face do I, de fato ameaçam a face do E, uma vez que ele emite juízo de valor sobre o tema, pelo fato de se ter que fazer silêncio, por ser no mês de agosto, etc. No entanto, não interpretamos que o I em algum momento se sentiu ofendido ou sentiu sua face ameaçada com as colocações da $\mathrm{E}$, pois responde todas as perguntas sem demonstrar descontentamento. No último trecho apresentado, observa-se que o próprio $\mathrm{E}$ se corrige na tentativa de atenuar sua pergunta anterior e evitar a ameaça da face do I.

\subsubsection{Atenuantes}

Abaixo apresentamos as ocorrências que contêm uso de atenuantes.

(220) I: (...) que más de uno y dos dicen ¡ah! / esa purpurina la das en un minutillo ¿no? (232) I: me he pintado también unas alpargatas y una camiseta / ¡en fin! / un poquito de

(570) I: (...) o te aconsejan / que vayas también tomando un poquito de nota / de ¡bueno!/ pues...

(974) I: ( ...) imira! / el conductor / el pobre agobiadito perdido

(976) I: ¡agobiadito perdido! / me dejó en la...

Conforme se pode observar nos exemplos apresentados acima, todos os atenuantes são compostos pela forma diminutiva seja do próprio adjetivo ou substantivo, seja do adjetivo poco. No primeiro caso, observa-se que se atenua o tempo ao qual o I se refere e nos outros trechos o uso do diminutivo atenua os adjetivos poco e agobiado.

\subsubsection{Expressão de opinião}

As expressões de opinião são feitas ao longo de toda a entrevista. Não há, como no corpus brasileiro, uma pergunta específica para isso. Abaixo, apresentamos os trechos encontrados, todos na fala do I.

(936) yo creo ¡fíjate! / que siempre la ha habido ¿eh?

(939) yo creo que siempre la ha habido / lo que pasa que / hay momentos en los que se escucha más que otros pero / eso de que en Málaga ahora es cuando empieza a haber delincuencia y problemas // yo recuerdo de siempre / yo me acuerdo un día una señora / hará como quince años o por ahí / aquí en la puerta de casa.

Essa entrevista apresenta a peculiaridade de ter pouca expressão de opinião do informante, mais concretamente há apenas duas ocorrências e em ambas observamos o uso do verbo creer como marcador de opinião e não como dúvida do I. Acreditamos que isso se deve ao fato de os temas girarem em torno da vida do informante, seus estudos, a congregação que frequenta sem a necessidade de se dar opinião sobre quaisquer dos temas tratados. 
Esse fato aponta a liberdade que se tem na obtenção de esse corpus, o entrevistador tem a função de direcionar as perguntas, porém não há qualquer tipo de exigência com relação ao conteúdo das respostas que se pretende obter. Como já dissemos anteriormente, a preocupação maior é com relação ao tempo que deve ter cada entrevista e não com o seu conteúdo, propriamente dito.

Além das expressões de opinião do I, observa-se a ocorrência de opiniões do E, como pode ser constatado na tabela apresentada no início desta análise. São opiniões e comentários bastante diretos, como que interesante, que barbaridad, entre outros, não desconsideramos a sua importância para a interação entre os participantes e fluidez do diálogo, no entanto optamos por não analisar tais ocorrências, atendo-nos apenas nas ocorrências encontradas na fala do I.

\subsubsection{Cortesia valorizante}

É possível encontrar também nessa entrevista, exemplos de cortesia valorizante, na qual o E emite alguns elogios para o I. Observe abaixo os trechos:

(332) E: ¡ya ves! / si se te da bien / por lo visto eres una artista / ya veo que eres una

(342) E: ¡ah! / ¡ya ya ya! ¡qué artista! ¿no? / ¡qué barbaridad!

São ocorrências que influenciam positivamente no andamento da entrevista, pois favorecem a interação entre os participantes, além de serem benéficas para a face do I.

\subsubsection{Solidariedade}

Outro dado encontrado está relacionado à cooperação existente na fala, em que um falante muitas vezes é solidário ao outro, ajudando-o no esquecimento de algum termo, por exemplo. Encontramos alguns exemplos dessa ocorrência. Abaixo, citamos os trechos:

(368) I: de costura / pero decían ¡bueno! costura / si fuera costura como enseñaros a coser una falda / o ojales o historias de esas / pero lo que os limitamos es a que / cojáis un bastidor y os pongáis a

(371) E: ¡ah! / o sea que bordábais

(627) I: ... pues hace falta gente que ayude / hace falta colaboración también / ¿por qué no te vas y le preguntas a fulanito? / le dices que vas de mi parte / que me conocen / y entonces pues a lo mejor / te metes en otro

(631) E: en otra zona.

(632) I: en otra zona / pero estás haciendo la misma labor ¿no?

(735) I: ... o sobre el papel de la virgen en la semana santa / o en navidad hacer determinadas reuniones / o en verano / dependiendo también un poco

(738)E: el tiempo / la época del año. 
(882) I: y además que ¡muy bien! Porque / la verdad que es que tengo horario de tarde // y me llevo fenomenal con la chica que estoy o sea que

(885)E: o sea que estás muy cómoda / muy a gusto entonces.

(909) I: mira / tardé / salí a las ocho y cuarto / porque me entretuve más / tenía en realidad todo listo / pero tuve que hacer una llamada y me entretuve / llegué a coger el treinta y dos de las ocho y veinte // yo no sé cómo / porque de la Plaza de las Flores al Parque hay un

(913) E: jun rato!

São situações altamente colaborativas para a entrevista, pois favorecem a fluidez da mesma. Observamos inclusive que no trecho entre as linhas 882 e 885 o E deduz o que o I vai dizer, ou seja, ele mesma tira suas conclusões.

\subsubsection{Formas de tratamento}

Observa-se que ao longo de toda a entrevista, o entrevistador usa a segunda pessoa do singular para se dirigir ao informante. Abaixo apresentamos alguns excertos, seguidos de breve análise.

(01) Entonces cuéntame tú que tú eres de Málaga ¿no?

(38) ¡claro! / ¡claro! / porque vosotros vivíais por allí cerca entonces

(65) y que ¿cómo era la / la casa? ¿tú te acuerdas de la guardería cómo era? / me la podrías describir?

(100) ¡ah! / ¡ya ya ya! / ¿y erais muchos niños en el?

(115) o sea / que eran todos amigos tuyos.

(257) ¡ah! / os aconsejáis mutuamente ¿no?

(287) ¡ah! / que no sois muchos ¿no?

(349) y ¿qué tipos de trabajos hacíais en / en la clase?

(356) eso lo hacía yo / se me daba fatal / ¿y qué modelabais? ¿arcilla o barro o?

(375) y ¿qué hacíais? / ¿manteles o?

Acreditamos que não havia necessidade de retirar todos os exemplos de uso de formas de tratamento devido à recorrência dos mesmos. Por meio dos trechos acima, podemos concluir alguns pontos com relação ao uso nessa amostra.

Como já mencionado, o entrevistador usa a segunda pessoa do singular quando se refere ao informante, havendo concordância também com o pronome oblíquo e com o pronome possessivo.

Cabe destacar que quando o entrevistador se refere aos amigos do informante ou às pessoas que frequentam o mesmo centro que ele, opta-se pelo uso dos verbos e do pronome oblíquo na segunda pessoa do plural, embora não haja o uso explícito do pronome vosotros, pode-se concluir que esse é o pronome utilizado, uma vez que na Língua Espanhola o pronome sujeito nem sempre é expresso explicitamente, uma vez que o verbo já contém as marcas pessoais ${ }^{33}$.

\footnotetext{
${ }^{33}$ Sobre esse assunto, consultar Matte Bon, F. Gramática Comunicativa del Español - de la lengua a la idea. Madrid: Edelsa, 1998, vol.1.
} 
Não observamos ao longo da entrevista o uso de formas nominais, como já esperado devido à idade dos participantes.

\subsection{Amostra 25}

Informante feminino -26 anos

Entrevistador feminino - 28 anos

Tema 1 - As ciudades Málaga e Benalmádena

\begin{tabular}{|c|c|c|}
\hline Perguntas Principais & Perguntas complementares & $\begin{array}{l}\text { Comentários / opiniões / } \\
\text { marcadores de interação }\end{array}$ \\
\hline $\begin{array}{l}\text { (02) ¡ya! / ¡bueno! Cuéntame } \\
\text { entonces tú naciste en Málaga } \\
\text { (23) ¿pero tú estuviste muchos } \\
\text { años viviendo aquí / en } \\
\text { Benalmádena? } \\
\text { (38) ¿ya os habéis venido todos? }\end{array}$ & $\begin{array}{l}\text { (04) ¿en qué parte de Málaga? } \\
(25) \text { ¿y era tan chico? }\end{array}$ & $\begin{array}{l}\text { (06) sí / en el dieciocho } \\
\text { dieciocho } \\
\text { (09) ¡ah! El Parque San Antonio } \\
\text { ese ¿dónde? / ese ¿cuál? ¡ah! Sí } \\
\text { ¡ese está al lado! } \\
\text { (13) ¡ah! ¿sí? } \\
\text { (15) ¿y eso? ¿por qué? } \\
\text { (33) además entonces ni la } \\
\text { carretera ni nada } \\
\text { (35) ¡uy! ¡la pobre! } \\
\text { (41) ¡igual que yo! }\end{array}$ \\
\hline
\end{tabular}

Tema 2 - O irmão da informante

\begin{tabular}{|c|c|c|}
\hline Perguntas Principais & Perguntas complementares & $\begin{array}{l}\text { Comentários / opiniões / } \\
\text { marcadores de interação }\end{array}$ \\
\hline $\begin{array}{l}\text { (44) y tu hermano ¿cómo está? } \\
\text { (90) aparte tienen que hacer } \\
\text { maquetas también ¿o algo de } \\
\text { eso? }\end{array}$ & $\begin{array}{l}\text { (58) ¿de qué va a hacer el } \\
\text { proyecto) }\end{array}$ & $\begin{array}{l}\text { (46) ¿sí? } \\
(48) \text { ¡muy bien! } \\
\text { (50) es que arquitectura tiene un } \\
\text { (53) es que } \\
\text { (60) ¡ah! / o sea que no lo/ } \\
\text { no lo } \\
\text { (62) uno no es libre } \\
\text { (64) ¡ah! / yo creía } \\
\text { (67) ¡claro! } \\
\text { (69) yo creía que eso / que lo } \\
\text { elegías tú } \\
\text { (71) lo que tú quisieras / de } \\
\text { hecho el otro día leí en el } \\
\text { periódico de un / un proyecto } \\
\text { que se va a hacer en Barcelona } \\
\text { (74) de un arquitecto / y que era } \\
\text { su proyecto de fin de carrera / y } \\
\text { ahora lo va a llevar a cabo/ } \\
\text { después de } \\
\text { (77) de muchos años / un } \\
\text { mercado que lo va a convertir en } \\
\text { / ¿en qué? / en biblioteca / y no } \\
\text { sé qué otra } \\
\text { cosa más } \\
\text { (80) sí / una cosa } \\
\text { (83) sí / que no se inventan } \\
\text { (87) o sea / tienes como un curso } \\
\text { más }\end{array}$ \\
\hline
\end{tabular}




\begin{tabular}{|l|l|}
\hline & $\begin{array}{l}\text { (93) o sea que es un trabajo } \\
\text { bueno. } \\
\text { (98) o sea que todos vais a poner } \\
\text { de vuestra parte } \\
(100) \text { ibueno! / esas son las } \\
\text { cosas que salen bien / cuando } \\
\text { todo el mundo te apoya / todo el } \\
\text { mundo te }\end{array}$ \\
\hline
\end{tabular}

Tema 3 - Habilidade do I e a carreira de arquitetura

\begin{tabular}{|c|c|c|}
\hline Perguntas Principais & Perguntas complementares & $\begin{array}{l}\text { Comentários / opiniões / } \\
\text { marcadores de interação }\end{array}$ \\
\hline $\begin{array}{l}\text { (106) ¿tú eres muy rápida? / } \\
\text { ¿tienes muchas pulsaciones? } \\
\text { (158) iy cómo queda } \\
\text { arquitectura? ¿siguen siendo } \\
\text { cinco años? / me imagino que sí }\end{array}$ & $\begin{array}{l}\text { (161) que a pesar de la re lo que } \\
\text { cambian entonces ¿qué son? } \\
\text { ¿asignaturas? }\end{array}$ & $\begin{array}{l}\text { (108) iestá bien! } \\
(110) \text { porque yo ahora he } \\
\text { empezado a transliterar las } \\
\text { entrevistas } \\
(112) \text { y ¡vamos! / yo sí cogí / } \\
\text { aprendí a escribir a máquina / se } \\
\text { supone que tengo doscientas } \\
\text { cincuentas teóricas / pero iqué } \\
\text { va! } \\
\text { (115) ahora espero cogerlas con } \\
\text { todas la } \\
(118) \text { isegún como te pille! } \\
(127) \text { ihombre! / ila verdad es } \\
\text { que sí! lógicamente todo el } \\
(129) \text { logian } \\
\text { mundo/ cuando empieza una } \\
\text { carrera lo que quiere es ya que / } \\
\text { verlo que haya acabado y } \\
\text { (133) sí / pero es que } \\
\text { arquitectura es así / o sea } \\
\text { (135) ique es que los tienen } \\
\text { mareados y entretenidos! } \\
\text { (140) pero esos no cuentan } \\
\text { (142) iclaro! / habrá gente que se } \\
\text { aburra ¿no? } \\
\text { (148) iqué horror! } \\
\text { (164) porque hay muchas } \\
\text { carreras que lo han dejado en } \\
\text { cuatro años / pero hay otras } \\
\text { como derecho / las ingenierías/ } \\
\text { arquitectura que creo que no } \\
\text { (167) por mucho que quieran }\end{array}$ \\
\hline
\end{tabular}

Tema 4 - Tempo livre da I e parque da cidade / a cidade

\begin{tabular}{|c|c|c|}
\hline Per & & $\begin{array}{l}\text { es / } \\
\text { ção }\end{array}$ \\
\hline $\begin{array}{l}\text { (171) Bueno y tu en tu tiempo } \\
\text { libre / ¿qué te gusta hacer? / } \\
\text { ¿qué te gusta? } \\
\text { (178) entonces / en tu tiempo } \\
\text { libre ¿qué? } \\
\text { (183) pero algo harás ¿no? En tu } \\
\text { tiempo libre irte a la playa } \\
\text { (214) ¿qué sueles hacer? / ¿te }\end{array}$ & $\begin{array}{l}\text { (173) nada ¿no? } \\
\text { (180) ¿nada? } \\
\text { (193) pero la tienes muy cerca } \\
\text { ¿no? } \\
\text { (240) pues ahora con el Proyecto } \\
\text { Olimpo se ha declarado / ¿o eso } \\
\text { era antes? lo del / el monte ¿no? } \\
\text { se ha } \\
\text { (250) y ¿qué? ¿qué ár? ¿qué tipo } \\
\text { de árboles quieren plantar allí? }\end{array}$ & $\begin{array}{l}\text { (175) vale. } \\
\text { (189) ¿no? } \\
\text { (195) ¡bueno! / pero si vas un } \\
\text { ratito / ya es bastante ¿no? } \\
(205) \text { iś! / la verdad es que los } \\
\text { domingos ¡se pone todo! / } \\
\text { además los autobuses } \\
\text { (208) y menos aquí / ¿verdad? } \\
\text { (212) iqué va! } \\
\text { (217) ¡no es por tu novio! / jes }\end{array}$ \\
\hline
\end{tabular}




\begin{tabular}{|c|c|c|}
\hline $\begin{array}{l}\text { los animales? ¡es muy } \\
\text { agradable! } \\
\text { (280) y tú ¿qué dices? / ¿qué el } \\
\text { restaurante y todo eso iría en la } \\
\text { roca del Calamorro? }\end{array}$ & $\begin{array}{l}\text { (253) ¿y ahí es donde quieren } \\
\text { poner el observatorio? } \\
\text { (269) y eso por / ¿el telecabina } \\
\text { iría también en el monte ese o va } \\
\text { en? } \\
\text { (273) el Calamorro ¿cuál es? / } \\
\text { ¿el segundo? } \\
\text { (277) ¡oye! / pues va a ser un } \\
\text { proyecto bonito ¿no? } \\
\text { (290) y por ¿hasta dónde } \\
\text { llegaría? ¿hasta Tivoli? / o sea/ } \\
\text { ¿saldría de Tivoli } \\
\text { (318) o sea / pero el recorrido va } \\
\text { a ir por todo / pasaje paisaje } \\
\text { natural ¿no? } \\
\text { (344) y ahora ¿cómo se puede } \\
\text { subir? ¿andando? } \\
\text { (354) ¡qué bien! O sea ¿va? / ¿va } \\
\text { a marcha? / ¿cuánto tiempo lleva } \\
\text { el proyecto? } \\
\text { (364) y los verdes ¿por qué? / si } \\
\text { precisamente } \\
\text { (403) pues ¡supongo que sí! / } \\
\text { pero ¡bueno! / es que por allí / } \\
\text { pero son las casas de esa zona } \\
\text { ¿es urbanizable toda esa zona de } \\
\text { allí para atrás? } \\
\text { (419) sí / un montón// y aún } \\
\text { están haciendo bloques / pero del } \\
\text { otro lado son / casitas adosadas } \\
\text { ¿no? } \\
\text { (422) pero y eso ¿es que en esa } \\
\text { zona no se pueden construir } \\
\text { bloques o es que? // ¿por qué es? } \\
\text { (438) ya no se puede construir a } \\
\text { mucha altura ¿no? }\end{array}$ & 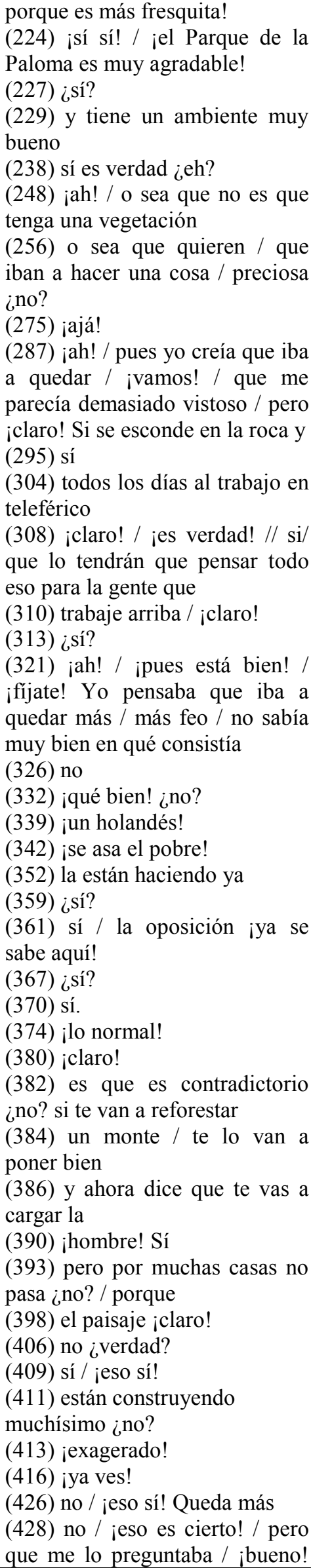 \\
\hline
\end{tabular}




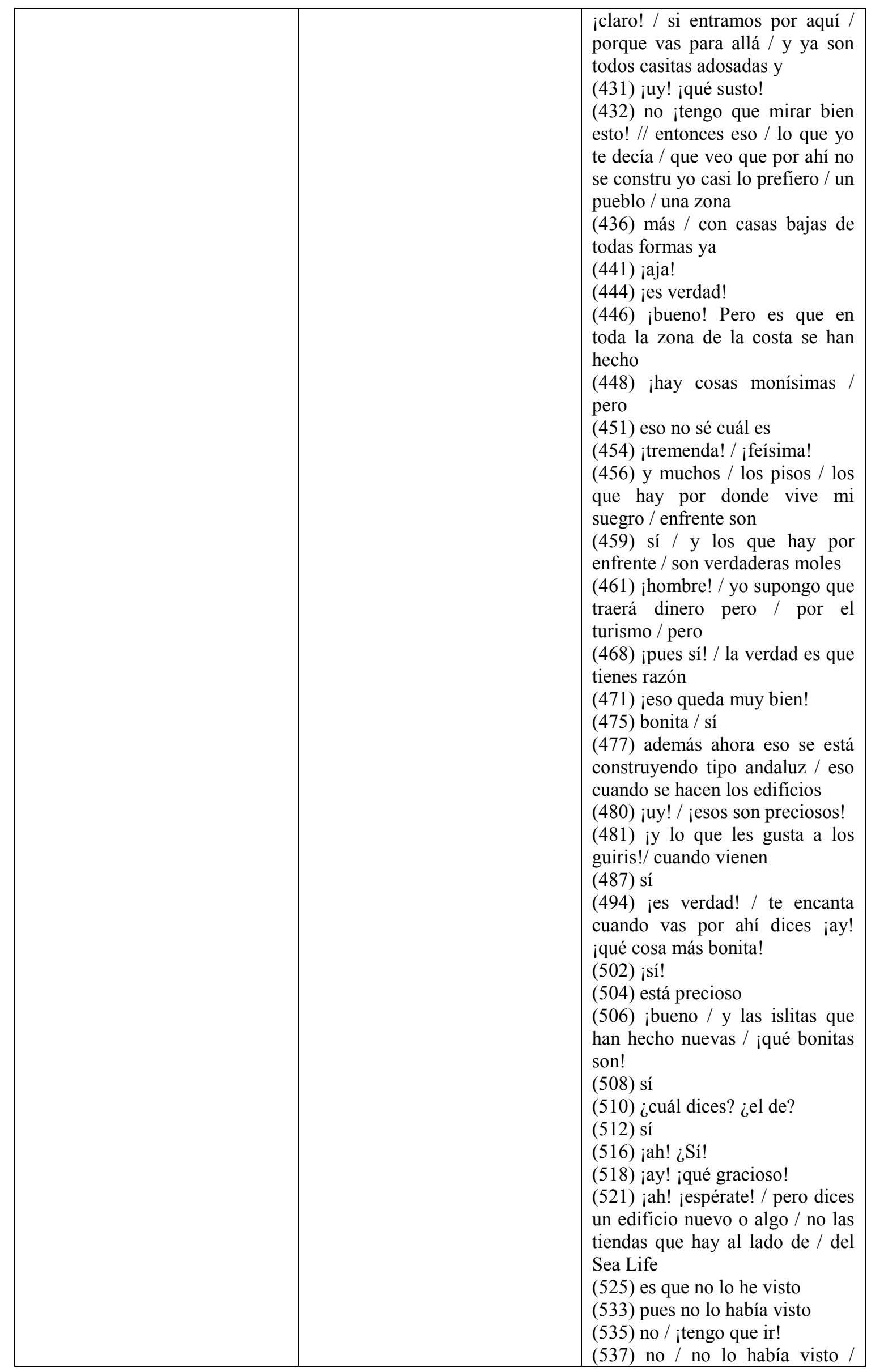




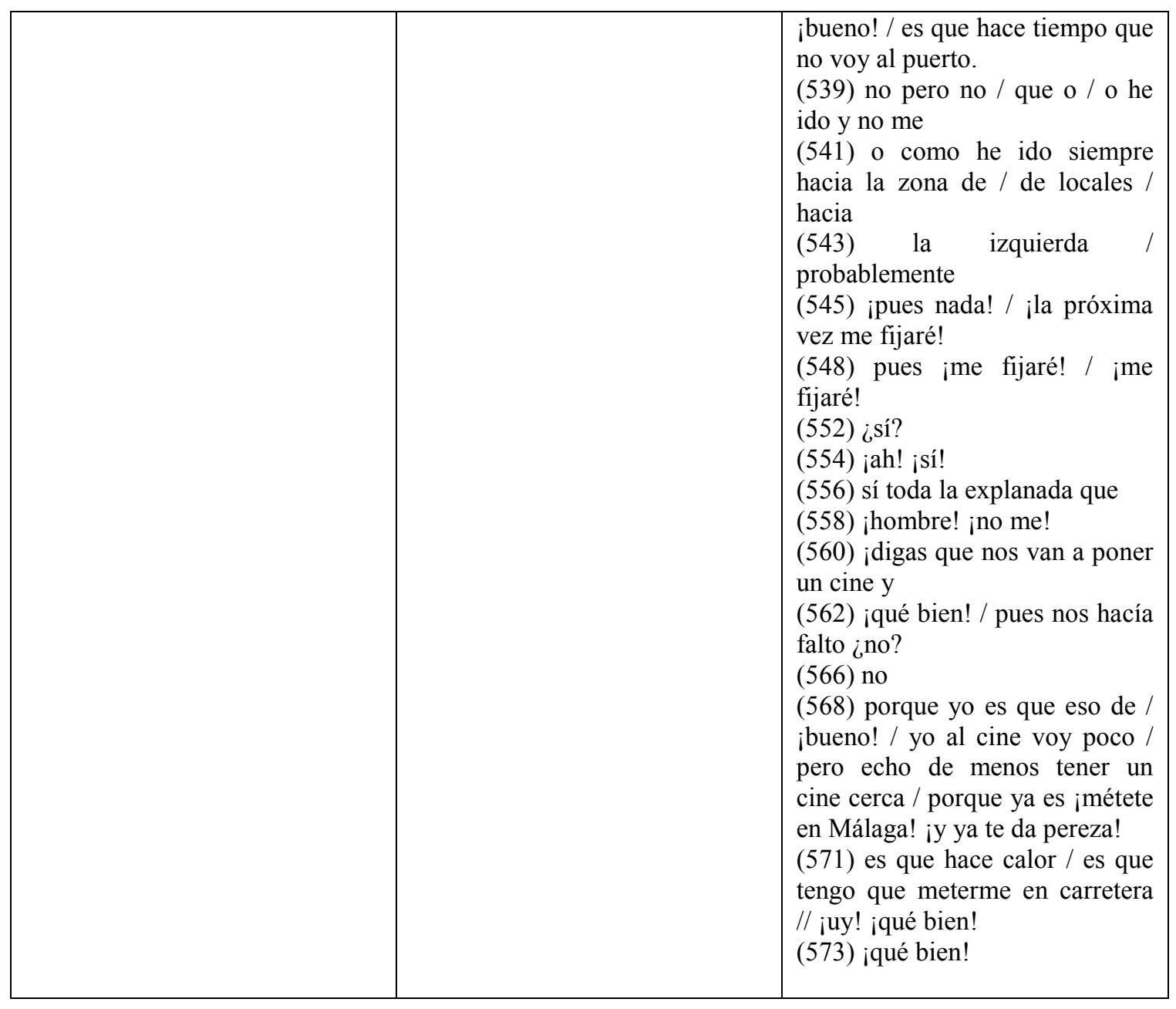

Tema 5 - O novo shopping que construirão na cidade

\begin{tabular}{|c|c|c|}
\hline Perguntas Principais & Perguntas complementares & $\begin{array}{l}\text { Comentários / opiniões / } \\
\text { marcadores de interação }\end{array}$ \\
\hline $\begin{array}{l}\text { (617) ¿tú crees que hacen } \\
\text { negocio? }\end{array}$ & & $\begin{array}{l}\text { (578) bien ¿no? diez } \\
\text { (580 caro ¿no? } \\
\text { (582) está la virtud / sí } \\
\text { (585) sí / que puede ser una } \\
\text { ruina el ponerte a } \\
\text { (596) ¡a lo grande! } \\
\text { (597) sí sí ¡es tremendo! } \\
\text { (600) es una pena ¿no? ¡un } \\
\text { puerto tan bonito! } \\
\text { (604) ¿sí? } \\
\text { (606) ibueno! / hay tiendas } \\
\text { bonitas / porque las de / hay una } \\
\text { así de decoración } \\
\text { (613) sí / la verdad es que sí } \\
\text { (619) sí ¿no? } \\
\text { (621) pues sí } \\
\text { (624) sí es verdad / es lo que tú } \\
\text { dices el saldo del año / y de }\end{array}$ \\
\hline
\end{tabular}


Tema 6 - Comparação com a cidade vizinha - Fuengirola

\begin{tabular}{|c|c|c|}
\hline Perguntas Principais & Perguntas complementares & $\begin{array}{l}\text { Comentários / opiniões / } \\
\text { marcadores de interação }\end{array}$ \\
\hline $\begin{array}{l}\text { (650) ¿es mucho más alta la } \\
\text { población de Fuengirola que la } \\
\text { de? }\end{array}$ & & $\begin{array}{l}\text { (631) Fuengirola es que está } \\
\text { muy bien } \\
\text { (634) y es curioso porque } \\
\text { Benalmádena es más bonita } \\
\text { (635) a mí me parece más bonita } \\
\text { / y sin embargo es verdad que la } \\
\text { el nivel es más alto allí. } \\
\text { (638) ibueno! / poquito a poco } \\
\text { (642) poco a poco } \\
\text { (644) pero un nivel comoel de } \\
\text { Fuengirola estaría bien/ ¡la } \\
\text { verdad es que sí! } \\
\text { (646) ique se consiguiera eso! } \\
\text { (654) supongo que también } \\
\text { ayuda } \\
\text { (656) pero esto es más coqueto a } \\
\text { mí me gusta más } \\
\text { (659) ia nosotros difícilmente } \\
\text { nos mueven! }\end{array}$ \\
\hline
\end{tabular}

Tema 7 - O colégio

\begin{tabular}{|c|c|c|}
\hline Perguntas Principais & Perguntas complementares & $\begin{array}{l}\text { Comentários / opiniões / } \\
\text { marcadores de interação }\end{array}$ \\
\hline $\begin{array}{l}\text { (661) vosotros cuando vivíais } \\
\text { aquí ¿ibas ¿ibais al colegio aquí } \\
\text { o? } \\
(671) \text { ¿y a qué colegio ibas? } \\
(680) \text { y ¿qué venía? / ¿un } \\
\text { autobús del colegio? } \\
\text { (682) ¡ah! / ¡muy bien! Y ¿qué } \\
\text { tal el colegio allí? ¿qué pa? ¿qué } \\
\text { tal? ¿qué recuerdos tienes? } \\
\text { (686) ¿siempre has estudiado } \\
\text { allí? ¿ ¿tenías } \\
\text { (731) y con los compañeros } \\
\text { ¿bien? } \\
\text { (736) o sea que aunque no tienes } \\
\text { / el nivel de estudios era / allí } \\
\text { tiene que ser } \\
\text { (747) ¿achas } \\
\text { actividades extraescolares? } \\
\text { (764) no / pues eso te iba a } \\
\text { preguntar / porque si vives aquí / } \\
\text { ¿en qué colegio? ¿qué colegio } \\
\text { hay por aquí? }\end{array}$ & $\begin{array}{l}\text { (704) pero unas gafas de sol o } \\
\text { unas gafas de ver } \\
\text { (706) ¡ah! Las gafas de sol ¿y } \\
\text { eso? } \\
\text { (739) de ser exigente } \\
\text { (752) él también va allí a } \\
\text { (767) ¿es bueno el colegio? / yo } \\
\text { es que no sé } \\
\text { (796) ¿cuántos hay? }\end{array}$ & $\begin{array}{l}\text { (662) ¿sí? } \\
(665) \text { ¡ah! ¿sí? } \\
(667) \text { ¡ah! ¿sí? } \\
\text { (673) ¡ah! ¡bueno! / que dentro } \\
\text { de lo que cabe era el más } \\
\text { (677) ¿sí? } \\
\text { (690) ¿sí? } \\
\text { (693) ¿sí? } \\
\text { (695) ¡qué deprimente! ¿no? } \\
\text { (697) yo pensaba / pensaba que } \\
\text { tenía un ambiente mejor } \\
\text { (701) ¡ah! ¿sí? } \\
\text { (709) sí / las marcas buenas } \\
\text { (711) ¡ah! / ¡bueno! No sabía / } \\
\text { ¡será que como yo llevo las gafas } \\
\text { muy antiguas no me las roba } \\
\text { nadie! } \\
\text { (715) sí / esas que se llevan } \\
\text { (717) ¡ah! / ¡de la misma clase! } \\
\text { (720) ¡qué susto! } \\
\text { (723) ¡qué pena! ¿no? } \\
\text { (727) ¡como todo! } \\
\text { (733) ¿sí? } \\
\text { (743) ¡a nadie! } \\
\text { (749) ¿no? } \\
\text { (756) no / lo que pasa que } \\
\text { cuando tienes la activi/ ¡bueno! } \\
\text { Antes no había tantas como hay } \\
\text { ahora } \\
\text { (759) ¡eso sí! / lo que pasa que } \\
\text { siempre que sean dentro del } \\
\text { mismo colegio / a ti te parece } \\
\text { todo lo mismo / también }\end{array}$ \\
\hline
\end{tabular}




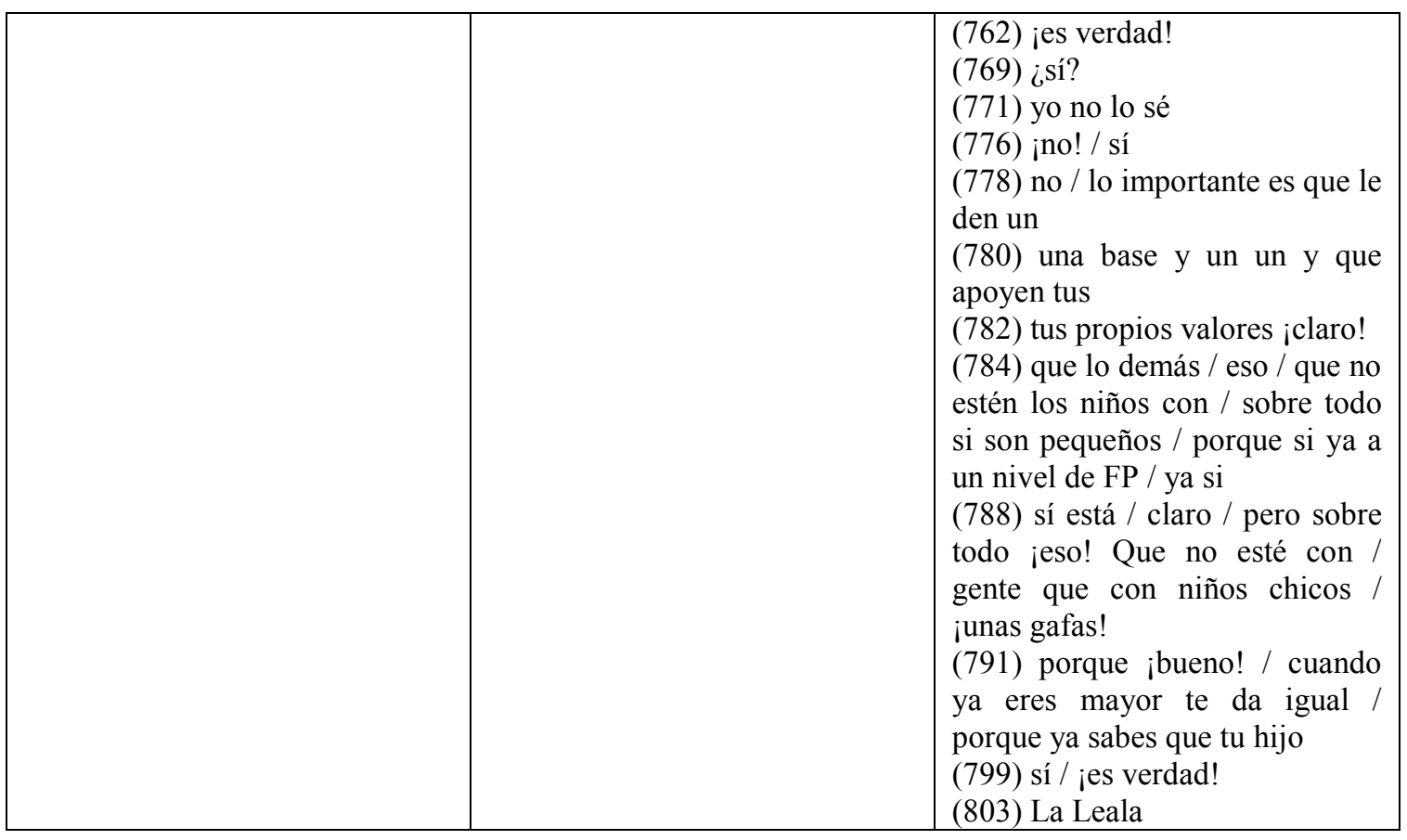

Tema 8 - Irlanda

\begin{tabular}{|c|c|c|}
\hline Perguntas Principais & Perguntas complementares & $\begin{array}{l}\text { Comentários / opiniões / } \\
\text { marcadores de interação }\end{array}$ \\
\hline $\begin{array}{l}\text { (805) yo conozco La Leala y El } \\
\text { Tomillar iahora!/ iya está! / ¿y } \\
\text { qué recuerdos tienes de Irlanda? } \\
\text { (818) ¿cuánto tiempo estuviste? } \\
\text { (824) ahora te parecerá / sin } \\
\text { embargo lo hace / lo vivirás } \\
\text { todavía muy cerca ¿no? } \\
\text { (828) ¿y cómo era tu vida allí? / } \\
\text { ¿era muy diferente de? } \\
\text { (850) ibas / pero ibas a estudiar a } \\
\text { allí al pueblo o } \\
\text { (864) ¿tú estabas muy cerca? / } \\
\text { ¿muy lejos de Dublín o } \\
\text { (881) aparte que dicen que es } \\
\text { muy bonita ¿no? Irlanda } \\
\text { (915) ¿sigues teniendo contacto } \\
\text { con la familia de de allí? } \\
\text { (945) sí ique tenías tu } \\
\text { independencia! / ¿tenías alguna } \\
\text { especie de i ¿alguna niña de tu } \\
\text { edad? ¿alguna chica de tu? }\end{array}$ & $\begin{array}{l}\text { (820) ¿dos años? } \\
(973) \text { tenías un ambiente } \\
\text { familiar entonces } \\
\text { (993) sí / confiaban en ti ¿no? } \\
\text { ¡hombre! / también supongo que }\end{array}$ & $\begin{array}{l}\text { (811) ¡claro! } \\
(813) \text { ies duro! } \\
(815) \text { además que tendrías } \\
(822) \text { ¡qué bien! } \\
(830) \text { ¿sí? } \\
(835) \text { ¿ya está? } \\
(840) \text { ¡la novedad! } \\
(847) \text { ¿sí? } \\
(853) \text { ¿sí? } \\
\text { (867) ¡ah! ¡muy bien! } \\
\text { (871) ¿sí? } \\
\text { (873) iqué bonito! } \\
\text { (878) ique bonito! } \\
\text { (883) Dublín dicen / yo es que } \\
\text { no / es mi mi / tengo como una } \\
\text { especie de / de promesa de ir a } \\
\text { Dublin y nunca voy } \\
\text { (887) ¡nunca voy! ¡nunca voy! } \\
\text { (889) ¿sí? } \\
\text { (894) vive la tente más } \\
\text { (911) iqué bueno! ¿no? } \\
\text { (920) sí que ellos tampoco } \\
\text { pusieron } \\
\text { (922) pero lo importante es que } \\
\text { se portarían bien contio ¿no? } \\
\text { (925) ¿sí? } \\
\text { (927) ¿sí? } \\
\text { (931) ¡qué horror! Que } \\
\text { (940) ¡claro! / si chocas con la } \\
\text { familia } \\
\text { (962) iqué horror! } \\
\text { (967) iqué agobio! ¿no? } \\
\text { (970) jcierto! }\end{array}$ \\
\hline
\end{tabular}




\begin{tabular}{|l|l|l|}
\hline & $\begin{array}{l}\text { (978) iqué bien! } \\
(984) \text { qué bien! } \\
(986) \text { que si se portan bien/ } \\
\text { estupendo } \\
\text { (991) eso es muy importante / } \\
\text { sentirte bien/ como en tu casa. } \\
\text { (995) y que / si hacían jhombre! } \\
\text { / si se fiaban en ti era también } \\
\text { porque podían fiarse } \\
\text { (1005) iqué bien! } \\
(1007) \text { ¡muy bien! }\end{array}$ \\
\hline
\end{tabular}

Tema 9 - A loteria

\begin{tabular}{|c|c|c|}
\hline Perguntas Principais & Perguntas complementares & $\begin{array}{l}\text { Comentários / opiniões / } \\
\text { marcadores de interação }\end{array}$ \\
\hline $\begin{array}{l}\text { (1009) ¡oye! Y tú si te tocase la } \\
\text { lotería ¿qué? ¿qué harías? } \\
(1012) \text { ¿dónde te ibas a ir? } \\
(1014) \text { ¿dejabas el trabajo? } \\
(1022) \text { ¿por dónde? }\end{array}$ & $\begin{array}{l}\text { (1020) pero por lo pronto un } \\
\text { viajecito bueno ¿no? } \\
\text { (1035) tú de jefa ¿no? }\end{array}$ & $\begin{array}{l}\text { (1027) ocupada ¿no? } \\
\text { (1032) sí ¡la verdad es que sí! } \\
\text { (1037) muy bien / pues yo me / } \\
\text { ¡yo creo que lo mismo! ¡me iría } \\
\text { por ahí también! Espera voy a } \\
\text { parar esto }\end{array}$ \\
\hline
\end{tabular}

De acordo com os temas encontrados, optamos por dividir essa entrevista em nove partes. Nota-se que há grande diversidade temática, conforme se pode verificar nas tabelas apresentadas anteriormente. Observa-se que alguns temas são expandidos, enquanto outros não. Acreditamos que isso se deve ao interesse do $\mathrm{E}$ em ampliar a conversa sobre determinado assunto ou encerrá-lo, sugerindo nova proposta.

A interação estabelecida entre os participantes é acentuada. Atribuímos isso a alguns fatores como o fato de já se conhecerem e as idades, bastante próximas. Observase que o E se sente à vontade para expor sua opinião sobre os assuntos tratados e o I em lhe fazer perguntas, invertendo os papéis.

Como já observado em análises anteriores, o ritual de iniciação é mantido, no qual o E pergunta se o I é de Málaga, de qual parte da cidade, etc. É interessante observar, como nessa entrevista, um assunto se enlaça ao outro, além disso, nem sempre é o E quem muda de tema ou quem redireciona o tópico a ser tratado, caracterizando o alto grau de interação existente entre os participantes.

Com relação às perguntas principais, observamos uma única ocorrência de uso do imperativo, os demais casos são todos de enunciados interrogativos diretos. Em momento algum se observa a frequência de atos preparatórios ou tentativas de proteção à face. Podemos interpretar o uso do imperativo como a forma que o E encontrou para dar início à entrevista. Abaixo analisaremos as outras formas de imperativo encontradas ao longo da entrevista em enunciados não interrogativos. 


\subsubsection{Imperativo}

Apresentamos os enunciados não interrogativos que contêm verbos no imperativo, na sequência uma breve análise sobre os trechos encontrados.

(150) I: o sea que / que es fuerte / también es que te meten asignaturas que después a lo mejor no no / no las necesitas / ¡tú fíjate! / él le queda física...

(296) I: que hay que hacer / por si / imagínate / ¡bueno! Para subir las mercancías...

(324) I: ... lo que tampoco puede hacer es un telecabina y que allí no haya nada / porque ¡imagínate! / ¡bueno! / las vistas son...

(337) I: y más imagínate en agosto / ¡no sé! // nosotros ¡anda!

(484) I: ... es que eso ellos no / no lo ven ¡mira! / yo he estado en en Irlanda

(524) I: al lado justo del Sea Life ¡mira!

(774) I: ... todos los colegios que hay son públicos pero ¡vaya! Que hoy en día real ¡mira! / yo pienso que el niño que quiere estudiar

(809) I: la verdad es que / ¡bueno! El / el día que me fui lloraba / como una magdalena / porque ¡imagínate! / pues no tenía ni idea de hablar inglés

(833) I: ... iyo que sé! / pues imagínate / la avenida principal de aquí / pues eso / eso era el pueblo

(847) I: ... pero que se ponían sentados en el jardín / ¡oye! / y se achcharraban

(902) I: ... tú entrabas ¡imagínate! / pues podía ser perfectamente como esta oficina...

(989) I: ... no podían ¡imagínate! / les entraba y no podían ir a coger una galleta...

(277) E: ioye! / pues va a ser un proyecto bonito ¿no?

(321) E: ¡ah! / ipues está bien!/ ¡fíjate! Yo pensaba que iba a quedar más...

(1009) E: ¡oye! y tú si te tocase la lotería ¿qué? ¿qué harías?

Como já observado em outras entrevistas, são os mesmos quatro verbos que se repetem quando o falante usa o modo imperativo para referir-se ao interlocutor. Utilizando mira e oye o falante se aproxima de seu interlocutor, procurando inclusive certa compreensão com o que está sendo dito. Já ao usar fijate e imagínate o falante busca uma chamada de atenção para com o outro, pois considera que a informação que ali está sendo transmitida tem relativa importância com relação às outras.

Observamos que o E também faz uso desse modo verbal referindo-se ao I. É mais um dado que comprova a interação entre ambos, pois houve liberdade para a chamada de atenção, tanto quando usa oye quanto fijate.

\subsubsection{Desfocalização do eu}

Nessa entrevista encontramos diversas ocorrências em que o falante usa outra pessoa verbal com a intenção de desfocalizar o eu, ainda que seja para falar dele mesmo. Abaixo apresentamos os trechos:

(65) suelen darte / o viviendas / o a lo mejor / no sé / polideportivos / campos de fútbol / entonces tú eliges $/ / \ldots$

(68) yo creía que eso / que lo elegías tú

(88) sí / prácticamente sí / además después / como no le gustes al profesor o lo que sea / te lo echan para atrás / y lo tienes que repetir

(122) pero / no / pero ya / si te pones a escribir todo el rato y eso te ¡claro! / coges práctica es que...

(149) o sea que / que es fuerte / también es que te meten asignaturas que después a lo mejor no no / no las necesitas... 
(186) (...) me me encanta la siesta / lo que pasa que la verdad es que después te levantas peor de / de cómo te has acostado / entonces...

(311) yo supongo que eso que / que aparcarás allí y subirás/ después el recorrido (...)

(327) (...) ¡la vista es increíble! / porque ves todo Málaga como / como piles un día despejado es que puedes ver Sierra Nevada...

(335) (...) tampoco vas a llegar allí / vas a subir puedes estar

(396) (...) va mirando a ver si tú estás colgando la ropa / o estás haciendo el puchero (...)

(402) (...) y viendo pasar a todo el mundo ipero bueno! / ;te acostumbrarás!

(488) no sabes realmente dónde estás ¿sabes? / en la típica casita que dibujas cuando eres pequeñito (...) ¡como la luz solar la ves poquísimo! ...

(563) (...) poniéndote un centro comercial que te pongan tiendas de ropa / te pongan un par de cines / es que ya no te hace falta moverte de aquí

(679) porque había que cruzar todo Málaga / y el tráfico / y esto / que quieras que no te metías por carretera y no / y no pilabas tanto tráfico

(744) ¡a nadie! / entonces da igual donde te metan / es algo que pero después cuando sales pues te acuerdas ...

(812) a un país nuevo / a una familia que no conoces / que quieras que no es duro

(859) era / aquello era / que te daba / te daba miedo / decías ¡bueno! Esto un día / estoy aquí y se me cae la mesa...

(912) además con el frío y eso / que llegabas allí / te metías y ese olor...

(978) sí / incluso el último año que estuve / que era el último año de curso que / yo hice comosi dijéramos la selectividad allí / y teníamos como una misa que / que te dan y todo...

(997) (...) pienso que sea un yo creo que es fácil / acomodarte ¡hombre! / siempre sabes que no es tu familia y que / y que contra me menos te meta en sus cosas / mejor...

(1034) (...) pero tú puedes aparecer cuando quieres

(494) E: ¡es verdad! / te encanta cuando vas por ahí dices ¡ay!...

(791) E: porque ¡bueno! / cuando ya eres mayor te da igual / porque ya sabes que tu hijo

(940) E: ¡claro! / si chocas con la familia

Observamos que essa estratégia de desfocalização pode ser encontrada tanto na fala do I quanto do E. Outro dado relevante é o fato de apenas uma entre todas as ocorrências estar na primeira pessoa do plural, todas as demais estão na segunda pessoa do singular. Entendemos que a intenção do falante ao utilizar esse tipo de estratégia é não centralizar todo o discurso na primeira pessoa. Assim, ainda que ele esteja falando dele mesmo e que isso esteja claro para o interlocutor, opta-se por uma terceira pessoa verbal, sem especificação. Atribuímos o uso da primeira pessoa do plural ao fato de o I pretender incluir os outros estudantes a que se refere no discurso, deixando claro que todos os alunos se submetiam aos exames, tinham a missa, etc.

\subsubsection{Prevenção de ameaça à face}

Abaixo apresentamos os trechos que contêm os atos ameaçadores da face dos participantes da entrevista.

(65) suelen darte / o viviendas / o a lo mejor / no sé / polideportivos / campos de fútbol / entonces tú eliges $/ /$ me parece que te ponen dos o tres cosas (251) pues ¡hombre! / yo supongo que plantarán pinos o // cosas que se den ahí ¿no?

(299) no sé / no va a estar preparado para que suban coches / se va a intentar que / que por ese camino pues solo se suba / eso / la carga y descarga / los camiones / gente que trabaje arriba a lo mejor que pues que no coja el telecabina ¿no? / yo la ¡tampoco sé como irá eso!

(353) me parece que ya está terminada 
(463) ¡hombre! ¡claro! / aunque yo supongo que // ¡no sé! / porque ¡claro! / también piensa que...

Todas as ocorrências acima são exemplos de expressões que o I usa para proteger a própria face pelo fato de não estar completamente seguro sobre a informação que está sendo fornecida. São marcadores que indicam dúvidas em diferentes intensidades. Assim me parece e supongo indicam maior certeza do que no sé, no qual o falante já indica seu completo desconhecimento sobre o assunto. Com isso ele protege também a face do $\mathrm{E}$ que, provavelmente, evitará fazer perguntas específicas sobre temas não dominados totalmente pelo I.

\subsubsection{Ameaça à face}

Ao longo da entrevista encontramos alguns trechos que podem ser interpretados como atos ameaçadores da imagem. O primeiro deles ocorre entre as linhas 528 e 541 , quando o assunto é a cidade em que estão.

I: ¿tú ves el Sea Life? / bueno pues a / al lado de donde está esta cosa verde que antes era un / una gran una cancha de baloncesto y eso / pues

E: sí.

I: eso ahora es un centro comercial / que se va a hacer

E: pues no / no lo había visto

I: i¿no?!

E: no / ¡tengo que ir!

I: que lo están pintando amarillo / ¿no lo has visto?

E: no / no lo había visto / ¡bueno! / es que hace tiempo que no voy al puerto.

I: pero / tiempo / hará / ¡más de un año!

E: / no pero no / que / o / o he ido y no me

I: y no te has fijado o no te

E: o como he ido siempre hacia la zona de / de locales / hacia

O comentário do I de que deve fazer mais de um ano que o E não vai ao lugar mencionado poderia ser interpretado como um ato ameaçador da imagem do E, no entanto, a nosso ver, demonstra confiança por parte do I. Acreditamos que se houvesse essa preocupação com a imagem, provavelmente o assunto se encerraria no momento em que o E diz que faz tempo que não vai ao porto. Ainda assim, é possível observar que imediatamente o I procura restabelecer o equilíbrio da conversação afirmando que ele não prestou atenção na cor do centro comercial. Com isso o I atenua sua fala anterior e o diálogo segue sem maiores interferências.

\subsubsection{Atenuantes}

Ao longo dessa entrevista, encontramos também algumas marcas de atenuação, tanto na fala do E quanto do I. Abaixo mencionamos alguns exemplos, tecendo nosso comentário a respeito de cada caso. 
(28) I: ... la verdad es que era un poquito deprimente / además cualquier cosa que tenías que comprar...

(190) I: no / yo voy a la playa dos horitas / y ya digo / a partir de dos horas ya me agobio...

(452)I: que son justo los bloques que están bajando al puerto / que / que te quedan a mano derecha / que es que esos ;son una mole!

(454) E: ¡tremenda! / ¡feísima!

(455) I: no queda bonito / la verdad es que no

(888) I: Dublín / es bonito sí / un poquito sucio

O primeiro e o último trecho apresentam semelhanças com relação a sua composição: ambos compostos pelo adjetivo poco no diminutivo atenuando o adjetivo que aparece ao lado. Em um há uma atenuação sobre a cidade a que se refere o I e no outro à quantidade de sujeira que se encontra em Dublin. No segundo trecho há uma atenuação com relação ao tempo máximo que o I passa na praia.

O terceiro exemplo é o trecho que mais nos chama a atenção, pois o E emite seu juízo de valor sobre as casas às quais eles estão comentando e a fala do I serve para contemporizar o enunciado do E. Mais uma vez temos um exemplo de interação entre os participantes dessa entrevista, pois se não houvesse essa característica de informalidade, não caberia ao E expressar sua opinião sobre determinado tema.

Cabe ressaltar que ao longo da entrevista observamos diversos exemplos de uso do diminutivo, porém não tinham a função de partícula atenuadora, por isso optamos por não mencioná-los em nossa análise.

\subsubsection{Expressão de opinião}

Como já dissemos anteriormente, a nosso ver o fato de o E expressar sua opinião diversas vezes ao longo da entrevista comprova que a interação entre ele e o I é bastante alta. Sendo assim, nesse campo apresentaremos e analisaremos os trechos em que o I expressou sua opinião e quais foram os recursos usados para isso. Todas as falas abaixo pertencem ao I.

(207) sí / ¡es horrible! / a mí la verdad es que el / el verano cada día me / me gusta menos.

(315) se ilumina // también le va a dar más / ta yo pienso que / que queda bonito / que puede quedar bonito / por la noche las lucecitas / si lo iluminas bien queda gracioso

(427) la verdad es que / yo creo que a lo mejor son más estéticas que

(463) ¡hombre! ¡claro! / aunque yo supongo que // ¡no sé! / porque ¡claro! / también piensa que / que ahora mismo se está construyendo muchísimo / pero que // que el / que Benalmádena tiene un límite / yo supongo que / en cuanto se construya todo o la gran mayoría / después tendrán que empezar a construir hacia arriba

(563) la verdad es que sí / porque yo creo que aquí/ poniéndote un centro comercial que te pongan tiendas de ropa / te pongan un par de cines / es que ya no te hace falta moverte de aquí

(590) ¡ag! / ¡tampoco es eso! / es que eso es / ¡de verdad! / yo es que lo digo / lo pienso / digo ¡no! / si quieren cambiar el turismo y quieren se están haciendo muchas cosas / se están cambiando y / y lo que se quiere es que el nivel del turista que venga aquí sea más alto digo ipero ¿cómo se te ocurre poner esa especie de tienda de los veinte duros?! 
(691) ¡aquello era horrible! / estaba La Palmilla metida allí

(763) pero ¡vamos! // pero ¡bien! / ¡hombre! / yo no metería a mis niños ahí / pero ¡bueno!

(772) aquí es que realmente / no hay colegio privado / todos los colegios que hay son públicos // pero ¡vaya! / que hoy en día real / ¡mira! / yo pienso que el niño que quiere estudiar

Os temas tratados ao longo dessa entrevista são amenos e expor sua opinião sobre os mesmos não faz com que o I exponha sua face negativa. Sendo assim, observamos que há situações em que ele faz uso de verbos ou expressões parentéticas como creer ou pensar, por exemplo, e há outras situações em que a opinião é dada diretamente, sem que se utilize qualquer tipo de partícula atenuadora, ou seja, são diretas. Entendemos que a diferença entre ambas está na proximidade que o I tem com o que está sendo descrito, assim se é algo que está mais próximo do I, algum assunto que ele domina plenamente não há a necessidade de se usar o tipo de verbo descrito acima, como no caso dos excertos 691 e 763 e por outro lado, se é algo que envolve juízo de valor, com exceção dos citados, todos os outros, há a preferência pelo uso de tais verbos de forma que o falante deixe claro que aquele é o seu ponto de vista sobre o tema, sem generalizar a questão.

Como pode ser observado nas tabelas apresentadas no início desta análise, há um alto índice de ocorrências nas quais o E expõe sua opinião ou tece algum comentário sobre o tema tratado. Embora não tenhamos o objetivo de analisar tais ocorrências, atribuímos isso ao fato de a idade dos participantes ser muito próxima e também pelo conhecimento prévio existente entre os mesmos. Como já observado, a interação entre E e I tem acentuada importância nesta amostra.

\subsubsection{Invasão do território pessoal}

Abaixo apresentamos um trecho que poderia dar sequência a uma ocorrência de invasão de território pessoal do I.

(724) I: pero ¡vaya! pero ¡bien!/ y los colegios pues ¡como todo! / yo me lo pasaba bien// ¡mal no me lo pasaba! / la verdad es que malos recuerdos de / a lo mejor / un poco en desacuerdo con algunas cosas (727) E: ¡como todo!

Nesse extrato podemos observar que o I não se aprofunda nos problemas que tinha no colégio e tampouco o E faz perguntas instigando esse tipo de resposta. Pelo contrário, posteriormente muda de assunto, perguntando sobre os companheiros, evitando correr o risco de ser indiscreto. 


\subsubsection{Solidariedade}

Situações em que um falante complementa a fala do outro também estão presentes ao longo dessa entrevista. Abaixo apresentamos os trechos:

(337) I: y más imagínate en agosto / ¡no sé! // nosotros ¡anda! / estamos acostumbrados pero / pero imagínate un / un inglés o un / uno de

(339) E: ¡un holandés!

(394) I: ¡no! / no pasa por muchas casas / ipero bueno! / tampoco / realmente la gente que va montada en un telecabina va mirando a ver si tú estás colgando la ropa / o estás haciendo el puchero ¿sabes? / la gente va mirando lo que

(398) E: el paisaje ¡claro!

(778) E: no / lo importante es que le den un

(779) I: una base

(780) E: una base y un un y que apoyen tus

(781) I: una educación

Nas três situações apresentadas acima temos duas ocorrências em que $\quad$ o $\quad E$ complementa a fala do I e uma em que é o I quem complementa a fala do E. Esse tipo de estratégia demonstra atitudes corteses por parte dos interlocutores, pois permite que o falante se recorde do que está falando, fazendo com que a dinâmica da interação seja mantida e o diálogo tenha fluidez. Nem sempre o que o interlocutor diz é exatamente a palavra que o falante se esqueceu, no entanto essa atitude pode ajudá-lo a se recordar do termo que necessita para dar sequência ao seu pensamento.

\subsubsection{Formas de tratamento}

Observa-se que a forma de tratamento utilizada pelo entrevistador para se dirigir ao informante é a segunda pessoa do singular. Abaixo apresentamos algumas ocorrências, seguidas de breve análise.

(02) ¡ya! / ¡bueno! Cuéntame entonces tú naciste en Málaga

(38) ¿ya os habéis venido todos?

(44) y tu hermano ¿cómo está?

(98) o sea que todos vais a poner de vuestra parte

(171) Bueno y tú en tu tiempo libre / ¿qué te gusta hacer? / ¿qué te gusta?

(661) vosotros cuando vivíais aquí ¿ibas ¿ibais al colegio aquí o?

(993) sí / confiaban en ti ¿no? ¡hombre! / también supongo que

Como pode ser observado por meio dos exemplos acima, há total concordância entre o pronomes pessoais do caso reto e oblíquo e o possessivo, todos na segunda pessoa do singular. Embora tenhamos apresentado apenas alguns trechos, afirmamos que isso se repete ao longo de toda a entrevista.

Observa-se o uso da segunda pessoa do plural, vosotros, quando o entrevistador se refere à família do informante, em que também nota-se concordância quando há o uso de 
outros pronomes como o oblíquo e o possessivo. É mais uma amostra que aponta a diversidade pronominal existente na região da Andaluzia, a qual contraria alguns teóricos, como pode ser observado na fundamentação teórica desse trabalho.

Novamente não há ocorrências de formas nominais, entendemos que a idade do informante fez com que toda a forma de tratamento utilizada ao longo dessa amostra estivesse no eixo de solidariedade.

\subsection{Amostra 31}

$$
\begin{aligned}
& \text { Informante masculino - } 35 \text { anos } \\
& \text { Entrevistador feminino - } 28 \text { anos }
\end{aligned}
$$

\begin{tabular}{|c|c|c|}
\hline Perguntas Principais & Perguntas complementares & $\begin{array}{l}\text { Comentários / opiniões / } \\
\text { marcadores de interação }\end{array}$ \\
\hline $\begin{array}{l}\text { (01) Así yo veo la lucecita y si } \\
\text { se le acaba la pila o no // } \\
\text { entonces tú me has dicho que tú } \\
\text { no naciste en Málaga pero llevas } \\
\text { viviendo aquí } \\
\text { (18) el emato / el economato ¿en } \\
\text { qué consiste? } \\
\text { (50) y ¿habéis vivido siempre } \\
\text { aquí en Arroyo o habéis? } \\
\text { (76) vives aquí / aquí se vive } \\
\text { bien en el / en Arroyo ¿no? / } \\
\text { ¡claro! / tú llevas toda tu vida }\end{array}$ & $\begin{array}{l}\text { (09) no / no te emancipaste tan } \\
\text { pronto ¿no? } \\
\text { (42) salió tirando ¿no? } \\
\text { (61) y ¿por qué los llaman? } \\
\text { (85) ¿no? ¡ya está! } \\
\text { (99) ¡ah! / que te están haciendo } \\
\text { (101) una plaza ¿no? } \\
\text { (127) es una cuestión de } \\
\text { educación ¿no? el }\end{array}$ & $\begin{array}{l}\text { (13) o sea / que a ellos mismos } \\
\text { les apetecía } \\
\text { (36) ¡qué mala sombra! ¿no? } \\
\text { (38) ¡qué mala suerte! } \\
\text { (47) muy pequeñito } \\
\text { (56) sí más o menos } \\
\text { (68) marrones // ya } \\
\text { (71) ¡qué horror! } \\
\text { (88) además está muy bien / yo } \\
\text { llevo ¿cuánto tiempo aquí? / un } \\
\text { año y medio o poco más } \\
\text { (91) desde que me casé / y poco / } \\
\text { y } \\
\text { (93) ¡exactamente! / es que he } \\
\text { notado el cambio a mejor } \\
\text { (105) ¡entonces te lo van a dejar } \\
\text { esto muy bien! } \\
\text { (113) ¡claro! / ¡mucho mejor! } \\
\text { (115) va a mejorar } \\
\text { (122) ¡para tener perro hay que } \\
\text { saber tenerlo! / yo creo que es } \\
\text { como } \\
\text { (124) ¡sí! / ¡también es verdad! } \\
\text { (129) el que tiene un perro tiene } \\
\text { que respetar a los demás / y que } \\
\text { el perro no moleste / a mí ¡mira } \\
\text { que soy la gran defensora de los } \\
\text { animales! / ¡y de los perros! } \\
\text { (132) pero ¡me da mucho coraje! } \\
\text { / ¡me da mucho coraje! } \\
\text { (134) porque también } \\
\text { ayuntamiento se está gastando } \\
\text { un dinero en limpiar todo } \\
\text { (141) ¡sí! ¡es verdad! } \\
\text { (164) ¡no te llamaron la atención } \\
\text { ni nada! / solamente } \\
\text { (167) ¡pues muy bien! / porque }\end{array}$ \\
\hline
\end{tabular}

Tema 1 - Málaga; o bairro e cachorros nas ruas 


\begin{tabular}{|l|l|l|}
\hline & & $\begin{array}{l}\text { ni te avergonzó / ipero tú ya no } \\
\text { la volviste a tirar! }\end{array}$ \\
\hline
\end{tabular}

Tema 2 - Viagens

\begin{tabular}{|c|c|c|}
\hline Perguntas Principais & Perguntas complementares & $\begin{array}{l}\text { Comentários / opiniões / } \\
\text { marcadores de interação }\end{array}$ \\
\hline $\begin{array}{l}\text { (176) ¡sí sí! / no te preocu / veo } \\
\text { que te gusta viajar ¿no? } \\
\text { (204) y ¿qué vais a ver de } \\
\text { Estados Unidos? } \\
\text { (289) y ¿para cuándo sería ese } \\
\text { viaje? ¿cuándo? } \\
\text { (295) vais cuatro ¿no? } \\
\text { (340) eres campi sois campistas } \\
\text { ¿no? / ¿os gusta? } \\
\text { (393) no si además lo tendré que } \\
\text { buscar / porque cuando lo } \\
\text { transcriba tendré que / que } \\
\text { buscarlo / oye iqué interesante! / } \\
\text { y y entonces y os / y os vais / ¿os } \\
\text { soléis ir a menudo de camping? } \\
\text { (416) ¿es fácil conseguir casa } \\
\text { rural o? ?sí? } \\
\text { (465) pero el turismo rural está } \\
\text { de moda / hace menos tiempo } \\
\text { ¿verdad? }\end{array}$ & 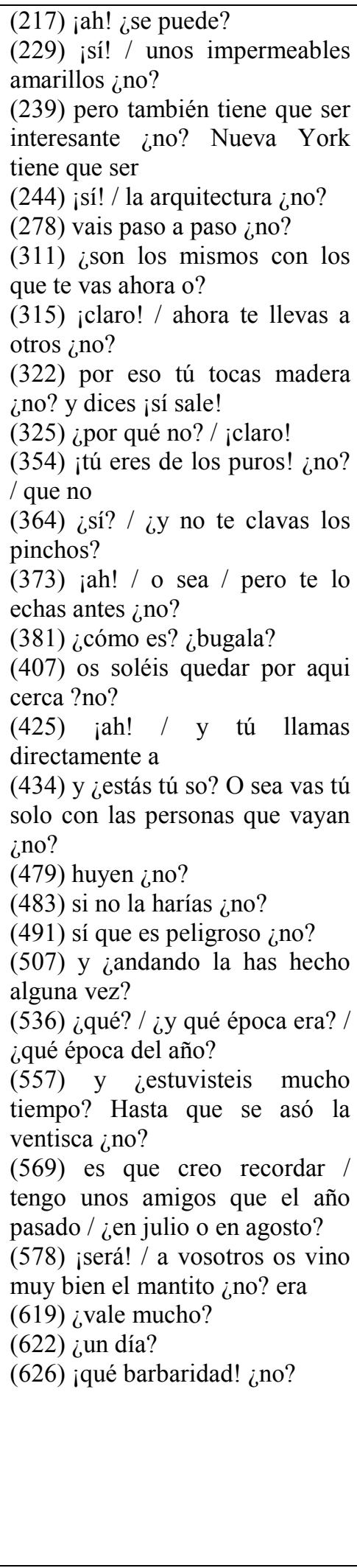 & $\begin{array}{l}\text { (195) ¡uy! iqué bien! } \\
\text { (197) iuy! iqué bien! ¿no? tener } \\
\text { una cuñada así / ito quiero una! } \\
\text { (199) ¡ah! ien la TWA! } \\
\text { (222) iqué chulo! } \\
\text { (248) la Estatua de la Libertad } \\
\text { me han dicho que no merece la } \\
\text { pena } \\
\text { (251) ique no merece la pena } \\
\text { meterse dentro! / ivamos! / no lo } \\
\text { sé! / yo si fuera a Nueva York a } \\
\text { lo mejor me metía / pero } \\
\text { precisamente el otro día una / } \\
\text { una entrevista que hice / me } \\
\text { contaba eso decía me tiré una } \\
\text { que había ido / me decía me pasé } \\
\text { una mañana esperando cola y me } \\
\text { dijo si vas a Nueva York no } \\
\text { vayas a la ipor eso te lo digo! / } \\
\text { tú has lo que } \\
\text { (260) no ella decía que lo que no } \\
\text { merecía la pena era me esperar } \\
\text { una cola } \\
\text { (262) jesperar! / que por lo visto } \\
\text { hay un ascensor hasta la / ¿hasta } \\
\text { dónde decía? } \\
\text { (265) y decía que / no se que lo } \\
\text { que se veía no merecía tanto la } \\
\text { pena ique yo a lo mejor voy y } \\
\text { me subo a ver si es verdad! } \\
\text { (274) que es una salida / ¡śi! / } \\
\text { porque a Nueva York no va uno } \\
\text { todos los días evidentemente } \\
\text { (282) iqué bien! } \\
\text { (291) jah! muy buena } \\
\text { (297) iqué bien! ijoder! iqué } \\
\text { suerte! } \\
\text { (304) iuy! iqué mala sombra! } \\
\text { (309) iqué mala sombra! } \\
\text { (313) son otros } \\
\text { (320) iqué mala sombra! } \\
\text { (328) porque si uno no / no se lo } \\
\text { prepara nadie lo } \\
\text { (331) ya / aparte /preparar un } \\
\text { viaje no solamente es el viaje } \\
\text { sino es prepararlo ¿no? / es la } \\
\text { ilusión de leerte } \\
\text { (334) los libros / las guías } \\
\text { (345) nosotros somos campistas } \\
\text { pero } \\
\text { (347) ino tanto! / ipero de } \\
\text { colchón inflable sí! } \\
\text { (383) jabugala! /yo en la abugala }\end{array}$ \\
\hline
\end{tabular}




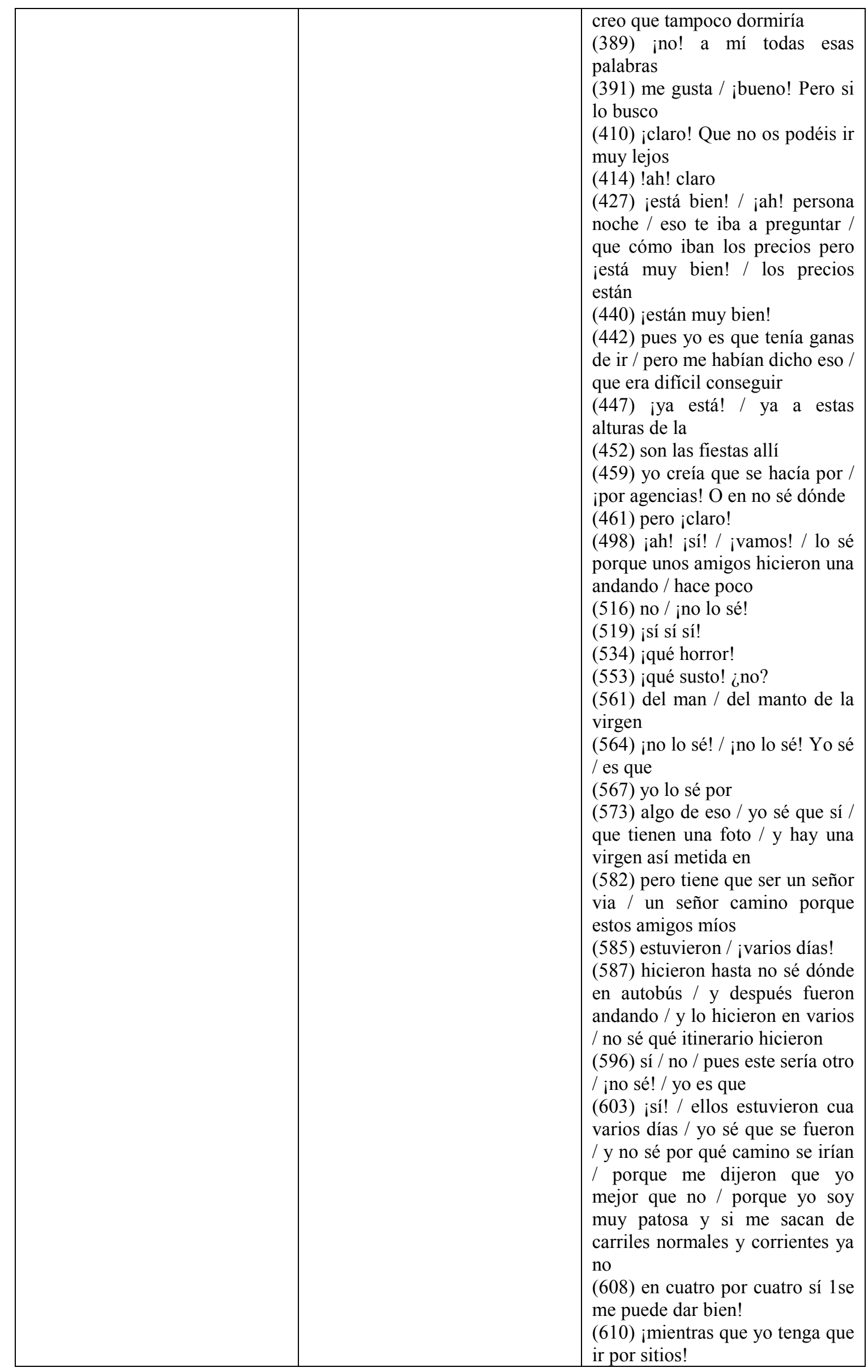




\begin{tabular}{|l|l|l|}
\hline & $\begin{array}{l}\text { (615) yo es que tampoco tengo / } \\
\text { ini amigos! / porque lo bueno es } \\
\text { tener un amigo que tenga un } \\
\text { cuatro por cuatro / que tiene }\end{array}$ \\
\hline
\end{tabular}

Tema 3 - Cigarro

\begin{tabular}{|c|c|c|}
\hline Perguntas Principais & Perguntas complementares & $\begin{array}{l}\text { Comentários / opiniões / } \\
\text { marcadores de interacão }\end{array}$ \\
\hline $\begin{array}{l}\text { (631) ¿nunca has intentado parar } \\
\text { de fumar? } \\
\text { (673) ¿te soportaba bien? }\end{array}$ & $\begin{array}{l}\text { (644) en este viaje ¿no? / dice / } \\
\text { Jaime siempre intenta dejarlo } \\
\text { (660) cambias de vida ¿no? / y } \\
\text { cambias de } \\
\text { (667) pero hay gente que lo } \\
\text { consigue ¿no? } \\
(679) \text { o sea una persona } \\
\text { respetuosa ¿no? }\end{array}$ & $\begin{array}{l}\text { (634) dicen que cuantas más } \\
\text { veces se intenta más / más } \\
\text { posibilidades hay de dejarlo } \\
\text { (639) a eso has llegado } \\
\text { (643) lo vas a dejar } \\
\text { (647) ¡ah! / ¡después! } \\
\text { (649) Jaime intenta dejarlo } \\
\text { cuando cambia de } \\
\text { (654) ¡ah! / eso le pasa a Jaime / } \\
\text { que le gusta / él disfruta el } \\
\text { cigarro que } \\
\text { (662) te vas a proponer } \\
\text { (664) pues Jaime lleva desde que } \\
\text { acabó la carrera diciendo que se } \\
\text { va a quitar de fumar // iy todavía } \\
\text { no se ha quitado! } \\
\text { (669) pero cuesta mucho trabajo } \\
\text { / ¡lo pasas muy mal! / la verdad } \\
\text { es que } \\
\text { (675) que exteriorices } \\
\text { (686) pues tiene mucno mérito } \\
\text { ¿no? / ¡eso es que tienes buen } \\
\text { carácter! } \\
\text { (688) ¡sí sí! Te entiendo }\end{array}$ \\
\hline
\end{tabular}

Tema 4 - trabalho

\begin{tabular}{|c|c|c|}
\hline & & $\begin{array}{l}\text { Comentários / opiniões / } \\
\text { marcadores de interação }\end{array}$ \\
\hline $\begin{array}{l}\text { (692) además tú decías que entra } \\
\text { / tú trabajas en el ayuntamiento } \\
\text { ¿no? } \\
\text { (695) te pegarás un madrugón } \\
\text { bueno ¿no? / todos los días } \\
\text { (700) ¿llevas muchos años } \\
\text { trabajando en? } \\
\text { (746) entonces la fotografía te } \\
\text { gusta / entiendes de } \\
\text { (765) ¿y aprendiste en algún } \\
\text { sitio a hacer fotos o? } \\
\text { (788) ¿tú has hecho reportajes de } \\
\text { boda y? } \\
\text { (938) ¿cuáles son las fotos que } \\
\text { más gustan? } \\
\text { (951) pero un montaje ¿a qué te } \\
\text { refieres? / ¿a poner varios } \\
\text { objetos o? }\end{array}$ & $\begin{array}{l}\text { (704) ¡ah! ¿sí? } \\
\text { (720) es que Campanillas está } \\
\text { (730) tenía que ser difícil } \\
\text { competir ¿no? } \\
\text { (748) tiene que ser un arte difícil } \\
\text { ¿no? } \\
\text { (799) cuando os vais de viaje / } \\
\text { ¡ntonces no! } \\
\text { (802) pero la boda tiene un / un } \\
\text { itinera ¿un recorrido se llama? / } \\
\text { ¡no sé! / porque yo cuando / nos } \\
\text { casamos que nos decía el } \\
\text { fotógrafo es que las fotos son } \\
\text { fijas prácticamente ¿no? } \\
\text { (829) los contactos ¿no? } \\
\text { (867) y todas esas cosas hay que } \\
\text { tenerlas en cuenta al hacer a la } \\
\text { hora de hacer una foto ¿no? } \\
\text { (883) pero después también } \\
\text { tienes que entender / no } \\
\text { solamente asnectos técnicos }\end{array}$ & $\begin{array}{l}\text { (716) isí! pero iuna inversión } \\
\text { tendrías que hacer! } \\
\text { (742) lo que hace negocio es el } \\
\text { revelado } \\
\text { (744) de todos los días ¡claro! } \\
\text { (763) iclaro que sí! } \\
\text { (781) iclaro! } \\
\text { (816) ¡las mismas fotos! } \\
\text { (850) doscientas mil pesetas te } \\
\text { sale } \\
\text { (855) es que yo me acuerdo sí / } \\
\text { en mi / ¡a mí me pasó eso! / me } \\
\text { gustaban todas no sabía cuál } \\
\text { elegir / era el fotógrafo que te } \\
\text { daba los contactos / pero ¿de } \\
\text { dónde saco yo el dinero? / y } \\
\text { aparte lo que tú dices / ¿dónde } \\
\text { voy yo con un reportaje tan } \\
\text { grande que? } \\
\text { (893) inunca nunca! He } \\
\text { adoptado tantas } \\
\text { (901) clásica }\end{array}$ \\
\hline
\end{tabular}




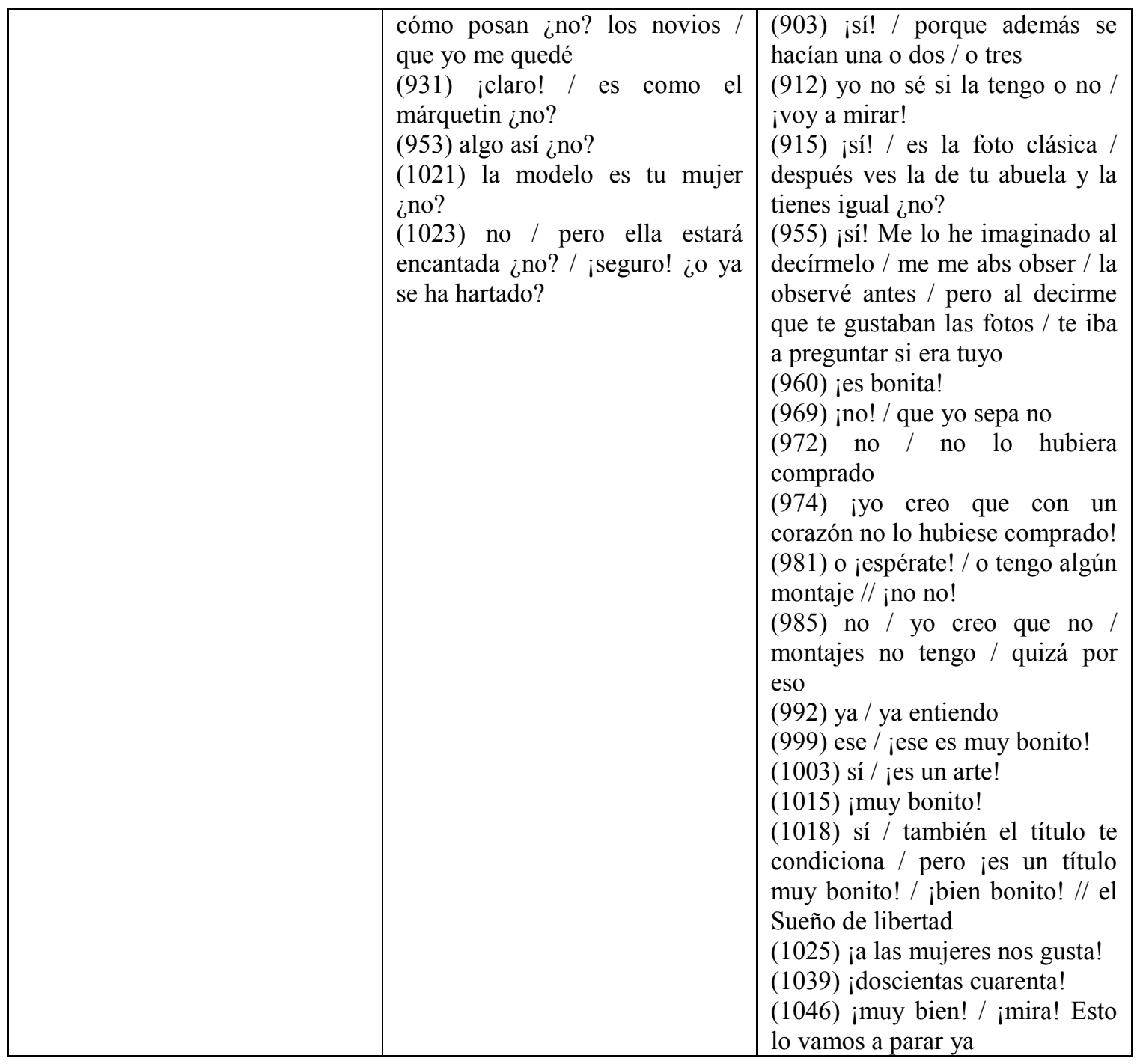

Tema 5 - loteria

\begin{tabular}{|c|c|c|}
\hline Perguntas Principais & Perguntas complementares & $\begin{array}{l}\text { Comentários / opiniões / } \\
\text { marcadores de interação }\end{array}$ \\
\hline $\begin{array}{l}\text { (1047) ibueno! / espera voy voy } \\
\text { a decir primero / informante } \\
\text { siete tres cero / porque si no digo } \\
\text { el nombre del informante / iya } \\
\text { está! / ¿tú qué harías si te tocase } \\
\text { la lotería? / ¿qué te gustaría } \\
\text { hacer? } \\
\text { ((1053) ¿te comprarías el cuatro } \\
\text { por cuatro para irte a? } \\
\text { (1082) te comprarías la máquina } \\
\text { esa ¿no? } \\
(1101) \text { ¿él hacía reportajes } \\
\text { también? }\end{array}$ & $\begin{array}{l}\text { (1060) a lo mejor por tu mujer } \\
\text { ¿no? tal vez } \\
\text { (1062) requiere mucho trabajo } \\
\text { ¿no? / un chalé / pienso yo } \\
(1099) \text { ¡bueno! Y a él ¿qué más } \\
\text { le daba? } \\
\text { (1139) es competencia desleal } \\
\text { ¿no? }\end{array}$ & $\begin{array}{l}\text { (1065) mucho dinero / si es lo } \\
\text { que yo te pregunto te tocaría } \\
\text { mucho / entonces podrías meter } \\
\text { a alguien iclaro! } \\
\text { (1071) alguien que te ayude a } \\
\text { (1073) también creas empleo } \\
\text { (1077) además le pagarías bien } \\
\text { (1085) iy lo hundías! } \\
\text { (1111) iqué barbaridad! } \\
\text { (1172) iqué mala sombra! / } \\
\text { ivamos! // vamos a parar esto ya } \\
\text { llevamos suficiente }\end{array}$ \\
\hline
\end{tabular}

Devido aos temas encontrados, optamos por dividir essa entrevista em cinco partes. Observa-se que há baixo grau de planificação, o entrevistador dá início à entrevista com a habitual pergunta sobre o bairro em que o informante mora e segue com 
perguntas mais específicas sobre a vida pessoal do informante. Os papéis são bem definidos, tanto que há um momento em que o informante pede que a entrevistadora lhe faça perguntas.

Com relação às perguntas principais feitas pelo entrevistador, são todos enunciados diretos sem a presença de verbos no imperativo ou de atos preparatórios compostos por verbos no Futuro do Pretérito, por exemplo.

A interação entre entrevistador (E) e informante (I) é elevada, fato comprovado pelas diversas expressões de opinião que o $\mathrm{E}$ faz, pelas perguntas que o I faz ao $\mathrm{E}$ e também pelas interjeições e brincadeiras que o $\mathrm{E}$ faz ao longo das respostas do I.

\subsubsection{Imperativo}

Abaixo apresentaremos os trechos que contêm verbos no imperativo que não estão em enunciados interrogativos e não apresentam a função de ordem ou pedido.

(456) I: (...) ¡vamos! Andando se va de un pueblo a otro / y que no está en fiestas ¿no? / aquí tengo / ¡mira! / aquí tengo el teléfono...

(548) I: mal // lo pasamos mal porque / ¡bueno! / imagínate una ventisca de esas / ¡no ves nada!...

(839) I: (...) ¡doscientas cincuenta y tantas! Fotos y decirme las quiero todas // ¡la verdad! / pues a mí / pues ¡imagínate la alegría que me da eso!

(1040) I: ¡de paisajes! // imagínate lo que tengo que ser / lo que pasa...

(1089) I: ¡fíjate! / lo que puedes hacer con el dinero

São poucas as ocorrências de uso de imperativo nessa entrevista. Além disso, diferente do que ocorreu em outras amostras do corpus, não observamos o uso do verbo oír em sua forma imperativa oye. No entanto, o uso dos três verbos encontrados também é uma referência ao interlocutor. Utilizando mira o falante se aproxima do outro, procurando obter inclusive certa compreensão com o que está sendo dito. Já ao usar fíjate e imagínate o falante busca uma chamada de atenção para com o outro, pois considera que a informação que ali está sendo transmitida tem relativa importância com relação às outras.

\subsubsection{Desfocalização do eu}

Abaixo apresentamos as ocorrências em que o falante deixa de usar a primeira pessoa e opta pela segunda ou terceira pessoas do singular ou primeira do plural de forma a desfocalizar o eu.

(360) I: (...) con pinchos unos pinchos muy / pero luego tú echas una manta / y te puedes tumbar en él y es muy cómodo.

(363) I: te tumbas en ella y no

(369) I: solo hay un problemilla / los insectos / sí // que sales con varias ronchitas / porque... 
(437) I: (...) ¡tiene de todo! Cocina / las habitaciones / le dices pues ¡mira! ¡vamos a ir seis! Te buscan una casita para seis...

(499) I: sí pues por ese carril vienen a salir / atraviesas/sales a Prado Llano a la zona esta de / de esquí / a la estación de esquí / a la estación de esquí / o sea lo que es atravesar la montaña y sales a la parte de Sierra Nevada...

(575) I: sí y puedes / y hay un / o sea tiene un manto así grande / y te puedes meter dentro /yo creo que...

(599) I: (...) sí te digo que si haces la ruta andando puedes tardar varios días/ porque hay ¡muchos caminos! / muchas cosas que ver y si lo haces andando...

(680) I: ¡sí! / tú sabes que muchas veces por la mañana te levantas de mal humor...

(689) I: (...) te han podido ir mal las cosas en el trabajo / yo no tengo por qué pagarlo / ¡con nadie! Porque te vaya una cosa mal ino tienes por que pagarlo con nadie!

(735) I: (...) si hay alguien que compra esa máquina / cerca de ti / y te puede competir con los precios de revelado / porque tú tengas que trabajar con laboratorio / que te los revelen a ti (...)

(750) I: (...) la fotografía es un reto / es intentar plasmar lo que tú quieres intentar/ que otros que vean la foto vean lo que tú intentaras que se viera...

(806) I: (...) tú te buscas los sitios que pueden ser pues donde puede quedar una foto mejor ... si te acostumbras ¿Qué vamos al puerto? / pues yo me acostumbro...

(817) I: entonces procuras llevártelos / a otros sitios / diferentes... pues te los llevas a ...

(870) I: (...) la luz es muy fundamental // y lo tienes tanto no puedes hacer / las fotos peores son las fotos con / con contrastes duros...

(922) I: (...) tú llevas / una serie de fotos que sabes que gustan y sabes que te la compran // entonces intentas porque ¡claro! / tú estás acostumbrado a hacer reportajes...

(949) I: (...) una parte muy difícil que se procura tocar muy poco en las bodas porque no / no puedes recrearte en un montaje ¿no?

(961) I: y lo procuras tocar poco porque es muy delicado no siempre sale lo que tú buscas y a veces te cuesta...

(986) I: (...) no es laboratorio / tú lo haces sobre el mismo negativo

(1004) I: sí es una creación tuya y yo por ejemplo pues todas mis...

(1007) I: tienen sus títulos porque es algo que tú quieres plasmar ...

(1012) I: (...) es muy significativo porque / intentas plasmar algo en la foto // este...

(275) E: que es una salida / ¡sí! / porque a Nueva York no va uno todos los días evidentemente.

(328) E: porque si uno no / no se lo prepara nadie lo

(669) E: pero cuesta mucho trabajo / ¡lo pasas muy mal! / la verdad es que

(882) E: pero después también tienes que entender / no solamente aspectos técnicos / sino también / si haces una boda cómo posan...

Como se pode observar nos trechos acima, esse tipo de ocorrência é encontrado tanto na fala do I quanto do E. Na fala do I todas as situações envolvem o uso da segunda pessoa do singular e entendemos que o seu uso busca uma aproximação com o interlocutor, pois na maioria das vezes o I está falando sobre seu trabalho como fotógrafo e ainda assim opta pela desfocalização do eu. Além disso, é uma forma também de se usar menos a primeira pessoa do singular, não demonstrando certo pedantismo sobre seus conhecimentos.

Já na fala do entrevistador, podemos observar que além da segunda pessoa do singular, há exemplos de generalização utilizando a forma uno, bastante comum na língua espanhola. Entendemos esse uso como uma maneira de abranger todas as pessoas que passam pela situação descrita em sua fala. Há marca também de interação, mostrando proximidade com o interlocutor. 
Cabe ressaltar que para a análise comparativa consideraremos apenas as ocorrências encontradas na fala do informante.

\subsubsection{Prevenção de ameaça à face}

Abaixo apresentamos os trechos que contêm esse tipo de ocorrência seguidos de breve análise.

(52) I: si / vivimos primero en Béjar // en después de Béjar en un piso que era de un tío mío y tal / alquiló / después mis padres compraron un piso en ¿conoces el Arroyo un poco?

(56) E: sí más o menos.

(64) I: las terrazas / está la Avenida de la Inmaculada Concepción ¡la conoces?

(129) E: el que tiene un perro tiene que respetar a los demás / y que el perro no moleste / a mí ¡mira que soy la gran defensora de los animales! / iy de los perros!

(131) I: ¡sí! / ¡no! / y que conste que yo también ¿eh?

(200) I: entonces le dan unos vales// para viajar la familia / y este año pues se los pedí yo / y me / me va a dar cuatro valecitos de esos / y me sale muy barato / ¡unos viajes muy baratos muy baratos! // tanto el avión como estancias como

Foram encontradas apenas essas quatro situações de prevenção de ameaça à face. Interpretamos as duas primeiras como uma forma de o informante se precaver e não ameaçar a face do entrevistador. Dessa forma, caso a resposta dele fosse negativa ele teria duas saídas: explicar onde ficavam os lugares a que se referia ou mudar de assunto. Especificamente no primeiro caso, o E também se previne de ameaçar sua própria face utilizando a expressão más o menos.

No terceiro caso, observa-se que há certa preocupação por parte dos dois participantes da entrevista em evitar que o outro faça algum tipo de juízo de valor sobre sua fala. Assim, o I emite uma justificativa sobre seu pensamento e talvez até como uma forma de aumentar a interação entre ambos, o E compartilha o mesmo ponto de vista.

Já o último trecho o interpretamos como prevenção de ameaça à face, pois é muito forte a necessidade que o I tem em justificar o porquê fará a viagem que pretende, que a cunhada lhe deu os vales, que pagará muito pouco, etc. É uma forma também de proteger a própria face, demonstrando humildade. Como já apontado ao longo da fundamentação teórica apresentada, ao se afastar da mensagem, o falante se aproxima do interlocutor.

\subsubsection{Ameaça à face}

Encontramos apenas três ocorrências de atos ameaçadores da face ao longo dessa entrevista. 
(176) I: (...) pues yo creo que llegaremos un día a concienciarnos / de que tenemos que mantener / ¡nuestra casa! Donde vivimos // ¡bueno! ¡venga! ¡pregunta!

(177) E: ¡sí sí! / no te preocu / veo que te gusta viajar ¿no?

(605) E: (...) porque me dijeron que yo mejor que no / porque yo soy muy patosa y si me sacan de carriles normales y corrientes ya no

(631) E: ¿nunca has intentado dejar de fumar?

(632) I: ¡sí! / lo dejé una semana // lo dejé una semana y volví otra vez

(633) I: dije ¡bueno!

(634) E: dicen que cuantas más veces se intenta más / más posibilidades hay de dejarlo

Interpretamos o primeiro caso como uma ameaça à face do $\mathrm{E}$, pois o informante indiretamente exige que ele cumpra seu papel na entrevista e lhe faça perguntas. Em sua resposta, o entrevistador ameaça dizer que ele não se preocupe, mas interrompe sua própria fala e faz uma nova pergunta. Entendemos que caso ele retrucasse, essa resposta poderia causar certo desequilíbrio, atrapalhando a fluidez da entrevista.

No segundo exemplo é o próprio E que expõe sua face, ameaçando-a, pois enfatiza uma característica negativa sua.

Já no terceiro e último caso, além de uma ameaça à face, poderíamos interpretar esse trecho também como uma invasão do território pessoal do informante, pois indiretamente há uma crítica por parte do E com relação ao vício do I. Inferimos que o que motivou essa pergunta foi o fato de ele acender um cigarro durante a entrevista, pois essa pergunta surgiu de repente no meio de outro assunto. Aparentemente o I não apresentou problemas com a pergunta e comentário do E, pois respondeu sua pergunta e continuou a entrevista sem demonstrar qualquer tipo de incômodo.

\subsubsection{Expressão de opinião}

Assim como ocorre com todas as entrevistas do material espanhol, as expressões de opinião dos informantes são dadas ao longo de toda a entrevista, além disso, há dependência com relação aos assuntos que vão surgindo, por isso é comum que haja certa irregularidade referente à quantidade desse tipo de ocorrência entre as entrevistas.

Ressaltamos que analisaremos aqui apenas as opiniões emitidas pelo informante, uma vez que entendemos que quando o entrevistador emite sua opinião sobre determinado assunto, está buscando interagir com o interlocutor.

(78) a mí me gusta mucho Arroyo para vivir // ¡realmente me gusta! / o sea no porque viva aquí o porque me considere de aquí / que me considero de aquí // ¡me gusta! / es un sitio que...

(147) ¡pero sí! / parte de Europa yo he viajado muy poco / lo poco que he viajado // por parte de Europa hay una diferencia enorme con / con España // por ejemplo Italia es lo más parecido en ese sentido a España / o sea iyo creo que peor! 
São apenas essas duas situações encontradas ao longo de toda a entrevista. No primeiro caso é apenas sua opinião sobre o lugar onde vive, como é uma opinião positiva, não se espera que haja qualquer tipo de atenuante, no entanto no segundo caso, o informante emite uma opinião negativa sobre Espanha e Itália e há atenuação de sua fala por meio da justificativa de que viajou pouco.

Como pode ser observada nas tabelas apresentadas no início desta análise, a participação do E com comentários e opiniões é bastante efetiva. Acreditamos que esse fato contribui positivamente com o andamento da entrevista, pois aumenta a fluidez e a interação entre os participantes. Ressaltamos que embora reconheçamos a importância dessas ocorrências, optamos por não analisá-las, focando-nos apenas nas ocorrências encontradas na fala do I.

\subsubsection{Cortesia valorizante}

Em oposição aos atos ameaçadores da face, encontramos nessa entrevista dois exemplos de cortesia valorizante, na qual se enaltece a face do interlocutor. Abaixo apresentamos os trechos:

(686) E: pues tiene mucho mérito ¿no? / ¡eso es que tienes buen carácter!

(959) I: ¡sí! / es una creación mía

(960) E: ¡es bonita!

As duas situações ocorreram na fala do E, nas quais ele tece um elogio ao I. É bastante positiva essa atitude, pois contribui com a interação e favorece o bom andamento da entrevista.

\subsubsection{Solidariedade}

Com relação ao que envolve a solidariedade entre os falantes, observamos apenas duas ocorrências nessa entrevista. Ambas são emitidas pelo entrevistador e como já pudemos observar em análises anteriores, são extremamente positivas para a fluidez da entrevista.

(561) I: (...) allí debajo estaríamos uma hora o / ¡o más! / hora y media / debajo de de

E: del man / del manto de la virgen

(675) I: ¡porque es que se me gusta! / ¡sí! / yo no soy una persona que

$E$ : que exteriorices 


\subsubsection{Formas de tratamento}

Observa-se que a forma de tratamento utilizada pelo entrevistador para se dirigir ao informante é a segunda pessoa do singular. Abaixo apresentamos algumas ocorrências, seguidas de breve análise.

(02) Así yo veo la lucecita y si se le acaba la pila o no // entonces tú me has dicho que tú no naciste en Málaga pero llevas viviendo aquí

(09) no / no te emancipaste tan pronto ¿no?

(50) y ¿habéis vivido siempre aquí en Arroyo o habéis?

(204) y ¿qué vais a ver de Estados Unidos?

(354) ¡tú eres de los puros! ¿no? / que no

(393) no si además lo tendré que buscar / porque cuando lo transcriba tendré que / que buscarlo / oye ¡qué interesante! / y y entonces y os / y os vais / ¿os soléis ir a menudo de camping?

(578) ¡será! / a vosotros os vino muy bien el mantito ¿no? era

(1060) a lo mejor por tu mujer ¿no? tal vez

Conforme pode ser observado, há total concordância entre o uso dos pronomes pessoais do caso reto e oblíquo, bem como do possessivo na segunda pessoa do singular quando o entrevistador se dirige ao informante.

Nota-se também o uso da segunda pessoa do plural quando há qualquer tipo de referência ao informante e terceiros, como alguém da família ou amigos. É mais um caso de uso do pronome vosotros, comprovando o uso de tal pronome nessa região da Andaluzia.

Não encontramos ao longo dessa amostra o uso de formas nominais.

\subsection{Amostra 32}

$$
\begin{aligned}
& \text { Informante feminino - } 43 \text { anos } \\
& \text { Entrevistador feminino }-28 \text { anos }
\end{aligned}
$$

\begin{tabular}{|c|c|c|}
\hline Perguntas Principais & $\begin{array}{c}\text { Perguntas } \\
\text { complementares }\end{array}$ & $\begin{array}{l}\text { Comentários / opiniões / } \\
\text { marcadores de interação }\end{array}$ \\
\hline $\begin{array}{l}\text { (02)Pero tú eres de Málaga ¿no? } \\
(04) \text { ¿dónde naciste? } \\
(06) \text { ¿y viviste allí muchos años? } \\
(08) \text { ¿ibas allí al colegio y todo? } \\
(10) \text { ¿y qué recuerdos tienes del } \\
\text { colegio? } \\
(14) \text { ¿qué hacías? ¿qué hacías } \\
\text { cuando eras pequeña? } \\
(26) \text { ¿con quién jugabas tú? } \\
\text { ¿con? } \\
(85) ¿ \text { qué edad? ¿con qué edad } \\
\text { hacíais esas fiestas? } \\
(100) \text { Entonces ¿tú encuentras } \\
\text { que ha cambiado mucho Málaga } \\
\text { desde? ¿o Pedregalejo por lo } \\
\text { menos? ¿desde que eras }\end{array}$ & $\begin{array}{l}\text { (35) Pero ¿había jabalíes? } \\
\text { (50) y la ya la ¿y tu madre qué le } \\
\text { dijo cuando lle } \\
\text { (110) ¿y ha crecido mucho? } \\
\text { (130) ¿y qué? } \\
\text { (132) pero por las monjas o } \\
\text { (134) ¿y qué? }\end{array}$ & 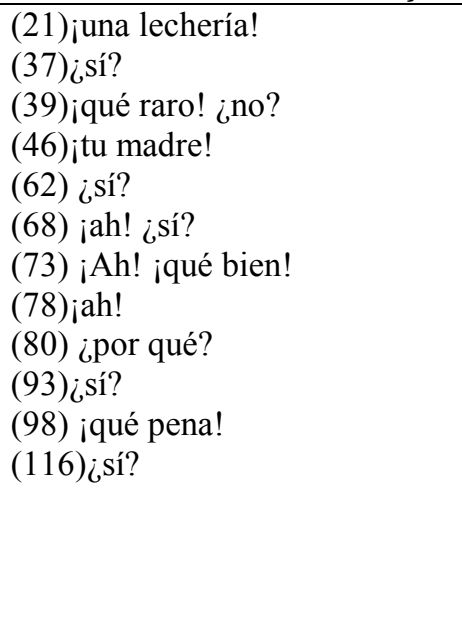 \\
\hline
\end{tabular}

Tema 1 - Málaga /o colégio 
pequeña?

(126) ¡qué pena! Y ¿qué más? y ¿qué recuerdos tienes del colegio? ¿qué asignaturas te gustaban más? ¿qué asignaturas te gustaban menos?

(140)¿qué hacíais los fines de semana? ¡bueno! Eso me lo has contado ya

Tema 2 - a casa / a família

\begin{tabular}{|c|c|c|}
\hline Perguntas Principais & $\begin{array}{c}\text { Perguntas } \\
\text { complementares }\end{array}$ & $\begin{array}{l}\text { Comentários / opiniões / } \\
\text { marcadores de interação }\end{array}$ \\
\hline 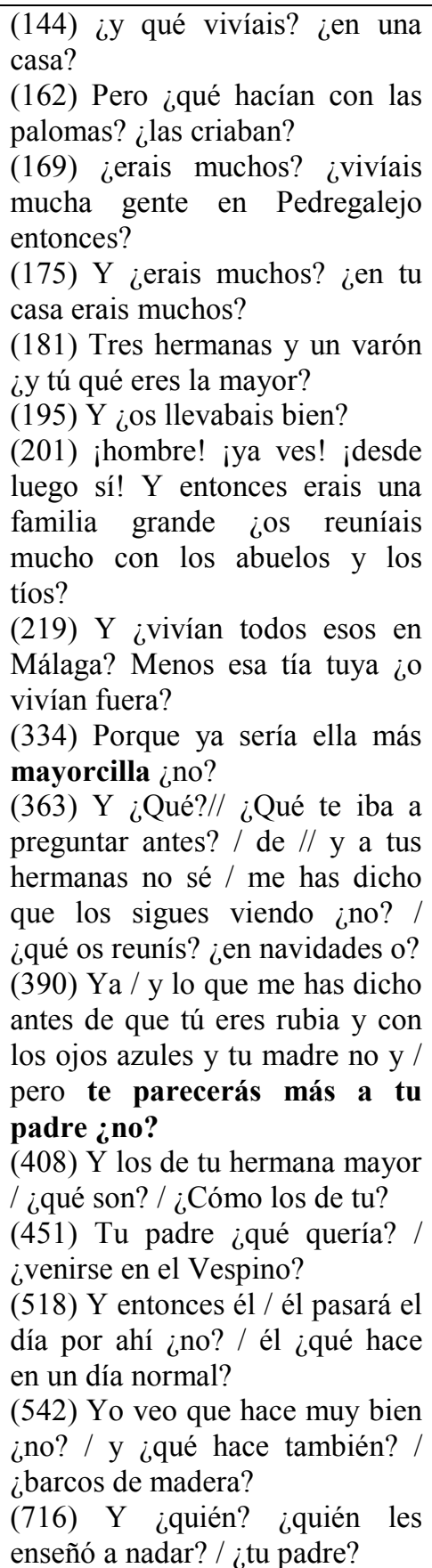 & 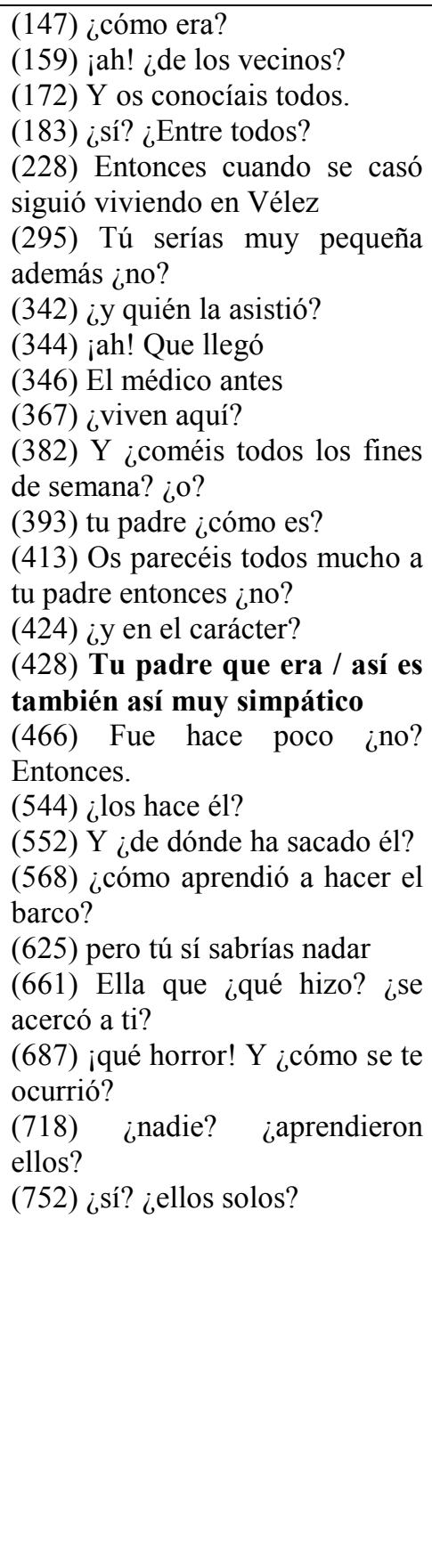 & 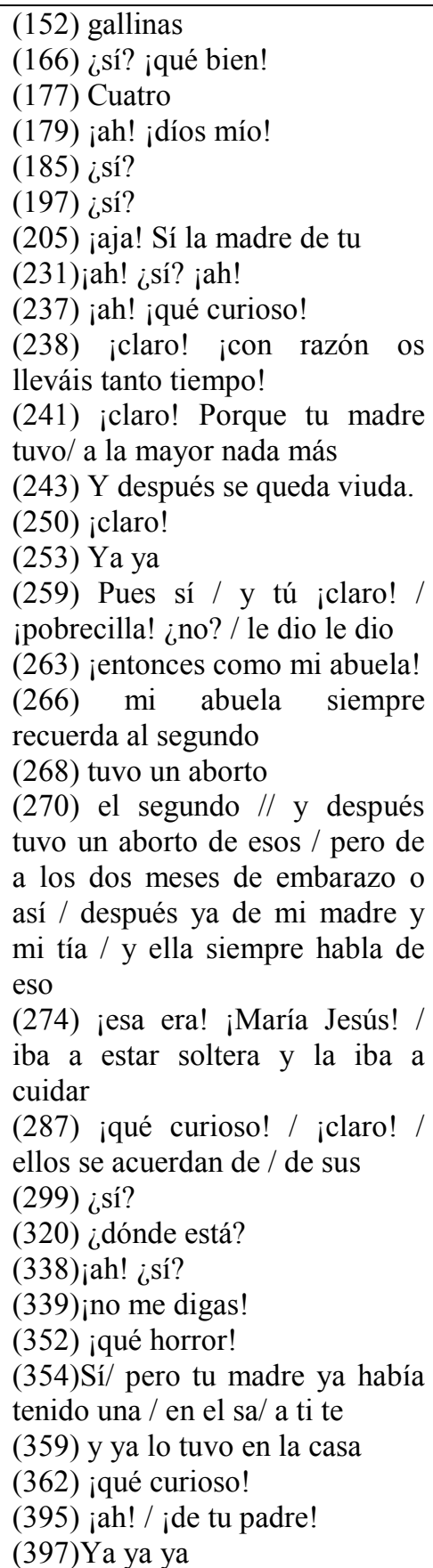 \\
\hline
\end{tabular}




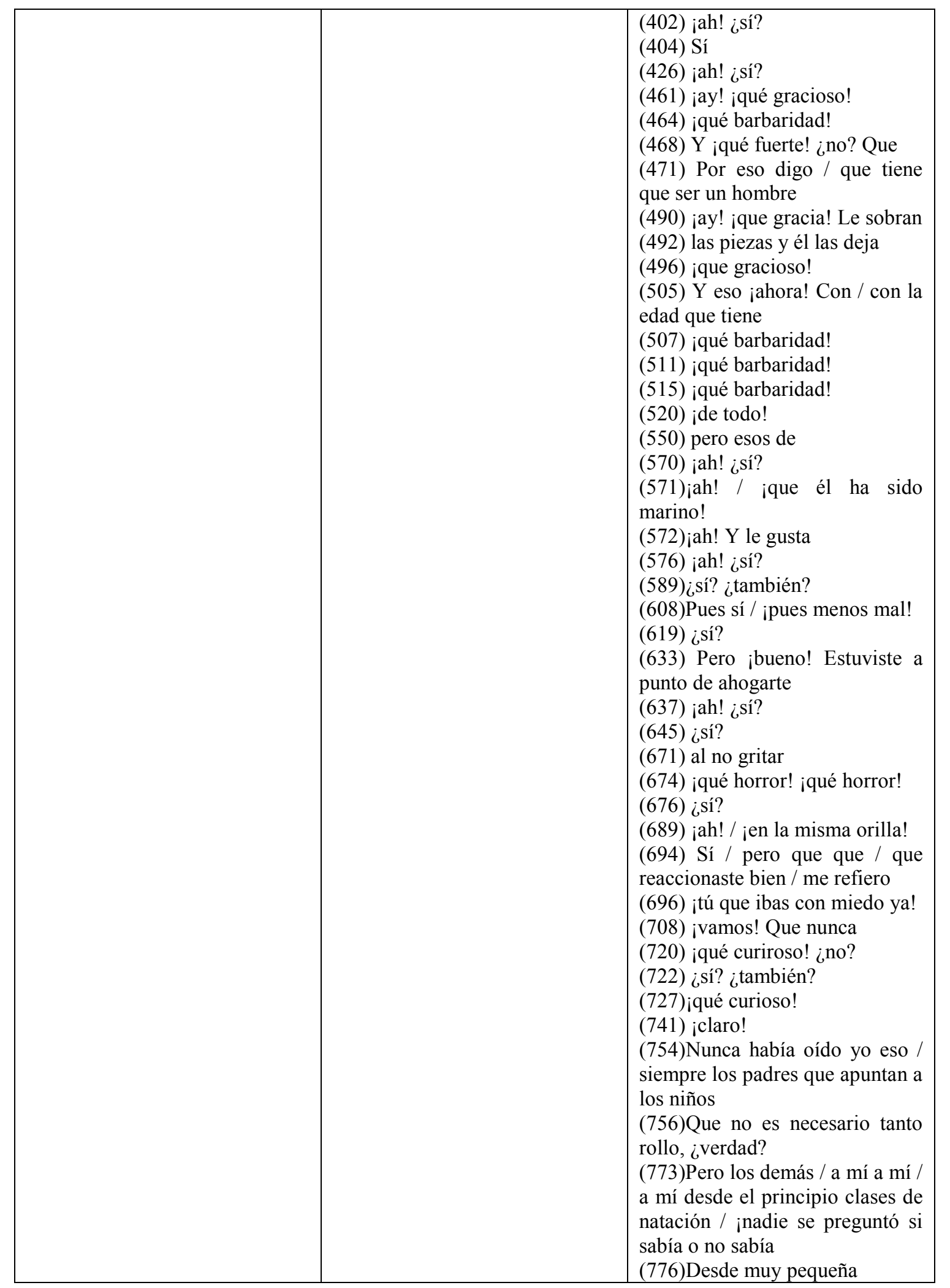

Tema 3 - Málaga / as corridas de touro

\begin{tabular}{|l|c|l|}
\hline Perguntas Principais & \multicolumn{1}{|c|}{$\begin{array}{c}\text { Perguntas } \\
\text { complementares }\end{array}$} & $\begin{array}{l}\text { Comentários / opiniões / } \\
\text { marcadores de interação }\end{array}$ \\
\hline $\begin{array}{l}\text { (779) Y ¿no había playa antes en } \\
\text { La Malagueta? }\end{array}$ & $\begin{array}{l}(784) \text { ¿Tampoco había? } \\
(810) \text { ¿de pequeña ibas al al }\end{array}$ & $\begin{array}{l}\text { (786) Sí / ipues a lo mejor! } \\
(804) \text { ini te acercas! }\end{array}$ \\
\hline
\end{tabular}




\begin{tabular}{|c|c|c|}
\hline $\begin{array}{l}\text { (806) ¿y qué te? ¿a ti te gusta? } \\
\text { Háblame de Málaga / ya que } \\
\text { estamos con las mal com eso / } \\
\text { con } \\
\text { (953) Y las costumbres de aquí } \\
\text { ¿te gustan? / la semana santa / la } \\
\text { feria } \\
\text { (1010) ¿y vas mucho a las } \\
\text { corridas? } \\
\text { (1044) Pero antes no era no era } \\
\text { en agosto ¿no? / la feria } \\
\text { (1078) ¿la plaza de toros siempre } \\
\text { ha estado en La Malagueta? } \\
\text { (1081) ¡vamos! ¡claro! / siempre } \\
\text { / como hay una calle por ahí que } \\
\text { se llama Plaza de Toros Vieja y / } \\
\text { o siempre me he preguntado } \\
\text { ¿habría aquí antes una plaza de } \\
\text { toros? }\end{array}$ & $\begin{array}{l}\text { centro? } \\
(907) \text { ¿la arena o el mar? / la } \\
\text { arena } \\
(968) \text { ¿y antes? } \\
(1031) \text { Y ¿qué ibas? ¿vestida de } \\
\text { gitana o? } \\
(1033) \text { ¿o de mantilla? ¿o } \\
\text { normal? } \\
(1080) \text { Siempre ¿no? }\end{array}$ & $\begin{array}{l}\text { (894) Sí / te entiendo } \\
(923) \text { ¡ay! ¡qué gracia! } \\
(935) \text { ¡qué bonito! } \\
(939) \text { ¡qué bonito! } \\
(970) \text { ¿no? } \\
(981) \text { ¡ah! ¿sí? ¿a quién? A } \\
(983) \text { ¡ah! / ¡tu abuelo! } \\
(1009) \text { Es curioso ¿no? } \\
(1020) \text { es que no soy muy } \\
(1035) \text { No te vistes } \\
(1046) \text { ¿sí? } \\
(1048) \text { no yo } \\
(1050) \text { yo tenía entendido } \\
(1062) \text { no / que es que / yo / } \\
\text { tenía entendido yo que era } \\
\text { (1064) antes / pero ¡vamos! } \\
\text { (1066) no / yo siempre la he } \\
\text { recordado en agosto } \\
(1070) \text { y en el parque } \\
\text { (1073) la plaza de toros en La } \\
\text { Malagueta siempre } \\
\text { (1100) ¡qué barbaridad! ¿eh? / a } \\
\text { mí lo de } \\
\text { (1102)ies una barbaridad } \\
\text { arquitectónica! } \\
\text { (1104) ¡qué lástima! }\end{array}$ \\
\hline
\end{tabular}

Tema 4 - O marido

\begin{tabular}{|c|c|c|}
\hline Perguntas Principais & $\begin{array}{l}\text { Perguntas } \\
\text { complementares }\end{array}$ & $\begin{array}{l}\text { Comentários / opiniões / } \\
\text { marcadores de interação }\end{array}$ \\
\hline $\begin{array}{l}\text { (1121) ¿y a tu marido? Lo } \\
\text { ¿cuándo lo conociste? ¿eras muy } \\
\text { jovencilla? }\end{array}$ & (1124) Lo conociste entonces & (1126) ¿sí? ¡No me digas! \\
\hline
\end{tabular}

Devido aos temas encontrados, optamos por dividir essa entrevista em quatro partes, sendo que três deles - a família, a cidade e o colégio são os que prevalecem ao longo de todo o diálogo. O quarto tema é iniciado ao final e acreditamos que, como o tempo de duração da entrevista expirou, foi finalizado sem qualquer tipo de aprofundamento.

Com relação às perguntas principais, observamos um único caso de uso de imperativo, sendo todas as outras compostas por enunciados interrogativos - sejam eles diretos ou não. Não há, por exemplo, o uso de verbos performativos ou atos de preparação antes de cada pergunta.

Entrevistador e informante criam um elo bastante interessante, em duas ocasiões a interação é tão relevante a ponto de a informante fazer perguntas para o entrevistador e esse passar a falar de sua vida pessoal. 


\subsubsection{Imperativo}

Como já exposto, há apenas um caso de verbo no imperativo entre as perguntas principais da entrevista. Analisaremos agora os casos em que esses verbos são encontrados fora do contexto de enunciados interrogativos e com diferentes funções. Abaixo apresentamos os exemplos, seguidos de breve análise. Todas as ocorrências foram encontradas na fala do I.

(45) (...) ¡pero el susto nos lo llevamos! ¡imagínate cuando yo llegué a mi casa!

(92) (...) ¡que hoy en día ya no la encuentras! / y es porque el agua esá ¡muy sucia! // había allí / pues ¡mira! ¡qué te digo yo! /pues cogías almejas...

(114) (...) o sea que está todo tan superpoblado que ya / ¡ya no me gusta! / no me gusta / imagínate que antes era Leon Trece no era del colegio / ¡era una finca!

(245) (...) y luego pues estuvo un tiempo que no tuvo niños // ¡fíjate que curioso! / luego me tuvo a mí...

(254) ¡fíjate! / mucho tiempo sin nada y después por poco...

(292) (...) me parece a mí que ni ella pensaba que estaba embarazada / ¡imagínate! Pues una cosa de de / muy poco tiempo...

(300) pues dos años y seis meses / o sea ¡imagínate! si era pequeña

(411) (...) ¡pero con ella no! / ¡oye! ¡es curioso! / ¡siendo la misma madre!...

(483) (...) y este es mi carné y yo soy y ¡claro! él lo cuenta ¡imagínate! ¡anda anda!...

(497) ¿gracioso? / pues ¡cállate! Que una vez se le estropea la moto...

(620) ¡claro! / como era tan atrevida / pues la cogió una ola / ¡oye! / y no la dejaba salir...

(708) ¡fíjate!

(744) (...) quería nadar / ¡le daba miedo! / ¡fíjate! / tres hermanos...

(788) (...) porque me refiero que a ese niño no le enseñó nadie a nadar / ¡y fíjate! / y a mi hermana (...) / ya no sé nadar / ¡fíjate! ¡que yo iba hasta a las piscinas!

(837) (...) la luz que hay en Málaga / porque ¡mira! En Las Bahamas...

(958) (...) lo que hago es que me quedo en mi casa y lo veo a través de la tele ¡fíjate! Yo / veo todos los años...

(980) ¡fíjate tú después! ¿eh? ...

Diferentemente do que ocorre em todas as entrevistas do corpus, além dos quatro verbos comuns nesse tipo de ocorrência, encontramos também o verbo callar (linha 497). O uso desse verbo demonstra a forte interação que houve entre os participantes da entrevista, a situação informal favorece e não há demonstração de ameaça à face por tal colocação.

Com relação aos outros verbos, os mesmos já foram encontrados em outras entrevistas e exercem a função de referir-se ao interlocutor. Utilizando mira e oye o falante se aproxima de seu interlocutor, procurando inclusive certa compreensão com o que está sendo dito. Já ao usar fijate e imagínate o falante busca uma chamada de atenção para com o outro, pois considera que a informação que ali está sendo transmitida tem relativa importância com relação às outras. 


\subsubsection{Desfocalização do eu}

Abaixo apresentamos os exemplos em que o I busca desfocalizar o eu fazendo uso de outra pessoa verbal.

(89) (...)salías del agua y era sal / ¡una cantidad de sal en el cuerpo! / que que que te molestaba ¿no? / ¡que hoy en día ya no la encuentras!

(136) (...) ¡ahí nada más que veías tú niñas! / si veías un niño era porque te asomabas / a lo mejor...

(168) (...) que ibas por la calle e ibas saludando a uno saludando a otro

(683) (...) ¡pero yo no me podía mover de allí! // ¡es que no podía! / es que aquello era ¡ya te digo! / que te aspiraba te echaba para fuera para dentro para fuera...

(850) (...) la mayoría de los días fue eso pues / un cielo negro / ¿eh? / que tú estabas en la playa y de buenas a primeras / unos truenos / unos relámpagos / iy te tenías que refugiar debajo de la sombrilla!

(860) (...) Miami ipasa igual! // Miami es que te asfixias en la calle / o sea ¡en Miami es que no puedes andar! / prácticamente había muy poca gente...

(922) sí / ¡verjas!/ tú sales del coche / la abres / entras sigues

(1027) (...) a ser las corridas tan malas y / y no / porque te aburrías porque era todos los días / era un abono pues tenías que ir todos los días (...) y no veías nada / salías que ¡aburridísimo!...

Como se pode observar por meio dos exemplos acima, o I utiliza apenas a segunda pessoa do singular para desfocalizar o eu. Entendemos que a intenção do falante ao utilizar esse tipo de estratégia é não centralizar todo o discurso na primeira pessoa. Assim, ainda que ele esteja falando dele mesmo e que isso esteja claro para o interlocutor, opta-se por uma generalização do conteúdo da enunciação, por exemplo, na linha 89 o I está descrevendo a praia que frequentava quando criança, ao utilizar a segunda pessoa do singular, procura reproduzir a sensação que qualquer pessoa tinha ao ter muito sal no corpo quando saía da água.

\subsubsection{Prevenção de ameaça à face}

Abaixo apresentamos os trechos em que há prevenção de ameaça à face tanto na fala do informante quando do entrevistador.

(347) I: si / ¡pero no! / llegó el médico pero no sé si ya había nacido mi hermana / porque nunca le he preguntado...

(477) I: (...) tiene que ir a cada dos por tres a la revisión una vez al año me parece o así y entonces...

(580) I: (...) no sé si fue el capitán / o no me acuerdo yo ya / porque era muy chica//...

(1017) I: (...) ahora tengo curiosidad por vera este que ha salido nuevo / este niño El Juli ¿tú has oído hablar de él?

(1020) E: es que yo no soy muy

(1021) I: ¡ah! / que no eres / ¡no! / pues un chiquillo madrileño / ¡vamos! / pero con un valor increíble

O trecho abaixo pode ser encontrado entre as linhas 1044 e 1070.

E: pero antes no era no era en agosto ¿no? / la feria.

I: ¡siempre!

E: ¿sí?

I: que yo me acuerde siempre ha sido en agosto 
E: yo no

I: ¡siempre! / lo que pasa la feria en agosto

E: yo tenía entendido

I: yo como tampoco he ido mucho a la feria / ya te digo que no he ido mucho a la feria porque como a mis padres no le han gustado/ pues desde chiquitilla pues tampoco nos llevaban a la feria / o sea que tampoco era // que no nos llevaban / y antes estaba en el parque / la feria en el parque de Málaga / pero ¡vamos! Que no / entonces ¡claro! Pues // tampoco no hemos tenido esas ganas de feria ni / ni nos ha gustado tanto ¿no?/ yo creo que a lo mejor ha sido por eso ¿no? lo pero / por eso te digo que la feria / ¡vamos! / que yo recuerde y tal / en agosto / ¡ahora! Como tampoco he sido una persona muy feriante / pues mira ¡no lo sé! / pero yo creo que sí / que en agosto

E: no / que es que / yo / tenía entendido yo que era

I: yo sé que siempre

E: antes/ pero ¡vamos!

I: ¡no! / ¡no! Creo que no / ¡vamos! / que yo me acuerde en agosto

E: no / yo siempre la he recordado en agosto.

I: ¿lo ves? / que yo me acuerde siempre ha sido en agosto ¡ahora! Pequeñita / pues ¡no lo sé! / porque como pequeñita no iba / ipues no lo sé!

E: y en el parque.

Os trechos que se encontram nas linhas 347, 477 e 580 são bastante semelhantes, pois tratam de uma prevenção que o informante faz a sua própria face. Ao utilizar termos como no sé, me parece, que yo me acuerde, o falante evita que o entrevistador elabore mais perguntas sobre esse tema, já alertando-o de que não poderá respondê-las.

No caso do trecho que está entre as linhas 1017 e 1021, há uma dupla prevenção. Primeiro por parte do informante que ao perguntar se o entrevistador tem conhecimento sobre o tema tratado já previne ameaçar a face do outro, pois sabendo de seu desconhecimento ou não, é capaz de fazer alguma explicação, caso haja necessidade. $\mathrm{Na}$ sequência o próprio entrevistador previne sua face ao dizer que não tem muito conhecimento sobre esse assunto. Em seguida o entrevistador explica quem é o toureiro ao qual ele se refere.

No último trecho, entre as linhas 1044 e 1070 notamos certa discordância com relação ao mês em que ocorria a feria. É interessante observar como o I não deixa o $\mathrm{E}$ falar e por mais que essa tente encerrar o assunto, colocando fim ao conflito, o I retoma, reforçando que era em agosto. No final, observamos que o próprio E concorda com o mês de agosto e redireciona a entrevista.

\subsubsection{Ameaça à face}

Ao longo dessa entrevista encontramos um único caso de ameaça à face, entre as linhas 980 e 983 :

I: (...) ¡fíjate tu después! ¿eh? / ¡que a la nieta le encanta ir a ver una buena corrida!

E: ¡ah! ¿sí? ¿a quién? A

I: ¡a mí a mí a mí a mí! / ¡a la nieta! / ¡que era mi abuelo!

E: ¡ah! / ¡tu abuelo! 
Interpretamos esse trecho como ameaça à face do entrevistador, pois se percebe que ele se distrai e por isso não entende o que diz o informante. Com isso, há certa exposição de sua face, uma vez que ele como condutor da entrevista não poderia se distrair a ponto de se perder no meio da fala do outro. Após esse trecho, o informante repetiu o que estava falando e o diálogo voltou a ter equilíbrio, não ficando claro se o informante se sentiu incomodado com o ocorrido ou não.

\subsubsection{Atenuantes}

São apenas dois trechos que contêm a estratégia de atenuar o conteúdo da enunciação. Abaixo os apresentamos:

(334) E: porque ya sería ella más mayorcilla ¿no?

(1106) I: ¡ya te digo! / y eso que Málaga / centro histórico no tiene practicam / iprácticamente nada! / La Alcazaba la Alcazabilla...

Observa-se que o primeiro exemplo está na fala do entrevistador que atenua a idade da mãe do informante, enquanto que o segundo exemplo está na fala do informante que procura atenuar sua afirmação sobre a falta de um centro histórico na cidade onde vivem, para isso ele faz uso do advérbio praticamente, diminuindo a intensidade do conteúdo de sua fala.

\subsubsection{Expressão de opinião}

O informante expressa sua opinião em diversos trechos da entrevista, sempre que o tema tratado exige tal necessidade. Abaixo mencionamos os excertos que contêm esse tipo de ocorrência:

(111) (...) porque donde había huertas hay pisos/ hay chalés adosados o / o sea que está todo tan superpoblado que ya / ¡ya no me gusta! / no me gusta / imagínate que antes era Leon Trece no era del colegio / jera una finca!

(826) (...) la costa tan maravillosa / porque lo que es el centro / la verdad / centro no tenemos / porque centro no tenemos centro histórico porque no lo tenemos / el centro es / para mi gusto feo ... (853) o sea / ¡un calor pegajoso! // ¡sí! / ¡que no me gustó! / que no me gustó / o sea que yo vi un clima / ¡pues eso! / con mucha humedad / un clima // no hay ola ¡no hay luz!...

(881) (...) ¡y es verdad! ¡Andalucía es muy bonita! / ¡entera! / ¡bueno! / España entera es bonita / que España es precisoso // pero luego Andalucía...

(895) visita ¡muy bien! / pero para vivirlo no porque / me veo rodeada de mar por todos los lados // entonces te agobia un poco / ¡además es muy pequeñita! o sea que en realidad pues / Mallorca sí es grande...

(954) pues siendo malagueña / como me considero muy malagueña / sin embargo lo que es / la semana santa me gusta // me encanta la semana santa de de Málaga / pero a mí me agobia mucho el / el ir a la calle ¡y tanta gente!...

(1003) (...) las corridas no me gusta verlas en la tele / no / el aliciente lo tiene la plaza / el estar allí / porque es un aliciente especial / las banderillas / el pasé́llo ...

(1106) ¡ya te digo! / y eso que Málaga / centro histórico no tiene practicam / iprácticamente nada! / La Alcazaba la Alcazabilla // el edificio de correos / que lo están arreglando ahora 
Como se pode observar, há diversas ocorrências de expressão de opinião do informante ao longo de toda a entrevista.

Algumas dessas expressões podem ameaçar à face do I e com o intuito de evitar tal ameaça, ele faz uso de certos marcadores de atenuação. No caso dos excertos das linhas 111, 853, 895 e 954 são atenuados por meio de justificativas. Ao justificar o motivo de sua opinião, o I se previne de um possível julgamento por parte do E. Já as linhas 826, 881 e 1003 apresentam opiniões positivas, fato que dispensa qualquer tipo de atenuação, pois não há risco de ameaça à face. Por fim a linha 1106 é atenuada pelo advérbio practicamente, embora retome uma opinião dada (linha 826) o I optou por esse modalizador de forma que não parecesse ser tão enfático em sua posição.

Como já observado em análises anteriores, observa-se uma intensa participação do E com comentários e opiniões, apresentados nas tabelas que iniciam esta análise. Tais ocorrências têm significativa importância, pois contribuem com a fluidez do diálogo e aumentam a interação entre os participantes. Ressaltamos que embora saibamos da importância das mesmas, optamos por analisar apenas as ocorrências contidas na fala do I.

\subsubsection{Cortesia valorizante}

Encontramos nessa entrevista um exemplo de cortesia valorizante, na qual se enaltece a face do interlocutor. Abaixo apresentamos o trecho:

(428) E: tu padre que era / así es también así muy simpático

Observa-se que de maneira indireta o E tece um elogio ao I. Como já observado em análises anteriores, é bastante positiva essa atitude, pois contribui com a interação e favorece o bom andamento da entrevista.

\subsubsection{Formas de tratamento}

Observa-se que a forma de tratamento utilizada pelo entrevistador para se dirigir ao informante é a segunda pessoa do singular. Abaixo apresentamos alguns exemplos, seguidos de breve análise.

(02)Pero tú eres de Málaga ¿no?

(50) y la ya la ¿y tu madre qué le dijo cuando lle

(85)¿a qué edad? ¿con qué edad hacíais esas fiestas?

(126) ¡qué pena! Y ¿qué más? y ¿qué recuerdos tienes del colegio? ¿qué asignaturas te gustaban más? ¿qué asignaturas te gustaban menos?

(140)¿qué hacíais los fines de semana? ¡bueno! Eso me lo has contado ya

(169) ¿erais muchos? ¿vivíais mucha gente en Pedregalejo entonces?

(195) Y ¿os llevabais bien? 
(363) Y ¿Qué?// ¿Qué te iba a preguntar antes? / de // y a tus hermanas no sé / me has dicho que los sigues viendo ¿no? / ¿qué os reunís? ¿en navidades o?

Como é possível observar por meio dos exemplos apresentados, há total concordância entre o uso dos pronomes pessoais do caso reto, oblíquo, bem como dos possessivos, também na segunda pessoa do singular.

Também há, nessa amostra, o uso da segunda pessoa do plural quando o entrevistador se refere à família do informante. Assim como observado na amostra 24, há verbos e pronomes na segunda pessoa do plural, porém não há nenhum registro de uso do pronome vosotros. Apesar disso, podemos considerar que a forma utilizada é vosotros, pois como já mencionado a Língua Espanhola não faz o uso explícito do pronome pessoal quando não há risco de ambiguidade de sentido.

Não há ocorrências de formas nominais ao longo de toda essa amostra.

\subsection{Análise comparativa - Málaga - médio}

Ao longo desse trabalho, procuramos também estabelecer um padrão de análise de forma que pudéssemos efetuar comparações, comprovando ou não as hipóteses que motivaram a realização dessa pesquisa. Para tanto, tivemos a preocupação de que os níveis - superior e médio - fossem analisados de maneira semelhante. Entendemos que para isso, era importante separar as entrevistas em tópicos, bem como selecionar os elementos que seriam analisados em todas elas, desde a idade e sexo dos informantes até as ocorrências relevantes e específicas do nosso trabalho como as estratégias de cortesia e atenuação.

Como já foi apresentado anteriormente, o corpus médio espanhol é composto por seis entrevistas, sendo três de informantes do sexo feminino e outras três do sexo masculino. O que o caracteriza como médio é o nível de escolaridade dos informantes. Além disso, em nosso recorte de análise, selecionamos apenas informantes com idades entre 25 e 45 anos, de forma que nosso estudo pudesse também ter um caráter comparativo entre pessoas pertencentes à mesma região e com a mesma faixa etária. Não consideramos como critério de seleção das entrevistas a profissão, uma vez que apenas o nível de escolaridade era suficiente.

A seguir apresentamos os dados dos informantes que compuseram o nosso corpus. 


\begin{tabular}{|l|l|l|}
\hline $\begin{array}{c}\text { Entrevista } \\
\text { número }\end{array}{ }^{\mathbf{3 4}}:$ & \multicolumn{1}{|c|}{ Sexo } & \multicolumn{1}{|c|}{ Idade } \\
\hline 20 & masculino & 27 anos \\
\hline 22 & masculino & 32 anos \\
\hline 24 & feminino & 30 anos \\
\hline 25 & feminino & 26 anos \\
\hline 31 & masculino & 35 anos \\
\hline 32 & feminino & 43 anos \\
\hline
\end{tabular}

Passamos à exposição da análise comparativa do material de nível médio, Optamos por separá-la em tópicos de acordo com o que foi trabalhado nas análises individuais das entrevistas. Em alguns casos, utilizaremos também gráficos que nos ajudarão a elucidar os dados apresentados.

\subsubsection{Fala do entrevistador}

Entendemos que ter conhecimento de alguns dados sobre o entrevistador é importante para que se possa fazer uma análise mais consistente. Assim, cabe mencionar que cinco, entre as seis entrevistas foram feitas por uma única pessoa, do sexo feminino, 28 anos e estudante da universidade. A outra entrevistadora realizou apenas uma entrevista, também pertence ao sexo feminino e possuía, na ocasião, 24 anos. Esses dados são relevantes a ponto de posteriormente efetuarmos uma comparação com o nível superior a fim de verificarmos se há diferença na forma como o entrevistador trata $\mathrm{o}$ informante de mais de 50 anos e aquele que tem uma idade próxima a sua.

Analisando a maneira como os enunciados interrogativos são elaborados, podemos observar que em todas as entrevistas houve a predominância de enunciados diretos. A entrevista que mais nos chamou atenção é a amostra 20 , na qual sempre que a entrevistadora inicia um novo tema utiliza um ato de preparação, alertando o informante sobre tal mudança. Abaixo apresentamos o gráfico correspondente a esse tipo de ocorrência.

\footnotetext{
${ }^{34} \mathrm{O}$ número de cada entrevista foi definido pelos organizadores do corpus.
} 


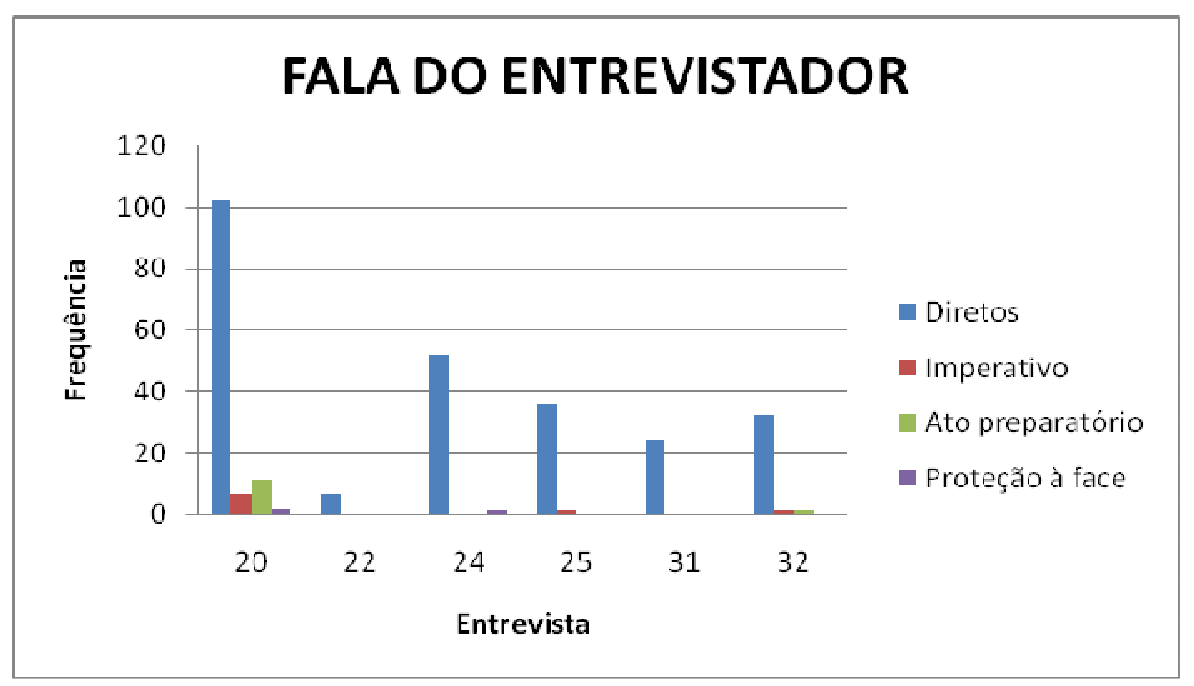

Para interpretar esse gráfico, deve-se considerar cada ocorrência representada por uma cor, conforme a legenda apresentada à direita. Os números que aparecem abaixo, referem-se ao número das entrevistas.

Os dados apresentados no gráfico acima ajudam-nos a voltar às questões que motivaram toda essa investigação: se seria o espanhol mais direto que o português, uma vez que fazendo uso de certas estratégias, o falante poderia ser considerado mais ou menos cortês. Por outro lado, a pouca frequência de verbos no imperativo também desmistifica a ideia de que os espanhóis ${ }^{35}$ optam por esse modo verbal por serem mais diretos, mais objetivos em seus pedidos ou solicitações. Não há dúvidas de que são diretos, porém sem usar necessariamente o modo imperativo. Por meio dos dados obtidos, podemos afirmar que praticamente não fazem uso de verbos performativos, ao contrário, optam por fazer a pergunta sem qualquer tipo de rodeio.

Em todas as entrevistas houve interação entre informante e entrevistador, é certo que em algumas essa interação se deu de forma mais acentuada do que em outras. Acreditamos que a idade próxima entre os participantes e os temas tratados, normalmente relacionados ao cotidiano dos mesmos, favoreceu essas ocorrências, comprovadas por meio da expressão de opinião do E e também da inversão de papéis, ou seja, do I fazendo perguntas para o $\mathrm{E}$.

A planificação temática do material é bastante baixa, observamos que o entrevistador tem em mente como iniciar e como finalizar seu diálogo, além disso, é mais importante o tempo de duração do que os conteúdos abordados ao longo desse tempo,

\footnotetext{
${ }^{35}$ Embora estejamos usando o termo espanhóis, cabe ressaltar que analisamos apenas a região andaluza de Málaga.
} 
fato esse comprovado durante as análises individuais. Assim, para iniciar a entrevista o entrevistador pergunta se o informante é de Málaga, de qual parte, etc. Já para finalizar o diálogo, há uma pergunta "chave" sobre o que o informante faria se ganhasse na loteria. Cabe ressaltar que nem sempre as entrevistas são finalizadas com o tema loteria, pois quando o tempo expira, o encerramento é com o assunto que está sendo tratado naquele momento.

Essa baixa planificação faz com que os temas surjam ao longo do diálogo e é inevitável que muitas vezes os papéis se invertam e o informante faça a pergunta para o entrevistador. Assim, os temas centrais giram em torno da infância e dos estudos do informante e algumas vezes se desviam para alguma atividade que o mesmo desenvolve como o trabalho, viagens, a cidade em que vive, entre outros. Entendemos que a necessidade de seguir um tempo pré-determinado é tão importante que obriga os entrevistadores a retomar algum tema já tratado, aprofundando-se no mesmo. É certo que se os entrevistadores tivessem informações prévias do informante antes de cada entrevista, facilitaria a preparação da mesma, evitando a repetição de assuntos já abordados. Fica bastante claro que o importante não é o conteúdo que está sendo tratado, mas sim a expressão verbal do informante.

\subsubsection{Uso do imperativo}

Ao iniciar nossos estudos sobre cortesia, como estudante da Língua Espanhola como língua estrangeira, tínhamos a expectativa de que o uso dos verbos no modo imperativo $^{36}$ fosse algo extremamente recorrente, reforçando a tese de que o Espanhol é um idioma direto, impositivo.

Baseando-nos nos dados obtidos por meio da análise dos enunciados interrogativos elaborados pelo entrevistador, já pudemos desmistificar essa ideia, comprovando que o falante é sim direto, objetivo, porém sem a necessidade de usar obrigatoriamente verbos no modo imperativo.

Por meio dos gráficos apresentados, podemos observar que esse modo verbal foi utilizado em apenas três entrevistas e em quantidade insignificante, se comparamos o uso dos enunciados diretos.

No entanto, ao longo da análise dos materiais espanhóis, encontramos outro tipo de uso de verbos no imperativo, os quais perdem a função de imperativo e adquirem nova

\footnotetext{
${ }^{36}$ Entendemos que os livros didáticos foram fortes influenciadores de tal ideia.
} 
posição: a de envolvimento com o interlocutor no caso de mira e oye e a de chamar sua atenção para a informação que está sendo passada no caso de imagínate e fijate.

Ressaltamos que todas as entrevistas apresentaram esse tipo de ocorrência, ainda que nem todas tenham apresentado os quatro verbos citados, como pode ser observado ao longo das análises individuais.

Além desses verbos, encontramos também uma ocorrência do verbo callar em sua forma imperativa (amostra 32). Não é um verbo que causa ameaça à face do interlocutor, porém denota a forte interação entre os participantes da entrevista.

\subsubsection{Desfocalização do eu}

Como já foi apresentado ao longo de nossa fundamentação teórica e também nas análises individuais, existem algumas estratégias que o falante pode usar para desfocalizar o eu, referindo-se, de forma generalizada, a uma $3^{\text {a }}$ pessoa do discurso.

Durante a nossa análise pudemos observar dois tipos de desfocalização - uma usando a segunda pessoa do singular e outra usando a primeira do plural, essa em menor quantidade.

A seguir apresentamos o gráfico com esse tipo de ocorrência para elucidar os dados obtidos ao longo da análise.

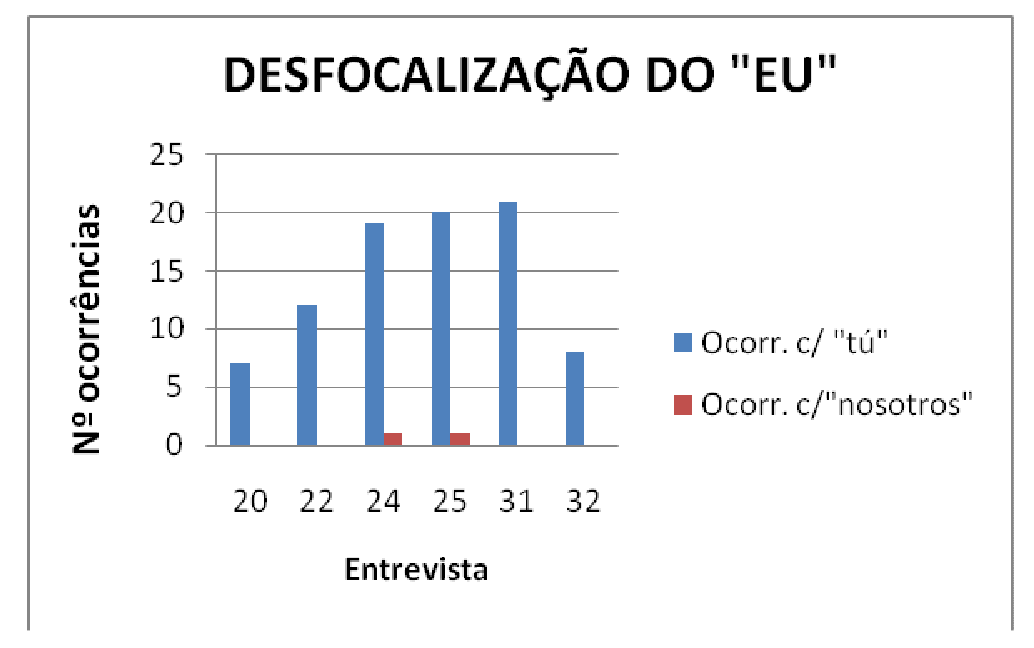

Os números que estão na horizontal se referem ao número de cada entrevista, designado pelos organizadores do corpus; já; os números que estão na vertical são referentes ao número de ocorrências que apareceram em cada entrevista.

Como pode ser observado no gráfico acima, em todas as amostras analisadas há a predominância da segunda pessoa do singular como forma de desfocalizar o eu, 
generalizando o enunciado em questão. Como já apontado ao longo das análises individuais, entendemos que o uso de tal forma gera maior aproximação com o interlocutor, aumentando a interação entre ambos. Apenas duas entrevistas apresentaram casos de desfocalização utilizando a primeira pessoa do plural.

\subsubsection{Prevenção de ameaça à face}

Conforme exposto ao longo de nossa fundamentação teórica, a prevenção de ameaça à própria face e à do outro é algo que se considera fundamental em qualquer tipo de interação. Já apontamos que para uma interação ser bem sucedida há que haver um constante equilíbrio na preservação das imagens, tanto do falante quanto de seu interlocutor, de forma que nenhuma delas se prejudique.

Entendemos que a frequência desse tipo de ocorrência não deve ser relacionada ao sexo dos informantes, pois ocorreram de forma bastante semelhante em todas as entrevistas.

Abaixo apresentamos os tipos de ameaça encontrados e o número da amostra, quando necessário.

\subsubsection{Proteção à própria face}

Esse tipo de ocorrência foi encontrado em cinco, entre as seis entrevistas analisadas. Utilizando-se de argumentos como no sé, no estoy seguro, no sé al cierto, os informantes deixam claro que não têm certeza sobre a precisão de certo dado ou fato. Conforme foi exposto ao longo das análises individuais, entendemos que o objetivo principal dessa estratégia é a prevenção de ameaça à própria face, porém sem deixar de proteger também a face do interlocutor, pois ao saber da dúvida apresentada, o entrevistador evitará perguntas mais específicas sobre o mesmo tema. A única amostra que não apresenta esse tipo de proteção é a 31.

\subsubsection{Justificativas}

Apenas duas amostras apresentaram esse tipo de ocorrência - 22 e 31 . Conforme já trabalhado em análises anteriores, a justificativa tem o objetivo de evitar que seu interlocutor faça juízo de valor sobre seus atos ou pensamentos. No caso da entrevista 22 , o informante não se lembra com precisão um dado geográfico e a justificativa é que faz muito tempo. Já no caso da entrevista 31, há duas ocorrências desse tipo. Na primeira, o informante faz uma crítica aos cachorros e a justificativa é que não tem nada contra os 
animais. Na segunda ocorrência, entendemos que há certa tentativa de se mostrar humilde por parte do I, pois o mesmo tece várias justificativas para o fato de ir viajar nas férias, alegando que ganhou a passagem, que se não fosse isso não teria condições, etc. Como se pode comprovar, todas foram justificativas explícitas, cuja principal função era proteger a face dos informantes.

\subsubsection{Proteção à face do entrevistador}

Entre as seis amostras analisadas, quatro apresentam esse tipo de ocorrência. Apenas as entrevistas 20 e 25 não contêm exemplos desse recurso atenuador. Essa estratégia visa proteger a face do interlocutor, no caso o entrevistador de cada amostra. Assim, o falante interrompe sua fala para perguntar declaradamente se o entrevistador sabe daquilo que está sendo tratado. Se a resposta for positiva, ele prossegue sua fala, porém se for negativa, para e explica. Acreditamos que quanto maior a interação, mais comum será esse tipo de ocorrência, pois demonstra certa liberdade entre os interlocutores.

\subsubsection{Proteção à face do informante}

Apenas a amostra número 20 apresenta esse tipo de ocorrência. Ao fazer uso desse tipo de recurso, o entrevistador não intimida seu interlocutor, criando certo espaço para que o mesmo não responda determinada questão. Além disso, segue uma das regras de cortesia apresentadas ao longo de nossa exposição teórica ${ }^{37}$, dando opções ao outro. É certo que, como já mencionado, é uma opção fictícia, uma vez que ao aceitar participar desse tipo de entrevista, fica subentendido que deverá responder algumas questões.

\subsubsection{Ameaça à face}

Como já trabalhado na apresentação da análise do corpus brasileiro e retomando a fundamentação teórica que embasa o nosso trabalho, pudemos observar que embora os participantes de uma conversação tenham a necessidade de cuidar para que ambas as faces sejam protegidas, muitas vezes é inevitável que uma delas seja ameaçada, seja por culpa de um dos participantes ou da própria situação de interação.

No caso específico do nosso corpus, por se tratar de uma entrevista, o cuidado deve ser ainda maior, principalmente por parte do entrevistador, pois o informante não

\footnotetext{
${ }^{37}$ Vide pág. 53
} 
pode se sentir ameaçado, uma vez que isso poderia findar o diálogo. Assim, ocorrendo qualquer tipo de ameaça, deve-se procurar restabelecer o equilíbrio para que a conversação possa prosseguir sem maiores danos.

Acreditamos que o fato de encontrarmos poucas ocorrências de ameaça à face seja um dado relativamente contundente que comprova a nossa tese.

Especificamente nesse corpus, pudemos observar que esse tipo de ocorrência pode ser encontrado em todas as entrevistas analisadas. Sendo que encontramos diversos tipos de ameaça à face: I ameaçando o E; E ameaçando o I e E e I se autodepreciando.

Abaixo apresentamos os tipos de ameaça encontrados:

\subsubsection{Exposição da própria face}

Esse tipo de ocorrência foi encontrado em cinco entre as seis amostras analisadas nesse corpus. Entendemos que embora os temas tratados sejam referentes ao cotidiano dos informantes, não há a necessidade de haver qualquer tipo de exposição de sua vida pessoal, como ocorreu, por exemplo, na amostra 20.

Também na entrevista 20 e na 22 a exposição é diferente, nela os informantes expressam pensamentos preconceituosos, seja sobre a religião muçulmana, seja aos turistas estrangeiros, enquanto que na amostra 31 o informante ameaça a própria face ao se autodepreciar, ainda que essa seja uma estratégia de cortesia, pois ele se distancia da mensagem, aproximando-se do interlocutor.

Já no caso das amostras 24 e 32 quem expõe sua face são os entrevistadores. $\mathrm{Na}$ primeira pelo fato de ele expor sua opinião sobre os retiros que a informante frequenta, opinião essa carregada de críticas. Na entrevista 32 o entrevistador se distrai e não entende a situação narrada pelo informante. Esse percebe o ocorrido e repete toda a história.

\subsubsection{Ameaça à face do interlocutor}

Como já tratado anteriormente, não é um tipo de ocorrência que esperávamos encontrar com muita frequência, porém há dois tipos de ameaça à face do interlocutor, ou seja, tanto do entrevistador para o informante, quanto do informante para o entrevistador.

$\mathrm{Na}$ amostra número 20 observamos que as perguntas que o $\mathrm{E}$ faz tendem a invadir o território privado do I, além de ameaçar sua face como perguntar quanto a família ganha, se ele é racista ou machista, por exemplo. Por outro lado, o informante também 
ameaça a face do entrevistador ao contrariá-lo quando pretende expor seu ponto de vista sobre um determinado assunto.

Já na amostra 25 observamos que há um desequilíbrio no diálogo, ao dizer que não havia notado a mudança nas cores do porto da cidade, o I brinca, dizendo que faz mais de um ano que as cores foram pintadas. Nota-se que o E ficou incomodado com o comentário, porém foi bastante cortês em não contra-argumentar, pois sempre é ele o maior responsável pelo equilíbrio na conversação.

$\mathrm{Na}$ entrevista 31 temos dois tipos de ameaça. Primeiro o I ameaça a face do E ao solicitar perguntas, observamos que ele tenta argumentar, porém desiste e elabora uma nova pergunta. Posteriormente é o E quem ameaça a face do I, fazendo críticas por ele fumar.

\subsection{Atenuantes}

Além de todos os recursos apresentados utilizados pelos falantes de nosso corpus como estratégias de cortesia e atenuação, observamos também o uso de algumas expressões que denominamos atenuantes, pois exercem a função específica de mitigar o conteúdo da fala do informante e do entrevistador.

Como se pode verificar nas análises individuais, nem todo uso de diminutivo pode ser considerado uma estratégia de atenuação, pois pode ser apenas uma forma carinhosa que o falante usa para se expressar.

Ao longo das análises, observamos que são encontradas atenuações tanto na fala do I quanto do E, em cinco entre as seis entrevistas analisadas. Chama-nos atenção as ocorrências em que um falante procura atenuar a fala do outro. Isso ocorre em duas entrevistas: na amostra 22 o entrevistador atenua a fala do informante quando ele lhe diz que ficou vermelho como uma lagosta justificando que isso se deu por ele ser branquinho e na amostra 25 ao falarem sobre um conjunto de prédios, o E diz que os mesmos ficaram feíssimos, já o I atenua dizendo que realmente não ficaram bonitos. Observamos que a fala do entrevistador é mais enfática.

As ocorrências que são recorrentes nas entrevistas são aquelas que usam o adjetivo poco com o objetivo de atenuar o adjetivo que está ao lado e também os diminutivos. Entre as seis entrevistas analisadas, a única que não apresenta esse tipo de ocorrência é a amostra 31. 
Devido às ocorrências encontradas, não podemos estabelecer relação entre essa estratégia e o sexo dos informantes. Acreditamos que a influência maior é o tema abordado ao longo de cada entrevista.

\subsection{Expressão de opinião}

Conforme mencionado ao longo das análises individuais, esse corpus não apresenta ordem de organização das perguntas que o entrevistador deveria fazer aos informantes. Assim, não há uma pergunta específica que vise a expressão de opinião do entrevistado, ao longo da entrevista essas opiniões são dadas de acordo com os temas trabalhados.

Os temas tratados ao longo dessa entrevista são bastante amenos e relacionados ao modo de vida de cada informante. Os pedidos de expressão de opinião sempre são relativos aos temas tratados ao longo de cada entrevista, o que faz com que, de maneira geral, os informantes não apresentem receio em se expor.

Todos os informantes de nosso corpus fazem uso de verbos ou expressões parentéticos ou epistêmicos como creo, pienso que..., en mi opinión..., e a conclusão que chegamos sobre esse uso é que tal uso ocorre com mais frequência quando o tema tratado envolve uma posição extremamente pessoal do informante, no entanto quando o assunto tratado aborda algo que o informante apresenta maior conhecimento, opta-se por não utilizar tal recurso.

Com exceção da amostra 24 , é possível observar em todas as outras o uso de expressões que visam atenuar o conteúdo da fala do I. Essas atenuações são feitas por meio de expressões modalizadoras e também de justificativas e têm o objetivo de proteger a face do I, normalmente, de um possível julgamento do E.

Como já tratado ao longo das análises individuais, os entrevistadores também expõem suas opiniões e tecem comentários sobre os temas abordados em todas as amostras analisadas. Ressaltamos que tais ocorrências são importantes para a fluidez do diálogo, além de aumentar a interação entre os participantes.

\subsection{Solidariedade}

Em quatro entre as seis entrevistas analisadas pudemos encontrar ocorrências de solidariedade entre os falantes. Observamos que tanto o entrevistador complementa a fala do informante, quanto o contrário. Conforme observado nas análises individuais, é uma forma de dar mais fluidez ao diálogo e de demonstrar também interação, uma vez que é necessário que o interlocutor esteja atento ao que lhe é contado, a ponto de interferir e 
contribuir com a fala do outro. Apenas as amostras 22 e 32 não apresentaram esse tipo de ocorrência.

\subsection{Cortesia valorizante}

Apenas as amostras 20 e 25 não apresentam esse tipo de ocorrência. Em todas as outras entrevistas, o tipo de ato de fala que se configura como cortesia valorizante é o elogio, o qual procura enaltecer a imagem do informante. É uma estratégica benéfica para a face do informante e contribui favoravelmente para a interação entre os participantes.

Não há ocorrências de saudações ou agradecimentos em nenhuma das seis amostras analisadas.

\subsection{Invasão do território pessoal}

De fato, há apenas uma amostra que apresenta esse tipo de ameaça à face do interlocutor. Trata-se da entrevista 20, na qual a entrevistadora faz perguntas sobre o salário que a família recebe, religião, pergunta se o informante é machista, etc. Como já observado na análise individual, não acreditamos que o falante se sentiu ameaçado, pois respondeu a todas as perguntas.

$\mathrm{Na}$ amostra 25, ao descrever um fato de sua vida pessoal, o informante dá margem para que o entrevistador lhe faça perguntas de âmbito mais pessoal, no entanto isso não ocorre, ao contrário, há uma mudança de assunto.

\subsection{Formas de tratamento}

Para elucidar as formas de tratamento encontradas ao longo das seis entrevistas analisadas, apresentaremos a seguir uma tabela e, na sequência, as considerações que chegamos a partir de tal análise no que concerne aos falantes de nível médio do Espanhol de Málaga. 


\begin{tabular}{|c|c|c|c|c|c|c|}
\hline Amostra & $\begin{array}{c}\text { Sexo } \\
\text { do Inf. }\end{array}$ & $\begin{array}{c}\text { Pronome } \\
\text { Pessoal }\end{array}$ & $\begin{array}{l}\text { Pessoa } \\
\text { verbal }\end{array}$ & $\begin{array}{c}\text { Pronome } \\
\text { Oblíquo }\end{array}$ & $\begin{array}{l}\text { Pronome } \\
\text { Possessivo }\end{array}$ & $\begin{array}{c}\text { Forma } \\
\text { Nominal }\end{array}$ \\
\hline 20 & $\mathrm{M}$ & tú & $2^{\mathrm{a}}$ sing. & te & tu / tus & ----- \\
\hline 22 & $\mathrm{M}$ & tú / vosotros & $2^{\mathrm{a}}$ sing. e pl. & te / os & ---/ vuestro & ----- \\
\hline 24 & $\mathrm{~F}$ & tú / ----- & $2^{\mathrm{a}}$ sing. e pl. & te / ---- & tuyos / --- & ----- \\
\hline 25 & $\mathrm{~F}$ & tú / vosotros & $2^{\mathrm{a}}$ sing. e pl. & te / ti / --- & tu / vuestra & ----- \\
\hline 31 & $\mathrm{M}$ & tú / vosotros & $2^{\mathrm{a}}$ sing. e pl. & te / os & tu / --- & ----- \\
\hline 32 & $\mathrm{~F}$ & tú / ----- & $2^{\mathrm{a}}$ sing. e pl. & te / os & tu / --- & ----- \\
\hline
\end{tabular}

Por meio do quadro acima, podemos comprovar alguns dados que foram expostos ao longo de nossa fundamentação teórica.

Considerando que os informantes das amostras analisadas têm idades próximas à idade dos entrevistadores, era esperado que a forma de tratamento estivesse no eixo de solidariedade.

Observa-se que quando o entrevistador se dirige ao informante, o único tratamento utilizado é a segunda pessoa do singular, na forma do pronome pessoal tú e dos respectivos pronomes oblíquos e possessivos, estabelecendo concordância.

Ainda que não seja o foco de nosso trabalho, ao apresentar a fundamentação teórica sobre as formas de tratamento e apoiando-nos em alguns teóricos como Carricaburo, Matte Bon e Fontenella de Weinberg, apresentamos o sistema pronominal de Málaga como um sistema dual e, conforme as teorias estudadas, afirmamos que a região de Andaluzia, onde está a cidade de Málaga, apresenta certa diversidade pronominal com relação ao uso de vosotros e ustedes.

Como pode ser observado na tabela acima, não é isso o que ocorre em nossas entrevistas. Apenas a amostra 20 não apresenta referência à segunda pessoa do plural, por conta disso, não deve ser considerada. Entre as outras cinco amostras, três apresentam explicitamente o pronome vosotros, enquanto que nas outras duas ele está elíptico. No entanto, se considerarmos que se trata do mesmo entrevistador, pode-se afirmar que houve a preferência de vosotros a ustedes. Entendemos que não podemos, baseando-nos apenas em nosso corpus, ser taxativos em afirmar que em Málaga se usa vosotros e não ustedes, mas sim que a presença do pronome na segunda pessoa do plural é frequente. Essa nossa cautela se deve também ao fato de esse não ser o objetivo central de nossa pesquisa e considerarmos que não temos amostras suficientes para tal comprovação. 
Com relação às formas nominais, não foram observadas em nenhuma das amostras analisadas. Fato esperado, uma vez que informantes e entrevistadores apresentam idades próximas.

\section{II. PRESEEA - Nível Superior}

\subsection{Amostra 54}

Informante masculino - 50 anos

Entrevistador feminino - 28 anos

Tema 1 - Málaga, família e colégio

\begin{tabular}{|c|c|c|}
\hline Perguntas principais & Perguntas secundárias & $\begin{array}{c}\text { Comentários / opiniões / } \\
\text { marcadores de } \\
\text { interação }\end{array}$ \\
\hline $\begin{array}{l}\text { (01) Entonces tú / tú tampoco eres } \\
\text { de Málaga ¿no? } \\
\text { (15) [uhum] y ¿qué recuerdos tienes } \\
\text { de de Velez? } \\
\text { (63) ¿cómo se llamaba? } \\
\text { (77) pero tú ya tenías novia ¿no? / } \\
\text { que me has contado } \\
\text { (94) [uhum] pero ¿ellos estudiaron } \\
\text { medicina también? } \\
\text { (164) y ¿os veníais mucho a } \\
\text { Málaga / cuando estabais } \\
\text { estudiando? }\end{array}$ & $\begin{array}{l}\text { (03) ¿y estuviste viviendo allí } \\
\text { mucho(s) años? } \\
\text { (18) ¿no? } \\
\text { (27) ¿sí? } \\
\text { (32) la de aquí? } \\
\text { (65) ¿picú? } \\
\text { (67) ¿cómo se escribe? / pe i } \\
\text { (98) pero ¿todos en Granada? } \\
\text { (112) además fue de las primeras } \\
\text { ¿no? / medicina } \\
\text { (116) pero en Granada ¡hombre!/ } \\
\text { ya que habías comenzado allí ¿no? } \\
\text { (126) pero ¿qué eran? / ¿casas } \\
\text { alqui } \\
\text { (131) ¡ah! ¿sí? / ¿qué bien! ¿no? } \\
\text { (150) os administrabais bien ¿no? } \\
\text { (173) [uhum] / y a ver a / a la } \\
\text { familia aquí ¿no? } \\
\text { (179) y no ¿por qué? }\end{array}$ & 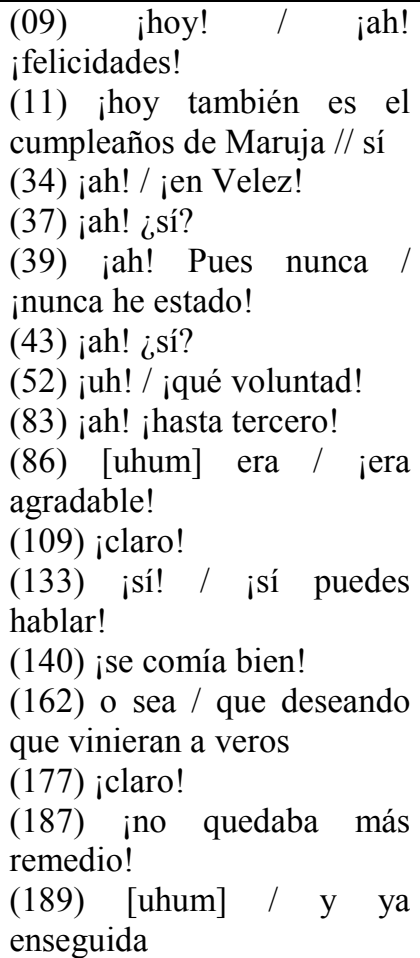 \\
\hline
\end{tabular}

Tema 2 - A profissão

\begin{tabular}{|c|c|c|}
\hline Perguntas principais & Perguntas secundárias & $\begin{array}{l}\text { Comentários / opiniões / } \\
\text { marcadores de interação }\end{array}$ \\
\hline $\begin{array}{l}\text { (262) [uhum/] pero y ¿eso es en } \\
\text { todos los? / ¿en casi todos los } \\
\text { centros? } \\
\text { (273) yo yo me refería a que suban } \\
\text { a los niños a / que estén los niños } \\
\text { con las madres / si eso ocurre } \\
\text { (338) estáis muy bien organizados } \\
\text { ¿no? } \\
\text { (393) ¿se tarda mucho en preparar } \\
\text { una sesión clínica? } \\
\text { (407) ¿cuánto dura una }\end{array}$ & $\begin{array}{l}\text { (347) ipues la verdad es que sí! / } \\
\text { siempre me lo había preguntado } \\
\text { cómo se organizaba un hospital } \\
\text { pero } \\
\text { (358) pero es duro ¿no? ¡claro! } \\
\text { (374) se ahorra tiempo ¿no? } \\
\text { (376) yo siempre me pregunto / } \\
\text { ¿cómo les dará tiempo a a? } \\
\text { (379) ¡sí! / pero estar al día de todo } \\
\text { porque } \\
\text { (381) tiene que ser / la cantidad de }\end{array}$ & $\begin{array}{l}\text { (214) ¡qué curioso! } \\
(222) \text { ¡qué bonito! } \\
(228) \text { ¡qué lástima! } \\
(233) \text { pero es un mundo ¿no? } \\
\text { / tener yo ¡claro! / como } \\
\text { ahora estoy en época / que he } \\
\text { empezado a plantearme } \\
\text { (245) porque ahora los dejan } \\
\text { / que las tengan las madres o } \\
(260) \text { ¡qué horror! } \\
(277) \text { ¡ah! / ¡qué bien! / a no }\end{array}$ \\
\hline
\end{tabular}




\begin{tabular}{|c|c|c|}
\hline $\begin{array}{l}\text { exposición? } \\
\text { (417) iestá bien! / pero el video lo } \\
\text { ¿lo graba? } \\
\text { (437) [uhum/] pero el ordenador } \\
\text { ¿cómo? / pero ¿qué saca? / una } \\
\text { imagen que es tan }\end{array}$ & $\begin{array}{l}\text { novedades que } \\
\text { (383) idebe ser impresionante! // y } \\
\text { eso son las sesiones clínicas / ¿dos } \\
\text { veces en semana? } \\
\text { (386) pero / expone uno cada vez } \\
\text { ¿no? / o }\end{array}$ & 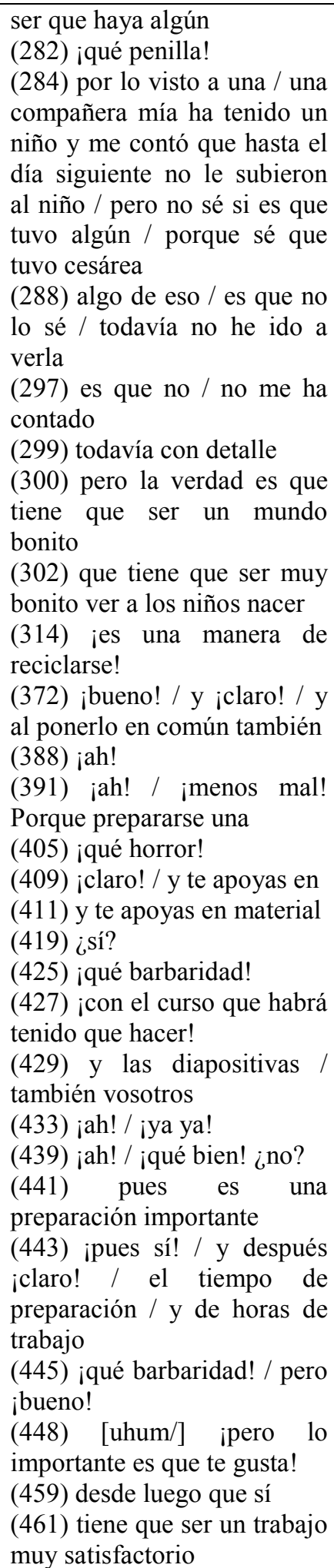 \\
\hline
\end{tabular}

Tema 3 - Tempo livre / basquete

\begin{tabular}{|l|l|l|}
\hline \multicolumn{1}{|c|}{ Perguntas principais } & \multicolumn{1}{|c|}{ Perguntas secundárias } & $\begin{array}{l}\text { Comentários / opiniões / } \\
\text { marcadores de } \\
\text { interação }\end{array}$ \\
\hline $\begin{array}{l}\text { (494) ¿cómo va ahora el Unicaja? } \\
\text { (516) iqué gracioso! Y cuan que / } \\
\text { los partidos del Unicaja ¿qué son? / }\end{array}$ & $\begin{array}{l}\text { (554) fieles ¿no? } \\
(560) \text { ¿nueve partidos? }\end{array}$ & $\begin{array}{l}\text { (463) [uhum] y después/ en } \\
\text { el poco tiempo libre que } \\
\text { queda }\end{array}$ \\
\hline
\end{tabular}




\begin{tabular}{|c|c|c|}
\hline $\begin{array}{l}\text { ¿todas las semanas? } \\
(534) \text { ¡ah! ¿ahí van a jugar ahora? } \\
(542) \text { ¿dónde está ahora? / ¿dónde } \\
\text { juega ahora? } \\
(575) \text { y pero / ¿creéis que se va a ir } \\
\text { mucha gente? } \\
\text { (589) no lo sé / y ¿los niños juegan } \\
\text { al baloncesto también? }\end{array}$ & $\begin{array}{l}\text { (567) y ¿cuándo termina? } \\
(596) \text { ¿sí? } \\
(605) \text { ¡ah! ¿sí? }\end{array}$ & $\begin{array}{l}\text { (469) ¡ah! ¿sí? } \\
(500) \text { ¡qué pena! } \\
(512) \text { iqué gracioso! } \\
(514) \text { iél pedía permiso! } \\
(519) \text { ¡ah! / ¡claro! / y vais a } \\
\text { las de aquí } \\
\text { (521) [uhum] pues yo creía } \\
\text { que iba mejor / porque tuvo } \\
\text { unos años malos } \\
\text { (530) ¡ah! jel pabellón! } \\
\text { (532) ese / ese que } \\
\text { (537) yo lo he visto por } \\
\text { fuera / por dentro no / como } \\
\text { no compro el Sur } \\
\text { (539) no / por fuera sí } \\
\text { porque se ve desde el } \\
\text { camino } \\
\text { (544) en Ciudad Jardín } \\
\text { (556) ies verdad! Pues el } \\
\text { ma/ que el Málaga también } \\
\text { va muy bien } \\
\text { (558) le queda muy poco } \\
\text { (569) ia ver a ver! / mientras } \\
\text { que } \\
\text { (570) muchos socios } \\
\text { (571) idel Unicaja al } \\
\text { Málaga! } \\
\text { (573) pues i a ver! } \\
(583) \text { yo tenía una amiga } \\
\text { que decía que ella gafaba al } \\
\text { Unicaja } \\
\text { (584) porque se era socia / } \\
\text { iy desde que se hizo socia } \\
\text { empezó a perder! / y se } \\
\text { quitó un año y fue otra vez } \\
\text { mejor } \\
\text { (586) pero ya no se volvió a } \\
\text { asociar }\end{array}$ \\
\hline
\end{tabular}

Tema 4 - Filhos

\begin{tabular}{|c|c|c|}
\hline Perguntas principais & Perguntas secundárias & $\begin{array}{l}\text { Comentários / opiniões / } \\
\text { marcadores de interação }\end{array}$ \\
\hline $\begin{array}{l}\text { (624) ¿dónde juega? } \\
\text { (649) iclaro! Están / y ¿seguís } \\
\text { yendo todos los? } \\
\text { (651) ¿Macarena también va al } \\
\text { baloncesto? } \\
\text { (686) y entonces / ¿cuál es la } \\
\text { última de acción que te haya } \\
\text { gustado? } \\
\text { (700) y ¿la del soldado Ryan la } \\
\text { habéis visto? }\end{array}$ & (653) ¿vais los cuatro? & $\begin{array}{l}\text { (619) jes verdad! } \\
(626) \text { jah! / jallí! } \\
\text { (641) iclaro! / ¡claro! / ES } \\
\text { que si puede compaginar las } \\
\text { dos cosas } \\
\text { (643) ¡sí! / iya me he dado } \\
\text { cuenta! } \\
(665) \text { iclaro! / es una manera } \\
\text { de / ide no intervenir! } \\
\text { (680) jentonces os pasa } \\
\text { como a Javier y a mí! } \\
(682) \text { a / a él le gustan } \\
(684) \text { las de acción } \\
\text { (703) no } \\
\text { (705) jah! / ique cada vez } \\
\text { elige uno! } \\
\text { (707) ¡ah! / ¡es un buen }\end{array}$ \\
\hline
\end{tabular}


Tema 5 - Família / Velez

\begin{tabular}{|c|c|c|}
\hline Perguntas principais & Perguntas secundárias & $\begin{array}{l}\text { Comentários / opiniões / } \\
\text { marcadores de interação }\end{array}$ \\
\hline $\begin{array}{l}\text { (714) ellos viven allí } \\
\text { (745) [uhum] iclaro! / y tú / pero } \\
\text { tú sí tienes hermanos allí } \\
\text { (793) [uhum] entonces eso ¿no } \\
\text { tomas cerveza por? }\end{array}$ & (803) para el verano ¿no? & $\begin{array}{l}\text { (739) ¡ah! / ¡está muy bien! } \\
\text { (743) jes una idea buena! } \\
\text { (749) ¡ah! iqué joven! } \\
\text { (754) se murió } \\
\text { (764) se conserva bien } \\
\text { (775) ¡claro! Que es el día } \\
\text { que sale la } \\
\text { (783) ique gracioso! } \\
\text { (790) nos queda poquillo } \\
\text { (792) quedan ya diez } \\
\text { minutos o menos } \\
\text { (805) aunque con el ejercicio } \\
\text { que hacéis casi } \\
\text { (814) [uhum] entonces os } \\
\text { mantenéis en forma } \\
\text { (818) y aparte con los gritos } \\
\text { de }\end{array}$ \\
\hline
\end{tabular}

Tema 6 - Loteria

\begin{tabular}{|c|c|c|}
\hline Perguntas principais & Perguntas secundárias & $\begin{array}{l}\text { Comentários / opiniões / } \\
\text { marcadores de interação }\end{array}$ \\
\hline $\begin{array}{l}\text { (820) y si os / a ti te tocase la } \\
\text { lotería } \\
\text { (848) y ¿dónde te gustaría a ti? } \\
\text { (865) y ¿qué tal los Países Bajos? } \\
\text { (882) pero dicen que es muy caro } \\
\text { ¿no? } \\
\text { (893) [uhum] y ¿qué país te ha } \\
\text { gustado más o que ciudad? }\end{array}$ & $\begin{array}{l}\text { (856) ¿toda entera o el norte? } \\
\text { (867) ¿sí? }\end{array}$ & $\begin{array}{l}\text { (844) ¡sí! Pero si } \\
\text { (854) [uhum] América } \\
\text { (863) a ver la realidad } \\
\text { (875) itodo el mundo que ha } \\
\text { estado en Paris me dice lo } \\
\text { mismo! } \\
\text { (887) [uhum] aparte que } \\
\text { cuando vas de viaje quieras } \\
\text { que no / isiempre te gastas! } \\
\text { (891) siempre ¿no? } \\
\text { (911) a mí flo / Florencia me } \\
\text { pasa igual / Venecia me } \\
\text { desilusionó / nosotros } \\
\text { estuvimos en viaje de } \\
\text { estudios / en COU / como } \\
\text { también lo hicimos en los } \\
\text { Maristas / iy nos pasó lo } \\
\text { mismo! } \\
\text { (917) nosotros ya casi hemos } \\
\text { terminado } \\
\text { (919) ipues sí! / yo creo que } \\
\text { ya vamos a empezar el } \\
\text { lingǘ́stico }\end{array}$ \\
\hline
\end{tabular}

De acordo com os temas trabalhados, optamos por dividir essa entrevista em seis partes. Analisando primeiramente as perguntas principais, podemos observar que não há uso de verbos no imperativo, tampouco de atos preparatórios, como o uso de verbos no 
Futuro do Pretérito, por exemplo. O entrevistador opta por elaborar apenas enunciados diretos.

A interação estabelecida entre os participantes ao longo dessa amostra é bastante significativa. Os papéis de entrevistador e entrevistado são bem definidos e a planificação da entrevista é relativamente baixa, ou seja, os temas vão surgindo no decorrer do diálogo. Chama-nos atenção a forma como o E expõe seus problemas e suas opiniões. Entendemos que o fato de estar dialogando com um médico faça com que ele busque sanar algumas dúvidas, algumas curiosidades sobre esse trabalho, além de se sentir à vontade para falar de questões pessoais suas, como a vontade de engravidar, por exemplo.

\subsubsection{Desfocalização do $e u$}

Assim, como em outras entrevistas analisadas, foram encontradas algumas ocorrências em que o I busca desfocalizar o eu, não se colocando como sujeito da situação descrita. Abaixo, apresentamos os trechos em que essas situações podem ser observadas, todas na fala do I.

(40) ... y aparte de eso / según dicen la / la gente / la forma de llevar los tronos aquí en Málaga lo / lo copiaron de la Axarquía / ¡de Vélez!

(240) ... después ya cuando nace el niño / nosotros los recogemos / le hacemos la primera / ¡bueno! / la la la / la primera reanimación que es aspirarle / [eeh/] si hay que darle un poquito de oxígeno y todas esas cosas / y después ya le hacemos / a las dos horas de vida / a las tres horas de vida / le hacemos una exploración al completo...

(394) depende ya de la bibliografía que $[\mathrm{mmm}]$ recojas y todas esas cosas / pero por lo menos el mes se lo lleva // mes / mes y medio te lo lleva / porque prepararla te / tienes/ tienes que hacer diapositivas / tienes que / leerte todo lo que nuevo que ha salido de / del tema o del caso clínico... eso te lleva tiempo... o sea que son cincuenta pediatras / y después / prepararte para las preguntas que te pueden hacer / porque te hacen tus / tus preguntas y tus / iy tus cosas!

(435) ... máquinas fotográficas que la acoplan con un aparato al ordenador / y el mismo ordenador te saca la diapositiva

(501)... pero se pasa bien en el partido porque / si gana Unicaja porque gana Unicaja / y si gana el otro pues como nos gusta el juego del baloncesto / porque el otro ha jugado bien / y se han visto buenas jugadas/ se han visto buenas cosas / y entonces ya se / ; te lo pasas bien!/ y ya discutes...

(612) ... porque nosotros tenemos ese lema / si a ti te gusta una cosa / aprende primero y luego ya / se le compraron los palos de golf

Embora não haja diversas ocorrências em que ocorra a desfocalização do $e u$, entendemos que os trechos encontrados são bastante significativos para nossa análise. No primeiro deles, o I optou pelo uso da $3^{\mathrm{a}}$ pessoa do plural, o que tira toda a responsabilidade do falante sobre aquilo que está sendo enunciado. Ao dizer dicen, ele não especifica quem, ou seja, não se compromete com o que foi dito, tampouco com quem disse.

Nos trechos em que utiliza a $1^{\text {a }}$ pessoa do plural, o contexto da entrevista explica quem são essas pessoas, no caso os médicos que fazem parte de sua equipe. 
Já com relação às ocorrências em que usa $2^{\mathrm{a}}$ pessoa do singular, ele se refere a ele mesmo e a todas as pessoas que têm esse mesmo trabalho, no entanto, assim como observado em outras análises, é uma estratégia que busca envolver o interlocutor no tema que está sendo discutido, aumentando a interação entre os participantes da entrevista.

\subsubsection{Prevenção de ameaça à face}

Abaixo apresentamos as ocorrências encontradas de prevenção à face, seguidas de breve análise.

(204) I: ... me dieron una plaza que se llamaba de becario / becario me parece a mí que era/ o de resi / residente era en el Carlos Hay / a nosotros nos llamaban becarios.

(535) I: allí van a jugar ahora / ¡un pabellón muy bonito! / por lo menos lo que sale en el periódico y eso / es muy / muy bonito / muy confortable y eso

(687) I: lo que pasa no me acuerdo yo cómo se llama / ¡era tan mala que no me acuerdo!

(736) I: del piso / como a nosotros nos / nos intervenía / entonces le quitamos metros a su casa para añadírsela a la nuestra / porque ellos necesitaban menos / y / y los tenemos puerta con puerta / los tenemos comunicados por el salón / y los tenemos

(739) E: ¡Ah! / está muy bien

(740) I: ¡Y muy bien! / entonces ellos están en su casa / ellos ven su televisión / ellos hacen su comida / ellos eso / y nosotros estamos en la nuestra / y no estamos todos / ¡estamos juntos pero no revueltos!

(743) E: ¡es una idea buena!

(744) I: es una idea buena / ¡sí sí! / porque eso de los abuelos es problemático

(745) E: [uhum] ¡claro! / y tú / pero tú si tienes hermanos allí

Observam-se apenas quatro ocorrências de prevenção de ameaça à face do I nessa entrevista. Duas delas (linhas 204 e 687) já foram encontradas em análises anteriores e se referem a uma precaução do falante. Assim, ao utilizar termos como me parece, no me acuerdo, ele se previne de que o $\mathrm{E}$ faça perguntas mais detalhadas sobre esse mesmo tema. Além de prevenir a sua face, evita que a face do outro, no caso o E, também seja ameaçada, recebendo uma resposta negativa.

Já na segunda ocorrência (linha 535), observamos que o I se previne de uma falsa informação, pois ele faz uma afirmação e em seguida diz que a responsabilidade sobre o dito é do jornal e não dele. A prevenção nesse caso é para o fato de a veracidade sobre o que foi dito não ser real.

Por fim, para explicar a última ocorrência apresentada, optamos por transcrever o diálogo entre o I e o E. A prevenção de ameaça à face, refere-se ao fato de o I ter diminuído a casa do sogro para aumentar a sua. Assim, para evitar qualquer tipo de julgamento por parte do E, ele tece uma série de justificativas. O E, por sua vez, mantém o ritmo da entrevista, elogiando a atitude do I. 


\subsubsection{Atenuantes}

Abaixo seguem as ocorrências encontradas, seguidas de breve análise.

(629) I: ... el segundo le gustaba mucho la bicicleta // y se daba unas pechuginas de bicletas y eso / pero ya lo / lo ha dejado / sea puesto más / más gordito / y ahora cuando coge la bicicleta / le cuesta trabajo... se ha dedicado a la vida más sedentaria / y ya se ha puesto más rellenito / más cosas / y le cuesta más trabajo...

(801) I: ... y a eliminar líquido / a ver si así pierdo un poquito de / de barriga

Ao longo dessa entrevista, o I faz uso de diversos diminutivos em sua fala, no entanto entendemos os mesmos como uma forma carinhosa de se expressar e não com o objetivo de fazer qualquer tipo de atenuação. Diferentemente do que ocorre nos dois trechos apresentados acima. No primeiro caso, o I se refere ao filho e para atenuar o adjetivo gordo faz uso do advérbio más e do diminutivo de gordo, a outra forma encontrada para atenuar o mesmo adjetivo é o uso de outro adjetivo, também no diminutivo, porém com um caráter mais informal. Esse adjetivo também é precedido do advérbio más.

Na segunda ocorrência, a face em questão é a do próprio I, também referindo-se ao excesso de peso. Nesse caso, a opção foi apenas pelo uso do adjetivo poco no diminutivo, atenuando o substantivo barriga.

\subsubsection{Expressão de opinião}

Conforme mencionado ao longo das análises das amostras de nível médio, as expressões de opinião aparecem ao longo de toda a entrevista, de acordo com a necessidade do tema, diferentemente do que ocorre no corpus brasileiro em que há uma pergunta específica para esse tipo de resposta. Abaixo apresentaremos os trechos em que tais opiniões são mencionadas, todos encontrados na fala do I.

(02) ... como yo digo / a mí Vélez es un pueblo que no me gusta

(563) ¡yo creo que sí! / que ¡vamos! / tendría muy mala suerte si no / si no ascendiera a primera división / porque está jugando muy bien / va el primero / le lleva cuatro o cinco / cinco puntos al cuarto / ¡seis puntos al cuarto! / o sea que / que yo creo sí ascenderá

(576) ¡yo ya no lo sé! // yo como ha quedado este año / la gente ha quedado muy desencantada de del Unicaja... ¡yo creo que sí! / que las / las cinco o las seis mil personas sí irán al baloncesto

(832) y dárselo a Cáritaso/ o sea a través de Cáritas / a través una asociación así / ¡al Ayuntamiento no! / ¡el Ayuntamiento es un es un liante! / Cáritas o / o alguna ONG...

Observa-se que são poucas as ocorrências de expressão de opinião por parte do I. Em apenas duas delas linhas 563 e 576 - há o uso do verbo creer que, em ambos os casos, está sendo usado para expressar opinião, não demonstrando dúvida por parte do E. No caso do excerto presente na linha 576 , além de sua opinião, há o uso da $3^{a}$ pessoa, o qual 
evita uma referência direta a sua pessoa e demonstra que outras pessoas, não especificadas, compartilham da mesma opinião.

Já na primeira ocorrência apresentada - linha 02, há a opinião do I sobre a cidade onde nasceu, observa-se que não há uso de atenuantes para amenizar tal afirmação. Entendemos que a convicção do I é bastante forte, o que faz com que não seja necessário o uso de tal recurso.

Por fim, a última ocorrência sobre esse tema refere-se ao que o I faria se ganhasse na loteria - linha 832. Sem utilizar qualquer tipo de atenuação ele faz críticas ao governo, dizendo que esse dinheiro seria doado para alguma instituição mais séria.

Como já observado, é alto o índice de ocorrências em que o E expõe sua opinião e tece comentários ao longo do diálogo. Interpretamos tal postura como benéfica para a fluidez da entrevista, pois com isso, aumenta-se a interação entre os participantes. Ressaltamos que, embora reconheçamos a importância dessas ocorrências, optamos por analisar somente a fala do I.

\subsubsection{Invasão de território pessoal}

Além das ocorrências apresentadas, encontramos nessa entrevista um caso de invasão do território pessoal do I:

(77) pero tú ya tenías novia ¿no? / que me has contado

Observa-se que a E utilizou a própria fala do I para a elaboração dessa pergunta. Consideramo-la como uma invasão de privacidade, pois além de ser algo bastante pessoal da vida do I, surge como um tom crítica, pois é elaborada após ele contar sobre as festinhas que ele e os amigos faziam na adolescência, das meninas que frequentavam tais festas.

O I se explicou, dizendo que ainda não era namorado de sua esposa, dando justificativas sobre a idade que tinha, etc.

\subsubsection{Formas de tratamento}

O tratamento utilizado pelo entrevistador para se dirigir ao informante é informal, representado pela segunda pessoa do singular. Abaixo apresentamos alguns exemplos.

(01) Entonces tú / tú tampoco eres de Málaga ¿no?

(150) os administrabais bien ¿no?

(338) estáis muy bien organizados ¿no?

(411) y te apoyas en material

(429) y las diapositivas / también vosotros

(820) y si os / a ti te tocase la lotería 
Por meio dos exemplos apresentados, é possível comprovar que o tratamento utilizado para se dirigir ao informante é a forma tú, acompanhada do verbo na segunda pessoa do singular. Além do pronome pessoal, há ocorrências do pronome oblíquo, também na segunda pessoa do singular, estabelecendo concordância entre ambos. Não há casos de uso do pronome possessivo. Apesar da idade do informante e também da profissão, que possibilitariam o uso de usted, a forma de tratamento dessa amostra está no eixo de solidariedade.

Quando o entrevistador se refere ao informante e outras pessoas, como os médicos que fazem parte de sua equipe ou a sua família, utiliza o pronome vosotros. Como já foi observado ao longo da análise do nível médio, esse uso aponta a diversidade pronominal existente na região onde se encontra a cidade de Málaga.

Ainda que esse não seja o foco de nosso estudo, apresentaremos os dados obtidos na análise comparativa a fim de se verificar essas ocorrências em todas as amostras.

Não há ocorrências de uso de formas nominais.

\subsection{Amostra 59}

Informante feminino - 53 anos

Entrevistador feminino - 28 anos

Tema 1 - Málaga, família e colégio

\begin{tabular}{|c|c|c|}
\hline Perguntas principais & Perguntas secundárias & $\begin{array}{c}\text { Comentários / opiniões / } \\
\text { marcadores de } \\
\text { interação }\end{array}$ \\
\hline $\begin{array}{l}\text { (18) ¿y la familia de tu madre es de } \\
\text { Málaga capital? } \\
\text { (29) tu familia entonces es de } \\
\text { maestros / tu madre tus tías } \\
\text { (69) ¿se casaron antes? } \\
\text { (81) ¿y cómo se conocieron tu } \\
\text { padre y tu madre? } \\
\text { (85) ¿y sois muchos hermanos? } \\
\text { (100) pero tú estudiaste en Málaga } \\
\text { ¿no? } \\
\text { (114) pero tu adolescencia la } \\
\text { pasaste en meli / en Melilla ¿no? / } \\
\text { con mi madre } \\
\text { (117) ¿qué recuerdos tienes? } \\
\text { (159) y Melilla es era una ciudad } \\
\text { bonita ¿no? } \\
\text { (192) y el / y ¿qué recuerdos tienes } \\
\text { del instituto / de / o del colegio allí? } \\
\text { (225) ¿entonces } \\
\text { estudiabais por las mañanas? } \\
\text { (256) ¿y los fines de semana? } \\
\text { (272) y ¿qué tipo de vida hacíais? }\end{array}$ & $\begin{array}{l}\text { (43) y ¿tu madre trabaja allí en } \\
\text { Nador? } \\
\text { (109) ¿para qué? } \\
(128) \text { ¿qué edad tendríais ahí? } \\
\text { (149) y erais /tú / o sea } \\
\text { (218) y ponían a los chicos / a los } \\
\text { chicos por las mañanas y } \\
\text { (228) ¿qué horario teníais? } \\
\text { (232) y después a casa } \\
\text { (274) ¿vivíais en el centro? }\end{array}$ & $\begin{array}{l}\text { (55) ¿sí? } \\
(65) \text { ¡ah! / itu padre } \\
\text { también! } \\
\text { (71) ¿sí? } \\
\text { (87) vosotros } \\
(89) \text { ¿sí? } \\
(91) \text { ¡ah! / ¡tú tienes una } \\
\text { hermana también! } \\
(93) \text { y dos / dos hermanos } \\
(209) \text { ¡ah! } \\
(235) \text { ¡ah! } \\
(251) \text { i y eran las que más } \\
\text { tiempo estaban! } \\
(254) \text { ¿sí? } \\
\text { (270) ¡y en verano para acá! } \\
(303) \text { sí }\end{array}$ \\
\hline
\end{tabular}


Tema 2 - El tranvía

\begin{tabular}{|c|c|c|}
\hline Perguntas principais & Perguntas secundárias & $\begin{array}{l}\text { Comentários / opiniões / } \\
\text { marcadores de interação }\end{array}$ \\
\hline $\begin{array}{l}\text { (307) ime tienes que hablar de } \\
\text { eso! } \\
\text { (320) ¿mixtos cachondeo? } \\
\text { (325) ¿sí? y pero ¿no era } \\
\text { peligroso? } \\
\text { (331) y con la / y / ¿qué me } \\
\text { decías? / ¿que ibais por las noches } \\
\text { también? / ial café a Puerto Rico } \\
\text { en el tranvía? }\end{array}$ & & $\begin{array}{l}\text { (322) ¿sí? } \\
\text { (340) era muy agra / tú no } \\
\text { querías venirte / pero era } \\
\text { agradable }\end{array}$ \\
\hline
\end{tabular}

Tema 3 - Comparação Málaga de antigamente e de hoje

\begin{tabular}{|c|c|c|}
\hline Perguntas principais & Perguntas secundárias & $\begin{array}{l}\text { Comentários / opiniões / } \\
\text { marcadores de } \\
\text { interação }\end{array}$ \\
\hline $\begin{array}{l}\text { (369) pero y ¿hay? ¿tú ves mucha } \\
\text { diferencia en mala o sea en Málaga } \\
\text { / de cuando venías de pequeña a } \\
\text { ahora? } \\
\text { (408) y tú ¿qué entras? / entras muy } \\
\text { temprano a trabajar ¿no? } \\
\text { (434) y y ¿es Málaga? / ¿bueno! Me } \\
\text { imagino que y y ¿era Málaga una } \\
\text { ciudad se segura antes / o era tanto } \\
\text { como }\end{array}$ & $\begin{array}{l}\text { (415) ¿en el mismo centro? } \\
\text { (417) y ¿cómo aparcas? }\end{array}$ & $\begin{array}{l}\text { (396) y el modo de vida } \\
\text { también } \\
(401) \text { ¡sí! } \\
(410) \text { ¿sí? } \\
(419) \text { jbueno! / ¡claro! } \\
(422) \text { iclaro! / es que si te } \\
\text { vas muy temprano } \\
(428) \text { sí! / y no tardas nada } \\
\text { en ir / ¡a esa hora no hay } \\
\text { tráfico! }\end{array}$ \\
\hline
\end{tabular}

Tema 4 - Televisão

\begin{tabular}{|c|c|c|}
\hline Perguntas principais & Perguntas secundárias & $\begin{array}{l}\text { Comentários / opiniões / } \\
\text { marcadores de interação }\end{array}$ \\
\hline $\begin{array}{l}\text { (507) ¿no leíste el otro día / no sé } \\
\text { si / es que leí un artículo de los sin } \\
\text { tele }\end{array}$ & $\begin{array}{l}\text { (509) un grupo de / ¡no un grupo de } \\
\text { gente! / son } \\
\text { (511) varias personas que no tienen } \\
\text { tele en su casa } \\
\text { (513) y decían que todos habían } \\
\text { ganado en horas de } \\
\text { (515) de trabajo de tiempo }\end{array}$ & $\begin{array}{l}\text { (460) ¡es que es una locura!/ } \\
\text { todo el mundo tiene tener } \\
\text { (499) y eso también hace } \\
\text { perder mucho tiempo ¿no? } \\
\text { Porque } \\
\text { (531) isí! ¡bueno! / en } \\
\text { cuestión de diez o quin } \\
\text { quince años ¿no? } \\
\text { (536) una máquina } \\
\text { (538) ¿de escribir? }\end{array}$ \\
\hline
\end{tabular}

Tema 5 - Computador

\begin{tabular}{|c|c|c|}
\hline Perguntas principais & Perguntas secundárias & $\begin{array}{l}\text { Comentários / opiniões / } \\
\text { marcadores de interação }\end{array}$ \\
\hline $\begin{array}{l}\text { (546) y ¿qué manejas? / ¿qué } \\
\text { programa de ordenador manejas? } \\
\text { (595) pero el ordenador es más el } \\
\text { susto que te da ¿no? / que después } \\
\text { cuando te metes / ino es tan } \\
\text { difícil! }\end{array}$ & (612) ¿y no meten gente? & $\begin{array}{l}\text { (557) ¡ah! / ¡menos mal! } \\
\text { (561) isí! pero facilita mucho } \\
\text { el trabajo } \\
\text { (567) quizás da hasta más } \\
\text { trabajo / porque has tenido } \\
\text { (569) que aprender / has } \\
\text { tenido que } \\
\text { (631) jah! / ipues a ver si } \\
\text { mejora la cosa y meten }\end{array}$ \\
\hline
\end{tabular}


Tema 6 - Profissão

\begin{tabular}{|c|c|c|}
\hline Perguntas principais & Perguntas secundárias & $\begin{array}{l}\text { Comentários / opiniões / } \\
\text { marcadores de interação }\end{array}$ \\
\hline $\begin{array}{l}\text { (633) y la carrera la hiciste en } \\
\text { Málaga ¿no? } \\
\text { (645) tu / tu madre seguía } \\
\text { viviendo allí } \\
\text { (649) ¿en dónde estaba? } \\
\text { (704) pero ¿no decían que había } \\
\text { tantos puestos de trabajo? } \\
\text { (731) ¿en qué Ministerio es? } \\
\text { (760) ¿no podíais recuperar el / las } \\
\text { horas perdidas? } \\
\text { (781) o sea que sales ¿sueles salir } \\
\text { a las tres o? }\end{array}$ & $\begin{array}{l}\text { (635) técnico de turismo } \\
\text { (651) ¡ah! / ¿dónde está ahora? } \\
(663) \text { ¡oye! / y los profesores no }\end{array}$ & $\begin{array}{l}\text { (637) técnico / iqué } \\
\text { interesante! } \\
(669) \text { o sea mandabais } \\
\text { compañeros } \\
\text { (723) vivir ¿no? } \\
\text { (754) ¡qué barbaridad! } \\
(756) \text { o sea os controlaban } \\
(771) \text { puedes compensar } \\
\text { después } \\
\text { (786) ¡qué bien! } \\
\text { (788) ¡ah! / ¡entonces tú eres } \\
\text { de las buenas! / tú recuperas } \\
\text { antes }\end{array}$ \\
\hline
\end{tabular}

Tema 7 - Pensão

\begin{tabular}{|c|c|c|}
\hline Perguntas principais & Perguntas secundárias & Comentários / opiniões / \\
\hline $\begin{array}{l}\text { (799) y me dijiste que estuvisteis } \\
\text { en una residencia de monjas ¿no? } \\
\text { (801) ¿cuántos años? } \\
\text { (840) entonces tú en verano / pero } \\
\text { tú en verano entonces / te ibas a } \\
\text { casa de tus abuelos / ¿o te volvías? } \\
\text { (909) ¿estaba abierto entonces el } \\
\text { Cervantes? / el Cervantes }\end{array}$ & $\begin{array}{l}\text { (871) y ¿por dónde } \\
\text { entonces? }\end{array}$ & $\begin{array}{l}\text { (843) ¡ah! ¡claro! } \\
\text { (876) ¡ah! ¡sí? }\end{array}$ \\
\hline
\end{tabular}

Devido aos temas trabalhados, optamos por dividir essa entrevista em sete partes, a fim de facilitar a compreensão do leitor. Como por ser observado em outras amostras, os temas são recorrentes, os quais tratam sobre a cidade de Málaga, a família, os estudos, a profissão, entre outros.

Observando as perguntas principais, podemos afirmar que não há ocorrências de uso de verbo no imperativo, todos os enunciados são diretos, sem tampouco a existência de atos preparatórios, como o uso de verbos no Futuro do Pretérito, por exemplo.

A interação estabelecida entre os participantes ao longo dessa entrevista é significativa, o I é bastante detalhista ao falar dos temas solicitados. Os papéis são bem definidos, no entanto facilmente se observa que o E dá autonomia para o I criar subtópicos ao longo de sua fala. Além disso, o E aproveita a própria fala do I para elaborar novas perguntas, o que comprova o baixo grau de planificação da entrevista. Os temas são mais diversificados do que os encontrados em outras entrevistas, porém são comuns ao cotidiano dos participantes da entrevista, o que facilita a elaboração das perguntas, as respostas imediatas e a interação como um todo. 


\subsubsection{Verbos no Imperativo}

Tratando especificamente dos verbos no imperativo, encontramos uma única ocorrência em que o mesmo é usado fora do contexto interrogativo. Abaixo apresentamos o trecho, seguido de breve análise.

(131) I: ... y ahora tenemos cincuenta y tres ¡con que tú imagínate! / la de años que hace ya que nos conocemos!

(398) I: el modo de vida / tú fíjate esta mañana / yo he salido...

Observamos que os verbos utilizados pelo I é imaginar e fijarse, cujo significado em espanhol é prestar atenção. Pode-se verificar que sua intenção é buscar a interação do E, além de prender sua atenção. Além disso, ao utilizar imagínate, por exemplo, o I cria uma situação que insere o $\mathrm{E}$ no acontecimento descrito. Já o uso do segundo verbo interpretamos como uma forma de fazer com que o interlocutor se atenha ao dado apresentado, no caso as mudanças que ocorreram na cidade nos últimos anos.

\subsubsection{Desfocalização do eu}

Assim, como em outras entrevistas analisadas, foram encontradas diversas ocorrências em que o I busca desfocalizar o eu, não se colocando como sujeito da situação descrita. Abaixo, apresentamos os trechos em que essas situações podem ser observadas, todos presentes na fala do I.

(140) ... y también jeso! y te podías bañar por la mañana y por la tarde pues / ibas a los bailes

(240) ... o sea las cosas no eran como ahora / que están los padres tan encima // tú estudiabas porque sabías que era tu obligación ... y sabías tus horas / tenías toda la mañana / para estudiar...

(354) ... que allí tenías tus / tus amigas de siempre// aquí venías y eran amigas que veías de año / de año en año / en aquellos tiempos que tampoco / no es como ahora / que tú / se va una amiga y le escribes...

(361) ... entonces tú te ibas cuando terminaba el verano y ¡sí! / ¡hombre! A tu familia le escribías / y a lo mejor / a tus amigas pues / en un montón de meses pues le escribías una vez... / ¡no habías llegado cuando ya tenías aquí una carta de tus amigas! / tú estabas contestando las cartas ¡sí! Y era el el / el escribir el día a día / y he visto a fulanito / y he visto / a tal / y / y estuvimos en tal cosa y tú viviendo aquello / que te estabas perdiendo por estar aquí/

(390) ... hacia el centro / y ¡bueno! / y esta parte / o sea la Malagueta y demás / a El Palo / venías también pero no / con / con frecuencia

(423) ¡sí! / a esa hora / ¡aparcas donde quieres! / normalmente

(425) ¡sí! / ¡ahora! / como entres más tarde / ya es el problema / porque la zona...

(453) ... lo de más allá / entonces no vives nada más / ¡para tener! // ¡antes no! / antes tenías / ¡yo qué sé! / lo que tenías y / ite duraba un montón de años y estabas contentísima! / y ahora tienes una televisión pero como ha salido otra mejor...

(470) ... para en vez comprarte unos tenis sin marca / comprártelos que sean Adidas / pero no estás... (475) ...porque estás aquí / y cuando tú llegas a las siete de la tarde a tu casa desde las siete de la mañana que has salido // pues ¡resulta que estás agotado!... aunque seas soltera / aunque no tengas hijos aunque / ¡da igual! / siempre tienes mucho que hacer / y mucha prisa para todo... tanta gente con con problemas / como ahora / los problemas te agobian / te agobian los los problemas los tuyos / los de tus amigos los / los de la gente que no conoces / ¡y encima la televisión te mete los problemas en tu casa!

(500) ... la televisión resulta que mientras la estás viendo no estás haciendo nada / antes pues hacías punto / croché ¡hacías un montón de cosas! // ahora estás ahí y pierdes el tiempo 
(526) ... y si estás acompañada es la pena // porque no hablas tampoco... entonces ¡no sé! / te diviertes más con una charla...

(558) ... y ya cada vez te van metiendo más programas puedes /... o sea ya no te tienes que levantar de tu mesa // para nada porque toda todo te lo van metiendo en el ordenador

(570) ... si no te gusta mucho y son o sea te pilla ya.../ es que son muchas cosas / no es tu / ¡no es tu época! Son muchas cosas / para ir aprendiendo... / a no ser que te / te guste y que te $j$ eso! / o sea hay gente de mi edad...

(586) ¡hombre! / cuando lo dominas pues ya

(587) ¡eso es una maravilla! / ¡claro! Y ya te tranquilizas / lo peor es ¡eso!... iy tú te lo tenías que aprender todo! ... ientonces para ti todo era un mundo! ... que cuando vas cumpliendo los años se va notando

(597) ... que tienes que / ¡que tienes que aprender mucho! / y sobre todo en las / en las edades...

(606)... entonces ¡eso! / pues eso también te angustia / no es decir...

(614) ... y tienes que aprender esos nuevos trabajos... y ahora cuando no tienes que hacer esto... tú ya llegas por las mañanas y dices buenos días y te sientas y te pones /porque si no ahí se te acumula el trabajo / y ya no preguntas y de pronto te acuerdas...y te vas y dices...

(639) ... o sea lo mismo estudiabas contabilidad / que estudiabas estadística / que estudiabas psicología...

(744) ... o sea / tú tenías que entrar/ entonces entrábamos de ocho y media a dos y media // y llegabas a las ocho y media y dos minutos / iy ya te estaban poniendo un punto rojo!... cuando tú veías que te ibas a retrasar un minuto / porque entonces no existían los... sino te pasaban unas listas y tú tenías que firmar... entonces te ponían un puntito rojo... te mandaban una carta diciendo...

(761) ... entonces no porque además no la perdías / o sea que es que tú / como mucho podías a lo / un día / podías llegar ¡eso!... a lo mejor un día llegabas media hora más tarde / pero ¡no!... o sea la perdías / te ponían tu punto y / y te llamaban la atención...

(821) ... tenías que estar / tú si querías comías / si no comías / no tenías que avisarlo...

(824) que estar / no podías llegar a las once ni a las diez y media... porque cerraban el portón y / iy te quedabas en la calle!...

(882) ... pero era un / un local / y te ponía saber escuchar es un arte / o sea y tú no podías cada vez que terminaba uno de cantar tú no / tú decías nada más / pero tú no tocabas las palmas ¿no?...

(897) ... una Coca-Cola / pues te podía costar / seis pesetas ... /eso no podías / ¡eso era mucho!

Como se pode observar, todas as ocorrências presentes na fala do I que contêm esse tipo de estratégia são feitas por meio do uso da segunda pessoa do singular. É interessante observar que ao narrar fatos de sua infância ou adolescência, o informante está se referindo a ele mesmo, porém opta pelo uso desse recurso. Entendemos que é uma forma de dirigir-se também às outras pessoas presentes na situação narrada. $\mathrm{O}$ tempo da lembrança faz com que se construa uma memória comum. O mesmo ocorre em outros momentos, por exemplo, quando ele conta que tem dificuldade em usar o computador (linhas 558-587), notamos que são situações que ocorreram com ele, no entanto, ao referir-se a uma terceira pessoa, envolve todas as pessoas que apresentam a mesma dificuldade, sem especificar quem e também sem assumir sozinho essa dificuldade.

Além disso, entendemos que é uma estratégia de também envolver o interlocutor, aproximando-o do fato, fala-se de maneira geral, referindo-se a uma terceira pessoa que pode ser tanto o falante, o ouvinte ou alguém não presente no momento da enunciação. Esse tipo de estratégia favorece a interação. 


\subsubsection{Prevenção de ameaça à face}

Abaixo apresentamos as ocorrências encontradas de prevenção de ameaça à face, seguidas de breve análise.

(20) I: ... vivieron siempre aquí / pero de pequeños uno era de / Villanueva de Algaida me parece / y mi abuelo sí era...

(118) I: pues ¡nada! / que éramos / seis amigas me parece

(220) I: ... entrábamos me parece que a las tres y salíamos a las nueve / o no recuerdo

(229) I: creo que teníamos de / de tres de la tarde a la nueve o / o a ocho / ¡o por ahí!/ yo recuerdo ¡eso! / que / que era / por la tarde / pero no sé exactamente // el horario

(277) I: ... en principio cuando era pequeña sí / cerca de calle Larios / vivíamos // pero de ahí yo no me acuerdo mucho / y después ya vivíamos...

(319) I: ... entonces comprábamos / mixtos cachondeo / que no sé ahora como se llaman

(329) I: mixtos cachondeo / ¡se llamaban! / ¡yo no sé! / o sea les decíamos / por lo menos / ¡no sé si se llamaban así o no! Y / ¡y nada!

(803) I: ... de las mismas monjas de / ¡de las de Melilla me parece que eran! / ¡no sé! / pero esto...

(832) I: ... o sea tu madre hizo magisterio pero ella no / no hizo / me parece que solo el bachiller y lo dejó en cuarto...

(837) I: ... puso a estudiar magisterio / ¡y nada más! / y tuvo que venir a examinarse / ¡no me acuerdo a / a qué venía!

(867) I: ... tenía / esta señora tenía tres hijos me parece y dos hijas

(880) I: ... ahora no sé si seguirá existiendo y si está en mejores condiciones

É significativo o número de ocorrências que visam proteger a face do informante. Entretanto, observamos que há apenas um tipo de proteção, composta por expressões de dúvida do I. Entendemos que visam fazer uma prevenção de ameaça, pois o protegem de uma possível passagem de dados equivocada e evitam que o $\mathrm{E}$ faça perguntas mais específicas sobre o tema, protegendo também a face do outro.

\subsubsection{Ameaça à face}

Como já exposto anteriormente, devido à natureza de nosso corpus, ocorrências de proteção à face não são muito comuns em entrevistas, porém estão presentes nessa amostra. Abaixo apresentamos os trechos, seguidos de breve análise.

(129) I: pues teníamos / pues doce años tendríamos a / cuando nos conocimos / ¡eso es! / y ahora tenemos cincuenta y tres...

(178) I: ... aquí los coches que había en Málaga eran más corrientes / ¡bueno! eso te estoy hablando de / de hace un montón de años ¿no?

(523) I: ¡ahora no! / ya / voy cumpliendo edad ¡y eso no puede ser!

(599) I: ... ique tienes que aprender mucho! / y sobre todo en las / en las edades / aparte ¡eso! / ¡que a mí no me gusta!

(805) I: ... era una residencia de chicas / y y / ¿qué te iba a decir yo? / ¡eso! / eso estaba en calle Granada...

Observamos que há apenas essas cinco ocorrências em que o I expõe sua própria face, sendo que quatro delas envolvem a questão da idade, tema recorrente quando a entrevista é feita com pessoas acima dos 50 anos. No entanto, ao contrário da maioria, esse I não se preocupa com isso, declarando, inclusive, a idade que possui. Não acreditamos que dizer a idade seja uma ameaça à face, porém quando se trata de 
mulheres, observamos que há certo receio de se apresentar tal dado, por isso o classificamos como exposição.

A penúltima ocorrência, além de voltar à questão da idade do I também expõe o quanto ele não aprecia o uso dos computadores. É uma questão pessoal, porém a interpretamos como uma ameaça a sua face, pois é passível de julgamento por parte do E. É certo que esse julgamento não ocorre explicitamente, já que ao fazê-lo o E poderia colocar em risco o andamento da entrevista.

Já no último trecho apresentado (linha 805) o I se perde no meio de suas histórias e esquece o tema central de sua resposta. No entanto, ele foi bastante rápido e se recordou, não houve a necessidade de o $\mathrm{E}$ fazer qualquer tipo de intervenção para lembrálo ou mudar o tema, como já aconteceu em outra análise do mesmo corpus.

\subsubsection{Atenuantes}

(429) I: a esa hora hay muy poco tráfico / entonces ¡eso! / pues suelo tardar un cuarto de hora o / o si hay un poquito más de tráfico veinte minutos

(918) I: ... que nos costaba más barato / un teatrito pequeño que era el teatro Ara...

Ao longo dessa entrevista, o I faz uso de diversos diminutivos em sua fala, no entanto entendemos os mesmos como uma forma carinhosa de se expressar e não com o objetivo de fazer qualquer tipo de atenuação. Diferentemente do que ocorre nos dois trechos apresentados acima, em que no primeiro o I recorre em um primeiro momento a um advérbio e a um adjetivo para atenuar a palavra tráfico e logo em seguida ao diminutivo do adjetivo seguido do intensificador más.

$\mathrm{Na}$ segunda ocorrência, apenas o uso do diminutivo da palavra teatro não the pareceu suficiente para expressar o tamanho do lugar, houve a necessidade da soma do adjetivo pequeño, criando inclusive um caso de redundância.

\subsubsection{Expressão de opinião}

Conforme mencionamos anteriormente, as expressões de opinião aparecem ao longo de toda a entrevista, de acordo com a necessidade do tema, diferentemente do que ocorre no corpus brasileiro em que há uma pergunta específica para esse tipo de resposta. Abaixo apresentaremos os trechos em que tais opiniões são mencionadas, todos encontrados na fala do I.

(454) ... entonces no vives nada más para / ¡para tener! // ¡antes no! / antes tenías / ¡yo qué sé! / lo que tenías y / ¡te duraba un montón de años y estabas contentísima! / y ahora tienes una televisión pero como ha salido otra mejor joye! / es que / yo quiero la otra ¿no? 
(494) ... yo creo que / que ya que tienes la suerte de poder contactar es para relacionarse ¿no? / no para estar con el rollo de la televisión / a no ser que sea algo muy especial...

(500) la ¿la televisión? / ¡claro! / ¡efectivamente! / la televisión resulta que mientras la estás viendo no estás haciendo nada / antes pues hacías punto / croché / ¡hacías un montón de cosas! // ahora es estás ahí y pierdes el tiempo // y y yo / o sea y me parece muy bien que exista la televisión ¿eh?/ ¡y yo veo televisión! / o sea que / ¡no mucha! Y cada vez menos / pero que me parece muy bien ¿no? / que / ique exista! / pero le veo los / los problemas

(598) ¡bueno! / lo que pasa es ¡eso! / que tienes que / ¡que tienes que aprender mucho! / y sobre todo en la / en las edades / aparte ¡eso! / ¡que a mí no me gusta! / porque yo hay mucha gente de / de mi edad que / que ¡eso!/ que se ve que se meten en los ordenadores y están encantados con los ordenadores / ¡yo no! / ¡ahora podría vivir sin el ordenador ya! /...

Como dissemos anteriormente, o I expõe sua opinião à medida que a conversa flui e necessita. Nessa amostra há poucas ocorrências e observa-se que todas elas são de caráter muito pessoal, visando apenas demonstrar o que o I pensa sobre o tema tratado.

No caso dos exemplos, presentes nas linhas 454, 500 e 598 a opinião é expressa por meio da desfocalização do $e u$, fica claro que aquela é a opinião do I, no entanto a forma como é apresentada enfatiza que é um fato que ocorre com qualquer pessoa.

Há o uso de verbos ou expressões parentéticos ou epistêmicos em apenas duas ocorrências, que no caso não expressam dúvida, mas apenas a opinião do I. Não interpretamos os marcadores conversacionais utilizados como eh ou no como tentativa de convencer o interlocutor sobre a opinião dada.

Não há, nessa entrevista, ocorrências de invasão do território privado do I. Como grande parte do diálogo é sobre temas corriqueiros, não houve a necessidade de o E entrar no âmbito pessoal do I.

Observa-se que a participação do E com comentários e opiniões se dá de maneira muito efetiva, como pode ser comprovado nas tabelas que iniciam esta análise. Entendemos que tais ocorrências contribuem positivamente com a entrevista, pois aumentam a interação entre os participantes e favorece a fluidez do diálogo. Ainda assim, como já mencionado anteriormente, objetivamos analisar apenas as ocorrências encontradas na fala do I.

\subsubsection{Cortesia valorizante}

Com relação à cortesia valorizante, também observamos um único exemplo. (788) E: ¡ah! / ¡entonces tú eres de las buenas! / ¡tú recuperas antes!

Nesse caso o E faz um elogio ao I. É um caso de cortesia valorizante que também aumenta a interação entre os participantes, contribuindo favoravelmente com o andamento da entrevista. 


\subsubsection{Solidariedade}

Há apenas um caso de solidariedade ao longo de toda essa amostra.

(720) I: (...) pues hubiera podido ganar veinte mil pesetas / y meses de verano y tal / que hubiera ganado mucho más / lo único que entonces pensé que no me / compensaba / que yo prefería (723) E: vivir

(724) I: ¡vivir! / ¡exactamente!

O E complementa a fala do I. Consideramos um dado que causa um efeito bastante positivo na entrevista, pois além de aumentar a interação entre os participantes, mantém a fluidez do diálogo.

\subsubsection{Formas de tratamento}

O tratamento utilizado entre o entrevistador e o informante é informal, representado pelo pronome tú, acompanhado do verbo na segunda pessoa do singular. Abaixo apresentamos alguns exemplos encontrados.

(18) ¿y la familia de tu madre es de Málaga capital?

(85) ¿y sois muchos hermanos?

(100) pero tú estudiaste en Málaga ¿no?

(225) ¿entonces vosotras estudiabais por las mañanas?

(422) ¡claro! / es que si te vas muy temprano

Como pode ser observado por meio dos exemplos apresentados, há total concordância entre o pronome pessoal do caso reto, o oblíquo e o possessivo, todos na segunda pessoa do singular.

Nota-se que quando o E se refere ao I e seus amigos, utiliza a forma vosotros, como já observado em análises anteriores. Novamente ressaltamos que esse uso confirma a diversidade pronominal existente na região de Málaga e apresentada ao longo de nossa fundamentação teórica.

Essa entrevista está no eixo de solidariedade e embora a diferença de idade entre os participantes seja considerável, o que possibilitaria o uso de usted, não há registro de uso de formas nominais ao longo desta amostra. 


\subsection{Amostra 60}

$$
\begin{aligned}
& \text { Informante masculino - } 60 \text { anos } \\
& \text { Entrevistador feminino - } 28 \text { anos }
\end{aligned}
$$

\begin{tabular}{|c|c|c|}
\hline Perguntas principais & Perguntas secundárias & $\begin{array}{l}\text { Comentários / opiniões / } \\
\text { marcadores de } \\
\text { interação }\end{array}$ \\
\hline $\begin{array}{l}\text { (10) Entonces ¿tú eres de Málaga? } \\
\text { (14) ¿dónde naciste? } \\
\text { (19) ¿sois una familia grande? } \\
\text { (32) ¿cuántos años te llevas con el } \\
\text { mayor? } \\
\text { (37) ¿y cómo recuerdas los años de } \\
\text { / de la infancia con tanta gente? } \\
\text { (62) y ¿dónde están tus hermanos / } \\
\text { los que están? } \\
\text { (92) ¿claro! Y ¿tus sobrinos trabajan } \\
\text { allí en Brasil? }\end{array}$ & $\begin{array}{l}\text { (12) ¿dónde? } \\
\text { (25) ¿el más pequeño? } \\
\text { (34) ¿sí? } \\
\text { (76) ¡claro! / y ese es el caso / ellos } \\
\text { ¿Qué están? Casados con } \\
\text { brasileñas ¿no? }\end{array}$ & $\begin{array}{l}\text { (30) sí } \\
\text { (47) ¡no! ¡desde luego! } \\
\text { (53) ¡ah! / !muy bien! } \\
\text { (58) ¡ah! ¿sí? } \\
\text { (65) ¡ah! / ¡en Brasil! } \\
\text { (70) ¡claro! / echas de } \\
\text { menos esto ?no? } \\
\text { (112) ¡sí! / ¡ah! ¡está bien! / } \\
\text { ¡está bien! / es importante } \\
\text { que se hayan colo / situado } \\
\text { todo }\end{array}$ \\
\hline
\end{tabular}

Tema 1 - Málaga, família e colégio

\begin{tabular}{|c|c|c|}
\hline Perguntas principais & Perguntas secundárias & $\begin{array}{l}\text { Comentários / opiniões / } \\
\text { marcadores de interação }\end{array}$ \\
\hline $\begin{array}{l}\text { (118) ¡sí! ¡eso es verdad! / y } \\
\text { ¿Brasil entonces lo conocéis? / } \\
\text { ¿habéis ido alguna vez? }\end{array}$ & $\begin{array}{l}\text { (120) y ¿qué tal? / tiene que ser } \\
\text { bonito ?no? } \\
\text { (137) y eso ¿qué es? / ¿cultural? / } \\
\text { ¿mentalidad? } \\
\text { (143) y ¿a qué se dedican entonces? } \\
\text { (155) pero y el empresario tiene } \\
\text { que cubrir }\end{array}$ & $\begin{array}{l}\text { (128) ¿no? } \\
(135) \text { u qué curioso ¿no? } \\
(138) \text { ¡qué raro! } \\
(141) \text { sí } \\
(149) \text { ¡ah! / y ¡claro! / } \\
\text { facilidades de trabajo sin } \\
\text { problema } \\
(164) ¡ a h ! / ~ ¡ m e n o s ~ m a l ! ~ \\
(167) \text { ¡ya ya! } \\
(171) \text { ¡ah! / ¡menos mal! / } \\
\text { porque ¡vamos! / que se te } \\
\text { despida un trabajador / y } \\
\text { ahora cobra ¡cúbrele tú! }\end{array}$ \\
\hline
\end{tabular}

Tema 2 - Brasil

\begin{tabular}{|c|c|c|}
\hline Perguntas principais & Perguntas secundárias & $\begin{array}{c}\text { Comentários / opiniões / } \\
\text { marcadores de } \\
\text { interação } \\
\end{array}$ \\
\hline $\begin{array}{l}\text { (176) ¡ah! ¡menos mal! // ¡bueno! Y } \\
\text { / y ¿cómo era Málaga antes? / ¿qué } \\
\text { recuerdas de / de / Málaga? } \\
\text { (246) eso te iba a decir / ¿cómo se } \\
\text { resuelven? } \\
\text { (273) pero ¿cómo se podría } \\
\text { solucionar? / porque ¡claro! / los } \\
\text { políticos lógicamente } \\
\text { (376) ¡qué pena! // pero ¡vamos!/ } \\
\text { por lo que me dices el / los casos de } \\
\text { riesgo están valorados ¿no? } \\
\text { (381) ¿cómo se valoran? / ¿cómo se } \\
\text { / estima el riesgo? } \\
\text { (431) ¡claro! Y ¿cuáles son los }\end{array}$ & & $\begin{array}{l}(232) \text { ¡claro! } \\
(242) \text { ¡claro! } \\
(288) \text { ya } \\
(300) \text { en discutirlo con } \\
\text { organismos } \\
(307) \text { a lo mejor habiendo } \\
\text { dinero para } \\
(309) \text { ya } \\
(315) \text { ¡claro! } \\
(324) \text { ¡claro! / y en los } \\
\text { países modernos se hace } \\
(340) \text { como el fútbol o un } \\
\text { concierto } \\
(371) \text { ¡claro! }\end{array}$ \\
\hline
\end{tabular}

Tema 3 - Málaga no passado 

$\begin{array}{lll}\text { principales } & \text { factores de riesgo en } \\ \text { Málaga } & \text { entonces? }\end{array}$ inundaciones

(438) ¿en las playas qué riesgo? ¿qué riesgo hay?

(476) las moto las motoras tienen una zona ¿no? Para ir

(501) pero vertidos ¿de qué tipo? ¿de los barcos o?

(521) y la valoración de los / de las infecciones / de las enfermedades infecciosas ¿qué la coges? ¿de los mismos hospitales? / ¿os las dan?// ¿os informan?
(411) sí

(423) ¡claro!

(446) pues iclaro! // todo esto / toda esta actividad / muchas veces / haciendo uso de ellas / personas que cometen muchas imprudencias // y personas que / que haciendo caso omiso / a ciertas ordenanzas municipales / pues ¡claro! / crean un cierto riesgo $\mathrm{y}$ cierta peligrosidad / y entonces ¡claro! Tú tienes que crear por ejemplo en las playas / pues unos servicios que se llaman de seguridad / de vigilancia / y $\mathrm{de} /$ primeros auxilios / y de / y de rescate

(465) ¡qué barbaridad! ¿no? / ¡cada año!

(481) ¡ah! / ¡también!

(483) ¡claro!

(541) ya // hay mucha gente que no hace ni caso $\mathrm{y}$ se sigue bañando

(571) ¡claro! / ¡y no se hace! (591) ¡claro!

(596) ¡claro! // ¡es un mundo!

(604) además con la eficacia / que / que debe tener (613) ¡claro!

(617) ¡claro! ¡efectivamente! / ¡una persona competente en el tema!

(619) entonces

(626) ¡claro!

(640) ¡pues sí!

(662) ya

(674) ¡hombre! ¡por supuesto!

(681) ¡no! / ¡desde luego! / ¡no creo que seas alarmista! / simplemente una persona que conoce lo que

(684) lo que hay en Málaga/ y evidentemente // trabajas en ello // y / cambiando totalmente de

(687) ¡de tema!

(688) ipero muy bien! ¡muy bien! / muy bien/ ¡además muy interesante! (691) ¡sí! / porque ES verdad que yo hay cosas que nunca me había planteado por ejemplo lo de / las 


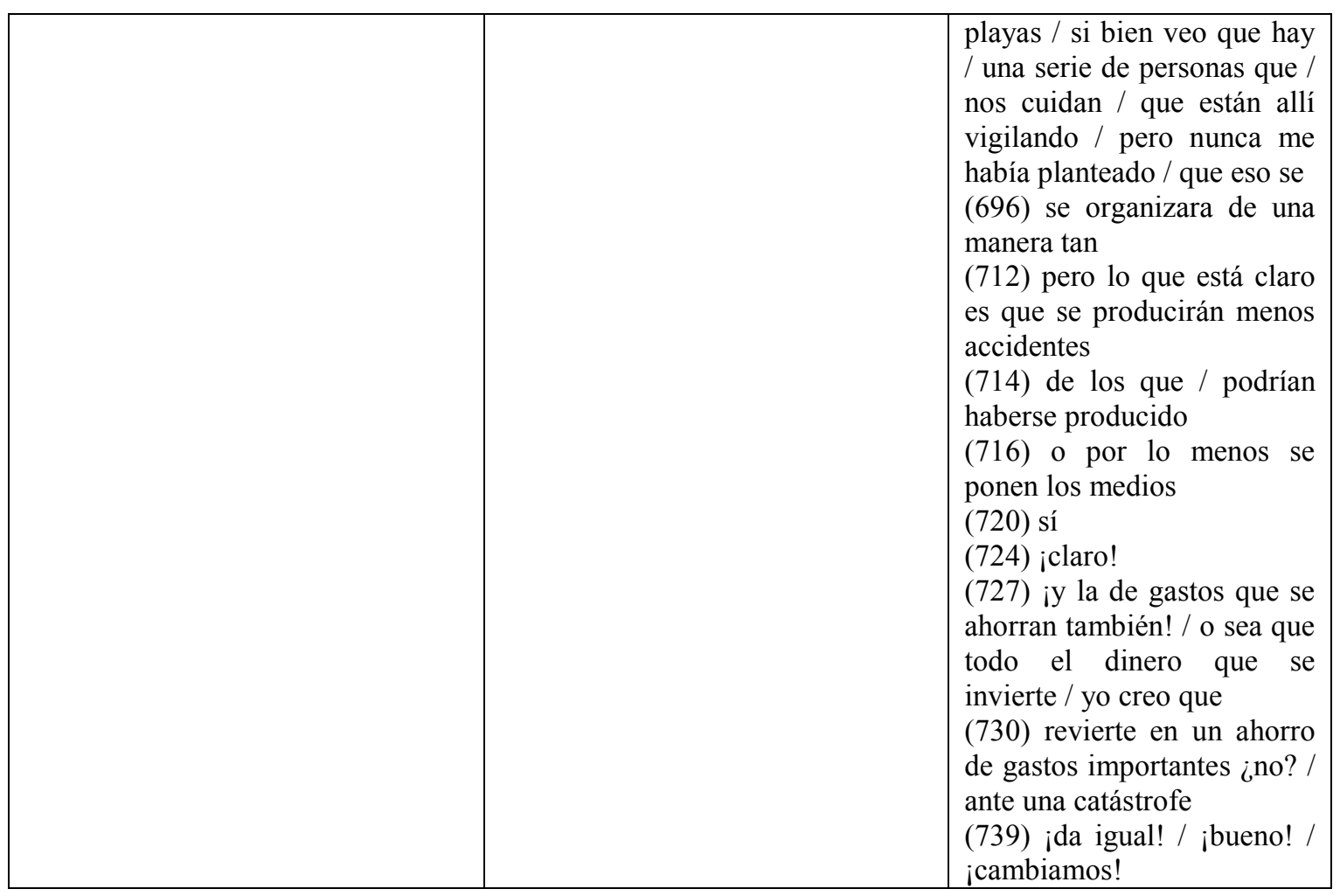

Tema 4 - Loteria

\begin{tabular}{|c|c|c|}
\hline Perguntas principais & Perguntas secundárias & $\begin{array}{l}\text { Comentários / opiniões / } \\
\text { marcadores de interação }\end{array}$ \\
\hline $\begin{array}{l}\text { (742) tú ¿qué harías / si te tocase } \\
\text { la lotería? } \\
\text { (833) y ¿dónde fuisteis de viaje? } \\
\text { (840) ¿en qué año os casasteis? } \\
\text { (901) y ¿de Europa tenéis algún } \\
\text { destino preferido? // del resto / del } \\
\text { resto de Europa }\end{array}$ & $\begin{array}{l}\text { (764) además en un momento } \\
\text { (767) de muchos gastos ¿no? } \\
\text { (849) ¿en vuestro tiempo libre? / } \\
\text { ¿cuándo podéis? } \\
\text { (921) Budapest creo que es } \\
\text { precioso ¿no? }\end{array}$ & $\begin{array}{l}\text { (744) ¡ah! / iqué bien! } \\
\text { (746) ¡ah! / ¿sí? } \\
\text { (826) isí! / al final pierde } \\
\text { dinero / jes cierto! } \\
\text { (831) iy punto! } \\
\text { (836) imuy bien! } \\
\text { (838) iqué bien! } \\
\text { (877) iqué bien! } \\
\text { (880) ino! / la verdad es que } \\
\text { en España tenemos sitios } \\
\text { preciosos y } \\
\text { (882) Palma de Mallorca } \\
\text { (884) tengo entendido que } \\
\text { las playas son } \\
\text { (895) ¿sí? } \\
\text { (898) no te agrada } \\
\text { (909) ese es el riesgo cuando } \\
\text { cuando uno va por ahí } \\
\text { (914) iclaro! } \\
\text { (917) Budapest } \\
\text { (926) juy! / ¡qué envidia! } \\
\text { (929) ia ver si podéis ver } \\
\text { Paris sin lluvia! ¿no? }\end{array}$ \\
\hline
\end{tabular}

Optamos por dividir essa entrevista em quatro partes sendo: a primeira composta por narrativas da infância, da cidade e da família do entrevistado; a segunda por algumas informações sobre o Brasil, país onde vivem dois de seus irmãos, a terceira parte retoma a 
cidade de Málaga e engloba também a profissão do informante e a quarta, encerrando a entrevista, aborda o tema da loteria. São temas bastante abrangentes, sendo que o segundo deles apresenta uma temática relativamente especializada, pois o I trata de diversas questões que envolvem o seu trabalho, despertando o interesse do E, o que o faz participar e interagir a todo momento.

Como já ocorreu em análises anteriores, a divisão apresentada acima foi elaborada por nós, de acordo com os temas propostos ao longo da entrevista. O motivo dessa sistematização já foi apresentado, pois entendemos que deveríamos facilitar a leitura das análises e a aproximação entre os corpora estudados auxiliaria os leitores.

Observando as perguntas principais, podemos afirmar que não há ocorrências de uso de verbo no imperativo, todos os enunciados são diretos, sem tampouco a existência de atos preparatórios como o uso de verbos no Futuro do Pretérito, por exemplo.

A interação estabelecida entre os participantes ao longo dessa entrevista é significativa, o I é bastante detalhista ao falar dos temas solicitados. Os papéis são bem definidos, no entanto facilmente se observa que o $\mathrm{E}$ dá autonomia para o I criar subtópicos ao longo de sua fala. Além disso, o E aproveita a própria fala do I para elaborar novas perguntas, o que comprova o baixo grau de planificação da entrevista. Embora a parte que trata da profissão do I não seja algo tão próximo do cotidiano do E, podemos observar que por se tratar de algo que envolve a cidade onde ele mora e também por ser algo desconhecido pela maioria da população, despertou seu interesse, fazendo com que participasse ativamente do diálogo.

\subsubsection{Verbos no Imperativo}

Tratando especificamente dos verbos no imperativo, encontramos algumas ocorrências em que o mesmo é usado fora do contexto interrogativo. Abaixo apresentamos os trechos, seguidos de breve análise.

(226) mientras que el problema del agua no estuviera resuelto / porque ¡claro! Imagínate lo que son miles de viviendas...

(392) ... ¿cuántas inundaciones hemos tenido en Málaga? / pues ¡mira! / en Málaga prácticamente...

(396) ¡bueno! Y ¿qué daños se han producido? / pues ¡mira! / daños materiales / pues hubo...

(429) pues im/ imagínate que la comparación de riesgo entre Málaga y los Pirineos...

(467) ¿cuáles son los motivos? / pues ¡mira! / el chico que / que no sabe nadar...

(510) imagínate / lo que eso supone en una zona de bañistas...

(736) ... aquello como supone ya tantas pesetas / pues ¡claro! / tú imagínate...

(759) / pues ¡mira! / lo que hice fue / pues / a mí me faltaban tres días...

(910) ¡mira! / cogimos allí / ¡nos pusimos empapados!/... 
Observamos que os verbos utilizados pelo I são mirar e imaginar e pode-se verificar que sua intenção é buscar a interação do E, além de prender sua atenção. Ademais, ao utilizar imagínate, por exemplo, o I cria uma situação que insere o E no acontecimento descrito. Já o uso do mira exerce mais a função de chamar a atenção do interlocutor, de forma que ele não se disperse e se atente aos detalhes narrados.

\subsubsection{Desfocalização do eu}

Assim, como em outras entrevistas analisadas, foram encontradas diversas ocorrências em que o I busca desfocalizar o eu, não se colocando como sujeito da situação descrita. Abaixo, apresentamos os trechos em que essas situações podem ser observadas e na sequência uma breve análise sobre tais ocorrências. Todas as falas abaixo foram encontradas na fala do I.

(68) ... cuando tú estás unos pocos años fuera / pues ¡claro! / tienes siempre la gran ilusión de volver a tu tierra ¿no?

(71) ... ... lo que ocurre es que / si te casas en el extranjero / y / y tu mujer es de allí / pues entonces ¡claro! / eso supone... / y una serie de/ negocios y de situaciones / que en un momento dado es difícil poder coger y hacer la maleta y venirte ¿no?

(80) porque cuando tú dices ¡bueno! / pues mira...

(88) entonces ¡claro! / ese momento te marca una etapa en tu vida / que ciertamente / te hace tomar decisiones de este tipo.

(144) ... como hay ciertamente mucho trabajo / pues ¡claro! / eso te permite / el decir...

(171) E: ¡menos mal! / porque ¡vamos! / que se te despida un trabajador / y ahora cobra ¡cúbrele tú! (194) pues tienes un abastecimiento deficiente...

(197) ... y si quieres tener unos rendimientos buenos / pues tienes que tener un abastecimiento también bueno // si te pasas al tema de saneamiento ocurre igual // si la ciudad crece mucho / y tú no tienes buen sistemade saneamiento... / esas aguas fecales / de alguna forma tú las tienes que / que evacuar

(204) / si tú no tienes por ejemplo depuradora / pues entonces empieza...

(233) pero eso en algunos casos te lo dicen / en otros / todo eso queda / envuelto...

(240) ... todo eso hay que hacerlo en base a que tú puedas / ofrecer también

(321)... aparezca un grupito diciendo que sí o que no ¡no no! ¡mire usted! / esto tiene esta valoración ...

(345) ... al estudiarlo y al hacer un análisis / pues inmediatamente te das cuenta // que ese riesgo se identifica en tu ciu/ en tu ciudad / y que inmediatamente tú tienes que decir / los medios que tienes

(349) y la valoración que le estás dando a aquel riesgo / e inmediatamente sacas la conclusión de decir... / un plan de este tipo como verás / el que tú lo tengas // no guardado en un armario...

(354) ... tú lo puedas aplicar / y no solamente que lo puedas aplicar / sino que en todo momento tú estés viendo / si los medios que tienes / son los adecuados... / pues entonces como verás un plan de estos... / si realmente tú tienes un seguimiento / y tú tienes unas valoraciones adecuadas...

(390) ... lógicamente tienes que manejar / una base de datos...

(407) ... y entonces pues ¡claro! / te dicen / si los daños superan tal índice / pues te dan numerito

(413) ... / pues ese producto / como comprenderás / si tú sacas un diez / en cada componente...

(419) ... si tú estás multiplicando // cero por...

(422) si tienes un cero / ¡pues ya sabes...

(450) ... pues tú tienes que crear por ejemplo...

(485) ... se ponen unas banderitas / y te están diciendo ;oiga usted / que hay peligro...

(491) ... y si en un momento dado no se respetan / aquello te crea serios problemas...

(493) ... eso cuando lo valoras / pues te das cuenta...

(498) o sea tú no debes de permitir...

(500) no debes de permitir

(510) ... lo que eso supone en una zona de bañista / donde tú estás me metiendo...

(534) ... cuando tú tienes una masificación...

(539) ... lo más que te dicen es que esta playa... 
(559) ... a diez metros // ¡bueno! Pues / ¡claro! a diez metros y además te la lanzaba / por la parte baja... / o sea que eso te crea una otitis / te crea una / ¡en fin! / por todos los órganos que te vaya tocando...

(576) eso es igual que cuando tú tienes un salidero / ...

(579) pues muchas veces tienes un salidero importante ... / si tú te encuentras un terreno / que es.../ cuando tú te enteras pues resulta que se... / ... hasta que no te has enterado / pues tú no has / no has podido actuar

(594) ... no ves el daño que aquello tiene...

(602) ... pues que te den la respuesta / que aquello necesita

(606) ... / como comprenderás muchas veces / creo que... / ... sino que si aparece / un servicio o un organismo diciendo / joiga usted! / jesto es necesario! / aquello va a misa y no tiene más discusión / si usted no tiene dinero...

(650) ... puede ocurrir / que tú no seas capaz de resolver una situación

(653) te ves desbordado // hay unas valoraciones... / y entonces pues te encuentras

(767) ... // te viene bien siempre / pero yo entiendo ... / que te da como digo mucha alegría / pero que no lo debes aprovechar / para que te sirva de referencia...

(779)... es interesante que te toque la lotería también / sobre todo si estás apretado / que te saque de apuros...

(813) pero / si actúas caprichosamente / y dejándote llevar por unas circunstancias... / si las analizas dices tú...

(819) ... / una experiencia / si te toca tres días antes de casarte es buenísimo... / pero luego ya otra referencia no... / si tienes por ejemplo / cincuenta mil números / pues / y tú juegas uno... / opciones a que le toque / y tú tienes una / o sea que está claro...

(827) ... si juegas una vez y te retiras... / pues por lo menos lo puedes contar...

(896) y entonces ¡claro! / eso ya no te gusta / cuando tú ves / esa masificación y esas cosas / no te / no te agrada ¿no?

(899) uno lo que quiere siempre es / ¡eso! / ¡estar un poquito más en contacto con la naturaleza!

(909) ese es el riesgo cuando cuando uno va por ahí

(930) ... porque / cuando tú vas por ahí...

(936) ... que cuando sales lo que de verdad vale / es el desplazarte al sitio donde vas ¿no?

(939) entonces que no puedas aprovechar el tiempo... que luego digas ;ay! / iqué lástima!...

Como se pode observar, todas as ocorrências presentes na fala do I em que se busca desfocalizar o eu há o uso da segunda pessoa do singular. Entendemos que o uso excessivo desse recurso é uma estratégia de inserção do interlocutor em sua conversa. É uma forma bastante gentil de expor suas opiniões e de explicar aquilo que lhe é perguntado, sem se mostrar demasiadamente egocentrista.

Por outro lado, há nessa entrevista algo que deve ser observado. Em dois momentos - linhas 321 e 485 - o I usa o discurso indireto para representar a fala de um funcionário falando com o público e para isso, não usa o tratamento informal de $2^{\mathrm{a}}$ pessoa do singular, mas sim um tratamento formal, representado pelo pronome usted e pelos verbos na $3^{\text {a }}$ pessoa do singular. Essas ocorrências demonstram claramente a consciência que os espanhóis têm na distinção do tratamento formal e informal, assunto que também será abordado em nossas análises. No momento em que ele está dialogando com o $\mathrm{E}$, pessoa com a qual ele demonstra apresentar certa liberdade, não só pela pouca idade, mas também pela forma como se tratam durante a entrevista, há apenas o uso do pronome tú seguido pela correta concordância do verbo na $2^{\mathrm{a}}$ pessoa do singular. Porém no momento 
em que vai apenas representar a fala de uma pessoa que em seu local de trabalho fala com um desconhecido, usa a $3^{\text {a }}$ pessoa do singular e seu respectivo pronome.

Observamos também em duas ocorrências o uso da partícula uno para desfocalizar o "eu", no entanto acreditamos que o uso de uno por tú é opção do falante, pois ambos exercem a função de indeterminar o sujeito, referindo-se a uma terceira pessoa, ficando sempre a dúvida sobre a quem o falante se dirige especificamente.

Outro dado que deve ser analisado, ainda tratando da desfocalização, é o fato de o E também fazer uso desse recurso - linhas 171 e 909 - porém nesse caso, entendemos que faz parte de sua estratégia de interação; ao usar o mesmo tipo de linguagem que seu interlocutor aumenta, consequentemente, a aproximação entre ambos.

\subsubsection{Prevenção de ameaça à face}

Abaixo apresentamos as ocorrências de prevenção à face, seguidas de breve análise.

(549) I: yo recuerdo / hace unos pocos años / cuando estaba / Torremolinos integrado al Ayuntamiento de Málaga // pues concretamente en El Bajondillo / había un emisario submarino / el emisario ya sabe que es / pues sencillamente arqueta de recogida de agua / y esta arqueta pues // recogía todo el agua del saneamiento de la barriada...

(668) I: ¡en fin! // no quiero que mi / que estas palabras mías / puedan catalogarme de persona / alarmista / en cuanto a situaciones...

(681) E: ¡no! / ¡desde luego! / ¡no creo que seas alarmista! / simplemente una persona que conoce lo que

(855) I: este año por ejemplo lo hicimos más tranquilos porque lo que es cierto es que / aunque todavía so ¡pues somos jóvenes! / estamos en el grupo ese / pero ¡vamos! Que // que el extranjero causa cierto respeto siempre / ¿eh?

Há apenas essas três ocorrências ao longo de toda a entrevista. No primeiro caso, nota-se certa preocupação do I em proteger a face do E. Observa-se que ele não pergunta se o E sabe ou não o que é um emissário, simplesmente faz a explicação. Já no segundo exemplo, podemos comprovar que o I é bastante seguro naquilo que conta sobre seu trabalho e realmente demonstra certa preocupação em ameaçar sua face ao expor suas ideias. O E cumpre seu papel de mediador e esclarece que não há motivo para preocuparse, justificando que compreende que ele realmente tem conhecimento dos problemas apresentados. Entendemos que essas palavras do I são uma forma de prevenção de ameaça a sua própria face, uma vez que ele poderia simplesmente não explicitá-las, sem a preocupação de parecer ou não uma pessoa alarmista. Por fim, no terceiro exemplo, há a preocupação com a sua face e de sua esposa, deixando claro que ainda que façam viagens 
em grupos, são pessoas jovens. Dessa forma, ele evita qualquer tipo de julgamento de seu interlocutor sobre a sua idade.

\subsubsection{Ameaça à face}

Ainda que não sejam comuns, devido à natureza de nosso corpus, identificamos ocorrências de ameaça ou exposição da face. Abaixo apresentamos os exemplos, seguidos de breve análise.

(670) I: ... todo esto lo digo bajo la experiencia / de llevar pues muchos años en temas municipales

(673) I: y de conocer la ciudad / pues con cierto detalle ¿eh?

(675) I: porque / yo ahora mismo estoy aquí / en / en el gabinete este técnico de protección civil / pero antes he sido / el jefe del Servicio de Agua del Ayuntamiento de Málaga / y he estado también en la / en Proyectos y Obras de la Gerencia de Urbanismo

(680) I: entonces ¡claro! / esto me ha dado / unos conocimientos amplios de la ciudad / ¿eh?

(737) I: perdona un instante no sé ipor dónde iba!

(738) E: ¡da igual! / ¡bueno! / ¡cambiamos!

(829) I: ¡ahora! / si juegas una vez y te retiras / como me pasó a mí / pues por lo menos lo puedes contar y decir ¡no no! / yo he ganado a la lotería / y además tengo la sensatez suficiente para decir que juego por Navidad / ¡pero ya está!

Observamos que há dois tipos de exposição à face do I nos trechos apresentados acima. O primeiro e o terceiro podem ser caracterizados como falta de modéstia do mesmo, pois ele se autoelogia, na primeira parte apresentando todo seu conhecimento sobre a cidade e na última, tratando de suas características psicológicas - ser uma pessoa sensata. Nota-se que não há preocupação por parte do falante com relação ao julgamento que o seu interlocutor possa fazer sobre essas declarações, diferentemente do que ocorreu no trecho apresentado anteriormente - linha 668.

Já no segundo trecho apresentado, observamos que a ameaça à face ocorre para os dois falantes envolvidos no diálogo e a nosso ver, ameaçando mais a face do $\mathrm{E}$ do que do I, uma vez que o seu papel pré-definido pela entrevista era o de condução da mesma. A face do I não foi prejudicada porque houve a mudança do tema, no entanto isso demonstra que o E não estava atento o suficiente para lembrá-lo qual assunto estava sendo tratado.

\subsubsection{Atenuantes}

Identificamos também ocorrências em que há uso de atenuantes.

(48) I: y con un nivel pues buenecito / en cuanto a que / ¡bueno! / tanto mis hermanos como mis sobrinos y toda la familia / pues todos están bien situados 
(760) I: ... a mí me faltaban tres días para casarme // y entonces lo que hice fue modificar un poquillo el / el viaje que teníamos previsto y tal // y / iy ya está! / y comprar algunas cosillas y tal / y regalos a la familia...

(852) I: pues aprovechamos y hacemos un viajecito

(875) I: ... Mabel que padece un poco de / de dolores reumáticos allí le dieron unos masajes y tal / y allí se pueso estupendamente

(891) I: ... ahí estaba el Bahía Palace / un poquito modificado tal / pero estaba allí...

(899) I: uno lo que quiere siempre es / ¡eso! / ¡estar un poquito más en contacto con la naturaleza!

Observam-se três tipos de ocorrência: o uso do diminutivo, o uso do adjetivo poco

e o uso do mesmo adjetivo em suas terminações de diminutivo com os sufixos -illo e -ito. Entendemos que a intenção do I sobre tudo nos primeiros quatro exemplos é mitigar a força de seus enunciados, inclusive para mostrar-se modesto com o conteúdo dos mesmos. No trecho em que cita o problema da esposa, entendemos que a intenção é contrária, pois visa atenuar a intensidade da doença, o mesmo ocorre no penúltimo trecho, em que há também a atenuação das modificações que o hotel sofreu.

\subsubsection{Expressão de opinião}

Conforme mencionamos anteriormente, as expressões de opinião aparecem ao longo de toda a entrevista, de acordo com a necessidade do tema. Abaixo apresentaremos os trechos em que tais opiniões são mencionadas. Ressaltamos que todos foram retirados da fala do I.

(121) ¡bueno! / Brasil ya sabes que es un país / grandioso // que todavía tiene / buena parte por / por urbanizar / con una gran selva y una ciudad pues / ¡bueno! ¡una ciudad no! / una nación que ciertamente merece la pena y con un futuro enorme ¿no?

Incalculable lo que allí / la riqueza que ellos tienen // pero ¡vamos! / también hay muchas dificultades porque es un pueblo que / que no trabaja mucho

(260) y entonces / esos planes que son directores / pues vienen / vienen a / a resolver pues muchas cuestiones / ¡ahora! Lo que sí es lamentable también / es que sacar un plan adelante / pues aparezcan ocho o diez años de discusión del plan / cuando realmente las necesidades son / evidentes / y muy claras...

(270) pero ¡vamos! / que todo esto / toda esta demanda / realmente como digo tendría que tener una diligencia / mucho / más distinta que la que / en este momento hay ¿eh?

(285)... pues creo que en ese tema no hay ningún organismo que pueda tener / más elementos de juicio / ni más análisis / de cuál es la situación para poder hacer una propuesta en el sentido positivo o negativo

(301)... se/ se pierde mucho tiempo ¡y no solamente eso! / sino que muchas veces no se lleva a feliz término / porque intervienen otras cuestiones // y entonces / esas cuestiones / ipues están ahí! // y y y tienen un peso específico muy alto...

(366) pero ¡claro! // ya te decía antes que esas propuestas si caen en un en un saco roto

(543) entonces ¡claro! / eso pues ciertamente tenía que estar resuelto / y si no se resuelve / pues tomar las medidas de forma tal que / que no tuviéramos luego que lamentar situaciones que

(789) una situación de apuro / pero / en los demás casos yo creo / ibueno! hay gente que se está habituando mucho a estos temas

(794) pero ¡vamos! / que eso es peligroso ¿eh? / eso es un vicio / y como tal vicio yo creo que tenemos que eliminarlo

(807) yo veo que siempre la persona / una cosa importante es que tenga un estado de equilibrio / que todas sus actuaciones pues sean lógicas / y que impere en esa persona un grado de sensatez / y de análisis / de decir ¡no! ¡mira!... y entonces actuar siempre / con esa claridad de ideas 
Observa-se no primeiro excerto apresentado que o I procura fazer uma série de justificativas para depois expor sua opinião sobre o Brasil. Já no caso das linhas 260, 270, 301, 366 e 543 o I dá sua opinião sobre assuntos relacionados ao seu trabalho, por isso há maior domínio e não é necessário o uso de verbos ou expressões parentéticos ou epistêmicos, ainda que nessas opiniões haja críticas severas ao governo. Nas demais ocorrências o uso de tais verbos reforçam que aquela é uma opinião sua e, de certa forma, atenuam o conteúdo das mesmas.

Nota-se que as opiniões expressas pelo I são firmes e com argumentos e explicações, há a prevalência de um saber não compartilhado pelo E.

Além dos trechos mencionados em que o I expõe a sua opinião, observamos outros dois que apresentam a opinião do $\mathrm{E}$.

(465) ¡qué barbaridad! ¿no? / ¡cada año!

(718) iy la de gastos que se ahorran también! / o sea que todo el dinero que se invierte / yo creo que

Entendemos que o fato de o E expor sua opinião ao longo da entrevista demonstra o alto grau de interação entre os participantes, pois se criou o espaço para que ele expusesse suas ideias. Além disso, chama atenção também que ambas as situações ocorreram quando o tema era o trabalho do I e não algo comum na vida dos dois, como, por exemplo, a cidade onde vivem. Embora tais ocorrências tenham importância significativa para a entrevista, optamos por analisar apenas a fala do I.

\subsubsection{Formas de tratamento}

O tratamento utilizado entre o I e o E é informal, representado pelo pronome tú acompanhado do verbo na segunda pessoa do singular. Abaixo apresentamos os exemplos.

(10) Entonces ¿tú eres de Málaga?

(19) ¿sois una familia grande?

(32) ¿cuántos años te llevas con el mayor?

(62) y ¿dónde están tus hermanos / los que están?

(840) ¿en qué año os casasteis?

(849) ¿en vuestro tiempo libre? / ¿cuándo podéis?

Por meio dos exemplos apresentados, observa-se total concordância entre os pronomes de segunda pessoa, tanto os pessoais quanto os possessivos, dado que se repete ao longo de toda a entrevista.

Como já observado em análises anteriores, o E utiliza a segunda pessoa do plural quando se refere ao I e sua família. 
Embora a diferença de idade entre os participantes seja acentuada, essa entrevista está no eixo de solidariedade e não há ocorrências de formas nominais ao longo dessa amostra.

\subsection{Amostra 61}

$$
\begin{aligned}
& \text { Informante masculino - } 59 \text { anos } \\
& \text { Entrevistador feminino }-28 \text { anos }
\end{aligned}
$$

\begin{tabular}{|c|c|c|}
\hline Perguntas principais & Perguntas secundárias & $\begin{array}{l}\text { Comentários / opiniões / } \\
\text { marcadores de interação }\end{array}$ \\
\hline $\begin{array}{l}\text { (03) Entonces ¿tú eres de Málaga? } \\
\text { (05) ¿sí? ¿dónde naciste? / ¿en qué } \\
\text { parte de Málaga? } \\
\text { (11) ¿tus padres son de allí de } \\
\text { Lebrija? } \\
\text { (60) y de pequeño / que te criaste en } \\
\text { Málaga entonces ¿no? } \\
\text { (68) y ¿qué recuerdos tienes de / de } \\
\text { la infancia de Málaga? } \\
\text { (112) ¿eras muy travieso? }\end{array}$ & $\begin{array}{l}\text { (28) entonces itú conoces bien / los } \\
\text { rasgos del andaluz! ¿no? } \\
\text { (91) y ¿qué buenos recuerdos } \\
\text { tienes? } \\
\text { (130) exige bastante ¿verdad? }\end{array}$ & $\begin{array}{l}\text { (09) ¡muy bien! / o sea que te } \\
\text { consideras malagueño } \\
\text { (17) de la e la Andalucía } \\
\text { (19) la Andalucía de la e / yo tuve } \\
\text { una compañera } \\
\text { (21) que ha estudiado ese } \\
\text { triángulo concreto } \\
\text { (24) ha estado haciendo lo mismo } \\
\text { que yo pero en / en en toda esa } \\
\text { zona en ese triángulo } \\
\text { (36) y pero que tienes / porque } \\
\text { para conocer la Andalucía de la e } \\
\text { /e } \\
\text { (42) ¡sí! } \\
\text { (58) ¡sí! / ipero de alguna manera } \\
\text { que te lo han referido! } \\
\text { (62) ¡ah! ¿sí? } \\
\text { (71) ¿sí? } \\
\text { (74) desde los ocho } \\
\text { (78) o del colegio de allí } \\
\text { (80) deportivo / te gustaba } \\
\text { (84) lo malo } \\
\text { (87) ¡claro! Sí si } \\
\text { (101) ¡no! } \\
\text { (103) sí } \\
\text { (105) sí lo sé por referencia } \\
\text { (108) pero que no } \\
\text { (111) recuerdillo de alguno } \\
\text { (119) sí sí / sigue sigue } \\
\text { (122) ¿sí? }\end{array}$ \\
\hline
\end{tabular}

Tema 1 - Málaga, família e colégio

\begin{tabular}{|c|c|c|}
\hline Perguntas principais & Perguntas secundárias & $\begin{array}{l}\text { Comentários / opiniões / } \\
\text { marcadores de interação }\end{array}$ \\
\hline $\begin{array}{l}\text { (149) y ¿la educación sigue siendo } \\
\text { tan estricta en? } \\
\text { (186) iqué curioso! / y y ¿qué tipo } \\
\text { de zona? } \\
(190) \text { porque tú estabas } \\
\text { trabajando en un colegio ¿no? }\end{array}$ & $\begin{array}{l}\text { (160) ¿siete u ocho años? } \\
(188) \text { ¿o de / de colegio? }\end{array}$ & $\begin{array}{l}(140) \text { ¡sí! / si } \\
(151) \text { a lo mejor } \\
(156) \text { ¡eso no lo sabía yo! } \\
(165) \text { ¡podían hacerlo! ¡claro! } \\
(174) \text { ¡sí? } \\
(178) \text { sí } \\
(204) \text { ambos estudios } \\
\text { (216) ¡igual que aquí / ¡ah! / pues } \\
\text { está bien pensado }\end{array}$ \\
\hline
\end{tabular}

Tema 2 - A profissão 


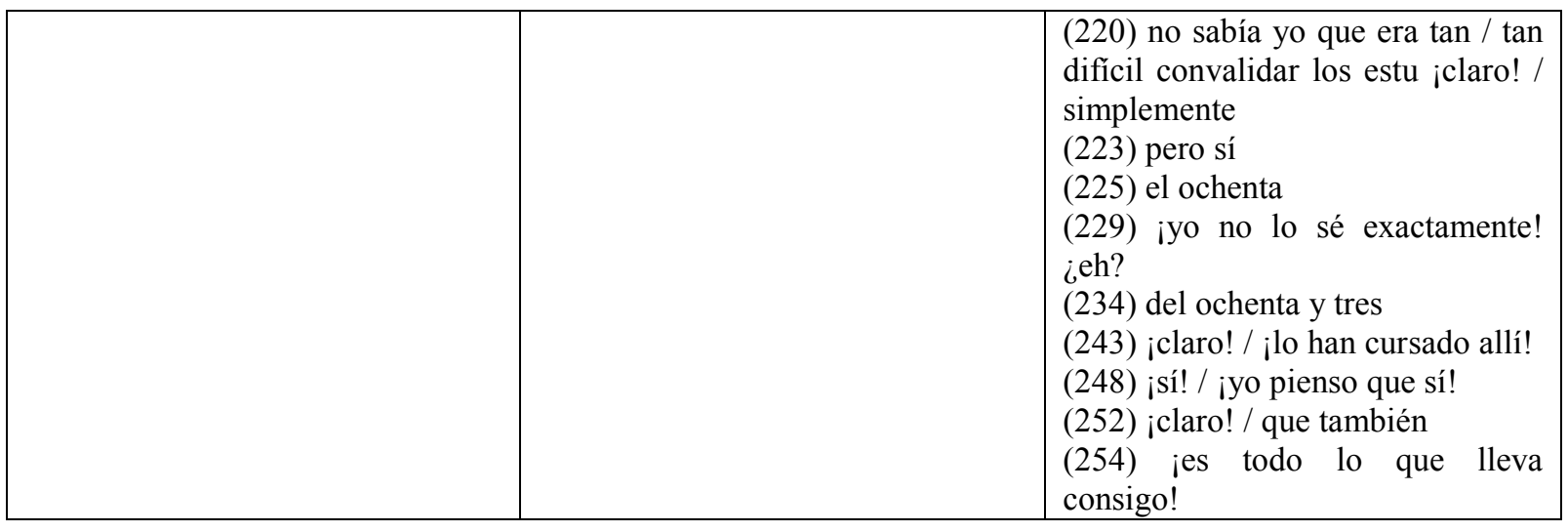

Tema 3 - Família / a educação na Inglaterra

\begin{tabular}{|c|c|c|}
\hline Perguntas principais & Perguntas secundárias & $\begin{array}{l}\text { Comentários / opiniões / } \\
\text { marcadores de interação }\end{array}$ \\
\hline $\begin{array}{l}\text { (264) ¿tienes muchos hijos? } \\
\text { (293) ¿dónde está eso? } \\
(338) \text { sí / y el último año ¿qué } \\
\text { estuviste? / en otro / en otro } \\
(375) \text { y entonces el sistema } \\
\text { educativo allí / es parecido en } \\
\text { realidad ¿no? / menos } \\
\text { (382) y las edades / ¿también las } \\
\text { edades? } \\
\text { (396) y ¿también es obligatorio } \\
\text { hasta los dieciséis años como } \\
\text { ahora? }\end{array}$ & $\begin{array}{l}\text { (290) ¿en qué parte? } \\
\text { (295) ¿al sur? } \\
\text { (347) lo que creo es que hace } \\
\text { mucho frío ¿no? } \\
\text { (350) ¡ah! ¿no? } \\
\text { (354) y anochece muy pronto en } \\
\text { invierno ¿no? } \\
\text { (368) y aprovechasteis para } \\
\text { conocer / todo el país } \\
\text { (370) fuisteis / ¿pudisteis ir a } \\
\text { Irlanda / que dicen que pues nada! } \\
\text { / ipodemos seguir! } \\
\text { (389) secondary bachelors jeso! } \\
\text { (405) pero se ha / ¿se ha hecho } \\
\text { aquí la reforma ya / la FP? / porque } \\
\text { la iban a hacer ¿no? } \\
\text { (411) jmuy mal! ¿no? } \\
\text { (416) puede ser ¿no? } \\
\text { (509) ¿eh? } \\
\text { (549) ¿y qué piensan? } \\
\text { (551) ¿hacer? }\end{array}$ & 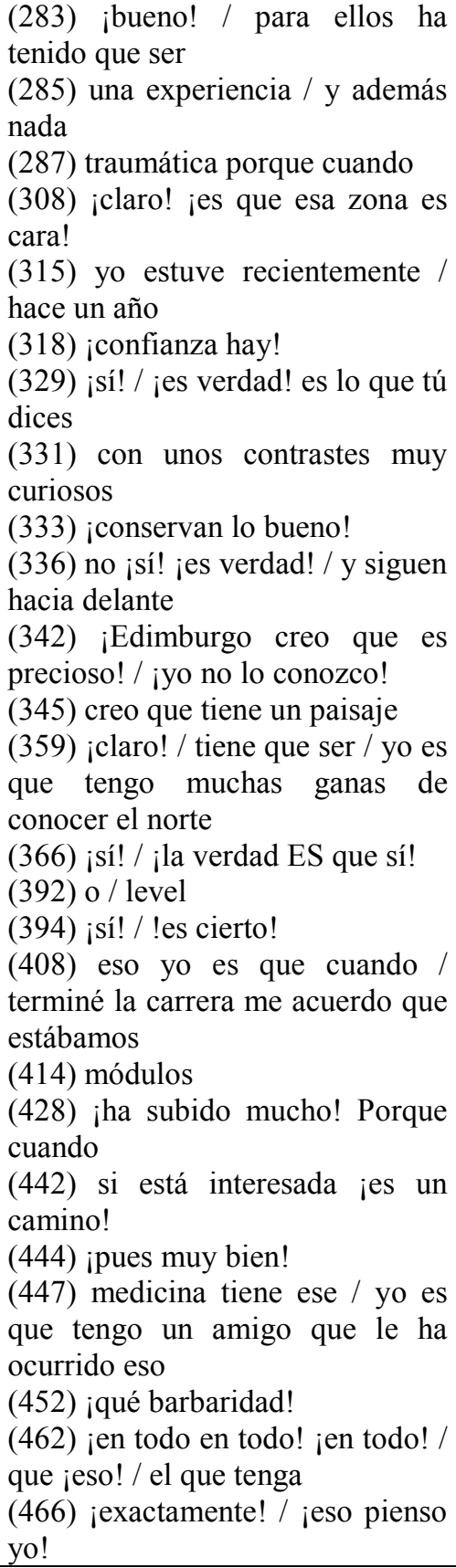 \\
\hline
\end{tabular}




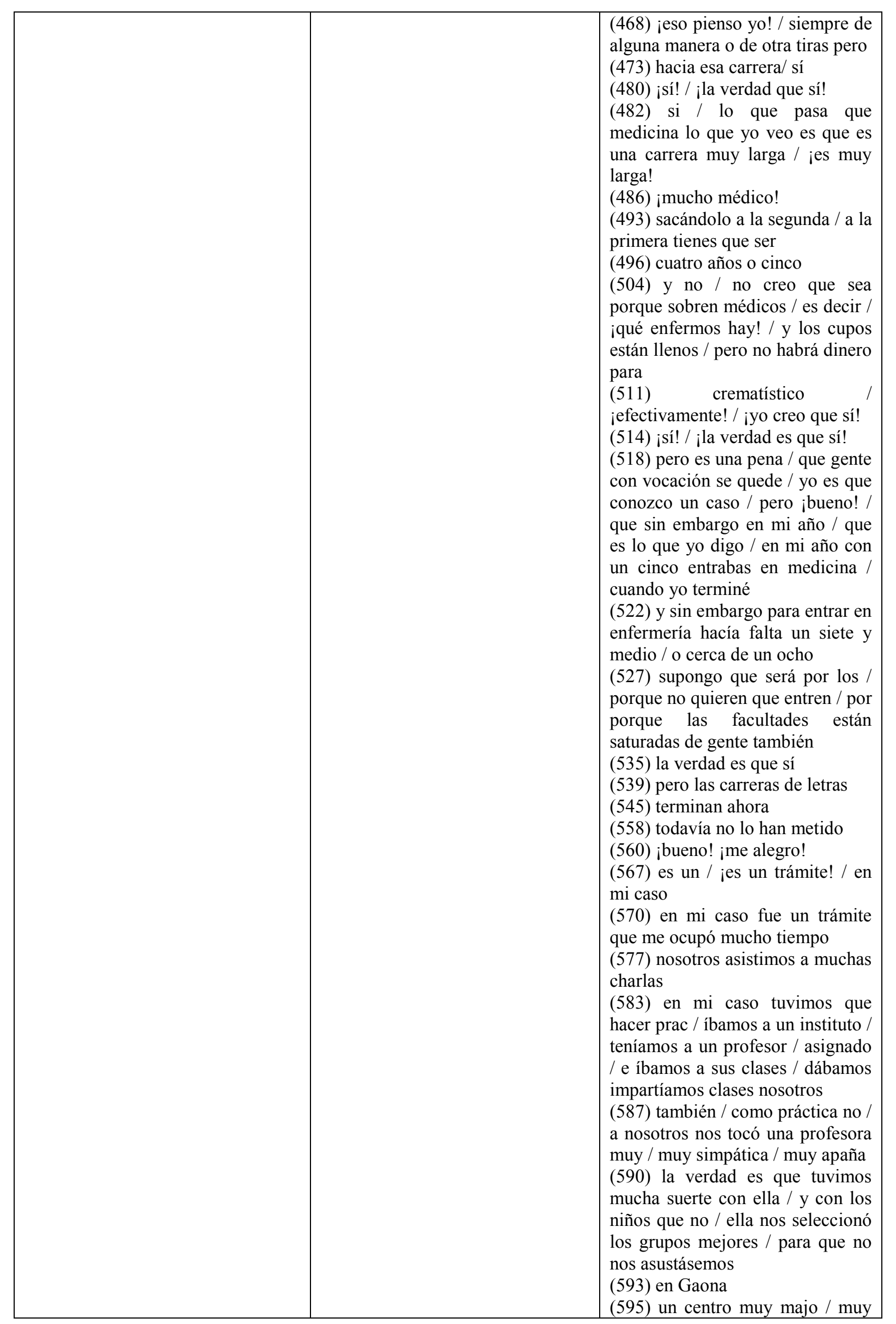




\begin{tabular}{|l|l|}
\hline & $\begin{array}{l}\text { agradable } \\
\text { (598) ja ver si lo dejan bonito! } \\
\text { Porque } \\
(611) \text { pues a mí gatona me gustó / } \\
\text { pero jeso! / jtenían que arreglarlo! } \\
(615) \text { no / yo estudié en en } \\
\text { ibueno! / el COU lo hice en los } \\
\text { maristas// y tengo muy buenos } \\
\text { recuerdos de / de allí / allí conocí } \\
\text { a mi marido / y pero jno! / no } \\
\text { estuve en / en la pública hasta } \\
\text { ieso! / hasta la Facultad }\end{array}$ \\
\hline
\end{tabular}

Tema 4 - Tempo livre

\begin{tabular}{|c|c|c|}
\hline Perguntas principais & Perguntas secundárias & $\begin{array}{l}\text { Comentários / opiniões / } \\
\text { marcadores de interação }\end{array}$ \\
\hline $\begin{array}{l}\text { (619) pero ¡bien! / y a ti en tu } \\
\text { tiempo libre ¿qué te gusta? }\end{array}$ & $\begin{array}{l}\text { (621) isi te queda tiempo libre! } \\
(623) \text { icon cuatro hijos! } \\
(635) \text { ¿qué tipo de? } \\
\text { (648) o sea que te gusta la historia } \\
\text { (650) te / te interesa la historia ¿no? } \\
\text { / parece ser } \\
\text { (683) de Velázquez ¡ah! / ¿pero la } \\
\text { han encontrado? } \\
\text { (697) tres mil y pico ¿no? }\end{array}$ & $\begin{array}{l}\text { (657) pero eso te da más riqueza / } \\
\text { más visión de todo / de todo } \\
\text { (660) no / iyo creo que no! } \\
\text { (674) jsí! jeso es verdad! } \\
\text { (678)empiezas profundizar ¿sabes? } \\
\text { / y acabas como los burros } \\
\text { ¡mirando solo lo que tienes } \\
\text { delante! / iy no miras hacia los } \\
\text { lados! } \\
\text { (691) no / yo creo que no } \\
\text { (701) mis padres la compraron / la } \\
\text { han leído } \\
(703) \text { ¡es gracioso! ¡sí! }\end{array}$ \\
\hline
\end{tabular}

Tema 5 - Educação

\begin{tabular}{|c|c|c|}
\hline Perguntas principais & Perguntas secundárias & $\begin{array}{l}\text { Comentários / opiniões / } \\
\text { marcadores de interação }\end{array}$ \\
\hline $\begin{array}{l}\text { (709) ¿se les facilita a los niños en } \\
\text { la / en la educación pública los } \\
\text { libros o? } \\
\text { (797) es curioso que no llevan } \\
\text { tareas pero itienen tiempo en el } \\
\text { colegio para hacerlas? }\end{array}$ & $\begin{array}{l}\text { (770) y ¿los niños? } \\
\text { (806) sí / se ha notado ¿no? }\end{array}$ & $\begin{array}{l}\text { (718) ¡claro! / ¡es que es verdad! / } \\
\text { que se va } \\
\text { (727) y yo me acuerdo en mis } \\
\text { tiempos / siempre estudiábamos } \\
\text { con los libros de los hermanos } \\
\text { mayores / y yo / y yo eso / yo eso } \\
\text { (730) cambian tanto los } \\
\text { (746) jclaro! } \\
\text { (748) yo recuerdo en mis tiempos } \\
\text { (750) yo recuerdo siempre a la } \\
\text { profesora diciendo / que los que } \\
\text { tengáis de los hermanos mayores } \\
\text { mirad la página tal / es que } \\
\text { cambiaba un poco y el maestro no } \\
\text { se perdía tanto / pero } \\
\text { (754) si te cambia mucho } \\
\text { (757) un tirón de orejas a los } \\
\text { (759)isí! / !efectivamente! } \\
\text { (777) ison niños! } \\
\text { (822) jsí! / lo que pasa es ¡claro! / } \\
\text { que también el padre } \\
\text { (833) a todo } \\
\text { (840) iclaro! } \\
(844) \text { jno! / jtodavía no! }\end{array}$ \\
\hline
\end{tabular}


Tema 6 - Loteria

\begin{tabular}{|c|c|c|}
\hline Perguntas principais & Perguntas secundárias & $\begin{array}{l}\text { Comentários / opiniões / } \\
\text { marcadores de interação }\end{array}$ \\
\hline $\begin{array}{l}\text { (870) ¿y tú qué harías? } \\
\text { (872) ¿tú qué harías si te tocase la } \\
\text { lotería? } \\
\text { (915) y ¿qué fue? / ¿un viaje de } \\
\text { esos que vas parando en donde vas } \\
\text { pudiendo? }\end{array}$ & $\begin{array}{l}\text { (894) comprarías una casa / te irías } \\
\text { a un viajecillo bueno ¿no? } \\
\text { (898) os gusta viajar a los dos } \\
\text { (902) y ella no conoce entonces } \\
\text { Galicia } \\
\text { (904) que os quedasteis hasta allí } \\
\text { (908) Salamanca es }\end{array}$ & $\begin{array}{l}\text { (881) ¡qué bien! } \\
\text { (923) ¡claro! / pero precisamente } \\
\text { por la cercanía muchas veces no / } \\
\text { ¡no vas! }\end{array}$ \\
\hline
\end{tabular}

Ao longo de toda essa entrevista o tema educação foi bastante recorrente. Ainda assim, optamos por dividi-la em seis partes, de forma que isso facilitasse a leitura e a identificação dos trechos mencionados ao longo da análise. Além de educação, tratou-se da cidade de Málaga, da família, do tempo livre do I e também, como finalização, sobre o que o mesmo faria se ganhasse na loteria.

Analisando primeiramente as perguntas principais, podemos observar que são mais frequentes as falas do entrevistador manifestando sua opinião ou interação com o informante do que enunciados interrogativos. No entanto, não há uso de verbos no imperativo, tampouco de atos preparatórios, como o uso de verbos no Futuro do Pretérito, por exemplo. O entrevistador opta por utilizar apenas enunciados diretos.

A interação estabelecida entre os participantes ao longo dessa entrevista é bastante significativa. Ao ler o diálogo, temos a nítida sensação de que tanto I quanto E sabem quais são seus papéis, no entanto não é raro que esses papéis se invertam e o I faça uma pergunta ao E. Acreditamos que isso se deve ao fato de o E falar bastante de sua vida pessoal e também por tratarem, ao longo de quase toda a entrevista, sobre a educação, tema comum tanto na vida do entrevistador quanto do informante.

\subsubsection{Verbos no Imperativo}

Com relação ao uso de verbos no imperativo com a intenção de chamar a atenção do interlocutor, encontramos algumas ocorrências, as quais mencionamos abaixo, seguidas de breve análise.

(92) I: ¡imagínate! / yo tengo cincuenta y nueve años...

(211) I: ... pues ¡mira! / tienen los estudios primarios porque los van haciendo...

(272) I: ... porque han cursado allí seis / ¡seis años! / ¡imagínate! / en la infancia eso es

(488) I: se come / ¡todo la juventud! / tú imagínate una carrera larga / seis años / ...

(641) I: ... es muy interesante ¡imagínate tú! es un diario digo...

(646) I: ... quizás negativa / ¡pues mira! / en directo leerlo me ha / me ha cautivado...

(725) I: ... he tenido que trapichear y ¡bueno! / ¡mira! / ¡ es que si no es un derrame!...

(794) I: ... de las / de // de planetas y de cosas / ¡oye! / ¡pues cogió una información...

(863) I:... pues ¡oye! / con el esfuerzo y esto hay...

(879) I: ... además ¡imagínate!/ dos hijos con filología inglesa / pues les iba yo a facilitar 
Assim como em outras entrevistas analisadas, podemos observar que o I faz uso dos verbos no imperativo com o objetivo de interagir e fazer com que seu interlocutor interaja ao longo do diálogo. Os verbos utilizados são os mesmos já vistos na fala de outros informantes, sendo os mais recorrentes imaginar e mirar. A nosso ver, o primeiro tem a intenção de inserir o ouvinte na história que está sendo contada, enquanto que o segundo visa fazer com que a atenção seja mantida. $\mathrm{O}$ fato de o verbo imaginar estar sempre seguido do pronome oblíquo é o que reforça a nossa ideia, sendo que em uma das vezes há além do pronome oblíquo, o pronome pessoal enfatizando ainda mais o interlocutor.

Observa-se também a presença do verbo oír. O uso desse verbo com o objetivo de chamar a atenção do interlocutor é bastante frequente na língua, sendo usado inclusive com estranhos nas ruas quando se deseja alguma informação, por exemplo.

\subsubsection{Desfocalização do $e u$}

Com relação à desfocalização do $e u$ foram encontradas algumas ocorrências, nas quais, assim como em outras análises, o falante busca a generalização, não se colocando como sujeito da situação descrita. Abaixo, apresentamos os trechos em que essas situações podem ser observadas.

(49) I: y ¡claro! / entonces tú piensas / dices de niño yo me acuerdo aunque vivía en el pueblo de mis padres hasta...

(57) I: simplemente se te retienen las cosas ¡y ya está!

(82) I: ... que yo creo que es que la mente humana es sabia / entonces tú vas quitando las cosas lo malo

(88) I: ... te quedas con lo mejor / ¡barres!

(90) I: tú seleccionas lo bueno / pero no es cierto...

(114) I: ¡pero si es que no / no hacía falta ser travieso! // simplemente con que tú / con que tú la resta decimales / que era muy difícil...

(120) I: entonces eso era / simplemente que noten nada / te cogía / uno me acuerdo que lo agarraba y le / y le zumbaba...

(499) I: pues te metes en los treinta o treinta y dos años ¡yéndote todo muy bien!

(501) I: y luego terminas y desgraciadamente no tienen colocación...

(604) I: ... el ingreso con diez anillos / ¡te asustabas! / para hacer el ingreso tenías quee / que pasar por esos sitios / ¡un respetazo enorme!

(658) I: ¡sí! / tienes que buscarte / ¡sí sí!/ ...

(684) I: ¡bueno! / ¡hablaban! / que decían que tal / ¡bueno! / ante la hipótesis el médico ese que salía...

(807) I: y a veces te sientes / no sabes si / no se sitúa uno bien

(809) I: porque ¡claro! / a veces piensas y dices ¡bueno! / ¡hay que ver lo que ha bajado el nivel!...

(831) I: ... porque hay un día que si tú les estás explicando / no te da y corriges lo que llevan hecho / no te da tiempo a...

(853) I: si tú por ejemplo estudias la comunidad andaluza / y tienes que estudiarte un poco / si estudias el relieve de Andalucía...

Observa-se nessa entrevista dois tipos de desfocalização na fala do I: o uso da segunda pessoa do singular e da terceira pessoa do plural. Entendemos o primeiro caso como uma forma de envolver o interlocutor, inserindo-o no assunto que está sendo 
tratado. Por outro lado, ao utilizar essa estratégia, o falante transfere a experiência que está sendo narrada para o outro, é como se todas as pessoas pensassem da mesma forma e não só ele. A responsabilidade daquilo que está sendo dito é compartilhada por terceiros, sem especificação.

O uso da segunda pessoa do singular é unicamente a transferência de responsabilidade sobre o conteúdo exposto. O falante se exime da autoria, sendo apenas um reprodutor da mensagem.

\subsubsection{Prevenção de ameaça à face}

Abaixo apresentamos os trechos de prevenção de ameaça à face, seguidos de breve análise.

(157) I: si a un niño insubordinado / que ha cometido tenía / y hasta hace pues / si no me falla la memoria puede hacer / siete u ocho años que abolieron eso / o sea que no estamos hablando de

(229) E: ¡yo no lo sé exactamente! ¿eh?

(230) I: ¡yo estaba allí! / a mí me cogió allí en Inglaterra / pues en el ochenta y tantos $i$ no? // ochenta y tres me parece

(316) I: yo tengo mi cierta admiración / digo que son / aquí no se pueden decir palabras fuertes / o por lo menos no se deben

(409) I: están hablando / pero yo no sé exactamente / en qué va la cosa / lo que si sé es que la FP que empezó / ahora mismo está muy

(579) I: ... por lo menos un trimestre me parece que fue de / por las tardes // pero ahora creo que hacen prácticas ¿no?

(680) I: mi hijo hacía un comentario ayer / no sé si viste la televisión / ...

(731) I: ... en los colegios tú sabes / y si no te lo digo yo / nosotros tenemos la obligación de mantener los textos...

(876) I: ... ¡un pico grande lo tengo clarísimo! / tú dirás es que este es un chinflado de Inglaterra / ¡evidentemente!

Observa-se que todas as ocorrências referentes à preservação da face estão na fala do I. Ademais, nem todas têm a mesma intenção. Assim, podemos observar que aquelas que se encontram nas linhas 157, 230, 409 e 579 são utilizadas com o objetivo de preservação tanto da face do I, quanto do E. Ocorrências já observadas em outras análises, nas quais o falante utiliza uma expressão de dúvida, de forma que, se estiver errado, o erro é atenuado por tal expressão. Com isso ele já alerta seu interlocutor que o assunto não pode ser muito estendido, pois não tem total certeza sobre o que diz.

A ocorrência encontrada na linha 316 é bastante atípica e tem o objetivo de proteger sua própria face, pois embora quisesse fazer uso de alguma palavra mais forte, no caso, entendemos que seja um palavrão, ele sabe que não deve. Ressaltamos que o uso desse tipo de vocabulário na Espanha não tem a mesma conotação que no Brasil, pois não é raro que homens e mulheres utilizem os palavrões em seu vocabulário sem que isso seja considerado vulgar. No entanto, é interessante observar que o falante tem 
consciência de que o momento não é o mais oportuno e que outras palavras podem ser utilizadas em substituição.

Os trechos presentes nas linhas 680 e 731 buscam a preservação da face do E, pois o I pretende dar uma informação pressupondo que seu interlocutor tinha conhecimento do assunto, como forma de se prevenir ele usa as expressões no sé si viste e tú sabes / y si no te lo digo yo para continuar a sua fala. Com isso, cria-se liberdade para que o interlocutor faça perguntas, aprofundando-se no assunto, caso não tenha conhecimento do mesmo.

Por fim, a última ocorrência apresentada trata também de uma prevenção de ameaça a sua própria face, em que o falante busca evitar possíveis julgamentos de seu interlocutor. O E não fez comentário algum após essa fala do I, no entanto ele já se precaveu de um possível mal entendido.

\subsubsection{Ameaça à face}

Ainda que não sejam tão comuns, devido à natureza do nosso corpus, há ocorrências de ameaça e exposição da face de um dos participantes. Abaixo apresentamos os trechos, seguidos de breve análise.

(30) ... jahora ya no! / ya creo que ya estoy más torpón y no me fijo / pero antes siempre conocía...

(636) pero no te / no te queda mucho tiempo / no te queda mucho tiempo / ¿qué ibas a decir? ¿qué tipo de lectura?

(724) ... pues yo siempre he trapicheado ¿no? Con ese ¡vale! ¡palabra andaluza! ¿no? / ¡el trapicheo! / he tenido que trapichear y ¡bueno! / ¡mira! / ¡es que si no es un derrame! / ¡un derrame!

São poucos os casos de ameaça à face encontrados ao longo dessa entrevista. Sendo que entre os quatro apresentados, apenas um é referente à fala do E. No caso, o I lhe pergunta quando a Espanha passou a fazer parte do Mercado Comum Europeu e ele foi sincero ao responder. É uma ameaça a sua face por desconhecer um fato importante da história de seu país, no entanto não podemos nos esquecer de que o I também é espanhol.

Já as ocorrências relativas à fala do I apresentam casos diferentes de ameaça à face. Na primeira delas o tema tratado é o fato de ele conhecer bem os traços da fala andaluza e ele usa esse adjetivo pejorativo para falar de si mesmo. Interpretamos esse trecho também como um caso de modéstia, observa-se que ele minimiza suas qualidades frente ao interlocutor.

Já no trecho apresentado na linha 636 houve uma interrupção da fala do E e posteriormente o I retoma, perguntando o que ele ia dizer e imediatamente supondo a pergunta interrompida. Embora a tomada de turno deva ser feita com atenção para não 
interromper a fala do interlocutor, esse tipo de ocorrência é bastante comum na língua falada, em que muitas vezes, para haver tal tomada do turno, é necessário interromper o outro.

Já a última ocorrência apresentada mostra uma ameaça à face do I. A diferença dessa ocorrência para a primeira apresentada é que essa sim tem um peso mais pejorativo, o que pode levar o interlocutor a tecer julgamentos sobre o falante. No entanto, essa preocupação parece não existir, pois é uma informação que poderia ter sido omitida. Acreditamos que o caráter informal e a interação entre os interactuantes foram tão intensos que diminuiu o receio de ameaça à face e de possíveis julgamentos.

\subsubsection{Atenuantes}

Abaixo apresentamos as ocorrências que se referem ao uso de atenuantes, seguidas de breve análise.

(38) I: ¡bueno! / pero es que eso lo sé yo por mera referencia / por ejemplo don Valentín Ayala / uno que / con el que preparé yo las oposiciones de magisterio

(55) I: entonces que no es que yo haya

(57) I: simplemente se te retienen las cosas iy ya está!

(99) I: entonces es / ¡es durillo! / lo que tú / eso lo sabrás ¿o no?

(305) I: ¡muy bonito eso! / una zona / carilla ¿sabes?

(633) I: dar una vueltecilla a veces con mi mujer / la compra o a dar una vueltecilla / ¡lo normal! / ¡la rutina ya! / la rutina / ¡leer! / cuando puedo leo un poquito

(672) I: el / un poquito el saber enciclopédico / ¡yo creo que es bueno!...

Observa-se que esse tipo de ocorrência também só ocorreu na fala do informante e que há diferentes objetivos para o uso de tal estratégia.

Nos dois primeiros trechos, o I busca atenuar seu conhecimento como uma forma de expressar certa modéstia, estratégia cortês já apresentada na fundamentação teórica desse trabalho. Há uma minimização do falante perante o interlocutor de forma que esse não tece possíveis julgamentos. É também uma estratégia de preservação da face.

Já os outros trechos apresentados tratam do uso do diminutivo como estratégia de atenuação, pois como vimos, nem todos os casos de uso desse sufixo tem esse objetivo. No caso das ocorrências encontradas nas linhas 99 e 305 também há essa preocupação com a própria face, tratada anteriormente, pois ele busca minimizar a dificuldade que sente no trabalho como professor e no segundo caso, também um exemplo de modéstia, ele fala da zona onde vivia na Inglaterra, alegando que era um lugar caro de se morar. Entendemos que o uso do diminutivo faz com que a intenção do falante não seja interpretada como arrogância, por exemplo. 
Interpretamos os outros casos como uma característica pessoal do falante, uma forma carinhosa de se expressar e também de diminuir a intensidade daquilo que está sendo expresso. Por exemplo, quando ele diz vueltecilla ele demonstra que não foi um grande passeio, assim como quando diz leo un poquito leva o leitor a interpretação de que fez algum tipo mais leve de leitura.

\subsubsection{Expressão de opinião}

Conforme mencionamos anteriormente, as expressões de opinião aparecem ao longo de toda a entrevista, de acordo com a necessidade do tema. Todas as ocorrências abaixo foram retiradas da fala do I.

(183) yo creo que era mayor indisciplina/ que aquí

(205) ¡hombre! / pensando / yo veo que estaba bien pensado

(244) lo han cursado / han estudiado / ¡hombre! / y a veces mejor / porque son niños que tienen dos idiomas y yo pienso que / a pesar que el bilingüismo ha tenido sus detractores y hay / escritos contrarios / en contra a favor y todo / parece ser que la balanza va en que es positivo / el bilingüismo

(249) es positivo / ¡claro! ¡hombre! / ¡abre la mente! / y es otra cultura / yo creo que amplía el / el panorama la persona más abierta ¿no? / no es solo por la lengua

(255) ¡claro! / ¡exactamente!/ ¡es otro mundo! / es otra vida / otra manera de / de ver el mundo que yo creo que enriquece ¿no?

(319) ... pero un poco cabritos / digo a veces / pero ¡vaya! / pero ¡no! / luego es un pueblo / singular ¿verdad?

(399) aunque yo creo que está mejor enfocado allí en la / lo que llamaríamos FP que aquí

(463) el que tenga una cosa muy definida pienso yo y / y va a algo que te gusta / ¡pues tendrá más posibilidades de / de situarse! ¡digo yo! ¿no?

(710) se les facilita a los que están verdaderamente / muy necesitados aquí en este centro pues / ¡bueno! El ayuntamiento ofrece algunas ayudas y demás / ¡hombre! / el que está verdaderamente...

(735) pero las editoriales no hay que olvidar / ¡hombre! / yo considero que tienen que ganar dinero todo el que tiene algo lo hace por algo pero / ; a veces hacer muchas triquiñuelas! / ¡vamos! / yo te lo digo jy no de oídas! / ni estoy diciendo / ¡lo he vivido! / es decir yo un libro de matemáticas que lo cursó Pablito...

(821) en demasiado / ¡ya yo creo que los agotamos ya demasiado!

Observa-se que com exceção da linha 319 em todas as ocorrências apresentadas há o uso de verbos ou expressões parentéticas ou epistêmicas. Entendemos que o uso de tais expressões não tem a finalidade de demonstrar dúvida, mas sim de expressar a opinião do I, de certa forma o uso de tais verbos atenua a intensidade do conteúdo. Todas elas tratam de temas comuns à vida dele, principalmente no âmbito profissional.

Entre os trechos apresentados, chama-nos atenção a diferença de intensidade de opinião entre o excerto presente na linha 735. A crítica que o I faz às editoras é bastante ríspida, porém muito bem fundamentada, com a justificativa de que ele sabe o que está dizendo, pois viveu tal fato. Já a ocorrência da linha 319 apresenta um modalizador com função atenuadora. Ao utilizar a locução a veces, o I protege sua face de um possível julgamento por parte do E. 
A participação do E com comentários e opiniões também ocorre de forma bastante efetiva. Como já observado em análises anteriores, temos conhecimento da importância de tais ocorrências, sobre tudo para a fluidez do diálogo e interação entre os participantes, porém optamos por não analisá-los, detendo-nos apenas nas ocorrências encontradas na fala do I.

\subsubsection{Solidariedade}

Há nessa entrevista também alguns trechos que demonstram solidariedade entre os falantes. São poucos, porém julgamos conveniente destacá-los:

(224) I: estamos hablando de en E: el ochenta

(345) E: creo que tienen un paisaje

I: ¡de ensueño! / ¡muy bonito muy bonito!

(409) I: están hablando / pero yo no sé exactamente / en qué va la cosa / lo que sí sé es que la FP que empezó / ahora mismo está muy

E: ¡muy mal! ¿no?

Observa-se que esse tipo de ocorrência acontecem tanto na fala do E quanto do I. Entendemos que isso se dá pelo fato de a interação entre os falantes ser alta. Acreditamos que além de favorecer a interação entre os falantes, esse tipo de ocorrência aumenta a fluidez do diálogo.

\subsubsection{Formas de tratamento}

O tratamento utilizado pelo E para se dirigir ao I está no eixo de solidariedade, representado pelo pronome tú. Abaixo apresentamos as ocorrências encontradas, seguidas de breve análise.

(03) Entonces ¿tú eres de Málaga?

(11) ¿tus padres son de allí de Lebrija?

(60) y de pequeño / que te criaste en Málaga entonces ¿no?

(368) y aprovechasteis para conocer / todo el país

(619) pero ¡bien! / y a ti en tu tiempo libre ¿qué te gusta?

(898) os gusta viajar a los dos

Por meio dos exemplos acima, podemos observar a concordância que há entre os pronomes de segunda pessoa do singular, tanto os pessoais quanto o possessivo, comprovando o tratamento informal dispensado ao informante.

Há o uso da segunda pessoa do plural para referir-se ao informante e sua família, no entanto, assim como ocorre na amostra 60, apresentada anteriormente, há apenas os 
verbos na segunda pessoa do plural, o pronome está sempre elíptico. Ao final das análises, elaboraremos um quadro comparativo, a fim de que se possa verificar o uso das formas nominais no corpus de nível superior.

Apesar da diferença de idade, o que motivaria o uso de usted, a entrevista está no eixo de solidariedade e não há ocorrências de uso de formas nominais ao longo dessa amostra.

\subsection{Amostra 65}

$$
\begin{aligned}
& \text { Informante feminino - } 64 \text { anos } \\
& \text { Entrevistador feminino - } 28 \text { anos }
\end{aligned}
$$

\begin{tabular}{|c|c|c|}
\hline Perguntas principais & Perguntas secundárias & $\begin{array}{c}\text { Comentários / opiniões / } \\
\text { marcadores de } \\
\text { interação }\end{array}$ \\
\hline $\begin{array}{l}\text { (02) Tú eres de Málaga ¿no? / ¿tú } \\
\text { eres de Málaga? } \\
\text { (43) ha cambiado en poco tiempo } \\
\text { ¿no? / la Alameda Colón } \\
\text { (61) y al colegio fuisteis juntas ¿no? } \\
\text { (92) y ¿dónde vereneabais? } \\
\text { (94) y ¿el Chorrillo dónde está? } \\
\text { (133) y entonces en Benalmádema } \\
\text { ¿qué? ¿qué } \\
\text { (149) ¡claro! Y / pero allí / pero } \\
\text { ¿ibais a la playa como se va ahora } \\
\text { o? } \\
\text { (158) ¿y en Málaga tampoco? } \\
\text { (162) ¿tu madre era de aquí / de } \\
\text { Málaga? } \\
\text { (182) y ¿Monda por dónde queda? } \\
\text { (196) y el colegio de La } \\
\text { Presentación/ ¿estaba en el centro o } \\
\text { estaba } \\
\text { (210) y ¿del colegio qué recuerdos } \\
\text { tienes? } \\
\text { (380) ¿cómo era el uniforme? } \\
\text { (418) ¡encargada de hacer todo! / y } \\
\text { tú tienes hermanos ¿no? } \\
\text { (600) y ¿qué recuerdos tienes de la } \\
\text { Normal? }\end{array}$ & $\begin{array}{l}\text { (38) y ¿qué eran? ¿edificios? } \\
(86) \text { ¡ah! ¿tus padres? ¿sí? } \\
\text { (97) pero ¿qué está? / ¿por el } \\
\text { pueblo o? } \\
(124) \text { ¿y allí conociste a? } \\
(219) \text { ¿no comías? } \\
(245) \text { ¿y eso era una vez al mes? } \\
\text { (352) y ¡no te ponían de reposo! } \\
\text { (394) ¡claro! / y el de invierno } \\
\text { ¿qué era? / ¿un vestido? } \\
\text { (472) pero sin embargo / vosotras / } \\
\text { o sea tú estudiaste sin ningún } \\
\text { problema / que hay otras mujeres } \\
\text { de entonces que no / no las dejaban } \\
\text { estudiar } \\
\text { (491) y entonces tu madre fue la } \\
\text { que ¿ } \\
\text { (604) ¿sí? ¿dónde? }\end{array}$ & 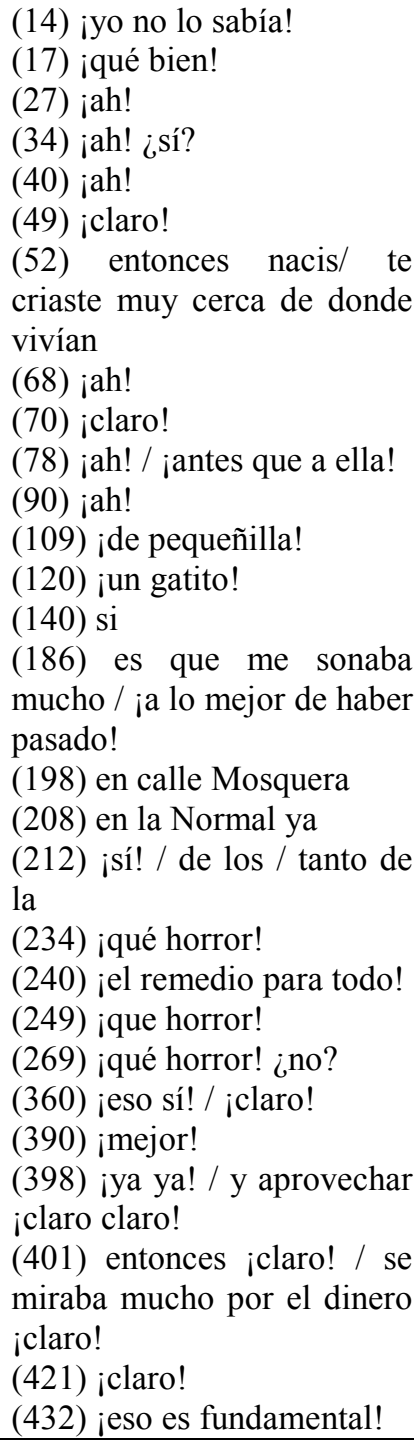 \\
\hline
\end{tabular}

Tema 1 - Málaga, família e colégio 


\begin{tabular}{|l|l|}
\hline & $\begin{array}{l}(505) \text { iqué horror! } \\
(426) \text { o sea que itodo te } \\
\text { tocaba a ti! } \\
(464) \text { jah! ¿sí? jqué bien! } \\
(642) \text { vosotras os lo } \\
\text { currasteis y } \\
(648) \text { isí! / jen dinero no sé! } \\
(651) \text { jclaro! } \\
(666) \text { ioye! } \\
(672) \text { iqué barbaridad! }\end{array}$ \\
\hline
\end{tabular}

Tema 2 - Trabalho

\begin{tabular}{|c|c|c|}
\hline Perguntas principais & Perguntas secundárias & $\begin{array}{l}\text { Comentários / opiniões / } \\
\text { marcadores de interação }\end{array}$ \\
\hline $\begin{array}{l}\text { (675) y después enseguida } \\
\text { empezaste a trabajar? } \\
\text { (695) iya ves! / icuarenta y cuatro } \\
\text { años! / ise dice pronto! / y iestás } \\
\text { muy harta de los niños o no? } \\
\text { (779) itienes niños muy chicos } \\
\text { en? } \\
\text { (802) y ellos iestán toda la } \\
\text { mañana contigo? } \\
\text { (821) pero más cómodo ¡claro! / } \\
\text { porque los viernes }\end{array}$ & $\begin{array}{l}\text { (783) eso son niños muy dinámicos } \\
\text { ¿no? }\end{array}$ & 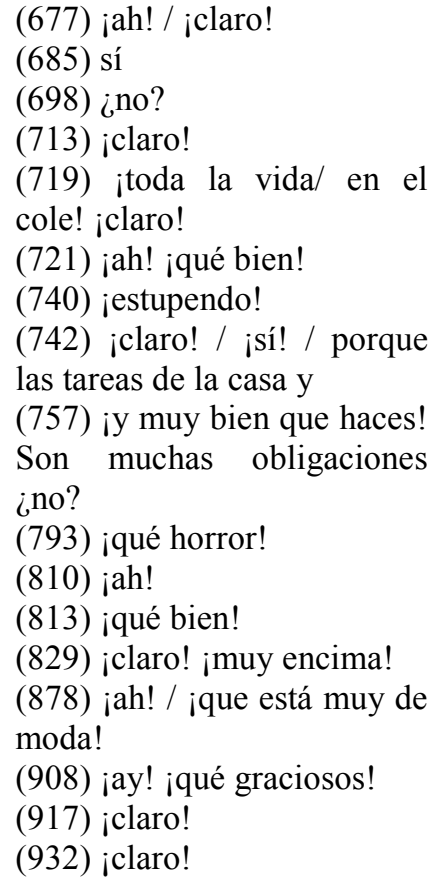 \\
\hline
\end{tabular}

Tema 3 - Loteria

\begin{tabular}{|l|l|l|}
\hline \multicolumn{1}{|c|}{ Perguntas principais } & Perguntas secundárias & $\begin{array}{l}\text { Comentários / opiniões / } \\
\text { marcadores de interaçãa }\end{array}$ \\
\hline $\begin{array}{l}\text { (935) ¿sí? Pues jestupendo! // } \\
\text { ioye! Y ¿tú qué harías si te tocase }\end{array}$ & & $(937)$ ¿no? \\
la lotería? & & $(939)$ ¿sor qué? \\
& & $(880)$ iclaro! \\
& & $(891)$ ¿sí? \\
& & \\
\end{tabular}

Tema 4 - Os estudos

\begin{tabular}{|c|c|c|}
\hline Perguntas principais & Perguntas secundárias & $\begin{array}{l}\text { Comentários / opiniões / } \\
\text { marcadores de interação }\end{array}$ \\
\hline $\begin{array}{l}(1068) \text { ¿te fuiste muy lejos a } \\
\text { trabajar? } \\
(1074) \text { ¿estaba muy lejos de } \\
\text { Málaga? } \\
(1078) \text { ¿tu marido es maestro } \\
\text { también? } \\
\text { (1102) pero ¿cómo se organizaba } \\
\text { eso? / ¿plazas de varones / plazas } \\
\text { de? }\end{array}$ & $\begin{array}{l}\text { (1004) pero sesenta plazas tampoco } \\
\text { son muchas ¿no? } \\
\text { (1085) ¿ibais siempre juntos? } \\
\text { (1155) y ¿qué hicisteis? } \\
\text { (1174) ¡en la Palmilla! / ¿y qué tal } \\
\text { allí? }\end{array}$ & $\begin{array}{l}\text { (985) ¡claro! } \\
(996) \text { ¿sí? } \\
(1001) \text { iqué bien! } \\
(1006) \text { ¡mejor que una! } \\
(1016) \text { ya } \\
(1050) \text { ¡claro! } \\
(1057) \text { iQué bien! } \\
(1064) \text { ¡claro! } \\
(1117) \text { yo he ido alguna vez }\end{array}$ \\
\hline
\end{tabular}




\begin{tabular}{|c|c|}
\hline $\begin{array}{l}\text { (1171) ¿aquí has estado siempre } \\
\text { en el mismo colegio? }\end{array}$ & $\begin{array}{l}\text { pero no } \\
(1128) \text { isí es verdad que está } \\
\text { más bonito! } \\
(1134) \text { iclaro! jesa zona es } \\
\text { buena! } \\
(1140) \text { además de una ruta } \\
\text { muy bien comunicada } \\
(1152) \text { jay! iqué horror! } \\
(1166) \text { jclaro! } \\
(1168) \text { ipues sí! / iqué } \\
\text { horror! } \\
(1087) \text { iah! ibien! } \\
(990) \text { jah! ¿sí? } \\
(997) \text { jah! / ique era plazas } \\
\text { de varones }\end{array}$ \\
\hline
\end{tabular}

De acordo com os temas tratados, optamos por dividir essa entrevista em quatro partes. Observa-se ao longo da mesma que a temática apresentada não é especializada, nota-se que o tema sobre a profissão do I é bastante recorrente, bem como temas comuns ao seu dia a dia. Além disso, nota-se que é o I quem conduz grande parte do diálogo, não havendo necessidade de o E elaborar muitas perguntas.

A interação estabelecida entre os participantes ao longo dessa entrevista é bastante significativa, como já dissemos anteriormente, quem normalmente direciona os temas é o próprio I, porém são temas cotidianos. Independente do tema, o E interage com o I, demonstrando interesse, fazendo perguntas complementares e comentários. Há momentos em que o E aproveita a própria fala do I para elaborar suas perguntas. Observa-se também trechos em que o I faz perguntas ao E, invertendo os papéis, ainda que esses sejam bem definidos ao longo de todo o diálogo, o que caracteriza acentuada interação.

As perguntas principais não são precedidas por qualquer ato preparatório, tampouco por verbos no imperativo. São sempre enunciados diretos.

\subsubsection{Verbos no imperativo}

Observa-se a presença de verbos no imperativo fora do contexto interrogativo. Abaixo apresentamos as ocorrências de verbos no imperativo.

(106) I: ... porque yo ¡ya ves tu! / ¡imagínate! / yo no llegué a ver a la niña porque mi madre...

(226) I: ... ipos imagínate! / yo para mi la comida / yo decía...

(353) I: ... digo ¡anda! // así que ¡fíjate tú! / o sea que no te creas tú que yo tengo...

(415) I: ... ¡tú imagínate lo que aquello era! /...

(636) I: ... ipero fíjate tú! / al año siguiente...

(1003) I: ... i así que fíjate tú la suerte!...

(1007) I: ¡una cada cinco años y en Burgos! / ¡pues tú imagínate! / ¡tú imagínate lo que eso fue! (1069) I: ¡sí! / ¡ah! / ¡calla calla! / a mí me mandaron...

Como se pode observar por meio dos trechos apresentados, o uso do imperativo tem a função de fazer com que o interlocutor seja envolvido com o que é dito, fato que 
pode ser comprovado pela recorrência dos verbos imaginarse e fijarse. Assim, entendemos que além de incluir o interlocutor, o I pretende que ele se detenha nos detalhes contados por ele. A última ocorrência é uma exceção e demonstra que o grau de interação entre os participantes é alto. Embora para falantes do português esse tipo de ocorrência possa soar como grosseira, entre os espanhóis é bastante comum e de nenhuma maneira representa uma ameaça à face do E.

\subsubsection{Desfocalização do $e u$}

Com relação às estratégias de desfocalização, foi encontrada a seguinte ocorrência:

(831) ... termina una ¡agotadísima!

Analisando esta amostra, observamos uma grande quantidade de ocorrências contendo estruturas na $1^{\text {a }}$ pessoa do plural, no entanto, nota-se que é um nós de relato, cuja função é contar fatos que ocorreram entre o I e outras pessoas envolvidas, sem desfocalizar o eu.

A única ocorrência em que há o uso de una e não da forma mais comum uno está na linha 731, quando o I fala de si especificamente, preferindo o uso dessa forma mais impessoal.

\subsubsection{Prevenção de ameaça à face}

Abaixo apresentamos as ocorrências de prevenção de ameaça à face, seguidas de breve análise.

(94) E: y jel Chorrillo dónde está?

(95) I: jyo no sé dónde estará ahora! / pero yo y / y la huerta Anales y toda esa parte de ahí

(169) I: ... cuando una vez echó un un una promesa / en san a San Roque que era el/ el patrón / y y como coincidía que era el cumpleaños de mi padre / pues nunca / nunca fue / a cumplir la promesa de San Roque / y yo no sé por lo que era y/ y ya muerto mi padre / ¡una pila de tiempo/1 / que eso hace poco tiempo ¡vaya! / pues un día dispuso a ir a / a / allí a cumplir la promesa de / de San Roque...

(300) I: ... tendría / qué te digo que och / nueve años / ocho nueve diez o así / ¡diez ya no! / porque diez... (692) I: ... yo me parece a mí que fue con veinte años o con veintiuno / yo llevo ahora mismo llevo / ¡cuarenta y cuatro años de servicio!

(732) I: ... tampoco / no necesito yo / pero después digo yo ¡bueno! / que vengo del colegio muy cansada / iporque eso sí! Vengo del colegio muy cansada / y y digo y ahora me tengo que poner a hacer de comer / a esto a lo otro / ipues yo voy a seguir con la muchacha! / y he decidido...

(750) I: ... he tenido pues una muchacha dos veces en / he tenido mucho / mucho tiempo / una muchacha dos veces en semana / con / y algunos días venía / otra vez para planchar de vez en cuando / pero ¡vamos! / que he tenido mucho tiempo dos veces en semana / pero ¡mira! / yo ya / el colegio y la casa y eso / ¡eso me viene a mi muy largo! / y ya me he acostumbrado / iy ya me cuesta mucho trabajo desacostumbrarme! (940) I: porque dice un un/ viene un hombre vendiendo lotería y se pone ¡señora! / ¡doscientos millones! y / yo venía de lejos diciendo le voy a comprar lotería / le voy a comprar lotería porque / ¡no! / por gusto de comprarla / ¡hombre! / ipor si me to /y de pronto / y digo yo jaunque si me toca no sé lo que voy a hacer! / $\mathrm{y}$ ahora viene un / un hombre / $\mathrm{y} \ldots$ 
(950) I: ... si me toca la lotería pues yo tendría que compartir / y entonces pues yo manda / primero sería una complicación porque / solamente el compartirla pues ya sería a quién le doy esto a quién le doy lo otro...

(1042) I: ... en las últimas oposiciones que yo ¡vamos! / que yo recuerdo ¡eso! Porque / ya después empezaron a estudiar muchos...

Esses são os exemplos encontrados ao longo da entrevista. Assim como ocorreu em análise anteriores, tanto a primeira como a terceira e quarta ocorrências são advertências que fazem uma dupla prevenção - previne a própria face, no caso do I, ao não precisar dizer que desconhece tal fato e também a face do E que evitará perguntas mais aprofundadas sobre o tema.

Ainda com relação à primeira ocorrência mencionada, é interessante observar que a face exposta é a da mãe do I que fez uma promessa e não cumpriu. No entanto, antes de expor a face de sua mãe, há uma justificativa, fundamentando tal ação.

No caso do segundo exemplo apresentado, observamos que a incerteza demonstrada pelo I é uma forma de prevenir uma ameaça a sua própria face caso ele não esteja certo. Essa prevenção não ocorreria se fosse dado um número exato.

Há também nessa entrevista algumas justificativas que também são usadas como prevenção de ameaça à face, seja do próprio informante ou de quem ele se refere.

Observa-se que na ocorrência presente na linha 732, o I procura justificar o motivo que o faz ter uma empregada diariamente em casa. Na cultura espanhola sabe-se que só possui uma empregada diariamente quem tem extrema necessidade e dinheiro para pagar, pois não é um serviço tão desvalorizado. É interessante observar que o próprio I volta no tema sem que o E lhe pergunte.

Já a linha 750 é referente à pergunta da loteria, nesse caso observamos que há uma primeira justificativa e quando o E lhe pergunta o porquê dessa opinião, o I lhe apresenta uma série de motivos que justificam sua posição.

A diferença que vemos entre essas duas ocorrências é que especialmente na primeira, há uma preocupação maior por parte do I em evitar julgamentos do E sobre sua atitude. No segundo caso, a precaução tomada é menor, pois primeiro o I foi direto em dizer que não gostaria de ganhar na loteria para depois expor os motivos sobre sua opinião. Além disso, houve a necessidade de o E perguntar o porquê de sua posição. Cabe-nos aclarar que o tema da primeira ocorrência é de uma natureza muito mais íntima do que a segunda. Ao questionar o I sobre a necessidade de manter a empregada doméstica ou não, o E poderia invadir o território privado do I e consequentemente ameaçar sua face. 


\subsubsection{Ameaça à face}

Acima citamos as ocorrências relacionadas à prevenção de ameaça à face. Observa-se que nessa amostra há também uma ameaça à face do E.

(466) I: ... yo decía ¡bueno! ¡sí sí! Y yo / yo que siempre he estado con / muy despistada!...

(809) I: ... me sustituye una maestra por / por la edad/ porque a partir de los sesenta años hay dos tres horas menos en semana

(935) E: ¿sí? Pues ¡estupendo! // ¡oye! y ¿tú que harías si te tocase la lotería?

(936) I: / no quiero que me toque ;la verdad!

Nota-se que há diferentes formas de ameaça à face. No primeiro caso, tanto $\mathrm{E}$ como I expressam desconhecimento sobre o que é perguntado, o I não faz rodeios para dizer isso, o faz de maneira direta. No segundo (linha 466) a I não teme expor um traço de sua personalidade, ainda que isso leve o interlocutor a fazer algum tipo de julgamento. No terceiro, o I tampouco procura omitir sua idade, sem constrangimentos declara possuir mais de 60 anos. Como observado em análises anteriores, é comum que as mulheres procurem omitir sua idade. Ressaltamos que não julgamos a informação sobre a idade como uma ameaça à face, porém, considerando as outras amostras analisadas, é conveniente apresentar tal informação.

O último caso é o único que apresenta uma ameaça à face do outro, pois indiretamente o I se nega a responder a pergunta elaborada pelo E. É certo que após essa negativa houve uma série de justificativas para esclarecer porque não queria ganhar na loteria. Além disso, o E também teve liberdade de perguntar o porquê dessa sua posição.

\subsubsection{Atenuantes}

Abaixo apresentamos as ocorrências que contêm atenuantes, seguidas de breve análise.

(159) I: ... ¡muy pocas veces fui yo a la playa!...

(223) I: ... entonces para mi la hora de la comida era un poco de suplicio / porque ¡la verdad! / porque / a pesar de eso yo estaba más bien igordita! / pero ¡claro!...

São poucas as ocorrências que contêm atenuantes ao longo dessa entrevista, três no total. Além disso, observamos que cada uma exerce uma função diferente no enunciado. Assim, a primeira não atenua, mas intensifica. Ao dizer muy pocas veces, o interlocutor entende que foram pouquíssimas. $\mathrm{O}$ advérbio muy intensifica o adjetivo pocas. No segundo caso, há sim uma atenuação do substantivo suplicio e no terceiro o uso do diminutivo também atenua o adjetivo gorda, ainda que antes dele apareça o advérbio bien. 


\subsubsection{Expressão de opinião}

Diferentemente do que ocorre no corpus brasileiro, no material espanhol não há uma pergunta específica sobre um tema polêmico que faça com que o I expresse sua opinião. Entendemos que no corpus de Málaga, a opinião do entrevistado é dada de forma mais natural, pois não há nenhum tema imposto, o próprio andamento do diálogo sugere que o interlocutor expresse suas ideias. Todos os trechos abaixo foram retirados da fala do I.

(402) ¿se miraba mucho por el dinero? / ¡una cosa exagerada! / pero era / ¡eran todos los padres! / yo todos los padres de mis amigas y mis amigos que yo conozco eran por el estilo / lo más que / que no / que tenían que ahorrar / ¡tenían que ahorrar! / una cosa obsesionada con el ahorro / y yo me acuerdo que que/ mi padre ¡ya digo! / cada vez que se le pedía dinero se ponía ipor la nubes!... pero esa era la mentalidad de todos los hombres de entonces / y entonces / pues va / y se puso una vez malo...

(438) ... ahora ya gracias a Dios / están los hombres / que ya han comprendido que que la que la convivencia es de los dos y que la casa es de los dos y que todo es de los dos / ipos antes no! / antes no no / ¡de ellos no querían saber nada!...

(482) ... porque entonces la mayoría de las mujeres / la única solución que tenía era el casamiento y y ¡vamos! Y ¡y de eso! No tenía otra cosa porque...

(647) ... yo creo que con el banco y con los giros y con esas cosas serán más rápidos...

Como dissemos anteriormente, o I expõe sua opinião à medida que a conversa flui e necessita. Acreditamos que esse seja o motivo que faz com que não use verbos e expressões parentéticos ou epistêmicos nas três primeiras ocorrências, pois são opiniões pontuais, sobre momentos vividos por ele, costumes de sua época.

Já na última ocorrência, a qual apresenta tais verbos não marcam expressão de dúvida, mas sim opinião. Com isso, o I protege a sua face uma vez que já demonstrou ao E que não está seguro sobre o assunto exposto.

Entendemos que a expressão que yo conozco, presente na linha 402 tem a função de atenuar o conteúdo da fala, prevenindo uma possível ameaça à face do I.

Como já observado em análises anteriores, a quantidade de ocorrências em que o E exprime sua opinião ou faz algum comentário é significante. No entanto, optamos por analisar apenas as ocorrências encontradas na fala do I.

\subsubsection{Formas de tratamento}

O tratamento utilizado entre os participantes dessa entrevista está no eixo de solidariedade, representado pelo pronome tú. Abaixo, apresentamos alguns exemplos.

(02) Tú eres de Málaga ¿no? / ¿tú eres de Málaga?

(61) y al colegio fuisteis juntas ¿no?

(86) ¡ah! ¿tus padres? ¿sí?

(162) ¿tu madre era de aquí / de Málaga?

(352) y ¡no te ponían de reposo!

(426) o sea que ¡todo te tocaba a ti! 
(472) pero sin embargo / vosotras / o sea tú estudiaste...

(642) vosotras os lo currasteis y

Como pode ser observado por meio dos exemplos, há total concordância entre os pronomes pessoais e possessivos, na segunda pessoa do singular, utilizados ao longo de toda essa entrevista.

Como já apontado em análises anteriores, o E utiliza a segunda pessoa do plural para se referir ao I e terceiros.

Ao final das análises individuais, apresentaremos uma análise comparativa entre todas as amostras que compõem esse corpus de forma que facilitará a verificação de tais ocorrências.

Essa entrevista está no eixo de solidariedade e ainda que a diferença de idade entre os participantes seja grande, o que motivaria o uso de usted, não há ocorrência de formas nominais ao longo desta amostra.

\subsection{Amostra 67}

Informante feminino - 56 anos

Entrevistador feminino - 28 anos

Tema 1 - Málaga, família e colégio

\begin{tabular}{|c|c|c|}
\hline Perguntas principais & Perguntas secundárias & $\begin{array}{l}\text { Comentários / opiniões / } \\
\text { marcadores de } \\
\text { interação }\end{array}$ \\
\hline $\begin{array}{l}\text { (03) ¡bueno! / pues ¡cuéntame! Tú } \\
\text { eres de Málaga ¿no? } \\
\text { (31) y ¿qué recuerdos tienes de } \\
\text { Málaga / cuando eras pequeña o? } \\
\text { (141) y ¿dónde dices que os } \\
\text { subíais? / ¿a los techos de dónde? } \\
\text { (171) pero ¿qué íbais? / ¿todas las } \\
\text { mañanas a misa o solo? } \\
\text { (191) ¿llevas mucho tiempo } \\
\text { enferma? / ¿llevas mucho tiempo } \\
\text { resfriada? } \\
\text { (244) pues ¡qué suerte tuviste! ¿no?/ } \\
\text { pero ¿qué hacíais? / ¿Qué le } \\
\text { pagábais a lo(s) sujetos? ¿a lo(s)? }\end{array}$ & $\begin{array}{l}\text { (82) La más chica está por / por } \\
\text { detrás de } \\
\text { (90) ¿ya no está? } \\
\text { (120) todos los días ¿no? / ¿los } \\
\text { días de diario después del colegio? } \\
\text { (187) iríais muy temprano ¿no? } \\
\text { (206) ¿una juanola? / ¿quieres una } \\
\text { juanola? }\end{array}$ & $\begin{array}{l}\text { (62) Benetton / sí } \\
\text { (104) sí } \\
(145) \text { sí } \\
\text { (147) pero eso en el centro } \\
\text { de / de Málaga } \\
(149) \text { ¡ah! / ¡en el puerto! } \\
(211) \text { ¡ah! } \\
(213) \text { ipues te traerá } \\
\text { mandarina! } \\
(215) \text { con Juan Villena } \\
(224) \text { ¡ah! ¡qué bien! } \\
(253) \text { ¡qué bien! }\end{array}$ \\
\hline
\end{tabular}

Tema 2 - Problemas da educação

\begin{tabular}{|c|c|c|}
\hline Perguntas principais & Perguntas secundárias & $\begin{array}{l}\text { Comentários / opiniões / } \\
\text { marcadores de interação }\end{array}$ \\
\hline $\begin{array}{l}\text { (274) entonces, ¿qué piensas tú de } \\
\text { la LOGSE / o ¿en qué consiste la } \\
\text { LOGSE? } \\
\text { (281) la ESO ¿qué es? } \\
\text { (372) ¿cómo está organizada? }\end{array}$ & $\begin{array}{l}\text { (374) ¿todo junto? } \\
\text { (437) ¡ah! ¡muy bien! ¿no? } \\
\text { (439) pero ¿eso es general o en? } \\
\text { (484) ¿qué lo hacen? / ¿en grupo? } \\
\text { (539) ¡no! ¿por qué? }\end{array}$ & $\begin{array}{l}\text { (270) íbais tomando } \\
\text { transcripción fonética ¡claro! } \\
\text { (272) pues ¡nada! / entonces } \\
\text { (318) y no tienes ninguna } \\
\text { medida de fuerza }\end{array}$ \\
\hline
\end{tabular}




\begin{tabular}{|c|c|c|}
\hline $\begin{array}{l}\text { (435) eso te iba a preguntar } \\
\text { ¿cuántos alumnos son por clase? } \\
(515) \text { ¿qué libro utilizas? } \\
\text { (686) te tienes que sentir muy } \\
\text { impotente ¿no? / decir "es que esto } \\
\text { es lo que me mandan por arriba y }\end{array}$ & $\begin{array}{l}\text { (748) y esos son niños de nocturno } \\
\text { me has dicho ¿no? }\end{array}$ & 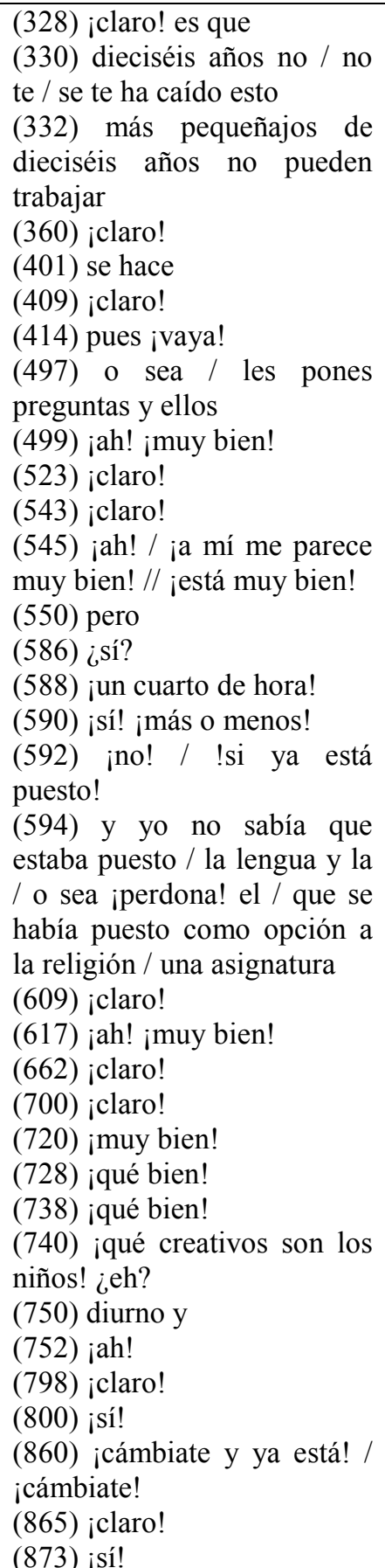 \\
\hline
\end{tabular}

Tema 3 - Loteria

\begin{tabular}{|c|c|c|}
\hline Perguntas principais & Perguntas secundárias & $\begin{array}{l}\text { Comentários / opiniões / } \\
\text { marcadores de interação }\end{array}$ \\
\hline $\begin{array}{l}\text { (878) ¡qué barbaridad! /antes que } \\
\text { has habla(d)o de los herederos / } \\
\text { ¿tú qué harías si te tocase la } \\
\text { lotería? }\end{array}$ & (890) algo de casa como & $\begin{array}{l}\text { (881) ¡mucho! ¡mucho! } \\
\text { (940) ¡claro! } \\
\text { (955) iigual que a mí! } \\
\text { (977) dicen que no es más } \\
\text { feliz el que más tiene sino el } \\
\text { que menos necesita ¿no? } \\
\text { (989) jestá bien! } \\
\text { (991) te voy a dejar ya } \\
\text { tranquila }\end{array}$ \\
\hline
\end{tabular}


De acordo com os temas tratados, optamos por dividir essa entrevista em apenas três partes. A primeira referente à cidade da informante, à infância e à família, a segunda relativa à profissão e a terceira, comum a várias entrevistas desse corpus faz menção ao que seria feito pelo I caso ganhasse na loteria. Como se pode observar, é uma temática não especializada que cria a possibilidade de que alguns subtópicos sejam trabalhados. Assim, é inevitável que o I fale algo de sua família quando está falando de sua infância, por exemplo. Em alguns momentos, nota-se que o próprio informante é quem cria os subtópicos.

Observando as perguntas principais, podemos afirmar que há apenas uma ocorrência de uso de verbo no imperativo, as demais são todas compostas por enunciados diretos, sem uso de atos preparatórios, precedendo-as.

A interação estabelecida entre os participantes ao longo dessa entrevista é significativa, o I é bastante detalhista ao falar dos temas solicitados. Os papéis são bem definidos, no entanto facilmente se observa que o E dá autonomia para o I criar subtópicos ao longo de sua fala. Todos os temas tratados são próximos também ao $\mathrm{E}$, o que facilita sua interação, contribuindo com perguntas e comentários ao longo da explanação do I. Assim como ocorreu em outras entrevistas analisadas, em alguns momentos, o E se vale da fala do I para elaborar suas perguntas, mantendo a fluidez do diálogo.

É interessante observar que há certa preocupação por parte do I com relação ao término da entrevista, abaixo citamos o trecho, o qual pode ser lido na íntegra nos anexos do trabalho entre as linhas 583 e 590 .

(583) E: un cuarto de hora/ desde ahora/ porque son três cuartos de hora en total/

I: ¡es que tengo que hacer!

E: ¿sí?

I: ¡sí! !bueno! ¡vamos! ¡venga!

E: ¡un cuarto de hora!

I: pero y itiene que ser tan exacto?

E: ¡sí! ¡más o menos!

Por meio desse trecho, podemos observar que uma das estratégias dos organizadores desse corpus é obter uma hora de diálogo, independentemente que todos os temas sejam tratados ou não. 


\subsubsection{Verbos no Imperativo}

Tratando especificamente dos verbos no imperativo, encontramos uma única ocorrência em que o mesmo é usado fora do contexto interrogativo. Abaixo apresentamos o trecho, seguidos de breve análise.

(721) I: porque una vez / esa es o por ejemplo ¡fíjate tú! / les hice una vez // cuando estudiábamos...

Assim como ocorreu na análise anterior, o verbo utilizado fijar tem a intenção de chamar a atenção do interlocutor de maneira que ele realmente preste atenção naquilo que está sendo exposto. Observa-se outro uso desse modo verbal, o qual denota uma forma de marcar interação e não ordem ou desejo.

\subsubsection{Desfocalização do eu}

Com relação às desfocalizações do eu, foram encontradas as seguintes ocorrências, todas elas retiradas da fala do I.

(47) ... a todos los niños que te gustaban / y que te vieran toda la gente que te tenía que ver / iy nada más! /

(52) ... y entonces hacías la cuenta... y después le decías a una / que habías visto al que le gustaba a ella...

(71) era ipues claro! / ¡acababas viendo a to(d)o (e)1 mundo!... / ¡si no te lo encontrabas en un momento te lo encontrabas en otro! //

(74) ... y eso era fundamentalmente lo que hacíamos / de vez en cuando pues ibas al cine / ibas a tomarte una cervecita...

(105) ... y cuando salíamos a las nueve menos cuarto / subíamos y bajábamos calle Larios

(113)... pero / tú ya los veías y medio hablabas / medio no hablabas / pero no podías ir con niños de uniforme...

(162)...y como antes no se comía antes de...

(183) ... te tenías ir a todo eso en ayunas

(185) pues tú te levantabas / te ibas... luego te tomabas un café...

(198) ... y me fui con fotocopias incluso para no hablar mucho / pero ¡claro! / ¡eso es inútil! / ¡tienes que hablar!/ yo me llevé...

(202) ... empiezan a hablar / tienes tú que callarlos//...

(564) ...voy atrasada porque la programación que hacen no la puedes cumplir / y si la cumples te siguen/ ¡no te sigue nadie! ¡vamos!

(566) tienes que hacer muchos ejercicios

(575) entonces si la realidad de tu clase es más lenta / pues ¡no te tienes que agobiar!

(600) ... y si te tienen que hacer una pregunta te la hacen/ o tú estás vigilando un poco...

(782) ... que cuando tú no estás acostumbra(d)o a estudiar lo de los estatutos...

(822) ... y que cada hora entre uno y te suelte un rollo...

Podemos observar que essa entrevista apresenta grande quantidade de ocorrências que visam desfocalizar o "eu", nas quais o falante utiliza apenas a $2^{\mathrm{a}}$ pessoa do singular.

Ao utilizar a $2^{\mathrm{a}}$ pessoa do singular, o I faz a inclusão de outras pessoas, é uma forma muito mais geral de se expressar, é como se qualquer pessoa passasse pela mesma situação, ou seja, o uso do plural, embora generalizador é mais pessoal do que o uso do singular. 


\subsubsection{Prevenção de ameaça à face}

Abaixo apresentamos as ocorrências de prevenção de ameaça à face, seguidas de breve análise.

(114) I: ... tú ya los veías y medio hablabas / medio no hablabas / pero no podías ir con niños de uniforme / ¡por lo menos en mi colegio! / en mi colegio no se podía ir con niños de uniforme...

(225) I: ... en su pueblo// eso fue en Motril/ y nosotros no sé cómo lo buscaron / no me acuerdo al final quien lo buscó...

(239) I: ... cuando volvimos a los exámenes y todo eso que estaba pendiente / como es natural porque eso / no me acuerdo en que año fue si fue en tercero o en quinto / ;sería en quinto!

(440) I: me parece que hay algunos grupos de más pero / ¡yo tengo veintiséis!...

(563) I: ... ¡también voy atrasada! / voy atrasada porque la programación que hacen no la puedes cumplir / y si la cumples te siguen / ¡no te sigue nadie! ¡vamos!

Essas são as únicas ocorrências encontradas ao longo da entrevista. Assim como ocorreu em análises anteriores, a segunda e a terceira ocorrências são advertências que fazem uma dupla prevenção - previnem a própria face ao não precisar dizer que desconhece tal fato e também a face do E que evitará fazer perguntas mais específicas sobre esse tema. Já a primeira e a quarta ocorrências são prevenções de ameaça à própria face caso o E tenha alguma informação diferente da que está sendo transmitida pelo I ou caso o número seja maior do que o informado. No caso da última ocorrência, o I faz uma justificativa para explicar o atraso de seus alunos na disciplina que leciona, eximindo-se parcialmente da responsabilidade de não ter o calendário cumprido.

\subsubsection{Ameaça à face}

Acima citamos as ocorrências relacionadas à prevenção de ameaça à face. No entanto, encontramos também ocorrências de exposição e ameaça à própria face do I.

(318) E: y no tienes ninguna medida de fuerza

(319) I: ¡bueno! ¡sí! / hay alguna medida de fuerza pero muy / ¡tampoco yo quiero ir de guardia de la porra! / o sea que/ yo lo con / ¡yo los comprendo!

(415) I: entonces pos tuve que/ decirles “ ¡hombre! ¡callaos! / que está hoy”/ y sí / al principio se impresionan mucho cuando te ven que vas mala

(418) I: digo “ ¡mira! / ¡hoy es que no puedo! / hacerme el favor / de no darme la lata / que esto va me vais haciendo esto y esto / va a contar mucho / y yo voy a guardar este ejercicio...

(686) E: te tienes que sentir muy impotente ¿no? / decir "es que esto es lo que me mandan por arriba y” (688) I: ¡no sé! Yo impotente no yo / lo que me veo impotente es de la realidad de la clase// cuando yo veo que le dedico / porque incluso / el nivel que hay/ si yo lo pudiera transmitir / realmente

(692) I: ... que yo siempre he pensado que los profesores de enseñanza media que no somos grandes investigadores ni grandes genios...

Observamos que, com exceção das ocorrências que aparecem entre as linhas 318319 e 686 - 688, todas as outras são falas do I expondo e correndo o risco de ameaçar sua 
própria face. Os demais casos são referentes a sua prática docente, em que ele não demonstra temor por passar a imagem de um professor autoritário na sala de aula (linhas 415 e 418). Nos trechos entre as linhas 318 - 319 e 686 - 688, observamos que o $\mathrm{E}$ ameaçou a face do I, afirmando que ele, como professor, não tinha força com os alunos e perguntando/afirmando se o mesmo não se sentia impotente. Imediatamente, o I o corrige, dizendo que sim, que há medida de força e no segundo trecho, dizendo que não se sentia impotente. Esse fato não ocasionou nenhum dano à entrevista, pois a mesmo prosseguiu, seguindo inclusive o mesmo tema. Por fim, a ocorrência mencionada na linha 692 aponta uma ameaça a sua própria face e também a dos outros professores aos quais se refere. Nesse trecho, observamos que em vez de fazer um elogio, ele expõe a face de todos.

\subsubsection{Atenuantes}

A seguir apresentamos as ocorrências que contêm atenuantes, seguidas de breve análise.

(75) ... ibas a tomarte una cervecita / pero muy poco/ generalmente / ¡vamos! No nosotros solo / que yo particularmente no tenía mucho dinero / muy poco dinero / ...

(307) ... tienen una edad son un poquito más chicos que los de antes...

(621) ... que me escribieran sobre ellos mismos un poquito...

(695) ... lo mejor que podemos hacer es / organizar un poquito / o sea decirle...

(762) ... es que nos vamos dando cuenta un poco de que los los cambios estos nunca...

(983) ... de los sitios muy baratos desconfiamos un poco porque sabemos que la comida es cara / y que un sitio de comida barato / es muy difícilmente bueno...

Observam-se dois tipos de ocorrência: com o advérbio muy acompanhado do adjetivo poco e em um único caso o advérbio dificilmente e o uso do diminutivo do adjetivo poco, transformando-o em poquito. É interessante ressaltar que a carga semântica desses usos é diferente. Entendemos que muy poco é mais forte do que poquito, que a nosso ver denota algo mais carinhoso, mais delicado.

Ainda sobre esse tema, cabe aclarar que há várias ocorrências de uso de diminutivo ao longo da entrevista por parte do I, no entanto para nós tais usos não têm uma configuração de atenuação, mas sim de delicadeza ao falar, demonstrando uma marca pessoal do I. Isso porque nem todo diminutivo pode ser caracterizado como marca de atenuação. Assim, tais ocorrências não foram consideradas em nossa análise. 


\subsubsection{Expressão de opinião}

Conforme mencionamos anteriormente, as expressões de opinião aparecem ao longo de toda a entrevista, de acordo com a necessidade do tema. Abaixo apresentaremos os trechos em que tais opiniões são mencionadas, todos eles retiradas da fala do I.

(101) ... pero yo creo que es un poco agobio de los padres / de que los apuntan a cuarenta cosas / pero nosotros lo que era el colegio / lo teníamos hasta las nueve menos cuarto de la noche

(278) pero le veo varios problemas fundamentales / uno que es / el que sea / hablo de la ESO / que es lo que yo estoy empezando / a experimentar / lo demás son papeles que como todos los papeles jestán muy bien! (323) ... la sociedad ¡mira! / tiene un problema / hay gente de una edad que no hay donde ponerlos / que no tienen van a tener trabajo que no / van a estudiar que / que esos serían los que antes pues estarían buscándose un trabajillo / pero como eso ahora ¡no existe! / pues ¡claro! / ¡los han metido en los institutos!

(345) pues ese problema le han dicho / ¡que se metan en los institutos! / y allí que los aguanten como sea // ¡y eso no puede ser! / porque un instituto es un sitio donde ya la gente / pues se supone que es que iba a seguir estudiando tiene un / un plan de estudio / con interés medio / no elementales

(353) ¡porque no hay otro sitio donde estar! // y eso ¿está bien o está mal? / pues ¡mira! / iyo no sé! / yo creo que si los pro / los próximos / hay que comprender que socialmente en algún lado la gente tiene que estar / pero ¿por qué exactamente en los institutos?

(378) pues(s) ¡claro! Yo / no me gusta porque ellos cuando tienen libros de texto / que es necesario / se acogen mucho al libro de texto y se lían si les dices / lo único que hago es en cada unidad / sencillamente dar todo lo que venga de literatura junto y todo lo que venga de lengua junto / pero a eso es lo que voy / yo no creo que tengan una visión de conjunto ni de la lengua ni de...

(396) ... lo veo digamos / inútil / la reforma que han hecho / porque casi deberíamos hacer sino cuatrimestres o algo así

(663) ¡y muy bien! / con eso estoy yo muy contenta / ¡eso es una asignatura preciosa! / y hay otra que creo que es muy bonita / que es patrimonio andaluz

(674) ... yo es que creo que se tenía que hacer un curso / que fuera como de cosa así

(678) ... porque tiene que ser una base / ¡yo es que no sé como van a llegar a la facultad! / te lo digo...

(684) estoy haciendo / pues / una cosa que / que ¡no están mal! / ¡no están mal! / pero en mi opinión de un nivel mucho más bajo que

(709) pero ¡claro! / si empieza por estar desorganizado / porque para mí esa mezcla de / un pedazito de lengua un pedazito de literatura un pe / cuando ya lleguemos ahora / en la otra lección / que me parece que viene La Celestina / ¡ya se ha olvidado Jorge Manrique!

(801) entonces / yo creo que estamos haciendo lo contrario de formarlos / porque ¡claro! // les estamos dando una idea de la vida / ¡equivocada por completo! /...

(828) esa sensación de que // de que jeso! / de que la vida va a ser fácil / y de que cualquier cosa mínima ¡ya ha cumplido! // pues me parece que es una idea / errónea / y una idea que se le está quedando...

Como dissemos anteriormente, o I expõe sua opinião à medida que a conversa flui e necessita. Embora o número de ocorrências em que há expressão de opinião seja elevado, há pouca incidência de verbos e expressões parentéticos ou epistêmicos.

Observa-se que há momentos em que o I faz críticas bastante severas ao governo e ao sistema de ensino e não usa marcadores de atenuação para mitigar sua fala. Em casos como o da linha 684 a expressão no están mal atenua o conteúdo que aparece na sequência. Já na linha 801, nota-se que ainda que seja comum e correto na Língua Espanhola o uso da $1^{a}$ pessoa do plural, há um favorecimento para a proteção à face do I, pois tira a responsabilidade apenas dele como professor, transferindo-a a todas as pessoas da mesma classe profissional. 
Entendemos essas opiniões como uma espécie de desabafo. $O$ fato de $o$ interlocutor também seguir a carreira acadêmica cria esse espaço para que o I fale com tanta franqueza sobre os problemas enfrentados na sua profissão.

Como podem ser observadas nas tabelas que iniciam essa análise, a participação do E com comentários e opiniões é significativa. Embora tenhamos ciência da importância de tais ocorrências para a fluidez do diálogo e aumento da interação entre os participantes, ressaltamos que nossa análise está focada apenas na fala do I.

\subsubsection{Formas de tratamento}

Observamos que a forma de tratamento utilizada pelo $\mathrm{E}$ está no eixo de solidariedade, representada pelo pronome tú. Abaixo apresentamos algumas ocorrências.

(04) ¡bueno! / pues ¡cuéntame! Tú eres de Málaga ¿no?

(171) pero ¿qué íbais? / ¿todas las mañanas a misa o solo?

(213) ¡pues te traerá mandarina!

Essa entrevista apresenta poucas ocorrências de formas de tratamento. Não encontramos, por exemplo, pronome possessivo. Com relação ao tratamento utilizado pelo E, observamos que há concordância entre os pronomes pessoais do caso reto e oblíquo, bem como do verbo na segunda pessoa do singular.

Assim como já observado em outras amostras, o E utiliza a segunda pessoa do plural para se referir ao informante e terceiros, porém o pronome vosotros fica elíptico nas frases. A seguir apresentaremos uma análise comparativa entre todas as entrevistas do corpus em que procuraremos facilitar a visualização de todas essas ocorrências.

Embora a diferença de idade entre os participantes seja significante, o que motivaria o uso de usted, não há ocorrências de formas nominais ao longo dessa amostra.

\subsection{Análise comparativa - nível superior}

Como todos os materiais analisados, o corpus superior espanhol também é constituído por seis entrevistas, sendo três de informantes do sexo feminino e outras três do sexo masculino. O que o caracteriza como superior é o nível de escolaridade dos informantes, no caso todos formados em universidades. Além disso, em nosso recorte de análise, selecionamos apenas informantes com idades entre 50 e 70 anos, de forma que nosso estudo pudesse também ter um caráter comparativo entre pessoas pertencentes à mesma região e da mesma faixa etária. Não consideramos como critério de seleção das 
entrevistas a profissão, uma vez que apenas o nível de escolaridade era suficiente e tampouco a renda familiar.

Abaixo apresentamos os dados dos informantes que compuseram o nosso corpus.

\begin{tabular}{|l|l|l|}
\hline $\begin{array}{c}\text { Entrevista } \\
\text { número }\end{array}{ }^{\mathbf{3 8}}:$ & \multicolumn{1}{|c|}{ Sexo } & \multicolumn{1}{|c|}{ Idade } \\
\hline 54 & masculino & 50 anos \\
\hline 59 & feminino & 53 anos \\
\hline 60 & masculino & 60 anos \\
\hline 61 & masculino & 59 anos \\
\hline 65 & feminino & 64 anos \\
\hline 67 & feminino & 56 anos \\
\hline
\end{tabular}

A seguir, passamos à exposição da análise comparativa do material de nível superior, optamos por separá-la em tópicos de acordo com o que foi trabalhado nas análises individuais das entrevistas. Em alguns casos, utilizaremos também gráficos que ajudarão a elucidar os dados apresentados.

\subsubsection{Fala do entrevistador}

Como já mencionado ao longo da análise de nível médio, acreditamos que conhecer alguns dados sobre o entrevistador é importante para que se possa fazer uma análise mais consistente. Assim, cabe mencionar que todas as entrevistas foram feitas por uma única pessoa, do sexo feminino, 28 anos e estudante da universidade. Acreditamos que são aspectos relevantes que devem ser considerados, pois a forma como um falante de 28 anos aborda um interlocutor de mais de 50 pode ser diferente da maneira como ele trata uma pessoa mais jovem.

Analisando a maneira como os enunciados interrogativos são elaborados, podemos observar que em todas as entrevistas houve a predominância de enunciados diretos. Não afirmamos que em $100 \%$ do corpus isso ocorreu porque houve uma única ocorrência em que a entrevistadora optou pelo uso do verbo no imperativo. No entanto, pode-se afirmar que nesse material, independente da idade ou do sexo dos informantes, o

\footnotetext{
${ }^{38} \mathrm{O}$ número de cada amostra foi definido pelos organizadores do corpus.
} 
entrevistador não faz uso de atos preparatório ou de algum recurso que vise proteger a face do informante.

Abaixo apresentamos o gráfico que contém os dados das ocorrências encontradas na fala do entrevistador. Embora haja certa repetição por conta da recorrência de enunciados diretos, acreditamos que como uniformidade de análise é importante que o apresentemos.

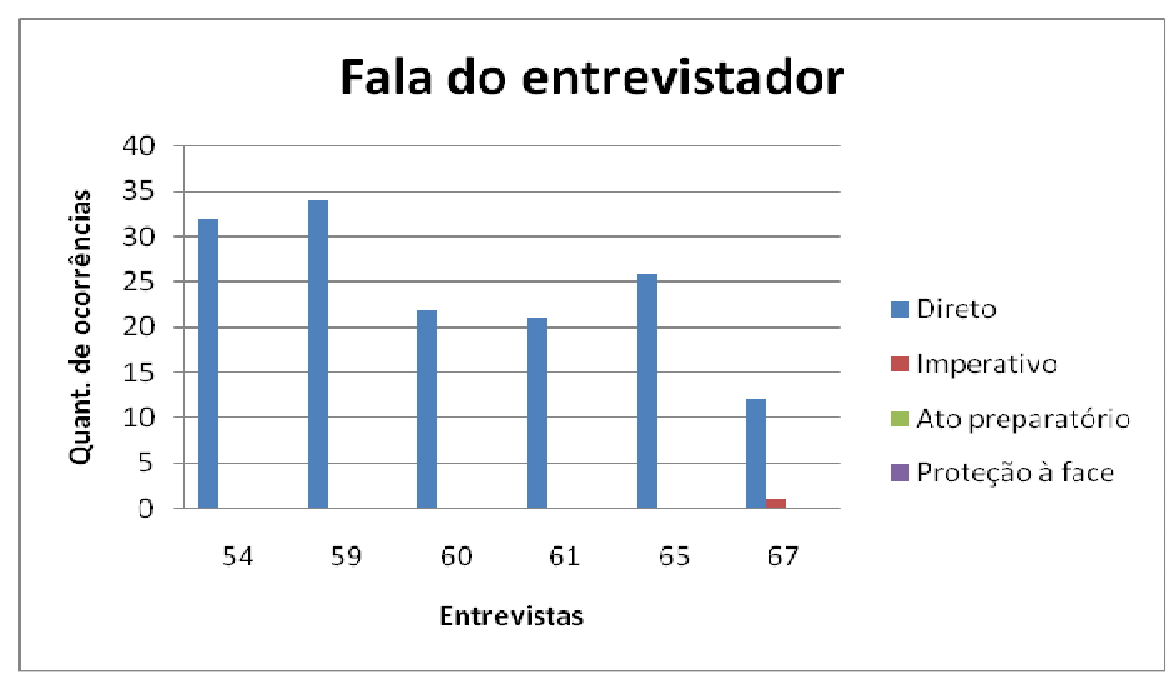

Esse dado ajuda-nos a voltar às questões que motivaram toda essa investigação: se seria o espanhol mais direto que o português, uma vez que fazendo uso de certas estratégias, o falante poderia ser considerado mais ou menos cortês. Por outro lado, a pouca frequência de verbos no imperativo também desmistifica a ideia de que os espanhóis optam por esse modo verbal por serem mais diretos e objetivos.

Com relação à interação entre os participantes das entrevistas, podemos afirmar que em todas elas o grau foi bastante alto e não nos resta dúvida em acreditar que isso se deve aos temas tratados.

A planificação temática do material é bastante baixa, observamos que o entrevistador tem em mente como iniciar e como finalizar seu diálogo, além disso, como também foi observado no material de nível médio, é mais importante o tempo de duração do que os conteúdos abordados ao longo desse tempo. Fato esse comprovado durante as análises individuais, todas as entrevistas tinham uma hora de duração aproximadamente.

Essa baixa planificação faz com que os temas surjam ao longo do diálogo e é inevitável que muitas vezes os papéis se invertam e o informante faça a pergunta para o entrevistador. Assim, com exceção da amostra 59, os temas centrais giram em torno da 
profissão do informante e propositalmente ou não, três deles são professores, a mesma profissão do entrevistador, o que faz com que os conhecimentos compartilhados sejam maiores, aumentando a interação entre ambos. Por outro lado, os informantes que não pertencem à mesma classe profissional do entrevistador também fazem com que suas profissões sejam o tema central, pois um é médico e o outro trabalha na parte de obras da cidade, fatos que despertam o interesse do entrevistador, levando-o a interagir ativamente ao longo dos diálogos. Por fim, a única entrevista em que o tema trabalho não é o mais discutido é a de $\mathrm{n}^{\circ} 59$, ressaltamos que se trata de informante do sexo feminino e outros temas são trabalhados com a mesma intensidade que os apresentados nas outras entrevistas, porém são mais cotidianos como a cidade, a televisão, o uso do computador, etc.

\subsubsection{Verbos no imperativo}

Não podemos deixar de mencionar que quando iniciamos nossos estudos para essa pesquisa, tínhamos a expectativa de comprovar algumas hipóteses que, muitas vezes, fazem parte do senso comum de quem estuda a Língua Espanhola como língua estrangeira. Não vamos nos ater naquilo que leva os estudantes a idealizarem o funcionamento da língua, mas acreditamos que, talvez, os livros didáticos ajudem a construir essa falsa ideia de uso da língua.

Procuramos comprovar se o uso de verbos no imperativo era o que deixava a língua espanhola com esse caráter mais direto, mais impositivo, acreditando que encontraríamos essa forma verbal na fala dos entrevistadores, como se estivessem solicitando aos seus informantes que respondessem às questões. Para nossa surpresa, esse tipo de ocorrência praticamente não existiu. Comprovamos sim, que são diretos, não fazem rodeios, porém sem a necessidade de utilização desse recurso.

Observamos que esse modo verbal foi utilizado ao longo das falas dos informantes, diferentemente do que pensávamos, com o intuito de chamar atenção de seu entrevistador, certificando-se que o mesmo estava atento àquilo que estava sendo contado.

Dessa forma, são três verbos os que mais se manifestam: imaginarse; fijarse e mirar. Além desses, encontramos duas ocorrências do verbo oír e uma de callar. Ainda que seja algo que tenha aparecido em praticamente todas as entrevistas, com exceção da amostra 54, entendemos que não podemos relacionar o uso desse modo verbal com a interação existente entre os interlocutores, pois há entrevistas como a 54 e a 67, por 
exemplo, em que a interação entre ambos foi alta e a frequência desse modo verbal inexistente no caso da primeira e baixa na segunda.

\subsubsection{Desfocalização do eu}

Como já foi apresentado ao longo de nossa fundamentação teórica e nas análises individuais, existem algumas estratégias que o falante pode usar para desfocalizar o eu, referindo-se a uma $3^{\text {a }}$ pessoa do discurso, sem que essa seja o seu interlocutor ou o próprio falante.

Durante a nossa análise pudemos observar cinco tipos de desfocalizações, algumas mais frequentes que outras, o que procuraremos demonstrar por meio dos gráficos. Assim, o falante pode utilizar:

- $1^{a}$ pessoa do plural, seja para exprimir um plural de modéstia ou para incluir outras pessoas em suas ações, não assumindo sozinho a responsabilidade por aquilo que está sendo narrado;

- $\quad 3^{\text {a }}$ pessoas do plural e do singular, transferindo integralmente o conteúdo do que é dito para outra pessoa, o falante assume o papel apenas de quem transmite a informação, sem se responsabilizar pelo que ali está contido;

- $2^{\mathrm{a}}$ pessoa do singular, um dos usos mais frequentes em nosso material, é aquele que sempre gera dúvida sobre a quem se refere. Algumas vezes fica claro que se refere ao próprio falante e em outras a qualquer outro sujeito;

- Uno, expressão que imaginávamos ser bastante comum na fala dos informantes de nosso corpus e que de fato ocorreu em apenas duas amostras. Entendemos o uso desse recurso de forma semelhante ao uso da $2^{\text {a }}$ pessoa do singular, fala-se de maneira geral, sem especificar a quem se refere, ainda que muitas vezes possa fazer referência ao próprio falante.

Abaixo apresentamos o gráfico com esse tipo de ocorrência, a fim de elucidar os dados obtidos ao longo da análise. 


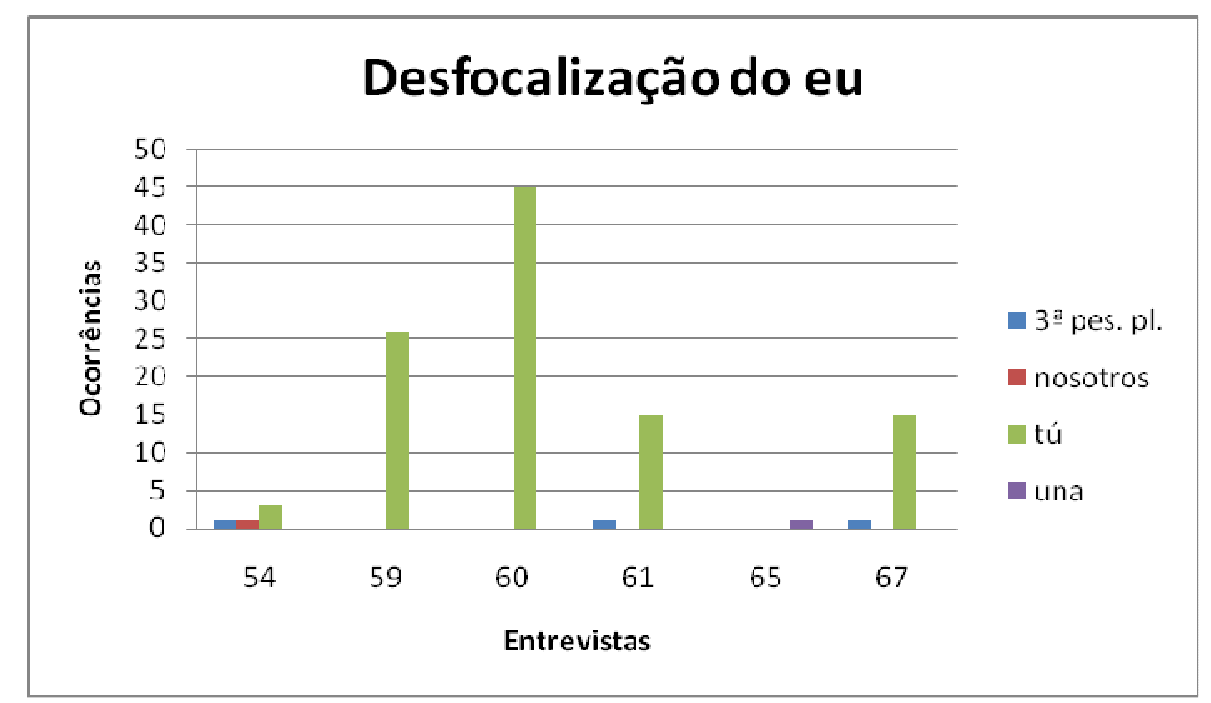

Como podemos observar por meio do gráfico, predomina como estratégia de desfocalização o uso da segunda pessoa do singular. Além disso, por meio das análises individuais, nota-se também que a preferência pelo plural ocorre principalmente quando o falante se refere a sua profissão, em que ao falar envolve também seus colegas de trabalho e quando há descrição de ações que envolviam outras pessoas como o que se fazia na infância ou adolescência. Esse dado chama-nos atenção pelo fato de o entrevistador desconhecer essas outras pessoas, além de muitas vezes não se saber quem são exatamente por meio dos relatos.

Já o uso da $2^{\mathrm{a}}$ pessoa do singular envolve questões mais gerais, embora também ocorra quando há a descrição de temas de trabalho. Entendemos que, nesse caso, o informante busca envolver o entrevistador no diálogo. Não se refere a ele, especificamente, mas faz com que ele participe mais ativamente do diálogo.

\subsubsection{Prevenção de ameaça à face}

Conforme apontamos ao longo de nossa exposição teórica, a prevenção de ameaça à própria face e à do outro é algo que se considera em qualquer tipo de interação. Vimos, que para que uma interação verbal seja bem sucedida há que haver um constante equilíbrio na preservação das imagens, tanto do falante quanto de seu interlocutor, de forma que nenhuma delas se prejudique.

Tendo esse aspecto tamanha importância, não poderíamos deixar de observá-lo ao longo de nossa análise. Pudemos comprovar que essa prevenção ocorre em todas as entrevistas de nível superior do corpus espanhol. Abaixo apresentamos os tipos de ocorrências encontradas. 


\subsubsection{Proteção à própria face}

Esse tipo de prevenção de ameaça à face é o mais recorrente, podendo ser encontrado em todas as amostras que compõem esse corpus. Observamos três tipos de proteção à face do informante.

O primeiro e mais comum é a expressão de incerteza sobre o dado ou fato que está sendo apresentado. Apenas a amostra 60 não apresenta esse tipo de ocorrência, no qual por meio de diversos argumentos como no sé, no estoy cierto, no estoy seguro, o informante expressa a sua dúvida. Entendemos que isso causa uma dupla proteção: protege a sua face, como já exposto e também a face do E, que evitará fazer perguntas mais aprofundadas sobre o tema, como já observado ao longo das análises individuais.

Outro tipo de proteção à própria face envolve a atribuição da responsabilidade sobre o que é dito a terceiros, como ocorre na amostra 54, na qual o I responsabiliza o jornal pelo fato narrado.

\subsubsection{Justificativas}

Esse tipo de ocorrência apenas não foi identificado nas amostras 59 e 65. Como já observado na análise do nível médio, ao justificar-se o I pretende evitar pré-julgamentos por parte do E. Observamos que muitas vezes é uma necessidade do falante fazer tal justificativa, como no caso da amostra 54 em que o informante diminuiu a casa dos sogros para aumentar a sua ou na 60 em que o I deixa claro que não quer passar a imagem de uma pessoa alarmista. $\mathrm{Na}$ amostra 61 , o próprio I imagina o que o E pensará dele, se antecipando e na 67 a intenção do I é apenas justificar o atraso de suas turmas no que se refere ao conteúdo da disciplina que leciona.

\subsubsection{Prevenção de ameaça à face do informante}

Esse tipo de ocorrência pode ser encontrado nas amostras 60 e 61 e em ambas ocorre da mesma forma, na qual o I se antecipa e explica detalhadamente o tema que está sendo tratado na tentativa de evitar que o outro tenha qualquer tipo de dúvida sobre o assunto.

\subsubsection{Ameaça à face}

Ainda retomando a fundamentação teórica que embasa o nosso trabalho, pudemos observar que embora os participantes de uma conversação tenham a necessidade de 
cuidar para que ambas as faces sejam protegidas, muitas vezes é inevitável que uma delas seja ameaçada, seja por culpa de um dos participantes ou da própria situação de interação.

No caso específico do nosso corpus, por não se tratar de uma conversação comum sem fins específicos, o cuidado deve ser ainda maior, principalmente por parte do entrevistador, o informante não pode se sentir ameaçado, uma vez que isso poderia findar a entrevista. Assim, ocorrendo qualquer tipo de ameaça, deve-se procurar restabelecer o equilíbrio para que o diálogo possa prosseguir sem maiores danos.

Acreditamos que o fato de encontrarmos poucas ocorrências de ameaça à face e de nem todas as entrevistas apresentarem as mesmas sejam dados relativamente contundentes que comprovam a nossa tese.

Especificamente nessas entrevistas, pudemos observar que esse tipo de ocorrência pode ser encontrado em cinco, entre as seis amostras analisadas, sendo que apenas a amostra 54 não apresentou nenhum tipo de ocorrência. Abaixo apresentamos as ameaças encontradas ao longo de nossa análise.

\subsubsection{Exposição da própria face}

Esse tipo de ocorrência foi encontrado em três, entre as cinco amostras que apresentam casos de ameaça à face. Chama-nos atenção a recorrência de alguns exemplos. Assim, nas amostras 59, 60 e 61 os informantes se distraem no meio de suas próprias histórias e se declaram perdidos, algumas vezes se recordam sozinhos do que falavam e em outras são auxiliados pelos entrevistadores.

Nas amostras 59 e 65 há referência à idade dos informantes. Não acreditamos que revelar a idade seja algo ameaçador para qualquer face, no entanto tendo em vista os dados obtidos em análises anteriores, observamos que para as mulheres há uma maior resistência em fornecer tal dado. No caso das amostras citadas, ambos os informantes são do sexo feminino e não se mostraram nada ameaçados em fornecer tal informação. Ressaltamos que não houve qualquer tipo de pergunta do entrevistador que exigisse tal resposta.

Já nas amostras 61 e 65 a ameaça que se repete é de autodepreciação. Entendemos que é uma maneira cortês de se manifestar, em que ao expor seus supostos defeitos, o falante se distancia da mensagem e se aproxima do interlocutor. 


\subsubsection{Falta de modéstia}

Assim como já observado em análises anteriores, entendemos que a falta de modéstia é também um tipo de exposição à face, no entanto optamos por apresentá-la separadamente.

Esse tipo de ocorrência aparece na amostra 60, na qual o falante não usa nenhum tipo de atenuante para expressar o quanto conhece a cidade em que mora e o quanto é sensato com relação aos jogos da loteria.

\subsubsection{Ameaça à face do interlocutor}

Como já apontado em análises anteriores, esse não é o tipo de ocorrência que esperávamos encontrar, devido à natureza de nosso corpus. No entanto, duas amostras, 65 e 67, apresentam casos em que há ameaça à face do outro.

$\mathrm{Na}$ amostra 65, como em outras entrevistas, o E pergunta o que o I faria se ganhasse na loteria e o I diz que não quer ganhar na loteria. Entendemos que é um tipo de ameaça pelo fato de ser apenas uma suposição. Acreditamos que faltou um pouco de tato para o I, que poderia ter entrado na brincadeira, afinal não era nenhuma pergunta que ameaçasse a sua face.

Já na amostra 67, a ameaça é do E para o I que faz insinuações sobre a falta de poder que os professores têm sobre seus alunos nos dias de hoje. Entendemos que foi uma ameaça, pois imediatamente o I contra-argumentou, contrariando o que o E havia dito.

Outro caso também encontrado na amostra 67 ocorre na fala do informante, o qual diz que não acredita que os professores do ensino médio sejam gênios. É interessante observar que ele se inclui ${ }^{39}$ entre esse grupo de professores, ameaçando não só a face deles, como a sua também.

\subsubsection{Atenuantes}

Além de todos os recursos apresentados utilizados pelos falantes de nosso corpus como estratégias de cortesia e atenuação, observamos também o uso de algumas expressões que denominamos atenuantes, pois exercem a função de mitigar o conteúdo da fala do informante e do entrevistador.

\footnotetext{
${ }^{39}$ É uma característica da língua espanhola o uso do pronome nós inclusivo, diferente do português que usa a terceira pessoa do plural, ainda que o falante faça parte das pessoas envolvidas. Ex. Os professores não têm poder sobre os alunos. / Los profesores no tenemos poder sobre los alumnos.
} 
Como se pode verificar nas análises individuais, nem todo uso de diminutivo pode ser considerado uma estratégia de atenuação, pois pode ser apenas uma forma carinhosa que o falante usa para se expressar.

Todas as amostras analisadas apresentam esse tipo de ocorrência. Entendemos que entre os casos encontrados, os que mais nos chamam atenção são aqueles que atenuam com a intenção de não ameaçar a face em questão. Na entrevista 54, por exemplo, o informante usa termos como más gordito e más rellenito para referir-se ao filho que estava acima do peso. Se em vez desses termos, ele optasse por outro como gordo seguramente colocaria em risco a face do filho, pois o interlocutor faria o seu juízo do que significa uma pessoa gorda.

Outro tipo de uso de atenuantes que ressaltamos é aquele no qual o falante se diminui de forma a não parecer arrogante para o outro. Essas ocorrências podem ser encontradas na entrevista 61 , na qual o informante deixa de salientar seus conhecimentos, dando inclusive justificativas para os mesmos.

Nas demais entrevistas as ocorrências encontradas foram bastante parecidas, pois utilizam termos como тиу росо ou somente росо para atenuar o adjetivo a que se referia.

\subsubsection{Expressão de opinião}

Conforme mencionado ao longo das análises individuais, esse corpus não apresenta ordem de organização das perguntas que o entrevistador deveria fazer aos informantes. Assim, não há uma pergunta específica que vise a expressão de opinião do entrevistado, ao longo da entrevista essas opiniões são dadas de acordo com os temas trabalhados.

Pudemos observar que de maneira geral, os informantes não apresentam receio em se expor, tratam os temas com bastante naturalidade, sejam eles referentes aos seus trabalhos, às críticas ao governo ou sociedade ou outros tipos de questões como o casamento, a educação dos filhos, etc.

Todos os informantes de nosso corpus fazem uso de verbos ou expressões parentéticos ou epistêmicos como creo, pienso, en mi opinión e a conclusão que chegamos sobre esse uso é que tal uso ocorre com mais frequência quando o tema tratado envolve uma posição extremamente pessoal do informante, no entanto quando o assunto tratado aborda algo que o mesmo apresenta vasto conhecimento como a educação no caso dos professores, por exemplo, opta-se por não utilizar tal recurso.

Durante as análises individuais, é possível observar que ao longo das expressões de opinião os informantes utilizam uma série de recursos atenuadores com o intuito de 
proteger a própria face, seja por meio de expressões que modalizam o conteúdo da fala, seja por justificativas que evitam o julgamento de interlocutor. Ressaltamos que todas as amostras apresentam esse tipo de ocorrência.

\subsubsection{Cortesia valorizante}

Apenas uma entrevista, a amostra 59, apresentou esse tipo de ocorrência. Diferentemente do que ocorre com as perguntas que invadem o território pessoal do I, a cortesia valorizante é uma estratégia que contribui favoravelmente com o diálogo. No caso específico da amostra que a apresentou, temos um caso de elogio, no qual ao enaltecer o I, o E se aproxima dele, aumentando a interação.

\subsubsection{Invasão de território pessoal}

Entendemos que esse é o tipo de ocorrência que deve ser evitado, principalmente quando o diálogo em questão é uma entrevista, pois por envolver questões pessoais, o limite é imposto por cada informante, dependendo de sua personalidade.

Acreditamos que esse fato é considerado, uma vez que apenas uma das amostras apresentou tal ocorrência, no caso a amostra 54. Como o E aproveitou a própria fala do I para elaborar esse pergunta mais íntima, não houve qualquer tipo de dano ao diálogo.

\subsubsection{Solidariedade}

Apenas as amostras 59 e 61 apresentam essa estratégia de cortesia, sendo que na primeira é o E quem complementa a fala do I e na segunda há os dois tipos de ocorrência, ou seja, um complementa a fala do outro.

Entendemos que esse tipo de ocorrência contribui favoravelmente com o andamento da entrevista, pois além de aumentar a interação entre os participantes, comprovando que estão atentos na fala do interlocutor, dá mais fluidez ao diálogo.

\subsubsection{Formas de tratamento}

Como já apontado ao longo da análise do nível médio, procuramos elucidar as formas de tratamento encontradas nas seis entrevistas analisadas apresentando abaixo uma tabela e em seguida as considerações que chegamos a partir de tal análise no que concerne aos falantes de nível superior do Espanhol de Málaga. 


\begin{tabular}{|c|c|c|c|c|c|c|c|}
\hline Amostra & $\begin{array}{c}\text { Sexo } \\
\text { do Inf. }\end{array}$ & $\begin{array}{c}\text { Idade } \\
\text { dos Inf. }\end{array}$ & $\begin{array}{c}\text { Pronome } \\
\text { Pessoal }\end{array}$ & $\begin{array}{l}\text { Pessoa } \\
\text { verbal }\end{array}$ & $\begin{array}{l}\text { Pronome } \\
\text { Oblíquo }\end{array}$ & $\begin{array}{l}\text { Pronome } \\
\text { Possessivo }\end{array}$ & $\begin{array}{c}\text { Forma } \\
\text { Nominal }\end{array}$ \\
\hline 54 & $\mathrm{~F}$ & 50 & tú / vosotros & $2^{\mathrm{a}}$ sing. e pl. & te / ti / os & ------ & ----- \\
\hline 59 & $\mathrm{M}$ & 53 & tú / vosotros & $2^{\mathrm{a}}$ sing. e pl. & te / ---- & tu / --- & ----- \\
\hline 60 & $\mathrm{M}$ & 60 & tú / ----- & $2^{\mathrm{a}}$ sing. e pl. & te / os & tus / --- & ----- \\
\hline 61 & $\mathrm{M}$ & 59 & tú / ----- & $2^{\mathrm{a}}$ sing. e pl. & te / ti / os & tu / ---- & ----- \\
\hline 65 & $\mathrm{~F}$ & 64 & tú / vosotros & $2^{\mathrm{a}}$ sing. e pl. & te $/ \mathrm{ti} / \mathrm{os}$ & tu / tus /--- & ----- \\
\hline 67 & $\mathrm{~F}$ & 56 & tú / ----- & $2^{\mathrm{a}}$ sing. e pl. & te / ---- & ------ & ----- \\
\hline
\end{tabular}

Por meio da tabela acima, podemos comprovar alguns dados que foram expostos ao longo de nossa fundamentação teórica.

Como pode ser observado, todos os informantes tinham idade superior a 50 anos, enquanto que o E apresenta, no momento da entrevista, 28 anos. Considerando tal informação, ressaltamos que o tratamento utilizado em todas as amostras analisadas, pertencentes a esse corpus está no eixo de solidariedade, no qual o $\mathrm{E}$ utiliza um tratamento informal, por meio do uso do pronome tú acompanhado do verbo na segunda pessoa do singular e dos pronomes oblíquo e possessivo também na segunda pessoa do singular, estabelecendo concordância entre os mesmos.

Em nosso entendimento é um dado que chama atenção, pois esperávamos que a idade dos informantes fosse um dado determinante para que o eixo de poder fosse estabelecido nos diálogos. Além disso, não há qualquer tipo de registro no qual o E pede permissão para utilizar o tratamento informal e tampouco se nota estranheza por parte dos informantes em ser tratados de tal forma. Com isso, comprova-se a ideia de que o tú está ganhando espaço frente ao usted.

Uma vez que o tratamento utilizado é o informal, não encontramos o uso de formas nominais, sejam elas representadas pela profissão ou pela idade dos informantes. Ademais, ressaltamos que em nenhuma das amostras analisadas há qualquer tipo de menção ao nome dos informantes, mesmo que fictício como forma de preservação da identidade, fato que impossibilita o uso da forma nominal antecedendo o nome do informante.

Bem como ocorreu na análise do nível médio e como pode ser observado na tabela acima, o entrevistador utiliza a segunda pessoa do plural para se referir ao 
informante e outras pessoas. Em três amostras há o uso explícito do pronome vosotros, nas outras três o pronome está elíptico.

Com base nos dados obtidos, podemos observar que embora alguns teóricos afirmem que em Málaga exista uma diversidade pronominal, na qual há o uso tanto de ustedes quanto de vosotros, em todas as entrevistas analisadas, houve apenas o uso de vosotros. 


\section{Capítulo 5 - Análise - corpus brasileiro}

Em momento anterior a essa análise, procuramos apresentar as características dos corpora estudados, fazendo-se desnecessária tal apresentação nesse capítulo.

Bem como fizemos na análise do material espanhol, apresentaremos primeiro o material de nível médio, seguindo a sequência numérica das entrevistas, uma breve análise individual e posteriormente uma análise comparativa entre as entrevistas de cada nível - médio e superior.

\section{I. ALIP - Nível Médio}

\subsection{Amostra 65}

Informante masculino - 27 anos

Entrevistador feminino - 22 anos

Tema 1 - História pessoal

\begin{tabular}{|c|c|c|}
\hline Perguntas Principais & Perguntas complementares & $\begin{array}{l}\text { Comentários / opiniões / } \\
\text { marcadores de interação }\end{array}$ \\
\hline $\begin{array}{l}\text { (02) bom queria que cê contasse } \\
\text { uma história que aconteceu com } \\
\text { VOCÊ assim... uma experiência } \\
\text { pessoal sua... pode ser uma briga } \\
\text { alguma coisa assim } \\
\text { (10) mas como foi que cês } \\
\text { discutiram assim? } \\
\text { (24) mas por que assim? Conta } \\
\text { pra mim como que aconteceu? } \\
\text { (33) e/ e o/ e uma assi/ ga/ } \\
\text { alguma bem séria assim?... que } \\
\text { cê machucou muito assim? } \\
\text { (46) e alguma outra coisa? Tem } \\
\text { uma coisa assim... alguma ... } \\
\text { vergonha assim que cê já passou } \\
\text { pode contar assim?... uma } \\
\text { situação que cê ficou assim } \\
\text { envergonhado ou pagou algum } \\
\text { mico assim? } \\
\text { (60) tem alguma outra que cê } \\
\text { lembra? } \\
\text { (62) tem algum problema assim } \\
\text { que cê teve assim alguma coisa } \\
\text { que... te marcou assim que cê } \\
\text { possa me contar? }\end{array}$ & $\begin{array}{l}\text { (06) ene / energia? } \\
\text { (13) mas cê cê brigou com } \\
\text { quem? } \\
\text { (15) mas cês brigaram assim de } \\
\text { bri/ de baTEr assim? } \\
\text { (17) e machucou? } \\
\text { (19) cê tem alguma outra? } \\
\text { (21) mas outra assim que cê já } \\
\text { passou sua?... outra BRIga? } \\
\text { (38) hum... nossa onde cortou? } \\
\text { (41) mas depois vocês ficaram... } \\
\text { de mal? } \\
\text { (44) é? } \\
\text { (53) cê teve de descer? } \\
\text { (55) esqueceu? } \\
\text { (58) aí cê voltou e pegou de } \\
\text { novo? } \\
\text { (68) é... nenhuma mais que cê } \\
\text { lembra? }\end{array}$ & $\begin{array}{l}\text { (31) sem problema nenhum } \\
\text { (74) éh... então tá }\end{array}$ \\
\hline
\end{tabular}

Tema 2 - História contada por terceiros

\begin{tabular}{|c|l|l|}
\hline Perguntas Principais & Perguntas complementares & $\begin{array}{c}\text { Comentários / opiniões / } \\
\text { marcadores de interação }\end{array}$ \\
\hline $\begin{array}{l}\text { (77) tem assim alguma história } \\
\text { que alguém contou pra você... }\end{array}$ & $\begin{array}{l}(82) \text {,as cê / cês lembra ou sua } \\
\text { mãe te contou? }\end{array}$ & $\begin{array}{l}(90) \text { tadinho } \\
(149) \text { ah então tá bom já }\end{array}$ \\
\hline
\end{tabular}


sua mãe contou ou algum uma arte que cê fez quando cê era criança... alguma coisa assim?

(86) e tem alguma outra que ela conta assim?

(94) e sua mãe te contou assim alguma história que/ dela como ela conheceu seu pai aconteceu alguma coisa com ela com o pai dela assim... lembra?

(99) mas cê / num teve assim alguma coisa assim... diferente ainda que esse pessoal te conta... algu / alguma coisa que ela passou assim quando ela era criança que ela te conta ou quando ela conheceu seu pai?

(107) mas cê num / e alguma coisa que ela conta do seu irmão num tem?... que ele fez quando era pequeno?... que cê num lembra mas que ela te $\mathrm{com} /$ tenha te contado?

(122) ham... cê num lembrou alguma coisa que alguém mais tenha te contado um amigo assim contou uma fofoca assim... uma briga que ele viu ou um acidente muito grave que... que cê num tenha visto mas ele te contou?

(147) ham... tem mais alguma coisa que cê lembra?... que alguém te contou?
(114) mas por quê? Que doença ela tinha?

(117) não?

(119) mas ela éh ela foi a primeira filha?

(126) que amigo?

(131) hum... mas fico / e como que aconteceu?

(134) mas éh... ele ele que acont/ que fez que el/ que ele bateu seu amigo que bateu ou ele viu?

(137) bateu com quê?

(140) o moto-táxi?

(143) nossa ele saiu correndo?

Tema 3 - Descrição de um lugar

\begin{tabular}{|c|c|c|}
\hline Perguntas Principais & Perguntas complementares & $\begin{array}{l}\text { Comentários / opiniões / } \\
\text { marcadores de interação }\end{array}$ \\
\hline $\begin{array}{l}\text { (152) agora eu queria que cê me } \\
\text { descrevesse um local uma } \\
\text { pessoa... pode ser sua casa... ou } \\
\text { um / seu quarto um lugar que cê } \\
\text { gosta muito que cê viajou que cê } \\
\text { viu... pode ser a casa que cê era } \\
\text { criança... cê pode escolher } \\
\text { (162) você lem/ lembra um } \\
\text { lugar bonito que cê foi? ... de lá? } \\
\text { (192) hum... e tem outro/ cê } \\
\text { lembra da casa que cê era } \\
\text { pequeno?... que cê morava? } \\
\text { (198) ham... como que era sua } \\
\text { casa lá? } \\
\text { (201) como que era o teu quarto? } \\
\text { (206) como era o quintal lá } \\
\text { assim? cê lembra? } \\
\text { (217) laá/ e... a cozinha? Cê } \\
\text { lembra assim? como que ficava } \\
\text { assim dentro da cozinha? }\end{array}$ & $\begin{array}{l}\text { (160) como que é lá? } \\
\text { (165) o shopping era uma } \\
\text { estrela? } \\
\text { (169) como que era assim o } \\
\text { shopping? } \\
\text { (173) tava tudo decorado? } \\
\text { (177) e /e tem alguma / lugar } \\
\text { mais/ tem outro lugar que você } \\
\text { foi lá bonito? } \\
\text { (179) pode ser um... um... a/ } \\
\text { onde cê ficou quando cê foi pra } \\
\text { lá?... ou cê foi só um dia assim } \\
\text { nem dormiu na cidade?... lá em } \\
\text { Bebedouro? } \\
\text { (183) como que era lá a fábrica } \\
\text { lá dentro? } \\
\text { (188) que cor que era assim?... a } \\
\text { fábrica? } \\
\text { (208) que que tinha assim como } \\
\text { que era? } \\
\text { (211) que cor que era tua casa? } \\
\text { (213) azul?... e as janelas assim? }\end{array}$ & $\begin{array}{l}\text { (167) legal } \\
(225) \text { ham... então tá }\end{array}$ \\
\hline
\end{tabular}


\begin{tabular}{|l|l|l|}
\hline & \\
\hline
\end{tabular}

Tema 4 - Receita

\begin{tabular}{|l|l|l|}
\hline \multicolumn{1}{|c|}{ Perguntas Principais } & Perguntas complementares & \multicolumn{1}{c|}{$\begin{array}{c}\text { Comentários / opiniões / } \\
\text { marcadores de interação }\end{array}$} \\
\hline $\begin{array}{l}\text { (228) agora eu queria que cề } \\
\text { me contasse assim alg/... cê sabe } \\
\text { cozinhar? }\end{array}$ & $\begin{array}{l}\text { (248) hum... seguido? } \\
\text { (263) e como que ganha? } \\
\text { (270) como que faz macarrão? }\end{array}$ & $\begin{array}{l}\text { (282) ham... no final quem ficar } \\
\text { com menos } \\
(238) \text { e jogar cê sabe jogar }\end{array}$ \\
$\begin{array}{l}\text { algum jogo? então tá } \\
\text { (240) e como que joga caxeta? } \\
\text { (272) dama?... então como que } \\
\text { joga?... conta pra mim }\end{array}$ & \\
\hline
\end{tabular}

Tema 5 - Relato de opinião

\begin{tabular}{|c|c|c|}
\hline Perguntas Principais & Perguntas complementares & $\begin{array}{l}\text { Comentários / opiniões / } \\
\text { marcadores de interação }\end{array}$ \\
\hline $\begin{array}{l}\text { (291) agora eu queria que cê } \\
\text { desse sua opinião sobre alguma } \\
\text { coisa... pode ser... assim por } \\
\text { exemplo... cê / que cê acha do do } \\
\text { nosso prefeito? Do Edinho? } \\
(299) \text { e ... e das / dos radar... que } \\
\text { cê acha? } \\
\text { (326) e... que cê achou do/ } \\
\text { daquele outro governo dele que } \\
\text { que cê achou? } \\
\text { (351) e do presidente que que cê } \\
\text { acha? }\end{array}$ & $\begin{array}{l}\text { (308) mas falaram que cê tava a } \\
\text { sessenta e cinco?... mas tava a } \\
\text { setenta e dois? } \\
\text { (315) às vezes só um pedaço ele } \\
\text { já pega né? } \\
\text { (338) não? } \\
\text { (340) por que que ele acha? }\end{array}$ & $\begin{array}{l}\text { (311) no máximo né? } \\
\text { (333) só come/ começou pra } \\
\text { ganhar voto } \\
\text { (355) é uma coisa assim [eu } \\
\text { também num lembro] } \\
\text { (376) é }\end{array}$ \\
\hline
\end{tabular}

A entrevista é dividida pelos organizadores do corpus, em cinco partes préestabelecidas. Apresenta baixo nível de planificação, no entanto observamos que há certo direcionamento em cada pergunta principal elaborada pelo entrevistador (E). Assim, na primeira parte, quando o informante (I) deve fazer uma narrativa de alguma experiência vivida, ele direciona a pergunta para que ele narre alguma briga da qual participou. Além disso, há certa insistência para que o I narre outras brigas ${ }^{40}$ nas quais esteve envolvido. Acreditamos que é interessante que haja algum direcionamento nas perguntas, porém quando a pergunta é muito fechada, obriga o E a refazer a mesma pergunta ou ampliá-la, de forma que obtenha o resultado esperado. É o que ocorre ao longo dessa entrevista, o E insiste nas perguntas até o momento em que o I alerta de forma bastante discreta que não pode acrescentar nada mais ao tema.

Com relação às perguntas principais, observa-se que em quatro dos cinco tópicos existentes o E faz uso de atos de preparação, no caso o verbo querer no Futuro do Pretérito, preparando o I para a pergunta em si. Além dessa forma, há outras utilizadas

\footnotetext{
${ }^{40}$ Como pode ser observado na primeira tabela apresentada na pág. 238.
} 
pelo entrevistador como o uso do imperativo, o verbo poder no presente e enunciados diretos. É interessante observar que esse entrevistador se apoia frequentemente na partícula assim para elaborar suas perguntas. É como se lhe faltassem palavras e o uso dessa partícula completasse o vazio na elaboração de suas perguntas.

Por meio das tabelas apresentadas, é possível observar que o E precisou fazer um grande número de perguntas para obter as respostas que necessitava para a composição do corpus. No entanto, nota-se que há pouca interação. O diálogo flui apenas por meio das perguntas e respostas e não pela interação entre os participantes.

\subsubsection{Desfocalização do $e u$}

Com relação às ocorrências que visam desfocalizar o eu, apresentamos os seguintes trechos encontrados, todos presentes na fala do I.

(65) é o problema que me marcou mais foi essa briga do meu irmão né? que... eu cortei ele e tudo... mesmo nós sendo amigo e tudo mas a gente nunca esquece né? é difícil mas... mas isso daí é... fica guardado...

(174) tava inclusive nós pegou um ganchinho rasgamos e comemos o chocolate aí nós rasgou e comeu chocolate...

(185) ... só num me recordo bem porque faz muito tempo éh... ela tinha uma... um portãozinho aí tinha uma entradinha... aí nós pegava e aí tinha um um grande portão...

(313) ... por causa de sete que mo/moto... cê quando cê menos espera cê... não que cê corre é que cê anda... (316) isso... hora que cê passa na frente... e tem aqueles radar também que tem no/nos farol que se ocê passa o sinaleiro vermelho...

Com base nas ocorrências encontradas, podemos observar que há três tipos de desfocalização: o uso do a gente, do você com suas variações próprias da língua falada cê e ocê e nós, ainda que nem sempre com a concordância verbal de acordo com a norma culta do Português do Brasil - $1^{\mathrm{a}}$ pessoa do plural.

Podemos constatar que o I usa $a$ gente para se referir a uma ação que aconteceu com ele, porém o uso do plural faz com que o I busque certa afiliação do E na ação descrita. O uso da $1^{\mathrm{a}}$ pessoa do plural se refere às ações que ele e outras pessoas cometeram. Entendemos que é uma forma de incluir o outro, ainda que esse seja desconhecido. Por fim o uso de você e suas variantes próprias da língua falada indicam a inclusão do interlocutor. Acreditamos que tal uso cria uma aproximação entre informante e entrevistador. Embora o I esteja falando diretamente com o E, não é a ele que o pronome de tratamento se refere, mas a uma terceira pessoa não especificada.

Tratando especificamente dos marcadores de atenuação, podemos encontrar alguns dos mencionados na fundamentação teórica dessa tese ao longo dessa entrevista. A seguir apresentaremos as ocorrências encontradas acompanhadas de breve análise. 


\subsubsection{Prevenção de ameaça à face}

Abaixo apresentamos as ocorrências encontradas, seguidas de breve análise.

(22) I: ... não tem várias tem que eu est/ que eu tava junto c'uns colegas e ... e por influência de outro amigo ... eu briguei c'o outro

(49) I: deixa eu pensar aqui... hum... ah foi quando foi quando eu fui... mas eu era mais novo antes... agora eu já to mais... e... e eu tava no ônibus ia pegar oônibus aí eu fui pegar minha carteira...

(94) E: e sua mãe te contou assim alguma história que/ dela como ela conheceu seu pai aconteceu alguma coisa com ela com o pai dela assim... lembra?

(127) I: o H... contou que ele viu um acidente d'um... moto-táxi que tava c'a... c'a passageira e eles tava contramão... e sofreram de... tipo no/ num só num lembro se foi se ele bateu ou se ele caiu... mas eu creio que ele bateu...

(184) I: a fábrica? Era... ah ela era grande tinha... só num me recordo bem porque faz muito tempo éh... ela tinha uma...

(352) I: ah o presidente... ele... eu acho que ele tava/ ele saiu muita coisa errada... num tá cumprindo também o... o prometido dele que era os ... eu num lembro muito bem se era dez... dez milhões de emprego dez mil emprego cem num sei

(352) I: ah o presidente... ele... eu acho que ele tava/ ele saiu muita coisa errada... num tá cumprindo também o... o prometido dele que era os ... eu num lembro muito bem se era dez... dez milhões de emprego dez mil emprego cem num sei

(355) E: é uma coisa assim [eu também num lembro]

Observa-se que há cinco ocorrências na fala do I e duas na fala do E. Todos os casos visam prevenir uma ameaça à face do I. A primeira ocorrência previne ameaçar a face do I caso ele não saiba a resposta solicitada e a segunda (linha 355) compartilhando a mesma dúvida, há uma tendência à minimização do conteúdo da fala do I. Já na fala do I, observamos dois tipos diferentes de prevenção, embora todas visem proteger a própria face do I. O primeiro caso, no qual inserimos as ocorrências das linhas 22 e 49, o I busca apresentar uma justificativa, evitando que o interlocutor faça algum julgamento de seu ato, já os outros três (linhas 127, 184 e 352) a prevenção se refere à dúvida do I com relação aos dados apresentados. Assim, o uso de expressões como não me recordo, não me lembro faz com que, caso haja algum erro, o mesmo não tenha tanta importância uma vez que o falante já alertou o interlocutor sobre a sua dúvida.

\subsubsection{Ameaça à face}

(361) I: ... eu acho que ele devia de fazer uma campanha... como tem em outros países né? PA... essas pessoas que num tem condições que tem baixo salário ou que num trabalha... pra que em vez de fazer camapnha pra fome... pra que num num ficasse fazendo filho né?

Entendemos a ocorrência acima como uma ameaça à face do I devido ao tom preconceituoso com que ele expõe a sua opinião. Observa-se que ele não faz uso de nenhum marcador de atenuação, o qual poderia mitigar tal ameaça. 


\subsubsection{Expressão de opinião}

Abaixo apresentamos as ocorrências de expressão de opinião. Normalmente relatadas na última parte da entrevista. Ressaltamos que todas elas estão presentes na fala do I.

(109) não ela só me contou que... eu tive uma irmãzinha que foi a primeira... nós somos em cinco né? uma falecida e contou que ela / ... que eu tive uma irmãzinha que quan/ que eles morava em São Paulo... que ela... ficou doente e aí ela... como ela morava em São Paulo... acho que o atendimento lá num é muito bom né?... e ela pegou e num aguentou e faleceu

(293) ah o nosso prefeito ele... falou que no nos comício deles... na televisão que ia fazer muito muito e infelizmente a cidade tá muito cheia de buraco acontece muitos acidente inclusive eu já passei de moto em dois três buraco (...) então tá difícil né? porque... ele falou muita coisa e num está fazendo nada o que ele... que ele falou... num tá cumprindo a / c'a palavra dele

(300) c'os radares... eles... eu acho que eles aproveita muito... porque às vezes é bom porque... muitos corre mas... infelizmente... isso prejudica um pouco as pessoas que eles colocam radar móvel

(356) (...) e ele tem essa campanha pa fome que isso eu acho que num resolve muito... porque muitos ... éh estão fazendo... eles fala que é campanha pa fome e tudo e pega e como se diz? E rouba essas coisas né (...)eu acho que ele devia de fazer uma campanha... como tem em outros países né? PA... essas pessoas que num tem condições que tem baixo salário ou que num trabalha... pra que em vez de fazer camapnha pra fome... pra que num num ficasse fazendo filho né? sem ter... e tá muito difícil filho... pedindo coisa no farol usando droga (...)

Entre todas as ocorrências de expressão de opinião, podemos observar que apenas a segunda não é precedida de verbos parentéticos ou epistêmicos. Nesse caso, o I expõe sua face ao dar sua opinião negativa sobre o prefeito da cidade. Em todos os outros casos entendemos que o I não faz uso do verbo achar por ter alguma dúvida sobre o que está sendo exposto, mas sim que aquele é um juízo seu. Os verbos epistêmicos situados à direita do enunciado funcionam como marcadores de opinião.

Apenas na ocorrência da linha 356 há a presença do atenuante muito, mitigando o conteúdo da fala do I.

\subsubsection{Invasão de território pessoal}

(13) E: mas cê brigou... cê brigou com quem?

(14) I: aí eu briguei c'o meu cunhado que ele tomou as dor dela

(15) E: mas cês brigaram assim de bri/ de bater [assim]?

(16) I: [isso] ... de soco... chute

(17) E: e machucou?

(18) I: não... teve uns arranhões éh... coisa pequena

Observa-se que a entrevistadora insiste na pergunta, correndo o risco de ameaçar a face do I. Acreditamos que com isso ela desvia um pouco a proposta da entrevista. No entanto, o I responde as perguntas solicitadas, sem demonstrar constrangimento. 


\subsubsection{Formas de tratamento}

O tratamento utilizado entre os participantes dessa entrevista é você e cê acompanhado de verbos na terceira pessoa do singular, o qual segue o paradigma de conjugação.

Abaixo apresentamos alguns exemplos, tanto do uso do pronome de tratamento, quanto dos outros pronomes encontrados, todos eles presentes na fala do E.

(02) bom queria que cê contasse uma história que aconteceu com VOCÊ assim... uma experiência pessoal sua... pode ser uma briga alguma coisa assim

(62) tem algum problema assim que cê teve assim alguma coisa que... te marcou assim que cê possa me contar?

(77) tem assim alguma história que alguém contou pra você... sua mãe contou ou algum uma arte que cê fez quando cê era criança... alguma coisa assim?

(94) e sua mãe te contou assim alguma história que/ dela como ela conheceu seu pai aconteceu alguma coisa com ela com o pai dela assim... lembra?

(107) mas cê num / e alguma coisa que ela conta do seu irmão num tem?... que ele fez quando era pequeno?... que cê num lembra mas que ela te com/ tenha te contado?

(198) ham... como que era sua casa lá?

(201) como que era o teu quarto?

(211) que cor que era tua casa?

(291) agora eu queria que cê desse sua opinião sobre alguma coisa... pode ser... assim por exemplo... cê / que cê acha do do nosso prefeito? Do Edinho?

Ao longo dessa entrevista, encontramos três tipos de pronomes: o pronome de tratamento utilizado no lugar do pronome pessoal do caso reto você, o pronome oblíquo te e alguns pronomes possessivos teu, tua, seu, sua.

Observamos regularidade de uso com relação aos dois primeiros pronomes mencionados, por isso retiramos apenas alguns exemplos para elucidar nossa análise, ainda que de acordo com a norma culta não seja a concordância mais indicada, pois o pronome oblíquo está na segunda pessoa do singular e o pronome pessoal na terceira.

Já com relação aos pronomes possessivos, nota-se certa irregularidade com relação aos usos de segunda e terceira pessoas, pois ora o entrevistador utiliza segunda pessoa ora utiliza terceira. Não conseguimos estabelecer nenhuma relação para tais usos, pois ambos os pronomes aparecem designando o mesmo substantivo, como nas linhas 198 e 211.

Podemos afirmar que essa entrevista está no eixo de solidariedade, confirmado tanto pelo uso dos pronomes citados quanto pela ausência de formas nominais. Fato já esperado, devido à idade dos participantes. 
Após a análise de todas as entrevistas pertencentes a esse corpus apresentaremos uma análise comparativa, a fim de que possamos elaborar um esquema de uso das formas de tratamento nessa região do Estado de São Paulo.

\subsection{Amostra 75}

Informante masculino - 34 anos

Entrevistador feminino - 22 anos

Tema 1 - História pessoal

\begin{tabular}{|l|l|l|}
\hline \multicolumn{1}{|c|}{ Perguntas Principais } & Perguntas complementares & \multicolumn{1}{|c|}{$\begin{array}{l}\text { Comentários / opiniões / } \\
\text { marcadores de interação }\end{array}$} \\
\hline (02) então tá... éh eu queria que & & (08) éh \\
cê contasse uma história pessoal & & $(11)$ é \\
sua assim & $(71)$ é isso daí \\
(39) tem alguma o(u)tra?... que & & $(72)$ então tá \\
cê lembra? & \\
(59) ele tava armado? & \\
(67) levou muito dinheiro? & \\
\hline
\end{tabular}

Tema 2 - História contada por terceiros

\begin{tabular}{|l|l|l|}
\hline \multicolumn{1}{|c|}{ Perguntas Principais } & Perguntas complementares & \multicolumn{1}{c|}{$\begin{array}{l}\text { Comentários / opiniões / } \\
\text { marcadores de interação }\end{array}$} \\
\hline $\begin{array}{l}\text { (75) bom agora eu queria que } \\
\text { cê contasse assim uma história } \\
\text { que alguém tenha contado assim } \\
\text { pra você }\end{array}$ & $\begin{array}{l}(119) \text { nossa } \\
(122) \text { demorou bem mais que o } \\
\text { (124) cê tem alguma outra? }\end{array}$ & \\
\hline
\end{tabular}

Tema 3 - Descrição de um lugar

\begin{tabular}{|l|l|l|}
\hline \multicolumn{1}{|c|}{ Perguntas Principais } & Perguntas complementares & $\begin{array}{l}\text { Comentários / opiniões / } \\
\text { marcadores de interação }\end{array}$ \\
\hline $\begin{array}{l}\text { (130) bom... agora eu queria } \\
\text { que cê descrevesse algum local } \\
\text { assim algum lugar bonito que } \\
\text { você já tenha ido conhecer } \\
\text { (150) cê se lembra onde cê } \\
\text { ficou hospedado assim como que } \\
\text { era o lugar? } \\
\text { (153) cê lembra como que era o } \\
\text { hotel assim pro cê descrever pra } \\
\text { mim? }\end{array}$ & \\
(155) mas quantante assim? & \\
assim? estrelas & & \\
(158) mas é como?... descreve & & \\
pra mim como que era assim & & \\
(mesmo)... (num importa) & & \\
(165) e cê fico/ tem algum outro & & \\
lugar que cê foi lá? Assim? Sem & & \\
ser... as cataratas? & \\
(178) como que era assim dentro & & \\
a decoração? & \\
(182) tem um outro lugar assim & & \\
\hline
\end{tabular}


po cê descrever pra mim assim?

Bem em detalhes?

Tema 4 - Receita

\begin{tabular}{|l|l|l|}
\hline \multicolumn{1}{|c|}{ Perguntas Principais } & Perguntas complementares & \multicolumn{1}{c|}{$\begin{array}{c}\text { Comentários / opiniões / } \\
\text { marcadores de interação }\end{array}$} \\
\hline $\begin{array}{l}\text { (206) bom... cê sabe cozinhar } \\
\text { alguma coisa? } \\
\text { (211) e como que faz? } \\
\begin{array}{l}\text { (231) num tem mais nenhum que } \\
\text { cê lembra assim que cê fazia } \\
\text { antes? }\end{array}\end{array}$ & $\begin{array}{l}\text { (243) como que joga?... no } \\
\text { caxeta?... por exemplo }\end{array}$ & $\begin{array}{l}(225) \text { a diferença é que... é } \\
\text { cozido na cerveja } \\
(265) \text { tá }\end{array}$ \\
$\begin{array}{l}\text { (235) doce assim cê nunca fez? } \\
\text { (239) e e o jogo... que cê você } \\
\text { sabe jogar algum? }\end{array}$ & & \\
\hline
\end{tabular}

Tema 5 - Opinião pessoal

\begin{tabular}{|l|l|l|}
\hline \multicolumn{1}{|c|}{ Perguntas Principais } & Perguntas complementares & $\begin{array}{l}\text { Comentários / opiniões / } \\
\text { marcadores de interação }\end{array}$ \\
\hline $\begin{array}{l}\text { (269) bom agora eu queria } \\
\text { assim que cê desse sua opinião } \\
\text { sobre alguma coisa... pode ser } \\
\text { política ou religião } \\
\text { (301) e so/ e sobre o que tá } \\
\text { acontecendo agora aq/ assim } \\
\text { com o Brasil com os deputados } \\
\text { que cê acha? }\end{array}$ & \\
\hline
\end{tabular}

Assim como todas as entrevistas que compõem esse corpus, observamos que há a divisão em cinco partes de acordo com as necessidades de informação que os organizadores do corpus estabeleceram.

Podemos observar que nessa entrevista o grau de planificação é relativamente baixo. O entrevistador (E) tem a preocupação em seguir a divisão de temas, mas aparentou não se preocupar com o conteúdo das perguntas. Comprovamos esse dado analisando os enunciados principais de cada tema. São demasiadamente abertos, é o informante quem escolhe o que deseja falar. Entendemos que isso acarreta falta de clareza no enunciado para o I. Assim, ele não entende que deve, por exemplo, descrever um ambiente minuciosamente, o que obriga o $\mathrm{E}$ a refazer algumas perguntas, insistindo em determinado tema. É certo que há que se considerar também as questões pessoais de cada informante. No caso dessa entrevista, o mesmo era bastante direto em suas respostas, não se prendendo a detalhes.

Com relação às perguntas elaboradas pelo entrevistador, observamos que quando o mesma deseja iniciar um novo tópico, ele faz uso de ato de preparação, no caso o verbo querer no Futuro do Pretérito. Esse dado foi observado em quatro, entre as cinco iniciações de novo tópico encontradas ao longo da entrevista. Por outro lado, é comum 
também o E utilizar outra estratégia de cortesia - dê opção ao seu interlocutor - ao utilizar o verbo lembrar, automaticamente há uma prevenção à ameaça a face do outro e a possibilidade de o I se negar a responder tal pergunta. Mais adiante, na análise comparativa apresentaremos os dados quantitativos de tal entrevista.

O grau de interação é bastante baixo, como podemos observar nas tabelas apresentadas, o E faz poucas intervenções tampouco expõe sua opinião.

\subsubsection{Desfocalização do eu}

Abaixo apresentamos as ocorrências encontradas, seguidas de breve análise.

(20) I: (...) um... uma dinâmica de grupo né? aquelas... coisa tudo que fazem quando cê vai... aquelas lavagem de... de mente que eles fazem né?...

(278) I: (...) num tem uma formação acadêmica alguma coisa assim... pra ser político porque... (então) a gente vê que / que que vê? Isso é tudo jogada de partido né?...

(284) I: (...) no caso o próprio governo deveria fazer... tipo d'um curso porque... pra você ser político nada mais é do que você administrar... eu dei exemplo de um vereador...

Observamos apenas essas três ocorrências de desfocalização do eu ao longo de toda a entrevista, sendo duas com o uso de você e sua respectiva forma própria da língua coloquial cê e uma com o uso de a gente. Nesse segundo caso, nota-se que há uma tentativa de afiliação de forma que o interlocutor partilhe da mesma opinião. Já o uso de você é uma forma generalizada de se referir a uma terceira pessoa. Na primeira ocorrência (linha 20) ele se refere a algo que aconteceu com ele mesmo, no entanto é como se todas as pessoas que passassem por uma dinâmica de grupo tivessem a mesma opinião e como se todas as dinâmicas fossem iguais, com os mesmos objetivos. Entendemos que é uma forma de aproximação do I com o E. No caso da segunda com você (linha 284) a generalização é ainda maior, essa sim não se refere nem ao I nem ao $\mathrm{E}$ mas a qualquer pessoa que deseja jogar caxeta ou fazer política.

\subsubsection{Prevenção de ameaça à face}

Observamos que essa prevenção pode ser encontrada tanto na fala do E quanto do I. Abaixo apresentamos as ocorrências observadas ao longo da análise:

(39) E: tem alguma outra?... que cê lembra?

(45) I: (...) e era uma noite de Natal de Ano Novo eu num me lembro era fim de ano uma noite assim... nós iríamos... passar...

(67) E: levou muito dinheiro?

(68) I: ah eu num me lembro

(87) I: (...) e a sogra brava... falava pro esposo dela - "ai C. eu/..." - não num é C... como é o nome dele?... me fugiu o nome do do sogro

(150) E: cê se lembra onde cê ficou hospedado assim como que era o lugar? 
(153) E: cê lembra como que era o hotel assim pro cê descrever pra mim?

(179) I: ah eu num lembro eu num lembro que era meio escuro sabe? Eu num realmente num lembro... eu sei que era bonita mas num... eu num... num num me lembro mesmo

(213) I: eu tomo a cerveja e mato a galinha eu to brincando eu num bebo éh... faz tempo que eu num faço eu sei que... eu refogava... o duro que agora eu num to lembrando certinho num vou lembrar certinho faz tanto tem que eu num faço eu sei que... eu refogava... a verdura lá... é que agora eu num lembro...

(228) I: (...) e eu achei interessante fiz e ficou bom as duas vezes que eu fiz ficou bom é que faz tempo e realmente eu nu/num lembro eu sei que o diferente mesmo é a cerveja né?

(231) E: num tem mais nenhum que cê lembra assim que cê fazia antes?

(244) I: caxeta é... você começa com... nove cartas né? que faz tempo que eu num faço... e é jogo éh... três jogos de três né? pra você... éh que nem eles falam bater com as nove né? (...) eu num lembro como que é ouro espada sete éh ouro espada copas... depois vem o outro eu num me lembro porque faz muito tempo que eu num jogo baralho né? faz muito tempo mesmo...

(272) I: bom eu... religião eu num... num tenho o que opinar porque eu sou evangélico... num num num gosto de discutir né? eu acho...

Observamos que há nessa entrevista exemplos diferentes de prevenção de ameaça à face. $\mathrm{Na}$ fala do E estão aquelas já mencionadas anteriormente destinadas a prevenir uma ameaça à face do I, caso ele não se lembre do dado perguntado. A diversificação mencionada está presente na fala do I.

As ocorrências encontradas nas linhas 213, 228 e 244, além de apresentarem a prevenção utilizando a evasiva de não se lembrar, apresentam também a justificativa do tempo que o I leva sem executar a ação descrita, no caso preparar a receita e jogar caxeta. Além disso, a ocorrência 213 também apresenta a expressão eu to brincando cuja função é atenuar o início da fala do I, no qual em vez de descrever como faz o frango na cerveja, ele diz que mata o frango e toma a cerveja. Já o trecho encontrado na linha 272 também previne sua própria face pelo fato de não querer expor sua opinião sobre religião, seja a sua ou qualquer outra e as demais ocorrências previnem também a face do próprio I pelo fato de ele não se recordar totalmente do fato, caso o mesmo não esteja totalmente correto.

\subsubsection{Ameaça à face}

Abaixo apresentamos as ocorrências que consideramos ameaçadoras da face de um dos participantes da entrevista.

(124) E: cê tem alguma outra?

(125) I: não tá bom de história né?

(126) E: ((risos))

(127) I: tá bom de história ((fala rindo))

É certo que a posição do E dentro da entrevista não permite que ele se ofenda com uma colocação dessas ou deixe transparecer que tem sua imagem ameaçada. Porém, não 
resta dúvidas que havia outras maneiras de o I encerrar esse tema mais sutilmente, dizendo, por exemplo, que não se lembrava de nenhuma outra história.

\subsubsection{Atenuantes}

Ao longo de toda essa entrevista, encontramos apenas uma ocorrência:

(301) E: e sobre o que tá acontecendo agora aq/ assim com o Brasil com os deputados que cê acha?

(302) I: oh vou ser sincero eu num tenho acompanhado muito... tá se perguntar pra mim sobre... esse negócio do Correio aí esse... foge até o nem/ eu num lem/ eu num tenho acompanhado muito... o que eu posso dizer...

O I faz uso do advérbio de intensidade muito visando atenuar o fato de não poder responder o que lhe foi perguntado pelo E. É interessante observar a ênfase desse uso, pois há a repetição da mesma frase reforçando também uma proteção a sua própria face.

\subsubsection{Expressão de opinião}

(272) (...) eu sou evangélico... num num num gosto de discutir né? eu acho que... a palavra é bem clara... mas eu tenho... assim uma ideia minha... que sobre a política... você pega aí... vamos pegar pela nossa cidade né? São José do Rio Preto... na época de política você vê vários candidatos que aparecem na televisão aí cê vê que a pessoa realmente... não... por ela assim mas ela num tem um... num vou falar um nível cultural mas vou falar assim num tem um nível de estudo né?... eu penso assim a pessoa pra ser político eu sempre comentei isso com várias pessoas... eu acho que ela teria que ter num vou falar uma faculdade porque seria aí uma coisa cara muitos não teriam condições de pagar... mas eu acho que... a própria prefeitura no caso o próprio governo deveria fazer...

Como se pode observar na tabela apresentada no início dessa análise, o E deu opções de resposta ao I quando elaborou sua pergunta. Ao responder o I utilizou dois verbos epistêmicos: pensar e achar. Entendemos sua resposta como mera exposição de sua opinião. Verifica-se que já no início de sua resposta o I expõe a sua religião, mas já indica que não quer discutir o tema. Além disso, faz uso da estratégia de desfocalização do eu para compartilhar a responsabilidade do que é dito. Ou seja, não é apena ele quem vê os políticos fazendo promessas em época de eleição, mas sim qualquer pessoa.

\subsubsection{Formas de tratamento}

O tratamento utilizado entre os participantes dessa entrevista é você e cê acompanhado de verbos na terceira pessoa do singular, o qual segue o paradigma de conjugação mais indicado pela norma culta da Língua Portuguesa.

Abaixo apresentamos alguns exemplos, tanto do uso do pronome de tratamento, quanto dos outros pronomes encontrados, todos eles presentes na fala do E.

(02) então tá... éh eu queria que cê contasse uma história pessoal sua assim (130) bom... agora eu queria que cê descrevesse algum local assim algum lugar bonito que você já tenha ido conhecer 
(269) bom agora eu queria assim que cê desse sua opinião sobre alguma coisa... pode ser política ou religião

Essa entrevista apresenta apenas dois tipos de pronomes: o pronome de tratamento você e sua forma abreviada comum na língua coloquial $c \hat{e}$ e o pronome possessivo sua, o qual aparece duas vezes ao longo de toda a entrevista.

Com relação aos pronomes utilizados, observa-se regularidade tanto no uso do pronome você quanto no uso do pronome possessivo, pois os verbos que acompanham o pronome pessoal sempre estão na terceira pessoa do singular e o pronome possessivo também é apresentado na terceira pessoa do singular, estabelecendo concordância entre os mesmos.

Ressaltamos que não estabelecemos como critério a análise quantitativa de uso de $c \hat{e}$ ou você, pois entendemos que não é um dado relevante para nossa pesquisa, no entanto cabe destacar que nessa entrevista a presença da forma abreviada é mais frequente do que a forma normal do pronome.

Podemos afirmar que essa entrevista está no eixo de solidariedade e como esperado, devido a idade dos participantes, não há a presença de formas nominais.

\subsection{Amostra 76}

Informante feminino -28 anos

Entrevistador feminino - 19 anos

Tema 1 - O namorado

\begin{tabular}{|l|l|l|}
\hline \multicolumn{1}{|c|}{ Perguntas Principais } & Perguntas complementares & \multicolumn{1}{c|}{$\begin{array}{c}\text { Comentários / opiniões / } \\
\text { marcadores de interação }\end{array}$} \\
\hline $\begin{array}{l}\text { (02) K. agora você pode me } \\
\text { fala(r) então... alguma coisa que } \\
\text { aconteceu com você... uma } \\
\text { história que você tenha vivido } \\
\text { que foi legal que te marcou? }\end{array}$ & $\begin{array}{l}\text { (12) (ninguém te contou né?) } \\
\text { (71) é alguma coisa né }\end{array}$ & $\begin{array}{l}\text { (23) que coisa } \\
\text { (38) um horror } \\
\text { (106) certo... (o)brigada }\end{array}$ \\
$\begin{array}{l}\text { (98) e todo mundo aceitou numa } \\
\text { boa? } \\
\text { (102) mas você tem filhos no } \\
\text { primeiro casamento ou não? }\end{array}$ & & \\
\hline
\end{tabular}

Tema 2 - O casamento dos pais

\begin{tabular}{|l|l|l|}
\hline \multicolumn{1}{|c|}{ Perguntas Principais } & Perguntas complementares & \multicolumn{1}{c|}{$\begin{array}{c}\text { Comentários / opiniões / } \\
\text { marcadores de interação }\end{array}$} \\
\hline $\begin{array}{l}\text { (110) K. agora você pode me } \\
\text { contar... uma história que }\end{array}$ & $\begin{array}{l}\text { (132) do mesmo jeito? } \\
\text { (134) e por que ele num queria? }\end{array}$ & $\begin{array}{l}(135) \text { ah certo } \\
\text { alguém te contou... éh pode ser... }\end{array}$ \\
$\begin{array}{l}\text { o casamento da sua mãe... éh... } \\
\text { qualquer coisa que alguém tenha }\end{array}$ & $(148)$ é ber quê? melhor? & \\
\hline
\end{tabular}


te contado que você NÃO tenha participado

(137) mas ele tinha outros pretendentes já tinha em mente outros pra tua mãe?

Tema 3 - Descrição de um lugar

\begin{tabular}{|l|l|l|}
\hline \multicolumn{1}{|c|}{ Perguntas Principais } & Perguntas complementares & \multicolumn{1}{|c|}{$\begin{array}{c}\text { Comentários / opiniões / } \\
\text { marcadores de interação }\end{array}$} \\
\hline $\begin{array}{l}\text { (152) K. agora você pode me } \\
\text { descrever... algum lugar... o } \\
\text { lugar que você mais gosta o }\end{array}$ & $\begin{array}{l}(172) \text { mas fica logo atrás... } \\
\text { pertinho? }\end{array}$ & (258) certo... (o)brigada K. \\
lugar que você trabalha... pode & $\begin{array}{l}\text { celas são grandes as celas dos } \\
\text { me contar...os detalhes como é } \\
\text { animais? }\end{array}$ & \\
(187) eles ficam num lugar & $(225)$ e o centro... é novo é... & \\
aberto ou fechado? & $\begin{array}{l}\text { assim a aparência dele? } \\
\text { (189) mas num tem nenhum }\end{array}$ & \\
lugar aberto? & $(227)$ é velho? & \\
\hline
\end{tabular}

Tema 4 - Receita

\begin{tabular}{|l|l|l|}
\hline \multicolumn{1}{|c|}{ Perguntas Principais } & Perguntas complementares & \multicolumn{1}{c|}{$\begin{array}{c}\text { Comentários / opiniões / } \\
\text { marcadores de interação }\end{array}$} \\
\hline $\begin{array}{l}\text { (262) éh agora K. cê pode me } \\
\text { ensinar como / alguma receita } \\
\text { como faz alguma comida? } \\
\text { Qualquer coisa }\end{array}$ & $\begin{array}{l}\text { (267) é gostoso? } \\
\text { (295) só um pouquinho? } \\
\text { (307) ham e rende bastante? }\end{array}$ & \\
\hline
\end{tabular}

Tema 5 - Relato de opinião

\begin{tabular}{|c|c|c|}
\hline Perguntas Principais & Perguntas complementares & $\begin{array}{l}\text { Comentários / opiniões / } \\
\text { marcadores de interação }\end{array}$ \\
\hline $\begin{array}{l}\text { (311) bom K. agora você pode } \\
\text { me falar que a gente tava } \\
\text { falando dos animais né? do } \\
\text { Centro... tem como você me } \\
\text { falar assim o que você pensa das } \\
\text { pessoas que deixam os animais } \\
\text { lá... daqueles que maltratam? }\end{array}$ & $\begin{array}{l}\text { (395) é e o presidente podia } \\
\text { ajudar né? } \\
\text { (403) éh é fácil né? } \\
\text { (407) éh ninguém dá mesmo } \\
\text { valor né? } \\
\text { (415) é a grande fase né? } \\
\text { (429) e tapam os olhos né? }\end{array}$ & $\begin{array}{l}\text { (347) e daí abandonar maltratar } \\
\text { (352) é verdade } \\
(358) \text { num / nem aí } \\
\text { (381) é e a punção éh... às vezes } \\
\text { num vem mesmo } \\
\text { (440) é são... ingênuos inocentes } \\
\text { do mesmo jeito independentes } \\
\text { (445) é... tá jóia K. (O)brigada } \\
\text { por ter ajudado a gente no } \\
\text { projeto de pesquisa... (o)brigada } \\
\text { mesmo } \\
\text { (448) tá joia }\end{array}$ \\
\hline
\end{tabular}

Observamos que essa entrevista segue o padrão estabelecido pelos organizadores do corpus brasileiro, no qual a mesma é dividida em cinco partes. A característica específica dessa amostra é o entrevistador (E) prolongar o tema até obter o relato desejado, feito isso, encerra esse tema e inicia outro.

O nível de planificação é baixo, sendo que o E aproveita as próprias respostas do I para elaborar novas perguntas. Observa-se que há certa interação entre entrevistador e informante. Essa afirmação é baseada nas interrupções do E na fala do I, mostrando que participa da conversa ativamente, sobretudo quando o I faz um relato de opinião. 
Com relação às perguntas principais feitas pelo E, podemos observar que toda vez que se inicia um novo tópico, há o uso do verbo performativo poder no presente do indicativo e os enunciados seguintes são constituídos de perguntas diretas sem uso de imperativo ou atos de preparação.

\subsubsection{Desfocalização do eu}

Abaixo apresentamos os exemplos desse tipo de ocorrência encontrados ao longo dessa amostra.

(315) I: (...) o que falta é educação... as pessoas têm que ter noção que quando você pega um animal... o tempo médio de vida é de dez anos (...) então são dez anos que você vai ter que... alimentar... você vai ter que... é recolher a sujeira dele... você vai ter que levar no veterinário dar banho você vai ter que cuidar quando ele tiver uma doença mais séria você vai ter gastos com veterinário...

(333) (...) se a pessoa der uma boa alimentação...

(338) (...) as pessoas não têm consciência elas dão comida pra cachorro...

(363) (...) é um problema estrutural da sociedade ... e que o governo não vê... o poder público não vê ... e as pessoas que estão no poder público...

(382) (...) a sociedade está doente... a sociedade não percebe...

(386) (...) a sociedade eu digo que é como um gafanhoto... que vem e destrói a plantação ...

(400) I: (...) porque todo filhote é lindo você pega um animal ele é lindo... quando ele cresce ele num fica do jeito que você achava que ele iria ficar e coloca ele na rua

Observa-se que todas as ocorrências estão presentes na fala do informante e que há a forma você como desfocalização do $e u$. Para se referir às pessoas de maneira geral, o I faz uso de expressões como as pessoas, a sociedade, o ser humano, sempre com a intenção de se referir às pessoas que abandonam animais nas ruas. Ao fazer uso de tais expressões, o I generaliza o conteúdo da fala, não se comprometendo com o conteúdo de sua fala.

\subsubsection{Prevenção de ameaça à face}

Abaixo apresentamos as ocorrências encontradas, seguidas de breve análise.

(15) I: (...) tinha uma república... numa/ num lugarzinho chamado (Kama)... num sei... se é do seu tempo mas eles fechavam o prédio embaixo...

(155)I: tem um lugar que não que eu goste mas que me sinto bem quando eu vou lá fazer alguma coisa que é o Centro de Zoonoses... éh... não é grande eu num sei te falar a metragem... ele tem uma área...

(182) I: (...) ela é separada... é uma casinha... éh eu nunca entrei lá sei que lá fica a/ éh a parte administrativa mesmo... o veterinário fica lá... eu num sei o que tem... lá porque a gente num tem acesso... éh... depois na lateral...

(218) I: (...) bem lá no fundo... que tem terra e tem uma árvore eu num sei bem do que que é essa árvore... mas ela faz sombra...

(228) I: a... a estrutura dele é bem antiga... eu até num se/ ... num sei bem quantos anos tem... é um prédio antigo...

(264) I: oh como eu num sou uma excelente cozinheira... é só um doce... porque esse eu sei e eu gosto éh... tem gente que chama de torta de bombom... né?... éh... eu esqueci o nome que eu dava pra isso

(425) I: (...) e eu fico muito revoltada porque eu não sou uma pessoa à toa... eu trabalho quarenta e quatro horas semanais... e no meu final de semana que eu poderia tá dormindo... eu vou lá... eu acho assim eu num sou louca... to tentando sanar um problema que a sociedade tá criando... e infelizmente 
Podemos afirmar que, basicamente, há dois tipos de prevenção de ameaça à face nessa entrevista e que todas elas são proferidas pelo informante tentando proteger sua própria face em primeiro lugar e com exceção de uma ocorrência a face do E também.

Exceto o último excerto, todos os anteriores são exemplos de proteção a ambas as faces, pois ao deixar claro que se esqueceu de algo ou que não sabe exatamente dados específicos do que está sendo contado, como por exemplo, a metragem de um espaço, a espécie de árvore, etc. o informante protege a sua face, caso o dado passado esteja incorreto e também a face do entrevistador que certamente evitará perguntas mais específicas.

Já o último excerto é um exemplo de justificativa, na qual o informante pretende prevenir-se de possíveis julgamentos do entrevistador. Assim, ele explica porque pensa ou age de determinada maneira buscando a compreensão do outro.

\subsubsection{Ameaça à face}

Encontramos nessa entrevista apenas uma ocorrência que interpretamos como uma ameaça à face. Logo no início da entrevista, o informante faz uma exposição de sua vida pessoal e consequentemente expõe também sua face. Abaixo, citamos o trecho:

(04) I: hum... foi meu namoro... com o C... éh a gente já se conhecia... há uns dois anos na época eu era casada e a gente tinha amizade eu ia muito no Correio onde ele trabalhava... então a gente já se via lá e falava brincava né? tinha amizade com todo mundo do Correio... e aí eu comecei a frequentar o Cursinho Alternativo e ele também fazia cursinho então a gente se via mais no cursinho...

O tema dessa pergunta foi criado pelo próprio informante, uma vez que a pergunta que o antecedia pedia que o mesmo contasse uma história que marcou a sua vida. Entendemos que ao expor sua vida pessoal dessa forma, o informante dá abertura para que o entrevistador lhe faça perguntas ainda mais íntimas, criando espaço para que haja certa invasão de seu território pessoal.

\subsubsection{Atenuantes}

(225) E: e o centro... é novo é... assim a aparência dele?

(226) I: não... é velho

(227) E: é velho?

(228) I: a... a estrutura dele é bem antiga... eu até num se/... num sei bem quantos anos tem... é um prédio antigo num sei nem se sempre foi Centro de Zoonoses...

Com relação aos elementos de atenuação, essa foi a única ocorrência encontrada. Observa-se que o informante atenua sua própria fala anterior, pois na resposta imediata 
houve a utilização do adjetivo velho e posteriormente uma espécie de eufemismo, ao designar a estrutura como bem antiga.

\subsubsection{Expressão de opinião}

Abaixo apresentamos as ocorrências de expressão de opinião encontradas ao longo dessa amostra. Todas elas presentes na fala do I.

(314) como muitas coisas que tem nesse país... e outras também não vou só criticar esse... o que falta é educação... as pessoas têm que ter noção que quando você pega um animal... o tempo médio de vida é de dez anos (...) então são dez anos que você vai ter que... alimentar... você vai ter que... é recolher a sujeira dele... você vai ter que levar no veterinário dar banho você vai ter que cuidar quando ele tiver uma doença mais séria você vai ter gastos com veterinário...

(348) olha aí abandonar e maltratar é algo inconcebível... uma pessoa que tem coragem... de deixar um animal na RUA... porque na rua ele vai passar fome... sede...frio...vai ser judiado... uma pessoa que é capaz de catar um animal e deixar na rua sabendo que ele vai sofrer tudo isso... é uma pessoa muito cruel

(362) (...) então é um / é um problema estrutural da sociedade... e que o governo não vê... o poder público não vê... e as pessoas que estão no poder público que não é só o poder público participam desse poder público de outra forma... elegendo éh indiretamente vamos dizer assim... elas também não se preocupam com isso... então sós os ditos loucos... que é eu e o pessoal que tá na associação de proteção...

(382) num vem mesmo... então éh a sociedade está doente... a sociedade não percebe... que ela precisa dessa relação éh natureza éh a cri/ a criatura e a criação tudo que ela cria ela... tem que destruir pra depois criar entendeu? ela cria um edifício ela destrói a natureza... então ela num consegue ter uma interação bacana...

(398) ... a sensação que eu tenho terra de ninguém... hoje você coloca um animal na sua casa amanhã você decide que/ porque todo filhote é lindo você pega um animal ele é lindo...

(420) (...) infelizmente o ser humano vai pagar um preço muito alto... tem mesmo que tenta controlar os loucos que ficam tentando... brigar contra éh... pessoas que fazem parte de / de grupos ecológicos de proteção aos animais... essas pessoas que ficam gritando o tempo todo ninguém ouve... são loucos... são pessoas que num tem nada pra fazer são pessoas à toa...

O I é bastante enfático ao expressar suas opiniões. Ele faz uso de expressão parentética ou epistêmica apenas na linha 398. Nas outras ocorrências, como pode ser observado pelo destaque em negrito, o I utiliza-se da desfocalização do eu ou de termos abrangentes como a sociedade ou o ser humano para atenuar suas críticas. Assim, essas são dirigidas a qualquer pessoa, sem haver a necessidade de especificação da mesma, isentando-o da responsabilidade do conteúdo da fala.

\subsubsection{Cortesia valorizante}

Com relação às ocorrências de cortesia valorizante, a única encontrada é a que se refere aos atos de agradecimento. Abaixo apresentamos os excertos:

(106) E: certo... obrigada

(107) I: nada

(258) E: certo... obrigada K.

(259) I: por nada

(445) E: é... tá joia K. obrigada... por ter ajudado a gente no projeto de pesquisa... obrigado mesmo

(446) I: por nada

(447) E: tá joia 
Os dois primeiros exemplos foram encontrados na mudança de tópico. É interessante observar que independentemente do uso ou não de agradecimento, o E inicia o tópico seguinte da mesma maneira. Chama mais atenção o último exemplo desse tipo de cortesia, no qual o E é bastante enfático em justificar tal agradecimento.

\subsubsection{Invasão do território pessoal}

Além da resposta dada à primeira pergunta, na qual, como já apontado anteriormente, o informante criou espaço para que o $\mathrm{E}$ lhe fizesse perguntas sobre sua vida pessoal, ocorreu uma segunda situação em que o E se mostrou bastante discreto, procurando não invadir o território pessoal do I. O I conta que os avós não queriam o casamento de seus pais e após a descrição de toda a história, há a seguinte sequência de falas:

(132) E: do mesmo jeito?

(133) I: do mesmo jeito

(134) E: e por que que ele num queria?

(135) I: ele num gostava do meu pai / ele não a/ ele num queria que minha mãe casasse com meu pai

(135) E: ah certo

Em princípio houve a pergunta, mas após a resposta vaga do I, não houve insistência, de forma que o E evita invadir o território pessoal do I.

\subsubsection{Formas de tratamento}

O tratamento utilizado entre os participantes dessa entrevista é você e cê acompanhado de verbos na terceira pessoa do singular, o qual segue o paradigma de conjugação indicado pela norma culta da Língua Portuguesa.

Abaixo apresentamos alguns exemplos, tanto do uso do pronome de tratamento, quanto dos outros pronomes encontrados, todos retirados da fala do $\mathrm{E}$.

(02) K. agora você pode me fala(r) então... alguma coisa que aconteceu com você... uma história que você tenha vivido que foi legal que te marcou?

(110) K. agora você pode me contar... uma história que alguém te contou... éh pode ser... o casamento da sua mãe... éh... qualquer coisa que alguém tenha te contado que você NÃO tenha participado

(137) mas ele tinha outros pretendentes já tinha em mente outros pra tua mãe?

Ao longo dessa entrevista, encontramos três tipos de pronomes: o pronome de tratamento utilizado no lugar do pronome pessoal do caso reto você e sua forma abreviada cê, o pronome oblíquo te e os possessivos tua e sua.

Observamos regularidade de uso com relação aos dois primeiros pronomes mencionados, por isso retiramos apenas alguns exemplos para elucidar nossa análise, 
ainda que de acordo com a norma culta não seja a concordância indicada, pois o pronome oblíquo está na segunda pessoa do singular e o pronome pessoal na terceira.

Já com relação aos pronomes possessivos, nota-se certa irregularidade com relação aos usos de segunda e terceira pessoas, pois ora o entrevistador utiliza segunda pessoa ora utiliza terceira. Não conseguimos estabelecer nenhuma relação para tais usos, pois ambos pronomes aparecem designando o mesmo substantivo, como nas linhas $110 \mathrm{e}$ 137.

Essa é a segunda amostra desse corpus que apresenta tal irregularidade. Após a análise de todas as entrevistas apresentaremos uma análise comparativa, a fim de que possamos elaborar um esquema de uso das formas de tratamento nessa região do Estado de São Paulo.

Essa entrevista está no eixo de solidariedade e como esperado, não há a presença de formas nominais.

\subsection{Amostra 80}

Informante feminino - 29 anos

Entrevistador feminino - 22 anos

Tema 1 - História pessoal

\begin{tabular}{|c|c|c|}
\hline Perguntas Principais & Perguntas complementares & $\begin{array}{l}\text { Comentários / opiniões / } \\
\text { marcadores de interação }\end{array}$ \\
\hline $\begin{array}{l}\text { (02) F. eu quero... gostaria } \\
\text { agora que você me contasse } \\
\text { uma... um fato na sua vida } \\
\text { alguma coisa que tenha } \\
\text { acontecido com você em algum } \\
\text { momento da sua vida } \\
\text { (51) no que cê trabalhava? }\end{array}$ & $\begin{array}{l}\text { (31) cê poderia ter escolhido o } \\
\text { Anglo? } \\
\text { (39) cê deixou de estudar? }\end{array}$ & $\begin{array}{l}\text { (33) ah } \\
\text { (49) sei cansada }\end{array}$ \\
\hline
\end{tabular}

Tema 2 - História contada por terceiros

\begin{tabular}{|c|c|c|}
\hline Perguntas Principais & Perguntas complementares & $\begin{array}{l}\text { Comentários / opiniões / } \\
\text { marcadores de interação }\end{array}$ \\
\hline $\begin{array}{l}\text { (63) F. olha... agora eu quero } \\
\text { que você me conta... uma } \\
\text { história que tenha acontecido } \\
\text { com alguém... que você não } \\
\text { esteve presente né? que alguém } \\
\text { tenha te contado essa história } \\
\text { (70) ela era fogueteira como } \\
\text { assim? Namoradeira? }\end{array}$ & $\begin{array}{l}\text { (85) todos tava atolando? } \\
\text { (90) tudo em cima } \\
\text { (96) ela num tava nem ligando? } \\
\text { (99) mas durou vinte e cinco } \\
\text { anos ainda? }\end{array}$ & $\begin{array}{l}\text { (66) hum } \\
(67) \text { hum } \\
\text { (71) hum tá } \\
\text { (76) meio que pra fazer pirraça } \\
\text { assim } \\
\text { (83) nossa } \\
\text { (101) até que durou bastante } \\
\text { então } \\
\text { (108) nossa... tá certo }\end{array}$ \\
\hline
\end{tabular}


Tema 3 - Descrição de um lugar que a E gosta

\begin{tabular}{|c|c|c|}
\hline Perguntas Principais & Perguntas complementares & $\begin{array}{l}\text { Comentários / opiniões / } \\
\text { marcadores de interação }\end{array}$ \\
\hline $\begin{array}{l}\text { (111) F. agora eu quero que } \\
\text { você... me descre/ me descreva } \\
\text { um local... me mostra pra mim } \\
\text { como que ele é assim só me } \\
\text { descrevendo falando como que } \\
\text { ele é }\end{array}$ & $\begin{array}{l}\text { (121) fica tudo na cozinha né? } \\
\text { (133) ele é pequeno o seu } \\
\text { quarto? } \\
\text { (143) aí como/ essa cozinha o } \\
\text { que tem? O que que você tem na } \\
\text { cozinha? } \\
\text { (155) essa varanda aí no fundo } \\
\text { ela é pequena? } \\
\text { (160) aquela feita mesmo de } \\
\text { tijolo assim? }\end{array}$ & $\begin{array}{l}\text { (128) mas é verdade } \\
\text { (141) tudo... toda casa tem um } \\
\text { quarto da bagunça também né? } \\
\text { (164) isso é verdade é } \\
\text { (167) ah já tá quase pronta então }\end{array}$ \\
\hline
\end{tabular}

Tema 4 - Receita

\begin{tabular}{|c|c|c|}
\hline Perguntas Principais & Perguntas complementares & $\begin{array}{l}\text { Comentários / opiniões / } \\
\text { marcadores de interação }\end{array}$ \\
\hline $\begin{array}{l}\text { (177) F. cê tá me falando que } \\
\text { você sabe fazer panqueca não é? } \\
\text { (179) então conta pra gente } \\
\text { como é que você faz } \\
\text { (194) explica pra gente como } \\
\text { que é esse molho também }\end{array}$ & $\begin{array}{l}\text { (198) uhum ficar douradinha? } \\
\text { (209) latinha pequena? } \\
\text { (226) quanto tempo que fica no } \\
\text { forno? }\end{array}$ & $\begin{array}{l}\text { (185) só isso } \\
(211) \text { meia da/ da latinha } \\
\text { pequena } \\
\text { (223) ai que ruim } \\
(228) \text { só pó queijo derreter } \\
\text { mesmo } \\
\text { (234) nossa... que delícia hein F. } \\
\text { (238) sei } \\
\text { (239) nossa... que coisa deliciosa }\end{array}$ \\
\hline
\end{tabular}

Tema 5 - Opinião pessoal

\begin{tabular}{|c|c|c|}
\hline Perguntas Principais & Perguntas complementares & $\begin{array}{l}\text { Comentários / opiniões / } \\
\text { marcadores de interação }\end{array}$ \\
\hline $\begin{array}{l}\text { (243) F... o que você acha o que } \\
\text { que você pensa sobre... é a } \\
\text { questão da extensão de vagas na } \\
\text { universidade? } \\
\text { (299) cê acha que o seu filho não } \\
\text { vai ter... uma uma faculdade } \\
\text { pública... com qualidade como é } \\
\text { hoje se continuar assim }\end{array}$ & $\begin{array}{l}\text { (267) acham que é uma } \\
\text { maravilha né? } \\
\text { (278) como que cê acha que vai } \\
\text { ser o desfecho? } \\
\text { (288) ainda... mais sendo uma } \\
\text { faculdade de medicina não é? }\end{array}$ & $\begin{array}{l}\text { (274) claro } \\
(315) \text { hum }\end{array}$ \\
\hline
\end{tabular}

Seguindo a estrutura determinada pelos organizadores do corpus, essa entrevista também está dividida em cinco partes.

O nível de planificação pode ser equiparado ao das outras entrevistas, no entanto nota-se maior interação entre os participantes, caracterizado pela maior fluidez do diálogo. Observamos que o E se preocupou em fazer perguntas mais objetivas, de forma que as respostas fossem mais precisas, evitando a necessidade de repeti-las.

Com relação às perguntas principais, observamos que com exceção do tópico que pede a descrição de uma receita, em todos os outros a primeira pergunta é elaborada com o apoio de verbos performativos, na sequência o $\mathrm{E}$ já faz perguntas diretas ou com verbo no imperativo. É uma espécie de preparação ao novo tópico, dispensando-se o uso de tais verbos nas perguntas seguintes. 
O E consegue desempenhar bem o seu papel por também saber aproveitar a própria fala do I para criar os temas de suas perguntas. Dessa forma, fica mais fácil o I falar sobre algo conhecido. Assim, observamos que ele aproveita a resposta da primeira pergunta para tratar do relato de opinião, pois o I já havia dado indícios de que poderia falar sobre educação. Esse fato explica a baixa planificação existente ao longo da entrevista.

A participação ativa do E durante as respostas do I favorece a interação entre os participantes, nota-se que há liberdade para que o E também dê sua opinião sobre o tema que está sendo tratado ou até teça comentários sobre os mesmos.

\subsubsection{Desfocalização do $e u$}

Abaixo apresentamos as ocorrências encontradas com esse tipo de atenuação, todos retirados da fala do I.

(15) (...) fosse aguçando a minha vontade de querer entrar na faculdade... mas aí vem as dificuldades... porque você num tem orientação... que eu convivia...

(124) (...) então num tem aquele horário pra ficar... à toa conversando então... cê chega e se acomoda na cozinha...

(161) a própria mesmo não a de campana a de campana que a gente fala que é... feita ele/ eles falam que eu não entendo muito eles falam... que é de roda de caminhão

(250) (...) profissionais adequados... pra que não se fique aí... no vento... como a gente vê... a gente tem uma afinidade em alguns casos aí... os alunos em si não se reparam mas nós que trabalhamos... nós vemos que...

(265) (...) porque há pessoas que acham que isso... tá levando o nome da universidade

Nessa entrevista há esses seis casos de desfocalização. Interpretamos os dois primeiros como uma maneira de o I se referir de maneira generalizada, ainda que se observe claramente que está falando dele mesmo.

No terceiro exemplo, ele também se refere de maneira generalizada, porém envolve ele e outras pessoas que não aparecem no diálogo, no caso as pessoas que como ele nomeiam a churrasqueira feita com roda de caminhão.

Já no quarto e quinto exemplos, entendemos que o I busca uma afiliação de suas ideias com as do E, é como ao usar tanto a gente como nós ele se referisse a ele e ao E, embora esteja falando dele mesmo. Ao envolver o E em sua fala, há consequentemente um aumento da interação. É como se o outro compartilhasse as mesmas ideias.

A última ocorrência refere-se a uma expressão geral, o I utiliza o termo as pessoas sem especificar quem são essas pessoas, eximindo-se da responsabilidade do conteúdo da fala. 


\subsubsection{Prevenção de ameaça à face}

Abaixo apresentamos as ocorrências encontradas, seguidas de breve análise.

(161) I: a própria mesmo não a de campana a de campana que a gente fala que é... feita ele/ eles falam que eu não entendo muito eles falam... que é de roda de caminhão

(291) I: (...) e plantões consomem... é... o número eu num sei dizer mais... uma... uma pos/ uma postura de três vezes a quatro vezes mais...

Esses são os únicos exemplos de prevenção encontrados ao longo dessa entrevista. Observa-se que ao dizer que não entende muito e ao deixar claro que não sabe o número exato o I previne uma ameaça a sua própria face, pois evita que o $\mathrm{E}$ lhe faça perguntas mais aprofundadas sobre o tema, prevenindo também a face do outro de uma possível ameaça.

\subsubsection{Ameaça à face}

Há apenas uma ocorrência ao longo de toda a entrevista.

(36) I: minha irmã... e a sustentar a casa... que meu pai tinha problema com alcoolismo... então era sempre... ali... em si...

Entendemos que com esse tipo de declaração o I expõe sua face ao ponto de ameaçá-la, no entanto o E se mostrou bastante discreto e não fez nenhum tipo de pergunta com a intenção de se aprofundar na declaração do I, evitando também a invasão de seu território pessoal. Salientamos que a pergunta que antecede essa declaração não tinha relação alguma com a mesma. Entendemos que foi apenas uma forma de o I justificar o motivo de precisar estudar no período noturno.

\subsubsection{Expressão de opinião}

As expressões de opinião são encontradas apenas na última parte da entrevista, cujo objetivo é obter esse tipo de resposta. Abaixo apresentamos os exemplos encontrados, todos retirados da fala do I. Salientamos que as respostas na íntegra podem ser encontradas nos anexos desse trabalho.

(245) olha... eu acho que a extensão... é uma melhoria... pra... pra quem... quer entrar na universidade... pública... desde que seja feita com responsabilidade... no momento que foi feito que tá sendo feito... do meu ponto de vista... é irresponsável... porque extensão de vagas é... mais alunos... que precisam (...) por mim a extensão é boa desde que tenha condições... tanto para... alunos... funcionários e docentes...

(268) e é uma mara/... que é uma maravilha... mas esquece de ver que a qualidade... isso pra mim tá sendo de péssima qualidade porque vai formar... péssimos profissionais... depois esses profissionais vão servir a comunidade (...) então eu acho que deveria se repensar... e... se olhar novamente... pra que não caminhem pro pr'um buraco sem fundo... como tá indo

(294) (...) sinceramente olhando eu tenho dó... de quem vem... pra entrar na universidade... em si... né... porque vai ser um ensino de péssima qualidade...

(301) eu acho que não... o que; o que dá pra ent/ pra se ver assim no futuro... longo... é aliás... perto a longo prazo como se diz aí fora... é a privatização... 
Observa-se que a todo momento há o cuidado, por parte do I em dizer que é o seu ponto de vista, sem generalizar ou atribuir essa fala a outras pessoas. Com exceção de apenas uma das ocorrências - linha 294- o I faz uso de verbos ou expressões epistêmicos em todas as outras. Não acreditamos que o uso de tais verbos ou expressões sejam indicadores de dúvida sobre o tema por parte do I, servindo meramente para apontar a sua opinião.

Além disso, não encontramos nenhum outro tipo de marcador de atenuação na tentativa de minimizar o conteúdo de sua fala.

\subsubsection{Cortesia valorizante}

Encontramos um único tipo de cortesia valorizante ao longo dessa entrevista. Abaixo expomos os trechos, seguidos de breve análise.

(223) E: ai que ruim

(234) E: nossa... que delícia hein F.

(239) E: nossa... que coisa deliciosa

Os outros três exemplos se referem ao momento em que o I descreve uma receita culinária e podem ser classificados como elogios ao prato em questão, favorecendo a face positiva do I.

Não encontramos nessa entrevista exemplos de marcadores de atenuação, bem como de invasão do território pessoal do I e de solidariedade entre os falantes.

\subsubsection{Formas de tratamento}

O tratamento utilizado entre os participantes dessa entrevista é você e cê acompanhado de verbos na terceira pessoa do singular, o qual segue o paradigma de conjugação indicado pela norma culta da Língua Portuguesa.

Abaixo apresentamos alguns exemplos, tanto do uso do pronome de tratamento, quanto dos outros pronomes encontrados, todos eles retirados da fala do E.

(02) F. eu quero... gostaria agora que você me contasse uma... um fato na sua vida alguma coisa que tenha acontecido com você em algum momento da sua vida

(63) F. olha... agora eu quero que você me conta... uma história que tenha acontecido com alguém... que você não esteve presente né? que alguém tenha te contado essa história

(133) ele é pequeno o seu quarto?

(299) cê acha que o seu filho não vai ter... uma uma faculdade pública... com qualidade como é hoje se continuar assim

Ao longo dessa entrevista, encontramos três tipos de pronomes: o pronome de tratamento utilizado no lugar do pronome pessoal do caso reto você e sua forma abreviada cê, o pronome oblíquo te e os possessivos seu e sua. 
Observamos regularidade de uso com relação a todos os pronomes mencionados, por isso retiramos apenas alguns exemplos do uso do pronome pessoal. Como já mencionamos anteriormente, de acordo com a norma culta, a concordância entre os pronomes pessoal e oblíquo não é a mais indicada, pois o pronome oblíquo está na segunda pessoa do singular e o pronome pessoal na terceira, no entanto ao longo de nossas análises podemos observar que tal uso é uma forma bastante recorrente na língua falada.

Com relação aos pronomes possessivos, também nota-se certa regularidade, pois em todas as ocorrências em que tal pronome é utilizado, o mesmo está na terceira pessoa do singular, concordando com o pronome você.

Essa entrevista está no eixo de solidariedade e não se observa a presença de formas nominais, fato esperado, devido à idade dos participantes envolvidos.

Após a análise de todas as entrevistas apresentaremos uma análise comparativa, a fim de que possamos elaborar um esquema de uso das formas de tratamento nessa região do Estado de São Paulo.

\subsection{Amostra 106}

Informante feminino - 40 anos

Entrevistador feminino - 22 anos

Tema 1 - História pessoal

\begin{tabular}{|c|c|c|}
\hline Perguntas Principais & Perguntas complementares & $\begin{array}{l}\text { Comentários / opiniões / } \\
\text { marcadores de interação }\end{array}$ \\
\hline $\begin{array}{l}\text { (08) o Vitor é o primeiro? } \\
\text { (109) e o que você acha... } \\
\text { daquelas pessoas que... } \\
\text { idolatram Maria? } \\
\text { (149) então assim você acha } \\
\text { que... quando as pessoas... } \\
\text { exaltam uma imagem na } \\
\text { realidade elas num tem } \\
\text { consciência daquilo que fazem } \\
\text { né? }\end{array}$ & $\begin{array}{l}\text { (31) nenhum dos dois? } \\
\text { (34) segue? } \\
\text { (238) já morava aqui também? } \\
\text { (275) as referências que vêm } \\
\text { dele né? }\end{array}$ & $\begin{array}{l}\text { (10) ah segundo } \\
\text { (23) não } \\
\text { (36) imagina } \\
\text { (42) gente } \\
\text { (44) imagina uma mãe vendo } \\
\text { isso } \\
\text { (70) ninguém fala nada } \\
\text { (71) olha } \\
\text { (85) um pulo } \\
\text { (97) ah é } \\
\text { (185) qualquer um } \\
\text { (205) não tinha que ser né? } \\
\text { (211) é você que escolhe } \\
\text { (226) é? } \\
\text { (234) de tanto que tem } \\
\text { (262) com certeza } \\
\text { (282) e num pára mais }\end{array}$ \\
\hline
\end{tabular}

Tema 2 - História contada por terceiros

\begin{tabular}{|l|c|c|} 
Perguntas Principais & Perguntas complementares & $\begin{array}{c}\text { Comentários / opiniões / } \\
\text { marcadores de interação }\end{array}$ \\
\hline
\end{tabular}


(291) e voc/ e você me disse né?... então... do seu filho né? mais novo que foi... algo que aconteceu com você e... e com alguém assim... com outra pessoa que nem o seu marido né? você falou... e assim tem outra pessoa que... viveu alguma coisa

(347) e eles... namoraram durante muito tempo? Ou foi muito rápido?
(328) ela mesma deu... né?

(334) e quando seu pai entrou?

Ele... num pensou... tudo isso que os outros pensavam? Em nenhum momento ele pensou (354) ah então foi complicado o seu nascimento?

(356) foi n/normal ou cesárea? (358) foi normal?
(303) ninguém sabia né?

(304) e naquela época num é casadas não engravida

(360) é... naquela época era mais (362) nossa... tava enrolado então

Tema 3 - Descrição de um lugar

\begin{tabular}{|c|c|c|}
\hline Perguntas Principais & Perguntas complementares & $\begin{array}{l}\text { Comentários / opiniões / } \\
\text { marcadores de interação }\end{array}$ \\
\hline $\begin{array}{l}\text { (399) assim já que a gente tá } \\
\text { falando né da/ de fé... da igreja... } \\
\text { éh cê pode me falar como é que } \\
\text { é essa igreja assim pode } \\
\text { descrever ela como que ela é se } \\
\text { ela é grande }\end{array}$ & $\begin{array}{l}\text { (418) a sala das crianças são... } \\
\text { desenhadas? Como é? } \\
\text { (445) e assim como que ela tá } \\
\text { que nem ela tá... certinha tá } \\
\text { pintadinha? } \\
\text { (467) então você falou assim que } \\
\text { tem salas... é como se fosse um } \\
\text { casa grande? }\end{array}$ & $\begin{array}{l}\text { (457) claro uma mão lava a outra } \\
\text { (462) e tá lá na igre/ } \\
\text { (471) ah aí é nesse daí que } \\
\text { acontece o culto } \\
\text { (477) e lá tem o altar } \\
\text { (493) são projetadas né? } \\
\text { (497) é a parede é clarinha que } \\
\text { dá pra projetar } \\
\text { (511) fica assim fora... dentro do } \\
\text { salão e aí } \\
\text { (515) ah o pastor tem o próprio } \\
\text { assim } \\
\text { (519) os jovens } \\
\text { (523) ah... então é... grandinha é } \\
\text { que tem muita gente } \\
\text { (526) às vezes parece pequeno }\end{array}$ \\
\hline
\end{tabular}

Tema 4 - Receita culinária

\begin{tabular}{|c|c|c|}
\hline Perguntas Principais & Perguntas complementares & $\begin{array}{l}\text { Comentários / opiniões / } \\
\text { marcadores de interação }\end{array}$ \\
\hline $\begin{array}{l}(538) \text { e as trufas agora... como } \\
\text { faz? } \\
\text { (617) e o brigadeiro branco } \\
\text { como faz? }\end{array}$ & $\begin{array}{l}\text { (551) qualquer forminha a } \\
\text { forminha compra em qualquer } \\
\text { lugar? } \\
\text { (590) ah porque não passa nada } \\
\text { pra descolar o chocolate } \\
\text { (605) e é rápida? } \\
(609) \text { tem chocolate que } \\
\text { endurece muito rápido né? } \\
\text { (621) só leite condensado e a } \\
\text { manteiga? } \\
\text { (672) então acaba usando mais o } \\
\text { chocolate... o brigadeiro } \\
\text { branco... do que o preto ou não? } \\
\text { (704) só tem que ter bastante } \\
\text { forminha né?... que aí vai pondo } \\
\text { na geladeira pra gelar? } \\
\text { (730) e você aprendeu? }\end{array}$ & 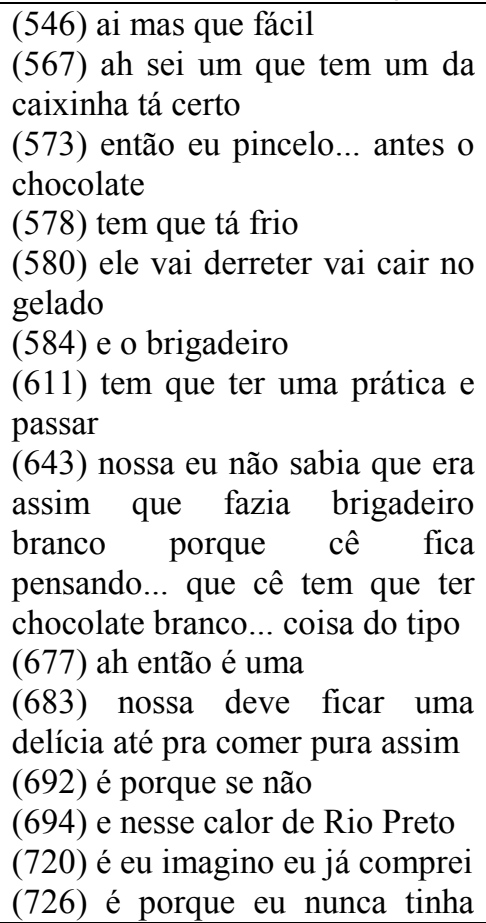 \\
\hline
\end{tabular}




\begin{tabular}{|l|l|}
\hline & $\begin{array}{l}\text { feito e/ eu sempre tinha/ tem } \\
\text { trufa né? de chocolate branco? } \\
(740) \text { mas é mais gostosa } \\
(744) \text { é porque o lucro é mínimo } \\
\text { o chocolate é caro } \\
(750) \text { a pessoa precisa mais }\end{array}$ \\
\hline
\end{tabular}

Tema 5 - Opinião pessoal

\begin{tabular}{|c|c|c|}
\hline Perguntas Principais & Perguntas complementares & $\begin{array}{l}\text { Comentários / opiniões / } \\
\text { marcadores de interação }\end{array}$ \\
\hline $\begin{array}{l}\text { (767) agora já que a gente tá } \\
\text { falando... assim desse assunto } \\
\text { né?... éh... e essas pessoas hein } \\
\text { menina? Que se aproveitam da } \\
\text { situação né? alheia pra conseguir } \\
\text { lucro pra conseguir assim... } \\
\text { qualquer coisa né que que cê } \\
\text { acha assim... disso sabe dessa } \\
\text { situação que é uma situação } \\
\text { chata né? e as pessoas... num } \\
\text { pensam mesmo né? assim... nas } \\
\text { outras acabam... fazendo essa/ a } \\
\text { coisas pra tirar proveito }\end{array}$ & $\begin{array}{l}\text { (791) borracha de apagar? } \\
(856) \text { oh o suicídio por } \\
\text { exemplo... porque será que as } \\
\text { pessoas se matam? }\end{array}$ & $\begin{array}{l}\text { (802) o ato é o mesmo } \\
\text { (807) às vezes as pessoas agem } \\
\text { sem pensar } \\
\text { (811) mas isso é uma coisa de } \\
\text { louco né? } \\
\text { (830) um termo } \\
\text { (842) e ela precisa sair } \\
\text { (853) e tá ali né? } \\
\text { (878) arte minha } \\
\text { (900) muito obrigada V. por } \\
\text { você ter par/ participado do } \\
\text { projeto de pesquisa... do } \\
\text { português falado na região de } \\
\text { São José do Rio Preto... muito } \\
\text { obrigada }\end{array}$ \\
\hline
\end{tabular}

Esta entrevista também está dividida de acordo com a ordem estabelecida pelos organizadores do corpus. No entanto, chama-nos atenção a maneira como o entrevistador elabora suas perguntas. Observa-se que os enunciados que abrem o segundo, terceiro e último tema são extremamente confusos, há todo um rodeio que faz com que os mesmos não fiquem claros. Além disso, com exceção do tema quatro, o qual trata de receitas culinárias, todos os outros envolvem o mesmo assunto - a religião do informante. Acreditamos que a falta de planificação por parte do entrevistador motivou tal fato.

Com relação às perguntas principais, observamos que apenas uma das partes apresenta atos de preparação, todas as outras são compostas por enunciados diretos.

A interação entre os participantes é bastante acentuada, observa-se que a todo o momento o entrevistador participa do diálogo, expõe suas opiniões, colaborando para a fluidez do mesmo.

Abaixo apresentamos as ocorrências que acreditamos ser relevantes para a nossa pesquisa.

\subsubsection{Desfocalização do eu}

Ao longo dessa entrevista encontramos diversos exemplos desse tipo de atenuação. Abaixo apresentamos os excertos, todos retirados da fala do I, seguidos de breve análise. 
(127) (...) por isso que a gente também... mas não falava católica elas falava que se você ler você vai ver... então ali fala...

(158) (...) eu posso fazer um desenho que você pedir... eu te desenho... mas a partir do momento que você põe o seu joelho no chão... e clama ao Senhor...

(161) (...) porque fala na bíblia que a gente num tem que repetir muita oração... mas o Senhor deixou...

(164) (...) então você põe o seu joelho no chão... e santifica o nome do Senhor... aí você começa... a ouvir o Pai-Nosso...

(171) (...) Ele quer o teu coração o que tá na tua mente o que você pensa... Ele quer o que sai de dentro de você... então Ele quer ouvir o que você tem pra falar pra Ele... aí você começa sabe?... falar as coisas... que você sente o que você precisa... Deus quer que você fala

(178) (...) Deus é muito mais que... do que um pai aqui na Terra... um pai da carne Ele é um Pai espiritual... só se você pedir pra Ele... já diz (...) então se você pedir à Deus... em nome de Jesus...

(209) (...) é o bem lutando contra o mal... Deus sempre maior sempre mais... mas você tem o livre arbítrio que aquele é o Senhor ou não

(212) é você que escolhe se você quer De/ Ele tá sempre à porta batendo batendo... te cla/ te chamando querendo você... porque o Senhor...

(246) (...) e jogarei tudo fora porque... tem gente louco mesmo... né?...mesmo...sabe? a gente pede as coisa pro o Senhor o Senhor mostra... (...) e vou ter a eternidade pra viver... que a gente tem uma vida só... eu vou viver a eternidade com o Senhor..

(276) é e outra é boa conduta de vida... você tem que ter uma co/as pessoas tem que ir tendo assim...

(375) (...) então aí cê começa... a aprender sabe? Quanto MAIS você aprende a palavra do Senhor... mais você começa a enxergar... e mais você começa a ser a mensagem...

(495) (...) então você tem a letra que tá cantando... então eles vão cantando...

(499) (...) pra você poder ler... bem a letra aí você canta né?... aí depois que você cantou aí começa tudo né?

(752) (...) você vê que eles têm amor... eu mandei uma vez pro posto Tropical...

(816) (...) ... uma revista só assim... sabe quando cê vai no consultório que você vê um monte de revista assim e cê começa

(827) (...)porque você tem... a célula cancerígena no teu corpo (...) das mulheres que se separam do marido... então cê vê daí fala assim...

(829) (...)então aí entra um campo espiritual... o MAL... que tá ali... o demônio...tá a gente fala demônio... cada um usa um

(843) e ela precisa sair de algum lugar... aí você começa a ter tensão no ombro... você começa a inflamar seu braço... você começa a ter o teu corpo dolorido...

(854) a/o/o/o o ser humano minha filha o que ele... pensa... é incalculável...

(870) (...) cê tá começando agora tem uma vida pela frente inteirinha... se você ficar usando...

(873) éh a gente tem que usar o coração tudo bem...mas a razão é que faz a gente crescer...

(875) (...) aí você pega e fala assim - "ai mãe mas eu num sei..."

(891) (...) no amadurecimento da nossa mente... na maneira que a gente vê as coisas... é é o crescimento espiritual

Observa-se que há a predominância da forma você como desfocalizadora do eu e algumas com o uso de a gente. Entendemos que ambas as formas visam envolver o interlocutor no diálogo, no entanto nota-se que todas as vezes que o informante usa $a$ gente, está fazendo menção a algo de sua religião. Nesse caso, além de aproximar o entrevistador, ele busca envolver também as outras pessoas que seguem a mesma religião, mostrando a universalidade de sua crença. Isso fica bastante claro na ocorrência encontrada na linha 829. Na linha 854 a ocorrência visa não comprometer o conteúdo da fala, é uma forma generalizada, ainda que o informante também não deixe de se incluir entre os seres humanos.

Ao longo da análise comparativa apresentaremos os gráficos para que se possa estabelecer comparações com as outras entrevistas do corpus. 


\subsubsection{Prevenção de ameaça à face}

Abaixo apresentaremos as ocorrências encontradas de prevenção de ameaça à face, seguidas de breve análise. Os trechos abaixo foram retirados da fala do I.

(14) (...) quando ele nasceu... o médico... eu não sei se foi o médico... ou se foi na... na pediatria... o que aconteceu...

(49) (...) falaram que o neurologista... na Bady Bassit... J.M.... se eu não me engano era o nome dele... e eu fui...

(121) (...) foram comprovados pelo espírito santo em outros ano... e se eu num me engano... sessenta e cinco sessenta e seis... bom a evangélica (...) só esses que/ os sessenta e seis se eu num me engano tá... num tenho certeza foi comprovado...

(131) (...) então é assim acho que eu me lembro que o milagre dele foi fazer a água virar vinho...(...) eu não sei te explicar essa passagem direito... mas eu lembro que ele falou assim...

(348) acho que foi três/ dois anos eu num tenho certeza né?... uns três de noivado...

(651) (...) eu vendo isso... muito na lan house na Órbita não sei se cê conhece onde é uma lan house...

(793) (...) eu lembro faz muitos anos isso há mais de dez vinte anos... num lembro se foi supermercado se foi loja de...

Todas as ocorrências acima foram encontradas na fala do I. Com exceção do exemplo que aparece na linha 651, todos os outros são casos que pretendem prevenir uma ameaça à face do próprio I e consequentemente do E, pois ao dizer que não sabe exatamente determinado dado, ele se previne caso a resposta não seja tão precisa e previne o outro que evitará perguntas mais aprofundadas sobre o tema, uma vez que já tem ciência da dúvida do interlocutor.

A ocorrência encontrada na linha 651 visa prevenir a face do E pois ao fazer uma afirmação como essa, o falante se mostra preparado para explicar mais detalhadamente o dado, caso o outro não tenha conhecimento. Além de criar espaço para que o interlocutor expresse sua dúvida sobre o fato.

\subsubsection{Ameaça à face}

Abaixo apresentamos as ocorrências que se referem à ameaça à face. Todos os exemplos foram retirados da fala do I.

(248) (...) eu tirei tudo... da minha casa que eu num acha/ achava que num era de Deus... livro espírita... que eu tinha muitos... eu coloquei tudo dentro de uma lata e queimei... pus fogo em tudo comecei quebrar minhas imagens começaram a falar "cê é louca"...

(647) (...) essa receita que eu tenho é d'uma prima minha de Brasília... aqui em Rio Preto só eu faço essa receita que eu saiba...

(749) (...) graças a Deus eu num preciso tá me preocupando... de ficar mandando... sabe? Não preciso tanto assim de dinheiro

(897) (...) eu vi tudo que uma pessoa pode ver também eu vi... eu sei...eu/eu sou uma pessoa que eu posso falar assim - "eu passei tudo"-

Ao longo dessa entrevista, há esses quatro casos de ameaça à face, sendo todos eles enunciados pelo informante ameaçando sua própria face. No primeiro caso há uma nítida exposição de pensamentos e atitudes que podem levar o interlocutor a julgamentos. 
Observa-se que o falante não faz qualquer tipo de justificativa para tal ato. Acreditamos que o fato de o interlocutor não compartilhar a mesma religião que o falante reforça ainda mais tal julgamento. Ressaltamos que tiramos essa conclusão sobre a religião do entrevistador devido às diversas explicações dadas pelo informante.

Nos outros três exemplos temos casos de falta de modéstia. Conforme apresentamos ao longo de nossa exposição teórica a modéstia é uma manifestação de cortesia. Briz (2004, p.68) acrescenta que à medida que nos distanciamos da mensagem, nos aproximamos do interlocutor. Cabe ressaltar que na ocorrência encontrada na linha 647 há uma atenuação, porém apesar de mitigar, essa não é capaz de apagar a falta de modéstia e consequentemente a exposição do informante. Já no terceiro e quarto exemplos não há qualquer tipo de atenuação.

\subsubsection{Atenuantes}

Ao longo dessa entrevista encontramos apenas uma ocorrência, a qual apresentamos abaixo.

(647) (...) essa receita que eu tenho é d'uma prima minha de Brasília... aqui em Rio Preto só eu faço essa receita que eu saiba...

Como foi apontado no tópico anterior, esse enunciado pode ser analisado como um exemplo de falta de modéstia por parte do falante. No entanto, ao complementar com a frase em destaque na transcrição, o falante atenua sua fala e consequentemente tenta proteger sua face, caso o que esteja falando não seja verdade.

\subsubsection{Expressão de opinião}

Abaixo seguem os exemplos de expressão de opinião do I, seguidos de breve análise.

(812) num conseguem... éh... ser mais aberta sei lá... se a timidez faz isso eu num sei... pra mim na verdade... eu... tá? Particularmente... e/eu acho que tem um campo espiritual aí... né? porque tem gente que é sem-vergonha... mas tem muita gente... que o MAL fica muito na mente dele... eu to falando assim cientificamente outro dia tava lendo um/a/... uma revista só assim... sabe quando cê vai no consultório que você vê um monte de revista assim e cê começa

(819) é... então... e eles... falam que... primeiro atinge a mente da pessoa... depois a doença tá? Então tratam a doença... atinge a mente... e quando o cor/alcança o corpo... o doutor F. falou pra mim... que... a maiori/a a maioria não... muitas mulheres com quarenta e oito anos... que se separam do marido... manifesta câncer na mama... por quê?... porque você tem... a célula cancerígena no teu corpo... e a tua mente... éh... a tristeza que essa pessoa entra é tão profunda... a depressão dela é tão profunda... que ela ativa... essa célula cancerígena... então muitas / isso aí foi comprovado cientificamente que o câncer na mama... das mulheres que se separam do marido... então cê vê daí fala assim... - "pô... e o que que fez?... o que que atinge a mente?" - então aí entra um campo espiritual... o MAL... que tá ali... o demônio...tá a gente fala demônio... cada um usa um 
Ao longo de toda a entrevista, é possível observar que o I é bastante enfático ao falar de sua religião, utilizando vários argumentos para defendê-la. Ele expõe sua opinião sem fazer uso de atenuantes e sem temer também a exposição de sua face. Por outro lado, sobretudo no primeiro trecho, procura demonstrar que aquela é a sua opinião e no segundo trecho, apoia-se em um médico para comprovar o que diz. Exibe autoridade e a apresenta como uma verdade incontestável.

\subsubsection{Cortesia valorizante}

(900) E: muito obrigada V. por você ter par/participado do projeto de pesquisa... do português falado na região de São José do Rio Preto... muito obrigada

Essa é a única ocorrência de cortesia valorizante encontrada ao longo de toda a entrevista. Foi enunciada pelo E e tem o objetivo de agradecer a participação do I. Na transcrição da amostra não está registrada a resposta do informante para o agradecimento. Esse tipo de ato de fala é bastante benéfico para a face do I.

\subsubsection{Solidariedade}

Abaixo apresentamos os dois exemplos de solidariedade entre os falantes dessa entrevista.

(517) I: (...) aí depois você vai entrar num pátio que nesse pátio tem uma sala de aula... tem um pátio maior que é pra ficar... te/

(519) E: os jovens

(520) I: é que os jovens ficam e a gente também fica bebe água lá tudo... depois tem o corredor...

(524) I: tem dois banheiros... é que sabe o que é? Ela é grande... mas tem muita gente... muita... a gente faz às vezes

(526) E: às vezes parece pequeno

(527) I: parece sim... pequeno quando você vai no culto... se você for lá...

Nos dois casos apresentados há solidariedade por parte do entrevistador, ou seja, é ele quem completa a fala do informante ainda que o mesmo não demonstre esquecimento do tema tratado. Entendemos que essa estratégia favorece a interação entre os participantes, demonstrando que o interlocutor está bastante atento ao que está sendo contado pelo informante.

\subsubsection{Formas de tratamento}

O tratamento utilizado entre os participantes dessa entrevista é você e cê acompanhado de verbos na terceira pessoa do singular, o qual segue o paradigma de conjugação indicado pela norma culta da Língua Portuguesa. 
Abaixo apresentamos alguns exemplos, tanto do uso do pronome de tratamento, quanto dos outros pronomes encontrados, todos retirados da fala do E.

(109) e o que você acha... daquelas pessoas que... idolatram Maria?

(291) e voc/ e você me disse né?... então... do seu filho né? mais novo que foi... algo que aconteceu com você e... e com alguém assim... com outra pessoa que nem o seu marido né? você falou... e assim tem outra pessoa que... viveu alguma coisa

(334) e quando seu pai entrou? Ele... num pensou... tudo isso que os outros pensavam? Em nenhum momento ele pensou

(767) agora já que a gente tá falando... assim desse assunto né?... éh... e essas pessoas hein menina? Que se aproveitam da situação né? alheia pra conseguir lucro pra conseguir assim... qualquer coisa né que que cê acha assim... disso sabe dessa situação que é uma situação chata né? e as pessoas... num pensam mesmo né? assim... nas outras acabam... fazendo essa/ a coisas pra tirar proveito

Nessa entrevista, observamos o uso de dois tipos de pronomes: você e sua forma abreviada cê e o pronome possessivo seu. Com relação a ambos os pronomes, observa-se certa regularidade pois pertencem a terceira pessoa do singular, o que aponta uma correta concordância de acordo com a norma culta do português do Brasil. Não há registro de uso do pronome oblíquo.

Podemos afirmar que essa entrevista está no eixo de solidariedade.

Além dos pronomes apresentados, observamos o uso de uma forma nominal que denota intimidade entre os interlocutores. Essa forma pode ser observada na linha 767 na fala do entrevistador e na linha 686 na fala do informante. Entendemos que ao longo da entrevista, criou-se um ambiente propício para tal liberdade entre os participantes dessa entrevista.

\subsection{Amostra 109}

Informante masculino - 42 anos

Entrevistador feminino - 23 anos

Tema 1 - História pessoal

\begin{tabular}{|l|l|l|}
\hline Perguntas Principais & Perguntas complementares & \multicolumn{1}{c|}{$\begin{array}{c}\text { Comentários / opiniões / } \\
\text { marcadores de interação }\end{array}$} \\
\hline $\begin{array}{l}\text { (03) bom T. eu gostaria que } \\
\text { você me contasse uma história } \\
\text { que tenha acontecido com você } \\
\text { que tenha sido engraçada alegre } \\
\text { ou triste alguma coisa } \\
\text { interessante }\end{array}$ & & $\begin{array}{l}(115) \text { graças a Deus } \\
(128) \text { que legal }\end{array}$ \\
\hline
\end{tabular}

Tema 2 - História contada por terceiros

\begin{tabular}{|c|l|l|}
\hline Perguntas Principais & Perguntas complementares & \multicolumn{1}{c|}{$\begin{array}{l}\text { Comentários / opiniões / } \\
\text { marcadores de interação }\end{array}$} \\
\hline $\begin{array}{l}\text { (201) éh agora eu gostaria que } \\
\text { você me contasse alguma }\end{array}$ & & $\begin{array}{l}(249) \text { que doido } \\
(254) \text { vixe }\end{array}$ \\
\hline
\end{tabular}




\begin{tabular}{|l|l|}
\hline $\begin{array}{l}\text { história que tenha ocorrido com } \\
\text { alguém que você conheça... } \\
\text { alguma coisa assim que você } \\
\text { ache de interessante }\end{array}$ & $\begin{array}{l}(276) \text { claro } \\
(312) \text { nossa } \\
(316) \text { esse foi esperto } \\
(322) \text { é } \\
(325) \text { cem anos de perdão } \\
(327) \text { tá jóia }\end{array}$ \\
\hline
\end{tabular}

Tema 3 - Descrição de um lugar

\begin{tabular}{|c|c|c|}
\hline Perguntas Principais & Perguntas complementares & $\begin{array}{l}\text { Comentários / opiniões / } \\
\text { marcadores de interação }\end{array}$ \\
\hline $\begin{array}{l}\text { (330) éh agora eu gostaria que } \\
\text { cê me descrevesse então a sua } \\
\text { escola } \\
(507) \text { e assim cê pode descrever } \\
\text { ela pra mim assim... a fachada } \\
\text { como seria assim se você fosse... } \\
\text { é dar o endereço pra algum } \\
\text { aluno vim aqui como como que } \\
\text { ele ia achar assim a fachada é de } \\
\text { que cor... como como que seria o } \\
\text { toldo }\end{array}$ & & $\begin{array}{l}\text { (385) pra cima } \\
\text { (385) é né? } \\
\text { (390) tipo família } \\
\text { (390) verdade } \\
\text { (399) aquela empolgação } \\
\text { (434) é } \\
\text { (448) ai que bom } \\
\text { (466) que trabalham o dia todo } \\
\text { (469) professor tem isso né? ... } \\
\text { ele é um pouco professor e um } \\
\text { pouco psicólogo } \\
\text { (479) é verdade } \\
\text { (491) olha só } \\
\text { (534) tá jóia }\end{array}$ \\
\hline
\end{tabular}

Tema 4 - Indicação para ir a algum lugar

\begin{tabular}{|l|l|l|}
\hline \multicolumn{1}{|c|}{ Perguntas Principais } & Perguntas complementares & $\begin{array}{c}\text { Comentários / opiniões / } \\
\text { marcadores de interação }\end{array}$ \\
\hline $\begin{array}{l}\text { (536) T. eu gostaria que você } \\
\text { me explicasse como que eu faço } \\
\text { pra sair na rodovia... daqui da } \\
\text { onde a gente tá }\end{array}$ & (564) éh na marginal ali \\
(541) daqui do Golfinho como \\
que a gente faz pra sair na \\
rodovia
\end{tabular}

Tema 5 - Opinião pessoal

\begin{tabular}{|l|l|l|}
\hline \multicolumn{1}{|c|}{ Perguntas Principais } & Perguntas complementares & \multicolumn{1}{|c|}{$\begin{array}{l}\text { Comentários / opiniões / } \\
\text { marcadores de interação }\end{array}$} \\
\hline $\begin{array}{l}\text { (586) agora éh T. eu gostaria de } \\
\text { saber então qual que é sua } \\
\text { opinião a respeito da da didática } \\
\text { que as escolas de música } \\
\text { utilizam... hoje em dia }\end{array}$ & $\begin{array}{l}\text { (619) é um verdadeiro comércio } \\
(653) \text { verdade é a melhor } \\
(696) \text { essa é a } \\
\text { propaganda } \\
\text { (706) porque aí a escola ganha } \\
\text { dos dois lados } \\
\text { (712) com certeza } \\
\text { (755) sempre atualizado } \\
\text { (760) legal }\end{array}$ \\
\hline
\end{tabular}

Essa entrevista apresenta a mesma divisão de temas, selecionados pelos organizadores do corpus. O nível de planificação é baixo, no entanto, é interessante observar que o E mantém certa distância do I. Há interação quando ele conta suas histórias, mas em momento algum ele busca mais detalhes das mesmas. Talvez isso se deva ao fato de o informante ser bastante detalhista e falar muito bem. Outro dado que 
pode contribuir com isso é o E fazer perguntas bem direcionadas, nas quais fica bem claro o tipo de resposta esperada. Há duas partes da entrevista que elucidam esses dados. Assim, ao pedir para o I descrever um local, ela pede a descrição da escola dele - pela entrevista podemos concluir que ele tem uma escola de música e ao pedir uma opinião pessoal, ele pergunta sobre a didática que as escolas de música utilizam - o informante já havia falado algo sobre esse tema anteriormente.

Outro dado que indica a distância entre os participantes da entrevista é o fato de o E não expor sua opinião, seus comentários são sempre no sentido de contribuir com a fluidez da entrevista, mas sem expor sua opinião sobre o tema. Por outro lado, entendemos que o informante busca certa aproximação ao fazer perguntas para o E.

Com relação às perguntas principais, observamos que sempre que abre um novo tema o E faz uso do mesmo ato preparatório, no caso o verbo gostar no Pretérito Imperfeito acompanhado pelo verbo principal no Pretérito Imperfeito do Subjuntivo ou de Infinitivo. É interessante observar que a quantidade de perguntas é baixa, acreditamos que isso se deve ao fato de o informante entender claramente o que lhe é perguntado e responder tais perguntas a contento.

\subsubsection{Desfocalização do eu}

Ao longo dessa entrevista encontramos algumas ocorrências de desfocalização do $e u$. Abaixo apresentamos os trechos, seguidos de breve análise.

(32) I: (...) dentro de Franca sair por dentro de Franca aí você pegava uma estrada né? e e e ia até Ibiraci tipo...

(86) I: (...) o dono da banda foi na escadinha na frente do ônibus que cê desce na na porta...

(95) I: (...) era horrível... era você ver a morte... e ele conseguiu engatar a quarta...

(102) I: (...) e eu fui controlando nisso cê olhava lá cê num via ninguém nos bancos lá atrás...

(106) I: (...) porque com um ônibus pesado o motor pesado cề num pode engatar uma segunda numa descida...

(166) I: (...) dormi uma hora um pouco mas cê acaba num dormindo... num tem/ cê num fica... e viemos embora...

(388) I: (...) e eu tive um apoio tão grande... desses amigos que são pouquíssimos... que na hora que a gente tá numa situação difícil... éh some os amigos da vida da gente... aqueles amigos de bar aqueles amigos...

(455) I: (...) mas eu acho forçado fazer uma coisa que cê num tava com vontade de fazer...

(459) I: (...) porque eu acho que é muito importante você ter um domínio sobre você... seus horários... só que você vê dá dez hora da noite...

(476) I: (...) sou dono do meu nariz você ser dono... de você...você se torna uma pessoa bonita por dentro... cê vai melhorando seu astral... cề se torna uma pessoa legal...

(525) I: (...) chegou em frente ao estacionamento do Golfinho você tá de fe/ de frente pra frente c'a escola Ton Maior...

(541) E: daqui do Golfinho como que a gente faz pra sair na rodovia

(612) I: (...) porque nós temos alunos com dificuldades maiores outros não...

(677) I: (...) e quando você começa dá muito detalhizinho coisas que saturam que enjoam...

(741) I: (...) então é aquilo quer quer se você num quer sai... sai entra outro... 
Observa-se que apesar da quantidade de ocorrências, há apenas três tipos de desfocalização. A primeira e mais recorrente se refere ao uso de você e de sua forma abreviada, comum na língua falada cê. O uso de tal pronome visa criar certa aproximação com o interlocutor, incluindo-o na descrição do fato que está sendo contado. Ao utilizar $a$ gente, ocorrência encontrada uma única vez, além de incluir o interlocutor, o falante conta o fato como se o mesmo ocorresse com todas as pessoas que padecem do mesmo mal, no caso a depressão sofrida por ele. O mesmo ocorre com nós, o qual também aparece uma única vez, porém acreditamos que a primeira pessoa do plural inclui ele e todos os professores, independentemente da disciplina que leciona.

Na fala do entrevistador há uma ocorrência de desfocalização - linha 541 - no caso com o uso de a gente. Acreditamos que se trata de um exemplo de plural de modéstia.

Mais adiante, ao longo da análise comparativa, apresentaremos os gráficos para melhor visualização das ocorrências encontradas nessa entrevista e nas outras, pertencentes ao mesmo corpus.

\subsubsection{Prevenção de ameaça à face}

Abaixo apresentamos as ocorrências encontradas, seguidas de breve análise. Todos os exemplos abaixo foram retirados da fala do I.

(46) (...) ele desceu do ônibus calçou o ônibus atrás entendeu po ônibus num descer é dentro da cidade né?

(192) (...) eu senti... treze ou catorze pessoas eu num me lembro... completamente...

(314) (...) e tem mais dois num outro lugar num sei como é que é que chama lá...

(590) (...) eu serei até ignorante em achar isso é até radical achar que a minha maneira é uma mane/ é uma maneira certa... éh éh... quando me falaram que eu tinha condições de dar aula de violão... eu falei pro M. "não eu num tenho" - porque eu num tinha... a teoria... eu tinha muita prática...

(628) (...) e eu vi num num num num num programa do Jô... éh eu num lembro o nome desse pedagogo... que eu citei agora...

(688) (...) desse pedagogo que eu citei agora que eu num me lembro o nome... uso a tese dele...

Por meio das ocorrências acima, podemos observar que há três tipos de prevenção de ameaça à face. O primeiro deles, apresentado na linha 46 o I visa proteger a face do $\mathrm{E}$, ao fazer a explicação, ele já antecipa uma possível dúvida do I. Já as ocorrências encontradas nas linhas 192, 314, 628 e 688 visam proteger a face do próprio informante, pois ao apresentar determinada informação, ele já antecipa a sua dúvida ou desconhecimento a fim de evitar uma pergunta mais aprofundada sobre o tema. Conforme já foi apontado em análises anteriores, esse tipo de prevenção tem dupla função, pois também previne o entrevistador, o qual evitará ou simplesmente não fará tais perguntas. 
Por fim o último caso encontra-se na linha 590, o qual é utilizado pelo informante com o intuito de evitar um possível julgamento do entrevistador sobre o dado que lhe é passado. Observa-se que ele se distancia do conteúdo da enunciação a fim de se aproximar do interlocutor, ou seja, por mais que ele confie e acredite em seu método de trabalho, não se coloca como detentor do saber, apresentando certa humildade.

\subsubsection{Ameaça à face}

Abaixo apresentamos as ocorrências encontradas, todas retiradas da fala do I.

(117) (...) o C. era moreno... ele tava branco pálido os lábios dele tavam branco... ele era BEM moreno mesmo assim... ele tava mais pra pra pra sete oito horas da noite do que pra seis cinco né?

(334) (...) eu tava numa crise depressiva uns problema sérios aí...

(341) (...) porque quando eu tive depressão... quer dizer foi muito repentina eu fiquei devendo pra bastante gente as pessoas vinham me cobrar e ninguém entendia o que eu tava passando... a situação minha que eu num aguentava parar em pé...

(473) (...) eu tive uma depressão... que eu fiquei eu fiquei em cadeira de roda... depressão tão forte que pensei que fosse morrer... e eu me levantei por mim mesmo de vez em quando dá uns piripaque agora to nem aí...

Observamos dois tipos de ameaça à face nessa entrevista, ambos relacionados à face do informante. O primeiro deles, encontrado na linha 117 aponta inclusive um comportamento racista por parte do falante ao comparar a cor de uma pessoa com a hora do dia. Ele expõe sua face negativamente, arriscando-se a se submeter a possíveis julgamentos por parte do interlocutor. Entendemos que devido à natureza de nosso material, o entrevistador não vai se manifestar, a fim de não prejudicar o andamento da entrevista. Como pode ser observado nos anexos do trabalho, é exatamente isso que ocorre.

As três ocorrências seguintes se referem à depressão ${ }^{41}$ sofrida pelo informante. É interessante observar que ele menciona esse assunto em vários momentos da entrevista. No entanto, o entrevistador não faz qualquer tipo de comentário com a intenção de ampliar o tema, ele apenas mostra que está atento ao que está sendo contado, porém sem fazer perguntas. Entendemos que esse tipo de ocorrência é uma ameaça à face, devido à exposição que o informante faz de si mesmo.

\footnotetext{
${ }^{41} \mathrm{Na}$ cultura brasileira ainda existe certo preconceito com relação às doenças psiquiátricas.
} 


\subsubsection{Atenuantes}

No que se refere à atenuação ou marcadores de atenuação, chamou nossa atenção duas falas do I quando ele trata algo sobre a raça negra. Abaixo citamos essas e as outras ocorrências encontradas, todas retiradas da fala do I.

(26) (...) era um ônibus um pouco antigo e tal... ele foi reformado a parte do motor mas não a parte do câmbio então tinha um câmbio meio complicado pa engatar... e eu era a pessoa de confiança da banda pra dirigir aquele ônibus... nós tínhamos um carregador da banda que também dirigia... mas num era uma pessoa muito confiável... os músicos em si num confiava muito nele...

(63) (...) tem um depósito de material de construção então eu tinha um pouco mais de experiência que ele... um pouco mais de vivência...

(116) a gente tava o C. era bem moreno... ele tava branco pálido os lábios dele tavam branco... ele era BEM moreno mesmo assim... ele tava mais pra pra... pra sete oito horas da noite do que pra pra seis $e$ cinco né?

(629) agora pra você que ele é considerado um dos maiores pedagogos do país... éh éh era um neguinho que veio da FEBEM..

As duas primeiras ocorrências encontradas apresentam vários elementos atenuadores, porém todos com a mesma função, a de mitigar a força do enunciado. Assim, ao dizer que o ônibus era um pouco antigo, o informante evita dizer que é velho, bem como quando conta que não confiava no outro motorista da banda, nesse caso há inclusive um reforço ao dizer que os outros integrantes também não tinham confiança no rapaz. No caso do segundo trecho, utilizando o adjetivo pouco acompanhado do advérbio mais, ele atenua a experiência e a vivência que dizia sentir ao dirigir um ônibus.

As outras duas ocorrências, embora apresentem um conteúdo racista também exibem elementos de atenuação. Ao descrever a pessoa citada como bem morena, o informante evita dizer que é negra, entendemos que é justamente essa tentativa de atenuação que transforma o enunciado em um enunciado racista. Já o uso do diminutivo do adjetivo negro também visa mitigar a força não só do adjetivo, como do enunciado como um todo, pois neguinho que veio da FEBEM ${ }^{42}$ apresenta uma carga bastante negativa, por parte da sociedade, devido às características dos menores que para lá eram levados.

\subsubsection{Expressão de opinião}

Ao longo dessa entrevista são encontrados alguns exemplos. Abaixo apresentamos os trechos, seguidos de breve análise. Os exemplos abaixo foram retirados da fala do I.

(404) (...) aqui é pequeno né? ficou bonitinha ficou como você tá vendo... uma coisa éh/éh simples pequena mas éh/éh/éh que é rica em em no/ no método de ensino sistema de ensino... as pessoas às vezes...

\footnotetext{
${ }^{42}$ Sigla de Fundação do Bem Estar do Menor, entidade paulista extinta, cujo objetivo era cuidar de menores infratores e reintegrá-los à sociedade.
} 
Infelizmente nesse país... tem pais mães pessoas que vive... que são orgulhosos né? então eles vê uma fachada muito grande numa escola então eles vão por aquela fachada né? e se enganam depois acabam vindo aqui... mas primeiro vão pra aquela fachada linda enorme que gasta uma fortuna... e lá dentro o ensino num num num é aquele ensino... aí depois eles acaba vindo aqui...

(721) eu eu eu tenho prazer em dar aula... se eu não tiver prazer em dar aula eu fecho a minha escola e vou mudar de profissão... eu acho que eles poderiam fazer a mesma coisa... deveriam ter mais amor naquilo que faz... prestar um pouquinho mais de atenção... e mudar aquele sistema errado de dar aula... essa história de que o aluno tem que ficar dentro de uma sala fazendo aquilo...

(738) (...) então eu acho que essa é a diferença na minha opini/ a minha opinião... com relação às escolas... é que as escolas... tão na época da da da numa época antiga... montaram um sistema de ensino... e ficou naquilo... então é aquilo quer quer se você num quer sai... sai entra outro... (...) éh éh éh um sistema de aula... que na minha opinião é infalível... eu posso estar com sessenta anos de idade... eu dando aula dessa forma eu vou tá sempre jovem no sentido didático de aula de música.

(756) agora/sempre atualizado sempre atualizado eu nunca vou me perder... então eu acho que é isso que as escolas deveriam fazer... tomara que façam... tomara que façam se não fizerem... com o tempo eu acredito que muitas delas vão fechar... muitas delas vão fechar... e eu torço pra que num fechem

Observa-se que todas as ocorrências nas quais o informante expressa sua opinião são referentes ao ensino de música ou às escolas de música. Nota-se que em apenas uma delas (linha 738) há o uso de expressão epistêmica. O informante é bastante enfático ao expor seu ponto de vista, demonstrando bastante segurança em suas afirmações.

Nas ocorrências encontradas nas linhas 404 e 721 podem ser verificados modalizadores que atenuam o conteúdo da fala do I. Na linha 404 o demonstrativo aquele modaliza a intenção do falante em dizer que o ensino não é bom e o adjetivo pouquinho na linha 721 modaliza a intensidade de atenção que os professores devem ter com seus alunos.

Além disso, a desfocalização também é utilizada como recurso para a expressão de opinião do I. Na ocorrência da linha 404 há expressões como tem pais mães pessoas que vive...

\subsubsection{Invasão de território pessoal}

Quando dissemos anteriormente que o E não instiga nada sobre a vida do I, podemos englobar a questão da invasão do território pessoal. Em vários trechos da entrevista o I fala sobre uma fase difícil que passou em sua vida quando sofreu de depressão. Em momento algum o E faz perguntas sobre a doença, embora o I demonstre ter necessidade de contar sobre seu sofrimento e pouco a pouco narra o fato. É interessante observar também que o I não apresenta problema algum em falar sobre sua vida pessoal, referindo-se inclusive a valores de alguns bens materiais que possui.

(334) eu tava numa crise depressiva uns problemas sérios ai

(341) porque quando eu tive depressão... quer dizer foi muito repentina eu fiquei devendo pra bastante gente as pessoas vinham me cobrar e ninguém entendia o que eu tava passando... a situação minha que eu num agüentava parar em pé... 
(420) aqui dentro de dez mil reais... eu num tinha nada... né? eu tenho éh éh éh eu tenho um gol noventa e oito... no valor de treze mil reais...

(474) sabe que eu tive uma depressão... que eu fiquei eu fiquei em cadeira de roda... depressão tão forte que pensei que fosse morrer... e eu me levantei por mim mesmo de vez em quando dá uns piripaque agora to nem aí...

A entrevista na íntegra encontra-se nos anexos do trabalho, porém por meio dos trechos citados, é possível notar o quanto ele precisava falar sobre o que passou. O E, por sua vez, interagia apenas com expressões como ah, hum, nossa, sem entrar em maiores detalhes, evitando invadir o território pessoal do informante.

\subsubsection{Solidariedade}

A solidariedade entre os falantes também é um dado presente nessa entrevista. (324) I: ladrão roubando ladrão é cem anos de pe [Doc.: cem anos de perdão]

Essa é a única ocorrência encontrada, na qual o E completa o ditado popular dito pelo I.

\subsubsection{Formas de tratamento}

O tratamento utilizado entre os participantes dessa entrevista é você e cê acompanhado de verbos na terceira pessoa do singular, o qual segue o paradigma de conjugação indicado pela norma culta da Língua Portuguesa.

Abaixo apresentamos alguns exemplos, tanto do uso do pronome de tratamento, quanto dos outros pronomes encontrados. Os trechos abaixo foram retirados da fala do E.

(03) bom T. eu gostaria que você me contasse uma história que tenha acontecido com você que tenha sido engraçada alegre ou triste alguma coisa interessante

(330) éh agora eu gostaria que cê me descrevesse então a sua escola

(586) agora éh T. eu gostaria de saber então qual que é sua opinião a respeito da da didática que as escolas de música utilizam... hoje em dia

Ao longo dessa entrevista, encontramos dois tipos de pronomes: você e sua forma abreviada $c \hat{e}$, comum na língua falada e o pronome possessivo sua. A regularidade é bastante evidente, pelo fato de ambos estarem na terceira pessoa do singular, estabelecendo a concordância de acordo com a norma culta. Não há registro de uso do pronome oblíquo.

Podemos afirmar que essa entrevista está no eixo de solidariedade, além disso, não há a presença de formas nominais, como já esperado, devido à idade dos participantes.

Em seguida, apresentaremos a análise comparativa entre todas as entrevistas pertencentes a esse corpus de forma que possamos elaborar um esquema de uso de tais pronomes no citado material. 


\subsection{Análise comparativa - nível médio}

As entrevistas que compõem esse corpus foram previamente divididas de acordo com seus tópicos pelos organizadores do material. Assim, todas elas seguem o mesmo padrão: são iniciadas com uma narrativa de experiência pessoal do informante, em seguida há uma narrativa recontada, na qual os informantes devem contar algo que lhe foi contado por uma terceira pessoa, a terceira parte é composta por uma descrição, geralmente de um local, a quarta pela explicação de uma receita culinária ou algo que o informante saiba fazer e a quinta e última por um relato de opinião.

O corpus de nível médio brasileiro é composto por seis entrevistas, sendo três de informantes do sexo feminino e outras três do sexo masculino. O que o caracteriza como médio é o nível de escolaridade dos informantes, no caso todos com instrução secundária, ou seja, o Ensino Médio. Além disso, em nosso recorte de análise, selecionamos apenas informantes com idades entre 25 e 45 anos, de forma que nosso estudo pudesse também ter um caráter comparativo entre pessoas pertencentes à mesma faixa etária. Não consideramos como critério de seleção das entrevistas a profissão e renda familiar, uma vez que apenas o nível de escolaridade era suficiente para nossa análise, embora esses dados estivessem disponíveis nas informações sobre o corpus.

Abaixo apresentamos os dados dos informantes que compuseram o nosso corpus. O número correspondente a cada entrevista foi determinado pelos próprios organizadores do material.

\begin{tabular}{|l|l|l|}
\hline $\begin{array}{c}\text { Entrevista } \\
\text { número: }\end{array}$ & \multicolumn{1}{|c|}{ Sexo } & \multicolumn{1}{|c|}{ Idade } \\
\hline 65 & masculino & 27 anos \\
\hline 75 & masculino & 34 anos \\
\hline 76 & feminino & 28 anos \\
\hline 80 & feminino & 29 anos \\
\hline 106 & feminino & 40 anos \\
\hline 109 & masculino & 42 anos \\
\hline
\end{tabular}

A seguir, passamos à exposição da análise comparativa do material de nível médio. Optamos por separá-la em tópicos de acordo com o que foi trabalhado nas análises individuais das entrevistas. Em alguns casos, utilizaremos também gráficos que nos ajudarão a elucidar e comparar os dados apresentados. 


\subsubsection{Fala do entrevistador}

Assim como expusemos alguns dados sobre o entrevistador do corpus espanhol, entendemos que há a necessidade de se fazer o mesmo com o material brasileiro. Diante disso, cabe mencionar que todas as entrevistas foram feitas por estudantes do curso de Letras da UNESP de São José do Rio Preto e supervisionadas pelos professores responsáveis pelo Projeto. Todas as entrevistadoras são do sexo feminino e possuíam idade entre 19 e 25 anos, o que nos possibilita uma comparação com o entrevistador do corpus espanhol que possuía 28 anos na data da elaboração da entrevista. Entendemos que dados como esse representam aspectos relevantes que devem ser considerados, pois a forma como um falante jovem aborda um interlocutor de mais de 50 pode ser diferente da maneira como ele trata uma pessoa da mesma idade que ele.

Analisando a maneira como os enunciados interrogativos são elaborados, observamos que cada entrevista tem a sua particularidade, porém há alguns elementos que coincidem, o que nos ajuda a levantar alguns dados que nos auxiliarão nas conclusões sobre cada corpus. Antes da apresentação dos gráficos, entendemos que é relevante a apresentação dos dados que, em geral, foram encontrados nos enunciados interrogativos elaborados pelos entrevistadores.

Em geral, encontramos nesse corpus quatro tipos de enunciados interrogativos: dois diretos e dois indiretos. Consideramos como atos diretos aqueles que não foram precedidos de atos de preparação com verbos performativos e também aqueles que continham verbos no imperativo e como indiretos aqueles que continham atos de preparação e de proteção à face do informante.

\subsubsection{Enunciados diretos}

\subsection{Enunciados sem ato de preparação}

Classificamos aqui todos os enunciados que vão diretamente para a questão, sem fazer uso de qualquer tipo de ato de preparação ou verbos que pretendiam proteger à face do informante.

\subsubsection{Verbos no Imperativo}

O uso de verbos no imperativo também foi caracterizado como parte dos enunciados diretos. Ressaltamos que não levamos em consideração o verbo utilizado como contar, explicar, descrever, etc. Classificamo-los apenas como uso de imperativo. 


\subsubsection{Enunciados indiretos}

\subsection{Uso de ato preparatório}

Classificamos como enunciados indiretos aqueles que contêm atos preparatórios no início de cada pergunta. Normalmente o entrevistador usa o verbo gostar ou querer no Futuro do Pretérito como forma de preparar o informante para a pergunta que se apresenta na sequência.

\subsection{Verbos de proteção à face}

Classificamos como verbos de proteção à face todos aqueles que davam certa liberdade ao informante, seja pelo uso do verbo poder ou lembrar. Como já exposto ao longo de nossa fundamentação teórica, essa liberdade é fictícia, pois a partir do momento que o informante aceita participar desse tipo de entrevista, fica subentendido que precisará responder algumas questões. No entanto, ao perguntar se o mesmo se lembra ou se pode contar algo, cria-se espaço para que o informante diga que não se lembra ou que não pode responder determinada pergunta.

Abaixo apresentamos os gráficos de forma que se possa visualizar os dados obtidos.

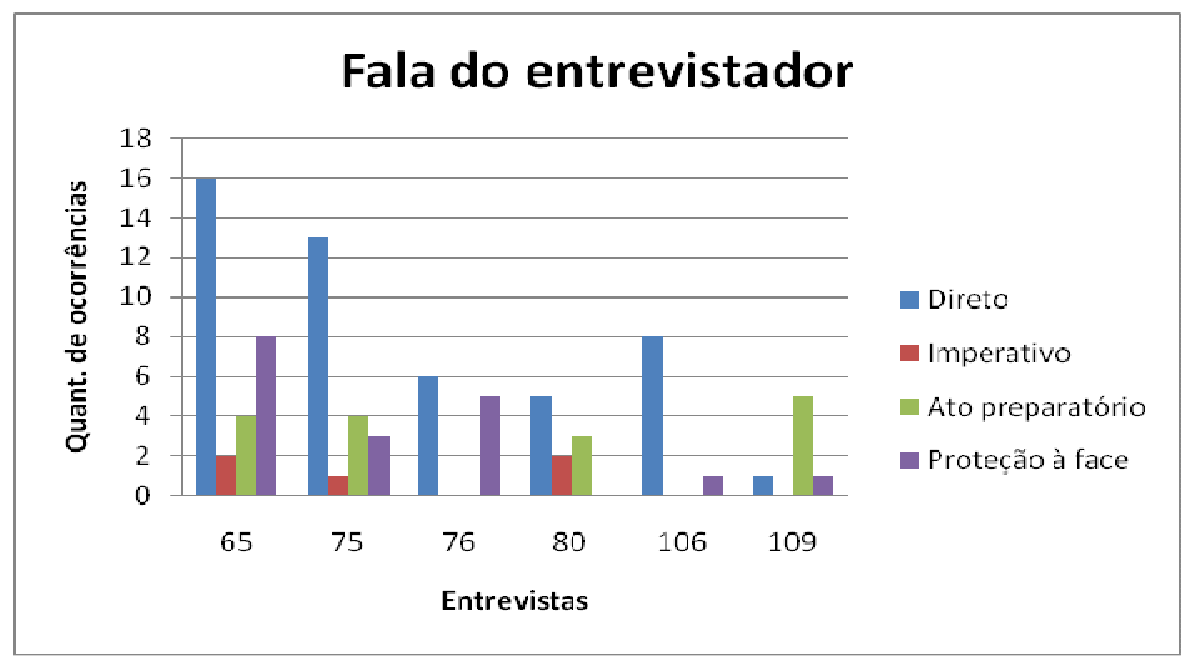

Conforme foi exposto ao longo das explicações sobre o corpus, ocorrências iguais são representadas por cores iguais de forma que isso facilite a leitura e interpretação dos gráficos.

Esses dados nos ajudam a voltar às questões que motivaram toda essa investigação: se seria o português menos direto que o espanhol e que verbos no imperativo, por exemplo, dificilmente seriam usados em enunciados interrogativos. A 
partir dos resultados acima conseguimos desmistificar algumas ideias prévias. Embora os verbos performativos também considerados atos de preparação tenha sido usado em 5 entre as 6 entrevistas analisadas, podemos observar que os enunciados diretos não podem ser desconsiderados, pois chegam a representar a maioria em 4 entrevistas. No entanto, embora três, entre as seis entrevistas analisadas apresentem verbos no imperativo, observamos que a frequência dos mesmos é bastante reduzida com relação aos enunciados diretos e atos preparatórios.

Voltando aos enunciados diretos, cabe aclarar que representam a maioria deles em 4 entrevistas, no entanto, como pode ser observado nas análises individuais, geralmente são usados quando o entrevistador já deu início a um novo tópico. Assim, quando pretende iniciar um novo tópico, o entrevistador utiliza mais elementos de atenuação e só a partir daí parte para perguntas mais diretas. Isso explica também a grande quantidade desse tipo de ocorrência.

Ainda baseando-nos no gráfico apresentado, podemos comprovar a nossa hipótese inicial, ao menos no que se refere a esse corpus especificamente, de que o Português do Brasil é menos direto ao fazer algum tipo de solicitação, no caso as perguntas de cada entrevista. Observa-se que com exceção de duas amostras, há a presença de verbos que visam proteger a face do informante e de atos preparatórios e nas amostras que não apresentam os dois tipos de ocorrência, encontra-se uma das duas, ou seja, ou ato preparatório ou proteção à face do informante.

Com relação à interação entre os participantes, podemos afirmar que a mesma não ocorreu em todas as entrevistas. Analisando caso a caso, observamos que há mais interação nas entrevistas em que os informantes são do sexo feminino. Ressaltamos que todos os entrevistadores também pertencem ao sexo feminino e isso pode ser um ponto favorável para que haja maior identificação e liberdade entre os participantes de cada entrevista.

Outro fator decisivo no grau de interação são os temas tratados ao longo de cada diálogo, ainda que o E possa ter total domínio sobre esse aspecto, observamos que na prática não é isso que ocorre. Todas as entrevistas abordam temas cotidianos e ao pedir que o informante conte algo que lhe aconteceu, como ocorre na primeira pergunta de cada entrevista, o próprio informante escolhe o tema que abordará. Assim, se o entrevistador tem algum conhecimento e interesse sobre o que lhe é contado, há mais interação, se não tem nenhum, a interação é menor. 
No caso específico das amostras de nível médio, observamos que as mulheres abordam temas mais subjetivos e pessoais como família, casamento, namorado, enquanto que os homens não, entre os três analisados, apenas um aborda na primeira resposta questões pessoais como o nascimento do filho, por exemplo.

A partir dos dados considerados, podemos concluir que em uma conversação como nas entrevistas analisadas, a interação entre os participantes depende mais do entrevistador do que do informante, pois a condução dos temas abordados é determinante. Acreditamos que a idade não é um fator fundamental e a relação que fizemos com o sexo dos informantes e entrevistadores também é correspondente aos temas abordados. Assim a identificação é maior com os informantes do sexo feminino pelo fato de o entrevistador também pertencer ao mesmo sexo e consequentemente se identificar mais com os temas abordados por tais informantes.

A planificação temática do material é bastante baixa, procurando abordar temas relacionados ao cotidiano de cada informante. Observamos que o entrevistador tem em mente cada tópico, porém o conteúdo das perguntas muitas vezes são extremamente vazios, obrigando os entrevistadores a reelaborá-las de forma que a resposta que se espera seja obtida. Não é raro encontrarmos entrevistas conduzidas pelos informantes, fato que pode comprometer a face do entrevistador caso não tenha conhecimento muito aprofundado do tema.

\subsubsection{Desfocalização do $e u$}

Como já foi apresentado ao longo de nossa fundamentação teórica e também nas análises individuais, existem algumas estratégias que o falante pode usar para desfocalizar o $e u$, referindo-se a uma $3^{\text {a }}$ pessoa do discurso, mas nem sempre ao seu interlocutor ou a si mesmo especificamente.

Durante a nossa análise pudemos observar quatro tipos de desfocalização, sendo uma no singular, usando o pronome de tratamento você e sua forma coloquial cê, duas referindo-se a mais de uma pessoa com o uso de a gente e de nós, embora a concordância de a gente seja, como sabemos, com o verbo na terceira pessoa do singular e um outro tipo, o qual classificamos como outros em nossa análise em que há referência a termos bastante gerais como a sociedade, o ser humano, as pessoas, entre outros.

Mais abaixo apresentamos o gráfico, contendo as ocorrências de cada amostra estudada a fim de elucidar e facilitar a interpretação. 


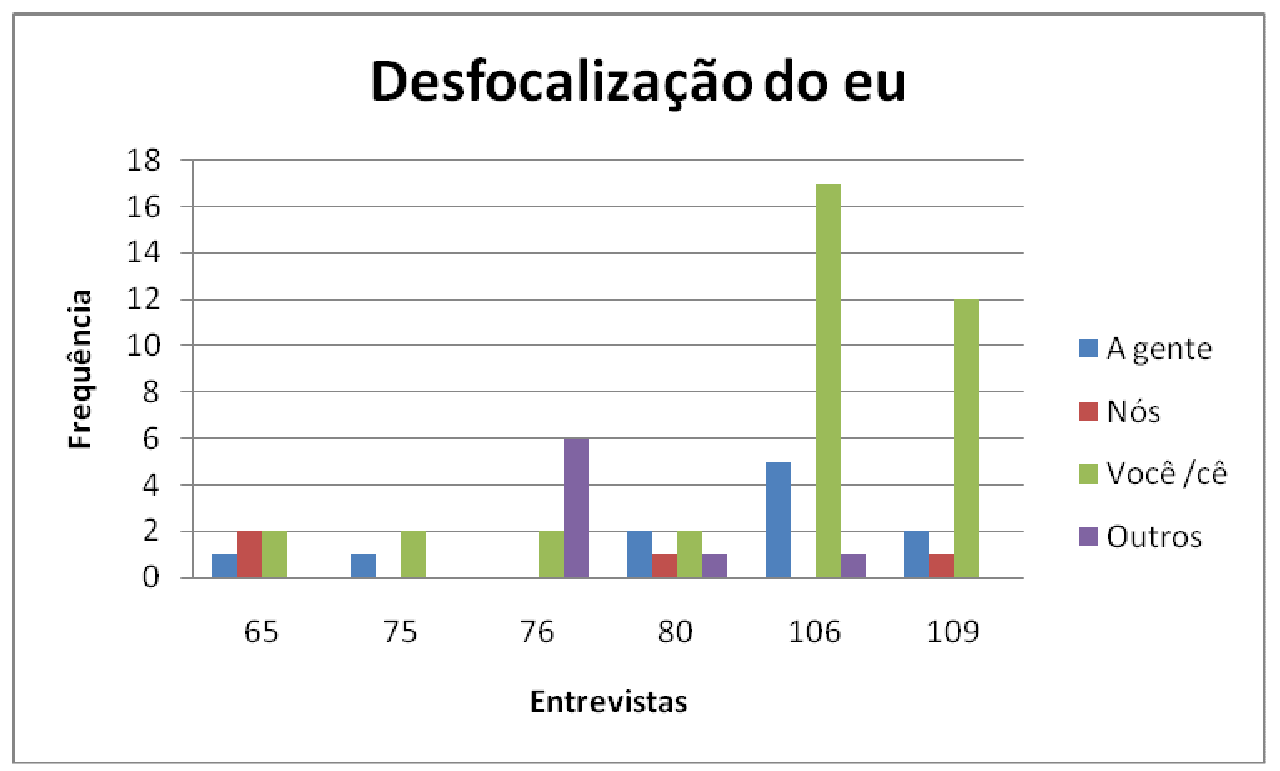

Os números que estão no eixo horizontal se referem ao número de cada amostra, já os da vertical fazem menção à quantidade de ocorrências encontrada em cada entrevista.

Com exceção da amostra 80 em que há um equilíbrio maior com relação ao uso de a gente e de vocêl cê, é possível observar que prevalece o uso de você /cê sobretudo quando o informante faz a descrição de uma receita culinária ou de algum jogo, como ocorre na fala dos informantes do sexo masculino. Embora esteja descrevendo algo que ele mesmo faz, o uso da terceira pessoa aproxima o interlocutor, incluindo-o em tal descrição. Já o uso de plural seja tanto com a forma a gente como com nós não inclui especificamente o interlocutor, mas sim qualquer outra pessoa que exerce a ação descrita pelo falante. Como meio de exemplificação, podemos observar que nas amostras 106 e 109, o uso do plural inclui todos os membros da igreja no caso da 106 e os professores de maneira geral na amostra 109 .

Tanto o pronome nós quanto a gente referem-se à primeira pessoa do plural. Em nossas análises, observamos que a forma a gente é mais utilizada, podendo ser encontrada em cinco amostras contra apenas três do pronome nós. Embora acreditemos que a quantidade de amostras analisadas seja insuficiente para uma conclusão definitiva, observamos que há preferência pelo uso do pronome a gente quando há uma referência mais indeterminada, enquanto que nós se refere a algo mais definido. Assim, o uso do singular se refere às pessoas de maneira mais generalizada, já o plural é mais pessoal. 
Com relação a esse tipo de ocorrência, observamos que o sexo do informante não interfere no resultado obtido, pois com exceção da amostra 76, todas as outras entrevistas apresentam exemplos de uso de você/cê e de a gente ou nós.

Ainda tratando da amostra 76, observa-se que se destaca nessa entrevista o uso de expressões gerais como a sociedade, o ser humano, as pessoas. O uso de tais expressões mostra um não comprometimento, a crítica pode ser feita sem que se dirija a alguém especificamente.

\subsubsection{Prevenção de ameaça à face}

Conforme apontamos ao longo de nossa exposição teórica, a prevenção de ameaça à própria face e à do outro é algo que se considera em qualquer tipo de interação. Para que tal interação seja bem sucedida há de haver um constante equilíbrio na preservação das imagens, tanto do falante quanto de seu interlocutor, de forma que nenhuma delas se prejudique.

Dessa forma, entendemos que tais aspectos não poderiam deixar de ser observados em nossas análises, ainda que os corpora analisados tenham a ressalva de serem entrevistas, em que o cuidado com a face do entrevistado tem uma importância ainda maior, cabendo ao entrevistador tal preservação. Ao longo de nossa análise, pudemos comprovar que em todas as amostras há trechos de prevenção de ameaça à face, seja do falante com a sua própria face, seja com a face alheia.

Abaixo apresentamos os tipos de ameaça encontrados e o número da amostra. Conforme poderá ser observado, não há relação desse tipo de ocorrência com o sexo dos informantes, pois todos os tipos de prevenção à face foram encontrados tanto nas amostras cujos falantes eram do sexo feminino, quanto nas amostras do sexo masculino.

\subsubsection{Proteção à própria face}

Esse tipo de prevenção é o mais recorrente, foi encontrado em todas as amostras. Utilizando-se dos mais diversos argumentos, como eu não me lembro...; não tenho certeza...; faz muito tempo...; os informantes deixam claro que não se lembram, não se recordam ou não têm certeza de algum fato ou dado. Com isso, não se comprometem com a precisão de suas afirmações. Conforme foi exposto ao longo das análises individuais, entendemos que o objetivo principal dessa estratégia é a prevenção à própria face, no entanto, é também uma forma de prevenir a ameaça à face do entrevistador, pois ao saber 
que o informante não está totalmente certo sobre determinado assunto, evitará perguntas mais específicas sobre o mesmo tema.

\subsubsection{Justificativas}

Ocorrências contendo justificativas foram encontradas nas amostras 65, 75, 76 e 109. Ao justificar-se sobre determinada ação ou pensamento, o informante pretende evitar que o entrevistador faça julgamentos sobre suas atitudes e, consequentemente, protege a própria face. Algumas vezes essa esquiva é explícita, como ocorre na amostra 75. Nesse caso, o informante deixa claro ao entrevistador que não vai falar de religião, pois tem a sua crença e acha que não é um assunto que deve ser discutido. $\mathrm{Na}$ amostra 65 , a justificativa do informante é que cometeu determinado ato por influência de um amigo, já na 76 a intenção é justificar o seu pensamento em defesa dos animais, enquanto que na 109 o informante se mostra bastante modesto e afirma que não acredita que sua maneira de ensinar seja a melhor.

\subsubsection{Proteção à face do entrevistador}

Nesse caso, é o informante quem visa proteger a face do entrevistador. Encontramos esse tipo de ocorrência nas amostras 76, 106 e 109. Foram observadas duas formas: o falante pergunta ao interlocutor se ele tem conhecimento daquilo que está sendo explicado. Caso a resposta seja negativa, faz a explicação, caso contrário, procede a sua fala. A segunda forma é mais direta, o falante se antecipa e explica o dado com mais detalhe sem perguntar se o interlocutor tem conhecimento do mesmo ou não. Tais dados e exemplos podem ser observados nas análises individuais de tais amostras.

\subsubsection{Proteção à face do informante}

Esse tipo de ocorrência pode ser encontrado na fala dos entrevistadores e já foi mencionado na exposição dos gráficos que explicam as perguntas principais de cada entrevista. No entanto como também são ocorrências de prevenção de ameaça à face, acreditamos ser conveniente apresentá-los nesse espaço.

Duas amostras apresentaram tais ocorrências: 65 e 75, em que ao elaborar seu enunciado interrogativo, o entrevistador utiliza o verbo lembrar como estratégia de cortesia. É como se indiretamente ele dissesse: responda se lembrar... É uma forma de não intimidar o informante, criando espaço para que ele não responda determinada questão, caso não saiba. 


\subsubsection{Ameaça à face}

Ainda retomando a fundamentação teórica que embasa o nosso trabalho, pudemos observar que embora os participantes de uma conversação tenham a necessidade de cuidar para que ambas as faces sejam protegidas, muitas vezes é inevitável que uma delas seja ameaçada, seja pela fala de um dos participantes ou da própria situação de interação.

No caso específico do nosso corpus, por não se tratar de uma conversação comum sem fins específicos, o cuidado deve ser ainda maior, principalmente por parte do entrevistador, pois o informante não pode se sentir ameaçado, uma vez que isso poderia findar a entrevista. Assim, ocorrendo qualquer tipo de ameaça, deve-se procurar restabelecer o equilíbrio para que o diálogo possa prosseguir sem maiores danos. Entendemos que esse é o motivo que faz com que praticamente não exista ameaça à face do outro, com exceção de uma amostra. Especificamente nesse material, as ameaças são voltadas para a face do próprio falante.

Embora todas as amostras do material de nível médio apresentem esse tipo de ocorrência, a baixa quantidade de exemplos comprova a nossa tese.

Assim como fizemos no tópico anterior, apresentaremos os tipos encontrados, seguidos do número das amostras e uma análise mais geral.

\subsubsection{Exposição da própria face}

Esse tipo de ocorrência foi encontrado em cinco, entre as seis amostras analisadas, sendo que em três a exposição é sobre sua vida pessoal, seja por meio da religião, vida sentimental ou problemas com doenças como depressão ou alcoolismo. Nesse último caso, o informante conta que o pai era alcoólatra, informação que poderia ter sido omitida, devido à pergunta elaborada pelo entrevistador. Como já abordado anteriormente, as mulheres têm mais facilidade para tratar de questões pessoais, embora os homens também o façam, como podemos constatar por meio dos dados apresentados.

Acreditamos que o fato de todas as entrevistas abordarem o cotidiano dos informantes contribui para que haja certo elo de confiança entre os interlocutores, facilitando confidências e exposições dessa natureza.

Outro tipo de exposição à face encontrado em duas amostras é um pouco mais ameaçador pelo fato de os informantes manifestarem ideias preconceituosas. No caso da amostra 65 o preconceito é com relação às pessoas que têm grande número de filhos e na amostra 109, racismo, no qual o informante compara a cor de uma pessoa com a intensidade da luz do dia e da noite. Além de fazer alusão ao temo neguinho. 
Ressaltamos que ambos os informantes que apresentaram tal ameaça são do sexo masculino.

Mais uma vez entendemos que a informalidade da entrevista, a proximidade e conhecimentos e preconceitos compartilhados entre os participantes favoreceram tais manifestações.

\subsubsection{Falta de modéstia}

Entendemos que a falta de modéstia também é uma exposição da própria face, no entanto optamos por apresentá-la separadamente. Em uma das amostras (106) encontramos três ocorrências deste tipo de ameaça à face, na qual o informante enaltece suas próprias qualidades. Acreditamos que esse tipo de exposição funciona na contramão dos atenuantes como estratégia de cortesia, pois ao se aproximar da mensagem, o falante se distancia do interlocutor.

\subsubsection{Ameaça à face do interlocutor}

Como dissemos anteriormente, esse não é um tipo de ocorrência que esperávamos encontrar em excesso devido à natureza de nossos corpora. Ao longo de todas as análises, encontramos uma única ocorrência deste tipo de ameaça (amostra 75), na qual o informante ameaça à face do entrevistador. Entendemos que essa ameaça foi provocada pelo próprio entrevistador ao insistir várias vezes que o informante lhe contasse mais histórias. Se não houvesse essa insistência, acreditamos que a ameaça não existiria.

\subsubsection{Atenuantes}

Além de todos os recursos apresentados utilizados pelos falantes de nosso corpus como estratégias de cortesia e atenuação, observamos também o uso de algumas expressões que denominamos atenuantes, pois exercem a função de mitigar o conteúdo da fala do informante ou do entrevistador.

Entre as seis entrevistas analisadas, duas (65 e 80) não apresentam esse tipo de ocorrência.

Nas amostras que contêm marcadores de atenuação com a função específica de mitigar a força do enunciado, as ocorrências encontradas foram bastante diversificadas.

A amostra que contém o maior número é a 109, com quatro exemplos, nos quais dois usam o adjetivo um pouco e o advérbio meio para explicar o estado do ônibus que a banda viajava e a falta de experiência de um dos motoristas, enquanto que os outros dois 
exemplos apresentam um conteúdo bastante racista e preconceituoso, sendo que no primeiro o informante faz uso da expressão bem moreno para acentuar a cor da pessoa mencionada e no último usa o diminutivo neguinho da FEBEM, nesse caso entendemos que a intenção é mitigar todo o conteúdo, uma vez que essa extinta instituição tinha como um dos objetivos cuidar de menores infratores, para reintegrá-los à sociedade.

A amostra 76 contém um tipo semelhante à entrevista apresentada acima, no qual o informante utiliza a expressão estrutura bem antiga para atenuar a fala anterior que qualificava a estrutura como velha.

$\mathrm{Na}$ entrevista 75, há também uma única ocorrência, na qual o informante procura se esquivar da resposta dizendo que não tem acompanhado muito as notícias sobre corrupção. Entendemos que ele evita dizer que não tem acompanhado nada, porém demonstra de maneira sutil a impossibilidade de responder a pergunta efetuada.

Por fim, a amostra 106 também apresenta um único caso, no qual após uma das ocorrências de falta de modéstia citada no campo de ameaça à face, o informante utiliza a expressão que eu saiba, prevenindo-se caso a informação não seja integralmente verdadeira.

\subsubsection{Expressão de opinião}

Conforme mencionado ao longo das análises individuais, as entrevistas que compõem esse corpus são apresentadas como um roteiro que segue uma rígida ordem de organização dos tópicos que devem ser abrangidos. Assim, o último tópico pede que o informante faça um relato de opinião e esse pode envolver um tema polêmico ou não, dependendo de cada entrevistador e dos próprios temas tratados ao longo das entrevistas.

Pudemos observar que de maneira geral, os informantes não apresentam receio em se expor, tratam os temas com bastante naturalidade, sejam eles referentes aos seus trabalhos, às críticas ao governo ou sociedade ou outros tipos de questões como o casamento, a educação dos filhos, etc., independentemente da idade e do sexo do informante.

Todos os informantes de nosso corpus fazem uso de verbos ou expressões parentéticos ou epistêmicos como achar, pensar ou crer e a conclusão a que chegamos sobre esse uso é que quanto mais conhecimento o falante tem sobre o tema que está sendo exposto, menor é a necessidade de uso de tais verbos, no entanto quando se trata de um tema polêmico em que há necessidade de expressar sua opinião mais uso o falante faz de tais verbos. Entendemos que é uma espécie de apoio e um reforço de que aquele é o seu 
ponto de vista sobre o assunto. No entanto, quando se trata de um tema que o falante domina e o mesmo não é polêmico, como por exemplo, quando um professor trata sobre a educação, menor é a necessidade de uso dos verbos mencionados.

Pode ser observado também o uso de atenuantes com a intenção de modalizar o conteúdo da fala dos informantes, dado que pode ser observado nas análises individuais.

\subsubsection{Cortesia valorizante}

Esse tipo de ato de fala foi encontrado em três entre as seis amostras do corpus de nível médio, sendo que em duas há formas de agradecimento e em uma elogio. Entendemos também que nas outras três amostras, não houve um agradecimento, porém o entrevistador utilizou-se de expressões como tá, tá certo, legal, tá joia para encerrar um tópico e introduzir outro. Classificamos tais atos de fala apenas como apoio para a mudança de tópico.

Apenas na amostra 80 encontramos também um elogio como ato de fala cortês quando o informante descreve a receita culinária.

Como já mencionado ao longo de nossa fundamentação teórica, para a cultura brasileira é comum e esperado que se agradeça algo ainda que o ato não seja considerado um favor, mas uma obrigação, como no caso de um garçom servir a bebida em um restaurante.

\subsubsection{Invasão de território pessoal}

Pelo fato das entrevistas que estamos analisando abordarem fatos do cotidiano dos informantes, o entrevistador precisa ter certo cuidado para não invadir o território pessoal dos mesmos com perguntas íntimas ou inoportunas.

Entre as seis entrevistas analisadas, consideramos que apenas uma apresenta esse tipo de ocorrência, no caso a amostra 65, em que o entrevistador procura saber detalhes da briga narrada pelo informante.

Em outras duas amostras - 76 e 109 - os entrevistadores poderiam também haver cometido tal deslize, no entanto isso não ocorreu. No caso da entrevista 76 , o entrevistador respeitou a resposta vaga dada pelo informante e mudou o tema, já na amostra 109, o informante fala sobre a depressão que sofreu e o entrevistador não faz nenhuma pergunta a fim de ampliar o assunto.

\subsubsection{Solidariedade}


Ao longo de nossos estudos sobre cortesia, observamos que a solidariedade entre os falantes também deve ser considerada como uma manifestação cortês. Assim, ao procurar completar o pensamento do falante quando esse demonstra algum lapso é uma forma de manter a fluidez do diálogo.

Pudemos observar que a frequência de tal manifestação é baixa, podendo ser encontrada em apenas duas amostras do referido corpus - 106 e 109, sendo que em ambos os casos é o entrevistador quem complementa a fala do informante, podendo dar continuidade ao diálogo.

\subsubsection{Formas de tratamento}

Com relação às formas de tratamento utilizadas ao longo de todas as entrevistas que compõem esse corpus, verificamos alguns dados relevantes. Conforme poderá ser constatado na tabela que apresentaremos adiante, pode-se afirmar que a língua falada apresenta divergências com relação à concordância, dentro do que rege a norma culta do Português do Brasil, no entanto devido à recorrência dos exemplos, observamos certa regularidade com relação ao uso.

\begin{tabular}{|c|c|c|c|c|c|}
\hline AMOSTRA & $\begin{array}{c}\text { SEXO DO } \\
\text { INF. }\end{array}$ & $\begin{array}{c}\text { PRONOME } \\
\text { PESSOAL }\end{array}$ & $\begin{array}{c}\text { PRONOME } \\
\text { OBLÍQUO }\end{array}$ & $\begin{array}{c}\text { PRONOME } \\
\text { POSSESSIVO }\end{array}$ & $\begin{array}{c}\text { FORMA } \\
\text { NOMINAL }\end{array}$ \\
\hline 065 & $\mathrm{M}$ & você / cê & te & $\begin{array}{c}\text { teu / tua } \\
\text { seu / sua }\end{array}$ & -------- \\
\hline 075 & $\mathrm{M}$ & você / cê & -------- & sua & -------- \\
\hline 076 & $\mathrm{~F}$ & você / cê & te & tua / sua & ------- \\
\hline 080 & $\mathrm{~F}$ & você / cê & te & seu / sua & ------ \\
\hline 106 & $\mathrm{~F}$ & você / cê & -------- & seu & menina \\
\hline 109 & $\mathrm{M}$ & você / cê & -------- & sua & ------- \\
\hline
\end{tabular}

Por meio da tabela acima, podemos comprovar alguns dados que foram apresentados ao longo da exposição teórica de nosso trabalho.

Devido às características específicas desse corpus, já esperávamos que a forma de tratamento estivesse no eixo de solidariedade ${ }^{43}$, pois entrevistadores e informantes apresentam faixas etárias compatíveis.

Ao expor as características específicas desse corpus e também a fundamentação teórica sobre as formas de tratamento, tivemos segurança em afirmar que essa região do

\footnotetext{
${ }^{43}$ Conforme pode ser observado na pág. 76.
} 
Estado de São Paulo não utilizava a forma $t u$ ou a segunda pessoa do singular, mas sim o pronome de tratamento com valor de pronome pessoal você, acompanhado do verbo na terceira pessoa do singular embora se dirigisse à segunda pessoa. Conforme pode ser observado na tabela acima, a forma $t u$ não foi encontrada em nenhuma das entrevistas analisadas.

Com relação ao pronome oblíquo que acompanha o pronome pessoal, podemos observar que três, entre as seis entrevistas analisadas, apresentaram tal pronome e que em todas a forma encontrada foi te, o que, como abordado anteriormente, diverge da norma culta devido à falta de concordância. No entanto, em razão da recorrência de uso do pronome, entendemos que essa é a concordância feita na língua falada nesta região. Como falante nativo do português, acreditamos que o uso do pronome oblíquo na segunda pessoa denota mais proximidade com o interlocutor, uma vez que o uso de lhe, como rege a norma culta, pode ser usado também para se referir a uma terceira pessoa.

Situação mais complicada é a análise dos pronomes possessivos ${ }^{44}$ utilizados, entre os quais se observa certa alternância de pronomes na segunda e terceira pessoas. Ainda que, devido às ocorrências encontradas ao longo das entrevistas, prevaleça o uso da terceira pessoa. Com relação aos falantes que alternaram segunda e terceira pessoas, não conseguimos atribuir isso a nenhum fato específico, pois em ambas as amostras os falantes utilizaram tanto os pronomes de segunda quanto os de terceira pessoa referindose ao mesmo substantivo.

Também em virtude do fato de esses falantes se tratarem de maneira informal, não esperávamos encontrar formas nominais nem relacionadas à idade e tampouco à profissão dos mesmos. A única forma encontrada está na amostra 106 e conforme já exposto anteriormente, atribuímos tal uso à intimidade criada pelos participantes da entrevista ao longo da mesma, uma vez que tal forma foi utilizada tanto pela entrevistadora para referir-se à informante, quanto pela informante para referir-se à entrevistadora.

\footnotetext{
${ }^{44}$ Moura Neves (2002, p.164) em seu estudo sobre os Possessivos na Gramática do Português Falado considera que o pronome possessivo teu pode representar duas diferentes formas de tratamento: tu e você. E o pronome possessivo de $3^{\text {a }}$ pessoa seu também remete à $2^{\mathrm{a}}$ pessoa, desde que representada por pronome de tratamento.
} 


\section{II. ALIP - Nível Superior}

\subsection{Amostra 115}

$$
\begin{aligned}
& \text { Informante masculino - } 50 \text { anos } \\
& \text { Entrevistador feminino }-22 \text { anos }
\end{aligned}
$$

\begin{tabular}{|c|c|c|}
\hline Perguntas Principais & Perguntas complementares & $\begin{array}{l}\text { Comentários / opiniões / } \\
\text { marcadores de interação }\end{array}$ \\
\hline $\begin{array}{l}\text { (04) bom eu gostaria que você } \\
\text { me contasse alguma história que } \\
\text { tenha acontecido com você que } \\
\text { tenha sido alegre triste alguma } \\
\text { coisa assim pra }\end{array}$ & $\begin{array}{l}\text { (19) na frente dele? } \\
\text { (46) o valor que tava faltando } \\
\text { era muito alto? } \\
\text { (59) sou } \\
\text { (96) e ele aprontou mais } \\
\text { alguma? }\end{array}$ & (106) foi tensão a todo momento \\
\hline
\end{tabular}

Tema 1 - História pessoal

Tema 2 - História contada por terceiros

\begin{tabular}{|l|l|l|}
\hline \multicolumn{1}{|c|}{ Perguntas Principais } & Perguntas complementares & $\begin{array}{c}\text { Comentários / opiniões / } \\
\text { marcadores de interação }\end{array}$ \\
\hline $\begin{array}{l}\text { (108) agora então eu gostaria } \\
\text { que você me contasse uma } \\
\text { história que tenha ocorrido com } \\
\text { alguém que você conheça que } \\
\text { tenha sido interessante... alegre } \\
\text { ou triste }\end{array}$ & & (189) que parece de filme \\
\hline
\end{tabular}

Tema 3 - Descrição de um lugar

\begin{tabular}{|l|l|l|}
\hline \multicolumn{1}{|c|}{ Perguntas Principais } & Perguntas complementares & \multicolumn{1}{c|}{$\begin{array}{c}\text { Comentários / opiniões / } \\
\text { marcadores de interação }\end{array}$} \\
\hline $\begin{array}{l}\text { (198) éh eu gostaria que você } \\
\text { me descrevesse o local para onde } \\
\text { você me contou que está indo } \\
\text { viajar }\end{array}$ & (210) é novo? & $\begin{array}{l}\text { (224) igual aquelas propagandas } \\
\text { da Coca-Cola } \\
(241) \text { que legal } \\
\end{array}$ \\
& & $\begin{array}{l}(259) \text { que legal } \\
\text { (266) deu certo }\end{array}$ \\
& $(276)$ que lindo \\
& $(280)$ que bonitinho \\
& & $(289)$ que legal \\
& & \\
\hline
\end{tabular}

\begin{tabular}{|c|c|c|}
\hline Perguntas Principais & Perguntas complementares & $\begin{array}{l}\text { Comentários / opiniões / } \\
\text { marcadores de interação }\end{array}$ \\
\hline $\begin{array}{l}\text { (293) bom você me disse que } \\
\text { gosta muito de... cozinha NE? } \\
\text { Então } \\
\text { (298) tem algum prato assim que } \\
\text { você poderia me ensinar como } \\
\text { faz? }\end{array}$ & $\begin{array}{l}\text { (361) uma pitadinha? } \\
\text { (395) se não talha né? }\end{array}$ & $\begin{array}{l}\text { (300) ah legal } \\
\text { (305) hum [que legal] } \\
\text { (309) nossa } \\
\text { (313) fresquinho } \\
\text { (331) é? } \\
\text { (351) acaba ficando um creme } \\
\text { de cebola } \\
\text { (356) hum aí é o segredo } \\
\text { (398) ele num vai cozinhar } \\
\text { (411) muito bom muito bom }\end{array}$ \\
\hline
\end{tabular}

Tema 4 - Receita

Tema 5 - Opinião pessoal

\begin{tabular}{l|l|l|} 
Perguntas Principais & Perguntas complementares & Comentários / opiniões /
\end{tabular}




\begin{tabular}{|l|l|l|}
\hline & marcadores de interação \\
\hline que que você... tá achando né? & & (430) cassações \\
Do do mandato do presidente & & \\
Lula... e da atual política & & \\
brasileira da da conjuntura & & \\
econômica do país & \\
(465) éh assim você éh disse éh & \\
a respeito das promessas que ele & \\
fez em campanha... depois de & \\
passado esses quase três anos de & \\
mandato dele você acha assim & \\
que... que ele prometeu... no & \\
sentido de conseguir se eleger ou & \\
você acha que ele num tinha & \\
noção do que era governar um & \\
país? & \\
\hline
\end{tabular}

Bem como ocorreu com as amostras de nível médio, analisadas anteriormente, há uma divisão elaborada pelos organizadores desse corpus que separa entrevista em cinco partes. As perguntas são relativamente direcionadas, o que faz com que não haja necessidade de a entrevistadora reelaborá-las a fim de torná-las mais claras, pois o informante prontamente as responde.

Entre os participantes dessa entrevista existe interação, notam-se papéis bem definidos entre ambos. $\mathrm{O}$ entrevistador elabora as perguntas e interage de diversas formas ao longo das respostas, como pode ser observado nas tabelas expostas acima. $\mathrm{O}$ informante se sente à vontade ao longo da conversa, fazendo inclusive perguntas para o entrevistador. Os temas tratados são pouco específicos, sendo que ora o E faz perguntas mais abertas para que o I direcione o tópico, como no início do diálogo, ora as elabora de maneira mais objetiva.

Com relação às perguntas principais, observa-se que em todas as aberturas de um novo tópico a E faz uso de atos de preparação, no caso o verbo gostar no Futuro do Pretérito, preparando o I para a pergunta em si. Esse fato só não é observado no tópico referente à receita culinária, mas ainda assim, podemos entender que embora não tenha usado o mesmo recurso, o efeito de sentido causado pela observação que antecede a pergunta é o mesmo.

\subsubsection{Desfocalização do eu}

Com relação à desfocalização do eu, observamos as ocorrências abaixo. Todas elas retiradas da fala do I.

(09) que quando começa um emprego a gente num tem às vezes muita malícia...

(11) ... e a gente tinha assim... grandes... éh não muito grande... 
(15) ... então a gente éh na época fazia o seguinte...

(120) ... então cê tinha que derruba(r) a casa pra arrumá(r) o esgoto...

(222) ... tipo televisão quando cê quando acende a luz assim...

(431) ... a gente sabia o seguinte...

(447) ... cê tem um per/ um um ganho...

(455) ... todos decepcionados deram com os burros n'água...

Com base nas ocorrências encontradas, podemos observar que predominam dois tipos: o uso do a gente e do você, abreviado para a forma cê, como coloquialmente é utilizado na língua falada. Com relação ao uso, no caso específico dessa entrevista, podemos constatar que o I usa a gente quando se refere a algo que aconteceu com ele e com outras pessoas também e cê para tratar de assuntos mais gerais que tenham acontecido ou não, mas que não envolvem outras pessoas. Ressaltamos que embora o I esteja falando diretamente com o E, não é a ele que o pronome de tratamento se refere, mas a uma terceira pessoa, não especificada. O terceiro caso encontrado, refere-se ao uso de todos quando o I está tratando do governo Lula. Na realidade ele expressa uma opinião sua e engloba todos os brasileiros, como se todos compartilhassem da mesma opinião.

\subsubsection{Prevenção de ameaça à face}

(24) I: ... e ele tinha falado - "o depósito o valor é xis" - ... mas eu não me recordo o valor no momento... o valor é xis...

(237) I: ... engraçado que essa piscina foi um modelo lá do do dos Estados Unidos eu num sei o nome da pessoa... da on/ da onde que foi tirado...

Nos dois casos o I expressa desconhecimento sobre parte de algo que está sendo contado, ao alertar o E sobre esse desconhecimento ele previne o $\mathrm{E}$, que certamente não fará uma pergunta sobre aquilo que é desconhecido pelo outro e se previne ao não ter que dar uma resposta negativa.

\subsubsection{Atenuantes}

(308) I: ... costumo fazê(r) eu sô(u) um po(u)co exagerado...

$\mathrm{O}$ uso da partícula um pouco tende a minimizar a força do adjetivo exagerado. $\mathrm{Na}$ entrevista em questão, foi a única ocorrência encontrada.

\subsubsection{Expressão de opinião}

As expressões de opinião foram retiradas da fala do I na última parte da amostra, destinada a um relato de opinião.

(417) ... então veja bem... éh no cenário político não sô(u) petista... eu sô(u) anti PT... NÃO votei no no no presidente Lula... mas torci para que desse certo... 
(425) ... todo mundo fico(u) preocupado apavorado para vê(r) o que que ia acontecê(r)... se ia bloquea(r) o... pouPANça... a desconfiança total... éh aí começo(u) o o governo Lula só que começo(u) pelo menos no meu no meu entende(r) o seguinte na minha opinião... que ele começo(u) fazê(r) umas indicações...

(469) eu acho que as duas... nas duas coisas... não por ele sê(r) por exemplo...

(481) ... o Lula o governo Lula... ele eu acho que é o seguinte... então tá trabalhando o PT... acho que o PT é um partido imaturo...

Entre todas as ocorrências de expressão de opinião, podemos observar que apenas a primeira não é precedida de verbos parentéticos ou epistêmicos. Nesse caso, o I expõe sua face, pois não sabe a opinião da E sobre esse tema, porém ao mesmo tempo a protege afirmando que torceu para que o Governo Lula desse certo.

Em todos os outros casos entendemos que o I não faz uso do verbo achar por ter alguma dúvida sobre o que está sendo exposto, mas sim que aquele é um juízo seu. Ainda que exista certa discordância entre os teóricos sobre a posição desse tipo de verbo, essa entrevista confirma a ideia que trata os verbos epistêmicos situados à direita do enunciado como meros marcadores de opinião.

Não foram encontradas nessa entrevista ocorrências de uso do imperativo, invasão do território pessoal, bem como atos de fala corteses como agradecimentos, elogios ou despedidas.

\subsubsection{Formas de tratamento}

Ao longo de toda essa entrevista a única forma de tratamento utilizada foi você. O falante não faz uso da forma abreviada, comum na fala coloquial cê e tampouco de pronomes oblíquos ou possessivos. Abaixo apresentamos algumas ocorrências encontradas.

(04) bom eu gostaria que você me contasse alguma história que tenha acontecido com você que tenha sido alegre triste alguma coisa assim pra

(415) éh eu gostaria de saber que que você... tá achando né? Do do mandato do presidente Lula... e da atual política brasileira da da conjuntura econômica do país

(465) éh assim você éh disse éh a respeito das promessas que ele fez em campanha... depois de passado esses quase três anos de mandato dele você acha assim que... que ele prometeu... no sentido de conseguir se eleger ou você acha que ele num tinha noção do que era governar um país?

Essa entrevista está no eixo de solidariedade e embora haja uma diferença de idade considerável entre os participantes não há uso de forma nominal. 


\subsubsection{Amostra 119}

Informante masculino - 54 anos

Entrevistador feminino - 22 anos

Tema 1 - História pessoal

\begin{tabular}{|l|l|l|}
\hline \multicolumn{1}{|c|}{ Perguntas Principais } & Perguntas complementares & \multicolumn{1}{c|}{$\begin{array}{l}\text { Comentários / opiniões / } \\
\text { marcadores de interação }\end{array}$} \\
\hline $\begin{array}{l}\text { (03) J. conta pra mim alguma } \\
\text { história que tenha acontecido c'o } \\
\text { senhor assim... que foi interessante } \\
\text { alegre ou triste }\end{array}$ & $\begin{array}{l}\text { (46) hum... mas qual era sua no banco? } \\
\text { funa ah é? } \\
\text { (57) ah é? hum }\end{array}$ & \\
\hline
\end{tabular}

Tema 2 - História contada por terceiros

\begin{tabular}{|l|l|l|}
\hline \multicolumn{1}{|c|}{ Perguntas Principais } & Perguntas complementares & $\begin{array}{c}\text { Comentários / opiniões / } \\
\text { marcadores de interação }\end{array}$ \\
\hline $\begin{array}{l}\text { (86) seu J. fala alguma história que } \\
\text { alguém te contô(u) e quem te } \\
\text { contô }(\mathrm{u})\end{array}$ & & (124) é \\
\hline
\end{tabular}

Tema 3 - Descrição de um lugar

\begin{tabular}{|l|l|l|}
\hline \multicolumn{1}{|c|}{ Perguntas Principais } & Perguntas complementares & $\begin{array}{c}\text { Comentários / opiniões / } \\
\text { marcadores de interação }\end{array}$ \\
\hline $\begin{array}{l}\text { (134) seu J. descreva pra mim uma } \\
\text { casa que o senhor morô(u) ou um } \\
\text { lugar que o senhor tenha vivido ou } \\
\text { que o senhor mora... como que é } \\
\text { assim }\end{array}$ & \\
\hline
\end{tabular}

Tema 4 - Aptidão do informante

\begin{tabular}{|c|c|c|}
\hline Perguntas Principais & Perguntas complementares & $\begin{array}{l}\text { Comentários / opiniões / } \\
\text { marcadores de interação }\end{array}$ \\
\hline $\begin{array}{l}\text { (181) seu J. fala pra mim como se } \\
\text { faz alguma coisa que o senhor saiba } \\
\text { fazê(r) }\end{array}$ & $\begin{array}{l}\text { (225) pode continuá(r) falan(d)o } \\
\text { sobre alguma o(u)tra coisa que o } \\
\text { senhor sabe como é que se faz } \\
\text { (257) quando é pênalti... que que } \\
\text { o jogador tem que fazê(r) tem } \\
\text { distância como que [é?] } \\
\text { (272) e quando é aquela falta que } \\
\text { tem aquela barre(i)Ra que tem } \\
\text { que fazê(r) como é que faz? } \\
\text { (284) pra fazê(r) a barre(i)Ra tem } \\
\text { um determinado número de } \\
\text { jogadores como é que faz }\end{array}$ & \\
\hline
\end{tabular}

Tema 5 - Relato de opinião

\begin{tabular}{|l|l|l|}
\hline \multicolumn{1}{|c|}{ Perguntas Principais } & Perguntas complementares & \multicolumn{1}{c|}{$\begin{array}{c}\text { Comentários / opiniões / } \\
\text { marcadores de interação }\end{array}$} \\
\hline $\begin{array}{l}\text { (294) seu J... fala sua opinião sobre } \\
\text { algum assunto sobre economia }\end{array}$ & $\begin{array}{l}\text { (334) o que que precisaria? } \\
\text { política futebol que que pode acontecê(r) }\end{array}$ & \\
assunto... fale sua opinião sobre algum & $\begin{array}{l}\text { se... éh colocá(r) a ALCA pra } \\
\text { funcioná(r)? }\end{array}$ & \\
\hline
\end{tabular}


Assim como todas as entrevistas que pertencem a esse corpus, há uma divisão elaborada pelos organizadores do mesmo que dividem a entrevista em cinco partes. As perguntas são bastante abertas, frequentemente o E utiliza o substantivo "coisa" na elaboração, o que deixa os enunciados sem um direcionamento. Assim, na maior parte da entrevista, quem conduz os temas é o informante. Entendemos que essa falta de planejamento por parte do E expõe sua face, pois o I pode escolher um tema desconhecido pelo E, dificultando a elaboração de novas perguntas e a interação ao longo do diálogo.

Entre os participantes dessa entrevista existe pouca interação, como apontamos no início dessa análise, o E elabora as perguntas, porém não exerce o seu papel de direcionar o diálogo, quem precisa fazer isso é o próprio I. Entendemos que isso faz com que a interação entre ambos fique comprometida. O momento em que mais se nota a participação do E é quando o I explica detalhes de um jogo de futebol, aí sim ele contribui com perguntas, interagindo com o I.

Todas as perguntas que abrem um novo tópico apresentam verbos no imperativo, não se observa o uso de atos de preparação. Ressaltamos que é a única entrevista do corpus que apresenta $100 \%$ dos enunciados interrogativos usando verbos no imperativo. Como poderá ser constatado no gráfico comparativo apresentado mais adiante.

\subsubsection{Desfocalização do $e u$}

Com relação às estratégias de desfocalização do eu, notamos que são usadas apenas na última parte da entrevista, quando o I deve fazer um relato de opinião. Abaixo transcrevemos as ocorrências encontradas seguidas de breve análise.

(299) I: nós que tamo(s) fora...

(299) I: a gente acha solução facinho pra ela...

(304) I: ... você pega a as prefeitura principalmente do do norte nordeste...

(347) I: ... há quem diga ... que vai ficar pior... que... eles vem lá de fora e... vamos dizer assim eles vão ter acesso...

(349) I: Dizem né? dizem que eles quer aqui será isso aí mas...

(362) I: uai eles vão pegar... segundo dizem ... eles têm livre acesso ATÉ foi dado um exemplo...

Com base nas ocorrências encontradas, podemos observar que não há predominância de um tipo ou outro de pronome. Nas duas primeiras ocorrências, o I inclui ele e outras pessoas que não são mencionadas, já quando usa você, está sendo mais generalizador, essa terceira pessoa pode ser tanto o entrevistador, quanto qualquer pessoa que leia a entrevista. Outro tipo de desfocalização encontrado refere-se às ocorrências 
presentes nas linhas 347, 349 e 362, nas quais é facilmente perceptível que o I visa não se comprometer com a opinião dada, deixando claro que quem faz tal afirmação não é ele.

\subsubsection{Prevenção de ameaça à face}

Ao longo dessa entrevista encontramos uma única ocorrência de prevenção de ameaça à face:

(118) I:... eles fala o nome de/ desse português aí eu num lembro de/ ele lembra até hoje que os português que ficaram moran(d)o na casado pai dele aí eu num lembro...

Nos dois casos o I expressa desconhecimento sobre parte de algo que está sendo contado, ao alertar o E sobre esse fato, faz uma prevenção, pois, provavelmente, o E não fará uma pergunta sobre aquilo que é desconhecido pelo outro e se previne ao não ter que dar uma resposta negativa.

\subsubsection{Atenuantes}

Há apenas uma ocorrência de uso de partícula atenuadora. Abaixo apresentamos o trecho, seguido de breve análise.

(141) I.... quando nós compramo(s)... era uma casa que tava... bem assim estado bem ruizinho... bem judiada vamo(s) dizê(r) né?

No primeiro caso temos a combinação do advérbio bem e do adjetivo no diminutivo e no segundo apenas o uso do advérbio, enfatizando o estado da casa. Observa-se que o interlocutor consegue entender qual era de fato a intensidade do estado da casa sem que o falante tenha que utilizar adjetivos mais depreciativos.

\subsubsection{Expressão de opinião}

Abaixo apresentamos as ocorrências de expressão de opinião, todas presentes na fala do I.

(310) ... porque eu acho o seguinte por exemplo... essa política que vem sendo feita no Brasil... é uma política de de de de remendo... sempre foi feito assim... e num adianta ninguém vim falá(r) aqui por exemplo na minha opinião - "ah o Brasil tem que chegá(r) lá” ...

(319) ... acontece que SE corTÁ(r) com esse FMI... na minha opinião... na Minha opinião... num é SÓ... o dinhei(i)ro...

(330) ... essa política que que que é feita de de COM esse FMI... na minha opinião é um MAL...

(332) ... que o Brasil conseguí(r)... estabilizá(r)... que eu acho que na minha opinião num é tão...

(345) ... nós tamo(s) sempre pendente... agora... tamo(s) falan(d)o dessa... dessa ALCA... que é... a ALCA é um... éh éh pra nós que tamos de fora... nós num sabemo(s) o que é isso... há quem diga... que vai ficá(r) pior... que... eles vem lá de fora e... vamo(s) dizê(r) assim eles vão tê(r) livre acesso aqui pra entrá(r) fazê(r) o que quisé(r) botá(r) uma empresa aqui e e sem pedi(r)... autorização... Dizem né? Dizem que eles... 
Nas quatro primeiras ocorrências de expressão de opinião observamos a presença de verbos e formas parentéticos ou epistêmicos, seja na forma do verbo achar ou da expressão na minha opinião. Fica bastante evidente que o I em momento algum pretende convencer o E sobre suas ideias, procura apenas expressá-las, deixando claro que o que diz não é nenhum consenso, mas uma opinião pessoal sua. Nessa entrevista, os verbos e expressões podem ser encontrados tanto à esquerda quanto à direita da ideia defendida, ainda assim entendemos que se trata da opinião do I e não de dúvidas que ele possa ter sobre o que está sendo exposto.

Já com relação ao trecho da linha 345 , é interessante observar que ao usar a terceira pessoa, seja do plural ou do singular, o I tira a responsabilidade de si. Essa responsabilidade não é transferida a ninguém especificamente. Além disso, a ausência de verbos ou expressões parentéticos ou epistêmicos evidenciam que o I procura enfatizar que aquela não é sua opinião.

Não foram encontradas nessa entrevista ocorrências de invasão do território pessoal e tampouco são citados atos de fala corteses como agradecimentos, elogios ou despedidas.

\subsubsection{Formas de tratamento}

Nessa amostra, observamos que as formas de tratamento utilizadas giram mais em torno do eixo de poder do informante sobre o entrevistador, pois além de apresentar forma nominal, o entrevistador utiliza a forma de tratamento o senhor. Abaixo apresentamos as ocorrências encontradas.

(03) J. conta pra mim alguma história que tenha acontecido c'o senhor assim... que foi interessante alegre ou triste

(46) hum... mas qual era sua função no banco?

(86) seu J. fala alguma história que alguém te contô(u) e quem te contô(u)

(134) seu J. descreva pra mim uma casa que o senhor morô(u) ou um lugar que o senhor tenha vivido ou que o senhor mora... como que é assim

(181) seu J. fala pra mim como se faz alguma coisa que o senhor saiba fazê(r)

(294) seu J... fala sua opinião sobre algum assunto sobre economia política futebol sobre algum assunto... fale sua opinião sobre

Como podemos observar por meio dos exemplos apresentados, o entrevistador faz uso da forma nominal seu, antecedendo o nome do informante e em todas as perguntas se refere ao mesmo como o senhor. Os pronomes possessivos encontrados estabelecem concordância de terceira pessoa, porém o pronome oblíquo utilizado é a forma te, divergindo do que rege a norma culta do Português do Brasil, que indicaria como a mais adequada a forma lhe. 
Essa entrevista está no eixo de poder, acreditamos que a idade do I motiva o uso da forma nominal e do tratamento o senhor.

\subsection{Amostra 120}

Informante feminino - 51 anos

Entrevistador feminino - 22 anos

Tema 1 - História pessoal

\begin{tabular}{|c|c|c|}
\hline Perguntas Principais & Perguntas complementares & $\begin{array}{l}\text { Comentários / opiniões / } \\
\text { marcadores de interação }\end{array}$ \\
\hline $\begin{array}{l}\text { (03) então dona M... agora eu } \\
\text { queria que a senhora me } \\
\text { contasse... é uma história assim } \\
\text { que tenha acontecido c'a } \\
\text { senhora... que que... tenha sido } \\
\text { divertida ou alegre... } \\
\text { constrangedora enfim... pode } \\
\text { contá(r) }\end{array}$ & $\begin{array}{l}\text { (19) a senhora se lembra assim } \\
\text { de algum episódio específico } \\
\text { assim... pra contá(r) pra gente } \\
\text { (34) isso já acabo(u) geran(d)o } \\
\text { assim alguma briga? mal } \\
\text { entendido? } \\
\text { (48) como que ele que ele se } \\
\text { dirigiu c'a senhora como foi que } \\
\text { ele? } \\
\text { (75) e esse sujeito que você } \\
\text { ligo(u) lá na firma pa reclamá(r) } \\
\text { dele... cê reclamô(u) com PA/ } \\
\text { patrão dele?... como que foi? } \\
\text { (88) num aconteceu nada com } \\
\text { ele? } \\
\text { (92) a senhora continua então } \\
\text { trabalhando com essa pessoa? }\end{array}$ & (105) tá certo dona $\mathrm{M}$. \\
\hline
\end{tabular}

Tema 2 - História contada por terceiros

\begin{tabular}{|c|c|c|}
\hline Perguntas Principais & Perguntas complementares & $\begin{array}{l}\text { Comentários / opiniões / } \\
\text { marcadores de interação }\end{array}$ \\
\hline $\begin{array}{l}\text { (108) dona } M \text {. agora eu quero } \\
\text { que a senhora me conta... uma } \\
\text { história que tenha acontecido... } \\
\text { com alguém que você conhece... } \\
\text { é que alguém tenha te contado } \\
\text { essa história }\end{array}$ & $\begin{array}{l}\text { (131) como que foi assim os } \\
\text { últimos anos dele? } \\
\text { (140) a sua cunhada que tava } \\
\text { com ele nesse momento? } \\
\text { (162) como é que ela conta } \\
\text { assim como que foi essas... esses } \\
\text { anos essas últimas horas assim } \\
\text { antes dele falecê(r) } \\
\text { (165) ele foi internado num foi } \\
\text { pra fazê(r) exame }\end{array}$ & $\begin{array}{l}\text { (118) ah é } \\
(179) \text { ah é? } \\
(182) \text { ai tadinho } \\
(189) \text { é verdade claro }\end{array}$ \\
\hline
\end{tabular}

Tema 3 - Descrição de um lugar

\begin{tabular}{|c|c|c|}
\hline Perguntas Principais & Perguntas complementares & $\begin{array}{l}\text { Comentários / opiniões / } \\
\text { marcadores de interação }\end{array}$ \\
\hline $\begin{array}{l}\text { (193) dona } \mathrm{M} \text {. agora eu quero } \\
\text { que a senhora me descreve... um } \\
\text { local... pra mim }\end{array}$ & $\begin{array}{l}\text { (198) cês dormiam cê e sua } \\
\text { irmã... com seus pais... junto } \\
\text { (212) era ali que seu irmão } \\
\text { dormia? } \\
\text { (232) era grande esse terreno do } \\
\text { fundo assim? } \\
\text { (241) ah éh [na mesma casa?] } \\
\text { (246) [e como que] era a frente }\end{array}$ & $\begin{array}{l}\text { (202) uhm conheço } \\
(204) \text { ah } \\
(231) \text { conheço } \\
\text { (243) [no] mesmo bairro } \\
\text { (257) ah é? } \\
\text { (268) tá certo }\end{array}$ \\
\hline
\end{tabular}


dessa casa?

(255) e tinha asfalto essa rua?

(261) desde aquela época já era?

Tema 4 - Receita culinária

\begin{tabular}{|c|c|c|}
\hline Perguntas Principais & Perguntas complementares & $\begin{array}{l}\text { Comentários / opiniões / } \\
\text { marcadores de interação }\end{array}$ \\
\hline $\begin{array}{l}\text { (271) dona } M \text {. a senhora tava me } \\
\text { falan(d)o que você sabe fazê(r) } \\
\text { muitas coisas né? que você } \\
\text { tam(b)em... éh sabe cozinhá(r)... } \\
\text { você pode me ensiná(r) como } \\
\text { que você faz algum prato? } \\
\text { (298) a senhora sabe mais de } \\
\text { alguma receitinha pra gente? }\end{array}$ & $\begin{array}{l}\text { (294) [oba]... o forno deve tá } \\
\text { pré-aquecido ou não? } \\
\text { (317) ah tá num pode tá com a } \\
\text { água ferven(d)o? } \\
\text { (324) esse aí é o recheio da } \\
\text { trufa? } \\
\text { (328) ah ela fica firminha pa } \\
\text { enrolá(r) } \\
\text { (340) na forminha [com aquele } \\
\text { chocolate?] }\end{array}$ & $\begin{array}{l}\text { (288) pó Royal mistura } \\
\text { separadamente } \\
\text { (300) ai que delícia } \\
\text { (303) ah tá } \\
\text { (311) fica macio } \\
\text { (318) ah tá } \\
\text { (321) aí acrescenta todos os } \\
\text { ingredientes } \\
\text { (325) ah tá } \\
\text { (326) ah é? } \\
\text { (344) já tá pronta... ai que delícia }\end{array}$ \\
\hline
\end{tabular}

Tema 5 - Opinião pessoal

\begin{tabular}{|c|c|c|}
\hline Perguntas Principais & Perguntas complementares & $\begin{array}{l}\text { Comentários / opiniões / } \\
\text { marcadores de interação }\end{array}$ \\
\hline $\begin{array}{l}\text { (347) dona M. éh a senhora me } \\
\text { disse que a senhora é espírita né? } \\
(349) \text { e/ então eu gostaria de } \\
\text { sabê(r)... da senhora é... se a } \\
\text { senhora acredita na reencarnação } \\
\text { né? ... e por quê? } \\
(386) \text { assim eu sô(u) católica eu } \\
\text { não conheço como que é a } \\
\text { doutrina do espiritismo... mas } \\
\text { vocês espíritas... que que vocês } \\
\text { acham da questão assim do } \\
\text { aborto?... Como que vocês } \\
\text { encaram essa questão? } \\
\text { (390) a senhora assim } \\
\text { especificamente o que que você } \\
\text { pensa disso? }\end{array}$ & $\begin{array}{l}\text { (368) a senhora acredita que a } \\
\text { pessoa reencarna pra... é... } \\
\text { pagá(r) alguma coisa? } \\
\text { (383) seria como [uma] evolução } \\
\text { (isso daí)? }\end{array}$ & $\begin{array}{l}\text { (353) isso } \\
(379) \text { certo } \\
(380) \text { é } \\
(399) \text { tô sabendo } \\
(416) \text { certo } \\
(426) \text { sei } \\
(434)[\text { uhum]... tá certo }\end{array}$ \\
\hline
\end{tabular}

Assim como todas as entrevistas que pertencem a esse corpus, há uma divisão elaborada pelos organizadores do mesmo que dividem a entrevista em cinco partes. Avaliamos essa entrevista como uma das mais bem conduzidas, embora em alguns momentos o $\mathrm{E}$ tenha feito perguntas bastante gerais, ao reelaborá-las conseguiu manter a fluidez e interagir em todos os tópicos. Além disso, observa-se baixa planificação, uma vez que o E utilizou as falas da I para elaborar novas perguntas. Com isso, obteve um diálogo bastante coloquial e próximo ao cotidiano do I.

A interação entre os participantes dessa entrevista é bastante acentuada. Atribuímos isso a dois fatos: o primeiro está relacionado aos temas tratados, próximos da vida do I o que causou fluidez na entrevista e o segundo foi a curiosidade do E, tornandose inclusive insistente em alguns momentos em busca de detalhes dos fatos narrados. No 
entanto, não se nota ao longo da fala do I incômodo devido a essa insistência, ao contrário, sempre que solicitados, os detalhes foram descritos.

As formas de elaboração das perguntas principais são bastante diversificadas. Não há em momento algum, por exemplo, o uso de verbos no imperativo, no entanto observamos que ao perguntar sobre a história contada por terceiros e a descrição de um lugar, o E utiliza a expressão eu quero, demonstrando uma imposição muito mais forte e menos cortês do que eu queria, utilizada na abertura da entrevista. Já ao pedir que o I descreva uma receita culinária o $\mathrm{E}$ opta pela expressão você pode... o que se caracteriza como uma das máximas da cortesia apresentadas na fundamentação teórica desse trabalho que diz que se deve dar opção ao interlocutor ${ }^{45}$. Por fim ao solicitar um relato de opinião, o E é direto e se apoia apenas na fala do I para justificar o motivo da pergunta.

\subsubsection{Desfocalização do $e u$}

Com relação às estratégias de desfocalização do $e u$, notamos que são poucas as ocorrências encontradas. Abaixo apresentamos os trechos, seguidos de breve análise.

(214) I: ... então cê abria o sofá e virava uma cama...

(359) I: ... existe o ditado que... o pessoal fala muito aqui...

(376) I: ... cê ia procurá(r) num fazê(r) aquilo ali...

(428) I:... então é todo questionamento tudo que a gente qué(r)...

(428) I: ...é só você buscá(r) que você encontra...

(429) I: ... então cê começa a entendê(r) uma série de coisas que você fala...

(431) I: ... aconteceu aquilo então cê.... começa a entendê(r)... coisas que aconteceu com você... que no momento cê se... desespera cê... mas cê encontra resposta... [pra tudo]

Com base nas ocorrências encontradas, podemos observar a predominância do pronome você e da sua forma abreviada, comum na língua falada, cê. Acreditamos que ao utilizar a terceira pessoa para desfocalizar o eu, o I busca aproximar o entrevistador, incluindo-o no diálogo. Entendemos que ao usar a forma a gente na linha 428 a referência é a todas as pessoas que seguem a doutrina religiosa descrita. Outro tipo de desfocalização do eu encontrado, está na linha 359, no qual o I generaliza o autor da mensagem, eximindo-se da responsabilidade sobre a mesma.

Outro fato observado nessa entrevista é a forma como o E elabora algumas de suas perguntas. Abaixo transcrevemos os trechos:

(19) E: a senhora se lembra assim de algum episódio específico assim... pra contá(r) pra gente

(298) E: a senhora sabe mais de alguma receitinha pra gente?

${ }^{45}$ Vide pág. 53 
Embora a forma "a gente" seja sempre usada com verbos na $3^{\text {a }}$ pessoa do singular, o seu referente sempre é plural, podendo ser substituído pelo pronome pessoal nós. Entendemos que o uso dessa forma na entrevista é uma ocorrência do plural de modéstia, tratado na fundamentação teórica desse trabalho ${ }^{46}$, pois ainda que E e I sejam as únicas pessoas presentes, a entrevista possui um grupo de pessoas envolvido na elaboração e o uso do plural procurou envolver tais pessoas.

\subsubsection{Prevenção de ameaça à face}

Abaixo apresentamos as ocorrências de prevenção de ameaça à face, seguidas de breve análise.

(203) I: éh... naquela época porque eu sô(u) jovem ainda mas naquela época não tínhamos televisão... (228) I: ... aí tinha um pé de... joão-bolão... num sei se cê conhece

Nessa entrevista temos dois casos distintos de prevenção de ameaça à face, ambos pertencentes à fala do I. No primeiro deles, ele visa proteger sua própria face, enfatizando que o fato de não possuir televisão não tem qualquer relação com a sua idade. $\mathrm{Na}$ segunda ocorrência há uma prevenção de ameaça à face do E, caso o mesmo desconheça o elemento que está sendo tratado. Ao fazer o comentário que aparece destacado na transcrição, o I evita o constrangimento de o E precisar expor seu desconhecimento e indiretamente se dispõe a explicar de qual planta se trata.

\subsubsection{Atenuantes}

Há apenas duas ocorrências de uso de atenuantes.

(64) I: ... já dei uma cortadinha nele também né...

(167) I: ... médico disse que tava bem ele tava assim meio que resfriadinho só...

No primeiro caso temos o uso de um vocabulário comum na gíria dos adolescentes no diminutivo, procurando enfatizar a chamada de atenção que ela deu em outra pessoa e no segundo a combinação do advérbio meio e do adjetivo no diminutivo, atenuando a intensidade do resfriado.

\subsubsection{Expressão de opinião}

Abaixo apresentamos as ocorrências de expressão de opinião do informante. Ressaltamos que foram retiradas da última parte da entrevista.

(352) bom eu acr/ lógico que eu acredito na reencarnação né? porque a própria doutrina ela prega a reencarnação agora cê qué(r) sabê(r) por que que eu acredito em reencarnação?... é porque... na minha

\footnotetext{
${ }^{46}$ Vide pág. 66
} 
opinião... né? e e e pelo conhecimento que a gente tem da doutrina... é... Deus... ele num iria criá(r) tudo isso daqui... pra simplesmente acabá(r)... morreu acabo(u)...

(366) ... o universo tá aí... então acho que... num tem porque não acreditá(r) na reencarnação cê entendeu?... éh

(391) existe é/ é/ veja bem éh... existe o livre arbítrio... cê entedeu?... agora nós num podemos julgar... nenhuma criatura... cê entendeu? porque a / a/ o livre arbítrio é dela... ELA que vai ter que responder... por tudo que ela faz... num vai ser eu num vai ser você (...) é um crime e a gente sabe que é um crime você tá interrompendo... éh... que um espírito reencarna...

(427) então eu falo pra você... é uma doutrina que num te de(i)xá é/ é dúvida de nada... cê entendeu... então é todo questionamento tudo que a gente qué(r) é só você buscá(r) que você encontra...

Todo o relato de opinião presente nessa entrevista gira em torno do tema da reencarnação e do aborto, conforme pode ser observado na íntegra da entrevista nos anexos do trabalho. As únicas ocorrências de expressão ou verbo parentético ou epistêmico são as descritas acima. Ao longo de toda a explanação do I não aparece mais o uso desses recursos. Entendemos que esse fato se dá devido à convicção do que é dito pelo I. Ele é muito seguro, demonstra realmente saber e acreditar naquilo que diz, podendo inclusive convencer o outro. Devemos ressaltar que o E fez uma pergunta de âmbito muito pessoal e é natural que as pessoas defendam sua religião, sua crença com tanto afinco.

É interessante observar na ocorrência da linha 391, a pergunta do E foi bem clara a senhora assim especificamente o que você pensa disso? Quando o tema tratado era o aborto. O I dá a sua opinião, afirmando que é um crime, porém para isso, faz toda uma justificativa sobre o que é o aborto para a doutrina espírita.

Apesar do exposto acima, não consideramos a pergunta do E como uma invasão do território privado da I, pois ele mesmo já havia dito que era espírita (linha 184), dando abertura para que perguntas sobre o tema fossem feitas.

Com relação aos atos de fala corteses como agradecimentos, elogios ou despedidas, podemos observar que em dois momentos, ao fazer a mudança de tópico, a $\mathrm{E}$ utiliza a forma tá certo. Não é um agradecimento, é uma forma de indicar que está encerrando um assunto e começando outro, conforme já observado em outras amostras.

Ainda analisando a fala do I, observamos que existe frequência acentuada do apoio conversacional cê entendeu?. Acreditamos que nesse caso isso seja um vício do I que certamente não percebe a quantidade de vezes que pronuncia essa expressão.

\subsubsection{Formas de tratamento}

Observa-se nessa entrevista uma mescla bastante acentuada dos pronomes de tratamento. Abaixo apresentamos algumas ocorrências e uma breve análise. 
(03) I: então dona M... agora eu queria que a senhora me contasse... é uma história assim que tenha acontecido c'a senhora... que que... tenha sido divertida ou alegre... constrangedora enfim... pode contá(r)

(19) I: a senhora se lembra assim de algum episódio específico assim... pra contá(r) pra gente

(75) I: e esse sujeito que você ligo(u) lá na firma pa reclamá(r) dele... cê reclamô(u) com PA/ patrão dele?... como que foi?

(92) I: a senhora continua então trabalhando com essa pessoa?

(108) I: dona M. agora eu quero que a senhora me conta... uma história que tenha acontecido... com alguém que você conhece... é que alguém tenha te contado essa história

(140) I: a sua cunhada que tava com ele nesse momento?

(193) I: dona M. agora eu quero que a senhora me descreve... um local... pra mim

(198) I: cês dormiam cê e sua irmã... com seus pais... junto

(212) I: era ali que seu irmão dormia?

(271) I: dona M. a senhora tava me falan(d)o que você sabe fazê(r) muitas coisas né? que você tam(b)em... éh sabe cozinhá(r)... você pode me ensiná(r) como que você faz algum prato?

(347) I: dona M. éh a senhora me disse que a senhora é espírita né?

(349) I: e/ então eu gostaria de sabê(r)... da senhora é... se a senhora acredita na reencarnação né? ... e por quê?

(390) I: a senhora assim especificamente o que que você pensa disso?

Retiramos um grande número de ocorrências dessa entrevista, pois o entrevistador faz uma mescla ao usar os pronomes de tratamento e, acreditamos que os exemplos poderão nos ajudar na explicação.

Observa-se que o tratamento dispensado ao informante gira em torno do eixo de poder, pois é um tratamento formal, caracterizado pela forma nominal antecedendo o nome do informante dona e também pelo uso de a senhora. Acreditamos que, embora o informante pertença ao grupo de nível superior, o poder tem relação com a idade dele.

Apesar de acreditarmos que o entrevistador visa dispensar ao informante um tratamento formal, não podemos desconsiderar a mescla do tratamento formal com o informal assinalado pelo uso de você e cê. Entendemos que o entrevistador, habituado a tratar as pessoas por você, descuidava-se e fazia tal mistura, retomando o tratamento formal no início de cada tópico. A nossa conclusão sobre isso se deve ao fato de as perguntas principais sempre serem iniciadas com o tratamento formal para depois passar para o informal. Não atribuímos tal fato a uma possível intimidade entre os informantes, pois se esse fosse o motivo, o entrevistador passaria a utilizar somente o tratamento informal, sem mesclá-los.

Com relação aos outros pronomes utilizados, observa-se apenas uma ocorrência do pronome oblíquo te, o que, como já observado em análises anteriores, contraria a concordância proposta pela norma culta do Português do Brasil. Já os pronomes possessivos encontrados foram todos de terceira pessoa seu, sua.

Após a análise individual das entrevistas, apresentaremos uma análise geral, no intuito de estabelecer comparações entre as mesmas, a fim de se chegar a algumas conclusões sobre os usos de tais formas de tratamento. 


\subsection{Amostra 146}

Informante feminino - 68 anos

Entrevistador feminino - 21 anos

Tema 1 - História pessoal

\begin{tabular}{|c|c|c|}
\hline Perguntas Principais & Perguntas complementares & $\begin{array}{l}\text { Comentários / opiniões / } \\
\text { marcadores de interação }\end{array}$ \\
\hline $\begin{array}{l}\text { (02) é uma outra questão a sê(r) } \\
\text { levantada é essa... se a senhora } \\
\text { tem alguma experiência pra } \\
\text { contá(r) né?... dessas... dessas } \\
\text { entrevistas... que como a senhora } \\
\text { disse é a senhora criava relações } \\
\text { de afeto entre os informantes } \\
\text { então tem alguma experiência? }\end{array}$ & & \\
\hline
\end{tabular}

Tema 2 - História contada por terceiros

\begin{tabular}{|c|c|c|}
\hline Perguntas Principais & Perguntas complementares & $\begin{array}{l}\text { Comentários / opiniões / } \\
\text { marcadores de interação }\end{array}$ \\
\hline $\begin{array}{l}\text { (68) bom professora eu gostaria } \\
\text { que a senhora me falasse é me } \\
\text { contasse alguma história ou } \\
\text { algum fato que a senhora... não } \\
\text { presencio(u) mas... que alguém } \\
\text { algum dia conto(u) pra senhora e } \\
\text { a senhora acho(u) interessante e } \\
\text { a senhora podia contá(r)... pra } \\
\text { mim }\end{array}$ & & \\
\hline
\end{tabular}

Tema 3 - Descrição das aulas

\begin{tabular}{|c|c|c|}
\hline Perguntas Principais & Perguntas complementares & $\begin{array}{l}\text { Comentários / opiniões / } \\
\text { marcadores de interação }\end{array}$ \\
\hline $\begin{array}{l}\text { (188) ISSO então como a } \\
\text { senhora me disse que a senhora é } \\
\text { professora deu... deu aula } \\
\text { durante muitos anos... professora } \\
\text { de História da Educação então } \\
\text { eu queria sabê(r) como que eram } \\
\text { as suas aulas assim se a senhora } \\
\text { podia me descrevê(r)... assim... } \\
\text { éh como que eram as suas aulas }\end{array}$ & & (249) num pensa depois \\
\hline
\end{tabular}

Tema 4 - Descrição das pesquisas que o I realizava

\begin{tabular}{|l|l|l|}
\hline Perguntas Principais & Perguntas complementares & $\begin{array}{c}\text { Comentários / opiniões / } \\
\text { marcadores de interação }\end{array}$ \\
\hline $\begin{array}{l}\text { (293) professora com relação a } \\
\text { essas pesquisas que a senhora } \\
\text { conto(u) eu queria sabê(r) como } \\
\text { que foi o procedimento utilizado } \\
\text { pra realizá(r) essas pesquisas... } \\
\text { como que foi feito assim... essas }\end{array}$ & & \\
pesquisas? & & \\
\hline
\end{tabular}


Tema 5 - Opinião pessoal

\begin{tabular}{|c|c|c|}
\hline Perguntas Principais & Perguntas complementares & $\begin{array}{l}\text { Comentários / opiniões / } \\
\text { marcadores de interação }\end{array}$ \\
\hline $\begin{array}{l}\text { (363) professora e QUAL que é } \\
\text { a importância que a senhora acha } \\
\text { nesse tipo de pesquisa assim que } \\
\text { que a senhora pensa desse tipo } \\
\text { de pesquisa que a senhora } \\
\text { realizo(u)... assim éh... uma } \\
\text { pesquisa assim tão ampla e tão } \\
\text { interessante qual que é a } \\
\text { importância disso pra senhora? }\end{array}$ & & (379) não \\
\hline
\end{tabular}

Assim como todas as amostras que pertencem a esse corpus, há uma divisão elaborada pelos organizadores do mesmo que dividem a entrevista em cinco partes. No entanto, o E teve o cuidado de manter um único tema ao longo de toda a entrevista - o trabalho do I. Dessa forma, ele adequou o objetivo de cada parte da mesma ao tema que estava sendo tratado. A nosso ver essa entrevista foi bastante tranquila para o I, porém muito distante para o E, o que fez com que a fluidez desse diálogo fosse muito comprometida.

Assim, não há interação entre os participantes dessa entrevista. Isso se comprova quando observamos que o E não faz qualquer tipo de comentário ao longo das respostas do I, são raros também os marcadores de interação como hum, aham. Atribuímos isso a dois fatos: o primeiro está relacionado ao tema tratado, extremamente distantes da vida do E o que não proporcionou fluidez na entrevista, foram apenas perguntas seguidas de respostas. $\mathrm{O}$ segundo fato é a distância existente entre os participantes desse diálogo. Ao longo de nossa análise, observamos que muitas vezes essa distância é quebrada com o desenrolar da entrevista, fenômeno que não ocorreu nessa amostra.

Podemos dividir as perguntas elaboradas pelo E em dois grupos: perguntas diretas e as que são precedidas de atos de preparação. Além disso, entre as cinco perguntas, duas delas possuem o verbo poder no pretérito imperfeito do indicativo oferecendo opção ao interlocutor. Assim como foi mencionado na análise da entrevista anterior, esse fato se caracteriza como uma das máximas da cortesia. É certo que essa opção que se dá ao interlocutor é bastante subjetiva, pois uma vez que o mesmo aceitou participar da entrevista, é muito difícil que haja a negação de uma resposta, no entanto podemos entender que é uma forma de fazer com que o entrevistado pré-selecione o que pode ou não ser contado. 


\subsubsection{Desfocalização do $e u$}

Com relação às estratégias de desfocalização do eu, notamos que há diversos exemplos, todos retirados da fala do I, abaixo apresentamos os trechos seguidos de breve análise:

(178) ... mas a gente escutando os mais velhos... você... acaba vivenciando... com eles...

(228) ... você tinha que escrevê(r) o seu trabalho... depois você tinha que í(r) a São Paulo pra re/ é pra LER

(230)... ele ouvia o que você tinha... escrito... e o seu colega acompanhava...

(232) ... você tinha que dá(r) uma aula... em em vinte e quatro horas você sorteava... se você tinha que dá(r)

(245) ... aquele negócio de... você já prevê... você já teve muita experiência...

(246)... então você vai utilizá(r) depois aquilo...

(369) ... mas acontece que se você... cê consegue... levantá(r)...

(391) ... é muito difícil você encontrá(r) pessoas...

(393) ... se você viesse com um questionário... pra você respondê(r)

(407) ... se você pegá(r) fato triste a morte dos meninos no Turvo... né?

(410) ... coisas assim que a gente tem... da história...

(411) ... e que às vezes a gente vê na na história apresentada...

(416) ... mas se você pega como eu tive a oportunidade...

(427) ... através da documentação cê vai encontrá(r)... coisas... concretas que você dá até ...

(428) ... cê vai encontrá(r) esse relato...

Com base nas ocorrências encontradas, podemos observar a predominância do pronome você. É importante observar que são 17 ocorrências do pronome você e apenas três da sua forma abreviada, comum na língua falada, cê. Por meio da entrevista, notamos que o I é uma pessoa bastante polida em sua forma de falar, trata-se de uma professora universitária e certamente esse é o motivo que faz com que não opte pelo uso da forma coloquial do pronome.

É possível verificar que em certos momentos o I está falando dele mesmo, porém opta por fazer essa generalização, talvez com o objetivo de deixar claro que esse fato não acontecia só com ele, mas com todas as pessoas que passavam pela mesma situação, no caso, participar de um concurso.

Já o uso da forma a gente se caracteriza pelo fato de o I se incluir e incluir também o E naquilo que está sendo exposto.

\subsubsection{Prevenção de ameaça à face}

Abaixo apresentamos os trechos de prevenção à face encontrados ao longo dessa entrevista, todos retirados da fala do I.

(127) ...fato que me foi contado... e que num é do meu tempo né?...

(138) ... e que mais tarde se transformaria numa cidade... e conta a lenda... né?... que isso...

(178) ... então as minhas sobrinhas e os meus sobrinhos netos falam assim - "mas tia... a senhora não pode sê(r) daquele tempo" exato... claro que num sô(u) mas a gente... 
Observa-se certa preocupação por parte do I com relação a sua idade. $\mathrm{Na}$ ocorrência da linha 138, observamos que o I procura demonstrar que a história contada é uma lenda, precavendo-se de que possa ser atribuída a ele a autoria da mesma.

Dificilmente encontraríamos nessa entrevista algum tipo de ameaça por parte do E, uma vez que o mesmo limitou-se a fazer as perguntas principais.

\subsubsection{Ameaça à face}

Acima citamos as ocorrências relacionadas à prevenção de ameaça à face. No entanto, encontramos também uma ameaça à própria face do $\mathrm{I}$.

(299) ... meu projeto foi... O Ensino em Rio Preto... pretensiosamente eu queria abrangê(r) TUdo como todo... iniciante deseja né?

Observa-se que nesse caso não é uma exposição da face negativa do I, mas sim da positiva. O próprio I se denomina pretensioso, porém se justifica ao dizer que isso ocorreu devido ao fato de ser iniciante. Ao fazer tal justificativa, há uma atenuação ao conteúdo de sua fala.

\subsubsection{Expressão de opinião}

Abaixo apresentamos as ocorrências de expressão de opinião encontradas na fala do I.

(247) ... mas não é uma utilização imediata... então para o aLUno...éh num satisfaz éh éh geralmente o jovem qué(r) o aqui... e o agora num é?

(402) ... importante que eu acho nas entrevistas... é o resgatá(r) a memória de cada um...

Todo o relato de opinião presente nessa entrevista gira em torno do tema da importância das entrevistas realizadas pelo I. Não há a necessidade de o I dar alguma opinião de fato, ele apenas justifica a importância de seu trabalho por meio de diversos exemplos. No primeiro exemplo apresentado acima, observamos que o I faz uma crítica aos jovens, não usa qualquer tipo de atenuante para isso, apenas expõe a sua opinião.

Não há, nessa entrevista, ocorrências de invasão do território privado do I, bem como atos de fala corteses como agradecimentos, elogios ou despedidas.

\subsubsection{Formas de tratamento}

Essa entrevista apresenta uma única forma de tratamento. Abaixo apresentamos as ocorrências encontradas, todas retiradas da fala do E, seguidas de breve análise. 
(02) é uma outra questão a sê(r) levantada é essa... se a senhora tem alguma experiência pra contá(r) né?... dessas... dessas entrevistas... que como a senhora disse é a senhora criava relações de afeto entre os informantes então tem alguma experiência?

68) bom professora eu gostaria que a senhora me falasse é me contasse alguma história ou algum fato que a senhora... não presencio(u) mas... que alguém algum dia conto(u) pra senhora e a senhora acho(u) interessante e a senhora podia contá(r)... pra mim

188) ISSO então como a senhora me disse que a senhora é professora deu... deu aula durante muitos anos... professora de História da Educação então eu queria sabê(r) como que eram as suas aulas assim se a senhora podia me descrevê(r)... assim... éh como que eram as suas aulas

(293) professora com relação a essas pesquisas que a senhora conto(u) eu queria sabê(r) como que foi o procedimento utilizado pra realizá(r) essas pesquisas... como que foi feito assim... essas pesquisas?

363) professora e QUAL que é a importância que a senhora acha nesse tipo de pesquisa assim que que a senhora pensa desse tipo de pesquisa que a senhora realizo(u)... assim éh... uma pesquisa assim tão ampla e tão interessante qual que é a importância disso pra senhora?

Fica bastante nítido para quem lê essa entrevista que o tratamento do informante para com o informante gira em torno do eixo de poder. Embora em termos de idade, esse seja o informante mais velho, acreditamos que esse poder se dá tanto pela idade quanto pela profissão do mesmo.

Observa-se que o único tratamento dispensado é a senhora, concordando com o pronome possessivo sua, não há ocorrências de uso do pronome oblíquo.

Além do pronome de tratamento indicando formalidade, observa-se o uso da forma nominal professora, a qual se refere à profissão do informante.

Como já observado ao longo de toda a análise individual, a interação entre os participantes dessa entrevista foi praticamente nula. Acreditamos que as ocorrências apresentadas acima, referentes à forma de tratamento reforçam tal afirmação.

Mais adiante apresentaremos um comparativo entre todas as entrevistas pertencentes a esse corpus.

\subsection{Amostra 149}

Informante masculino - 55 anos

Entrevistador feminino -22 anos

Tema 1 - História pessoal

\begin{tabular}{|c|c|c|}
\hline Perguntas principais & Perguntas complementares & Comentários e opiniões \\
\hline $\begin{array}{l}(02) \text { Seu P. gostaria que o } \\
\text { senhor contasse/ contasse para } \\
\text { mim alguma história que } \\
\text { aconteceu c'o senhor... }\end{array}$ & $\begin{array}{l}\text { (07) faculdade aqui? Que } \\
\text { faculdade o senhor fez? } \\
\text { (12) Você estudou lá em São } \\
\text { Paulo } \\
\text { (16) [o] senhor gosta de dar aula? }\end{array}$ & \\
\hline 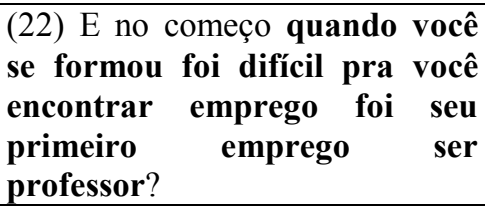 & $\begin{array}{l}\text { (26) Ah é? } \\
\text { (30) Ah cê começou dando aula lá } \\
\text { em São Paulo? } \\
\text { (37) Nessa época o senhor } \\
\text { conheceu sua mulher lá:: }\end{array}$ & \\
\hline
\end{tabular}




\begin{tabular}{|l|l|l|}
\hline & $\begin{array}{l}\text { [conheceu aqui] } \\
\text { ( 40) Conheceu ela na igreja então } \\
\text { como é que foi? } \\
\text { ( 43) Ela foi com você? } \\
\text { ( 46) Ah ela foi atrás de saber do } \\
\text { senhor? } \\
\text { (50) e aí?... aí vocês construíram } \\
\text { aqui aí cê começou a trabalhar } \\
\text { aqui [e ela a trabalhar ou não?] } \\
\text { (54) Ah o senhor fez concurso? }\end{array}$ & \\
\hline $\begin{array}{l}\text { (59) Hum...P. continua contado } \\
\text { alguma história da vida do } \\
\text { senhor }\end{array}$ & & \\
\hline
\end{tabular}

Tema 2 - História contada por terceiros

\begin{tabular}{|c|c|c|}
\hline Perguntas principais & Perguntas complementares & Comentários e opiniões \\
\hline $\begin{array}{l}\text { (75) senhor P. o senhor lembra } \\
\text { de alguma historinha que } \\
\text { alguém te contou algum fato } \\
\text { interessante algu/ alguma coisa } \\
\text { que alguém te contou? }\end{array}$ & (81) Ela te contava? & \\
\hline $\begin{array}{l}\text { (102) Senhor P. o senhor lembra } \\
\text { de alguma história que seus } \\
\text { pais contavam pro senhor } \\
\text { quando o senhor... ainda num } \\
\text { tinha nascido ou que o senhor era } \\
\text { pequeno mas que o senhor num } \\
\text { lembra o senhor num participou } \\
\text { mas que seus pais te contavam } \\
\text { que o senhor... assim achava } \\
\text { interessante assim? }\end{array}$ & & $\begin{array}{l}\text { (122) Né? Tão diferente daquela } \\
\text { época? }\end{array}$ \\
\hline
\end{tabular}

Tema 3 - descrição de um lugar

\begin{tabular}{|l|l|l|}
\hline \multicolumn{1}{|c|}{ Perguntas principais } & Perguntas complementares & Comentários e opiniões \\
\hline $\begin{array}{l}\text { (125) seu P. descreva pra mim } \\
\text { um lugar que o senhor já morou } \\
\text { um lugar que o senhor mora } \\
\text { descreva assim os cômodos... os } \\
\text { os móveis como eles são... coisa } \\
\text { e tal }\end{array}$ & & \\
\hline $\begin{array}{l}\text { (165) Hum:: falando em de/ verdade? } \\
\text { descrever ainda seu P. o senhor } \\
\text { lembra como que era a casa dos } \\
\text { seus pais quan/quando você } \\
\text { morava com seus pais? }\end{array}$ & & \\
\hline
\end{tabular}

Tema 4 - descrição de alguma habilidade do I

\begin{tabular}{|l|l|l|}
\hline \multicolumn{1}{|c|}{ Perguntas principais } & Perguntas complementares & Comentários e opiniões \\
\hline $\begin{array}{l}\text { (180) Seu P. fala pra mim } \\
\text { alguma coisa que o senhor sabe } \\
\text { fazer consertar algum aparelho } \\
\text { doméstico alguma coisa que o } \\
\text { senhor sabe fazer assim? }\end{array}$ & & \\
\hline $\begin{array}{l}\text { (183) Hum como é que faz pra } \\
\text { consertar o ventilador? }\end{array}$ & & \\
\hline
\end{tabular}


(216) Hum e o senhor assim sabe plantar já plantou alguma árvore ou alguma planta alguma coisa assim seu $P$.

Tema 5 - Relato de opinião

\begin{tabular}{|c|c|c|}
\hline Perguntas principais & Perguntas complementares & Comentários e opiniões \\
\hline $\begin{array}{l}\text { (247) Seu P. dá opinião sobre } \\
\text { alguma coisa opinião sobre a } \\
\text { educação no Brasil }\end{array}$ & & $\begin{array}{l}\text { (267) Não não pode continuar } \\
\text { seu P. }\end{array}$ \\
\hline $\begin{array}{l}\text { (275) Hum seu P. o senhor dá } \\
\text { aulas em duas escolas uma escola } \\
\text { particular e uma pública... eh... } \\
\text { com o convívio éh de dar aula o } \\
\text { senhor acredita que é mais } \\
\text { complicado lecionar num tipo } \\
\text { de escola do que em outra por } \\
\text { que tem uma certa dificuldade? } \\
\text { Que que o senhor poderia me } \\
\text { falar sobre isso? }\end{array}$ & & \\
\hline $\begin{array}{l}\text { (293) O senhor acha que essa } \\
\text { preocupação do pai com o } \\
\text { aluno essa observação do aluno } \\
\text { ajuda no desenvolvimento do } \\
\text { aluno na escola é importante? }\end{array}$ & & \\
\hline $\begin{array}{l}\text { (301) O senhor acredita que } \\
\text { por quand// quando os alunos } \\
\text { saem da escola... eh que têm } \\
\text { mais chance de passar no } \\
\text { vestibular que um aluno de } \\
\text { escola particular sempre tem } \\
\text { mais chance de... de progredir na } \\
\text { vida o senhor acha que isso } \\
\text { desanima os alunos de escola } \\
\text { pública... por isso que eles agem } \\
\text { como como agem eles são meio } \\
\text { que éh ficam meio que alienados } \\
\text { na escola porque eles sabem que } \\
\text { eles num têm tantan chance } \\
\text { quanto um aluno que que ta } \\
\text { numa escola particular? É isso } \\
\text { que faz eles ser indisciplinados } \\
\text { o senhor acredita nesse fato? }\end{array}$ & (310) Prejudica? & \\
\hline $\begin{array}{l}\text { (319) E aquilo que o governo ta } \\
\text { querendo criar um ma/ um quarto } \\
\text { ano no colegial... no sentido } \\
\text { desse quarto ano ser um no } \\
\text { sentido tipo um cursinho... ser } \\
\text { uma revisão dos três anos que já } \\
\text { foi cê acha que isso ajudaria... } \\
\text { faria sentido é os alunos num } \\
\text { teriam interesse isso } \\
\text { prejudicaria ou ajudaria no no } \\
\text { para os alunos? }\end{array}$ & & (334) Num acontece \\
\hline
\end{tabular}

Assim como todas as entrevistas que pertencem a esse corpus, há uma divisão elaborada pelos organizadores do mesmo que dividem a entrevista em cinco partes. Os 
temas propostos pela E são bastante diversificados, embora grande parte da entrevista seja sobre a educação, os problemas que envolvem os alunos, etc. Isso se justifica pelo fato de o I ser professor, o que torna a entrevista mais próxima da sua realidade.

A interação estabelecida entre os participantes ao longo dessa entrevista é bastante significativa, os temas tratados são próximos tanto da vida do E como do I, o que facilita a elaboração de perguntas. Observa-se que a temática não é especializada e que tampouco houve extensa preparação de perguntas, no entanto a partir das próprias respostas do I o E demonstra habilidade em manter a fluidez do diálogo. A distância entre os interlocutores diminui à medida que a conversa flui.

Houve também uma diversificação quanto à forma de elaboração das perguntas que conduziram o diálogo e é interessante observar que tal diversificação se deu devido à confiança que o E foi adquirindo com o I no decorrer da entrevista. No início do diálogo, o E elaborou uma pergunta precedida do ato de preparação gostaria, utilizando o verbo no Futuro do Pretérito, a pergunta seguinte desse mesmo tema foi direta. No segundo tema, o E optou pelo uso do verbo lembrar no Presente do Indicativo. Entendemos que é também uma forma de proteger a face do I, uma vez que se referia a alguma história contada no passado. A partir do terceiro tema já observamos o uso de verbos no imperativo e perguntas complementares diretas. Interpretamos tais perguntas como uma evolução para a informalidade à medida que a entrevista avançava. $\mathrm{O} E$ não ficou preso $\mathrm{a}$ formas de cortesia e sentiu-se à vontade para realizar suas perguntas de diversas formas.

\subsubsection{Desfocalização do $e u$}

Com relação às estratégias de desfocalização do $e u$, notamos que são diversas as ocorrências encontradas, todas presentes na fala do I. Abaixo apresentamos os trechos, seguidos de breve análise:

(19) ...isso daí dificulta um pouco o trabalho da gente...

(248) ... éh quando a gente se forma... a gente pensa que o trabalho pra gente em sala de aula...

(250)... enfim... éh tudo ajuda pra gente realizá(r) um bom trabalho... mas quando a gente começa lecioná(r)... a gente percebe que... em muitos momentos a gente está completamente despreparado...

(255) ... ao mesmo tempo a gente sabe... que... dificilmente isso...

(259) ... a gente... éh se sente até usado nesses programas...

(260)... muitas vezes a gente se sente assim éh...

(262) ... não que a gente se arrependeu de tê(r)... escolhido...

(263) ... mas em muitos momentos a gente... pensa

(265) ... existe um... alunos que... éh a gente percebe que éh...

(268) ... que a gente pode ajudá(r)... às vezes nem tanto pela disciplina que a gente em/ ensina...

(270) ... de vir agradecer a gente... por um conselho...

(271) ... ou às vezes mesmo quando a gente num fica propriamente...

(272) ... nesses momentos a gente percebe que...

(299) ... a gente vê a fisionomia... 
Com base nas ocorrências encontradas, podemos observar que todas as generalizações foram feitas com a expressão a gente. Além disso, todas elas se referem aos professores. O I, como professor, não fala apenas por ele, mas por toda a classe, é como se ele estivesse certo de que todos os colegas de profissão pensassem e agissem dessa maneira.

\subsubsection{Prevenção de ameaça à face}

Ao longo de toda essa entrevista, há apenas uma ocorrência de prevenção de ameaça à face.

(112) I: ...eu num lembro bem quantos dias... mas aí reunia...

Como já observada em análises anteriores, esse tipo de advertência previne ambas as faces. O I já adverte que não se lembra e simultaneamente alerta o E para que não lhe faça perguntas mais aprofundadas sobre tal fato.

\subsubsection{Ameaça à face}

Acima citamos as ocorrências relacionadas à prevenção de ameaça à face. No entanto, encontramos também exemplos de ameaça à própria face do I.

(60) ... olha éh Macaubal onde eu nasci é uma cidade pequena... e lá eu tinha facilidade assim de cria(r) mais laços de amizade com... os colegas de classe com os primos os os parentes todos de lá praticamente... quando eu vim pra Rio Preto... eu tive dificuldade assim eu sentia ficava triste é eu num entendia bem o motivo do meu pai ter... saído de Maucaubal e ter vindo pra São José do Rio Preto então foi uma fase assim da adapta/ da adaptação difícil e tanto é que eu cheguei até reprová(r) na escola na terce(i)Ra série (203) ... eu conserto assim éh com uma facilidade muito grande

O I deu essa declaração sem que nada lhe tivesse sido perguntado, entendemos que é uma ameaça a sua própria face, pois relata um fracasso ocorrido em determinado momento de sua vida, porém devemos ressaltar que antes do relato há uma preparação do interlocutor, de forma que antes que ele faça qualquer juízo de valor sobre o fato, ele entenda as justificativas apresentadas pelo I.

Na segunda ocorrência também classificamos essa declaração do I como uma ameaça a sua própria face, pois ele se faz um autoelogio, podendo levar o outro ao julgamento de falta de modéstia.

\subsubsection{Atenuantes}

Abaixo apresentamos as ocorrências em que há a presença de marcadores de atenuação, presentes tanto na fala do I, quanto do E. 
(19) I: ... dificulta um pouco o trabalho da gente...

(63) I: ... eu num entendia bem o motivo do meu pai ter... saído de Maucaubal

(304) E: ... eles são meio que... éh ficam meio que alienados... na escola porque...

(308) I: ... incomoda assim um po(u)co os alunos...

Todos esses atenuantes encontrados - três ocorrências na fala do I e uma na fala do $\mathrm{E}$ - exercem a função de minimizar a força dos enunciados aos quais pertencem. Observa-se que esse objetivo é alcançado independentemente da forma como a atenuação é composta, seja pelo uso dos adjetivos pouco ou meio ou pelo advérbio bem.

\subsubsection{Expressão de opinião}

Abaixo apresentamos algumas ocorrências de expressão de opinião encontradas ao longo da entrevista. Todas presentes na fala do I.

(21) ... eu creio que tomei a decisão certa...

(248) éh quando a gente se forma... a gente pensa que o trabalho pra gente em sala de aula... vai ser bastante facilitado... pelo fato de falar que o gov/ éh a secretaria... enfim tudo ajuda pra gente realizar um bom trabalho... mas quando a gente começa a lecionar... a gente percebe que... em muitos momentos a gente está completamente despreparado...

(402) ... eu penso... de uma conscientização pra melhorá(r) o nosso trabalho...

O I é bastante seguro ao manifestar suas opiniões, todas sobre a educação, sua área de atuação. Encontramos apenas duas ocorrências em que o mesmo fez uso de verbos parentéticos ou epistêmicos realmente com o intuito de opinar sobre aquilo que estava sendo pedido. Em todos os outros momentos houve justificativa daquilo que era dito, inclusive quando fazia críticas ao governo.

Acreditamos que o fato de as perguntas pertencerem ao cotidiano do I permitem essa segurança nas respostas. É interessante observar que em diversos momentos o I faz uso da desfocalização do eu para expressar sua opinião, ele não fala só por ele, mas por todos os professores. O exemplo contido na linha 248 elucida tal fato.

Não há, nessa entrevista, ocorrências de invasão do território privado da I, bem como atos de fala corteses como agradecimentos, elogios ou despedidas.

\subsubsection{Formas de tratamento}

Como já observado em análise anterior, o entrevistador mescla as formas de tratamento dispensadas ao informante. Abaixo apresentamos algumas ocorrências, seguidas de breve análise.

(02) Seu P. gostaria que o senhor contasse/ contasse para mim alguma história que aconteceu c'o senhor...

(12) Você estudou lá em São Paulo

(22) E no começo quando você se formou foi difícil pra você encontrar emprego foi seu primeiro emprego ser professor? 
(30) Ah cê começou dando aula lá em São Paulo?

(43) Ela foi com você?

(46) Ah ela foi atrás de saber do senhor?

(75) senhor P. o senhor lembra de alguma historinha que alguém te contou algum fato interessante algu/ alguma coisa que alguém te contou?

(102) Senhor P. o senhor lembra de alguma história que seus pais contavam pro senhor quando o senhor... ainda num tinha nascido ou que o senhor era pequeno mas que o senhor num lembra o senhor num participou mas que seus pais te contavam que o senhor... assim achava interessante assim?

(125) seu P. descreva pra mim um lugar que o senhor já morou um lugar que o senhor mora descreva assim os cômodos... os os móveis como eles são... coisa e tal

(165) Hum:: falando em de/ descrever ainda seu P. o senhor lembra como que era a casa dos seus pais quan/quando você morava com seus pais?

(180) Seu P. fala pra mim alguma coisa que o senhor sabe fazer consertar algum aparelho doméstico alguma coisa que o senhor sabe fazer assim?

(216) Hum e o senhor assim sabe plantar já plantou alguma árvore ou alguma planta alguma coisa assim seu $P$.

Analisando as formas de tratamento utilizadas pelo entrevistador dessa amostra, observamos que prevalece o eixo de poder. Acreditamos que mais pela idade do informante do que pela profissão.

Embora o entrevistador dessa entrevista não seja o mesmo da amostra 120, observamos a mesma presença de mescla de formas de tratamento. Assim, ele começa tratando o informante por o senhor e, algumas vezes, na mesma fala muda para você. Entendemos que o motivo que leva a essa troca seja o mesmo da amostra 120, desatenção, pois caso houvesse a mudança devido a uma intimidade criada ao longo do diálogo, essa mudança seria integralmente para o tratamento informal. Outro dado também observado na amostra 120 é que sempre que inicia um novo tema o entrevistador faz uso da forma formal para posteriormente passar para a informal.

Com relação aos outros pronomes utilizados, observa-se que o pronome oblíquo é o te, não havendo a concordância regida pela norma culta. Já referente aos pronomes possessivos, todos os que foram encontrados estão na terceira pessoa do singular seu, sua.

Outro dado que nos leva a acreditar que o eixo existente é o de poder se refere à forma nominal utilizada. Sempre que se refere ao informante, o entrevistador utiliza a forma seu ou senhor antecedendo o nome do mesmo.

Mais adiante apresentaremos uma análise comparativa entre todas as entrevistas que compõem esse corpus. 


\subsection{Amostra 150}

Informante feminino - 57 anos

Entrevistador feminino - 21 anos

Tema 1- História pessoal

\begin{tabular}{|c|c|c|}
\hline Perguntas principais & Perguntas complementares & Comentários e opiniões \\
\hline $\begin{array}{l}\text { (02) éh:: dona G... eu queria } \\
\text { que a senhora me contasse } \\
\text { uma história que tenha } \\
\text { acontecido com a senhora }\end{array}$ & $\begin{array}{l}\text { (51) Ah [você] olhou e já } \\
\text { (107) ela mora lá } \\
\text { (162) cê se voltou contra ele então }\end{array}$ & $\begin{array}{l}\text { (63) ele é mais reservado } \\
\text { (133) um de cada vez } \\
\text { (147) talvez por você ter } \\
\text { reagido bem eles [também] } \\
\text { reagiram } \\
(156) \text { eram } \\
\text { mis/misturadas } \\
\text { (192) com certeza } \\
\text { (201) e ela trabalha lá } \\
\text { (205) com certeza } \\
(210) \text { uma filha }\end{array}$ \\
\hline
\end{tabular}

Tema 2 - História contada por terceiros

\begin{tabular}{|l|l|l|}
\hline \multicolumn{1}{|c|}{ Perguntas principais } & Perguntas complementares & Comentários e opiniões \\
\hline $\begin{array}{l}\text { ( 215) dona G... eu queria que a } \\
\text { senhora me contasse uma } \\
\text { história que alguém tenha } \\
\text { contado pa senhora }\end{array}$ & & (227) (a)cabo(u) a barriga \\
\hline
\end{tabular}

Tema 3 - Descrição de um local

\begin{tabular}{|l|l|l|}
\hline \multicolumn{1}{|c|}{ Perguntas principais } & Perguntas complementares & Comentários e opiniões \\
\hline $\begin{array}{l}\text { ( } 264) \text { dona G. eu queria que } \\
\text { você me descrevesse... algum } \\
\text { local }\end{array}$ & & (278) era precária \\
( 326) Alberto Andaló
\end{tabular}

Tema 4 - Receita culinária

\begin{tabular}{|l|l|l|}
\hline \multicolumn{1}{|c|}{ Perguntas principais } & \multicolumn{1}{|c|}{ Perguntas complementares } & Comentários e opiniões \\
\hline $\begin{array}{l}\text { ( 338) Dona G... eu queria que } \\
\text { você me ensinasse... como que } \\
\text { você faz um bolo }\end{array}$ & $\begin{array}{l}\text { (347) é quanto de leite de coco? } \\
\text { (360) a margarina primeiro } \\
\text { (362) manteiga ou margarina }\end{array}$ & $\begin{array}{l}\text { ( 349) pequeno } \\
\text { (375) assadeira de buraco } \\
\text { (382) depois de... pôr a farinha } \\
\text { e leite de coco tem que... } \\
\text { incorporar } \\
\text { (384) a clara } \\
\text { (391) hum tá bom }\end{array}$ \\
\hline
\end{tabular}

Tema 5 - Relato de opinião

\begin{tabular}{|l|l|l|}
\hline \multicolumn{1}{|c|}{ Perguntas principais } & Perguntas complementares & Comentários e opiniões \\
\hline $\begin{array}{l}\text { ( } 396) \text { dona G... eu queria que } \\
\text { você me dissesse... o que você } \\
\text { pensa o que você acha sobre } \\
\text { casamento nos dias atuais }\end{array}$ & & (425) por convicção \\
\hline
\end{tabular}


Assim como todas as entrevistas que pertencem a esse corpus, há uma divisão elaborada pelos organizadores a qual divide a entrevista em cinco partes. Essa entrevista não apresenta uma temática especializada, ao contrário, são perguntas gerais que dão espaço para que o I conduza os temas discutidos ao longo do diálogo. Além disso, observa-se que há poucas perguntas elaboradas pelo E. A nosso ver isso se deve ao fato de o I falar muito, suas respostas são sempre longas e provavelmente para o entrevistador eram suficientes para a coleta de dados pretendida.

A interação estabelecida entre os participantes ao longo dessa entrevista é bastante significativa, como já dissemos anteriormente, quem direciona os temas é o próprio I, porém são temas cotidianos, não há conteúdos específicos de sua profissão, por exemplo, e embora o E tenha feito poucas perguntas ao longo de toda a entrevista, houve bastante interação, dado que pode ser constatado na terceira coluna das tabelas apresentadas no início de nossa análise.

Outro dado que deve ser ressaltado é o fato de todas as perguntas principais serem precedidas de atos de preparação, nesse caso o verbo querer no Futuro do Pretérito. É uma forma bastante cortês de o $\mathrm{E}$ obter as respostas pretendidas, uma vez que a diferença de idade entre os participantes criava certa distância entre eles.

\subsubsection{Desfocalização do eu}

Com relação às ocorrências de desfocalização do $e u$, apresentamos o trecho abaixo seguidos de breve análise:

(191) I: ... são fatos que mudam vidas que transforma mas que você tem que te(r) um sentimento assim... éh... de compreensão das coisas né?

Observamos que há apenas uma ocorrência de desfocalização nessa entrevista, a qual é feita por meio do pronome de tratamento você. Assim como já mencionado em análises anteriores, acreditamos que o uso de tal recurso visa aproximar o interlocutor, incluindo-o na situação descrita.

\subsubsection{Prevenção de ameaça à face}

Abaixo apresentamos as ocorrências de prevenção de ameaça à face, seguidas de breve análise.

(81) I: ...eu num me lembro bem agora muito bem as datas históricas...

(127) I: ... eu num me lembro bem a idade mas eles teriam o que... 
Essas são as únicas ocorrências encontradas ao longo da entrevista. Como já observado em análises anteriores, esse tipo de advertência previne ambas as faces. O I já adverte que não lembra e simultaneamente alerta o $\mathrm{E}$ para que não lhe faça perguntas mais aprofundadas sobre o tema tratado.

\subsubsection{Ameaça à face}

Acima citamos as ocorrências relacionadas à prevenção de ameaça à face.

(10) I: ... com dezesseis anos e basicamente nada na cabeça...

(218) I: ... eu nasci... éh... em vinte um de março de quarenta e sete... então isso faz muito tempo... tá

(252) I: ... cê imagina... há... há séculos... né?... mais de meio atrás...

Todas essas declarações do I tendem a ameaçar sua própria face, no entanto observa-se que ele aparenta não se preocupar com isso. Enquanto outros entrevistados procuram demonstrar que não são velhos, essa, ao contrário, diz a idade que tem e emite até brincadeiras sobre o fato. Ressaltamos que a nosso ver, o fato de o I expor a idade não é algo que possa lhe ameaçar a face, no entanto considerando outras amostras, nas quais sobretudo as mulheres procuram omitir tal fato, temendo uma possível ameaça, acreditamos ser importante mostrar quando o contrário acontece.

\subsubsection{Proteção à face}

Encontramos nessa entrevista algumas justificativas que também são usadas como proteção à face, seja do próprio informante ou da pessoa a quem ele se refere. Abaixo apresentamos as ocorrências, seguidas de breve análise.

(137) I: ... o do meio... que como um bom recheio de sanduíche num tava precisando de mais irmão de jeito nenhum...

(163) I: na verdade não era bem contra eu num sei (foi) tudo muito rápido mas tinha um sentimento que DEPOIS... eu vim sabê(r) o que era... por quê?... depois que eu fui me Ava/ a não... CHEGO(U)... a minha sobrinha que era pequena hoje tá uma moça (...) ... é que eu percebi que o que tinha... era uma coisa assim de de de... uma mistura de sentimento que devia tê(r) uma ligação com ciúme... porque eu nunca fui ciumenta entende?... eu nunca fui uma pessoa ciumenta... então... eu num sabia defini(r)... qué(r) dizê(r)... ela me tro(u)xe a explicação... a definição de ciúme... é horrível e eu falo que tem até gosto entende?...

Observa-se que na primeira ocorrência o I procura justificar a atitude de seu filho e na segunda a sua própria atitude. Em ambos os casos ele expõe as face, do filho ao dizer que ele não gostou muito de ter uma irmã e a sua ao assumir que sentia ciúmes da enteada e, ao mesmo tempo, justifica esses sentimentos de forma que o $\mathrm{E}$ não faça préjulgamentos sem antes saber o que motivou tais sensações. 


\subsubsection{Atenuantes}

Abaixo apresentamos as ocorrências que contêm atenuantes, seguidas de breve análise.

(163) I: ... na verdade não era bem contra eu num sei foi tudo muito rápido...

(339) I: ... eu vou te dá(r) a receita de um bolo bem simples

As duas ocorrências de atenuantes encontradas exercem a função de minimizar a força dos enunciados aos quais pertencem, embora apareçam em posições diferentes: no primeiro caso a posição é semelhante a de exemplos anteriores, ou seja, intermediária entre o verbo e o adjetivo a que se refere e no segundo é intermediária entre o substantivo e o adjetivo a que se refere.

\subsubsection{Expressão de opinião}

Como já apontado anteriormente, essa entrevista apresenta um tópico específico para a expressão de opinião do I. Abaixo apresentamos algumas ocorrências encontradas, seguidas de breve análise.

(180) ... eu acho que ... bota expectativa em cima da pessoa...

(248) ... acho que tinha ido com a mãe naquela confusão...

(328)... e eu acho muito interessante...

(331) ... eu acho muito interessante tê(r) acompanhado... a evolução disso tudo...

(398) ... eu acho que o casamento... é... uma... uma instituição... que sempre foi muito válida... embora eu veja mudanças de de... no decorrer dos anos... há mudanças da da da cabeça Jovem com relação às coisas... mas eu acho que o casamento... é uma base... e e um vínculo que se forma... assim... com mais solidez... e e... eu acho MUITO... muito importante isso... como base de família... e... eu penso que... que... no decorrê(r) dos tempos... essa...essa... éh... a o ponto de vista do Jovem com relação ao casamento vem... tendo... essa mudança... mas eu num sinto isso como uma Regra... eu vejo... que os jovens se debatem um po(u)co...

O tema solicitado ao I é bastante polêmico, pois além da opinião pessoal, existem também questões religiosas por detrás. No entanto, observamos que o I tem uma opinião formada sobre o assunto e dá vários argumentos para sustentar tal opinião. O número de marcadores usados é bastante elevado e embora haja o uso de vários, prevalece o verbo parentético ou epistêmico achar. Entre todas as ocorrências apresentadas acima, acreditamos que apenas na segunda esse verbo é utilizado como expressão de dúvida. Em todas as demais serve para expressar a opinião do informante.

O que também foi possível encontrar nessa entrevista é uma ocorrência em que o I expressa sua opinião e busca a aprovação do E. Abaixo, transcrevemos o trecho:

(191) I: ... são fatos que mudam vidas que transforma mas que você tem que te(r) um sentimento assim... éh... de compreensão das coisas né?

(193) E: com certeza 
O que nos faz interpretar esse trecho como uma solicitação de aprovação é o fato de o E respondê-lo. Não há nem tempo para que ela pense se isso é certo ou não, porém uma resposta negativa poderia ameaçar à face do I e colocar em risco os objetivos da entrevista.

Não há, nessa entrevista, ocorrências de invasão do território privado do I, bem como atos de fala corteses como agradecimentos, elogios ou despedidas. O próprio informante narra fatos de sua vida pessoal quando lhe é solicitado que conte uma história, com isso não podemos interpretar o E como indiscreto ao interagir com o I ao longo da entrevista.

\subsubsection{Solidariedade}

Por fim, outro tipo de ocorrência, incomum em outras entrevistas, e presente nessa foram os exemplos de solidariedade, nos quais o interlocutor complementa a fala do locutor a fim de ajudá-lo a elaborar sua fala. Abaixo apresentamos os exemplos.

(61) I: ... num fala tanto quanto eu entende?... parece uma pessoa mais assim

(63) E: ele é mais reservado

(276) I: ... eram ruas assim... sem calçamento... éh... e... muito mato... então uma rele/ uma região assim (278) E: era precária

(323) I: (...) muito escuro... então eu... eu tenho algumas lembranças assim (dessa rua) de polícia procurando ladrão no mato então num dá pra acreditar... entende?... quem passa na na na

(326) E: Alberto Andaló

Nos três casos apresentados, observamos que o I tenta explicar algo e para isso faz vários rodeios, mas não encontra o adjetivo adequado para esclarecer a sua ideia. Rapidamente o E o ajuda, complementando sua fala. É interessante observar que em ambos os casos, o I se apoiou na palavra assim quando lhe faltavam palavras. Como já observado em outras análises, esse tipo de ocorrência dá mais fluidez ao diálogo, além de aumentar a interação entre os participantes.

\subsubsection{Formas de tratamento}

Conforme poderá ser observado nas ocorrências que apresentaremos a seguir, ao longo da entrevista, o entrevistador muda a forma de tratamento dispensada ao informante.

(02) éh:: dona G... eu queria que a senhora me contasse uma história que tenha acontecido com a senhora

(147) talvez por você ter reagido bem eles [também] reagiram 
(162) cê se voltou contra ele então

(215) dona G... eu queria que a senhora me contasse uma história que alguém tenha contado pa senhora

(264) dona G. eu queria que você me descrevesse... algum local

(338) Dona G... eu queria que você me ensinasse... como que você faz um bolo

(396) dona G... eu queria que você me dissesse... o que você pensa o que você acha sobre casamento nos dias atuais

Observa-se que o tratamento utilizado pelo entrevistador para com o I gira em torno do eixo de poder, acreditamos que motivado mais pela idade do mesmo do que pela profissão.

Assim como observado nas amostras 120 e 149, o entrevistador mistura o tratamento formal e informal para referir-se ao informante. No entanto, observamos que esse fato ocorre nas duas primeiras partes da entrevista, sendo que nas três seguintes ele passa a utilizar apenas a forma voce, embora continue utilizando a forma nominal dona antecedendo o nome da informante. Ao ler essa entrevista na íntegra, é possível observar que a interação entre os participantes é bastante acentuada. A liberdade criada devido a essa interação possivelmente gerou a mudança na forma de tratamento. Fato que não ocorreu nas outras amostras analisadas.

Não encontramos nessa entrevista exemplos de uso de outros tipos de pronome como os oblíquos ou possessivos.

Ao longo da análise comparativa das entrevistas que compõem esse corpus será possível apresentarmos uma comparação entre todas as amostras.

\subsection{Análise comparativa - Rio Preto - superior}

O corpus superior brasileiro é composto por seis entrevistas, sendo três de informantes do sexo feminino e outras três do sexo masculino. O que o caracteriza como superior é o nível de escolaridade dos informantes, no caso todos formados em universidades. Além disso, em nosso recorte de análise, selecionamos apenas informantes com idades entre 50 e 70 anos, de forma que nosso estudo pudesse também ter um caráter comparativo entre pessoas pertencentes à mesma faixa etária. Não consideramos como critério de seleção das entrevistas a profissão e renda familiar, uma vez que apenas o nível de escolaridade era suficiente, embora esses dados estivessem disponíveis em todos os informantes.

Abaixo apresentamos os dados dos informantes que compuseram o nosso corpus. O número correspondente a cada entrevista foi determinado pelos próprios organizadores do corpus. 


\begin{tabular}{|l|l|l|}
\hline $\begin{array}{c}\text { Entrevista } \\
\text { número: }\end{array}$ & \multicolumn{1}{|c|}{ Sexo } & \multicolumn{1}{c|}{ Idade } \\
\hline 115 & masculino & 50 anos \\
\hline 119 & masculino & 54 anos \\
\hline 120 & feminino & 51 anos \\
\hline 146 & feminino & 68 anos \\
\hline 149 & masculino & 55 anos \\
\hline 150 & feminino & 57 anos \\
\hline
\end{tabular}

A seguir, passamos à exposição da análise comparativa do material de nível superior, optamos por separá-la em tópicos de acordo com o que foi trabalhado nas análises individuais das entrevistas. Em alguns casos, utilizaremos também gráficos que nos ajudarão a elucidar os dados apresentados.

\subsubsection{Fala do entrevistador}

Assim como expusemos alguns dados sobre a entrevistadora do corpus espanhol, entendemos que há a necessidade de se fazer o mesmo com o material brasileiro. Diante disso, cabe mencionar que todas as entrevistas foram feitas por estudantes do curso de Letras da UNESP de São José do Rio Preto e supervisionadas pelos professores responsáveis pelo projeto. Apenas para efeito de comparação, todas as entrevistadoras são do sexo feminino e possuem idade entre 19 e 25 anos, o que nos possibilita uma comparação com a entrevistadora espanhola que possuía 28 anos. Entendemos que dados como esse representam aspectos relevantes que devem ser considerados, pois a forma como um falante jovem aborda um interlocutor de mais de 50 pode ser diferente da maneira como ele trata uma pessoa da mesma idade que ele.

Analisando a maneira como os enunciados interrogativos são elaborados, observamos que cada entrevista tem a sua particularidade, porém já podemos adiantar que há uma predominância dos enunciados que contêm atos de preparação, ou seja, verbos performativos que antecedem o conteúdo principal da questão que também podem ser considerados uma estratégia cortês do entrevistador, pois transmitem ao informante a falsa ideia de que ele lhe está dando opção em responder ou não a sua pergunta. Entendemos que é uma falsa ideia porque a partir do momento em que o indivíduo aceita participar dessas entrevistas, fica subentendido que precisará responder algumas questões. 
Por outro lado, se é uma questão que envolve a invasão de seu território pessoal, o uso desses verbos performativos realmente lhe dá mais liberdade para esquivar-se de alguma pergunta.

Antes da apresentação dos gráficos, entendemos que é relevante a apresentação dos dados que, em geral, foram encontrados nos enunciados interrogativos elaborados pelos entrevistadores.

Em geral, encontramos nesse corpus quatro tipos de enunciados interrogativos: dois diretos e dois indiretos. Consideramos como atos diretos aqueles que não foram precedidos de atos de preparação com verbos performativos e também aqueles que continham verbos no imperativo e como indiretos aqueles que continham atos de preparação e de proteção à face do informante.

\subsubsection{Enunciados diretos}

\subsection{Enunciados sem ato de preparação}

Classificamos aqui todos os enunciados que iam diretamente para a questão, sem fazer uso de qualquer tipo de ato de preparação ou verbos que pretendiam proteger à face do informante.

\subsection{Imperativo}

O uso de verbos no imperativo também foi caracterizado como parte dos enunciados diretos. Ressaltamos que não levamos em consideração o verbo utilizado como contar, explicar, descrever, etc. Classificamo-los apenas como uso de imperativo.

\subsubsection{Enunciados indiretos}

\subsection{Uso de ato preparatório}

Entendemos como enunciados indiretos aqueles que contêm atos preparatórios no início de cada pergunta. Normalmente o entrevistador usa o verbo gostar ou querer no Futuro do Pretérito como forma de preparar o informante para a pergunta que se apresenta na sequência.

\subsection{Verbos de proteção à face}

Classificamos como verbos de proteção à face todos aqueles que davam certa liberdade ao informante, seja pelo uso do verbo poder ou lembrar. Como já exposto ao longo de nossa fundamentação teórica, essa liberdade é fictícia, pois a partir do momento 
que o informante aceita participar desse tipo de entrevista, fica subentendido que precisará responder algumas questões. No entanto, ao perguntar se o mesmo se lembra ou se pode contar algo, cria-se espaço para que o informante diga que não se lembra ou que não pode responder determinada pergunta.

Abaixo apresentamos o gráfico de forma que se possa visualizar os dados obtidos.

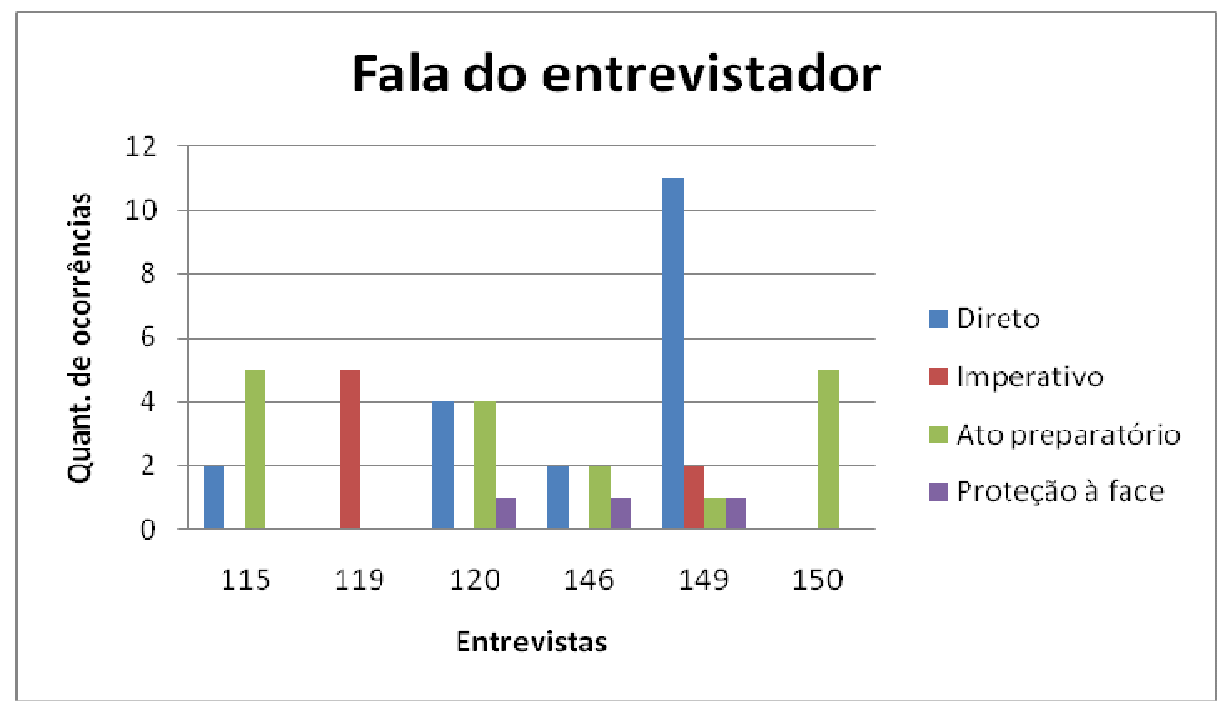

Esses dados nos ajudam a voltar às questões que motivaram toda essa investigação: se seria o português menos direto que o espanhol e que verbos no imperativo, por exemplo, dificilmente seriam usados em enunciados interrogativos. A partir dos resultados acima conseguimos desmistificar algumas ideias prévias. Embora os verbos performativos também considerados atos de preparação tenham sido usado em $83 \%$ das entrevistas, podemos observar que os enunciados diretos e aqueles que apresentam verbos no imperativo não podem ser desconsiderados.

Com relação à interação entre os participantes, podemos afirmar que a mesma não ocorreu em todas as entrevistas. Observamos que alguns dados são de extrema importância para se obter interação entre interlocutores ainda que sejam desconhecidos antes do momento do diálogo. Entre as seis entrevistas analisadas, atentamos que numa escala gradativa elaborada por nós, em apenas uma das amostras a interação foi zero e em outra foi dez, as demais apresentaram esse tipo de ocorrência, porém de forma menos acentuada. Atribuímos esses dados a dois fatores: os temas abordados e a distância que se estabeleceu entre os participantes.

A entrevista 146 apresentou grau zero de interação. Atribuímos isso a dois fatores: o tema tratado era extremamente desconhecido para o entrevistador, o que o impossibilitava de interagir e a grande distância estabelecida entre ele e o informante. $\mathrm{O}$ 
fato de se tratar de uma professora universitária de 68 anos contribuiu para que houvesse um respeito hierárquico, levando inclusive o entrevistador a tratar o interlocutor o tempo todo por professora. Além disso, observamos que houve direcionamento na primeira pergunta, porém na segunda e na terceira não, prejudicando a fluidez do diálogo.

Em contrapartida, a entrevista 120 foi a que apresentou o grau mais alto de interação pelos mesmos motivos que levaram a 146 à interação zero: os temas tratados eram cotidianos e o interesse do entrevistador pelos mesmos diminuiu a distância entre as participantes e acentuou a fluidez do diálogo.

A partir desses dados, podemos concluir que em uma conversação como nas entrevistas analisadas, a interação entre os participantes depende mais do entrevistador do que do informante, pois a condução dos temas abordados é determinante. Além disso, pudemos observar também que a idade não é um dado fundamental, pois a interação pode ocorrer ainda que haja grande diferença entre os participantes.

A planificação temática do material é bastante baixa, observamos que o entrevistador tem em mente cada tópico, porém o conteúdo das perguntas muitas vezes são extremamente vazios, obrigando os entrevistadores a reelaborá-las de forma que a resposta que se espera seja obtida. Não é raro encontrarmos entrevistas conduzidas pelos informantes, fato que pode comprometer a face do entrevistador caso o mesmo não tenha conhecimento muito aprofundado sobre o tema.

Com exceção da entrevista 146, na qual a professora entrevistada fala sobre as pesquisas que fazia, todas as outras entrevistas do corpus brasileiro apresentam temas bem diversificados. Acreditamos que isso seja devido à própria condução do diálogo que exige vários tipos de relatos - vida pessoal, história contada por terceiros, descrição de um lugar, uma receita e um relato de opinião. Como dissemos anteriormente, além do tema comum a ambos os participantes, é o envolvimento do entrevistador que estabelece equilíbrio na entrevista e faz com que haja interação.

\subsubsection{Desfocalização do $e u$}

Como já foi apresentado ao longo de nossa fundamentação teórica e também nas análises individuais, existem algumas estratégias que o falante pode usar para desfocalizar o eu, referindo-se a uma $3^{\text {a }}$ pessoa do discurso, sem ser ao seu interlocutor ou a si mesmo especificamente.

Durante a nossa análise pudemos observar quatro tipos de desfocalização. A mais frequente, presente em cinco entre as seis amostras analisadas refere-se ao pronome de 
tratamento você e sua forma coloquial $c \hat{e}$. Outra que embora pertença à terceira pessoa do singular, tenha o sentido de primeira do plural é a gente. A forma nós foi identificada em apenas uma das amostras.

Conforme já observado na análise do material malaguenho, o falante pode-se utilizar da $1^{\text {a }}$ pessoa do plural, seja para exprimir um plural de modéstia ou para incluir outras pessoas em suas ações, não assumindo sozinho a responsabilidade por aquilo que está sendo narrado. Já o uso da $3^{a}$ pessoa do singular transfere integralmente o conteúdo do que é dito para outra pessoa, o falante assume o papel apenas de quem transmite a informação, sem se responsabilizar pelo que ali está contido. Encontramos também ocorrências utilizando as formas todos, nós e todo mundo, todas elas com sentido de primeira pessoa do plural, essas são mencionadas no gráfico como outros. São utilizadas para generalizar, eximindo o falante da responsabilidade sobre o que é dito.

Abaixo apresentamos os gráficos com esse tipo de ocorrência, a fim de elucidar os dados obtidos ao longo da análise.

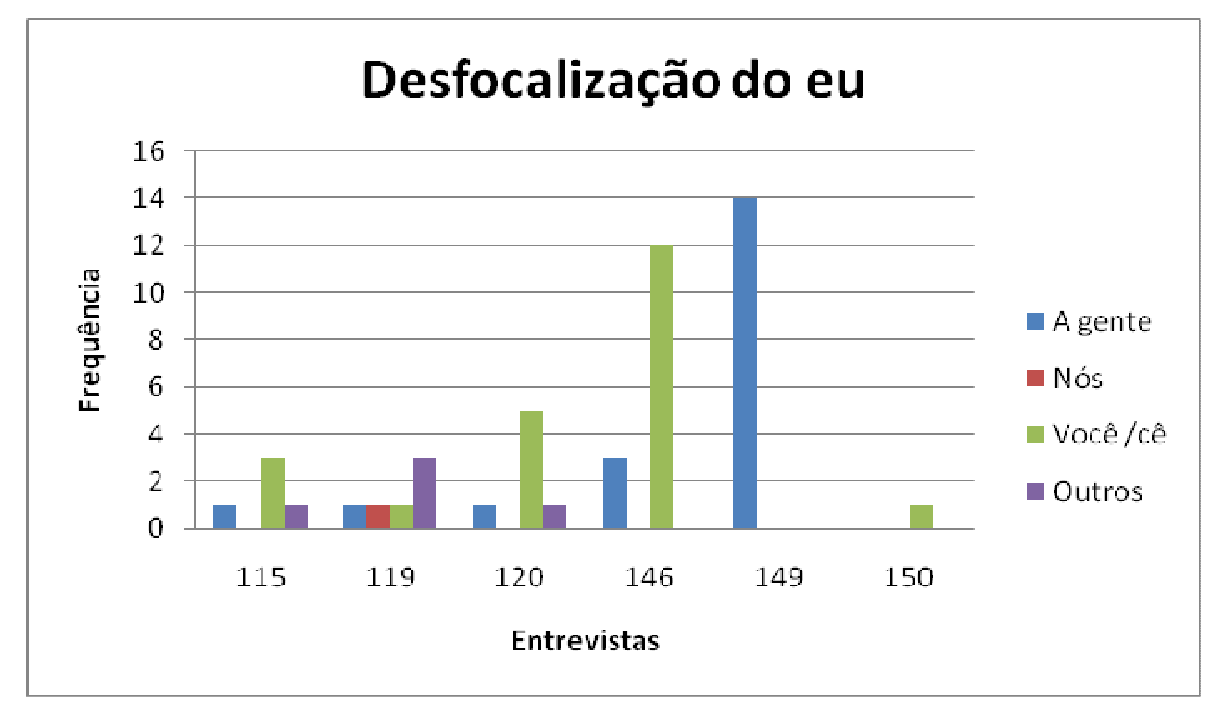

Os números que aparecem na horizontal se referem às amostras.

Como podemos observar, por meio dos gráficos, predomina como estratégia de desfocalização o uso da terceira pessoa do singular. Ao longo das análises individuais, pudemos constatar que a preferência pela forma a gente ocorre principalmente quando o falante se refere a sua profissão, em que ao falar envolve também seus colegas de trabalho, enquanto que o uso de você está relacionado às descrições em geral, em que o falante opta por não se colocar no centro do diálogo e para isso, faz uso da terceira pessoa do singular. Entendemos que, nesse caso, o informante busca envolver o entrevistador no 
diálogo. Não se refere a ele, especificamente, mas faz com que participe mais ativamente do diálogo.

Cabe ressaltar que nos detivemos apenas nas ocorrências encontradas na fala dos informantes, no entanto na entrevista 120 há duas ocorrências em que o entrevistador ao fazer sua pergunta usa a expressão pra gente, solicitando informações. São dois casos de plural de modéstia, pois ele evita o uso da primeira pessoa do singular pra mim, ainda que esteja só ele e o informante no momento da entrevista. Por outro lado, também podemos interpretar o uso do plural envolvendo ele e as outras pessoas que fazem parte desse projeto de pesquisa e trabalharão com essa entrevista.

\subsubsection{Prevenção de ameaça à face}

Conforme apontamos ao longo de nossa exposição teórica, a prevenção de ameaça à própria face e à do outro é algo que se considera em qualquer tipo de interação. Para que tal interação verbal seja bem sucedida há de haver um constante equilíbrio na preservação das imagens, tanto do falante quanto de seu interlocutor, de forma que nenhuma delas se prejudique.

Sendo assim, não poderíamos deixar de observá-lo ao longo de nossa análise, ainda que, como já apontamos anteriormente, os corpora analisados tenham a ressalva de serem entrevistas, em que o cuidado com a face do entrevistado tem grande importância, pois ao se sentir ameaçado, o mesmo pode deixar de responder as questões, colocando fim na entrevista.

Analisando o corpus de nível superior, pudemos comprovar que essa prevenção ocorre em todas as entrevistas. Abaixo apresentamos os tipos de ocorrência encontrados e quando necessário, o número da amostra ao qual pertence.

\subsubsection{Proteção à própria face}

Entre as seis amostras analisadas, apenas uma não apresenta esse tipo de ocorrência (120). Consiste em argumentos apresentados pelo informante para deixar claro que não tem certeza sobre a precisão de algum dado ou que não se lembra do mesmo. Entendemos que esse tipo de estratégia visa proteger a própria face, porém, como foi exposto ao longo das análises individuais, também é uma forma de proteger a face do entrevistador, pois sabendo da dúvida do informante, o mesmo não fará perguntas mais específicas sobre o tema tratado. 


\subsubsection{Justificativas}

Duas amostras apresentaram o mesmo tipo de justificativa (120 e 146). Cabe aclarar que é o tipo de estratégia que visa evitar pré-julgamentos por parte do interlocutor. Ambos informantes utilizaram tal recurso para referir-se a sua idade, alegando que sabiam sobre determinado assunto, mas que não era da "sua época", de forma que a idade de cada um não ficasse em evidência.

Ambos informantes pertencem ao sexo feminino. Entendemos que apesar do esforço das entrevistadas, esse recurso foi desnecessário, pois os entrevistadores tinham conhecimento da idade de todos os informantes, uma vez que esse era um dos prérequisitos para a composição do corpus.

\subsubsection{Prevenção de ameaça à face do entrevistador}

Apenas a amostra 120 apresenta esse tipo de ocorrência, ao fazer determinada explicação, o informante pergunta ao entrevistador se ele tem conhecimento sobre o que está sendo explicado. Ao fazer esse tipo de pergunta o informante pode parar e fazer a explicação necessária ou prosseguir sua fala, caso o interlocutor tenha conhecimento do que está sendo explicado.

\subsubsection{Ameaça à face}

Ainda retomando a fundamentação teórica que embasa o nosso trabalho, pudemos observar que embora os participantes de uma conversação tenham a necessidade de cuidar para que ambas as faces sejam protegidas, muitas vezes é inevitável que uma delas seja ameaçada, seja por culpa de um dos participantes ou da própria situação de interação.

Como já apontado em situações anteriores, por não se tratar de uma conversação comum sem fins específicos, os interlocutores de nosso corpus devem ter um cuidado ainda maior, principalmente por parte do entrevistador, pois o informante não pode se sentir ameaçado, uma vez que isso poderia findar a entrevista. Assim, ocorrendo qualquer tipo de ameaça, deve-se procurar restabelecer o equilíbrio para que o diálogo possa prosseguir sem maiores danos.

Acreditamos que o fato de encontrarmos poucas ocorrências de ameaça à face e de nem todas as entrevistas apresentarem as mesmas sejam dados relativamente contundentes que comprovam a nossa tese.

No caso específico dessas entrevistas, esse tipo de ocorrência foi encontrado em apenas $50 \%$ delas, sendo que em todos os trechos a ameaça é sempre do informante 
ameaçando sua própria face, nunca a do outro. Abaixo apresentamos os tipos de ameaça à face apresentados nesse corpus.

\subsubsection{Exposição da própria face}

Apenas duas amostras apresentam esse tipo de ocorrência. Interpretamos como exposição da própria face, depoimentos dos informantes que contenham trechos de sua vida pessoal, muitos deles espontâneos, ou seja, sem que o entrevistador tenha feito qualquer tipo de pergunta que levasse a tal exposição.

Assim, na amostra 149 o informante descreve uma difícil fase que passou quando mudou de cidade e na amostra 150, ao contrário dos outros dois informantes do sexo feminino, o informante se refere a sua idade. Observa-se que há três ocorrências desse tipo. Na primeira ele mostra o quanto era imaturo aos dezesseis anos, na segunda ele diz claramente a sua data de nascimento e na terceira, ao fazer referência ao dia de seu nascimento, utiliza a expressão há séculos. Reforçamos que não acreditamos que mencionar a idade seja algo prejudicial ao informante, no entanto considerando os outros dois informantes do sexo feminino e o senso comum de que mulheres não gostam de dizer a idade, chamou-nos atenção a sinceridade desse informante.

\subsubsection{Falta de modéstia}

Como apresentamos na análise do nível médio, acreditamos que a falta de modéstia distancia o falante do interlocutor, aproximando-o da mensagem, por isso funciona na contramão dos atenuantes. Esse tipo de ocorrência foi encontrada em duas amostras e, embora procure enaltecer a face do informante, não acreditamos que haja qualquer tipo de comprometimento da entrevista como um todo.

\subsubsection{Atenuantes}

Além de todos os recursos apresentados utilizados pelos falantes de nosso corpus como estratégias de cortesia e atenuação, observamos também o uso de algumas expressões que denominamos atenuantes, pois exercem a função de mitigar o conteúdo da fala do informante ou do entrevistador.

Observamos que há poucos trechos que contêm esse tipo de ocorrência e estão em cinco entre as seis entrevistas analisadas. Apenas a amostra 146 não apresenta tal ocorrência. 
Todas as ocorrências encontradas foram utilizadas para minimizar os enunciados e para isso o falante se apoiou em marcadores como bem..., meio... e um pouco. Há também um caso de diminutivo na entrevista 120 , em que a informante usa também uma gíria, comum na linguagem dos jovens.

\subsubsection{Expressão de opinião}

Conforme mencionado ao longo das análises individuais, as entrevistas que compõem esse corpus são apresentadas como um roteiro que segue uma rígida ordem de organização dos tópicos que devem ser abrangidos. Assim, o último tópico pede que o informante faça um relato de opinião e esse pode envolver um tema polêmico ou não, dependendo de cada entrevistador.

Pudemos observar que de maneira geral, os informantes não apresentam receio em se expor, tratam os temas com bastante naturalidade, sejam eles referentes aos seus trabalhos, às críticas ao governo ou sociedade ou outros tipos de questões como o casamento, a educação dos filhos, aborto ou religião.

Todos os informantes de nosso corpus fazem uso de verbos ou expressões parentéticos ou epistêmicos como achar, crer, pensar e a conclusão que chegamos sobre esse uso é que quanto mais conhecimento o falante tem sobre o tema que está sendo exposto, menor é a necessidade de uso de tais verbos, no entanto quando se trata de um tema polêmico em que há necessidade de expressar sua opinião mais uso o falante faz de tais verbos. Entendemos que é uma espécie de apoio e um reforço de que aquele é o seu ponto de vista sobre o assunto. No entanto, quando se trata de um tema que o falante domina e o mesmo não é polêmico, como, por exemplo, quando um professor trata sobre a educação, menor é o uso dos verbos mencionados.

Além desse tipo de verbo ou expressão, é comum que o informante se apoie em justificativas ou outros tipos de atenuantes para mitigar o conteúdo de sua fala, como pode ser observado nas análises individuais.

\subsubsection{Solidariedade}

Apenas uma amostra apresenta um caso de solidariedade, no caso o entrevistador complementa a fala do informante. Como já observado ao longo da análise individual, esse tipo de ocorrência é extremamente benéfico para a entrevista, pois além de aumentar a fluidez do diálogo, contribui para a interação entre os participantes. 


\subsubsection{Formas de tratamento}

Com relação às formas de tratamento utilizadas ao longo de todas as entrevistas que compõem esse corpus, verificamos alguns dados bastante relevantes. Conforme poderá ser constatado na tabela que apresentaremos adiante, pode-se afirmar que a língua falada apresenta divergências com relação à concordância, dentro do que rege a norma culta do Português do Brasil, no entanto devido à recorrência dos exemplos, observamos certa regularidade com relação ao uso.

\begin{tabular}{|c|c|c|c|c|c|}
\hline AMOSTRA & $\begin{array}{c}\text { SEXO DO } \\
\text { INF. }\end{array}$ & $\begin{array}{c}\text { PRONOME } \\
\text { PESSOAL }\end{array}$ & $\begin{array}{c}\text { PRONOME } \\
\text { OBLÍQUO }\end{array}$ & $\begin{array}{c}\text { PRONOME } \\
\text { POSSESSIVO }\end{array}$ & $\begin{array}{c}\text { FORMA } \\
\text { NOMINAL }\end{array}$ \\
\hline 115 & M & você & -------- & -------- & ------- \\
\hline 119 & M & o senhor & te & sua & Seu \\
\hline 120 & F & $\begin{array}{c}\text { a senhora / } \\
\text { você / cê }\end{array}$ & te & seu / sua & Dona \\
\hline 146 & F & $\begin{array}{c}\text { a senhora } \\
\text { o senhor / } \\
\text { você / cê }\end{array}$ & te & seu & Seu \\
\hline 149 & M & F senhora / & -------- & Professora \\
\hline 150 & Focê & & & Dona \\
\hline
\end{tabular}

Por meio da tabela acima, podemos comprovar alguns dados que foram apresentados ao longo da exposição teórica de nosso trabalho.

Observa-se que, embora alguns entrevistadores misturem o tratamento dispensado aos informantes, prevalece o eixo de poder. Com exceção da amostra 146, na qual esse eixo também é devido à profissão do informante, em todas as outras entrevistas esse poder é determinado pela idade dos entrevistados.

É interessante ressaltar que o informante da amostra 149 também é professor, no entanto não é professor universitário como a informante da amostra 146, mostrando que o status socioeconômico é determinante na escolha da forma de tratamento que será utilizada.

Com relação ao pronome oblíquo que acompanha o pronome pessoal, podemos observar que apenas três, entre as seis entrevistas analisadas, apresentaram tal pronome e que em todas a forma encontrada foi te, o que, como abordado anteriormente, diverge da norma culta pela falta de concordância. No entanto, devido à recorrência de uso do 
pronome, entendemos que essa é a concordância feita na língua falada. Esse dado já havia sido observado na análise do corpus de nível médio, observando os dados do nível superior, podemos constatar que não importa se o tratamento é formal ou informal, o pronome oblíquo utilizado na língua falada é o te.

Já com relação à utilização dos pronomes possessivos, diferentemente do que ocorreu na análise de nível médio, a única forma encontrada é a de terceira pessoa.

Com exceção de uma única amostra, todas as outras apresentam formas nominais antecedendo os nomes dos informantes. Esse dado também nos ajuda a considerar o eixo de poder como predominante nessa entrevista, sobretudo porque as formas mais utilizadas referem-se a pessoas mais velhas, exceto a amostra 146 que faz alusão à profissão e não à idade do informante. 


\section{Capítulo 6 - Confrontação dos dados}

Como já apresentado ao longo da introdução e da fundamentação teórica de nosso trabalho, o objetivo desta pesquisa é observar e analisar a manifestação de elementos de cortesia e atenuação na fala de brasileiros e espanhóis, mais especificamente brasileiros da região de São José do Rio Preto e espanhóis da região de Málaga.

Apesar de se tratarem de grupos bastante distintos, cuidamos para que houvesse uma série de características compatíveis, a fim de que a comparação fosse o mais verossímil possível. Essa compatibilidade foi pensada desde a seleção dos corpora, bem como dos grupos de informantes dentro de cada corpus, além dos elementos de atenuação e cortesia que analisaríamos, pois como já abordado anteriormente, por serem muitos, havia a necessidade de se fazer um recorte teórico.

Foram esses aspectos que nos levaram a considerar dois grupos de informantes um de nível médio e outro de nível superior, de forma que pudéssemos observar se o nível de instrução influenciava ou não na manifestação da cortesia. Já com relação à faixa etária diferente, o propósito foi outro, pois pensamos mais especificamente nas formas de tratamento. Considerando que os entrevistadores eram, na maioria das vezes, mais jovens do que os informantes, a intenção era observar se havia um tratamento diferenciado, qual era esse tratamento e também se havia a presença de algum outro elemento que marcasse essa diferença, como as formas nominais, por exemplo.

\subsection{Comparação nível médio}

Os informantes do nível médio possuem entre 25 e 45 anos. A denominação médio se deve ao nível de escolaridade.

Analisando em um primeiro momento a fala do entrevistador, podemos observar que, por possuírem objetivos diferentes, cada corpus tem uma maneira de condução da entrevista. Como já apontado anteriormente, o material brasileiro tem como meta principal a obtenção dos diferentes tipos de relato, enquanto que o material espanhol visa obter uma hora de diálogo, em média, sem preocupação com o tipo de tema que será tratado.

Por outro lado, há em comum o fato de ambos os materiais apresentarem entrevistadores jovens, todos estudantes, pertencentes ao grupo de pesquisa que visa a 
conseguir tais materiais, além disso, os anos em que as entrevistas foram coletadas também são próximos, como já observado na apresentação do corpus.

Com relação às perguntas que cada entrevistador elaborou, podemos afirmar que os entrevistadores espanhóis são mais diretos do que os brasileiros. Por meio dos gráficos ${ }^{47}$ apresentados, é possível visualizar tal diferença. No material brasileiro, não há sequer uma única entrevista que não contenha algum tipo de ato preparatório ou de proteção à face, enquanto que no material espanhol esse tipo de recurso é bastante restrito.

É certo que a quantidade de enunciados diretos no material brasileiro também é superior aos outros tipos de enunciados analisados, no entanto nota-se maior equilíbrio. Outro dado observado é que normalmente o entrevistador faz uso de atos preparatórios e de verbos de proteção à face para começar um novo tema e posteriormente utiliza os enunciados diretos. Já no material espanhol, a utilização dos enunciados diretos mesmo no início de novos temas é mais frequente.

Ressaltamos que nos chamou atenção o uso do modo imperativo nos enunciados interrogativos, pois como apontado antes, havia a expectativa de que sua frequência na língua espanhola fosse considerável, o que de fato não ocorreu.

Já o uso desse modo verbal fora do contexto de enunciados interrogativos não pode ser considerado em nossa análise para efeito comparativo, pois há registros apenas no material espanhol, provando que essa maneira de chamar atenção do interlocutor não é comum entre os brasileiros.

As ocorrências de desfocalização do eu mostram algo bastante semelhante entre os dois idiomas, pois em ambos o uso mais frequente foi tú no espanhol e você no português, pronomes correlatos. Esperávamos que houvesse certa frequência do pronome uno na língua espanhola e, ao menos nesse material, o índice foi bastante baixo.

Em nosso entendimento, a predominância dos pronomes de segunda pessoa do singular apontam certa aproximação do informante para com o entrevistador, na tentativa de incluí-lo no discurso, fazendo com que fizesse parte da história que estava sendo contada.

Em ambos os corpus observamos ocorrências de prevenção de ameaça à face e também em ambos há os mesmos subtipos de prevenção, sendo o mais recorrente aqueles que visam a proteger a face do próprio informante com expressões como não tenho certeza, não sei ao certo, se não me engano, etc.

\footnotetext{
${ }^{47}$ Vide págs. 163, 227, 278 e 323.
} 
Ainda que não fossem esperadas, observamos ocorrências também de ameaça à face, tanto do informante quanto do entrevistador, sendo as mais recorrentes aquelas que expunham a face do próprio informante por meio de declarações sobre a vida pessoal desse informante. Sobre esse aspecto, não podemos dizer que uma cultura é mais cuidadosa do que outra ao falar de si, pois em ambos os materiais, entre as seis entrevistas analisadas em cada, cinco apresentaram esse tipo de ocorrência, o que nos faz interpretá-las como equivalentes.

As ocorrências encontradas ao longo das análises sobre o uso de atenuantes são bastante diversificadas, sendo que as mais comuns são aquelas que atenuam o substantivo por meio do adjetivo pouco em ambos os idiomas.

Com relação aos casos de expressão de opinião, observamos que de maneira geral, em ambos os materiais, os informantes não demonstram qualquer tipo de intimidação em expor suas opiniões. Acreditamos que isso se deve às características gerais das entrevistas, as quais apresentam um tom bastante informal, similares a uma conversação sem fins específicos.

Sem exceção, todos os informantes fazem uso de verbos ou expressões parentéticas, sobretudo quando a opinião a ser dada é sobre algum assunto que o informante não tem grande conhecimento ou que envolve temas polêmicos, em que o uso de tais verbos ou expressões tem a função de reforçar que se trata de uma opinião pessoal e não ideias generalizadas. Justificativas e atenuantes também são comuns na tentativa de não levar o outro a um pré-julgamento.

É interessante observar as ocorrências de cortesia valorizante, as quais muito nos têm a dizer sobre as características de cada grupo de falantes. Nas amostras do corpus brasileiro, três entre as seis entrevistas apresentam tal cortesia na forma de agradecimentos, não só no encerramento dos diálogos, mas algumas vezes também na mudança de tópico. É interessante ressaltar que nas amostras em que não há agradecimento, há uma forma de se encerrar o tópico para abrir outro. Já no material espanhol, quatro, entre as seis entrevistas analisadas, apresentam tal tipo de cortesia, porém todas na forma de elogios do entrevistador para com o informante. Esse dado comprova o exposto ao longo de nossa fundamentação teórica, em que, apoiando-nos nas teorias de Haverkate, apresentamos a Língua Espanhola como uma cultura que não faz agradecimentos em atos rotineiros, em que se pressupõe que a atitude do outro não corresponde a nenhum favor, mas sim ao cumprimento de uma obrigação. 
Em nossas análises, os falantes espanhóis apresentam mais exemplos de solidariedade do que os brasileiros. Ressaltamos que analisamos esse tipo de ocorrência apenas quando um falante complementa a fala do outro, o que, para nós, denota maior interação entre os participantes, demonstrando certa atenção dispensada na fala do outro.

Com relação à invasão de território pessoal, em ambos os materiais, apenas uma entrevista apresentou tal tipo de ocorrência. Era esperado que não houvesse grande número de casos, pois por ser considerado invasivo, poderia prejudicar o andamento da entrevista, causando danos principalmente à face do informante.

Por fim, analisando as formas de tratamento, observamos que na Língua Espanhola há total regularidade com o uso dos pronomes, todos os pronomes encontrados ao longo das amostras - pessoais do caso reto, oblíquo e possessivos na segunda pessoa do singular. Embora não tenhamos encontrado nenhuma ocorrência de uso de usted com informantes mais velhos. Já na Língua Portuguesa, não há divergência no uso dos pronomes pessoais do caso reto, pois em todas as amostras as formas encontradas foram você e cê, porém o pronome oblíquo apresentado em todas as amostras que o continham, três no total, é o te, no lugar de lhe. Divergência maior está no uso do pronome possessivo, em que não há qualquer tipo de regularidade entre as segunda e terceira pessoas, em que os falantes usam indistintamente os dois pronomes. Seria importante aprofundar esse estudo, porém foge aos objetivos de nossa pesquisa.

Acreditamos que tais divergências sejam causadas pelo fato de se tratar de um pronome que faz referência à segunda pessoa do discurso, porém com concordância verbal na terceira pessoa. Nota-se que os falantes não apresentam dificuldade em concordar o verbo com o pronome, no entanto têm bem claro que o pronome oblíquo é o te e o possessivo se alterna entre segunda e terceira pessoas.

Apenas uma entrevista apresenta forma nominal no corpus brasileiro, a qual se mostra bastante informal e íntima. Como já observado ao longo das análises individuais, não era esperado que houvesse formas nominais pelo fato de informante e entrevistador possuírem idades próximas. Todas as entrevistas do nível médio estão no eixo de solidariedade.

Observam-se ainda outras particularidades no Português do Brasil Coloquial falado na região estudada, como a ausência de concordância nominal e verbal, a ausência de uso do subjuntivo, do pronome lhe, como já mencionado, entre outros. 


\subsubsection{A influência do sexo do informante}

Analisando os materiais sob a ótica do sexo dos informantes, podemos chegar a alguns dados relevantes.

No material brasileiro, observamos que os entrevistadores - todos do sexo feminino - são mais diretos, quando os informantes pertencem ao mesmo sexo. Assim, ao entrevistarem informantes homens, nota-se maior frequência de atos preparatórios ou de verbos de proteção à face. Acreditamos que o fato de ambos participantes pertencerem ao sexo feminino gera maior liberdade e, consequentemente, aumenta a interação entre informante e entrevistador. No material espanhol, esse dado não é significativo, pois não se observa maior incidência de determinado tipo de enunciado, de acordo com o sexo do informante.

No que se refere às estratégias de desfocalização, uso de atenuantes e expressão de opinião não conseguimos estabelecer relação entre o sexo e o tipo de ocorrência apresentada pelos informantes, devido à irregularidade das ocorrências.

Já com relação às ocorrências de prevenção de ameaça à face, observamos que essa é uma preocupação de todos os informantes, independente do sexo. Com exceção de apenas uma amostra do material espanhol, todas as outras apresentaram esse tipo de ocorrência na tentativa de o informante proteger sua própria face. As justificativas foram mais constantes na fala dos entrevistados do sexo masculino, bem como com as ocorrências de proteção à face do informante.

É interessante observar que em ambos os materiais, as mulheres têm mais facilidade para falar de sua vida pessoal, chegando a expor sua face em determinados momentos. Por outro lado, os informantes do sexo masculino não se constrangem em expor idéias preconceituosas.

Analisando as estratégias de solidariedade, observamos que o sexo não é um fator determinante, pois em ambos os sexos foi encontrada esse tipo de ocorrência. Diferentemente do que ocorreu com os casos de invasão do território pessoal, em que foram encontradas ocorrências apenas na fala dos informantes do sexo masculino. Cabe ressaltar que em números pouco significativos, apenas um caso em uma amostra em cada um dos corpora.

Como já apontando anteriormente, as ocorrências de cortesia valorizante também não podem ser analisadas considerando-se apenas o sexo dos informantes, pois todas as amostras do corpus brasileiro apresentaram exemplos de agradecimentos e quatro 
amostras do material espanhol casos de elogio aos informantes, sendo que as amostras que não apresentaram tal estratégia são com informantes de ambos os sexos.

Por fim, tampouco podemos estabelecer qualquer tipo de relação entre o sexo e as formas de tratamento utilizadas entre os participantes. Com exceção da amostra 106 do material brasileiro que apresenta uma forma nominal, a qual certamente foi utilizada por conta da forte interação que houve entre informante e entrevistador ao longo da entrevista. Entendemos que no caso das formas de tratamento, prevalece o eixo de solidariedade e isso independe do sexo dos informantes, sendo a idade o fator mais relevante.

\subsection{Comparação nível superior}

Os informantes desse nível possuem entre 50 e 70 anos. A denominação superior se deve ao nível de escolaridade, correspondente ao ensino universitário.

Com relação às perguntas que cada entrevistador elaborou, podemos afirmar que os entrevistadores espanhóis são mais diretos do que os brasileiros. Por meio dos gráficos ${ }^{48}$ apresentados, essa diferença é visível. No material brasileiro, com exceção de uma entrevista, todas apresentam ocorrências de ato preparatório ou proteção à face e em três delas os dois casos são encontrados. Já no material espanhol, há uma única ocorrência de verbo no imperativo, todas as restantes referem-se a enunciados diretos.

Diferentemente do que ocorre no nível médio, os enunciados diretos no material brasileiro não representam a maioria das ocorrências, com exceção da amostra 149. Há duas entrevistas (119 e 150) em que esse tipo de enunciado não aparece.

Bem como ocorreu nas amostras de nível médio do material espanhol, os verbos no imperativo pouco foram utilizados na formulação dos enunciados interrogativos. Desmistificando a ideia de que são amplamente utilizados, ao menos no contexto em que nossas amostras estão inseridas.

Como já mencionado anteriormente ao longo da confrontação dos dados de nível médio, o uso do imperativo fora do contexto de enunciados interrogativos não pode ser considerado em nossa análise para efeito comparativo, pois há registros apenas no material espanhol, provando que essa maneira de chamar atenção do interlocutor não é comum entre os brasileiros.

\footnotetext{
${ }^{48}$ Vide págs. $163,227,278$ e 323.
} 
Assim como foi observado na análise do nível médio, as ocorrências de desfocalização do $e u$ mostram algo bastante semelhante entre os dois idiomas, pois em ambos o uso mais frequente foi tú no espanhol e você no português, pronomes correlatos e em menor quantidade dos pronomes referentes a $1^{\mathrm{a}}$ pessoa do plural, nosotros no espanhol e a gente no português. Nas amostras malaguenhas foram encontradas também ocorrências de verbos na terceira pessoa do plural e do pronome indefinido uno, ainda que em número bastante reduzido.

Acreditamos que a predominância dos pronomes de segunda pessoa do singular apontam certa aproximação do informante para com o entrevistador, na tentativa de incluí-lo no discurso, fazendo com que fizesse parte da história que estava sendo contada.

Ambos os materiais apresentam ocorrências de prevenção à face, o que comprova que ambas culturas têm a preocupação com a exposição e, consequentemente, com a ameaça à face, seja de si mesmo, seja do outro. Além disso, os dados obtidos apontam certa proximidade entre as ocorrências encontradas, as quais são constituídas de proteção a própria face, justificativas que visam a evitar julgamentos por parte do outro e proteção à face do outro, no caso do material espanhol é referente à face do informante e do brasileiro refere-se à face do entrevistador. Ressaltamos que assim como no nível médio, prevalecem os casos que visam a proteger a face do próprio informante com expressões como não tenho certeza, não sei ao certo, se não me engano, entre outros.

Como já observado anteriormente, considerando as características de nossos corpora, não esperávamos encontrar casos de ameaça à face, no entanto comprovamos que, embora em menor número, ocorrências desse tipo também fazem parte das amostras que estamos analisando. Comparando os dois materiais, apenas o corpus de Málaga apresenta ameaça à face do outro, no caso o informante e em ambos são encontradas ocorrências de exposição da própria face e a falta de modéstia, sendo a primeira caracterizada quando o falante narra algo de sua vida pessoal e a segunda quando enaltece algum dom seu.

Com relação ao uso de atenuantes, considerando os dados obtidos, verificamos que os corpora se equiparam, pois no material espanhol todas as amostras apresentam tal ocorrência e no brasileiro apenas uma não contém tal estratégia. Bem como ocorreu nos materiais de nível médio, as ocorrências são bastante diversificadas, sendo que as mais comuns são aquelas que atenuam por meio do adjetivo pouco, mitigando o substantivo a que se refere. 
Com relação às ocorrências de expressão de opinião, os dados obtidos são semelhantes aos encontrados no material de nível médio. Assim, de maneira geral, em ambos os corpora, os informantes não demonstram qualquer tipo de intimidação em expor suas opiniões. Acreditamos que isso se deve às características gerais das entrevistas, as quais apresentam um tom bastante informal, similares a uma conversação sem fins específicos.

Sem exceção, todos os informantes fazem uso de verbos ou expressões parentéticas, sobretudo quando a opinião a ser dada é sobre algum assunto que o informante não tem grande conhecimento ou que envolve temas polêmicos, em que o uso de tais verbos ou expressões têm a função de reforçar que se trata de uma opinião pessoal e não ideias generalizadas.

Diferentemente do que ocorreu no nível médio, a análise das ocorrências de cortesia valorizante é pouco significativa, pois há apenas uma ocorrência no material espanhol e nenhuma no brasileiro. O mesmo ocorre com a invasão ao território pessoal do interlocutor, uma ocorrência nas amostras de Málaga e nenhuma nas de Rio Preto.

Já com relação à solidariedade entre os falantes, o material espanhol apresenta mais exemplos do que o brasileiro. Ressaltamos que analisamos esse tipo de ocorrência apenas quando um falante complementa a fala do outro, o que, para nós, denota maior interação entre os participantes, demonstrando certa atenção dispensada na fala do outro.

Por fim, analisando as formas de tratamento, observamos que, seguindo os dados observados no nível médio, a Língua Espanhola apresenta total regularidade com o uso dos pronomes, todos os pronomes encontrados ao longo das amostras - pessoais do caso reto, oblíquo e possessivos na segunda pessoa do singular. Não há como negar que devido à idade dos informantes, esperávamos que o tratamento desse material estivesse no eixo de poder, no entanto por conta dos pronomes utilizados, da ausência de formas nominais, observa-se que o eixo é o de solidariedade. Além disso, todas as amostras apresentam a segunda pessoa do plural, representada pelo pronome vosotros, quando há a necessidade de se referir a mais de uma pessoa, bem como ocorreu nas amostras de nível médio.

Já na Língua Portuguesa, há certa instabilidade no uso dos pronomes pessoais do caso reto, pois em três amostras há alternância entre os pronomes você/cê e o senhor. Em nosso entendimento, isso se deve à consciência que o entrevistador tinha de que devido à idade do informante, o tratamento deveria estar no eixo de poder, porém ao longo das respostas, criava-se certa confiança entre os interlocutores que permitia o uso do 
tratamento informal inconscientemente. Isso porque quando se iniciava um novo tema, novamente o pronome utilizado era o formal. Cabe ressaltar que a posição do informante é crucial na escolha da forma de tratamento. Observa-se que em duas amostras o único pronome utilizado foi o formal. Todas as amostras em que se usou o senhor apresentou forma nominal antecedendo o nome do informante, sendo que apenas uma delas referiase à profissão, todas as outras quatro utilizaram a forma seu ou dona.

Com base nesses dados obtidos, podemos averiguar que nem sempre você é uma marca de intimidade e que $o$ senhor, em determinadas ocasiões, pode funcionar como uma espécie de sinal que marca a distância em um primeiro contato.

É interessante observar o uso do pronome oblíquo. Apenas três amostras o continham e o único utilizado foi te, pronome de segunda pessoa do singular. Comparando com o nível médio, fica claro que na língua falada dessa região do país a segunda pessoa do singular é a forma utilizada, independente da forma de tratamento dispensada ao interlocutor. Já com relação aos pronomes possessivos não houve divergência, todos os entrevistadores utilizaram a terceira pessoa do singular, a qual concorda tanto com você quanto com o senhor.

\subsubsection{A influência do sexo do informante}

Analisando os materiais sob a ótica do sexo dos informantes, podemos chegar a alguns dados relevantes.

Diferentemente do que ocorreu no nível médio, não acreditamos que o sexo do informante exerça algum tipo de influência nas perguntas do entrevistador. De acordo com os dados obtidos, não podemos afirmar que o entrevistador é mais direto ou mais indireto.

No que se refere às estratégias de desfocalização, acreditamos que o tema de cada entrevista influencia mais do que o sexo do informante. Há que se considerar também características pessoais, em que se fala de uma forma mais inclusiva, agregando pessoas que não estão presentes no momento da fala ou de forma mais pessoal, optando-se pela primeira pessoa do singular.

Já com relação às ocorrências de prevenção de ameaça à face, observamos que essa é uma preocupação de todos os informantes, independente do sexo. Com exceção de apenas uma amostra do material espanhol, todas as outras apresentaram esse tipo de ocorrência na tentativa de o informante proteger sua própria face. As justificativas foram mais constantes na fala dos entrevistados do sexo feminino no material espanhol e de 
ambos os sexos no brasileiro. Referente à proteção à face do outro, houve dois informantes do sexo feminino que tiveram tal preocupação no material brasileiro e apenas uma ocorrência no espanhol, porém era o entrevistador que se preocupava com a face do informante.

Tampouco estabelecemos relação entre o sexo e as ocorrências de ameaça à face, pois nos dois materiais, ambos os sexos apresentaram ocorrências de exposição da própria face. A falta de modéstia foi encontrada em amostras de um homem e uma mulher no material brasileiro e de um homem no espanhol. Apenas a ameaça à face do interlocutor que foi observada unicamente no material espanhol e na fala de mulheres, uma vez que todos os entrevistadores são do sexo feminino.

As ocorrências referentes ao uso de atenuantes e expressão de opinião, a nosso ver, também não podem ser relacionadas ao sexo do informante, pois no material espanhol todas as amostras contêm elementos que visam a mitigar o conteúdo da fala. Já no material brasileiro, apenas a amostra 146 não contém esse tipo de ocorrência. Entendemos que isso se deve ao informante e aos temas tratados, pois entre todas as amostras analisadas essa é aquela em que não há qualquer tipo de interação entre os interlocutores, além de haver uma distância evidente entre informante e entrevistador. Com relação à expressão de opinião, como já foi observado no nível médio, todos os falantes expressam suas opiniões e não se intimidam se estão falando do governo ou de algum tema polêmico, independente do seu sexo.

Analisando as estratégias de solidariedade, observamos que o sexo não é um fator determinante no material espanhol, pois em ambos os sexos foi encontrado esse tipo de ocorrência. Já no material brasileiro, houve apenas uma ocorrência entre as seis entrevistas analisadas, o que consideramos um número insignificante para fazer qualquer tipo de afirmação sobre o uso de tal estratégia.

O mesmo ocorre com as questões que envolvem a invasão do território pessoal e cortesia valorizante, as quais foram apresentadas apenas no material espanhol, sendo uma ocorrência de cada.

Por fim, tampouco podemos estabelecer qualquer tipo de relação entre o sexo e as formas de tratamento utilizadas entre os participantes. Acreditamos que, sobretudo no material brasileiro, a idade e profissão do informante são fatores determinantes na escolha da forma de tratamento. A diferença do corpus espanhol, no qual todos os informantes foram tratados informalmente, independente da idade ou profissão. 


\section{A comprovação das hipóteses iniciais}

Após esse longo e aprofundado estudo, acreditamos que chegamos ao momento de confirmar se as hipóteses que motivaram esta pesquisa podem ou não ser comprovadas por meio dos corpora analisados e da metodologia por nós elaborada.

Com relação à primeira hipótese, a qual era composta por um questionamento sobre se seria o espanhol uma língua mais direta do que o português, acreditamos que sim, podendo isso ser comprovado tanto nas perguntas elaboradas pelos entrevistadores, quanto nas respostas dos informantes. Observa-se que os espanhóis do nosso corpus não fazem rodeios, para formular tanto perguntas, quanto respostas, pode-se observar que pouco utilizam recursos como proteção à face ou atos preparatórios. Comprovamos isso com os gráficos apresentados nas páginas 163 e 227. Esse fato já não ocorre nas entrevistas do corpus brasileiro, nas quais, embora o número de enunciados diretos seja considerável, a presença dessas outras estratégias é alta, como mostram os gráficos apresentados nas páginas 278 e 323. Além disso, observamos diferenças importantes na variável idade, foi possível constatar que entre os falantes mais velhos a incidência de atos preparatórios é ainda maior entre os brasileiros, enquanto que entre os espanhóis, observa-se que houve predominantemente o uso de enunciados diretos sem diferenciação de idade.

Ressaltamos que o fato de uma cultura ser mais direta do que outra, nos intercâmbios verbais no gênero entrevista analisado, não deve ser um instrumento de medição, julgamento ou caracterização de descortesia. A dinâmica dos intercâmbios verbais respondem às características que essa cultura impõe como modelo esperado ou desejado de perguntas e respostas. Ser mais ou menos direto está também relacionado a valores sociais e discursivos de clareza, de sinceridade, entre outros.

A segunda grande pergunta de nosso trabalho fazia um questionamento sobre se o que é cortês em uma língua pode não ser interpretado como tal na outra. Entendemos que da mesma forma que essa pergunta complementava a primeira, a resposta também é um complemento do que foi exposto acima. Certamente que o que é cortês para um cultura pode não ser em outra e vice-versa. Brasileiros lendo nossas análises do corpus espanhol poderiam entender que o fato de os entrevistadores serem diretos e de não utilizarem formas nominais com falantes mais velhos são indelicados. Ao passo que, espanhóis 
poderiam interpretar os brasileiros como extremamente polidos, exagerados ou obsequentes. A recepção e percepção dos recursos de cortesia remetem a questões socioculturais de difícil explicitação.

Se colocamos as entrevistas dentro de um contexto, livrando-nos de preconceitos com relação a nossa própria língua e à língua estrangeira analisada, observamos que nem os espanhóis são indelicados, nem os brasileiros extremamente polidos, há apenas um uso convencionalizado dentro de cada comunidade linguística que estrutura a natureza dos intercâmbios verbais em sua dinâmica social.

Nosso terceiro questionamento abordava os objetivos e estratégias da atenuação. Entendemos que a atenuação pode ter em uma conversação diferentes funções. Quando um informante faz uso de elementos de atenuação para mitigar o conteúdo de sua fala para expressar sua opinião sobre algum tema, tais elementos têm a função de estratégia conversacional, pois visam a proteger a face positiva do indivíduo. Por outro lado, sobretudo no corpus brasileiro, quando um entrevistador utiliza formas nominais e a forma de tratamento $o$ senhor para se referir ao informante, esses elementos têm a função de distanciamento social. Entendemos que tal distanciamento é imposto pela própria sociedade, haja vista que em algumas entrevistas o entrevistador "esquecia" a maneira mais formal e mudava para a informal no meio da pergunta, passando de $o$ senhor para você. Esse fato constatado permite algumas deduções que questionariam se as fórmulas de tratamento o senhor / a senhora no português coloquial são só indicadores de contato inicial. Consideramos que esse fenômeno merece estudos posteriores mais aprofundados.

Além disso, entendemos que outros recursos analisados neste trabalho também podem trazer algumas revelações sobre a dinâmica interacional de cada língua. No caso da desfocalização do eu, observamos que ambas as línguas apresentam tal estratégia, a qual em determinados momentos visa a aproximar o interlocutor, incluindo-o naquilo que está sendo contado. Porém, em outras situações, presentes no corpus brasileiro, há o objetivo de proteção à face, seja incluindo terceiros, como um caso de modéstia ou ainda a desfocalização, cujo objetivo é eximir o falante da responsabilidade do conteúdo de sua fala, no qual ele usa expressões gerais como a sociedade, as pessoas, entre outras, como apresentamos ao longo das análises individuais. Com a não expressão direta, evita-se o enfrentamento pessoal, a necessidade de ter que explicitar uma opinião e, principalmente, possíveis conflitos.

Ressaltamos que a questão da cortesia valorizante não pôde ser analisada como pretendíamos, pois o fato de as gravações já começarem com a entrevista diretamente, 
impossibilitou-nos saber como foi o cumprimento e a despedida entre os informantes. Dessa forma, não pudemos comprovar a teoria mencionada de Haverkate, a qual diz que o agradecimento em atos rotineiros não é comum entre os espanhóis.

A seleção de ambos os sexos para compor nossos corpora também teve importância relevante, pois pudemos observar, por exemplo, que as mulheres têm mais facilidade para falar de sua vida pessoal. Infelizmente nos corpora selecionados não havia entrevistadores do sexo masculino para que pudéssemos observar se esse fato se daria também entre interlocutores do sexo oposto.

\section{Relevância do estudo}

Considerando que as pesquisas sobre cortesia e atenuação no Brasil são ainda muito recentes, entendemos que esse estudo pode despertar o interesse de outros pesquisadores na aplicação de tal teoria em outros corpora. Pensando que os principais teóricos estudados estão em contínua produção, outros enfoques podem ser dados e outros resultados obtidos.

$\mathrm{Na}$ prática, como docente de Espanhol Língua Estrangeira, professores e futuros professores podem aproveitar os dados levantados e os resultados obtidos a fim de ampliar o conhecimento de seus alunos, apresentando de forma didática os elementos de atenuação e cortesia encontrados ao longo de nossas análises.

Para um estudo posterior, acreditamos que a aplicação dessa teoria em amostras de fala espontâneas, nas quais os interlocutores não sabem que estão sendo gravados, possibilitaria uma comparação entre os resultados obtidos.

\section{Considerações Finais}

Ao iniciar nossos estudos para a realização desta tese, tivemos contato com linguistas como Antonio Briz e Salvador Pons ${ }^{49}$, os quais apresentaram algumas críticas sobre nosso trabalho, alegando que não seria possível encontrar marcadores de cortesia e atenuação em entrevistas semidirigidas, as quais compõem nosso corpora. Acreditamos que isso corrobora o trabalho de Albeda $\mathrm{Marco}^{50}$, no qual a autora discursa sobre a dificuldade de se encontrar manifestações de cortesia em entrevistas.

\footnotetext{
49 Ambos estiveram na USP nos anos de 2007 e 2009, respectivamente, para ministrar um seminário aos alunos de Graduação e Pós-Graduação a convite dos Departamentos de Letras Modernas e Letras Vernáculas.

50 ALBEDA MARCO, M. Cortesía en diferentes situaciones comunicativas. La conversación coloquial y la entrevista sociológica semiformal. In: Pragmática Sociocultural. Barcelona: Ariel, 2004, págs. 109-134.
} 
Ainda assim, a nossa postura foi de persistir em nosso estudo, uma vez que o objetivo era a comprovação ou não das hipóteses que nortearam este trabalho, pois apoiando-nos nas leituras realizadas e por meio de análises prévias, já observávamos marcadores de cortesia e atenuação.

A conclusão a que chegamos sobre esse tema é que é sim possível realizar esse tipo de investigação em entrevistas semidirigidas, sobretudo em um material como o que nos propusemos a analisar, cuja temática era livre, assemelhando-se diversas vezes a uma conversação informal.

Considerando toda a teoria estudada e apresentada, bem como as análises realizadas, afirmamos com segurança que o ponto chave de todo o estudo é a análise do contexto em que a situação está inserida. Sem tal análise, possivelmente não chegaríamos às conclusões aqui apresentadas.

Sem o estudo do contexto, nenhum marcador de atenuação ou cortesia pode ser considerado, pois podem-se obter conclusões irreais.

Não estaríamos sendo sensatos ao afirmar que os espanhóis são menos corteses que os brasileiros. Acreditamos que os motivos para isso já foram apresentados anteriormente, porém estamos de acordo com Briz (2007, p.20) que defende a existência de culturas de mais aproximação e de mais distanciamento. De acordo com o que pode ser observado por meio de nossas análises, a cultura espanhola é uma cultura de mais aproximação, em que as relações podem ser estreitadas sem que haja a necessidade de tantas formalidades. Diferentemente do que ocorre com a cultura brasileira, na qual é visível que a interação entre os participantes é acentuada, mas certas formalidades como o uso de formas nominais ou o tratamento o senhor devem ser mantidas.

Para elucidar tais observações, Briz sugere uma linha contínua e graduada, na qual cada cultura é apresentada em uma extremidade. Nós sugerimos outro esquema, como pode ser observado abaixo:

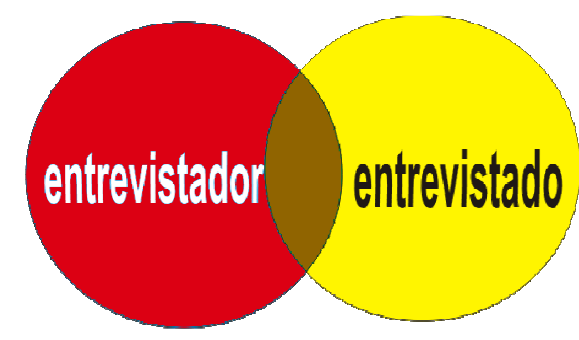

corpus espanhol
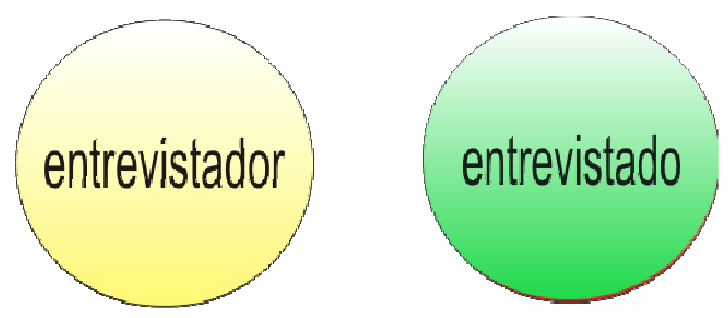

corpus brasileiro 
A intersecção visa a apontar a relação entre os participantes e a forma como os elementos de cortesia e atenuação são observados em cada corpora. Espanhóis representados pelas cores vermelho e amarelo - tendem a encurtar mais rapidamente as distâncias, aproximando-se do interlocutor, enquanto que os brasileiros - representados pelo verde e amarelo - se distanciam mais, preservando a exposição do eu. No entanto, é importante ressaltar que ambas as culturas atingem seus objetivos de comunicação, mediante esses mecanismos nos seus intercâmbios verbais que obedecem a rituais de interação próprios de cada cultura. 


\section{Referências Bibliográficas}

AGUILAR GONZÁLEZ, F.B. Los andaluces en busca de su identidad. In: Identidades lingüísticas en la España autonómica: actas de las Jornadas Hispánicas 1997 de la Sociedad Suiza de Estudios Hispánicos. Vervuert: Madrid, 2000, págs.. 151-186.

ALBEDA MARCO, M. Cortesía en diferentes situaciones comunicativas. La conversación coloquial y la entrevista sociológica semiformal. In: Pragmática Sociocultural. Barcelona: Ariel, 2004, págs. 109-134.

- ¿Cómo se reconoce la atenuación? Una aproximación metodológica basada en el español peninsular hablado. In: Actas de $4^{\circ}$ Coloquio Edice - (Des)cortesía en español. Espacios teóricos y metodológicos para su estudio. Roma-Estocolmo: Università degli Studi Roma Tre-Edice, 2010, págs.. 47-70.

ÁlVAREZ MURO, A. Cortesía y descortesía: teoría y praxis de un sistema de significación. Mérida: Universidad de los Andes, 2005.

AMARAL, A. O dialeto caipira. São Paulo: Hucitec, 1982.

AMOSSY, R. (org.) Imagens de si no discurso: a construção do ethos. São Paulo: Contexto, 2005.

BAGNO, M. Preconceito linguístico - o que é, como se faz. Edições Loyola: São Paulo, 2004. $34^{\mathrm{a}} \mathrm{ed}$.

BASTO, C. Formas de tratamento em português. In: Revista Lusitana, XXIX, p.182-202. BECHARA, E. Moderna Gramática Portuguesa. Rio de Janeiro: Editora Lucerna, 2004.

BLAS ARROYO, J.L. Tú y usted: dos pronombres de cortesía en el español actual. Datos de una comunidad Peninsular. In: E.L.U.A., volumen 10, 1994-1995, pp. 21-44

BORETTI, S. Aspectos de la cortesía lingüística en el español coloquial de Argentina. In: Oralia - Análisis del Discurso Oral. Madrid: Arco/Libros, 2001, p.75-102, v.4.

BRAVO, D. Sobre la cortesía lingüistica, estratégia y conversacional en español. In: Oralia - Análisis del Discurso Oral. Madrid: Arco/Libros, 2001, p.299-314, v.4.

Tensión entre universalidad y relatividad en las teorías de la cortesía. In: Pragmática Sociocultural. Barcelona: Ariel, 2004. Págs. 15-37.

Categorías, tipologías y aplicaciones - Hacia una definición de la "cortesía comunicativa”. In: Estudios de la (des)cortesía en español. Estocolmo-Buenos Aires: Editorial Dunken, 2005. Págs.21-52.

BRIZ,A.G.; GÓMEZ, J.R.; MARTÍNEZ, M.J. (eds.) Pragmática y Gramática del Español Hablado. Valencia: Libros Pórtico, 1996.

BRIZ, A. Para un análisis semántico, pragmático y sociopragmático de la cortesía atenuadora en España y América. In: Lingüística Española Actual XXIX, 2007. Págs. 0544.

Eficacia, imagen social e imagen de cortesía. In: Estudios de la (des)cortesía en español. Estocolmo-Buenos Aires: Editorial Dunken, 2005. Págs.53-91.

Cortesía verbal codificada y cortesía verbal interpretada en la conversación. In:

Pragmática Sociocultural. Barcelona: Ariel, 2004. Págs. 67-93.

et. all Un sistema de unidades para el estudio del lenguaje coloquial. In: Oralia, vol.6. Madrid: Arco/Libros, 2003, p.7-61.

. La estrategia atenuadora en la conversación cotidiana española. In: Actas del

Primer Coloquio del Programa EDICE - La perspectiva no etnocentrista de la cortesía: identidad sociocultural de las comunidades hispanohablantes. Editado por Diana Bravo. Estocolmo: Universidad de Estocolmo, 2002, págs. 17-46.

. El español coloquial en la conversación. Barcelona: Editorial Ariel, 2001. 
BROWN, P. e GILMAN, A. The pronouns of power and solidarity. In: Style in language. Cambridge: MIT Press, 1960, p.253-276.

BROWN, P. e LEVINSON, S. Politeness - some universals in language usage. Cambridge: Cambridge University Press, 1994.

CARRASCO,S. Revisión y evaluación del modelo de cortesía de Brown y Levinson. In: Pragmalinguistica. Cádiz: Universidad de Cádiz, 1999.

CARRICABURO, N. Las fórmulas de tratamiento em El español actual. Madrid: Arco/Libros, 1997.

CASTILHO, A.T. e PRETI, D. (orgs.) A linguagem falada culta na cidade de São Paulo - vol.I - Elocuções formais. São Paulo: T.A. Queiroz,1986.

. Gramática do Português falado - vol.IV - Estudos Descritivos. Campinas:

Editora da Unicamp, 1996.

. A linguagem falada culta na cidade de São Paulo - vol.II - Diálogos entre dois informantes. São Paulo: T.A. Queiroz,1987.

CESTERO MANCERA, A.M. Los turnos de apoyo conversacionales. Valencia: Servicio de Publicaciones de la Universidad de Cádiz, 2000.

CUNHA, C. E LINDLEY CINTRA, L.F. Nova gramática do português contemporâneo. Rio de Janeiro: Nova Fronteira, 2001.

DE JONGE, Bob. El desarrollo de las variantes de 'vuestra merced' a 'usted'. In: Actas del II Congreso de la Región Noroeste de Europa de la Asociación de Lingüística y Filología de América Latina (ALFAL). 2005. Disponível em http://elies.rediris.es/elies22/cap.7.htm Acesso em fevereiro de 2008.

ESCANDELL VIDAL, M.V. Los Enunciados Interrogativos. Aspectos semánticos y pragmáticos. In: Gramática Descriptiva de la Lengua Española 3 - Entre la oración y el discurso. Madrid, 1999, págs. 3929-3991.

. Introducción a La Pragmática. Barcelona: Ariel, 2006.

FARACO, C.A. O tratamento você em Português: uma abordagem histórica. In: Fragmenta. Curitiba: Editora da UFPR, 1996, p.51-82, nº13.

FANJUL, A.P. Portugués-Espanhol: línguas próximas sob o olhar discursivo. São Carlos: Claraluz Editora, 2002.

FERNÁNDEZ GARCÍA, F. Ironia y (des)cortesía. In: Oralia - Análisis del Discurso Oral. Madrid: Arco/Libros, 2003, p. 103-127,v.4.

FIORIN, J.L. As astúcias da enunciação - as categorias de pessoa, espaço e tempo. São Paulo: Ática, 2001

FONTANELLA de WEINBERG, M.B. Sistemas Pronominales de Tratamiento usados en el mundo hispánico. Gramática Descriptiva de la Lengua Española 1 - Sintaxis básica de las clases de palabras. Madrid, 1999, págs. 1400-1425.

FRAGO GRACIA, J.A. Historia de las hablas andaluzas. Madrid: Arco/Libros, 1993.

GARCÌA MOUTON, P. Lenguas y dialectos de España. Madrid: Arco/Libros, 1999.

GARRIDO MEDINA, J. Los Actos de Habla. Oraciones Imperativas. Gramática Descriptiva de la Lengua Española 3 - Entre la oración y el discurso. Madrid, 1999, págs. 3879-3925.

GOFFMAN, E. Ritual de la interacción. Argentina: Tiempo Contemporáneo, 1970.

GÓMEZ MOLINA, J.R. El Español hablado de Valencia - materiales para su estudio. Valencia: Universitat de València, 2005.

GONÇALVES, Sebastião Carlos Leite Gonçalves. Banco de dados Iboruna: amostras eletrônicas do português falado no interior paulista. Disponível em: http::/www.alip.ibilce.unesp.br/iboruna. 
HAVERKATE, H. Cortesia y descortesia em los diálogos del Quijote. Análisis de representación de las imágenes positivas y negativas de los protagonistas. In: Oralia Análisis del Discurso Oral. Madrid: Arco/Libros, 2001, p.129-148, v.4.

La cortesía verbal. Madrid: Gredos, 1994.

HERNÁNDEZ-FLORES, N. La cortesía como la búsqueda del equilibrio de la imagen social. In: Pragmática Sociocultural. Barcelona: Ariel, 2004. Págs. 95-108.

KERBRAT-ORECCHIONI, C. ¿Es Universal la Cortesía? In: Pragmática Sociocultural. Barcelona: Ariel, 2004. Págs. 38-53.

Os Atos de linguagem no Discurso. Niterói: EdUFF, 2005. Tradução de:

Fernando A. de Almeida e Irene E. Dias.

Análise da conversação - princípios e métodos. São Paulo: Parábola, 2006.

Trad. Carlos Piovezani Filho

LAKOFF, R. La lógica de la cortesía, o acuérdate de dar las gracias. In:Textos Clásicos de Pragmática. Madrid: Arco/Libros, 1998, págs.. 259-278.

LEECH, G.N. Principios de pragmática. Universidad de La Rioja, 1997.

LEVINSON, S. Pragmática. São Paulo: Martins Fontes, 2007.

LINDLEY CINTRA, L.F. Origens do sistema de formas de tratamento no Português. In: Brotéria - Revista da Cultura. Lisboa: , 1967, págs. 49-70, v. 84.

MATTE BON, F. Gramática Comunicativa Del español - de la lengua a la idea. Madrid: Edelsa, 1998, vol. 1.

MEDINA, C.A. Entrevista, o diálogo possível. São Paulo: Ática, 2002.

MEDINA, J.L. Variación sociolingüistica en las formas de trato - El análisis probabilístico según los datos del español de Canarias. In: Actas del II Coloquio Internacional del Programa Edice. Costa Rica: Universidad de Costa Rica, 2005, págs. 97-113.

MEIRELES, S.M. Estratégias para manutenção de uma boa interação lingüística: dissensão e trabalho da face em diálogos do alemão. São Paulo: Humanitas, 1999.

MIGUEL, A. La vida cotidiana de los españoles en el siglo XX. Barcelona: Editorial Planeta, 2001.

MOCCERO, M.L. Las selecciones pronominales como estrategias de cortesía. In: Actas Primer Coloquio del Programa EDICE - La perspectiva no etnocentrista de la cortesía: identidad sociocultural de las comunidades hispanohablantes. Estocolmo: Universidad de Estocolmo, 2002, págs. 346-354.

MORENO-FERNÁNDEZ, F. Principios de Sociolingüistica y Sociología del lenguaje. Barcelona: Ariel, 2005. $2^{\mathrm{a}} \mathrm{Ed}$.

MOURA NEVES, M.H. Possessivos. In: Gramática de uso do Português Falado.vol.IIIAs abordagens. Campinas: Editora da Unicamp, 2002.págs. 149-211.

. Gramática de uso do Português Falado. São Paulo: Editora da UNESP, 2000.

PÊCHEUX, M. Semântica e discurso - uma crítica à afirmação do óbvio. Tradução de Eni Orlandi. Campinas: Editora da Unicamp, 1988.

Análise Automática do Discurso. In: Gadet, F. Hak, T. (orgs.) Por uma análise automática do discurso - uma introdução à obra de Michel Pêcheux. Campinas: Editora da Unicamp, 1990, págs. 61- 161.

PORTOLÉS,J. Pragmática para Hispanistas. Madrid: Síntesis, [s.d.]

PRETI, D. Sociolinguistica - os níveis da fala: um estudo sociolingüístico do diálogo na literatura brasileira. São Paulo: Companhia Editora Nacional, 1982, 4ª ed.

e URBANO, H. (orgs.). A linguagem falada culta na cidade de São Paulo - vol.

III - Entrevistas (Diálogos entre informante e documentador). São Paulo: T.A.Queiroz, 1988.

(org). O discurso oral culto. São Paulo: Humanitas, 1997. 
Papéis sociais e formas de tratamento em A Ilustre Casa de Ramires, de Eça de Queiroz. In: A ilustre Casa de Ramires - cem anos. São Paulo: Educ, 2000.

PUGA, J.L. La atenuación en el castellano de Chile: un enfoque pragmalingüístico. Valencia: Universitat de València, 1997.

RECUERO, S. I. Los estudios de la cortesía en el mundo hispánico. Estado de la cuestión. In: Oralia Análisis del discurso oral, Madrid: Arco/Libros, 2001, págs. 245-298, v.4.

REYES, G. La Pragmática lingüística. Barcelona:Montesinos Editor, 1990.

RODRÍGUEZ, L.C. Los estudios del español hablado entre 1950 y 1999.

ROSA, M.M. Marcadores de atenuação. São Paulo: Contexto, 1992.

SEARLE, J.R. Os actos de fala. Coimbra: Livraria Almedina, 1981. Tradução de : Carlos Vogt, Ana Cecília Mareronka, Balthazar Barbosa Filho, Maria Stela Gonçalves, Adail Ubirajara Sobral.

Mente, linguagem e sociedade - Filosofia do mundo real. Rio de Janeiro: Rocco, 2000. Tradução de F. Rangel.

SILVA, L.A. Poder y escolaridad en el discurso academico. Separata de ACTAS DEL V CONGRESO DE LINGUISTICA GENERAL, 2002, León. Madrid: Arco/Libros, 2002, p.5-8.

Tratamentos familiares e referenciações dos papéis sociais. In: Léxico na língua oral e na escrita. São Paulo: Humanitas, 2003. Págs.169-194.

Cortesia e formas de tratamento. In: Cortesia Verbal. São Paulo: Humanitas, 2008, págs. 157-192.

SOTO, U. Cartas através do tempo: o lugar do Outro na correspondência brasileira. Niterói: EdUFF, 2007.

VILLENA POSODA, J.A. Identidad y variación lingüistica: Prestigio nacional y lealtad vernacular en el español hablado en Adalucía. In: Identidades lingüísticas en la España autonómica: actas de las Jornadas Hispánicas 1997 de la Sociedad Suiza de Estudios Hispánicos. Vervuert: Madrid, 2000, págs.. 107-150.

ZIMMERMANN, K. Construcción de la identidad y anticortesía verbal. In: Estudios de la (des)cortesía en español. Estocolmo-Buenos Aires: Editorial Dunken, 2005. Págs.245271. 